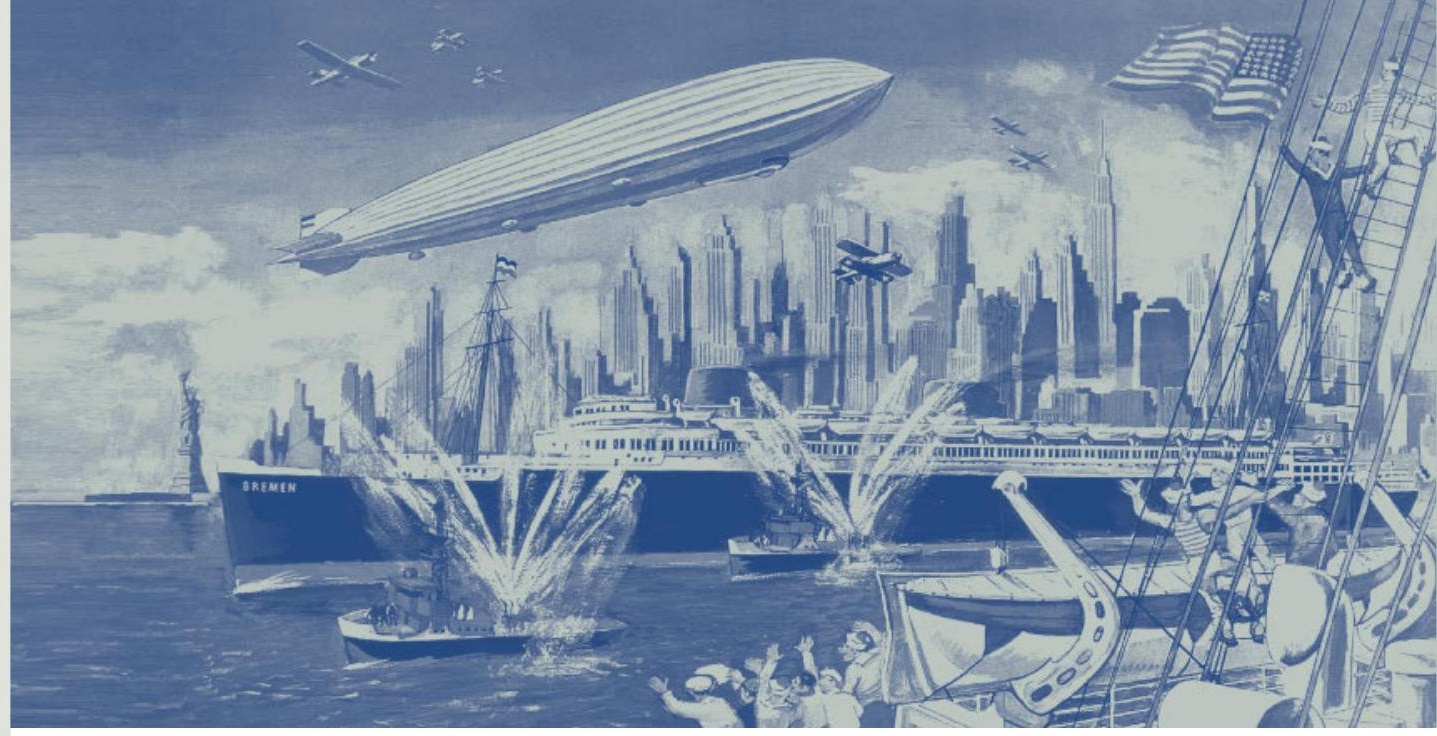

History

Elisabeth Piller

\title{
Selling Weimar
}

German Public Diplomacy and the United States,

1918-1933

Franz Steiner Verlag 
(4) 


\section{TRANSATLANTISCHE HISTORISCHE STUDIEN}

Publications of the German Historical Institute Washington

Edited by

Elisabeth Engel, Axel Jansen, Jan C. Jansen,

Simone Lässig and Claudia Roesch

Volume 60

The German Historical Institute Washington is a center for the advanced study of history. Since 1992, the Institute's book series Transatlantic Historical

Studies (THS) has provided a venue for research on transatlantic history and American history from early modern times to the present. Books are published in English or German. 
Elisabeth Piller

\section{Selling Weimar}

German Public Diplomacy and the United States, 1918-1933

Franz Steiner Verlag 
Cover illustration:

Technische Leistungen öffnen die Tore zur Welt. Luftschiff Zeppelin und Dampfschiff Bremen in New York. Farbdruck nach unbez. Original. Schulwandbild. Aus der Serie: Zeitgeschichte / 1918-1932; München (Lehrmittelanst. Köster \& Co.) o. J. Dortmund, Westfälisches Schulmuseum.

(C) akg-images

This book is an open-access-publication.

This book is distributed under the terms of the Creative Commons Attribution CC-BY-NC-ND NonCommercial-NoDerivatives 4.o.

\section{(c) $\underset{\mathrm{BY}}{\mathrm{NC}} \bigodot_{\mathrm{ND}}$}

https://creativecommons.org/licenses/by-nc-nd/4.o/deed.de

Bibliographic information published by the German National Library: The German National Library lists this publication in the Deutsche Nationalbibliografie; detailed bibliographic information is available at $<$ http://dnb.d-nb.de $>$.

This publication and all parts thereof are protected by copyright. Any usage beyond the narrow limits of the Copyright Act is not permissible and liable to prosecution.

(C) Franz Steiner Verlag, Stuttgart 2021

Layout and production by Franz Steiner Verlag

Typesetting: Fotosatz Buck, Kumhausen

Print: Memminger MedienCentrum, Memmingen

Printed on acid-free and age-resistant paper.

Printed in Germany.

ISBN 978-3-515-12847-6 (Print)

ISBN 978-3-515-12851-3 (E-Book) 


\section{Acknowledgements}

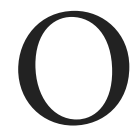

ver the course of writing this book I have incurred many personal and intellectual debts. It is with deep gratitude that I acknowledge them. The book could not have been written without the help of the many archivists and librarians at the Library of Congress, the American Philosophical Society, the University Archives in Heidelberg, Berlin, Marburg, Princeton, Columbia and Cornell, the Bundesarchiv in Berlin and Koblenz, the Joseph P. Horner Memorial Library, the Historical Society of Pennsylvania, the New York Public Library, the Hoover Institution Archives, the Bayerisches Hauptstaatsarchiv, the Bayerische Staatsbibliothek, the Rheinisch-Westfälisches Wirtschaftsarchiv, the Krupp and Bayer Company Archives, the Geheimes Staatsarchiv Preußischer Kulturbesitz, the Rockefeller Archive Center, the National Archives at College Park, MD, and above all the Politisches Archiv des Auswärtigen Amts. All of them have been unfailingly helpful and courteous in the face of even the most exasperating Friday afternoon request.

My research has also benefited greatly from the financial support of the Historical Society of Pennsylvania, the Horner Memorial Library, the Rockefeller Archives Center, the German Historical Institute Washington, and especially the Faculty of Humanities at the Norwegian University of Science and Technology (NTNU). I would also like to thank my colleagues at NTNU, and since 2018 at the University College Dublin, the University of Oslo, and the University of Manchester for their kindness and intellectual fellowship. Finally, I would like to convey my gratitude to the German Historical Institute Washington and the Franz Steiner Verlag for awarding my book manuscript the Franz Steiner Prize and supporting its publication in the Transatlantic His- 
torical Studies series. I am especially indebted to the series' editors, particularly Axel Jansen and Jan C. Jansen, for their great help in preparing the manuscript for publication. I was also extremely fortunate to have the support of one of the GHI's editors, the fabulous Patricia (Casey) Sutcliffe, who greatly improved this book. Finally, I would like to thank GHI interns Sandra Kastenberger und Hanna Bosse, who took several trips to the National Archives to secure scans of crucial images.

This is also the time to convey my gratitude to my two doctoral advisors. Professor Manfred Berg at the University of Heidelberg supported this project from its very beginning and continued to do so after I moved to Norway. He generously shared his expertise on Weimar foreign policy and the United States and commented carefully on this manuscript, always asking the right questions at the right time. At NTNU, Professor Tore Petersen brought his rich knowledge of international and diplomatic history to bear. Throughout, he maintained his very own "open (office) door" policy, readily listening to my concerns and giving freely of his time even when all I needed was an intellectual "pat on the back."

I am also grateful to my parents, Gerhard and Christiane Piller, who have always nurtured my curiosity through travel, reading, and detective-themed birthday parties. Very special thanks are in order for my aunt and uncle, Angelika and Fritz Stahlberg, whose extraordinary hospitality tremendously sweetened my many archival visits to Berlin. The single greatest debt, however, I owe to Jonas Scherner, who was with me every step of the way, who shared all my moments of excitement and exasperation, and who gracefully traded his (never entirely serious) aspiration to become a "golf professor," i. e., having real weekends and vacations, for spending Saturdays and summers in the library. It is often said that writing a book is a lonely undertaking; Jonas made sure it never was.

Finally, I want to thank my grandparents, Ludwig and Charlotte Piller, whose sharp wit, story-telling talents, and abundant humor are an inspiration to me. They still remember the end of World War I, the election of von Hindenburg, the death of Stresemann, the flight of the zeppelin, and the 1936 Olympics - and many other events that this book touches on. They are my personal connection to the early days of the twentieth century and my role models for the twenty-first. At 99 and 106 years old, they eagerly await the publication of this book (even as they would clearly prefer a great-grandchild), and it is to them that I dedicate it. 
Meinen Großeltern 



\section{Contents}

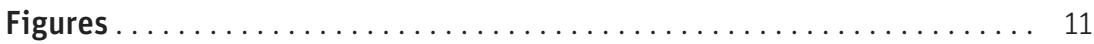

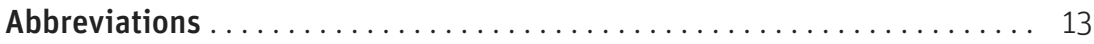

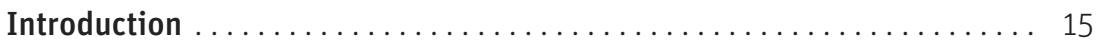

\section{Part I}

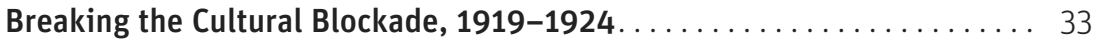

Backdrop: The Cultural Blockade . . . . . . . . . . . . . . . . . . . 35

1 Isolation, Revision, and Amerika, 1919-1921 . . . . . . . . . . . . . . . . . 39

2 Culture, Propaganda, and Transatlantic Relations, 1902-1921. . . . . . . . . 57

3 Obstacles and New Beginnings, 1921-1924 . . . . . . . . . . . . . . . . 117

\section{Part II}

Peaceful Revision: Winning American Hearts and Minds, 1924-1929 . . . . 161

Backdrop: Peaceful Revision and Peaceful Revisionists, 1924-1929 . . . . . . . . . 163

4 German Cultural Diplomacy Between German Americans and Anglo-

Americans............................... 171

5 "The Best German Politics": Academic Diplomacy and the United States 211

6 “Germany Invites You!”: Tourism Promotion as Public Diplomacy . . . . . . 275

Reflections: German Cultural Diplomacy and the Transatlantic Rapprochement, 1924-1929 . . . . . . . . . . . . . . . . . . . . . . . . . . . . . . . . . . . . . 319 


\section{Part III}

Maintaining Transatlantic “Friendship”?, 1930-1937

7 Public Diplomacy, the Great Depression, and the Intrusion of German Politics, 1930-1932. . . . . . . . . . . . . . . . . . . . . . . . . . . . . . . . . . . 329

8 "Submerged Under a Nazi Wave”? Continuity and Change in German Public Diplomacy, 1933-1937

Conclusions: German Public Diplomacy and the United States 379

Bibliography 393

Index 423 


\section{Figures}

1: J.N. Darling, "Outcasts," editorial cartoon, October 1918 @ "Ding” Darling Wildlife Society

2: Hans-Maria Lindloff, "German Hope in America: The German Michel Dreams of the Fair Towers of Gold," Literary Digest, Jan. 5, 1924

3: "The Latest Suitor," Puck, Feb. 19, 1902

4: "As the World Sees It," Literary Digest, May 22, 1915

5: Zeppelin over New York City, 1928, Bundesarchiv, Georg Pahl, Bild 102-06709

6: Erich Schilling, "Kunstraubzug des Dollars [The Dollar's Art Pillage]," Simplicissimus, 1922

7: The Steuben Club from New York touring Berlin, 1929, Bundesarchiv, Georg Pahl, Bild 102-08179

8: Willi Dzubas, "German Universities," German Tourism Promotion Office, ca. 1930

9: German Exchange Students at the Arrival Camp at Storm King, 1930, Rockefeller Archive Center, Collection: IIE RG 4 Series 1, Photographic Files FA\#1288 Box 35 Folder 284

10: Inge von Müller at Bates College Rockefeller Archive Center, Collection: IIE RG 4 Series 1, Photographic Files FA\#1288 Box 34 Folder 283

11: Stresemann and Schurman receiving honorary doctorates in Heidelberg, May 1928, Bundesarchiv, Robert Senneck, Bild 146-1978-029-05 A

12: Interior of the German Tourist Information Office in New York City, ca. 1931, NARA RG 131/65, Folder 131-GR-273 Window Displays

13: Window Display of Neuschwanstein Castle at Whitcomb Travel Agency in New York, NARA, RG 131, Box 65, Folder 131-GR-273, Window Displays

14: Ernst Schmitz, Werbespiegel, 1926, Politisches Archiv des Auswärtigen Amts, R 65090

15: Ludwig Hohlwein, "Summer in Germany," Poster, German Tourism Promotion Office, 1928 
16: Jupp Wiertz, "Germany Wants to See You," Poster, German Tourism Promotion Office, ca. 1926

17: Willi Dzubas, “Germany," Poster, German Tourism Promotion Office, ca. 1930

18: The Reichstag draped in American and German flags during the Washington BiCenntenial, 1932, Bundesarchiv, Georg Pahl, Bild-102-13208 A

19: National Socialist Student Organization, "Die Juden bringen den lebendigen Geist [The Jews bring the living spirit]," Pamphlet, June 1931, Heidelberg University Archive, B-5135/7 


\section{Abbreviations}

AA Auswärtiges Amt, German Foreign Ministry

AAD Akademischer Austauschdienst, Academic Exchange Service

ADAP Akten zur deutschen auswärtigen Politik

AdRk Akten der Reichskanzlei

AEG Allgemeine Elektricitäts-Gesellschaft

AO Auslandsorganisation der NSDAP, National Socialist Party's

Foreign Section

APS American Philosophical Society

AWD Amerika-Werkstudenten-Dienst, America Work Student Service

BArch Bundesarchiv

CEIP Carnegie Endowment for International Peace

CSMF Carl Schurz Memorial Foundation

CUNY City University of New York

DAAD Deutscher Akademischer Austauschdienst, German Academic

Exchange Service

DDP Deutsche Demokratische Partei, German Democratic Party

DGFP Documents on German Foreign Policy

DNVP Deutschnationale Volkspartei, German National People’s Party

DVP Deutsche Volkspartei, German People's Party

FRUS Foreign Relations of the United States

GHI German Historical Institute

GTIO German Tourist Information Office (New York)

HAPAG Hamburg-Amerikanische Packetfahrt-Actien-Gesellschaft, Hamburg America Line 


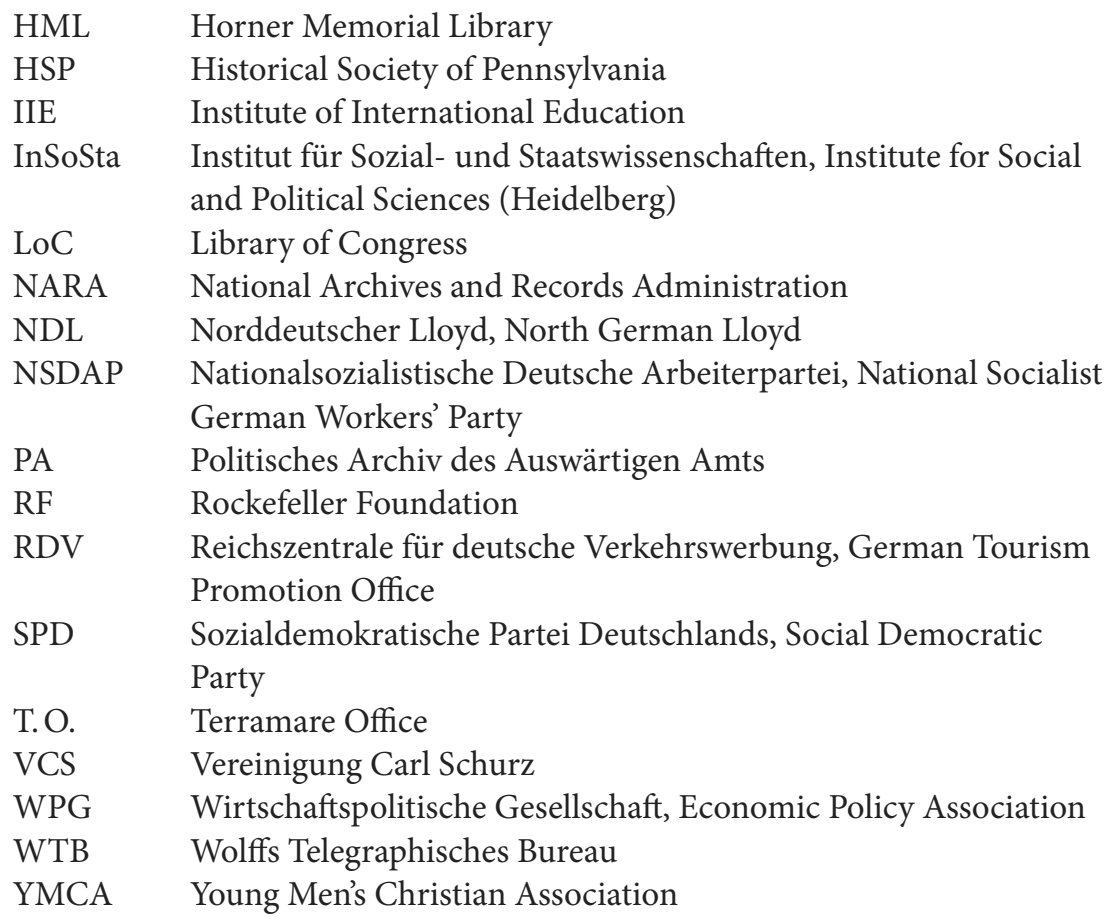




\section{Introduction}

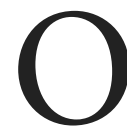

n March 1, 1917, Gustav Stresemann addressed the German Reichstag. Commenting on recent international developments, the rising star of the National Liberal Party had much to ponder. After the German Reich had resumed unrestricted submarine warfare just one month earlier, U.S. President Woodrow Wilson had cut off diplomatic relations. After thirty-one months of neutrality, it no longer seemed likely that the United States would refrain from joining the war coalition against Germany. Not yet forty years old, Stresemann, Germany's future foreign minister and Nobel peace laureate, applied his oratory skill to explaining the deterioration of German-American relations in the preceding years. Trying to comprehend why the U.S. stance on Germany had shifted from neutral to somewhat belligerent, Stresemann focused not on the Reich's violation of Belgian neutrality in August 1914, not on its infamous sinking of the ocean liner Lusitania in May 1915, not on its acts of sabotage on American soil during 1915 and 1916, and not even on the resumption of unrestricted submarine warfare (which he had supported); instead he told his audience: "with regard to German-American relations, we now have to pay the price for the distorted image of Germany that was able to develop abroad because we have not even tried to properly influence international public opinion."' At the heart of America's growing enmity, Stresemann held, lay not Germany's wartime decisions but a fundamental misunderstanding of Germany and the German people. Ultimately, a "distorted image" of the Reich as an aggressive, militaristic, and autocratic nation was to blame for the trans-

1 See Gustav Stresemann in Verhandlungen des Deutschen Reichstags, Mar. 1, 1917, 2470 A. 
atlantic discord. ${ }^{2}$ As the two countries edged toward war, Stresemann regarded Germany's international isolation and even U.S. belligerence as the product of failures in German public relations.

Given Stresemann's strong support for the resumed submarine warfare just a few months earlier, it would be easy to dismiss his focus on such an imponderable factor as Germany's "distorted image" as a convenient excuse for a policy gone wrong. But Stresemann was far from alone in this assessment. The left-liberal opponents of submarine warfare, too, widely attributed American belligerence to the Imperial government's long-standing neglect of public diplomacy. While Allied propaganda had successfully turned Germans into "Huns," German leaders had apparently not mustered any determined or effective countermeasures. ${ }^{3}$ On the contrary: for decades already, they claimed, the German government had failed to pursue a modern communications strategy as it lacked both the necessary expertise and interest. With its foreign service steeped in aristocratic privilege and the Reichstag relegated to the fringes of foreign policy-making, the Kaiserreich had never perceived international opinion as a "power factor" at all. A few days after the Reichstag debate, news broke of the intercepted Zimmermann Telegram, wherein German Undersecretary of State Arthur Zimmermann had promised parts of the United States to Mexico in exchange for its military support in case of war. For many critics, this seemed to be merely the most recent in a long string of diplomatic blunders, and yet another indication of the disregard for foreign psychology in German statecraft.

For Germany's future leaders, including Stresemann, the importance of public relations and the need for systematic public diplomacy was among the central lessons of the Great War. From 1917 onward, they set out "to make up," as Stresemann put it, "for what we have long neglected." 4 Spurred on by the realities of defeat in late 1918 and the loss of hard power options in 1919, a debate emerged in the postwar years about the significance of public opinion in international relations, along with a commitment to reshaping Germany's image in the world. Whatever their previous positions, many Germans realized the international impact of public sentiment as a result of World War I. Henceforth, foreign policy could no longer be conducted as it had been before. As Stresemann had already concluded in March 1917: "We just have to get used to the fact that today throughout the world we live in a democratic age, in which these public attitudes have such great importance, are so powerful a factor, that we have no option but to counter Britain's enormous efforts in this field with

2 Gustav Stresemann in Verhandlungen des Deutschen Reichstags, Mar. 29, 1917, 2850 D-2851 A.

3 For more details on this discussion, see Chapter 2.

4 Stresemann in Verhandlungen des Deutschen Reichstags, Mar. 1, 1917, 2470 A. 
something similar of our own."5 And nowhere would this be more apparent than in the United States, where Germany had suffered its most spectacular wartime failure and where it had its greatest postwar ambitions.

This study is about Weimar Germany's American project. It traces the Weimar Republic's efforts to make public diplomacy an essential part of its foreign policy toward the United States. At the same time, it follows the initiative of a group of educated bourgeois German publicists, educators, and parliamentarians to rebuild trust and sympathy within America after the devastations of the war. In the 1920s, official and private groups were united in their desire to overcome German isolation and secure the support of the United States, in the hope that it could help bring about a revision of the Versailles peace treaty. Realizing that this would first require a solution to Germany's postwar "image problem," this group of peaceful revisionists established a new way of thinking about foreign relations that differed notably from the nineteenth century and became commonplace thereafter; the cultural institutions and transatlantic outreach programs they created continue to define Germany's foreign representations even now, a century later.

World War I famously ended on November 11, 1918, when the German delegation signed the armistice in a railroad car in the forest of Compiègne. ${ }^{6}$ In the preceding weeks, the German military effort had collapsed, German monarchies had broken down, and, only two days prior, the German Republic had been established. Few could have foreseen these developments just weeks earlier. In the early summer, German victory had still seemed possible, even probable, to many contemporaries. Only in late September had the German Supreme Army Command admitted that defeat was imminent and asked the civilian leadership to call immediately for a ceasefire. The parliamentarization of the German monarchy, long demanded by reformers, was now deemed expedient. On October 3, 1918, the liberal Max von Baden formed a new reform government, which included members of the Social Democratic Party for the first time. The following day, the von Baden government called on U.S. President Wilson to negotiate an armistice based on his fourteen points in order to avoid the Allies' more punitive peace terms. When the harsh armistice terms dashed German hopes, the German Navy Command decided on a last "battle of honor" in late October, sparking first local mutiny, then a national revolu-

5 Ibid.

6 I refer here narrowly to the military confrontation of World War I. I am aware of recent literature on the continuation of violence in Europe and elsewhere, even as the war had officially come to a close; see, e. g., Robert Gerwarth, The Vanquished: Why the First World War Failed to End (New York, 2016). 
tion, after four years of deprivation, death, and now unexpected defeat. On November 9, Social Democrat Philipp Scheidemann announced the abdication of the Kaiser, proclaimed the German Republic, and appointed a new leftwing provisional government. Two days later in Compiègne, the representatives of the new republic assumed responsibility for ending a war whose origins and direction they had influenced only marginally. As the Kaiser and his generals fled the country, the republic was left to deal with the consequences of defeat.

The gravity of these consequences only dawned slowly on many Germans during the long armistice period. Those who had held on to illusions of a lenient "Wilson Peace" were shocked by the actual peace terms, which had to be signed, with only minor modifications, on June 28,1919 . While none of the victors were satisfied with the treaty, the Germans experienced it as a devastating injustice and calculated humiliation. The treaty had placed responsibility for the war squarely on Germany's shoulders, sharply reduced its army and navy, and dissolved its air force entirely; sizeable German lands and all colonies had been lost, the Rhineland and the Saar area were to be occupied, and reparations - in an amount yet to be determined - would have to be paid. In a consensus rare during the Weimar period, opposition to the Versailles "dictate" was nearly unanimous at the time. Even as the treaty was ratified in the Reichstag, public discussion focused on how to revise its economic, military, and territorial terms. From then on, revision became the leitmotif of German foreign policy. ${ }^{7}$

It was clear that the United States would have to play a crucial role in Weimar's revisionist project. It had emerged from World War I not only as the leading economic power and main creditor nation - France alone owed it more than $\$ 3$ billion - but with substantially increased international visibility and moral capital. While German strategists had previously dismissed the very notion of U.S. military power, one million fresh American troops had indeed helped to secure an Allied victory in the summer of 1918 just as President Wilson's vision of a liberal world order had resonated powerfully around the world. ${ }^{8}$ As the United States entered the 1920 s unburdened by staggering debt and national trauma, the global distribution of power shifted dramatically in its favor. Compared to postwar Europe, engulfed in economic chaos and civil strife, America seemed (at least to European observers) more united, prosperous, and confident than ever.

The new political and economic weight of the United States in the world placed it at the heart of German foreign policy ambitions. On October 4, 1918, the newly established German government had approached not the Allies but

7 On the pathological forms of the "Weimar Revision Syndrome," see Michael Salewski, "Das Weimarer Revisionssyndrom," Aus Politik und Zeitgeschichte B2/80 (Jan. 1980): 14-25.

8 Erez Manela, The Wilsonian Moment: Self-Determination and the International Origins of Anticolonial Nationalism (New York, 2007). 
President Wilson about armistice negotiations, and, despite the lack of American encouragement, unrealistic German hopes of American goodwill flourished. ${ }^{9}$ It was in deference to perceived American wishes that further constitutional reforms were initiated in October, and the abdication of the Kaiser, even the declaration of the republic, were widely perceived as accommodating the United States. After the armistice, the German government and civil groups tried to keep up direct lines of communication with the United States. It was on this country that they settled their hopes for a just peace and economic reconstruction since it seemed more benevolent and had fewer apparent direct interests than the other Allies. ${ }^{10}$ Even after the profound disappointment over Versailles (and President Wilson's alleged "betrayal"), German democratic leaders clung to their "basically pro-American orientation." ${ }^{11}$ The most pressing issue - in particular, the settlement of the reparations question - depended in part on the United States. As the main creditor to the Allies it was the only nation in a financial and economic position to broker a reasonable settlement, to ward off the large Allied demands, and to finance Germany's economic recovery. Consequently, German hopes were set overwhelmingly on Amerika. ${ }^{12}$ Convincing an increasingly isolationist, still hostile American public to get involved on Germany's behalf became one of the republic's central foreign policy concerns of the 1920 .

This study details how Germans addressed this concern, that is, how they tried to reach out to a country that seemed to hold a solution to the Weimar Republic's many troubles and what strategies they employed to win over the American public, which they widely perceived as hindering U.S. support and involvement. Throughout the 1920s, German state and nonstate groups created organizations and programs designed to loosen the Allied grip on America and to rebuild German prestige and transatlantic influence. For more than a decade, they fought an uphill battle to overturn Germany's "distorted image," which they felt had contributed to their defeat.

9 As the Reich finance minister explained to the cabinet on April 26, 1919: "Wilson's 14 points are a shield against the demands of our victorious enemies." Akten der Reichskanzlei. Weimar Republik (AdRk) - Das Kabinett Scheidemann/Bd. 1/Dokumente 54 b Ausführungen des Reichsfinanzministers vor dem Reichskabinett über die finanzielle Leistungsfähigkeit des Reiches, Apr. 26, 1919, 233.

10 ADAP Serie A, I, Document 36, "Aufzeichnung des Leiters der vorbereitenden Maßnahmen für die Friedensverhandlungen Graf von Bernstorff," Nov. 24, 1918, 55.

11 Klaus Schwabe, "The United States and the Weimar Republic: A 'Special Relationship' That Failed," in America and the Germans: An Assessment of a Three-Hundred-Year History, ed. Frank Trommler and Joseph McVeigh, 2:18-29 (Philadelphia, 1985), 24; on the German discussion about Wilson, see Philipp Gassert, Amerika im Dritten Reich. Ideologie, Propaganda und Volksmeinung 1933-1945 (Stuttgart, 1997), 34-46.

12 Manfred Berg, Gustav Stresemann und die Vereinigten Staaten von Amerika. Weltwirtschaftliche Verflechtung und Revisionspolitik (Baden-Baden, 1990), 17; Peter Berg, Deutschland und Amerika 1918-1929. Über das deutsche Amerikabild der 2oer Jahre (Lübeck, 1963), 71. 
This story is not widely known. While German-American relations in the 1920 are generally well researched, scholars have focused primarily on economic and financial relations in the context of the reparations tangle. They have underlined how central the United States was to Germany's foreign policymakers and have detailed their efforts to convince a reluctant America to become involved in revising the reparations question and the peace treaty at large. ${ }^{13}$ To this end, Germany appealed strategically to the U.S. interest in a stable and prosperous Europe as a market for Americans goods and a bulwark against Bolshevism. Foreign Minister Gustav Stresemann was determined to use Germany's remaining economic weight to return it to great power status; he systematically - and ultimately successfully - pursued an America-focused strategy that underlined the need for U.S. involvement in an economically interdependent world. ${ }^{14}$ U.S. informal participation in the 1924 Dawes reparations settlement and the subsequent inflow of American capital facilitated Weimar's "relative stabilization" and its reintegration into the family of nations in the mid-1920s. Throughout the 1920s, German-American relations were underpinned by a mutuality of interests and methods: the German policy of recapturing Germany's international position by way of economic recovery matched the American inclination to conduct world affairs through (informal) economic diplomacy; Germans' desire for a peaceful revision of the Versailles treaty dovetailed with American support for peaceful change in Europe.

This mutuality of interest and America's substantial ( $\$ 3$ billion) investments in the Weimar Republic are generally credited with underwriting a remarkable transatlantic rapprochement. While German-American relations had reached a historic low point in 1919, the former enemies proclaimed an extraordinary "friendship" just ten years later. By 1929, German and American diplomats, educators, and businessmen alike agreed that Germany and the United States had reconciled and that, in fact, German-American relations had "never been better." ${ }^{15}$ As a number of studies have shown, this rapprochement also went hand in hand with Americans' more sympathetic perception of Germany. ${ }^{16}$ A decade after the war, Germany's negative image had been largely reversed, and there

13 See Werner Link, Die amerikanische Stabilisierungspolitik in Deutschland 1921-32 (Düsseldorf, 1970); Michael Wala, Weimar und Amerika. Botschafter Friedrich von Prittwitz und Gaffron und die deutsch-amerikanischen Beziehungen von 1927 bis 1933 (Stuttgart, 2001); Klaus Schwabe, Deutsche Revolution und Wilson-Frieden. Die amerikanische und deutsche Friedensstrategie zwischen Ideologie und Machtpolitik, 1918/1919 (Düsseldorf, 1971).

14 Berg, Gustav Stresemann und die Vereinigten Staaten von Amerika, passim.

15 Friedrich Wilhelm von Prittwitz und Gaffron, Deutschland und die Vereinigten Staaten seit dem Weltkrieg (Berlin, 1934), 25.

16 Carmen Müller, Weimar im Blick der USA. Amerikanische Auslandskorrespondenten und öffentliche Meinung zwischen Perzeption und Realität (Münster, 1997), 253, 276-326; Klaus Fer- 
was even a tendency to see the increasingly stable and prosperous Weimar Republic as an "American prodigy" or a "junior partner" in Europe. ${ }^{17}$

This historiography, however, with its heavy focus on economics, leaves many questions unanswered. While we know that both public relations and the United States acquired a new significance for German foreign policy after World War I, few efforts have been made to analyze the two together. Indeed, research on Weimar public diplomacy, especially its cultural variant, has paid relatively little attention to the United States. This is true for comprehensive studies on the subject, ${ }^{18}$ for many older studies on single institutions, ${ }^{19}$ and for more recent bilateral explorations alike. While we have detailed studies on German public diplomacy during that period toward Spain, Turkey, Latin America, and the Netherlands, we have none on the United States, which was vital in many respects. ${ }^{20}$ At the same time, there are in-depth studies on this aspect of German-American relations for the Wilhelmine era, ${ }^{21}$ the Nazi peri-

dinand Schoenthal, "American Attitudes toward Germany, 1918-1932" (PhD diss., Ohio State University, 1959), 182-203.

17 John G. Siemann, “The American Response to Weimar: Public Perception and Foreign Policy Development in the Decade of the 1920s" (PhD diss., Columbia University, 1986), 63.

18 Frank Trommler, Kulturmacht ohne Kompass. Deutsche auswärtige Kulturbeziehungen im 20. Jahrhundert (Cologne, 2013); Kurt Düwell, Deutschlands auswärtige Kulturpolitik, 1918-1932 (Cologne, 1976).

19 Ernst Ritter, Das Deutsche Ausland-Institut in Stuttgart 1917-1945. Ein Beispiel deutscher Volkstumsarbeit zwischen den Weltkriegen (Wiesbaden, 1971); Volkhard Laitenberger, Akademischer Austausch und auswärtige Kulturpolitik. Der Deutsche Akademische Austauschdienst (DAAD) 1923-1945 (Göttingen, 1977); Hans Adolf Jacobsen, "Auswärtige Kulturpolitik als geistige Waffe. Karl Haushofer und die Deutsche Akademie [1923-1937]," in Deutsche auswärtige Kulturpolitik seit 1871, ed. Kurt Düwell and Werner Link, 218-256 (Cologne, 1981); Kurt Possekel, "Studien zur Politik des Vereins für das Deutschtum im Ausland [VDA] in der Weimarer Republik" (PhD diss., Universität Rostock, 1967); Gerhard Weidenfeller, VDA. Verein für das Deutschtum im Ausland. Allgemeiner deutscher Schulverein [1881-1918]. Ein Beitrag zur Geschichte des deutschen Nationalismus und Imperialismus im Kaiserreich (Frankfurt am Main, 1976); for a more recent study, see Eckard Michels, Von der Deutschen Akademie zum Goethe-Institut. Sprach- und auswärtige Kulturpolitik 1923-1960 (Munich, 2005); Holger Impekoven, Die Alexander von Humboldt-Stiftung und das Ausländerstudium in Deutschland 1925-1945 (Bonn, 2013); Daniela Siebe, Germania Docet. Ausländische Studenten, auswärtige Kulturpolitik und deutsche Universitäten. 1870-1933 (Husum, 2009).

20 Stefan Rinke, Der letzte freie Kontinent. Deutsche Lateinamerikapolitik im Zeichen transnationaler Beziehungen, 1918-1933 (Stuttgart, 1996); Ernst Pöppinghaus, Moralische Eroberungen. Kultur und Politik in den deutsch-spanischen Beziehungen der Jahre 1919-1933 (Frankfurt, 1998); Friedrich Dahlhaus, Möglichkeiten und Grenzen auswärtiger Kultur- und Pressepolitik dargestellt am Beispiel der deutsch-türkischen Beziehungen 1914-1928 (Frankfurt am Main, 1990); Nicole Eversdijk, Kultur als politisches Werbemittel. Ein Beitrag zur deutschen kultur- und pressepolitischen Arbeit in den Niederlanden während des Ersten Weltkrieges (Münster, 2010).

21 Bernhard vom Brocke, "Der Deutsch-Amerikanische Professorenaustausch. Preußische Wissenschaftspolitik, internationale Wissenschaftsbeziehungen und die Anfänge einer deutschen auswärtigen Kulturpolitik vor dem Ersten Weltkrieg," Zeitschrift für Kulturaustausch 31, no. 2 (1981): 128-182; Franziska von Ungern-Sternberg, Kulturpolitik zwischen den Kontinenten. Deutschland und Amerika. Das Germanische Museum in Cambridge, Mass. (Cologne, 1994); 
od, ${ }^{22}$ and the Bundesrepublik ${ }^{23}$ but none for the Weimar years. To be sure, we know that the Weimar governments made many efforts to communicate more effectively with the American public. Foreign Minister Stresemann valued public relations highly as part of his revisionist politics. ${ }^{24}$ The German Foreign Ministry systematically cultivated American news correspondents in Berlin, ${ }^{25}$ subsidized the agitation against German "war guilt," and aided nonstate and semiofficial bodies like the Berlin-based Vereinigung Carl Schurz in their transatlantic endeavors. ${ }^{26}$ Moreover, Michael Wala has skillfully, if briefly, sketched Weimar's attempts to draw on the emotional attachments of German Americans as well as the networks and prestige of German universities to re-establish Germany's standing across the Atlantic. ${ }^{27}$ But even though scholars have begun to investigate certain aspects of Weimar's public diplomacy toward the United States, there is no comprehensive study on this topic. Indeed, scholarship on this subject remains, as Wala himself concluded, "rather disappointing." ${ }^{28}$ In short, public diplomacy remains underexplored as a factor in Weimar Germany's Amerikapolitik.

The present study broadens, complements, and challenges our understanding of transatlantic relations in a number of ways. At its narrowest, it deepens our understanding of German public diplomacy and counterbalances the

Martin Wroblewski, Moralische Eroberungen als Instrumente der Diplomatie. Die Informationsund Pressepolitik des Auswärtigen Amts 1902-1914 (Göttingen, 2016); World War I is well researched; for a recent study, see Chad Fulwider, German Propaganda and U.S. Neutrality in World War I (Columbia, MO, 2016).

22 Klaus Kipphan, Deutsche Propaganda in den Vereinigten Staaten 1933-1941 (Heidelberg, 1971); Arthur L. Smith, The Deutschtum of Nazi Germany and the United States (The Hague, 1965); Gregory Kupsky, “The True Spirit of the German People’: German Americans and National Socialism, 1919-1955” (PhD., Ohio State University, 2010); Cornelia Wilhelm, Bewegung oder Verein. Nationalsozialistische Volkstumspolitik in den USA (Stuttgart, 1998).

23 Most recently, see Brian Etheridge, Enemies to Allies: Cold War Germany and American Memory (Lexington, KY, 2016).

24 Hans Jürgen Müller, Auswärtige Pressepolitik und Propaganda zwischen Ruhrkampf und Locarno, 1923-1925. Eine Untersuchung über die Rolle der Öffentlichkeit in der Außenpolitik Stresemanns (Frankfurt, 1991).

25 Müller, Weimar im Blick der USA, esp. 276-326.

26 Christian Freitag, "Die Entwicklung der Amerikastudien in Berlin bis 1945 unter Berücksichtigung der Amerikaarbeit staatlicher und privater Organisationen" (PhD diss., Freie Universität Berlin, 1977); Rennie Brantz, "German-American Friendship: The Carl Schurz Vereinigung, 1926-1942," International History Review 11, no. 2 (1989): 229-251.

27 Michael Wala, “Gegen eine Vereinzelung Deutschlands': Deutsche Kulturpolitik und akademischer Austausch mit den Vereinigten Staaten von Amerika in der Zwischenkriegszeit," in Deutschland und die USA in der Internationalen Geschichte des 20. Jahrhunderts. Festschrift für Detlev Junker, ed. Manfred Berg and Philipp Gassert, 303-315 (Stuttgart, 2004); Michael Wala, "Reviving Ethnic Identity: Foreign Office, Reichswehr, and German Americans during the Weimar Republic," in German-American Immigration and Ethnicity in Comparative Perspective, ed. Wolfgang Helbich and Walter Kamphoefner, 326-341 (Max Kade Institute for German-American Studies, 2004).

28 Wala, "Gegen eine Vereinzelung," 304. 
disproportionate attention paid to sensational, but largely unrepresentative, propaganda campaigns such as the agitation against the so-called "black horror," that is, the French use of North African troops in the occupied Rhineland and their alleged transgressions. ${ }^{29}$ While focusing on this particular campaign suggests that German policy was committed to abrasive propagandizing, the wider American case reveals an altogether different approach, one that diligently avoided even the semblance of "German propaganda." Rather than embracing atrocity propaganda, Weimar strategies hinged on a less obtrusive and ultimately more constructive information and cultural policy geared toward both short-term revisionist objectives and longer-term transatlantic alliance building. From this perspective, public diplomacy emerges as an integral aspect of Weimar's Amerikapolitik. Moreover, this study challenges the commonly held notion that the Weimar Republic was relatively unsuccessful in its publicity strategies. ${ }^{30}$ While this might have been true domestically - and there is growing doubt about whether it truly was ${ }^{31}$ - Weimar was neither unable nor unwilling to represent itself in the United States. Rather, it pursued an often innovative policy to normalize German-American relations and build a politically desirable transatlantic friendship.

The present study also facilitates a more nuanced understanding of the process of reconciliation between the United States and Germany. In fact, the two former enemies' rapid postwar rapprochement still remains something of a puzzle. Although economic factors and growing respect for German statesmen like Stresemann are usually and rightly credited with the development of friendly transatlantic relations, ${ }^{32}$ numerous other factors contributed to diminishing wartime resentments, too. Indeed, while we know much about the development of wartime animosities, that is, the process of "cultural mobilization,"

29 This campaign, which appealed strategically to American racism, has received major attention; for a recent bibliography, see Julia Roos, "Nationalism, Racism and Propaganda in Early Weimar Germany: Contradictions in the Campaign against the 'Black Horror on the Rhine," German History 30, no. 1 (2012): 45-75, 45. A work that is still seminal on this campaign is Keith Nelson, "Black Horror on the Rhine: Race as a Factor in Post-World War I Diplomacy," Journal of Modern History 42, no. 4 (1970): 606-627.

30 See, for example, Manuela Aguilar, Cultural Diplomacy and Foreign Policy: German-American Relations 1955-1968 (New York, 1995), 28.

31 Corey Ross, "Mass Politics and the Techniques of Leadership: The Promise and Perils of Propaganda in Weimar Germany," German History 24, no. 2 (2006): 184-211; there is increasing scholarship challenging this very notion, such as Nadine Rossol, Performing the Nation in Interwar Germany: Sports, Spectacle and Political Symbolism, 1926-1936 (London, 2010); Michael Meyer, Symbolarme Republik? Das politische Zeremoniell der Weimarer Republik in den Staatsbesuchen zwischen 1920 und 1933 (Frankfurt, 2014); see also Christian Welzbacher, Edwin Redslob. Biografie eines unverbesserlichen Idealisten (Berlin, 2009).

32 Müller, Weimar im Blick, 276-326; Schoenthal, "American Attitudes toward Germany," 182203. 
we know comparatively little about the process of "cultural demobilization." 33 How, precisely, were transatlantic contacts rekindled and networks rebuilt? What psychological hurdles had to be overcome to that end and what factors drove or inhibited the process? This process was neither straightforward nor predictable. Rather, resentments could and did flare up again relatively easily during the entire 1920s. Yet if we are to understand cultural demobilization, we need to move beyond economic explanations and into the intangible field of emotions and psychology.

Finally, unlike many studies that extend neither back into Wilhelmine nor forward into the Nazi era, this study both goes back to about the turn of the century and forward to the late 1930s. In doing so, it tries to trace significant continuities and ruptures between these periods - a question that has long preoccupied scholars of German foreign policy. Importantly, this longer perspective highlights a paradigm shift in the conducting of German foreign affairs. Public diplomacy as it developed in the 1920 s was only a part of a larger process of adapting diplomatic practices as the world was increasingly transformed by the communication and transportation revolutions of the late nineteenth century. Around 1900, diplomats began to face an increasingly well connected, well informed, and influential global public, whose opinions and sentiments constituted, in Bismarck's memorable phrase, the "imponderables" of foreign relations. ${ }^{34}$ The weight of these imponderables necessitated the expansion of foreign policy beyond "high politics" and thereby, as this study will show, turned more and more elements of foreign relations into subjects of foreign policy: Around the turn of the century hardly anyone in the Wilhelmstrasse thought of foreign students or tourists or news correspondents as foreign policy assets; thirty years later, few thought of them as anything else.

In the German case, I contend, this larger development cannot be understood without looking at both the 1920 s and the United States. While the process began around the turn of the century and continued during the 1930s, it was during the 1920 s that German statecraft expanded into many heretofore "nonpolitical" fields; diverse groups, such as tourists, students, or Germans abroad first became "geopoliticized"; and an official infrastructure emerged to manage and coordinate these new world-political "resources." ${ }^{5}$ Germany's postwar situation greatly facilitated this development. Its loss of hard-power

33 On the concepts of cultural mobilization and demobilization, see John Horne, "Demobilizing the Mind: France and the Legacy of the Great War, 1919-1939," French History \& Civilization 2 (2009): 101-119.

34 "We Germans Fear God and Nothing Else in the World!": Bismarck Addresses the Reichstag (February 6, 1888), German History in Documents and Images, http://germanhistorydocs. ghi-dc.org/sub_document.cfm?document_id $=1865$.

35 I borrow the term "geopoliticization" from Paul Kramer, "Is the World Our Campus? International Students and U.S. Global Power in the Long Twentieth Century," Diplomatic History 33 (2009): 775-806, 781 . 
options re-directed attention to many previously neglected soft-power assets. The peculiarities of the American case, however, truly pushed Berlin to adopt a more systematic approach to public diplomacy. Not only did the American public seem particularly influential and particularly ill-informed, but America's self-imposed political isolation and suspicion of foreign propaganda forced Germany to pursue informal, not overtly political relations. While scholars have long acknowledged U.S. influence on the Weimar Republic's embrace of economic foreign policy, it was equally important in the cultural realm: America's disdain for - and Germany's lack of - hard power conspired to turn public relations and cultural affairs between the two nations into a field of "proxy diplomacy" in the 1920 .

Finally, this study on German public diplomacy in the interwar period helps to shift historical interest away from the American-sponsored programs and the Cold War era. In recent years, in particular, so many studies on Cold War public diplomacy have appeared that historians have cautioned us to "soft pedal our ongoing fascination with the Cold War" 36 and direct more historical attention to the time "before the cultural cold wars." 37 Doing so reveals that many of the Cold War's defining strategies and transatlantic networks had roots in the interwar period. Moreover, the study counterbalances the substantial scholarship on the cultural Americanization of Germany in the 1920s. American economic expansion in Europe, as studies have shown, was flanked by the extension of its cultural influence. Whether wittingly (through American foundations or Herbert Hoover's humanitarian relief) or unwittingly (through American tourism, movies, and music), this process of cultural "Americanization" shaped German discourses about modernity and forged an image of America as efficient and progressive, which in turn facilitated the country's growing economic influence..$^{38}$ But, as we will see, even in the $1920 \mathrm{~s}$ Americans were as much targets as they were sponsors of public diplomacy. ${ }^{39}$

36 Jessica Gienow-Hecht, "The Anomaly of the Cold War: Cultural Diplomacy and Civil Society since 1850," in The United States and Public Diplomacy: New Directions in Cultural and International History, ed. Kenneth Osgood and Brian Etheridge, 25-56, 31-32; an effort to shift this focus is also made by the contributions in Jessica Gienow-Hecht and Marc Dornfried, eds., Searching for a Cultural Diplomacy (New York, 2010).

37 Katharina Rietzler, "Before the Cultural Cold Wars: American Philanthropy and Cultural Diplomacy in the Inter-war Years," Historical Research 84, no. 223 (2011): 148-164.

38 Emily Rosenberg, Spreading the American Dream: American Economic and Cultural Expansion, 1890-1945 (New York, 1982); Frank Costigliola, Awkward Dominion: American Political, Economic and Cultural Relations with Europe, 1919-1933 (Ithaca, NY, 1984); scholarship on the Americanization of Weimar is extensive; a good starting point is Egbert Klautke, Unbegrenzte Möglichkeiten. Amerikanisierung in Deutschland und Frankreich 1900-1933 (Stuttgart, 2003).

39 There is a lack of studies on the United States as a target, not just as a sponsor of cultural diplomacy; see Osgood and Etheridge, eds., The United States and Public Diplomacy, 11; a pioneering work is Jessica Gienow-Hecht, Sound Diplomacy: Music and Emotions in Transatlantic Relations, 1850-1920 (Chicago, 2009). 
While the impact of "Americanization" was profound, Germany was far from just passive and on the "receiving end." 40 The war had effected a sea change in the two countries' economic and financial relationship, yet not in their cultural relations. Germany's cultural prestige had suffered - and perhaps more than German contemporaries realized or liked to admit - but its feelings of cultural importance had survived nearly unscathed. Many Germans, indeed, were ready to ignore the Americanizing undertones of aid programs, U.S. tourism, or America's philanthropic largesse and see them for what they also were: opportunities to escape postwar isolation, to mend transatlantic ties, and to draw the United States back into Germany's cultural domain. If this project ultimately failed, it was not for lack of trying.

To be sure, many aspects of interwar diplomacy between Germany and the United States lie beyond the scope of this study. It offers no exhaustive treatment of transatlantic diplomacy or even of transatlantic public diplomacy. It does not aim to cover all private cultural exchanges or state-sponsored propaganda initiatives and casts only a cursory glance at Weimar's official press and information policy. Instead, it is concerned with public relations in the basic sense of the word. It traces how German officials and private groups sought to recultivate and manage transatlantic cultural and social relations in the national interest, that is, how they conducted what Americans call public diplomacy and Germans call cultural diplomacy (or external cultural policy). ${ }^{41}$

40 Scholars today operate with a much more interactive concept of Americanization. As Jessica Gienow-Hecht has pointed out, processes that have long been understood as tokens of "cultural imperialism" should be considered processes of potentially bi-directional "cultural transmission." Jessica Gienow-Hecht, "Shame on US? Academics, Cultural Transfer and the Cold War: A Critical Review," Diplomatic History 24, no. 3 (2000): 465-494, 491; as a recent historiographical essay put it: "Where there was Americanization, there always was Europeanization, too." See Egbert Klautke, "Anti-Americanism in Twentieth-Century Europe," Historical Journal 54, no. 4 (2011): 1125-1139, 1137; scholars of tourism, albeit for the post-WWII period, recently provided an apt example: Neal Rosendorf, "Be El Caudillo's Guest: The Franco Regime's Quest for Rehabilitation and Dollars after World War II via the Promotion of Tourism to Spain," Diplomatic History 30, no. 3 (2006): 366-406, 373.

41 For a concise presentation that addresses the different terms, see David Welch, "Cultural Propaganda," in Propaganda and Mass Persuasion: A Historical Encyclopedia, 150o-Present, ed. Nicholas J. Cull, David Culbert, and David Welch (Santa Barbara, CA, 2003), 101: "Cultural Propaganda is a long-term process intended to promote a better understanding of the nation that is sponsoring the activity. The United States refers to it as 'public diplomacy,' whereas Britain and France prefer to call it 'cultural diplomacy' or 'cultural relations.' Such activity involves the dissemination of cultural products-films, magazines, radio and televisions programs, art exhibitions, traveling theater groups and orchestras-as well as the promotion of language teaching and a wide range of 'educational' activities, such as student-exchange schemes. Over a period of time, these activities are designed to enhance the nation's image among the populations of other coun- 
In doing so, the study focuses on three distinct "fields": Germandom policies (Volkstumspolitik), that is, German relations toward German Americans; academic diplomacy, that is, the harnessing of academic relations to foreign policy ends; and the management of transatlantic travel, including aspects of tourism promotion and visitor hospitality. While these fields are treated separately only in the second part of the book, they underpin the analysis throughout.

There are very good reasons to focus on these three fields of transatlantic public diplomacy. For one, they were among the most prominent of their time, drawing a disproportionate share of resources, attention, and expertise. As a result, by the early 1930 all of them had become more or less firmly integrated in a state-sponsored public diplomacy apparatus. Second, from the perspective of historiography it is precisely because these fields were embedded in (semi) official infrastructures that they reveal instructive continuities and ruptures between Wilhelmine, Weimar, and Nazi Germany. While, for example, lecture tours of individual German authors in the 1920s can tell us a great deal about the Weimar period, they do not lend themselves as readily to longerterm observations as, say, the organization of academic exchanges. Third, because these different fields aimed to activate different American target groups, namely, Americans of German birth or descent, academic audiences, and a broader travel-minded public, respectively, they allow for a fairly comprehensive assessment of German efforts to shape the American climate of opinion. Finally, there is an exceptional wealth of archival material on them. Whereas the files of the Foreign Ministry's Art and Music Section were destroyed during World War II, files on ethnic, academic, and travel matters have largely survived. In short, a focus on these fields affords the chance to write a relatively comprehensive study based on archival research that elucidates major trends from 1900 into the 1930 .

The official publications of diplomatic sources - Foreign Relations of the United States (FRUS) and Akten zur Deutschen Auswärtigen Politik (ADAP) are of limited use regarding cultural affairs, but the surviving archival base is nothing short of excellent. In Germany, the Foreign Ministry Archives offer an unparalleled wealth of files on a broad range of cultural activities, particularly for the Weimar period. Although the files of the state secretary and foreign minister usually yield little information on cultural policy - a clear indication of how far it was removed from "high politics" - the files of the Cultural Department, the America Department, as well as parts of the Press Department cover this subject in great detail. Unfortunately, only small remnants of the German consular files for the interwar period have survived - an irretrievable loss. The German consulate general in New York, especially, seems to have handled a 
substantial part of German public diplomacy in the United States, which the embassy files (themselves decimated) cannot fully replace. The Foreign Ministry's personnel files, a number of personal papers, and memoirs have thus been used to reconstruct some of the activities of German consulates. Diplomatic records are complemented and challenged by the repositories of student, professorial, and tourist associations (Bundesarchiv), university archives (Munich, Marburg, Heidelberg, Berlin), company archives (Bayer and Krupp), and personal papers (Stresemann, Maltzan, Bonn, Morsbach, etc.). The roughly two hundred boxes of material left by the German Tourist Information Office in New York, 1925 - 1941 (held at the U. S. National Archives in College Park, MD) proved to be particularly valuable - and not just for the study of tourism.

On the American side, official diplomatic materials have been considerably less useful. Not until the late 1930s did the State Department show significant interest in cultural affairs. Nevertheless, the records of American foundations (especially the Carnegie Endowment for International Peace), universities (Columbia, Princeton, Cornell), and the papers of key cultural internationalists (like Nicholas Murray Butler) offer a veritable treasure trove of information on U.S. informal cultural policy. Moreover, the papers of American ambassadors to Germany William Dodd (1933-1937) and Jacob Gould Schurman (1925-1929) document the intimate connection between U.S. diplomacy and academia at the time. The records of the German Society of Pennsylvania and the Carl Schurz Memorial Foundation also help elucidate the key role played by German-American organizations in German policies. The archives of the Institute of International Education at the Rockefeller Archive Center have fortunately just been opened to researchers.

To be sure, official public diplomacy impacted only a small number of transatlantic encounters, and even where it did, its influence is near impossible to measure. The successes of other policy initiatives are visible in the durability of treaty provisions or the development of trade statistics, for example, yet the public impact of foreign study and travel is much more difficult to ascertain. Moreover, public diplomacy, by virtue of its very intention, is often a long-term project. In its cultural variant, in particular, it aims not so much to convey immediate information but to project a desirable national image. Its ultimate aim, as one German publicist concluded in 1916, is to create among foreign elites an "inclination of the heart" toward Germany, that is, to engender a public climate in which German economic and political objectives can be more easily attained. ${ }^{42}$ But such an "inclination of the heart" cannot be measured and its political implications cannot be predicted. The pursuit of such a policy at all,

42 Clipping: "Ein Fortschritt deutscher Kulturpolitik," Weser Zeitung, Oct. 28, 1916, Politisches Archiv des Auswärtigen Amts (PA) R121333. 
then, requires a leap of faith. Astonishing, above all, is that in the precarious 1920 so many Germans were ready to take this leap.

This leap was certainly greatest for the German Foreign Ministry. Following the public relations disaster of the war, the Wilhelmstrasse was thoroughly reformed and two public diplomacy departments - one for cultural policy and one for press policy - were established. In line with the newly established America Department, they set out to conceptualize and coordinate the campaign to rewin American hearts and minds. A number of high-ranking officials with a distinct interest in public diplomacy, first and foremost, Foreign Minister Stresemann (1923-1929), ensured that the originally haphazard efforts to improve Germany's image turned into manageable, increasingly well-designed programs. Often outpacing Berlin's lead, German ambassadors and consuls in the United States also worked diligently to "create a general attitude of sympathetic understanding" for Germany. ${ }^{43}$ From 1926 to 1929 alone, the Foreign Ministry's cultural diplomacy budget rose from 4.7 to 8.3 million marks.

However, the Wilhelmstrasse (as it was itself most painfully aware) could pursue none of its cultural activities on its own. Its constitutional competence, funds, staffing, and expertise were all severely limited. As a consequence, it depended on the cooperation of other ministries, especially the Prussian Ministry of Culture, university administrations, and a mushrooming array of organizations, institutes, and makeshift propaganda bureaus. Some of these were longstanding mass membership organizations like the Association for Germandom Abroad (Verein für das Deutschtum im Ausland, est. 1881), while others like the German Tourism Promotion Bureau (Reichszentrale für deutsche Verkehrswerbung, est. 1920) or the Association of German Universities (Verband deutscher Hochschulen, est. 1920) were of more recent origin. Following agendas of their own, they were at times indifferent, at times hostile, to reconciliation with the West, and the Foreign Ministry spent considerable time cajoling or restraining them to suit its foreign policy needs. With time, the Foreign Ministry thus created a number of ostensibly private but financially dependent organizations (like the German Academic Exchange Service, est. 1923/25) to manage new policy fields while hiding state involvement.

To this end, it relied on a group of what I call "peaceful revisionists," who operated outside - albeit usually in close touch with - the German foreign policy establishment. ${ }^{44}$ These men (and a very few women) provided funds,

43 Consulate General, San Francisco [Wiehl] to AA, Dec. 6, 1927, "Französische Kulturpropaganda in San Francisco," PA R 61130.

44 Link, Amerikanische Stabilisierungspolitik, 565, 572. 
sat on committees, directed semiofficial organizations or assumed quasi-diplomatic functions at international conferences or roundtable discussions. This illustrious group included financier Max Warburg, industrialists Carl Duisberg and Robert Bosch, parliamentarians like Anton Erkelenz, publicists like Ernst Jäckh, and educators like Albrecht Penck, Moritz Julius Bonn, Alfred Weber, Reinhold Schairer, and Adolf Morsbach, as well as (former) diplomats like Walter Simons or Johann Heinrich von Bernstorff. As heterogeneous as this group appears at first, these men shared an educated bourgeois background, a comparatively positive attitude toward the republic (they were often, like Stresemann himself, "republicans by reason"), a staunch commitment to revisionism, and a common agenda: to win American sympathy and support. In concert with the Foreign Ministry, they would turn public diplomacy into a key instrument of peaceful revision.

In telling this story, this book is divided into three parts, which correspond to the larger political and economic periodizations of the Weimar Republic. Though alternative chronologies were considered, in the end the economic and political caesurae of the years $1923 / 24$ and $1929 / 1930$ proved too momentous to ignore.

The first part focuses on the tumultuous years from 1918 to 1924. Chapter 1 begins on the heels of German defeat. It points to the depth of German moral isolation and the nature of America's anti-German sentiments, analyzing their implications for Germany's revisionist politics. As will be shown, Germany recognized that the hostile and isolationist American public was a major stumbling block to American support and began to realize that revision would require improvement in America's sentiments toward Germany. The strategies they decided on, however, were heavily informed by earlier experiences. Chapter 2 thus returns to the prewar period and retraces earlier German steps to win American public opinion. Germany had already pursued a substantial goodwill campaign among Americans since 1902. This section on pre-1917 developments is intended to offer an English-language overview of the extensive German-language scholarship on this subject. At the same time, it demonstrates that the sensational failure of this German campaign, as reflected in the U.S. entry into the war in 1917, profoundly affected postwar initiatives. Without an understanding of their prewar and wartime experiences, the decisions of Weimar-era public diplomats are incomprehensible. Only substantial postwar reforms placed the Foreign Ministry (theoretically at least) in a position to conduct more effective public diplomacy. However, German efforts, as Chapter 3 demonstrates, met with limited success until 1923/24. German inflation and lingering wartime resentment did not create the financial or psychological ba- 
sis for successful public diplomacy. Nevertheless, the obstacles and frustrations of the early 1920s, often ignored by historians, reinforced the government's commitment to public diplomacy and profoundly informed later strategies.

The second part details the true "founders' period" of German public diplomacy from 1924 to 1929. It turns from larger developments to three case studies. Chapter 4 focuses on German Americans. Given the extensive attention that both pre-1918 and post-1933 "Germandom policies" have received, the chapter details continuities and ruptures after 1918. It shows that the 1920 s led to a major departure in this field. Weimar public diplomats came to assess Americans of German birth and descent more realistically and to take a more cautious approach toward them, which played a significant role in facilitating the transatlantic rapprochement of the 1920s. Chapter 5 focuses on aspects of academic diplomacy; it shows that the Foreign Ministry tried ever more systematically to harness the prestige and networks of German universities for use in its agenda of peaceful revisionism. However, this effort was often complicated by Germany's conservative academic establishment. The chapter traces the development of substantial academic diplomacy programs and details the process of cultural demobilization among at least parts of the academic communities on both sides of the Atlantic. Chapter 6 looks at the "discovery" of the American tourist for German commercial and political ambitions. Assessing efforts to promote German tourism and tracing American travel patterns, it tries to gauge the influence of tourist perceptions on larger American debates about Germany. Collectively, the three chapters underline the broadening scope of German outreach from German Americans to a more elite traveling and travel-minded public. A brief summary of findings after Chapter 6 shows that (i) transatlantic contacts were largely restored during that period, and (ii) public diplomacy was established as a distinct component of Germany's Amerikapolitik.

Finally, the third part (1930-1937) explores how public diplomacy fared during the economic depression, rising nationalist agitation, and the demise of the republic. Chapter 7 details the increasing challenges but also the unique opportunities that Weimar's public diplomacy faced in the context of economic distress and political illiberalism in the early 1930s. Chapter 8 , then, details the transition and, in many cases, the absorption of Weimar structures into the Nazi propaganda and cultural policy apparatus. Despite significant and deliberate structural continuities, the Nazis ultimately did not continue Weimar's Amerikapolitik. Instead, they used the existing infrastructure to pursue a more forceful expansionist policy in southeastern Europe and Latin America.

In all, this study's findings go beyond German cultural diplomacy and the United States from 1918 to 1933. They not only broaden our understanding of German foreign policy and German-American relations but also offer insights into the nature of transatlantic relations at a crucial moment in the twentieth 
century. By tracing the Weimar Republic's intense efforts to develop a politically desirable transatlantic partnership with the United States, and by acknowledging its competition with France and other European countries while doing so, this book underlines the significant role that an allegedly isolationist United States played, and was accorded, in interwar Europe. Ultimately, it is to be hoped that this German-American case study may inspire further research into how the Old World sought to come to terms with U.S. ascendency after the turn of the century. 
Part I

Breaking the Cultural Blockade, 1919-1924 



\section{Backdrop: The Cultural Blockade}

Usually, historians pay too little attention to how German defeat and the peace settlement isolated Germany not only politically and economically, but also culturally. But just as Allied statesmen, clerks, and advisors met to determine the contours of the peace treaty, so did Allied scholars, journalists, students, sport functionaries and humanitarians descend on Paris to remake a broader cultural postwar order without - and sometimes against - Germany: In the world of science, Article 282 of the Versailles Treaty voided nearly all scientific conventions, while the newly established International Research Council excluded Germany from membership and barred the German language and German scientists from international conferences and collaborations in the postwar years. ${ }^{1}$ On the student level, a newly founded Confédération Internationale des Étudiants re-organized international student relations without German participation..$^{2}$ In the field of communications, the cartel agreements between global news agencies were nullified and the largest German news agency (Wolffs Telegraphisches Bureau) was shut out of the world market. ${ }^{3}$ In the sphere of sports, Germany would not be invited to participate in Olympic games until 1928. Even in the humanitarian realm, the Allies sought to replace the neutralist International Committee of the Red Cross in Geneva with a freshly formed (Allied) League of Red Cross Societies in order to exclude Germany from international cooperation. In myriad ways, a host of new organizations and agreements perpetuated the inter-Allied accord and cemented the Great War's recalibration of cultural affairs away from Germany. ${ }^{4}$ Their former enemies, Germans felt, were enacting a "cultural blockade" (geistige Kontinentalsperre) against them, hoping to deprive their nation of the remnants of its international standing and influence. 5

1 Manfred Abelein, Die Kulturpolitik des Deutschen Reiches und der Bundesrepublik Deutschland. Ihre verfassungsgeschichtliche Entwicklung und ihre verfassungsrechtlichen Probleme (Cologne, 1968), 24.

2 Walter Zimmermann, "Deutsche Studentenschaft und Ausland," Der Auslanddeutsche 5, no. 2 (1922): 34 .

3 Heidi Evans, "The Path to Freedom'? Transocean and German Wireless Telegraphy, 19141922," Historical Social Research 35 (2010): 209-33, 210.

4 Tomás Irish, "From International to Interallied: Transatlantic University Relations in the Era of the First World War, 1905-1920," Journal of Transatlantic Studies 13, no. 4 (2015): 311-325.

5 This term is used by a number of observers; see Prof. Dr. Gast, "Die Auslandsbeziehungen der deutschen Hochschulen," Mitteilungen des Verbandes der deutschen Hochschulen, 2. Sonderheft 17-24, 18; Friedrich Beck, "Ausländerstudium im Ausland und in Deutschland," Süddeutsche Monatshefte 28, no.4, (1931): 250; Georg Schreiber, "Die Kulturpolitik des Völkerbunds," in Zehn Jahre Versailles, ed. Heinrich Schnee and Hans Draeger, 2:245-62, (Berlin, 1929), 246. 
This "cultural blockade" was never as systematically organized nor as Machiavellian in design as German observers liked to imagine. ${ }^{6}$ In part, it was a matter of timing: the upsurge of international institution-building after the war simply happened when Germany was absent, thus perpetuating the status quo of inter-Allied cooperation as it existed in mid-1919. In many cases, these new organizations expressed less a desire to exclude Germany than a lack of desire to include it. At the heart of these developments lay a pronounced moral outrage over the complicity of German scholars, journalists, and even humanitarians in the alleged and real crimes of the German war effort. Acknowledging the role of German science in the gas and propaganda war, U.S. President Woodrow Wilson characterized it as "science without conscience." The notion that Germany had to undergo a sort of probationary period before it could be readmitted into the fold of "civilized nations" pervaded not just (some of) the founders of the League of Nations but humanitarian and academic circles. Summing up a widespread feeling in March 1919, the American magazine Literary Digest remarked that "Hans must go to the bottom of his class."

And still, the cultural blockade was not less powerful for being more of an informal consensus than a formal agreement. Contemporaries recognized that such efforts were part of a power play intended to break German influence in prestigious fields of international relations, ${ }^{9}$ fueled as much, German observers suspected, by lingering wartime resentments as by a desire to deprive Germany of prestige in the world. With the war largely regarded as a cultural struggle, it seemed only logical that in the field of culture, as in politics or trade, Germany

6 On German suspicions, see Karl Kerkhof, "Die internationalen naturwissenschaftlichen Organisationen vor und nach dem Weltkriege," Internationale Monatsschrift für Wissenschaft. Kunst und Technik 15, no. 3 (Jan. 1921): 225-42; "Aufzeichnung über den Stand der internationalen wissenschaftlichen Beziehungen," June 16, 1924, PA R64980.

7 For Wilson's address at the Sorbonne on Dec. 21, 1918, see Brigitte Schröder-Gudehus, "Challenge to Transnational Loyalties: International Organizations after the First World War," Science Studies 3, no. 2 (1973): 93-118, 100. For Americans, German arguments in favor of unrestricted submarine warfare played a special role. As George Ellery Hale, a scientist and science organizer on the National Research Council, wrote in a memorandum on the reorganization of international science on September 18, 1917: "The part German men of science have played in the initiation of gas attacks, and the demand upon their government last autumn for the resumption of unrestricted submarine warfare, must militate against the early establishment of cordial personal relations with men in other countries whose relatives and friends have been the victims of these methods or of others still more barbarous"; qtd. in Roy MacLeod, "Wissenschaftlicher Internationalismus in der Krise. Die Akademien der Alliierten und ihre Reaktion auf den Ersten Weltkrieg," in Die Preußische Akademie der Wissenschaften zu Berlin 1914-1945, ed. Wolfram Fischer, 317-49 (Berlin, 2000), 338.

8 "German Academic Prestige Lost," The Literary Digest, Mar. 15, 1919.

9 French scholars, in particular, saw Wissenschaft as a means of German domination and contended that, on account of the predominance of the German language in science, "German professors [had before the war] set up a kind of scientific Empire which covered all of northern, central, and eastern Europe and exerted considerable influence on the science of Russia, the United States, and Japan." Qtd. in Schröder-Gudehus, "Challenge to Transnational," 99. 
would no longer occupy its prewar position. The French, in particular, seemed determined to use the postwar situation to arrest Germany's cultural imperialist ambition and assert French civilization in its place. ${ }^{10}$ The French-dominated International Research Council was "quite openly part of the general postwar policy, whose spearhead was the Treaty of Versailles, of isolating the Central Powers, of demanding from them expressions of penitence, and of ensuring that Germany in particular never regained her old dominance in military affairs, industry, trade or science." ${ }^{11}$ Accordingly, if Germany were going to regain its great power status and its standing in the world, it would have to alter not only the treaty's territorial, economic, and political provisions; it would also have to overturn the recalibration of the cultural world.

10 As Charles Cestre, Professor of American Literature and Civilization at the University of Paris, noted, educational facilities with regard to the United States "would serve powerfully to cement bonds of sympathy and friendship between the two republics; it would enhance the intellectual reputation of our country and the prestige of our higher education in a country that the war has seized from the German hold"; qtd. in Whitney Walton, "Internationalism and the Junior Year Abroad: American Students in France in the 1920 s and 1930s," Diplomatic History 29, no. 2 (2005): 255-78, 260.

11 A. G. Cock, "Chauvinism and Internationalism in Science: The International Research Council, 1919-1926," Notes and Records of the Royal Society of London 37, no. 2 (1983): 249-88, 249. 



\section{Chapter 1 \\ Isolation, Revision, and Amerika, 1919-1921}

The proud nation which sought to dominate the world is reduced to a country without army or navy, with an enormous burden of debt, and without influence or prestige in international politics. ${ }^{1}$

W ith these astute words, the Literary Digest characterized the German situation in May 1919. Just days earlier, the terms of the Versailles peace accord made clear that Germany, in defeat, would have to bear heavy territorial losses, military disarmament. and the burden of reparations. But the American magazine recognized that, in addition to economic and political isolation Germany had an ominous lack of "prestige in international politics," an absence that weighed perhaps as heavily on Germany as the more tangible provisions of the peace treaty. As Germany would soon come to realize, the ramifications of its defeat extended beyond the economic or military fields to include the moral and cultural realms. Conversely, for it to regain great power status, it would not only need to overturn the written terms of the peace treaty but also to recapture its prestige and moral standing in the world. Not least, it needed to achieve this in the one country that German diplomats, businessmen, and publicists soon identified as a key partner in revising the Versailles treaty: the United States.

\section{Postwar Germany, Moral Isolation and the Revision of Versailles}

To note that Germany had an "image problem" in 1918/19 would be a gross understatement. German defeat was not limited to the military battlefield but extended to world opinion. The exigencies of a total war had necessitated the

1 “Terms That Take All the Fight Out of Germany, Literary Digest, May 17, 1919. 
cultural mobilization of civilian populations on all sides of the conflict, leading to an unprecedented demonization of the enemy. Although at least some Allies had initially been inclined to distinguish between what they deemed to be the detestable German leadership and a hapless public, between conniving elites and innocent people, these distinctions had long since given way to a near wholesale condemnation of the German nation. ${ }^{2}$ The German breach of Belgian neutrality in August 1914 and the German army's ruthless behavior in invading that country (which Allied propaganda called the "rape of Belgium") had turned public opinion against Germany, even in neutral nations. By the war's end, a once-admired nation of "thinkers and poets" had been recast in the public imagination as an aggressive, militarist power out to rape, pillage, and mutilate.

The long armistice period, from November 1918 to June 1919, did little to normalize relations. The democratic sea change that had taken place in Germany just days before the armistice never profoundly altered public sentiment or official policies. On the contrary, the armistice period revealed the full extent of anti-German feeling. The general election campaigns in the United Kingdom in December 1918 were famously built around the slogans that read "Hang the Kaiser" and "Make Germany Pay," and through the spring of 1919 the Allies maintained the blockade of Germany to force it to accept the peace terms. ${ }^{3}$ German claims of widespread civilian suffering at first elicited limited compassion or were dismissed as "German propaganda." For example, America's chief propagandist George Creel, in responding to suggestions that the former enemy needed to be fed to avert social unrest, pointed out what he saw as German hypocrisy on November 16, 1918: "Even the women of Germany ... who never lifted their voice in protest when the babies of Belgium were slaugh-

2 By the time of the armistice, the distinction once drawn between the German ruling class and the common people had collapsed in American news reporting. As the North American Review asserted in February 1918: "You can no more separate the German government from the German people than you can separate the bite of the mad dog from his blood. The wickedness and infamy of the German people is in their blood; it is the corruption and poison of their blood that have made the German people [...] a nation of savages [...] We must kill to save," North American Review (February 1918), qtd. In Cynthia Wachtell, "Representations of German Soldier in American World War I Literature" in "Huns" vs. "Corned Beef": Representations of the Other in American and German Literature and Film on World War I, ed. Schneider and Wagener, 59-83 (Osnabrück, 2007), 61; The New York Sun found that "the Germans are not human beings in the common acceptation of the term," qtd. in Frederick Franklin Schrader, 1683-1920 (New York, 1920), 28; for a few more sophisticated analyses in the Saturday Evening Post, see Michaela Hoenicke-Moore, Know Your Enemy: The American Debate on Nazism, 1933-45 (New York, 2010), 37.

3 In January 1919, an American newspaper reminded its readers that though Germany's wartime careers as an "armed enemy of civilization" had come to a halt, "she can no more be trusted than a torpid serpent warmed into renewed vitality at a friendly hearth." "The War Not Yet Over," Christian Science Monitor, Jan. 24, 1919, 16; Paul Vincent, The Politics of Hunger: The Allied Blockade of Germany, 1915-1919 (Athens, OH, 1985), 101. 
tered at the breasts of their mothers ... are now flashing their cry to America for sympathy and for help, while the male propagandists are holding out their hands dripping with blood and begging for mercy ... the damnable cant of Germany is trying to poison the mind of the world at this late date."4

Indeed, the distrust and disdain toward Germany on the Allied home fronts proved to be so strong that they complicated the peace-making process in Paris. With his constituents in a punitive mood at home, even U.S. President Woodrow Wilson almost immediately shrank back from his commitment to "open covenants, openly arrived at" and returned to closed sessions just days into the peace negotiations. ${ }^{5}$ The Paris conference itself was replete with small humiliations and symbolic indictments of Germany. ${ }^{6}$ German delegates left ample record of the hostility they encountered. They went for weeks without being invited to the conference table, isolated from the other delegates in unheated, freezing cold accommodations. This situation prompted Ernst von Simson, the director of the Foreign Ministry's legal department, to speak of an "ice wall between us and the former enemies."

The peace terms and the accompanying correspondence embodied this sense of moral tribulation. According to the Allied and Associated Governments' cover letter of June 16, the harsh peace terms expressed the "judgment passed upon the war by practically the whole of civilized mankind." Germany was accused of having planned and started the conflict in pursuit of its expansionist aims and was held directly responsible for the war's millions of dead and maimed. Moreover, the communication once more elaborated on Germany's ruthless conduct of war, including the illegal invasion and occupation of neutral Belgium, the pioneering use of poison gas, civilian bombings, submarine warfare, and the maltreatment of prisoners of war. Furthermore, the cover letter made it clear that such behavior placed Germany - a nation that had chosen "to gratify her lust for tyranny by resort to war" - outside of the pale of the family of "civilized" nations. ${ }^{8}$ While such moralistic language was largely absent from the treaty itself, articles 227 to 230 still demanded the extradition and trial of the emperor and other war criminals to conform to the requirements of "international morality." Article 231 asked Germany to assume responsibility for the damages caused to the Allies in a "war imposed upon them by the

4 See Creel in the New York Times, Nov. 17, 1918, qtd. in Klaus Schwabe, Woodrow Wilson, Revolutionary Germany and Peacemaking (Chapel Hill, NC, 1985), 143.

5 William R. Keylor, "Versailles and International Diplomacy," in The Treaty of Versailles: A Reassessment after 75 Years, ed. Boemeke, Feldman, and Glaser, 469-505 (New York, 1998), 481 ff.. 6 See Gerd Krumeich, "Versailles 1919. Der Krieg in den Köpfen," in Versailles 1919. Ziele Wirkung - Wahrnehmung, ed. Gerd Krumeich, 53-64 (Essen, 2001).

7 See Dieter Neizert, "'Das Amt' zwischen Versailles und Rapallo. Die Rückschau des Staatssekretärs Ernst von Simson," Vierteljahreshefte für Zeitgeschichte 6o, no. 3 (2012): 443-490, 455.

8 Reply of the Allied and Associated Powers to the Observations of the German Delegation on the Conditions of Peace, June 16, 1919, FRUS, Paris Peace Conference (PPC) 6, 928. 
aggression of Germany and her allies." Whereas this much-debated "war guilt" clause served in a strictly legal sense only to justify reparations payments, Germans interpreted it as a concerted humiliation. ${ }^{9}$ When the Versailles treaty was signed on June 28,1919 , and ratified a few weeks later, this ended the legal state of war, but the "cultural demobilization", i.e., the waning of war mentalities, had hardly begun..$^{10}$

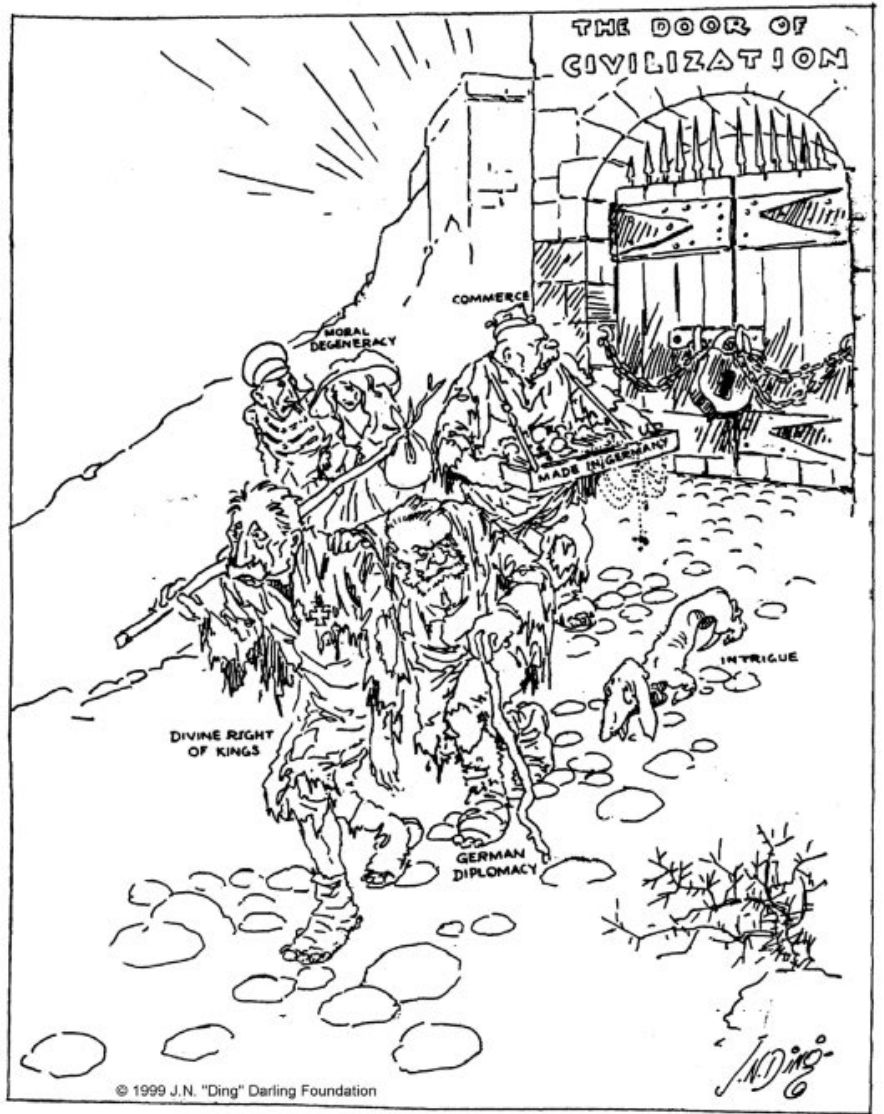

Fig. 1: J. N. Darling, “Outcasts," editorial cartoon, October 1918

(C) “Ding” Darling Wildlife Society

9 Ulrich Heinemann, Die verdrängte Niederlage. Politische Öffentlichkeit und Kriegsschuldfrage in der Weimarer Republik (Göttingen, 1983), 17.

10 On the concepts of "cultural mobilization" and "cultural demobilization," see Horne, "Demobilizing the Mind"; contemporaries tended to speak of "moral demobilization." See, for example, Gustav Stresemann, "Rede vor der ausländischen Presse vom 30. Dezember 1924," in Reden der Kanzler- und Außenministerzeit (1923-1929), by Gustav Stresemann, ed. Wolfgang Elz, 516-533. 


\section{Revision as leitmotif}

Germany's international ostracism would soon prove to be a significant political problem. It was in this hostile climate, and from this circumscribed, isolated position, that Germany had to begin its efforts to revise the provisions of the peace treaty. While none of the victors was truly satisfied with the treaty, Germans saw it as a devastating injustice and a calculated humiliation heaped upon an exhausted people. The treaty placed the odium of responsibility for the war on German shoulders, heavily reduced its army and navy and entirely dissolved its air force, took sizeable German lands and all colonies away from it, saw the Rhineland and the Saar area occupied, and stipulated that Germany would have to pay reparations of a yet to be determined amount. In a rare Weimar consensus, opposition to the Versailles dictate was nearly ubiquitous at the time. German professors, publicists, and politicians of nearly all political persuasions described the peace as a major injustice, even as "Carthaginian" in nature. ${ }^{11}$ An internal memorandum by the German peace delegation astutely summarized German sentiment, characterizing the peace terms as "insufferable," "unfulfillable," "dishonest," and "dishonorable."12 Although the Weimar National Assembly ratified the treaty (under the threat of Allied military occupation and continuing blockade), German debates began to focus on how to revise its terms even before the ink had dried. ${ }^{13}$ Revision would become the leitmotif of foreign policy in the Weimar period.

Despite some discussion about the respective priority of overturning the treaty's economic, military, and territorial provisions, economic questions soon emerged as the most pressing concern. Settling the amount of German reparations payments to the Allies, in particular - which had remained unresolved due to inter-Allied disputes at Paris - would pre-occupy the great powers during the 1920 s. ${ }^{14}$ Between 1921 and 1924 alone, more than two dozen international conferences sought to determine the final amount and payment methods. The centrality of the reparations question to European politics derived from a number of factors: For one, the fight over who would have to shoulder the immense financial burdens of the war was crucial because it would greatly

11 Michael Grüttner, "Nachkriegszeit," in Geschichte der Universität unter den Linden, Vol. 2, Die Berliner Universität zwischen den Weltkriegen, ed. Grüttner et al., 5-65 (Berlin, 2012$), 28$.

12 Denkschrift der deutschen Friedensdelegierten zu den Friedensforderungen der Entente, June 17 1919, Akten der Reichskanzlei (AdRk), Weimarer Republik/Das Kabinett Scheidemann/ Vol. 1/No. 113, 469-475.

13 German leadership had definitely been aware that the peace treaty would not resemble Wilson's 14 Points since March 21, 1919; for the detailed instructions on how the peace negotiations were to be approached, see Kabinettssitzung, Mar. 21, 1919, AdRk, Das Kabinett Scheidemann. Vol. 1/No. 19, 74-83.

14 Walter Zechlin, Pressechef bei Ebert, Hindenburg und Kopf. Erlebnisse eines Pressechefs und Diplomaten (Hanover, 1956), 39. 
affect the redistribution of power in postwar Europe. For France, in particular, with its destroyed departments, staggering war debt (it owed 3 billion dollars to the United States alone), clouded demographic prospects, and fears of German revanchism, the question of reparations amounted to the question of its future standing in Europe. ${ }^{15}$ Only large reparation payments, by economically weakening Germany and strengthening France, could ensure France's security and truly reinforce the reality of German defeat and French victory. Conversely, for Germany, a viable reparations settlement was of eminent political importance because it would determine the pace of its economic recovery and therewith many German decisionmakers believed - its return to great power status. ${ }^{16}$ If Germany succeeded in minimizing its reparations burden, it could attract the necessary capital from abroad to rebuild its dominant economic position on the continent. For this reason, a favorable settlement of the reparations question was both a financial prerequisite and a potential precedent for the revision of other peace terms. As a consequence, reparations became one of the determining foreign policy questions of the decade and, in many respects, the linchpin of Germany's revisionist politics.

\section{Treaty Revision and the United States}

These questions kept the United States - the world's main creditor nation - at the heart of German attention. Indeed, since October 1918 the United States had stood at the center of German foreign relations. When the collapse of the German military was imminent, Germany's newly established democratic government under Chancellor Max von Baden had approached U. S. President Wilson on October 4, 1918, about armistice negotiations on the basis of his Fourteen Points. There were both ideological and strategic reasons for this "turn" to the United States. At least partly, it was due to the enormous psychological impact that Wilson's vision of a new world order had on war-weary publics around the world. ${ }^{17}$ German liberals close to the von Baden government like Max Warburg, Walter Simons, and Moritz Julius Bonn embraced Wilson's vision as a

15 Even the German finance minister, if only internally, admitted that the "French economic position, if that is even possible, is even a lot sadder than ours. The French have about 180 billion debt, much of it abroad, their industrial territories are destroyed, their industry is to a large part a luxury industry, that can find no markets in an impoverished world (and) they have only 40 million people." Ausführungen des Reichsfinanzministers vor dem Reichskabinett über die finanzielle Leistungsfähigkeit des Reichs, Apr. 26, 1919, AdRk, Das Kabinett Scheidemann/ Vol. 1/No. 54, 233.

16 Berg, Gustav Stresemann und die Vereinigten Staaten, 17.

17 Manela, The Wilsonian Moment. 
solution to Europe's long-standing problems. ${ }^{18}$ But the appeal to the American president was also a strategic decision. The war had not only left the United States with greatly enhanced international prestige and economic strength, but Wilson's Fourteen Points (at least in the way that Germans liked to understand them) simply promised the most lenient possible peace to Germany. It was partly in deference to perceived American wishes that Germany further reformed its constitution in October 1918; the abdication of the Kaiser, even the declaration of the German Republic on November 9, 1918, were widely perceived as concessions to American democratic ideals. ${ }^{19}$

After the armistice, Germany tried hard to keep up direct lines of communication with a powerful Amerika. It was to the American president and the American public that German foreign secretary Wilhelm Solf and civil society groups first turned to relax the armistice terms on November 12. Throughout the long armistice period, the German government invoked Wilson's Fourteen Points on every occasion both to calm revolutionary unrest at home and to avert the more punitive intentions of the Allied governments abroad. ${ }^{20}$ In a memorandum on the United States in late November 1918, Johann Heinrich von Bernstorff, the former German ambassador to Washington (1908-1917), who was now in charge of preparing what Germans believed would be peace negotiations, held that "because the United States has decided the war, its position and especially that of President Wilson has become decisive for the future." Consequently, "the entire world will become economically and financially dependent on the United States. [...]We will thus have to lean on the United States politically during the peace negotiations and arrange the later reconstruction of Germany with its help." ${ }^{21}$ While this process would not be as straightforward as Bernstorff might have hoped at the time, these thoughts already reflected the main approach that German governments would take toward the United States in the 1920s, aspiring to recover Germany's place in the world with American support.

Germans' prevalent hope in the United States was not lost on Americans. Summing up his impressions after a two-week special mission to Germany

18 Horst Gründer, Walter Simons als Staatsmann, Jurist und Kirchenpolitiker (Neustadt an der Aisch, 1975), 69 .

19 Klaus Schwabe, "America's Contribution to the Stabilization of the Early Weimar Republic," in Germany and America: Essays on Problems of International Relations and Immigration, ed. Hans Trefousse, 21-28 (New York, 1980), 26.

20 As the Reich finance minister explained to the cabinet on April 26, 1919: "Wilson's 14 points are a shield against the demands of our victorious enemies." Ausführungen des Reichsfinanzministers vor dem Reichskabinett über die finanzielle Leistungsfähigkeit des Reichs, Apr. 26, 1919, AdRk, Das Kabinett Scheidemann/Vol. 1/No. 54, 233.

21 "Aufzeichnung des Leiters der vorbereitenden Massnahmen für die Friedensverhandlungen Graf von Bernstorff," Nov. 24, 1918, ADAP Series A, Vol. 1, No. 36, 55. 
in December 1918 and January 1919, Ellis Loring Dresel, the future American chargé d'affaires in Berlin, reported back:

The most conspicuous feature of all conversations, which I had with all classes was that somewhat over-friendly disposition toward America and Americans. This is undoubtedly partly due to self-interest, but is also largely owing to the former close ties with America, to social, economic and financial intercourse which existed before the war and to the large population of German extraction in the United States: also to an appreciation of the fact that America has no selfish ends to serve and to the hope that she may be induced to plead the German cause with her allies. The result is that there is a strong wish to take up relations again with the United States at the same point where they were before the war, and the hope is cherished that the events of the war will be overlooked and condoned and that by the help of America, Germany will be enabled to rehabilitate herself. It is perhaps needless to add that I was careful to give no encouragement to this desire for a policy of forgiving and forgetting. ${ }^{22}$

Just as Dresel was personally careful not to encourage German hopes, few American actions could justify German belief in the nation's particular goodwill during the armistice period. In reality, the Wilson administration had never made republican government in Germany a prerequisite for peace negotiations, and the events of the German Revolution elicited apprehension rather than enthusiasm in Washington. If Germany's independent socialists smacked dangerously of Bolshevism, the moderate Social Democrats, who had supported the German war effort in 1914, seemed hardly less militarist than the old regime. President Wilson, indeed, remained suspicious of the republican and democratic credentials of the new German government and regarded the young republic in many respects as the moral equivalent of the bygone empire. ${ }^{23}$ Had Germans believed that democratic reforms would entitle them to a lenient "Wilson Peace" based on the Fourteen Points, not even Wilson himself - quite apart from the other heads of Allied governments - was willing to modify his earlier judgments. As a consequence, American support for the new German government was tacit at best. American food sales to Germany, the most profound measure of American support to the fledgling republic, were intended to ward off Bolshevist infiltration, not to actively support German democracy. ${ }^{24}$ Official U.S. representatives closest to the German situation

22 The Chief of the Special Mission in Germany (Dresel) to the Secretary of the Commission to Negotiate Peace (Grew) FRUS PPC Vol. 2, 138.

23 In Klaus Schwabe's words, "Wilson was inclined [...] to see the German Republic, morally and in terms of international law, as the equivalent of Wilhelm II's monarchy"; Schwabe, qtd. in Daniel Larsen, "Abandoning Democracy: Woodrow Wilson and Promoting German Democracy, 1918-1919," Diplomatic History 37, no. 3 (2013): 476-508, 504.

24 On this issue, see Larsen, "Abandoning Democracy." 
urged Americans to engage on behalf of a Germany that "will do anything the president wants at present," but these admonitions fell largely on deaf ears. ${ }^{25}$ "The Weimar Republic," Klaus Schwabe concluded, "was to America an unwanted or, at best, a half-wanted child." ${ }^{26}$ Even without American encouragement, however, Germany's unrealistic hopes in a benevolent "Wilson peace" continued to flourish during the armistice.

The reality of the Versailles peace terms came as a shock. ${ }^{27}$ The grave general disappointment was coupled with particular indignation at President Wilson. Previously hailed as a savior-like figure, even German liberals now spoke with bitterness of the American president's "betrayal" at the Paris Peace Conference. Though they conceded that Wilson was an honest idealist and had ameliorated some of the harsher Allied demands, this hardly moderated their disappointment. "In light of the devastating peace terms," wrote the centrist Deutsche Allgemeine Zeitung, "no rape and no dishonoring that our enemies have devised against us has been so disappointing to the German people as the realization that Wilson has betrayed us." ${ }^{28}$ On the political right, which had never really trusted Wilson in the first place, he swiftly became a near Machiavellian character and was given a distinct role in the "stab in the back"-legend. Clever Wilsonian peace propaganda, right-wing groups now claimed, had (deliberately) tricked a militarily undefeated Germany into laying down its arms in the expectation of a just peace - with the gravest consequences. ${ }^{29}$ This disappointment turned Wilson into a rallying point of right-wing anti-Americanism. ${ }^{30}$ At the same time, it also affected the stability of the Weimar Republic by undermining the credibility of its liberal, pro-American leaders and recasting it as an American, essentially un-German, creation. ${ }^{31}$

Still, Germans' broader hope in the United States outlived this disillusionment with Wilson. Despite the harsh peace, Germany's governments, and a

25 This is a statement by a neutral diplomat quoted in Grant-Smith to Secretary of State, Nov. 21, 1918, FRUS PPC Vol. 2, 96; Larsen, "Abandoning Democracy," 482.

26 Klaus Schwabe, "The United States and the Weimar Republic," 20.

27 On the reaction to the peace terms and Wilson in Germany's public discussion, see Berg, Deutschland und Amerika, 24-33.

28 Deutsche Allg. Zeitung, No. 232, May 14, 1919, quoted in Berg, Deutschland und Amerika, $24-25$.

29 To a conservative historian like Eduard Meyer, Germany - weakened by the "hunger blockade" and socialist agitation - had foolishly trusted in Wilson's fourteen points only to be bitterly disappointed; see Eduard Meyer, Die Vereinigten Staaten von Amerika. Geschichte, Kultur, Verfassung und Politik (Frankfurt a. M., 1920), 283; the former ambassador Bernstorff called this popular version of events an utter "historical misrepresentation" (glatte Geschichtsfälschung); see Johann Heinrich von Bernstorff, Erinnerungen und Briefe (Hamburg, 2010) (orig. Zurich, 1936), 99. 30 "For Germany," wrote Meyer in August 1919, "Wilson will always remain the type of the sententious, canting hypocrite, in whose persona is concentrated everything that is antipodal and repugnant to the German character (deutsches Wesen)." Meyer, Die Vereinigten Staaten von Amerika, 288.

31 Schwabe, "America’s Contribution to the Stabilization of the Early Weimar Republic," 26. 
significant part of the German public, clung to their "basically pro-American orientation." ${ }^{32}$ They remained convinced, as the leader of the German People's Party (DVP) and future foreign minister Gustav Stresemann put it, that "the determination of Europe's future depends in the last analysis on the United States." 33 This applied especially to reparations, the one issue fast becoming the key focus of German foreign policy. In this, the United States, as the economic "world victor," attained a new importance for Germany. Since it was seen as the only nation in the financial position to exert the necessary pressure for a sober settlement of the reparations question and to finance Europe's economic stabilization, the involvement of the Allies' creditor seemed indispensable to German recovery. ${ }^{34}$ Notions of America's fabulous wealth and a strong sense of entitlement after the frustrated promises of the armistice only intensified this transatlantic focus. German hopes for economic recovery rested to a large degree in Amerika.

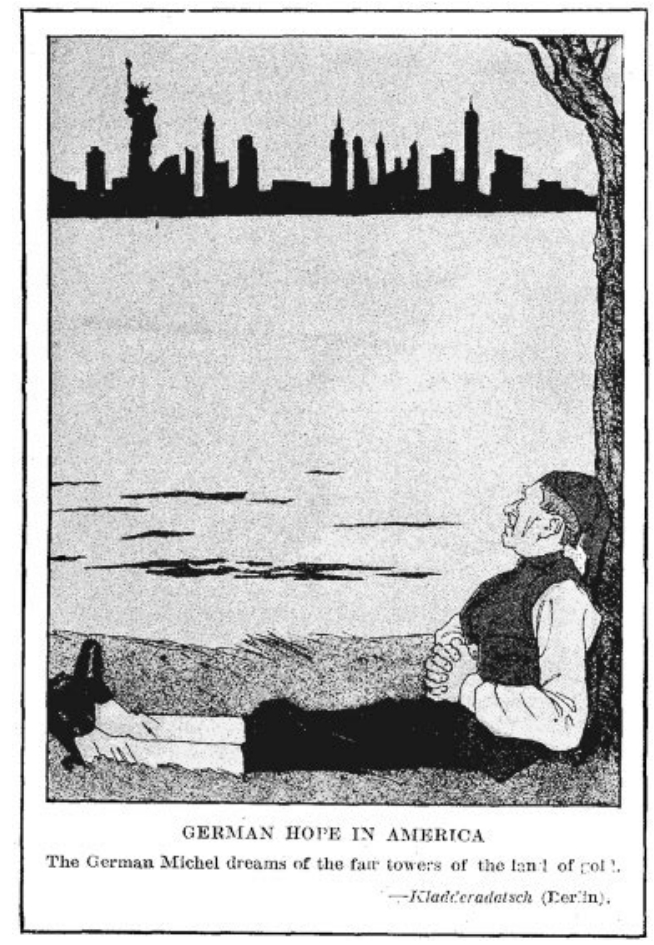

Fig. 2: Hans-Maria Lindloff, “German Hope in America: The German Michel Dreams of the Fair Towers of Gold," Literary Digest, Jan. 5, 1924

32 Schwabe, "The United States and the Weimar Republic," 24.

33 Andreas Dorpalen, "American Isolationism and German Foreign Policy During the Weimar Era," in Deutschland und die USA, 1918-1933, ed. Georg Eckert, 44-52 (Braunschweig, 1968), 44. 34 Peter Berg has shown that between 1919 and 1924 the subject of the need for and prospects of American economic aid to Germany preoccupied the German public like no other; Berg, Deutschland und Amerika 1918-1929, 71. 
As the 1920 s would reveal, German hopes in the United States were more than just wishful thinking in the long run. There were good reasons to suggest the United States as a likely partner for the revision of the treaty. Of all the main former enemies, the United States alone had no serious political or commercial grievances against Germany. Germany's defeat had removed its threat to American interests in Latin America, and the United States, in turn, entertained neither territorial interests in Europe nor held major claims on Germany. ${ }^{35}$ Indeed, by virtue of wartime constellations, Germany alone was not heavily indebted to the United States, sparing it the tensions of a debtor-creditor relationship that would soon develop between France and the United States - another factor that worked in Germany's favor. When the U.S. Senate rejected the Treaty of Versailles and the Republican presidential candidate Warren G. Harding won a landslide victory in late 1920, these events also seemed to signal a rift in the victors' alliance; the United States took no major part in the enforcement of the peace treaty. ${ }^{36}$ On the issue of disarmament, moreover, the one political project the United States remained committed to during the 1920s, a disarmed Germany (for reasons of its own) emerged as a natural partner. And though U.S. administrations were at first skeptical about the authenticity of Germany's democratic conversion, its new form of government could theoretically count on American sympathy and could challenge the favored position long enjoyed by the French "sister republic" in the long run. In hindsight, there was no doubt that time would work for Germany.

Even if these constellations only successively became clear to contemporaries, there was from 1919 onward a near unfaltering belief that American economic self-interests would ultimately lead it to support Germany. German economists, journalists, and diplomats did not tire of pointing to considerable U.S. interest in a stable and prosperous Germany both as a market for its goods and, no less important, a bulwark against Bolshevism. With a destitute and unproductive Germany at its center, Europe was unlikely to recover, and would thus work against American political and economic interests. It was on this notion of an economically interdependent world - a world whose prosperity hinged on Europe's largest economy - that a growing number of German foreign policymakers, including later foreign ministers Walther Rathenau and Gustav Stresemann, based their firm belief in American support. ${ }^{37}$ Trusting American administrations to think more in terms of business than of national

35 One exception may be the protracted negotiations over German property and war claims; see Burkhard Jähnicke, Washington und Berlin zwischen den Kriegen. Die Mixed Claims Commission in den transatlantischen Beziehungen (Baden-Baden, 2003).

36 The United States did, of course, participate in the occupation of the Rhineland; see Henry T. Allen, Mein Rheinlandtagebuch (Berlin, 1923).

37 See Stresemann in the Frankfurter Zeitung, Apr. 10, 1921 in Berg, Weimar und Amerika, 63; and also Berg, Gustav Stresemann, 103. 
emotions, it did not seem absurd for them to hope that the United States would be a partner in the revision of the treaty.

\section{The Problem of American Public Opinion}

These German expectations would soon establish U.S. opinion as a primary foreign policy problem. Indeed, the hope in American involvement clashed with the realities of American withdrawal from Europe. While German foreign policymakers rightly believed that the United States would eventually get involved, owing to its strong interest in a stable and prosperous Europe, they overestimated "the pace of the politicization of economic factors." ${ }^{8}$ In the immediate postwar years, U.S. administrations showed little inclination to get involved in Europe. Ratification of the Versailles treaty was defeated in the U.S. Senate in March 1920, thus voiding all American obligations agreed on in Paris. Even though Germany welcomed this rejection of the peace treaty and inter-Allied cooperation, its leaders also worried that the United States was retreating from European problems. Despite the widespread belief in Germany that America would ultimately get involved, the question of how to secure this involvement proved complicated.

American public opinion was first identified as a major stumbling block to American involvement within this context. Germans assumed that America's powerful but ill-informed public was primarily to blame for this astounding and (to their minds) incomprehensible retreat from international influence, Although neither German diplomats nor German scholars at the time ever arrived at a sophisticated understanding of just how American public opinion affected American foreign policymaking, they generally believed it to be more influential than anywhere else. ${ }^{39}$ As the former German ambassador to Washington, Johann Heinrich von Bernstorff, acknowledged in a 1920 publication, no mayors, congressmen, nor even the President of the United States could defy public opinion. Before long, they would invariably adjust their policies to suit the sentiment of the American people..$^{40}$ Although Bernstorff recognized that American leaders could and would also actively influence public opinion, the conviction in the policy-shaping power of public sentiment ran high after the propaganda battles of the preceding years. ${ }^{41}$ Consequently, the U.S. gov-

38 Link, Amerikanische Stabilisierungspolitik, 53.

39 In his wartime memoirs, Ambassador Bernstorff admitted how hard it was "to grasp the actual extent of the power of public opinion in the Union." Bernstorff, Deutschland und Amerika, 28.

40 Bernstorff, Deutschland und Amerika, 30.

41 Jeffrey Verhey, "Some Lessons of the War: The Discourse on the Propaganda and Public Opinion in Germany in the 1920s," in War, Violence and the Modern Condition, ed. Bernd Hüppauf, 99-118 (Berlin, 1997). 
ernment would only have a mandate for action in Europe if American public opinion changed, paving the way for loans, political support, and a positive response to Germany's revisionist demands. Whether, when, and how the U.S. administration would decide to act in Europe, Germans believed, depended largely on how the American public thought and felt about Germany.

With U.S. involvement hinging on American public opinion, the prospects by 1920 were not encouraging at all. For one, anti-German sentiment was still widespread and particularly strong in the influential Northeast. Patriotic groups like the Daughters of the American Revolution or the veterans' organization American Legion at first held fast to wartime positions. Among pro-Allied periodicals like the Independent, the Outlook, or the Saturday Evening Post, Germany's primary responsibility for the war went nearly unquestioned..$^{42}$ Through the early 1920s, upper-class, Northeastern organizations like heiress Anne Morgan's Committee for Devastated France sought to maintain cordial relations with France, backed French reparations demands against Germany, and lashed out against any pro-German stirrings. Indeed, some of the attacks on German-friendlier groups were so vile that one liberal American journalist was left to wonder "why $[\ldots]$ the worst, the meanest, the most revengeful, the most German public opinion in the world is the American?"43

But increasing disinterest in European problems was almost as disconcerting as anti-German sentiment after 1920. Many Americans had never had much interest in European affairs and regarded America's role in World War I not as an opportunity for world leadership but an aberration in the nation's history. ${ }^{44}$ Around 1920, according to Robert Young, no more than five percent of Americans kept abreast of foreign affairs, and while there were some regional variations - interest tended to be highest on the East Coast - most Americans either did not care about European troubles, and/or objected to America becoming formally involved in European affairs on principle. When the U.S. Senate rejected the Treaty of Versailles (and the League of Nations) in March 1920, it marked one expression of the U.S. swinging back into isolationism, despite all the other factors involved. ${ }^{45}$ The Republican administrations of the 1920s, for their part, fully heeded this public sentiment. Both President Harding, elected in November 1920 promising a "return to normalcy," and his suc-

42 Müller, Weimar im Blick, 47.

43 John A. Thompson, Reformers and War: American Progressive Publicists and the First World War (Cambridge, 1987), 246.

44 An early study that is still relevant on American isolationism is Selig Adler, The Isolationist Impulse: Its Twentieth-Century Reaction (New York, 1966).

$45 \mathrm{I}$ am aware of the intense debate surrounding this term but will continue to employ it because it captures how Germans thought of U.S. policy. For a recent critique of the concept, see Brooke L. Blower, "From Isolationism to Neutrality: A New Framework for Understanding American Political Culture, 1919-1941," Diplomatic History 38, no. 2 (April 2014): 345-376. 
cessors retreated from America's formal involvement and "entangling alliances" in Europe, joining neither the League of Nations nor the World Court.

To be sure, American attitudes toward Germany notably diversified once the peace treaty had been signed. Apart from the majority isolationist group and a pro-Allies, anti-German patriotic group, there were three groups with a basically more positive attitude toward Germany by mid-1920. ${ }^{46}$ First and foremost, there were the millions of Americans of German birth and descent who had been persecuted during the war. The leaders of this ethnic group grew more vocal again once the peace had been signed. From the beginning, much of the German-language press espoused a decidedly pro-German position, advocating American action on behalf of Germany to redress what they, too, considered Wilson's broken promises and revise the Versailles treaty. ${ }^{47}$ Wartime propagandists like Harvard professor Edmund von Mach and publicist George Sylvester Viereck also took up their pro-German work again, rallying against German war guilt and the French use of North African troops in the occupied Rhineland. German-American leaders saw this fight against the peace treaty as a way to revive the group's ethnic identity and forge a more unified and politically conscious German-America. ${ }^{48}$ The average German American, to be sure, had little appetite for militancy or public controversy. Though many harbored concern and sympathy for the German situation, they expressed it, if at all, through transatlantic charity or quiet action at the ballot box.

A second, much smaller, but also more influential group was comprised of left-leaning liberals in the United States who advocated American responsibility in Europe but rejected the peace treaty as the basis of the postwar order. ${ }^{49}$ During the war, many of them, like Oswald Garrison Villard, editor of the $\mathrm{Na}$ tion, had fully subscribed to Wilson's vision of offering a reformed, democratic Germany a "peace without victory." Following the abdication of the Kaiser, they had adopted a conciliatory and supportive stance toward the German republic and came to reject the peace treaty - "the madness at Versailles" as the Nation termed it - as the very "antipode" of the "democratic peace" they had envisioned. Though most supported American ratification of the peace treaty for lack of alternatives, they imagined the League of Nations as an instrument to

46 I follow the findings of Klaus Schoenthal, who groups American opinion in early 1920 along a spectrum of five positions; Schoenthal, "American Attitudes toward Germany," 63-65.

47 Barbara Wiedemann-Citera, Die Auswirkungen des Ersten Weltkrieges auf die Deutsch-Amerikaner im Spiegel der New Yorker Staatszeitung, der New Yorker Volkszeitung und der New York Times 1914-1926 (Frankfurt, 1993), 179; see the editorial line in Viereck's American Monthly, 1919-1920.

48 They were convinced that "if it had been the intention of the conquerors utterly to destroy Germany, they hardly could have made a more thorough job of it." Richard Bartholdt, From Steerage to Congress (Philadelphia, 1930), 409.

49 Thompson, Reformers and War, 242. 
correct its more onerous terms..$^{50}$ Already shortly after the war, liberal opinion journals like Herbert Croly's New Republic or Villard's Nation offered generally favorable coverage of the new Germany: they championed relief of German distress, challenged the notion of exclusive German war guilt, and advocated that the United States play an active role in securing the revision of the peace treaty. ${ }^{51}$

Most important, however, were the attitudes of a third group that called upon America to take some responsibility for the reconstruction and welfare of Europe but within the Versailles order. This group was comprised of a diverse and influential lot of businessmen, bankers, educators, and politicians of both major parties, including Republican leaders like Secretary of State Charles Evans Hughes or Secretary of Commerce Herbert Hoover, and was represented by such sophisticated press organs as the New York Times and the Chicago Daily News. By upbringing and ideological outlook, this group leaned toward the Allies, but only as long as they accorded with their overarching desire for a stable, liberal, and capitalist world order. Consequently, they were clearly interested in German economic recovery to bolster the democratic republic and to provide a market for U.S. goods but understood their German policy always as part of a larger European policy.52 Over time, they would come to adopt a policy of "peaceful change" in Europe, advocating a gradual and consensual revision of the peace terms to economically, and, by extension, politically, stabilize Germany. Still, by 1920, those in public positions, especially, were "resolved not to get ahead of an isolationist [and divided] electorate." ${ }^{3}$

For a Germany anxious for American support, this widespread public distrust, dislike, and disinterest seemed like a major stumbling block. By 1920, it could count on sympathetic consideration of its problems only among the largely marginalized group of German Americans and a small number of left-leaning American Progressives, who, moreover, found themselves attacked by patriotic groups riding high on the nativist wave of the postwar years. ${ }^{54}$ Even those in favor of, and in a position to effect, American involvement were not willing to ignore the generally isolationist climate at home.

50 For a grouping of the American press according to these categories, see Müller, Weimar im Blick, 47-49.

51 As early as April 1919, the New Republic held that none of the major powers had been innocent in 1914; for an early summary, see Lewis Gannett, "They All Lied," Nation, Oct. 11, 1922; see also Selig Adler, "The War-Guilt Question and American Disillusionment, 1918-1928," Journal of Modern History 23 (March 1951): 1-28.

52 See Link, Amerikanische Stabilisierungspolitik, 57; Alanson B. Houghton, first as ambassador in Berlin and then in London, was a major proponent of that strategy; see Jeffrey Matthews, Alanson B. Houghton: Ambassador of the New Era (Lanham, MD, 2004).

53 Robert J. Young, Marketing Marianne: French Propaganda in America, 1900-1940 (New Brunswick, NJ, 2004), xix.

54 A liberal supporter of Germany was maligned "as pro-German, or as a bolshevist, or an agitator." Thompson, Reformers and War, 259. 
It was only during the spring of 1921 that the problem of U.S. opinion, as well as the extent of America's withdrawal from Europe, first became really visible to the German government. At that point, both the reparations struggle and American interest in Europe had reached a low point. In January of that year, the Allies had finally fixed the total reparations sum to be paid by Germany at 226 billion gold marks, shortly thereafter occupying the Rhine ports of Duisburg, Ruhrort, and Düsseldorf to compel German acceptance. In this situation, Germans looked to the incoming U.S. administration under President Harding for support; they hoped Harding would steer a more active, business-oriented course in European reconstruction. ${ }^{55}$ In a desperate public plea in April 1921, the German government appealed to the U.S. to mediate in the reparations tangle, promising to subject itself unconditionally to American suggestions. Across the Atlantic, however, Germany's unprecedented step inspired only a non-committal answer, forcing Germany to accept what became known as the London schedule of reparations, which fixed German payments at 132 billion gold marks, payable over 42 years. Though there were many good reasons for the U.S. administration to keep out of the European imbroglio, the German Foreign Ministry attributed America's caution also to public sentiment. Americans, it realized, neither trusted Germany nor considered it worthy of U.S. support in a situation it had brought upon itself. State secretary Adolf Boyé characteristically attributed U.S. reluctance to get involved to the continued "influence of the war propaganda of our enemies." 56 By early 1921, Germany's moral isolation had become a serious political problem.

Accordingly, German image-building in the United States seemed absolutely imperative. If American action in Europe depended on U.S. public opinion, then more serious efforts would have to be undertaken to persuade a reluctant American public that Germany deserved American support in revising the peace treaty. From this perspective, a primary objective of German foreign policy had to be widening the circle of those with favorable attitudes toward Germany. As things stood, Germany had to rewin transatlantic trust, rebuild appreciation, and recapture lost prestige. ${ }^{57}$ When, a few months after the Spring 1921 debacle, Reich President Friedrich Ebert appointed businessman Otto Wiedfeldt as the first postwar German ambassador to Washington,

55 For the many different hopes placed in President Harding, see Berg, Deutschland und Amer$i k a, 59$.

56 Der Staatssekretär im Auswärtigen Amt Boyé an den Reichsverband der Deutschen Industrie und den Deutschen Handelstag, Apr. 18, 1921, ADAP Serie A Vol. 4, No. 247, 509-510; on the importance of public opinion with regard to reparations in the spring of 1921, see also Bernstorff, Erinnerungen und Briefe, 200-201.

57 The former German ambassador to the United States Bernstorff published his wartime memoirs, Deutschland und Amerika. Erinnerungen aus dem fünfïhrigen Kriege, in December of 1919 as a way to learn from the sins of omission during the war; Bernstorff, Erinnerungen und Briefe, 92. 
he expressed Wiedfeldt's two-fold mission in no uncertain terms: to improve American public opinion toward Germany and to get the United States to partake in German reconstruction. ${ }^{58}$ In the minds of many, as we have seen, the two questions were intimately connected.

Henceforth, then, the main question confronting German policymakers was how to win the American public over to intervening on Germany's behalf. What measures and methods would Germany have to adopt? Who should organize and oversee them? What sort of German "image" or message about Germany was it to convey? Which American audiences should it address, and, perhaps more importantly, which ones could it even hope to reach? To understand the answers German officials arrived at, however, we need to review Germany's efforts at public diplomacy as they had developed in a transatlantic context since the turn of the century.

58 Wiedfeldt to Ebert, Apr. 20, 1924, in Otto Wiedfeldt als Politiker und Botschafter der Weimarer Republic. Eine Dokumentation zu Wiedfeldts 10o. Geburtstag am 16. August 1971, ed. Ernst Schröder, 159-238, 225. 



\section{Chapter 2 \\ Culture, Propaganda, and Transatlantic Relations, 1902-1921}

All states are today pursuing an extensive general propaganda abroad, a kind of expansion of ideas or attitudes not for the distinct, clearly demarcated ends of a single undertaking, but in order to create a favorable climate for all present and future undertakings, whether they be political, economic or cultural; to surround themselves with an atmosphere of power, of economic and financial prowess, of cultural standing, in short, with prestige. (J.J. Ruedorffer [Kurt Riezler], Grundzüge der Weltpolitik, 1914, 243)

I $\mathrm{n}$ trying to win over a disinterested, even hostile American public, the Weimar Republic often felt that it was facing an entirely novel situation. Seen from the perspective of the 1920s, Imperial Germany often appeared to be a happy place of unchallenged German prestige, worldwide influence, and considerable cultural sway. Unburdened by the deadweight of recent enmity and unfettered by financial troubles, the Kaiserreich seemed never to have needed to advertise itself abroad in the first place. It had attracted international students and tourists, respect and esteem - all seemingly without effort. This nostalgic assessment was as alluring as it was wrong. ${ }^{1}$

Quite the contrary, when Germans began to debate how to improve American sentiment in the early 1920s, they had already been courting Americans for nearly two decades. After 1900, Germany had tacitly begun to build a cultural pillar of foreign policy alongside economic and political ones, and it was in the United States that it first developed key elements of a soft power approach, a subtler promotion of Germany. By 1914, it had already built a substantial transatlantic infrastructure to promote itself in the United States, and during the war, it had waged a major, if ultimately ineffective, campaign for the hearts and minds of what it regarded as the most important neutral power. ${ }^{2}$ The present chapter traces the origins of this campaign, its fate during World War I, and its implications for Germany's postwar public diplomacy. It will intro-

1 Gärtner, Botschafterin des Guten Willens, 19-20.

2 Abschrift zu UIK 33681 Amerika-Institut [R. W. Drechsler] to Minister der geistlichen und Unterrichts-Angelegenheiten, Nov. 20, 1914, PA R 64997. 
duce key groups of actors, such as Germany's "peaceful imperialists," German Americans and American cultural internationalists, who would continue to play a critical role in the 1920s. Moreover, it examines some of the underlying conceptions that made the United States such a prominent target for German public diplomacy and analyzes why the positive effects of German prewar and wartime efforts were so limited. All in all, I argue that it was precisely because the German campaign ended in such resounding failure with the U.S. entry in the war in April 1917 that it came to define the approaches of the 1920s: the lessons of the war established German public diplomacy as a legitimate policy field just as they demarcated the pace, shape, and nature of German initiatives during the 1920s. Therefore, understanding Weimar's decisions requires first and foremost some insight into Wilhelmine ambitions, conceptions, and disappointments.

\section{Prince Heinrich's Visit and the Origins of German Public Diplomacy in the United States}

For all public purposes, Wilhelmine Germany's campaign for American hearts and minds began on February 25, 1902, the day Prince Heinrich of Prussia arrived in the United States as an envoy of goodwill for his older brother, the German emperor, Wilhelm II. For Heinrich, a navy admiral and passionate traveler, this was far from his first semi-diplomatic assignment. In the preceding years, this likeable and modest member of the Hohenzollern dynasty had repeatedly accepted semiofficial missions to smooth over the international unease his brother's imprudent remarks tended to produce. But with regard to German-American relations, the prince's visit constituted an unprecedented event. No German royal had ever traveled to the republican United States on an official mission, and Heinrich was but the fourth high-ranking European aristocrat ever to do so. His visit thus set off a flurry of etiquette problems and, much to the chagrin of many a staunch American republican, a wave of public excitement.

From the time Heinrich's visit was announced in mid-January 1902 to his arrival in New York six weeks later, all major American newspapers reported on the Prussian prince's preparations almost daily and cities vied to be included in the continental tour that was to follow his East Coast visit. Symbolic gestures of German courtesy and monarchical interest caught the attention of American journalists. It was reported, for example, that Wilhelm II had hand-picked about one thousand of his choicest pieces of silverware, valued at over five million dollars, to entertain American guests on board the royal yacht Hohenzollern in New York harbor; the news that Prince Heinrich had systematically read up on the United States and that visiting the New World had been a boy- 
hood dream of his were equally suited to generating enthusiasm. ${ }^{3}$ Despite some reservations about celebrating European royalty, the American press published favorable portraits of the "democratic" nature of "Wilhelm's friendly envoy" and found "these courtesies exchanged between a republic and a monarchy $[\ldots]$ interesting and useful. They tend to banish distrust and to create a better feeling."4 By the time Prince Heinrich set foot in the United States, his visit had already evolved into a media spectacle of remarkable proportions. ${ }^{5}$

Once Heinrich was in the United States, media interest and public enthusiasm soared as an impressive range of special courtesies were showered upon him. President Theodore Roosevelt declared Heinrich a guest of the nation and honored him with a large state dinner at the White House. The U.S. House of Representatives welcomed the Prussian prince with a two-minute ovation; Harvard University bestowed an honorary doctorate upon him. Heinrich then went on a whirlwind tour through thirteen American states, always paying his respects to the shrines of American history, including Civil War battlefields and Mount Vernon. Wherever he went, crowds lined the railroad tracks to catch a glimpse of the Imperial train (where one carriage was reserved for the accompanying press correspondents), and the crème-de-la-crème of the American business, education and political worlds entertained him at splendid banquets. On several of these occasions, cable messages between Wilhelm II and the Americans in attendance were exchanged, creating the impression of two modern nations bridging the Atlantic divide in a world shrunk by the recent revolutions in communication and transportation. ${ }^{6}$ In short, Heinrich's tour became precisely what his brother had intended it to be: a display of German respect for American traditions, a reminder of German influence on American culture, and a celebration of German-American "friendship." American journalists characterized it as a German "master stroke of diplomacy," marking "a new epoch of cultural relations between the so greatly befriended countries."

Indeed, the prince's visit was but the beginning of a much broader German attempt to enhance its reputation and influence in the United States, which

3 "Prince Henry Is Studying," Washington Post, Jan. 31, 1902, 1.

4 "Emperor and President," Chicago Daily Tribune, Jan. 14, 1902, 12; a similar take can be found in "Affair of the State," Boston Daily Globe, Jan. 12, 1902, 2; one measure of this popular enthusiasm is the considerable amount of memorabilia produced to commemorate Heinrich's visit and the careful efforts German Americans, especially, took to collect and archive everything having to do with it; see Prince Heinrich Scrapbooks, German-American Collection Manuscripts (Non-Catalogued) 15, Horner Memorial Library.

5 “Germany Won Over," Washington Post, Feb. 26 1902, 1.

6 See, for example, Jürgen Osterhammel, The Transformation of the World: A Global History of the Nineteenth Century (Princeton, NJ, 2014), 37-39, 711-724.

7 As Wilhelm II explained in a letter to President Roosevelt, his brother's visit was to "express to you once more my sincere feelings and friendship for the United States." "Emperor and President," Chicago Daily Tribune, Jan. 14, 1902, 12.

8 "Prince Henry Is Welcomed by Roosevelt," Chicago Daily Tribune, Feb. 25, 1902. 
it pursued not through traditional channels of diplomacy, but through public and cultural relations. Contemporaries rightly identified a Wilhelmine policy of "gifts and gestures" in the decades before the war. ${ }^{9}$ During his visit to Harvard University, for example, Heinrich announced his brother's financial support for a "Germanic Museum" to be opened on the campus of America's oldest and most prestigious university. ${ }^{10}$ Over the next several years, Wilhelm II also gifted statues of famous Germans (such as Frederick the Great), bestowed decorations and medals on prominent Americans, and regularly sent congratulatory telegrams to ethnic German organizations. Meanwhile, the Prussian Ministry of Culture initiated professorial exchanges with Harvard University and Columbia University and in 1910 opened an Amerika-Institut in Berlin. ${ }^{11}$ (German-)American philanthropists, businessmen, and scholars mirrored German enthusiasm for transatlantic cultural exchange and established the Germanistic Society of America (est. 1904), a number of visiting professorships, as well as a Deutsches Haus at Columbia University (est. 1911) to familiarize a broader American public with German cultural achievements. ${ }^{12}$ In short, the decade after Prince Heinrich's visit witnessed a host of private and official initiatives,

9 Emil Witte, Aus einer deutschen Botschaft. Zehn Jahre Deutsch-Amerikanischer Diplomatie (Leipzig, 1907), 238.

10 These cultural initiatives, in particular, the professorial exchange and the Germanic Museum, have been detailed in a number of studies; see Reiner Pommerin, Der Kaiser und Amerika. Die USA in der Politik der Reichsleitung (Cologne, 1986), 255-290; Bernhard vom Brocke, "Internationale Wissenschaftsbeziehungen und die Anfänge einer deutschen Auswärtigen Kulturpolitik: Der Professorenaustausch mit Nordamerika," in Wissenschaftsgeschichte und Wissenschaftspolitik im Industriezeitalter. Das 'System Althoff' in historischer Perspektive, ed. Bernhard vom Brocke, 185-242 (Hildesheim, 1991); Ragnhild Fiebig-von Hase, "Die politische Funktionalisierung der Kultur: der deutsch-amerikanische Professorenaustausch 1904-1914," in Zwei Wege in die Moderne: Aspekte der deutsch-amerikanischen Beziehungen 1900-1918, ed. Ragnhild Fiebig-von Hase and Jürgen Heideking, 45-88 (Trier, 1997); Charlotte Lerg, "Uses and Abuses of the First German-American Professorial Exchange 1905-1914," in German-American Educational History: Topics, Trends, Fields of Research, ed. Anne Overbeck and Jürgen Overhoff, 63-80 (Bad Heilbrunn, 2017); for an in-depth study of the Germanic Museum, see Ungern-Sternberg, Deutschland und Amerika (Cologne, 1994); on the diplomatic importance and dynamics of American-German university relations more generally, see Charlotte Lerg, Universitätsdiplomatie. Wissenschaft und Prestige in den transatlantischen Beziehungen, 1890-1920 (Göttingen, 2019).

11 The quasi-diplomatic objective of the Columbia-Berlin exchange was apparent from its name: In Berlin, the American exchange professor held the "Theodore Roosevelt Professorship," the German exchange professor in New York City, the "Kaiser-Wilhelm-Professorship." It was Columbia President Butler who insisted that the Columbia-Berlin exchange was not an academic but a national affair; Butler to Schmidt, Oct. 6, 1910, and Dec. 28, 1910, NL Schmidt-Ott 418 Butler, New York, Korrespondenz 1909-15, Geheimes Staatsarchiv Preussischer Kulturbesitz (GSPK); The Amerika-Institut, too, was founded with (German-)American support. Its founding director, Harvard professor Hugo Münsterberg, conceptualized it as "a clearing house for all the cultural relations between Germany and the United States"; see Margaret Münsterberg, Hugo Münsterberg, His Life and Work (New York, 1922), 188; Amerika-Institut-Rundbrief, Dec. 7 1910, PA R 64997.

12 Germanistic Society, Activities of the Germanistic Society of the United States, 1904-1910. 
establishing a transatlantic infrastructure of academic exchanges, museums, institutes, and societies to showcase German cultural grandeur, cultivate American elite and ethnic sympathies for Germany, and engender closer transatlantic cooperation between the two nations. Looking back in 1914, the German ambassador to Washington, Johann Heinrich von Bernstorff (1908-1917) identified Heinrich's trip as the beginning of a German "Amerikapolitik."13

Before we turn to the distinct motivations behind this Amerikapolitik, we should pause to appreciate just how novel these measures were in terms of international relations. At the time, quasi-diplomatic endeavors like the Germanic museum, the professorial exchange, the Deutsches Haus at Columbia University, and the Amerika-Institut in Berlin were among the first of their kind. As scholars have pointed out, they count among the very first acts of German cultural diplomacy. ${ }^{14}$ To be sure, cultural and especially academic relations had long been a significant factor in transatlantic affairs. Ever since the 1820s, German universities had attracted a large number of American students in search of the specialized scientific training not yet available back home. ${ }^{15}$ Collectively, about 10,000 German-trained Americans shaped the American university landscape as well as a generally positive image of Germany in the United States. ${ }^{16}$ Academic relations, alongside German immigration to the United States and American high regard for German music, wove an intricate web of personal and emotional connections at a time when German-American official relations were otherwise characterized by benign disinterest. ${ }^{17}$

But these cultural networks were not the product of a coherent policy, let alone a state-directed one. Throughout the nineteenth century, the German state had made no attempt, for example, to send symphony orchestras abroad or even to influence individual musicians, professors, or emigrants (many of whom did consider themselves informal ambassadors) venturing overseas. With few exceptions, German officials did not regard such matters as falling within the purview of foreign policy; there were no official bodies, funds, con-

13 Abschrift A 1380 Imperial German Embassy Washington to Reichskanzler von Bethmann-Hollweg, Jan. 8, 1914, PA Botschaft Washington, 1523, Bernstorff.

14 Prince Heinrich's visit and the subsequent cultural campaign have been identified as milestones in the development of German public diplomacy; see vom Brocke, "Der Deutsch-Amerikanische Professorenaustausch," 128; Ungern-Sternberg, Deutschland und Amerika, 131.

15 For decades to come, German-American relations would benefit from the language skills and sympathy of these students; for example, well into the 1920s, most American ambassadors to Germany had received at least part of their education in Germany.

16 Between 1870 and 1890, Americans constituted the single largest group of foreigners enrolled at German universities; see Siebe, Germania Docet, 109; on German educational influences more generally, see Henry Geitz, Jürgen Heideking, and Jurgen Herbst, eds., German Influences on Education in the United States to 1917 (New York, 1995).

17 Even decades later, many an American professor would think back fondly to his German student days and acknowledge the "complete intellectual rebirth" he had experienced there; see Louis Viereck, Die Vereinigung alter deutscher Studenten in Amerika (New York, 1902), 31. 
certed plans, or even significant interest in them. ${ }^{18}$ For most of the nineteenth century, there was no German cultural diplomacy in the sense of a strategic use of cultural relations for national ambitions.

Importantly, this revealed a general characteristic of German foreign policy at the time: a disregard for public relations. Even by the turn of the century, institutions to interpret or advertise Germany to the world were few and far between. While there had been a press office at the Foreign Ministry to communicate government policies to the domestic and international press since 1871, the high-handed manner in which Bismarck liked to conduct his foreign affairs had long stifled its development. ${ }^{19}$ Even after 1900, its staffing remained dismal (Chancellor Bernhard von Bülow only half-jokingly referred to its staff as his "three and a half men") and its competencies disputed by career diplomats. Their aristocratic background and exclusive understanding of foreign policy as arcane high politics led them to hold publicity in correspondingly low regard. ${ }^{20}$ In terms of methods and infrastructures, too, the press office lagged far behind the mass agitation and sophisticated publicity already adopted by the Imperial Naval Office or larger German companies. ${ }^{21}$ Not until 1900 did Germany even lay its own telegraph cable across the Atlantic. ${ }^{22}$ Wilhelmine Germany's conduct of foreign policy, in short, had failed in many respects to keep pace both with the massive changes in information, communication, and transportation technology of the preceding decades as well as with its own soaring global ambitions.

So what transformed this apparent disregard for foreign opinion around the turn of the century? What led Wilhelmine Germany to embrace new forms of public and especially cultural diplomacy at the time? And why was it that many of these new measures were first developed in the United States?

The answer lies in a combination of Germany's immediate political concerns and longer-term assumptions about the United States. First and foremost, the decision to appeal more systematically to an American public was

18 See Gienow-Hecht, Sound Diplomacy, 11.

19 Nathan Orgill, “'Three and a Half Men': The Buelow-Hammann System of Public Relations before the First World War" (PhD Diss. Duke University, 2009), 9-23.

20 The press bureau was frequently bypassed by career diplomats, who refused to share insights into actual policymaking with "outsiders" like Otto Hammann, the bureau's long-time director (1894-1916), and communicated directly with the foreign press whenever it seemed opportune; the bureau, for example, only found out about the Kaiser's interview with the Daily Telegraph when it had already become a major scandal; on the press bureau, see Zechlin, Pressechef bei Ebert, Hindenburg und Kopf, 18.

21 See Wilhelm Deist, Flottenpolitik und Flottenpropaganda. Das Nachrichtenbureau des Reichsmarineamtes, 1897-1914 (Stuttgart, 1976); for a detailed account of commercial public relations, see Michael Kunczik, Geschichte der Öffentlichkeitsarbeit in Deutschland (Cologne, 1997), $188-242$.

22 Rainer Pommerin, "Seekabel und Nachrichtenbüros. Determinanten des Deutschlandbilds im Zeitalter des Imperialismus 1871-1914," Vierteljahresschrift für Sozial- und Wirtschaftsgeschichte 73, no. 4 (1986): 520-531. 
a product of rising anti-German sentiment at a time of heightened imperial rivalries. Indeed, on the eve of Heinrich's visit, German-American relations had taken a decided turn for the worse. For much of the nineteenth century, relations had been quite good. Especially when compared to American antagonisms with France or Britain, there were few economic disputes between the United States and what became the German Empire, let alone territorial ones. Quite the contrary: the large number of Americans who studied at German universities had returned with respect for German thought and organization, and despite the failed revolutions of 1848 , there was a widespread sense that Germany, of all European countries, had the greatest potential for democratic reform and stable government. ${ }^{23}$ The good qualities of German immigrants and their service to the Union during the Civil War seemed only to validate this impression. Tending to see unity as a trailblazer for liberty, the American press thus favorably received the unification of Germany in 1871. In terms of foreign policy, too, Bismarck accommodated American wishes, especially with regard to Latin America, and there was little to cloud transatlantic relations. For the better part of the century, German-American relations were cordial, which, as Alfred Vagts pointed out long ago, was basically "a diplomatic euphemism for the lack of competition between the two countries." ${ }^{4}$

It was this element of competition that slowly transformed American sentiment toward Germany in the two decades before World War I. As the two nations rose to industrial pre-eminence and broadened their international reach, protective trade policies began to sow the first seeds of discord in their relationship after the 188 os. Germany's imperialist ambition, however, was what truly alienated the American public. After 1897, Wilhelm II and his foreign secretary (after 1900, Chancellor) Bernhard von Bülow embarked on a Weltpolitik that aimed to carve out a worldwide sphere of influence for the German Empire concurrent with its economic power. Accompanied by rash actions and imprudent remarks, this policy increased tensions around the world, including with the United States. ${ }^{25}$ The Venezuelan Crisis of 1902/03, in particular, intensified longer-standing U.S. apprehensions about Germany's imperialist ambitions in Latin America and its apparent disregard for the Monroe Doctrine. ${ }^{26}$ In the years that followed, Germany's shortsighted obstruction of an arbitration agreement with the United States ignited further qualms about its intentions. ${ }^{27}$ Americans began to perceive Germany as an increasingly milita-

23 Manfred Jonas, The United States and Germany: A Diplomatic History (Ithaca, NY, 1984), $19-23$.

24 Quoted in Freitag, Die Entwicklung der Amerikastudien, 20.

25 For some of these issues, see Pommerin, Der Kaiser und Amerika, 90-91.

26 Ragnhild Fiebig-von Hase, Lateinamerika als Konfliktherd der deutsch-amerikanischen Beziehungen, 1890-1903, 2 vols. (Göttingen, 1986), passim.

27 Negotiations on an arbitration treaty began in 1904 and dragged on to 1909. For the discussions on the German side, see Reinhard Doerries, Washington, Berlin 1908/1917. Die Tätigkeit 
ristic and autocratic state - an image heightened by pan-German agitation and U.S. reliance on British news cables at a time of rising Anglo-German conflict. ${ }^{28}$ Already around 1900, America's benevolent disinterest had given way to suspicion about the German Empire's true motives. While there were no protracted grievances between the two nations, the U.S. public increasingly came to perceive Germany as an expansionist, perhaps even bellicose, power unwilling to accept American zones of influence. ${ }^{29}$

This development alone might not have particularly worried Berlin. After all, America was a recent and distant great power that enjoyed nothing akin to the prestige and influence it would have after World War I. What made the deterioration of German-American relations important were rising European tensions as well as the concurrent and seemingly successful efforts of Germany's key rivals, France and Britain, to improve their relations with the United States. British influence, in particular, seemed to be on the rise. In the decade after the Spanish-American War, America's traditional Anglophobia gave way to a "hands across the Atlantic" ideology that played out culturally, economically, and, albeit tacitly, politically. After the 189os, Great Britain publicly accepted the Monroe Doctrine and agreed to submit any future transatlantic grievances to international arbitration. In 1898, it was the only European country not to protest America's war against Spain, and the United States alone, returning the favor, did not officially condemn British actions during the Boer War. This "great rapprochement" was assisted by the influence of British news, with London serving as the hub for American international newsgathering, as well as contemporary racial assumptions about an "Anglo-Saxon destiny to dominate and uplift the globe." ${ }^{\circ}$ Elite initiatives like the Rhodes Scholarships or the Pil-

des Botschafters Johann Heinrich Graf von Bernstorff in Washington vor dem Eintritt der Vereinigten Staaten von Amerika in den Ersten Weltkrieg (Düsseldorf, 1975), 38-47; see also Bernstorff, Deutschland und Amerika, 15; Reiner Pommerin has interpreted Wilhelmine foreign policy much more positively than Doerries. He notes that initially Germany was quite willing to sign an arbitation treaty and that the Foreign Ministry, in particular, was eager to harmonize relations with the United States wherever possible; see Pommerin, Der Kaiser und Amerika, e. g., 10, 376; however, scholars usually agree that Germany was not able to establish fruitful relations with the U.S. press and that it often thought all too little about the "optics" of its actions.

28 For the negative German press coverage of the Spanish-American War, see Emil Witte, Aus einer deutschen Botschaft. Zehn Jahre Deutsch-Amerikanischer Diplomatie (Leipzig, 1907), 21.

29 Pommerin, Der Kaiser und Amerika, 113-130; Doerries, Washington-Berlin, 38-47; as Nancy Mitchell has shown, this was at least partly due to the interests of the U.S. Navy, which quite systematically promoted the idea of a "German peril" in Latin America; see Nancy Mitchell, The Danger of Dreams: German and American Imperialism in Latin America (Chapel Hill, NC, 1999).

30 Bradford Perkins, The Great Rapprochement: England and the United States, 1895-1914 (New York, 1968); John E. Moser, Twisting the Lion's Tail: Anglophobia in the United States, 1921-48 (London, 1999), 3. 
grims Society (est. 1902) helped promote a nascent "special relationship." ${ }^{31}$ At the same time, France, too, stepped up its courtship of the United States. ${ }^{32}$ Its defeat in the Franco-Prussian War of 1870/71 had triggered a renaissance of its mission civilisatrice, which gave rise to a growing network of private groups promoting its culture and language abroad. By 1900, the most important of these, the Alliance Française (est. 1883) already had some 150 local committees across the United States, just as France became a magnet for American tourists and students venturing to the Old World. ${ }^{33}$ Driven by a strong sense of cultural pre-eminence, French elites skillfully capitalized on American feelings of cultural inferiority to sell social distinction and savoir vivre in the form of French wine, fashion, education, vacation, and art. ${ }^{34}$ They never left any doubt that their attempts to draw America into their cultural domain ultimately served political, anti-German objectives. ${ }^{35}$

In light of rising German-American tensions, these subtle and effective British and French efforts to pull America onto their side were clearly disquieting for Berlin. They gave political weight to longer-standing trepidations about Germany's declining influence in the United States. ${ }^{36}$ German-born professors at American universities, especially, like Germanist Kuno Francke and psychologist Hugo Münsterberg of Harvard University, had long sought to alert German ministries to German culture's waning attractiveness to Americans and the threat this posed to German standing. ${ }^{37}$ According to a memorandum, which Münsterberg submitted to the Prussian Ministry of Culture in 1908, French and British actions had already reversed earlier trends whereby the most promising American students "had received their seminal impressions in Germany and returned [to the United States] as missionaries of German scholarship." If this decline were not addressed, he predicted, American academia would be replete with "enemies of German science" in merely a few

31 Important, too, was the ambassadorship of Oxford scholar and liberal politician James Bryce (1907-1913). His The American Commonwealth (1888) was frequently hailed as the English equivalent of Alexis de Tocqueville's Democracy in America $(1835,1840)$.

32 Young, Marketing Marianne, 10.

33 Gienow-Hecht, Sound Diplomacy, 23.

34 On French efforts, see Young, Marketing Marianne, esp. Chapter 1.

35 As Le Temps asserted in 1908, "clearly, French culture is entangled in a combat with German culture." Cited in Gienow-Hecht, Sound Diplomacy, 22.

36 For this argument, see Fiebig-von Hase, "Die politische Funktionalisierung der Kultur," 49.

37 Ungern-Sternberg, Deutschland und Amerika, 62; Vom Brocke, "Professorenaustausch," 137; Hugo Münsterberg, "Die deutsche Kultur und das Ausland," Internationale Wochenschrift für Wissenschaft, Kunst und Technik 4 (1910): 1471-78; at the University of Heidelberg, for example, the percentage of Americans among international students fell from 22 percent (1870-90) to 12 percent (1890-1914); see Siebe, Germania Docet, 267; by 1908 U.S. Ambassador to Germany David J. Hill (a former president of Rochester University) voiced his concern that Germany no longer attracted the very best American students. Auswärtiges Amt, Abschrift IIIc 16521, Aug. 17, 1908, PA R 64997. 
years' time..$^{8}$ Given the broader political issues of the time, such professorial concerns drew the attention of the Prussian Ministry of Culture and Wilhelm II, leading ultimately to the founding of the Germanic Museum, the professorial exchange, and the Amerika-Institut. It was the disconcerting coincidence of Germany's decline in cultural standing in the United States at a time of rising transatlantic tensions that first prompted official attention to cultural diplomacy, a field that had hitherto been far outside state interest.

And still, we should note that in adopting a more determined policy to strengthen its cultural and intellectual influence, Germany hardly centered its interest on the United States because of the New World nation itself. Instead, cordial relations with the United States were meant to counterbalance British hostility and allow Berlin to pursue its policy of a "freie Hand", or free hand, unhampered by the fear of an Anglo-American agreement. ${ }^{39}$ Since Germany was not willing, or able, to address the real grievances that underlay transatlantic tensions - by accepting the Monroe Doctrine or signing an arbitration treaty - a public relations campaign appeared to be the most readily available and least costly means to salvage the deteriorating relationship with the United States. After 1902, in short, the purpose of public diplomacy was to neutralize transatlantic tensions at minimum cost.

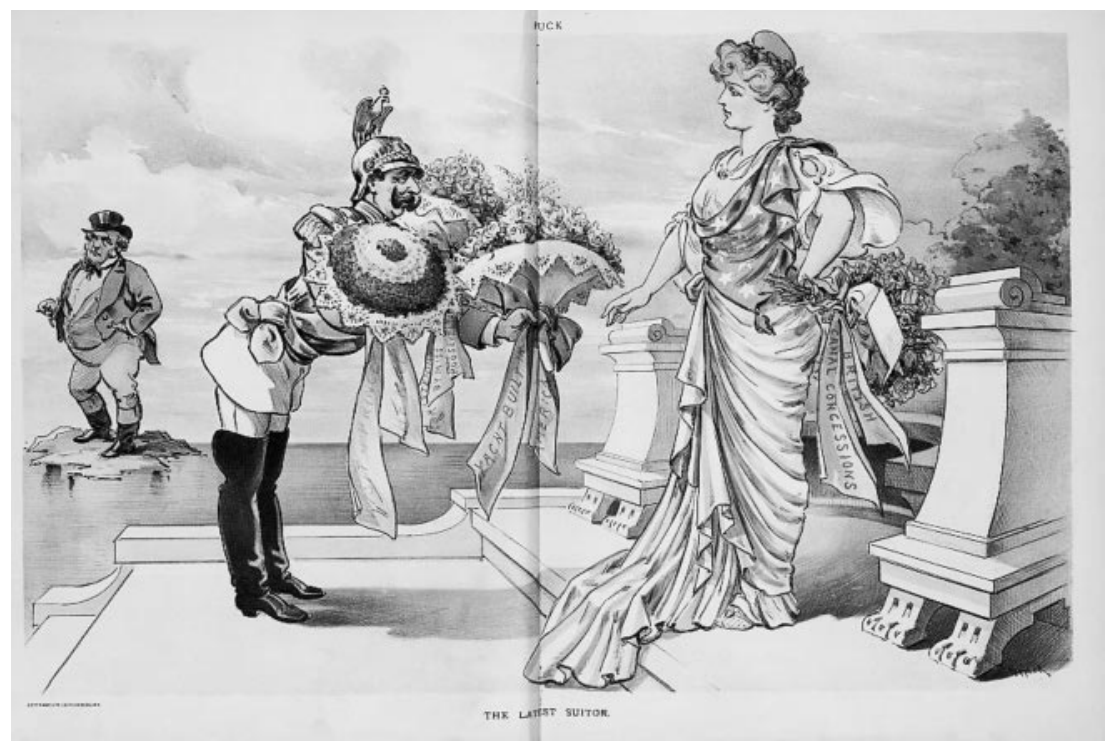

Fig. 3: The Anglo-German competition for U.S. sympathies was not lost on U.S. observers,

"The Latest Suitor," Puck, Feb. 19, 1902

38 Auswärtiges Amt, Abschrift IIIc 16744, Aug. 20, 1908; and Hugo Münsterberg, "Das Amerikanische Institut," Aug. 12, 1908, PA R64997.

39 See Fiebig-von Hase, "Die politische Funktionalisierung der Kultur," 60. 


\section{German Peaceful Imperialism and the United States}

Although the American campaign, as we shall see, was unique in some respects, it also anticipated and reflected a broader German reorientation toward new modes of conducting foreign policy. Major impulses to this end came not at first from within the German government but from liberal members of Germany's Bildungsbürgertum and export industries. This well-educated and often widely traveled middle and upper middle class of professors, teachers, publicists, lawyers, pastors, bankers, and merchants championed commercial and cultural outreach as a subtler form of German influence in the world. Especially the Bildungsbürgertum, a group shaped by the privilege of university education and missionary notions of Bildung and Kultur, saw the expansion of ideas and cultural practices as an important and hitherto neglected tool for Germany's ambitions in the accelerating imperialist race in China, the Ottoman Empire, and parts of Latin America. Based on the French example of a pénétration pacifique, these "peaceful imperialists" were convinced that the German language, music, technology, medicine, and education could build trust and sympathy in faraway regions and pave the way for commercial expansion and political influence. They imagined that instilling foreign people with respect for the unique grandeur of German Kultur and a sounder understanding of the German character would provide a competitive advantage over rival powers in the future. ${ }^{40}$ These ideas gained momentum after the Moroccan Crises of 1905 and 1911, in particular. As these two crises revealed the sharp limits of Germany's power politics and the extent of its international isolation, economic and cultural expansion appeared to be a soft(er)-power alternative to its hard-power pursuit of Weltpolitik.

While this group of peaceful imperialists pursued their agenda primarily through a host of private international clubs (Auslandsvereine), they also increasingly demanded a state-supported drive for global sympathies and commercial influence. ${ }^{41}$ In the liberal press and the Reichstag, they called for state-funded cultural and information policies, globally minded university education, and, ultimately, a democratization of the German Foreign Service to bring in more practically educated and widely traveled men who cared about matters of international trade and public opinion. ${ }^{42}$ Reichstag appropriations for public diplomacy rose steeply from 1905 to 1914, and book-length exposi-

40 On this group, see Jürgen Kloosterhuis, Friedliche Imperialisten. Deutsche Auslandsvereine und auswärtige Kulturpolitik, 1906-1918 (Frankfurt a. M., 1994); Rüdiger vom Bruch, Weltpolitik als Kulturmission. Auswärtige Kulturpolitik und Bildungsbürgertum in Deutschland am Vorabend des Ersten Weltkrieges (Paderborn, 1982); more recently, see Stefan Manz, Constructing a German Diaspora: the "Greater German Empire", 1871-1914 (London, 2014).

41 Düwell, Deutschlands Auswärtige Kulturpolitik, 15.

42 See Gustav Stresemann in Verhandlungen des Deutschen Reichstags, Vol. 236, 238. Sitzung, $7907 \mathrm{D}$. 
tions of peaceful imperialism like Paul Rohrbach's Der deutsche Gedanke in der Welt (German Thought in the World, 1912) became bestsellers. ${ }^{43}$ A better-funded, coordinated, and conceptualized policy of economic and cultural expansion, a policy of "moral conquests" as Rohrbach called it, was intended to advance Germany's worldwide expansion without further isolating it. ${ }^{44}$

As the American example illustrates, such peaceful imperialist ideas also resonated with German officials. Although the Prussian Ministry of Culture was the driving force in the American campaign until at least 1914, the Wilhelmstrasse was decidedly more active than was long believed. ${ }^{45}$ Under Bülow's chancellorship, a "school desk" was founded at the German Foreign Ministry in 1906 to support German schools and language education abroad; his successor Bethmann-Hollweg and his associates also took an interest in these matters. A few months before the war, Kurt Riezler, one of Chancellor Bethmann-Hollweg's close confidants, and a member of the Foreign Ministry's press office, pondered the nature of modern diplomacy in his Grundzüge der Weltpolitik (Fundamentals of World Politics). ${ }^{46}$ The modern age, Riezler (writing under the pseudonym of J. J. Ruedoerffer) acknowledged, had introduced two new factors in foreign affairs: the global influence and dependencies of economics, and the power of public opinion. To increase diplomatic influence in any given country, it no longer sufficed to cultivate kings and dukes, ministers and mistresses; instead, one had to export ideas and establish prestige among a larger, diverse group of opinion-shapers to "create a favorable climate

43 State funds for German schools abroad rose from 400,00o marks in 1900 to 1 million marks in 1912; allocations for information policy rose from 500,000 in 1905 to 1 million marks in 1910 and to 1.3 million marks in 1911; see Kloosterhuis, Friedliche Imperialisten, 109; on the success of Rohrbach's book, see Comment Kloosterhuis in Deutsche Auswärtige Kulturpolitik seit 1871, ed. Kurt Düwell and Werner Link (Cologne, 1981), 60.

44 What united many of them was a sense of cultural mission, rooted in two different intellectual currents. On the one hand, the educated classes were gripped by cultural pessimism in the last decades of the nineteenth century, fearing a cultural decay amidst a world apparently focused on purely civilizatory and materialist progress. On the other, and more visible after the turn of the century, a "new idealism" took root, which recognized German culture, technology, and science as among the greatest in the world and demanded for it to be shared more widely. From their perspective, the world was a field of cultural competition against both stale materialism - not least associated with the United States - and other national cultures, like the British and French, which seemed to have gained a foothold around the world.

45 Under Friedrich Althoff, the headstrong and broad-visioned director of the universities department, the Prussian Ministry of Culture steered a particularly active course. Following a decade of domestic higher education reform (admired and despised as the "system Althoff"), Althoff turned his attention to further the world renown of German scholarship as a key field of international competition. On Althoff, see vom Brocke, "Internationale Wissenschaftsbeziehungen," 185-242; the Foreign Ministry's concern for and involvement in a concerted global information and press policy before 1914 is shown in Wroblewski, Moralische Eroberungen.

46 On Riezler, see Karl Dietrich Erdmann, ed., Kurt Riezler - Tagebücher - Aufsätze - Dokumente (Göttingen, 1972). 
for all present and future undertakings." ${ }^{37}$ Extrapolating from these thoughts, Bethmann-Hollweg declared in December 1913 that a concerted economic and cultural expansion would form an integral part of Germany's Weltpolitik. ${ }^{8}$ Though his official statement declared that such an expansion was best left to private initiative, there was already substantial state involvement behind the scenes, especially in China and the Ottoman Empire. ${ }^{49}$ In this sense, the German response to deteriorating relations with the United States was but an early expression of a broader German turn to "soft power" in the decade before World War I.

\section{American Idiosyncrasies: Cultural Assumptions, German Americans and Cultural Internationalism}

Still, the American case showed a number of instructive differences, which reveal central German assumptions about the United States. Obviously, the United States had little in common with other objects of Germany's budding cultural imperialism, that is, the crumbling Ottoman Empire, Latin America, and China. Unlike these countries, America prompted Germany's interest because of its strength rather than its weakness. So why did Germany choose to employ a cultural strategy toward the United States that it otherwise reserved for "backward" places of colonial interest? It is notable, indeed, that Germany did not launch a cultural offensive involving a comparable level of state sponsorship, innovation, and public interest toward any other Western power. The Prussian Ministry of Culture, for example, seems to have professed little interest in establishing an exchange professorship with France, despite the fact that Franco-German relations certainly needed improving. And although Imperial Germany faced hostility and distrust in many places around the world, the establishment of institutes, museums, and exchange professorships - the uniquely cultural thrust of the campaign - remained nearly singular to the American case. To understand why Imperial Germany would utilize such a groundbreaking approach toward the United States, in particular, we have to consider three distinct factors: cultural assumptions, German Americans, and U.S. cultural internationalism. Because these remained important during the 1920 and 1930s, we will look at these factors in some detail.

47 Ruedorffer, Grundzüge der Weltpolitik, 242.

48 See Kloosterhuis, "Deutsche Auswärtige Kulturpolitik und ihre Trägergruppen vor dem 1. Weltkrieg," in Deutsche Auswärtige Kulturpolitik seit 1871, ed. Düwell and Link, 11.

49 Vom Bruch, Weltpolitik als Kulturmission, 101. 
For one, the choice of a cultural strategy had everything to do with basic perceptions and assumptions Germans had about the United States. First, America's politically isolationist attitude toward Europe suggested a nonpolitical field of action. Ever fearful of entangling alliances, America required a different approach than most European countries. ${ }^{50}$ As German ambassador Theodor von Holleben (1897-1903) had already noted in 1899, cultural relations "are almost the only means remaining to us on this side of the pond to gradually bridge (our) differences." 51 This was only reinforced by the German belief in the extraordinary influence of public opinion on U.S. foreign policymaking. Though its precise impact remained difficult to gauge, few German observers doubted that public opinion - partly because of America's democratic politics, partly because of its highly developed mass journalism - was more powerful in the United States than in other Western nations. ${ }^{52}$ As German ambassador Hermann Speck von Sternburg (1903-1908) concluded in 1904, "it is no exaggeration to contend that it is more important here to win the press for German interests than the State Department."'53 America's unique tradition of isolationism and the special influence attributed to its public opinion thus were weighty factors in pushing Berlin to consider alternate strategies to resuscitate American trust and sympathy.

Equally decisive, however, was the peculiar European perception of the United States as a country devoid of (high) culture or, at best, having only a "culture in the making." Only a few hundred years old and long preoccupied with settling a vast continent, the United States appeared to be a land of stunted aesthetic tastes, where crass materialism had pushed aside concern for the finer things in life. ${ }^{54}$ Germans ignored most evidence to the contrary and largely regarded America as a European cultural colony. Ambassador Bernstorff

50 Abschrift A 1380 Imperial German Embassy Washington to Reichskanzler von Bethmann-Hollweg, Jan. 8, 1914, PA Botschaft Washington, 1523, Bernstorff.

51 Quoted in Ungern-Sternberg, Deutschland und Amerika, 140.

52 James Bryce began his chapter on public opinion (tellingly titled "How Public Opinion Rules in America") with the observation that "public opinion stands out in the United States as the great source of power, the master of servants who tremble before it." James Bryce, The American Commonwealth (Philadelphia, 1906 [orig. 1888]), 258; on the rising influence of public opinion in the late nineteenth century more generally, see Friedrich Kießling, "(Welt-)Öffentlichkeit," in Dimensionen internationaler Geschichte, ed. Jost Dülffer and Wilfried Loth, 85-105 (Munich, 2012), 89-91.

53 Quoted in Stefan Rinke, Zwischen Weltpolitik und Monroe Doktrin: Botschafter Speck von Sternburg und die deutsch-amerikanischen Beziehungen, 1898-1908 (Stuttgart, 1992), 178; this was also repeatedly underlined by Americans. During a press dinner given in Prince Heinrich's honor, President Roosevelt found it "eminently fitting that such a dinner should be given in our country, in which the press has attained a power greater than that which it holds in any other land," Horner Memorial Library, German-American Collection Manuscripts (Non-Catalogued) 15 Prince Henry Scrapbook \# 1, Theodore Roosevelt to New Yorker Staatszeitung, Sep. 15, 1902. 54 See Alexander Schmidt, Reisen in die Moderne. Der Amerika-Diskurs des deutschen Bürgertums vor dem Ersten Weltkrieg im europäischen Vergleich (Berlin, 1997), esp. chapter 3. 
concluded as much shortly before the war: "today an American culture does not yet exist. After a short acquaintance with any American, it is soon clear whether his culture is of English, German or French origin." 55 Perhaps more than any other factor, this nearly ubiquitous cultural conceit explains why European powers would choose to employ a policy of "peaceful penetration" - one usually reserved for semi-colonial spheres of interest - toward a leading industrial nation. This odd constellation of economic power and cultural backwardness made the United States such an attractive target for Germany's cultural outreach. Molding the cultural affinities of a nascent American civilization seemed to offer Germany one way to forge beneficial economic and political relations with the emerging world power in the West.

While these assumptions underpinned European endeavors in general, the way Germany's cultural campaign was conceived and implemented had much to do with German Americans in particular. As the European competition for American hearts and minds accelerated in the decade before the war, the nine million first- and second-generation German Americans and the nearly 25 million Americans of German ancestry appeared to be a unique asset to Germany's economic, cultural, and even political cause in the New World. As representatives of the German character and as active promoters of German positions, German Americans seemed well suited to improving the German image and transatlantic relations. To this end, however, Germany would have to engage in more strenuous efforts to keep their sense of ethnic identity alive in the face of the forces of Americanization. This thought gained wider currency as a burgeoning group of German associations, church organizations and state ministries committed themselves to keeping in contact with "Germans abroad" after the 1890 os..$^{56}$ Historical notions of the German Kulturnation, a deterritorialized German nation defined by cultural and linguistic rather than geographical boundaries, helped to construe Germany's global diaspora as a "Greater Germany," a worldwide sphere of potential German cultural and economic influence. ${ }^{57}$ In the imagination of large organizations like the Association for Germandom Abroad (Verein für das Deutschtum im Ausland) or the Pan-German League (Alldeutscher Verband), the millions of Germans abroad began to look like a "multitude of Reich-oriented little Germanys." ${ }^{8}$ German émigrés, the "national deserters" of Bismarck's day, were now recast as an untapped national resource for Germany's global ambitions.

55 Abschrift A 1380 Imperial German Embassy Washington to Reichskanzler von Bethmann-Hollweg, Jan. 8, 1914, PA Botschaft Washington, 1523, Bernstorff.

56 On the largest such organization, see Weidenfeller, VDA; and Manz, Constructing a German Diaspora.

57 See Stefan Manz, "Diaspora and Weltpolitik in Wilhelmine Germany," in Germans as Minorities during the First World War, ed. Panikos Panayi, 27-46 (London, 2014), 27.

58 See Manz, "Diaspora and Weltpolitik," 27. 
German Americans, to be sure, had long been unlikely objects for such ethnic politics. Their notorious factionalism, lack of effective ethnic leadership, and overwhelmingly lower-class background had facilitated their rapid assimilation and kept them from gaining cultural or political influence commensurate to their numbers. Viewed from a "Germandom" perspective, the United States had always appeared to be only a "mass grave of Germandom." 59 Around the turn of the century, however, several developments suggested that a sort of ethnic reawakening was taking place. From the 189 os onwards, a plethora of organizations had been established or revived to uphold and memorialize German cultural heritage in the United States. On the local, regional, and, finally, on the national level, German gymnastic, singing, and veterans groups peaked in membership; ethnic festivities, like the annual German Day celebrations (held since 1883), drew record numbers of visitors. ${ }^{60}$ In 1901, German-American leaders founded the first national organization, the National German-American Alliance, to maintain German language education in American schools, highlight German contributions to American society, fight Prohibition and, not least, advance amiable transatlantic relations. ${ }^{61}$ Many German Americans followed their old fatherland's rise to world power with pride, and it was in part their enthusiastic welcome of Prince Heinrich in 1902 that suggested to Berlin that they could be a means of German influence. For the first time, there seemed to be a chance of saving them from traceless "Americanization" and harnessing their ethnic loyalties for the interests of the fatherland.

The mobilization of German Americans, then, was a distinct part of Germany's cultural campaign. In the decade before the war, German-American veterans and social clubs received countless greetings, gifts, and decorations from the other side of the Atlantic. German navy cruisers were dispatched to visit American ports, and German-American societies were invited to visit Germany. ${ }^{62}$ Germany's university-oriented campaign, too, was designed to link German Americans to the intellectual life of the fatherland and awaken

59 The fate of ethnic Germans in the United States was often seen as an ominous sign of the impending cultural preponderance of Anglo-American values in the world; see Michael Ermarth, "Hyphenation and Hyper-Americanization: Germans of the Wilhemine Reich View German-Americans, 1890-1914," Journal of American Ethnic History 21, no. 2 (2002): 33-58, 36.

60 Heike Bungert, "Demonstrating the Values of 'Gemüthlichkeit' and 'Cultur': The Festivals of German Americans in Milwaukee, 1870-1910," in Celebrating Ethnicity and Nation: American Festive Culture from the Revolution to the Early Twentieth Century, ed. Geneviève Fabre, Jürgen Heideking, and Kai Dreisbach, 175-193 (New York, 2001), 176.

61 Charles T. Johnson, Culture at Twilight: The National German-American Alliance, 1901-1918 (New York, 1999), 11.

62 The various measures are outlined in Emil Witte, Aus einer deutschen Botschaft, 281 ff.; on the special importance of ethnic festivities and veteran groups, see Heike Bungert, "Migration und Internationale Beziehungen im Kaiserreich: Wilhelm II., das Auswärtige Amt und ihr Interesse an den Deutschamerikanern," Zeitschrift für Geschichtswissenschaft 63, no. 5 (2015): 413-434; 
pride in German achievements. In 1905, for example, the Prussian Ministry of Culture sent Eugen Kühnemann, a professor of German literature at the University of Posen (and later Breslau), on an American lecture tour to sound out the chances for an ethnic revival. ${ }^{63} \mathrm{~A}$ cultural missionary of the highest persuasion, Kühnemann conceived of his tour as part of a larger effort to "assert and establish a world empire of German culture" and sought to convince his ethnic audience that cultural attachment to Germany and political loyalty to the United States were not incompatible. 64 "The stronger German," he explained to the German Societies of New York in 1906, "is the better American." ${ }^{65}$ Apparently Kühnemann hit just the right note. In the following years, he returned to the United States three times: as a Harvard exchange professor in 1908, as a visiting professor at the University of Wisconsin's newly established Carl Schurz Professorship in 1912-13, and as an itinerant propagandist from 1914 to 1917. He summed up the new German policy as follows: "the old fatherland had just lost the men around [Carl] Schurz. The new one recognizes its duties as center of the 'Greater Germany', which encompasses all Germans around the world; [these are] duties of a spiritual nature toward [its] children abroad, which in no way encroach on the national territories of foreign peoples."66

Despite this allegedly solely "spiritual nature," Germandom policies pursued clear economic, even political, motives. The sheer number of German Americans in the United States invited Berlin to dream of political influence. Either directly through a "German vote" or indirectly through their mere presence as a large, ethnically conscious pressure group, they hoped that German Americans would induce the American press and politicians to adopt a more German-friendly position. Could German Americans not draw America closer toward Germany - or at least away from Great Britain? Realizing that ethnic mobilization could never take the form of open political agitation without antagonizing U.S. opinion, German representatives in the United States advocated a broadly cultural course, although clearly to political ends. ${ }^{67} \mathrm{Am}-$ bassador Bernstorff argued "that the political weapon that we have in German Americans should be kept clean and sharp as long as it is still available to us.

"Stimmen zur Deutschlandfahrt des Lehrerbundes und zu seiner Tagung in Berlin," Monatshefte für deutsche Sprache und Pädagogik 13, no. 10 (Dec. 1912): 350-367.

63 Eugen Kühnemann, "Von der Tätigkeit des ersten Karl-Schurz-Professors an der Staatsuniversität von Wisconsin," in Vom Weltreich des deutschen Geistes. Reden und Aufsätze, ed. Kühnemann, 268-319 (Munich, 1914), 268.

64 Kühnemann, Vom Weltreich des deutschen Geistes, vii.

65 Kühnemann, "Deutsch-Amerika und Deutschland," in Vom Weltreich des deutschen Geistes, ed. Kühnemann, 221-226, 221.

66 Kühnemann, "Deutsch-Amerika und Deutschland," Vom Weltreich des deutschen Geistes, ed. Kühnemann, 221-226, 226.

67 On the difference between the Kaiser and diplomats regarding this question, see Fiebig-von Hase, "Die politische Funktionalisierung der Kultur," 68; Doerries, Washington-Berlin, 34. 
If we act accordingly, the memory of German descent will for all times remain effective for us in the United States." ${ }^{68}$ Only too slowly did it dawn on Germany's peaceful imperialists that political and cultural mobilization could not be so neatly separated in a nativist era.

German Americans, to be sure, were not just passive objects of Germany's ambitions. They were partners. While a majority of German Americans professed little interest in their heritage beyond its sociable aspects, a small group of educated and affluent professors (like Francke and Münsterberg), businessmen and financiers (like Adolphus Busch, Jacob Schiff, and the Warburg family), and ethnic leaders (like the Ridder family, publishers of the New Yorker Staats-Zeitung) provided significant initiative and funds to promote German culture among Americans. ${ }^{69}$ Indeed, long before the Germanic Museum, the professorial exchange, or the Amerika-Institut ever became German projects, they were German-American projects; and even thereafter they often continued to rely on ethnic initiative and generosity. ${ }^{\circ}$ In this way, German-American involvement always defined the shape, pace, and reach of German public diplomacy in the United States.

Still, the mutuality of interests between Germans and German Americans should not be overstated. At first glance, their motives were closely connected. Both groups sought to raise the prestige of German culture among their ethnic kin and "Anglo-Americans." ${ }^{11}$ But German Americans' ultimate objectives differed notably. By underlining their superior cultural background, they primarily hoped to stem the rising tide of Anglo-American nativism, which sought to impose Anglo-conformist norms - most notably Prohibition - on more recent immigrant groups. ${ }^{72}$ Even though their actions dovetailed with German agen-

68 Abschrift A 1380 Imperial German Embassy Washington to Reichskanzler von Bethmann-Hollweg, Jan. 8, 1914, PA Botschaft Washington, 1523, Bernstorff.

69 Most German-American organizations were made up of "stomach Germans," that is, German lower-middle classes in urban settings whose "devotion to German culture [...] did not transcend an appreciation for traditional food and drink." Luebke, Bonds of Loyalty, 44. There was a considerably smaller group of "soul Germans" who regarded German culture as superior and saw their "mission [...] to promote and defend German culture in the American setting, and to graft its ideals, if possible, onto American practicality and inventiveness to produce the finest civilization in the history of mankind." See Luebke, Bonds of Loyalty, 28.

70 See, for example, the funding structure of the Amerika-Institut in vom Brocke, "Der Deutsch-Amerikanische Professorenaustausch," 155.

71 For one example, see Julius Goebel, Das Deutschtum in den Vereinigten Staaten von Nord-Amerika (Munich, 1904), 38; Johnson, Culture at Twilight. For many an ethnic newspaper, association, restaurant, and church advocating Kultur and maintaining ethnic identity was also a way to stay in business. Many of the men most prominently involved in ethnic organizations ran ethnic businesses, and their livelihood depended on the survival of an ethnically conscious clientele. The president of the German Society of Pennsylvania, for example, ran a German restaurant, and the Ridder family, owners of the New Yorker Staats-Zeitung, was active in many German-American endeavors; for this point, see Luebke, Bonds of Loyalty, 46.

72 Luebke, Bonds of Loyalty, 67. 
das, ethnic spokesmen usually felt no strong allegiance to Imperial Germany. The National German-American Alliance, for example, admitted only American citizens as members and insisted that it was not a German but an American organization. ${ }^{73}$ If German Americans welcomed and supported Germany's cultural campaign, it was ultimately not so much to promote the positions of the Reich as to advance their own place in America's ethnic pecking order. In the last analysis, their concerns were of an American nature, not of a German one. This distinction, unfortunately, tended to be lost on German and American observers alike.

Finally, if German Americans - as both targets and partners - played a key role in the development of German cultural diplomacy in the United States, so too did a distinct group of educated and international-minded "Anglo-Americans." University presidents like Charles W. Eliot of Harvard and Nicholas Murray Butler of Columbia gladly institutionalized professorial exchanges, invited German writers and scholars to their universities, and opened German houses and museums on campus. Without them (as without German Americans) Germany's cultural campaign could never have materialized. Respect for German learning and thought certainly figured prominently in their decisions. Many in this group had at one point studied in Germany and viewed German higher education as one model for their own ambitious university-building projects. ${ }^{74}$ But their cooperation with Germany expressed not just a desire for academic advancement, let alone a notion of continued American discipleship, but for their own international visibility and prestige in the "golden age" of scientific internationalism. ${ }^{75}$ Interest in Germany was driven not least by stiff competition among America's leading universities, which used their connections to old and world-renowned centers of learning to raise their scientific profiles and, by extension, enrollment and endowment figures. ${ }^{76} \mathrm{~A}$ streak of peace-building idealism also pervaded these initiatives because international education was often cast as a perfect means for bringing the world closer together. ${ }^{77}$

73 Johnson, Culture at Twilight, 9.

74 To Harvard president, Charles W. Eliot, for example, who had spent decades of his life reforming Harvard along the lines of a German research university, "German is the language of scholarship and education and no student may be entitled to these, without a thorough knowledge of the German language." Quoted in Ungern-Sternberg, Deutschland und Amerika, 26.

75 Elisabeth Crawford, Nationalism and Internationalism in Science, 1880-1939: Four Studies of the Nobel Population (New York, 1992), 61.

76 Columbia University and Harvard University, especially, competed actively for German academic contacts, using them to build their own prestige and visibility; see Lerg, "Uses and Abuses," 72-73; on the case of the Berlin-based Amerika-Institut, see PA Botschaft Washington, Nr. 465 Amerika-Institut in Berlin, 1910-1914.

77 In 1912 President Butler laid out his ideas of an "International Mind [...] which, given the adoption of a universal set of values, would function as an international superego. To a large degree, moral transformation would be achieved through transnational contacts, with cultural 
But while U.S. cultural internationalism aided the implementation of German cultural programs, such internationalist strategies on the part of Americans did not apply to Germany alone. German aspirations for cultural preponderance were thwarted by American universities, which welcomed French houses, associations, and exchange professors with equal ease and enthusiasm..$^{78}$ If anything, Americans conceived of their cultural internationalism in distinctly American terms. For all their regard for European culture, men like Eliot or Butler were confident enough in the merits of American education to consider academic programs meaningful transatlantic encounters rather than one-way streets of European influence. For them, the idea of an intellectual exchange - often arrogantly dismissed on the German side as mere goodwill rhetoric - was quite real. They saw the American educational system as on par with or even surpassing the European system in the near future, and the American nation as possessing many of its own valuable ideas and principles to impart to the Old World. If academic exchanges seemed to Europeans an avenue to reach the American public, they could also heighten the prestige and influence of the United States across the Atlantic. In short, although Germans imagined these exchanges as a way to curry American favor, their American interlocutors were ready to export their own progressive ideology to a Europe that seemed mired in endless imperialist squabbles and fruitless arms races. While Germans still believed they were primarily extending their influence in the United States, Americans were already pushing to extend their own across the Atlantic. In the short run, however, this made them not less but more committed partners of German cultural diplomacy.

By 1914, Germany could look back on a decade of concerted cultural campaigning in the United States. More than thirty exchange professors had crossed the Atlantic, and a transatlantic infrastructure of institutions, organizations, and committees had come into existence. Though German Americans and German "peaceful imperialists" initially spurred these actions, the degree of German state involvement, particularly of the Prussian Ministry of Culture, was already substantial. Even before World War I, German state actors increasingly recognized German cultural networks abroad as assets in international relations, especially in the United States. America's tradition of isolationism, the influence ascribed to its public opinion, German cultural conceits, and the availability of strategic American partners all strengthened this perception. For these

relations serving as the vehicle of reeducation." Ninkovich, Diplomacy of Ideas: U. S. Foreign Policy and Cultural Relations, 1938-1950 (New York, 1981), 11.

78 In the years after 1905 Columbia University, just as it had done with Germany, initiated professorial exchanges with France, the Netherlands, Japan, and Austria. 
reasons, Germany first practiced seminal forms of cultural diplomacy in the United States, thereby laying the groundwork for its modern public diplomacy more generally.

Nevertheless, contemporaries were not certain whether Germany's cultural strategy was successful, and historians have not been, either. Not surprisingly, in light of World War I, they doubted whether this strategy engendered a better understanding between the two nations. Some even posited that academic programs like the professorial exchanges exacerbated, rather than ameliorated, American apprehensions about Germany. ${ }^{79}$ If this is true, personal deficiencies were, not least, to blame. Frequently selected from a small pool of English-speaking candidates, German exchange professors at times proved to be ill-suited to a task that demanded not (just) scholarly brilliance but tact, people skills, and a willingness to immerse oneself in another culture. ${ }^{80}$ Their chauvinistic, even bellicose, assumptions about Germany's role in the world and their thinly veiled disdain for American culture and democracy provided ready confirmation of American accusations of German militarism. ${ }^{81}$ Seen as official spokespeople of the German nation, exchange professors often left a rather negative impression.

Nor did all of America's professorial envoys to Germany return as determined advocates of German-American friendship. Their contact with German nationalism and cultural conceit was just as likely to deepen their transatlantic distrust and alert Americans to different notions of state power, military necessity, and international law. ${ }^{82}$ It is thus not entirely surprising that several of America's exchange professors would later become harsh critics of German war policy. ${ }^{83}$ Nor did American scholars necessarily help to forge a more realistic image of the United States in Berlin. Some of them were so eager to please their German audience that they simply misrepresented prevalent American sen-

79 See Fiebig-von Hase, "Die politische Funktionalisierung der Kultur," 87.

80 On this point, as well as on the perception of German professors more generally, see the report of the economist Joseph Alois Schumpeter, who served as the first Austrian exchange professor in 1913. Joseph Alois Schumpeter, Bericht über die Mission als Austauschprofessor an der Columbia-Universität in New York, 1913-14, ed. Ulrich Hedtke, www.schumpeter.info2012, 14; on the arrogance of his German colleagues, 34 .

81 By defending the purifying and heroic aspects of warfare against American pacifism, the well-known Berlin historian Eduard Meyer, for example, provided only ready proof for American accusations of German militarism; see Fiebig-von Hase, "Die politische Funktionalisierung der Kultur," 73.

82 Ibid., 87.

83 Paul Shorey of the University of Chicago, exchange professor in Berlin in 1913/14, felt so arrogantly treated by Berlin classical philologist Ulrich von Wilamowitz-Moellendorff that they no longer got along; see Bernhard vom Brocke, "Wissenschaft und Militarismus'. Der Aufruf der 93 'An die Kulturwelt!' und der Zusammenbruch der internationalen Gelehrtenrepublik im Ersten Weltkrieg," in Wilamowitz nach 50 Jahren, ed. William M. Calder III, Hellmut Flashar, and Theodor Linken, 649-719 (Darmstadt, 1985), 679. 
timents. For example, in a lecture titled "The Germanization of South America," Professor John Burgess of Columbia University encouraged Germany to become more active in Latin America - a suggestion that ran directly counter to American official and public opinion. ${ }^{84}$ In the extensive press reports about the professorial exchanges, such dissonances and mishaps often received the greatest coverage..$^{85}$

Germany's obvious interest in German Americans, too, increasingly roused suspicion. The openness with which exchange professors like Eugen Kühnemann proselytized among them gave credence to suspicions of a pan-German conspiracy in which German Americans were supposedly to be used as imperial agents on American soil. ${ }^{86}$ Above all, it made this ethnic group look closer to the Imperial government than it actually was. Just when Germans were trying to argue for the compatibility of cultural attachment to Germany and political loyalty to the United States, rising nativism made Americans less likely to accept any such distinction, especially where a foreign government was involved ${ }^{87}$ If anything, German efforts helped convince Americans that German culture was a dangerous element of ethnic separatism. Thus, even before the war, Germandom policies had begun to cast doubt on German intentions and German-American loyalties alike.

Nor could frequent public expressions of amiability suppress elements of rivalry that came into play, especially in transatlantic academic relations. To many Americans, professorial exchanges with the foremost European universities were a sign that America was leaving behind its dependence on $\mathrm{Eu}-$ ropean culture. Proud of their own increasingly well-equipped, well-staffed, and well-endowed research universities, American scholars saw themselves as representatives of an emerging academic world power; Germans, on the other hand, held on to notions of American discipleship, interpreting professorial exchanges as a favor granted for purely political reasons. ${ }^{88}$ At times, these different interpretations became starkly obvious. When exchange professor Arthur Hadley, the president of Yale University, praised American scholarship in his final lecture at Berlin, the dean of Berlin University, Adolf Wagner, replied: "Yesterday it was said: Bononia [Bologna] docet; today: Germania docet. It

84 "Professor Burgess Gave an Un-American View," New York Times, Oct. 31, 1906; on German Americans and German consular officials warning about the inaccuracy of Burgess's representations, see Clipping: "Dichtung und Wahrheit," Chicagoer Abendpost, Oct. 30, 1906, Kaiserlich Deutsche Botschaft in Washington, No.461, Akten betr. Professoren und Lehrer-Austausch, Vol. 2, 1906-1909.

85 For example: Clipping: "Exchange of Professors," NY Evening Post, Mar. 24, 1911, PA Kaiserlich Deutsche Botschaft in Washington, No. 462.

86 A particularly prominent example can be found in Johnson, Culture at Twilight, 24.

87 Luebke, Bonds of Loyalty, 77.

88 See vom Brocke, "Der Deutsch-Amerikanische Professorenaustausch," 140-141. 
may be that tomorrow it will say: America docet. In any case, we have reason to use our best endeavors to keep that from happening." 9

This is not to say that these professorial exchanges contained no attempts at transatlantic understanding, that no friendships developed in them, or that no national positions were clarified..$^{\circ}$ Still, many of the exchange's underlying assumptions were flawed, and their ultimate impact was limited. German professors could comment favorably on the industrial strides America made and even find words of praise for its university system while dismissing American culture as nonexistent. They could spend an entire year in the United States, enjoy American hospitality, and still regard democracy as an inferior form of government. By the same token, American professors could enjoy the attention showered upon them in Berlin while still disagreeing with the political and ideological tenets of Wilhelmine Germany. They could respect, even admire, German scholarship without coming to like the German state, or even German scholars. Cultural familiarity and political distrust were by no means incompatible.

\section{Rising German Criticism}

While these dissonances were not as apparent then as they are in hindsight, criticism of Germany's public diplomacy grew significantly in the last few years before the war. The Second Moroccan Crisis of 1911, in particular, made German isolation very apparent, just as German rivals beame more successful in their American courtship. ${ }^{91}$ Under these circumstances, liberal, bourgeois groups in Germany amplified their earlier demands for a cultural and economic reorientation of foreign policy. Even though the German Foreign Ministry was far more active than was (for obvious reasons) publicly known,

89 Schmidt-Ott, Erlebtes und Erstrebtes, 111; on the competition between German and American universities since the turn of the century, see Emily J. Levine, "Baltimore Teaches, Göttingen Learns: Cooperation, Competition, and the Research University," American Historical Review (June 2016): 780-823.

90 Willi Paul Adams traced the positive influence of the exchanges on the development of American studies in Germany; see Willi Paul Adams, "Die Geschichte Nordamerikas und Berliner Historiker," Working Paper No. 15/1988 (John F. Kennedy-Institut, Freie Universität Berlin), esp. 11-21.

91 In 1909 a group of prominent Americans and Frenchmen founded the Paris-based Comité France-Amerique and the New-York based France-America Society to "make France known and loved in America, and America in France." In 1913 a Maison Francaise was established at Columbia University. For the history of the Maison Française, see http://www.maisonfrancaise.org/ centennial/the-france-america-society (last accessed July 24, 2020). In 1913 France even surpassed Germany in international student enrollment; see Kloosterhuis, Friedliche Imperialisten, 129; more generally on French academic efforts, see Young, Marketing Marianne, 17. 
these critics had a point. ${ }^{92}$ Whereas the Quai d'Orsay had opened a cultural diplomacy department in 1909, Germany remained without any such office to even begin to coordinate and formulate cultural programs in accordance with foreign policy objectives, let alone to implement them. After a decade of efforts, Germany seemed to have moved no closer to establishing cultural diplomacy as a legitimate policy field with ample funds, expertise, and reliable commitment. The ballooning number of "international clubs" committed to these questions - no less than fifty were created between 1912 and 1914 - seemed to carry on without state support; 93 and although German diplomats were expected to cultivate international opinion by then, the level of official instruction remained low, the machinery to influence foreign publics rudimentary, and even the overall place of shaping opinion in German foreign policy disputed. ${ }^{44}$ Many older (and high-ranking) diplomats, moreover, still regarded public diplomacy as an undignified form of self-advertisement foreign to the German character and inimical to their ideal of diplomatic negotiations undisturbed by the meddlesome public. ${ }^{95}$ Even the Foreign Ministry's press office seemed to lack the qualities any office hoping to shape opinions abroad needed: an understanding of foreign psychology and a feeling for the mass public. ${ }^{96}$ By 1914, German foreign policy still failed to take the imponderables of foreign affairs sufficiently into account.

At that point, developments in the United States, too, appeared to be stagnant. In a long report to the German chancellor in January 1914, Ambassador Bernstorff reflected on the last decade of German foreign policy with regard to the United States. To Bernstorff, Prince Heinrich's visit had marked the be-

92 This impression was actually intended by the German Foreign Ministry, which carefully obscured its (in Turkey and China quite substantial) involvement. By 1914, Kloosterhuis notes, the German Foreign Ministry had established itself as the primary state actor in this field of Weltpolitik; Kloosterhuis, Friedliche Imperialisten, 246.

93 See Kloosterhuis, "Deutsche Auswärtige Kulturpolitik und ihre Trägergruppen vor dem 1. Weltkrieg," in Deutsche Auswärtige Kulturpolitik seit 1871, ed. Düwell and Link, 7-36.

94 Johann Heinrich von Bernstorff, Erinnerungen und Briefe (Hamburg, 2010 [orig. Zurich, 1936]), 77 .

95 A 1912 initiative by Chancellor Bethmann-Hollweg to enlarge the press bureau had foundered on inter-ministerial resistance; see Walter Vogel, "Die Organisation der amtlichen Presse und Propagandapolitik des Deutschen Reiches von den Anfängen unter Bismarck bis zum Beginn des Jahres 1933," Zeitungswissenschaft 16 (Aug./Sep. 1941): 81. In fact, the diplomatic preference for arcane negotiations only increased as public and published opinion turned out to be ever more influential but also ever more volatile and emotional after the turn of the century; on this paradoxial development, see Friedrich Kießling, "Das Paradox der Geheimdiplomatie. Offizielle Außenpolitik und Öffentlichkeit vor 1914," in Außenpolitik im Medienzeitalter. Vom späten 19. Jahrhundert bis zur Gegenwart, ed. Frank Bösch and Peter Hoeres, 73-94 (Göttingen, 2013).

96 Peter Jungblut, "Unter vier Reichskanzlern. Otto Hammann und die Pressepolitik der deutschen Reichsleitung 1890 bis 1916," in Propaganda. Meinungskampf, Verführung und politische Sinnstiftung 1789-1989, ed. Ute Daniel and Wolfram Siemann, 101-116 (Frankfurt, 1994), 114. 
ginning of a German "Amerikapolitik," that is, a policy that aimed to establish American markets for German goods, maintain the ethnic identity of German Americans, and maximize Germany's intellectual influence on an emerging great power. "In this last task," Bernstorff added, "lies one of the most important global historical duties of the German people."97 After five years in Washington, however, Bernstorff was forced to admit that German policy seemed "least successful" in precisely this cultural field. The pre-eminence of the English language and literature and America's predilection for French fashion, lifestyles, and art called for a more systematic cultural diplomacy from Germany.

Though the immediate occasion of Bernstorff's report was the German government's decision not to participate in the international exposition in San Francisco in 1915, his frustration revealed longer-standing grievances that cut to the heart of Germany's Amerikapolitik in the decade before the war. ${ }^{98}$ Indeed, Bernstorff regarded the San Francisco decision as symptomatic of German foreign policy - it was conducted by a group of men who knew and cared little about the United States and who systematically underestimated the impact of public opinion on transatlantic affairs. ${ }^{99} \mathrm{He}$ explained in a private letter: "Therein lies the saddest aspect of the affair that it has shown how little 'Weltpolitik' we actually pursue. America, so near to us today, is already 'terra incognita' for our official circles, the United States, the greatest world power of tomorrow, a quantité négligeable. ${ }^{100}$ Bernstorff, as well as a growing number of private associations and officials, believed that greater attention to the imponderables of international relations was urgently needed. He summed up this decade-long discussion with a nod to the superiority of German culture: "Our cultural endeavors are not meant as a favor to Americans, but are to secure German culture its rightful place; a rightful place which - as the first culture of the world - it absolutely has a claim to. This, too, is a piece of Weltpolitik." ${ }^{\prime 10}$

97 Abschrift A 1380 Imperial German Embassy Washington to Reichskanzler von Bethmann-Hollweg, Jan. 8, 1914, PA Botschaft Washington, 1523, Bernstorff.

98 Though Bernstorff had been repeatedly assured of German participation while in Berlin and despite the fact that the U.S. government considered the world's fair in honor of the Panama Canal a prestige project, the German government had not only decided against participating but (in order to explain its decision) had also downplayed the world's fair's importance. This led to very unfavorable reporting in the American press. Ambassador Bernstorff considered the entire episode highly symptomatic of the way in which Berlin conducted its American affairs. In contrast, the Prussian Ministry of Culture and academic circles had championed German participation and a large German "educational and scientific exhibition" to halt the apparent decline of Germany's academic and scientific position in the United States; see Eckhardt Fuchs, "Das Deutsche Reich auf den Weltausstellungen vor dem Ersten Weltkrieg," Comparativ 5/6 (1999): $61-88,86$.

99 Bernstorff to Bussche-Haddehausen, Jan. 2, 1914, in Bernstorff, Erinnerungen und Briefe, 88. 100 Bernstorff to Dr. Heckscher, Dec. 30, 1913, in Bernstorff, Erinnerungen und Briefe, 90-91. 101 Abschrift A 1380 Imperial German Embassy Washington to Reichskanzler von Bethmann-Hollweg, Jan. 8, 1914, PA Botschaft Washington, 1523, Bernstorff. 
Bernstorff's report, however, came too late to address the deficiencies of German foreign policy. Indeed, although there had been notable efforts to harmonize German-American relations, Germany had done too little outside of "gestures and gifts" to quiet American distrust. ${ }^{102}$ While Berlin was careful to avoid the impression of German meddling in Latin America, it still refused to sign an arbitration treaty after 1908 or to officially recognize the Monroe Doctrine. While there were many good reasons for these actions, here, as in many other instances, the German government seemed oblivious to how such actions appeared to Americans and the American press. For example, mere months before the July crisis, even as a banquet was being held in honor of an American exchange professor and to celebrate transatlantic friendship in Berlin, a German shipping line was ignoring the American arms embargo of Mexico and delivering weapons to the Huerta government. ${ }^{103}$ In light of these and similar actions, German expressions of amiability had the look of mere lip service to Americans. Here, then, lay the crux of the problem in German-American relations before the war: As long as Germany failed to act according to its pronouncements of goodwill, no German public diplomacy, however skillful, could have improved transatlantic relations.

\section{Kultur, War and Propaganda, 1914-1917}

The advent of war in 1914 uniquely accelerated and amplified the promises and problems of Germany's public diplomacy. For one, it increased attention to American public opinion and raised the funds and expertise devoted to advertising German positions abroad. The war professionalized and institutionalized public diplomacy, turning a field that had lingered on the margins of international relations into a legitimate, even pivotal, policy field. At the same time, it created and emphasized the suspicions, resentments, and psychological hurdles that would circumscribe Germany's Amerikapolitik in the 1920 .

Within months of the beginning of the conflict, World War I had transformed the significance accorded to American opinion. The warring parties faced each

102 See Reinhard Doerries, "Transatlantic Intelligence in Krieg und Frieden," in Deutschland und die USA in der internationalen Geschichte des 2o. Jahrhunderts, ed. Manfred Berg and Philipp Gassert, 279-302 (Stuttgart, 2004), 283; Rainer Pommerin, too, while taking a more benevolent perspective on German efforts, notes that Germany proved unable to communicate its policy credibly to the American press; see Pommerin, Der Kaiser und Amerika, 380.

103 Reinhard Doerries, "Imperial Berlin and Washington: New Light on Germany's Foreign Policy and America’s Entry into World War I," Central European History 11, no. 1 (March 1978): $23-49,26$. 
other not only in the trenches of the Western front but also on the battlefield of international opinion. Consequently, this "war of words" was bitterly fought for the (moral) allegiance of the neutral world, with the United States being by far the most important theater. Indeed, World War I elevated the United States to a position of importance it had never previously enjoyed. As the largest industrial non-belligerent nation, America had the potential to help determine the outcome of the war based on its attitude toward the conflict. It was unclear how Americans would understand their neutrality, whether their banks would lend money and how much, whether their industry and agriculture would supply warring parties and the government would accept the inconveniences of the war. These decisions depended not least on how the American people interpreted the cause and conduct of the different warring parties, as well as on how they assessed the compatibility of these parties with American interests and the likelihood of their victory. The ensuing battle for American sentiments, fought especially between Britain and Germany, was characterized as "the most decisive battle of World War I."104 Nowhere else were the stakes so high, the competition so fierce, and, ultimately, Germany's defeat so resounding.

The war obliterated America's indifference to international affairs. The outbreak of hostilities at the height of the 1914 travel season surprised tens of thousands of Americans on the continent and left them scrambling to return home as borders were closed, trains requisitioned, and bank accounts frozen. ${ }^{105}$ For these elite Americans, including university presidents, congressmen, bankers, and industrialists, these first few days provided seminal impressions of the European conflict. ${ }^{106}$ Across the Atlantic, the first response to the war was not, as interwar memoirs would have it, shock or revulsion, but excitement and expectation. ${ }^{107}$ In major American cities, thousands of European reservists reported for duty at consulates, and ethnic groups staged large parades and demonstrations in support of their homelands. The largest mass gathering in response to the outbreak of the war was held not in Berlin, Paris, or London, but in New York City. The American press reported on frontline movements several times a day, and it was not long before Americans began to see the war

104 Chad Fulwider, “The Kaiser's Most Loyal," 85.

105 See the experiences of Nicholas Murray Butler, Across the Busy Years, 247-64.

106 The effect that these experiences had, especially in light of the fact that most American tourists vacationed among the Allies and not the Central Powers, deserves more scholarly attention; for some of these impressions, see Christopher Endy, "Travel and Power: Americans in Europe, 1890-1917," Diplomatic History 22, no. 4 (1998): 565-594, 590-592.

107 Phillips Payson O’Brien, "The American Press, Public, and the Reaction to the Outbreak of the First World War," Diplomatic History 37, no. 3 (2013): 446-475, 474. 
as an economic opportunity. By the first weeks of August, the New World already seemed transformed by the conflict of the Old World.

Few Americans saw this more clearly than U.S. President Woodrow Wilson. Realizing that open partisanship could easily corrode the multiethnic fabric of American society (and preclude the U.S. peace mediation he desired), he implored his fellow Americans to remain neutral, stating on August 18 that

every man who really loves America will act and speak in the true spirit of neutrality, which is the spirit of impartiality and fairness and friendliness to all concerned. The spirit of the nation in this critical matter will be determined largely by what individuals and society and those gathered in public meetings do and say, upon what newspapers and magazines contain, upon what ministers utter in their pulpits, and men proclaim as their opinions upon the street. [...] The United States must be neutral in fact, as well as in name, during these days that are to try men's souls. We must be impartial in thought, as well as action, must put a curb upon our sentiments, as well as upon every transaction that might be construed as a preference of one party to the struggle before another. ${ }^{108}$

Such sentiment was as noble as it was vain. While the United States officially tried to walk the difficult line of impartiality, many Americans developed clear sympathies during the period of neutrality, most of which did not rest with the Central Powers. ${ }^{109}$ The breach of Belgian neutrality in violation of international law, rumors of German atrocities, and the destruction of cultural artifacts like the Louvain library alienated many Americans early on. ${ }^{10} \mathrm{Al}$ though large swaths of American society remained indecisive about the war and others-primarily German Americans, Irish Americans and Jewish Americans-tended to oppose the Allied cause, the Anglo-American establishment largely sided with France and Great Britain. Upon his return from Germany in late August 1914, Ambassador von Bernstorff found the East Coast's "upper 400 " had all drifted into the Allied camp. ${ }^{111}$ Outside the traditionally German-friendly Midwest, the American press, too, shared a pro-Allied bias, and even at American universities only a handful of German-born or anti-British scholars rose to defend Germany. ${ }^{112}$ Many others, like former Harvard presi-

108 Woodrow Wilson, Message to Congress, 63 rd Cong., 2d Sess., Senate Doc. No. 566 3-4; Aug. 19, 1914, http://wwi.lib.byu.edu/index.php/President_Wilson\%27s_Declaration_of_Neutrality 109 Clara Eve Schieber, "The Transformation of American Sentiment toward Germany, 18701914," The Journal of International Relations 12, no. 1 (1921): 50-74, 70.

110 The German occupation of Belgium has been called the "defining act of the war"; John Horne and Alan Kramer, German Atrocities, 1914: A History of Denial (New Haven, 2001), 251.

111 Bernstorff, Erinnerungen und Briefe, 75.

112 Fulwider, German Propaganda and U.S. Neutrality, 18. 
dent Charles William Eliot, almost immediately became vocal critics of German "autocracy" and "militarism."113

European propaganda was at least partly to blame for this state of affairs. In the summer of 1914, the Anglo-German competition for America's favor gave way to a vigorous propaganda battle for "the most important neutral." The British, in particular, took early steps, hoping to draw the United States onto the Allied side, first in moral and economic terms, and later in military terms. Just hours after Britain declared war, a British cruiser cut Germany's transatlantic telegraph cables, turning Britain's already considerably transatlantic communications advantage into a virtual monopoly for a time. ${ }^{114}$ Britain's "very first act of war" was soon followed by more comprehensive measures to influence American perceptions of the European conflict. ${ }^{15}$ By mid-August, all outgoing cables, including American ones, were subject to British censorship, and by early September Wellington House, a government-sponsored propaganda hub of journalists, Oxbridge scholars, and famous writers, set out to create a powerful image of the German enemy. It asserted a fundamental difference between Germany and the Western powers, with the highly publicized "Rape of Belgium," in particular, effectively demonizing a militarist and autocratic Prussia. These propagandists argued that Prussia had forced the war upon its own people and the entire world. ${ }^{116}$ The skillful use of sensational details, the cultural authority of its authors, and the discreetness of its operations - which passed invisibly through news channels or personal networks - guaranteed British propaganda the widest circulation and credibility in the United States. ${ }^{117}$ Most Americans, indeed, remained unaware of its very existence until after the war.

While such British propaganda went largely unnoticed in the United States, it received all the more attention and determined countermeasures in

113 See, e.g., Charles Eliot, "Imperialistic and Democratic Ideals of National Greatness - A Contrast," New York Times, Sep. 22, 1914, 10. Eliot, in fact, came out so strongly and publicly against Germany that Hugo Münsterberg saw him as the leader of the anti-German party in the United States; Hugo Münsterberg, The War and America (New York, 1914), 35.

114 A substantial amount of the material reprinted in American newspapers was tinged in British favor; Michael Kunczik, "British and German Propaganda in the United States from 19141917," in Propaganda in the $20^{\text {th }}$ Century: Contributions to Its History, ed. Jürgen Wilke, 25-51 (New York, 1998), 27.

115 Fulwider, German Propaganda and U. S. Neutrality, 50.

116 The Berlin theologian Adolf von Harnack referred to the "international lying press" as the "fourth great power $[\ldots]$ which pours lies all over the world against our straight-laced army and slanders all that is German." Quoted in Christian Nottmeier, Adolf von Harnack und die deutsche Politik 1890-1930. Eine biographische Studie zum Verhältnis von Protestantismus, Wissenschaft und Politik (Tübingen, 2004), 390.

117 When the British propaganda apparatus was re-organized in 1917, even an otherwise critical report found that the "American campaign could not have been handled more successfully and with more tact and better results than it has been." See Robert Donald, "Report on Propaganda Arrangements," Jan. 9, 1917, 10; quoted in M. L. Sanders, "Wellington House and British Propaganda during the First World War," The Historical Journal 18, no. 1 (1975): 119-146, 123. 
Germany. Following prewar precedents, it was the group of "peaceful imperialists" rather than the German government that first rose to the task. By the second week of the war, many of them had become convinced that the distortions of the media-savvy British enemy were to blame for anti-German sentiments and that the American public, in particular, had been left in the dark about the "true" state of affairs, at least as many Germans saw it: that, encircled by malevolent powers, a peace-loving Germany had invaded a not truly neutral Belgium as a pre-emptive act of self-defense; that its army was charging heroically toward victory; and that the German people were enthusiastically united behind the war effort. If only this "truth" could be made known, they believed, Americans would have a German-friendlier assessment of affairs. ${ }^{118}$ Long aware of German deficiencies in this field, the publicists Paul Rohrbach and Ernst Jäckh, in league with the Imperial Naval Office, improvised a small propaganda bureau. On August 11, it published the war's first propaganda brochure, tellingly titled The Truth about Germany: Facts about the War, which it distributed to American tourists returning home. In the following weeks, a combination of patriotic self-mobilization and the (mistaken) notion of an ignorant but benevolent America unleashed a flood of similar German pamphlets, letters, and public manifestos across the Atlantic. ${ }^{119}$ The historian Karl Lamprecht recalled the situation pretty accurately when he stated that the average German professor (including himself, one might add) "obtained the largest possible goose quill, and wrote to all his foreign friends, telling them that they did not realize what splendid fellows the Germans were."120 For the first weeks of the war, the self-mobilization of the German Bildungsbürgertum filled the gap left by a largely unprepared state propaganda apparatus.

Only in late September did the Foreign Ministry begin to take greater initiative in this field. At that point, the unregulated growth of makeshift propaganda offices as well as Germany's military misfortune at the Marne called for a more coordinated effort to explain the German war effort. The result was a transition from private to state-sponsored undertakings. On October 5, 1914,

118 Ernst Jäckh, Paul Rohrbach, et al., Truth about Germany: Facts about the War (New York, 1914), 43.

119 The literature on this subject is extensive. For a good introduction, see the essays in Wolfgang Mommsen, Kultur und Krieg: Die Rolle der Intellektuellen, Künstler und Schriftsteller im Ersten Weltkrieg (Munich, 1996); still seminal is Fritz Ringer, The Decline of the German Mandarins: The German Academic Community, 1890-1933 (Middletown, CT, 1990 [reprint]). For special appeals to the United States, see, for example, "Scientists Plead Germany's Cause: Professors Ask Universities of America to Stand by Kaiser," New York Tribune, Sep. 25, 1914, 3; Georg Kerschensteiner, "Offener Brief an meine amerikanischen Freunde," Süddeutsche Monatshefte (Oct. 1914): 120-221; Otto Hintze, "Unser Militarismus. Ein Wort an Amerika," Internationale Monatsschrift für Wissenschaft, Kunst und Technik 9, no. 4 (Nov. 1914): 209-220, 215; for a contemporary selection, see Hermann Kellermann, Der Krieg der Geister 1914 (Weimar, 1915).

120 Lamprecht cited in Harold Laswell, Propaganda Technique in the World War (New York, 1938), 24 . 
the Foreign Ministry incorporated Rohrbach's and Jäckh's bureau into a new Central Office for Foreign Services (Deutsche Zentralstelle für Auslandsdienst), which was to oversee all non-press-related propaganda directed at neutral countries. ${ }^{121}$ Staffed with bourgeois publicists and overseen by the Foreign Ministry, it pursued a prolific publishing strategy: between October 1914 and March 1918, the Central Office commissioned and distributed no less than 574 different publications, ranging from official German white books to novels and war pictorials. ${ }^{122}$ Even in 1917, when the British blockade had tightened considerably, it was still sending around 7,400 parcels a day to individuals, public libraries, clubs, and universities around the world. ${ }^{123}$

In the United States, the Central Office for Foreign Services worked closely with the German Information Office in New York City, an institution that the German embassy had set up in early September to be able to conduct German propaganda without implicating German envoys. ${ }^{124}$ Headed by Bernhard Dernburg, former state secretary of the Imperial Colonial Office, it was staffed with a more or less random group of German diplomatic personnel stranded in the United States and sympathetic (German-)American journalists. Receiving its instructions, material, and funds from the Wilhelmstrasse, it aimed to improve U.S. public sentiment toward Germany and to effect a harder American stance towards British blockade policies and munitions sales. ${ }^{125}$ The number of people involved in the German Information Office remained small, just as its understanding of mass psychology remained rudimentary and the transatlantic information flow patchy. Yet its establishment constituted a new level of governmental involvement in transatlantic propaganda. ${ }^{126}$ Within a few

121 On this office, see Jürgen Wilke, "German Foreign Propaganda in the United States during World War I: The Central Office for Foreign Services," in Propaganda in the 2oth Century, ed. Jürgen Wilke, 7-23.

122 Kunczik, Geschichte der Öffentlichkeitsarbeit, 146.

123 Jürgen Wilke, "Deutsche Auslandspropaganda im Ersten Weltkrieg: Die Zentralstelle für Auslandsdienst," in Pressepolitik und Propaganda: historische Studien vom Vormärz bis zum Kalten Krieg, ed. Jürgen Wilke (Cologne, 1997), 79-125, 93.

124 Bernstorff, Deutschland und Amerika, 33; an in-depth portrait of this group and their activities can be found in Johannes Reiling, Deutschland: Safe for Democracy? Deutsch-amerikanische Beziehungen aus dem Tätigkeitsbereich Heinrich F. Alberts, kaiserlicher Staatsekretär der Reichskanzlei, der Weimarer Republik, Reichsminister, Betreuer der Ford-Gesellschaften im Herrschaftsgebiet des Dritten Reiches 1914 bis 1945 (Stuttgart, 1997), esp. 166-195.

125 Bernstorff, Deutschland und Amerika, 39; Brewing and Liquor Interests and German Propaganda. Hearing before a Subcommittee of the Committee on the Judiciary United States Senate. Sixty-Fifth Congress Second and Third Session Pursuant to S.Res. 307 (Washington, 1919), 1392. 126 On the office's many problems, see Reinhold Doerries, "Promoting Kaiser and Reich: Imperial German Propaganda in the United States during World War I," in Confrontation and Cooperation: Germany and the United States in the Era of World War I, 1900-1924, ed. Hans-Jürgen Schröder, 135-166 (Providence, RI, 1993); for a contemporary perspective, see Horst Falcke, Vor dem Eintritt Amerikas in den Weltkrieg (Dresden, 1928), 251. 
months of the war, public diplomacy had become recognized as a significant policy field, especially in the "most important neutral country." ${ }^{127}$

Although Germany's wartime propaganda campaign had many new elements, it also drew heavily on prewar connections. ${ }^{128}$ In particular, it sought to activate transatlantic elite and ethnic networks through public appeals, lecture tours, and direct mail campaigns. With Germany's transatlantic telegraph cables cut, personal access to potentially sympathetic "multiplier" groups seemed to be its most promising alternative. Consequently, peacetime initiatives and networks were quickly expanded, centralized and - as far as possible - harnessed to Germany's wartime agenda. ${ }^{129}$ The Amerika-Institut, for example, essentially became part of the Foreign Ministry's newly established news department, functioning as a "news center for America." ${ }^{130}$ Just two weeks into the war, Friedrich Schmidt-Ott, the Prussian official in charge of the professorial exchange, was recalled from military service to instead take his place on the emerging propaganda front. Drawing on his contacts across the Atlantic, he now explained Germany's position to all professors and university presidents affiliated with the exchange program and encouraged former German exchange professors to follow suit. ${ }^{131}$ Scholars already present in the United States, like the economist Moritz Julius Bonn, were asked to promote German points of view, while others, like Eugen Kühnemann, were once more dispatched specifically for this purpose. ${ }^{132}$ Given their degree of patriotic elation and the widespread inter-

127 Abschrift zu UIK 33681 Amerika-Institut [R.W. Drechsler] to Minister der geistlichen und Unterrichts-Angelegenheiten, Nov. 20, 1914, PA R 64997; Eugen Kühnemann identified the United States as the propaganda war's main battlefield; Eugen Kühnemann, Mit unbefangener Stirn (Heilbronn, 1937), 238.

128 The New York Office published a daily German news service, covertly purchased and subsidized American periodicals, and used new technologies such as wireless telegraphy and film, albeit not always successfully, to overcome the constraints imposed by the British communications blockade. On the use of wireless telegraphy, see Evans, "The Path to Freedom"; in the spring of 1915 Berlin also established the American Correspondence Film Company to supply U. S. movie theaters with German war films and news reels; Reiling, Deutschland: Safe for Democracy?, 171. 129 Peter Grupp, "Vorraussetzungen und Praxis deutscher amtlicher Kulturpropaganda in den neutralen Staaten während des Ersten Weltkrieges," in Der erste Weltkrieg, Wirkung, Wahrnehmung und Analyse, ed.Wolfgang Michalka, 799-825 (Munich, 1994), 802.

130 Its job was to supply American news correspondents with information, provide regular analysis of American published opinion to German diplomats, and oversee the production of the Continental Times, an English-language paper distributed in Europe and the United States. The Continental Times was almost entirely funded by the German Foreign Ministry, which used the Amerika-Institut as a "cover address"; details in PA R 122219. For a very negative assessment of the Continental Times, see James Gerard, My Four Years in Germany (New York, 1917), 228.

131 Schmidt-Ott, Erlebtes und Erstrebtes, 113-114.

132 Moritz Julius Bonn, So macht man Geschichte (Munich, 1953); Abschrift Kühnemann (1914), NL Schmidt-Ott 411, GSPK. 
pretation of the war as a "great war of ideas," it took minimal state prodding to enlist scholars' moral and cultural authority for a state-sponsored propaganda campaign: ${ }^{133}$ they gladly edited war documents, authored popular pamphlets, issued public manifestos, went on lecture tours, and even initiated personal correspondence. ${ }^{134}$ In the single most (in-)famous of these efforts, ninety-three luminaries of German scholarship, literature, and art issued a public manifesto titled "To The Civilized World" on October 4, which refuted Allied accusations of German "war guilt" and civilian atrocities and - responding to Allied claims that German military and political leaders had forced the war upon the German people - aligned German culture with Germany's "so-called militarism." 135 Invoking German cultural achievements, the ninety-three asked the world to "trust in us" that "we shall carry on this war to the end as a civilized nation, to which the legacy of a Goethe, a Beethoven, and a Kant, is just as sacred as its own hearths and homes." And although the Foreign Ministry distributed the appeal around the world, its effect was hoped to be strongest once again in the United States.

The first few months of the war, then, witnessed a thorough politicization of the cultural sphere. German intellectuals were placed - or, more accurately, placed themselves - in the service of the nation's cause. This process, it should be noted, was neither uniquely German nor especially difficult: on the contrary, intellectuals easily reconciled their previous work for transatlantic understanding with that of wartime propaganda. ${ }^{136}$ In fact, they often saw it as

133 Eugen Kühnemann, Deutschland und Amerika. Briefe an einen deutsch-amerikanischen Freund (Munich, 1917), 13. Both the Manifesto of the 93 and the later Declaration of German Professors were, if not initiated, at least strongly encouraged by state officials; see Jürgen von Ungern-Sternberg, "Wie gibt man dem Sinnlosen einen Sinn? Zum Gebrauch der Begriffe 'deutsche Kultur'und 'Militarismus' im Herbst 1914," in Kultur und Krieg, ed. Wolfgang J. Mommsen, 7796, 90.

134 The historian Hermann Oncken explained to the Foreign Ministry that there was "no intellectual activity important to the war I would have refused to take on." Studt, "Geistiger Luftkurort," 381 .

135 An English translation is "To the Civilized World: By Professors of Germany," North American Review 210, no. 765 (1919): 284-287. On the manifesto, see Wolfgang von, and Jürgen von Ungern-Sternberg, Der Aufruf "An die Kulturwelt!": Das Manifest der 93 und die Anfänge der Kriegspropaganda im Ersten Weltkrieg (Stuttgart, 1996); and Bernhard vom Brocke, "Wissenschaft und Militarismus."'

136 French cultural institutes followed the same approach. See "Wissenschaft und Schule im Dienste der französischen Propaganda," Deutsche Arbeit 23, no. 11 (Aug. 1924): 283-288; on academic mobilization in other countries, see Tomás Irish, The University at War, 1914-25: Britain, France and the United States (London, 2015); Carol S. Gruber, Mars and Minerva: World War I and The Uses of Higher Learning in America (Baton Rouge, 1975). 
the logical continuation and "crowning act" of such efforts. ${ }^{137}$ The exigencies of the war first blurred, then collapsed, the already porous line between cultural diplomacy and propaganda. Since the cultivation of U.S. relations had always served political ends, this collapse seemed neither remarkable nor disconcerting to contemporaries. The war simply revealed the functional character that Germany's cultural campaign had possessed all along. The prewar policy of "gifts and gestures" was now expected to pay dividends.

\section{From German Culture to Kultur: Professorial Propaganda and Its Disappointments}

These expectations were to be disappointed. German propaganda never improved anti-German sentiment in the United States. While it did make the German viewpoint more widely known, it failed to resonate with a larger American public, including many of those more familiar with Germany. ${ }^{138}$ This had a lot to do with the quality of German propaganda. Whereas the British worked quietly and unobtrusively, German propaganda tended to be visible and brash, an impression only intensified by language barriers and German-American agitation. ${ }^{139}$ But it also reflected different German and American attitudes toward state authority and military intervention. ${ }^{140}$ Moreover, deep-seated cultural, political, and familial affinities for the Entente as well as U.S. disapproval of the invasion of neutral Belgium - not to mention German atrocities - limited the potential success of German propaganda from the beginning. ${ }^{141}$ While German Americans, in particular, supported Germany's cause, American elites proved largely unreceptive to German arguments.

137 Kühnemann. to Schmidt, Sep. 2, 1914, NL Schmidt-Ott 411, GSPK. Abschrift zu UIK 3368 1 Amerika-Institut to Minister der geistlichen und Unterrichts-Angelegenheiten, Nov. 20, 1914, PA R 64997.

138 Charles A. Elwood, "Germany and American Opinion," The Sociological Review 8 (1915): 106-111.

139 The German Information Bureau in New York, for example, consisted of a more or less randomly assembled group of amateurs who lacked the necessary experience and language skills for the difficult task ahead. See Reinhard Doerries, "Imperial Berlin and Washington: New Light on Germany's Foreign Policy and America’s Entry into World War I," Central European History 11, no. 1 (March 1978): 23-49, 28-33.

140 Fulwider has pointed to the "very real 'cultural divide' between German and Anglo-American perceptions of authority and opinion"; see Fulwider, German Propaganda and U.S. Neutrality in World War I, 52.

141 There is, in fact, evidence that Americans, well-versed in sensational press coverage, were skeptical about Belgian atrocity stories; but this never changed their disdain for Germany's willful violation of Belgian neutrality. As one well-known American journalist summed up: "We need not look for individual atrocities. Belgium herself is the capsheaf atrocity of this war." Irvin Cobb cited in Michael S. Neiberg, "Blinking Eyes Began to Open: Legacies from America’s Road to the Great War, 1914-1917," Diplomatic History 38, no. 4 (2014): 801-812, 803. 
But German outreach was not simply ineffective; it was counterproductive. This can be seen with regard to the two groups singled out by German propagandists: academic and ethnic circles. With regard to American professors, indeed, their drift into the Allied camp was only accelerated by the pronouncements of German scholars. ${ }^{142}$ Despite their critical stance toward the German government and military, few would have initially held Germany's respected culture responsible for its transgressions of civilized behavior. Like their British colleagues, many Americans originally adhered to a theory of "two Germanies," distinguishing the German people from the Prussian government and Germany's culture from its allegedly autocratic and militaristic political system. According to this widespread notion, there was one Germany of unabashed navy enthusiasm, of the Kaiser's boastful remarks, of stunted parliamentarization, of clicking heels and shiny helmets; and then there was another Germany of Goethe, Kant, and Beethoven, of pleasant university life, critical inquiry, admirable social reform, and a docile, peaceful people. Prussia's military and political leaders, many believed at first, had simply forced the war upon that "other Germany."143

Within a few months, however, German intellectuals' open alignment with the war effort had collapsed this distinction. For one, their professorial proclamations damaged them morally. By defending Germany's cause and its military conduct, these academics linked German culture to a military system that had invaded and occupied a defenseless neutral country, terrorized its civilian population, and drawn Europe into a terrible war. This explicit connection of Germany's admired cultural achievements to its despised "militarism" was deeply disturbing to many American scholars, who were used to scholars taking a more reserved position toward state power. Failing to understand that German academics aligned themselves with a "so-called German militarism" not because they were especially bellicose but because they felt it was their duty to testify to the German people's support of the war effort, Americans interpreted this as a "melancholy demonstration of the obscuration of $[\ldots]$ great intelligences under the spell of militarism!"144

Consequently, German culture was increasingly implicated in America's general rejection of the German war effort. American scholars were ever more inclined to believe French claims that German culture and militarism were not only compatible but intrinsically connected, and that German Kultur was actu-

142 Gruber, Mars and Minerva, 70.

143 The New York Evening Post exemplified this thought in an editorial, stating that the defeat of German militarism would lead to a liberation of Germany's cultural sphere; see Kellermann, Der Krieg der Geister 1914, 22-23.

144 Frank Jewett Mather, "Eucken and Haeckel: Sad to See Them Sink to the Level of Chauvinists," New York Times, Sep. 12, 1914, 8; on the motives of German scholars, see Ungern-Sternberg and Ungern-Sternberg, Der Aufruf "An die Kulturwelt!," 65. 
ally embedded in an inherently aggressive and expansionist German mentality and, as such, constituted a serious threat to world peace. ${ }^{145}$ German thought from an older and nobler era (represented by Goethe and Kant, for example), they argued, had since been replaced by a newer, militaristic philosophy influenced by Friedrich Nietzsche, Heinrich von Treitschke, and Friedrich von Bernhardi, who had all preached that "might is right" and led Germany away from Western traditions. Within this perspective, the mutilation of Belgian women and children, as well as the destruction of cultural artifacts, libraries, and churches, had not taken place despite German culture but because of it. ${ }^{146}$ In short, while German scholars had wanted to use their moral capital to elevate the German military effort, their unconditional alignment with the military's conduct, in fact, dragged German culture down.

These propagandist efforts also damaged German scholars academically. As ethically disturbing as the substance of their claims might have seemed to Americans, German scholars aroused the most indignation because of the uncritical spirit with which they repeated their government's pronouncements. Known the world over for their attention to detail and their tiresome erudition - in short, known to base the smallest insight on a mountain of evidence - German scholars were now asking the outside world to "believe," to "have faith," to "trust" in their statements simply because they stood in the intellectual tradition of Kant, Beethoven, and Goethe. To many American scholars, the manifestos, with their strong claims, apodictic rhetoric, and lack of evidence, violated the principles of sound scholarship and detached critical inquiry for which German scholarship had long been revered. ${ }^{147}$ Worse still, many Americans saw this propaganda as dismissing their own intellectual capacities. German scholars' claim that they ought to be believed because of their proven contributions to science and culture, not because they were making a persuasive, evidence-based argument, seemed to impose a standard on Americans that Germans would never have accepted for themselves. ${ }^{148}$ Perhaps German appeals would not have provoked such opposition had Americans

145 On French scholars, see Martha Hanna, The Mobilization of Intellect: French Scholars and Writers during the Great War (Cambridge, MA, 1996), 75; Robert Norton, "Wilamowitz at War," International Journal of the Classical Tradition 15, no. 1 (2008): 74-97, 90; Gerd Krumeich, "Ernest Lavisse und die Kritik an der deutschen 'Kultur, 1914-1918," in Kultur und Krieg, ed. Mommsen, 143-54, 153.

146 George Trumbull Ladd in the Times, Nov. 21, 1914, reprinted in Sixty American Opinions on the War, ed. Samuel Harden Church, 100-103 (London, 1915), 103.

147 John Grier Hibben to New York Times, Nov. 24, 1914, reprinted in Sixty American Opinions, ed. Church, 87-88.

148 "German Professors Insult American Intelligence Says Albion W. Small," Chicago Daily Tribune, Jan. 10, 1915; for very similar perspectives, see Edgar Ewing Brandon, "German Propaganda Answered: Dean Edgar Brandon of Miami University Resents Its Slight Upon American Intelligence," New York Times, Jan. 13, 1915, 8; and Peabody to Schmidt, Oct. 20, 1914, NL Schmidt-Ott 420, GSPK. 
not long sensed German condescension in their transatlantic dealings. But as things stood, they appeared to be yet another instance of German arrogance and further antagonized American scholars. ${ }^{149}$

While we ought to be careful not to mistake German propaganda as the source of anti-German sentiment - the roots of this alienation go much further back ${ }^{150}$ - the onslaught of German letters and manifestos hastened the process of intellectual disassociation from German scholarship among American academics. ${ }^{151}$ The Manifesto of the 93, in particular, became so famous because it offered Americans an opportunity to air longer-standing grievances about German feelings of superiority and, no less important, provided them with a psychologically important excuse for their position toward a country to which they were bound by so many personal and professional ties. ${ }^{152}$ A survey of American scholars taken in early 1915 shows how pervasive this intellectual disassociation was: only about 6-percent of American scholars were sympathetic to the German cause, and on the Eastern seaboard, where acquaintance with Germany tended to be greatest, only 3.4-percent were. ${ }^{153}$ While a small number of American scholars kept up correspondence with their German peers after 1914, American academia had largely begun to drift into the Allied camp. ${ }^{154}$

These developments occasioned a major disruption in transatlantic academic relations, which would have wide-ranging implications for the 1920 s. To German scholars, American reactions came as a shock. Because they had hoped for at least "honest neutrality" once Americans were informed of the "truth about the war," the hostile responses were frustrating, ${ }^{155}$ especially in light of the strenuous efforts they had made in previous years. Indeed, in light of their own "devoted and selfless" cultivation of American goodwill, as Eduard Meyer called it, and persistent notions of a transatlantic teacher-student relationship, German professors deemed the rejection of their arguments nothing

149 Elwood, "Germany and American Opinion," 107.

150 These developments are summed up in Jörg Nagler, "From Culture to Kultur: Changing American Perceptions of Imperial Germany, 1870-1914," in Transatlantic Images and Perceptions: Germany and America since 1776, ed. David E. Barclay and Elisabeth Glaser-Schmidt, 131-154 (New York, 1997).

151 Reinhard Doerries has noted that "the manifesto [...] merely contributed to the growing cultural estrangement of the Germans from the rest of Europe and North America." Doerries, Promoting Kaiser and Reich, 143.

152 Gruber, Mars and Minerva, 46.

153 Falcke, Vor dem Eintritt Amerikas in den Weltkrieg, 251-252.

154 Tomás Irish, "From International to Interallied: Transatlantic University Relations in the Era of the First World War, 1905-1920," Journal of Transatlantic Studies 13, no. 4 (Nov. 2015): 311325.

155 Meyer, Die Vereinigten Staaten von Amerika, 259. 
short of ingratitude, even an insult. ${ }^{156}$ The dividends of German cultural investments in the United States seemed utterly disappointing.

The lessons Germans drew from this experience were often radical: they would have to cease all efforts to win the American public immediately and never take them up again. Had German observers hitherto believed that American antipathy stemmed merely from misinformation created by English propaganda - in other words, that Americans were only to blame for their gullibility - they now attributed American hostility to the cultural predominance of Anglo-Americans and a fundamental and irreconcilable dissimilarity of the German and American character. ${ }^{157}$ Germany's prestige, a vocal group of professors argued, had only suffered from its courtship of the United States, which had proved fruitless as demonstrated by the wartime animosity at Columbia and Harvard. ${ }^{158}$ Under these circumstances, the professorial exchanges, which had been temporarily halted at the outbreak of the war, finally collapsed. Though U.S. universities expressed their desire to continue them throughout 1915, the Prussian Ministry of Culture now wished to sever relations with such ungrateful institutions to preserve German dignity. ${ }^{159}$ More conciliatory positions, such as those of church historian Adolf von Harnack or economist Moritz Julius Bonn, were marginalized in a climate in which the predominant view was that the German universities should be closed to foreigners altogether. ${ }^{160}$ By January 1915, the prevailing opinion among German scholars was that "whoever is with us should have loyalty for loyalty and, as far as we are concerned, all the rest can go to hell." ${ }^{161}$

At this point, both sides felt that the decade-long experiment in cultural exchange had failed. In Germany, scholars' feelings of indignation and resent-

156 Eduard Meyer, Leipziger Illustrierte Zeitung, Feb. 18, 1915, reprinted in Eduard Meyer, Nordamerika und Deutschland, 9-10 (Berlin, 1915); Ludwig Fulda, Amerika und Deutschland während des Weltkrieges (Leipzig, 1916), 19-20.

157 In terms of lifestyle, norms, and language, the United States had remained a "British cultural colony," and political and institutional sympathy for England and cultural predilections for French art, design, and fashion were blamed for America's siding with the Allies; see Fulda, Amerika und Deutschland, 22; a similar perspective is Hermann Oncken, "Deutschland, England und Amerika. Historisch-politische Betrachtungen über den Kampf in der öffentlichen Meinung," Internationale Monatsschrift für Wissenschaft. Kunst und Technik 9, no. 7 (Feb. 1915): 537$562,541$.

158 See "Selbstachtung vor den Neutralen!," Süddeutsche Monatshefte (Dec. 1914): 415.

159 Schmidt-Ott to Wilhelm II, Nov. 8, 1914, I HA Rep 8913367 Förderung der geistigen Beziehungen zu Amerika, Vol.3, 1914-1916, GSPK; Schmidt-Ott to Dobschütz, June 17, 1915, NL Schmidt-Ott 420, GSPK.

160 On these moderate voices, see Nottmeier, Adolf von Harnack und die deutsche Politik, 399; Schmidt(-Ott) to Bonn, Aug. 11, 1915, NL Schmidt-Ott 420, GSPK; on the increasingly radical solution, see Clipping: Prof. Dr. Conrad Bornhak, "Das Ausländertum an den deutschen Hochschulen, “ Der Tag, June 15, 1915, I HA Rep 8913367 Förderung der geistigen Beziehungen zu Amerika, Vol. 3, 1914-1916, GS PK.

161 See “Selbstachtung vor den Neutralen!," Süddeutsche Monatshefte (Dec. 1914): 415. 
ment would interfere with resuming relations after the war. More fatal in the short run, their public rejection left them with the impression that America was not a truly neutral power. ${ }^{162}$ Before long, even former exchange professors, who should have been better at gauging America's industrial strength, seconded military voices that belittled American military potential and advocated unrestricted submarine warfare at the risk of drawing America into the war. ${ }^{163}$ In the United States, German intellectuals' public alliance with a military effort responsible for many alleged and real war crimes helped discredit German culture even among Americans who had long held it in high esteem. Just months into the war, many long-standing transatlantic ties had been severed and great emotional and psychological obstacles had been raised to renewing them. When on May 7, 1915, a German submarine sank the British passenger liner Lusitania with about 1,200 civilians, including 120 Americans, on board, American cartoonists pictured drowning women and children torpedoed by German "Kultur." Within less than a year of the war's outbreak, respected German culture had become "Kultur" - and, as such, part of the "German problem."

Fig. 4: "As the World Sees It,"

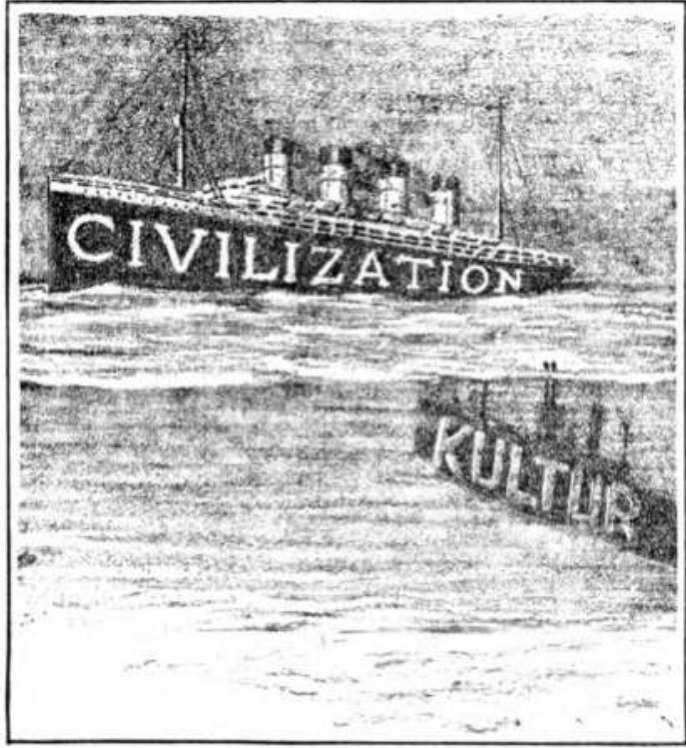

AS THE WOH.D SEES IT. Literary Digest, May 22, 1915

- Sykes in the Phlladelphia Evening Ledger.

162 Stresemann's take on this is in Verhandlungen des Deutschen Reichstags, Apr. 6, 1916, $868 \mathrm{~A}$.

163 Klaus Schwabe, Wissenschaft und Kriegsmoral. Die deutschen Hochschullehrer und die politischen Grundfragen des Ersten Weltkrieges (Göttingen, 1969), 121-123; Reiling, Deutschland: Safe for Democracy?, 74. 


\section{German Americans in the Middle}

However, it was with regard to German Americans that German propaganda would prove most detrimental. Once their broader U.S. appeal had failed, German propagandists redoubled their efforts with German Americans. The war had initially inspired a resurgence of ethnic feeling among this group. ${ }^{164}$ In larger American cities, they staged parades, waved German flags, and held demonstrations in support of the fatherland. As early as August 3, the National German-American Alliance had established a "literary defense" campaign to oppose the "lies" spread about Germany, and shortly thereafter the young German-American poet George Sylvester Viereck began publishing the English-language weekly The Fatherland to champion the German cause. ${ }^{165}$ While we should not confuse the militant positions of ethnic leaders with those of the "average" German American, even many who had shown little regard for ethnic activities, let alone Germany's political leadership, felt compelled to defend their old fatherland against the charges of barbarism leveled against it and, indirectly, against themselves. ${ }^{166}$ The circulation of German-language newspapers rose impressively as German Americans sought news less tainted by what they considered a pro-Allied bias, and The Fatherland (aided by German subsidies) soon reached a circulation of 100,000. ${ }^{167}$ Ethnic leaders, for their part, embraced the fight for "fair play" and an arms embargo as a chance to "revitalize a disintegrating ethnic community." 168

German propagandists were delighted to encourage these developments. From August 1914 onwards, a substantial part of German propaganda targeted German Americans. ${ }^{169}$ After the sinking of the Lusitania, especially, Germany's shrinking access to mainstream American society reoriented its efforts toward

164 Don Heinrich Tolzmann, "The Survival of an Ethnic Community: The Cincinnati Germans, 1918 through 1932" (PhD diss., University of Cincinnati, 1983), 120.

165 The proclamation of the National German-American Alliance can be found in Karl Jünger, Deutsch-Amerika Mobil (Leipzig, 1915), 67.

166 There is still considerable uncertainty about the position of the majority of German Americans. Luebke has surmised that "it is even possible that a majority of persons of German stock in the United States in 1914 were either indifferent to the war in Europe or actually hostile to the German government in its goals"; Luebke, Bonds of Loyalty, 88. Henry J. Schmidt has noted that "after 1914, the German-American community was split essentially into four camps: the pro-Germans, the pro-Americans, the neutralists (out of religious conviction or the desire for anonymity) and the socialists, who opposed the war from the start as a manifestation of capitalistic imperialism." Henry J. Schmidt, "The Rhetoric of Survival: The Germanist in America from 1900 to 1925," in America and the Germans, ed. Trommler and McVeigh, 2:204-216, 209.

167 Wüstenbecker, Deutsch-Amerikaner im Ersten Weltkrieg, 55.

168 Luebke, Bonds of Loyalty, 96.

169 As early as September 1914, Hermann Oncken was put to the task of writing a greeting to German Americans to be published as the sixth volume in a series of propaganda brochures edited by Ernst Jäckh: Hermann Oncken, Deutschlands Weltkrieg und die Deutschamerikaner: Ein Gruß des Vaterlandes über den Ozean (Stuttgart, 1914). 
pro-German, or at least anti-Allied, ethnic groups, including those of German, Irish, and Jewish descent. ${ }^{170}$ The exigencies of the war only deepened earlier misconceptions about German Americans. German propagandists systematically overestimated the unity, influence, and commitment of "Germans" in the United States. ${ }^{171}$ In some German minds, the war had transformed a highly diverse ethnic group into a "powerful entity" and a "force to be reckoned with" that could be used to keep the United States neutral. In one reckless moment, Eugen Kühnemann confided to Friedrich Schmidt-Ott that "Americans will have to learn to fear German Americans." ${ }^{172}$ In reality, of course, the initial ethnic unity had already fractured into a multitude of different opinions, and after the sinking of the Lusitania many German Americans fell silent, no longer defending their old fatherland. ${ }^{173}$ Above all, most German Americans had neither the authority nor the visibility to effectively champion Germany's position. The German-language press found few readers among "Anglo-Americans," and English-language periodicals like The Fatherland were so militantly partisan that they began to discredit rather than advertise German positions.

More fatefully still, many German propagandists continued to harbor an astonishing lack of regard for the sensitivities of a multiethnic society. In their thinly veiled political hopes in German Americans, their repeated intimations that German Americans might physically oppose American belligerence, ${ }^{174}$ and their contention that Americans "would have to learn to fear German Americans," they ignored - despite numerous warnings on both the German and American sides ${ }^{175}$ - how detrimental such insinuations of ethnic disloyalty could be. As they had before 1914, they also failed to understand that cultural and political loyalties could not be neatly separated in an increasingly nativist America. As Ambassador Bernstorff summed up, looking back in 1920, "already before the war we lacked a true understanding of the awkward position

170 Reiling, Safe for Democracy?, 177; Falcke, Vor dem Eintritt Amerikas, 19.

171 As scholars have shown, "the German perception of a large body of well-organized Germans in America who could rise up in support of the goals of the Fatherland and maintain American neutrality was a creation of German officials' imaginations. In reality, Germans in America were fragmented along multiple lines, such as community size, region, religion, politics, class, time of immigration, generation and family connection." Fulwider, "The Kaiser's Most Loyal," 151; for contemporary examples, see Oncken, Deutschlands Weltkrieg und die Deutschamerikaner, 12; Jünger, Deutsch-Amerika Mobil, 4.

172 Kühnemann to Schmidt(-Ott), Feb. 61915, NL Schmidt-Ott 411, GSPK.

173 Frank Trommler, "The Lusitania Effect: America’s Mobilization against Germany in World War I," German Studies Review 32, no. 2 (2009): 241-266, 247.

174 Jünger, Deutsch-Amerika Mobil, 141-155.

175 Under State Secretary Arthur Zimmermann had felt it wise to suggest to Ambassador Gerard that the 500,000 German reservists in the United States might rise up in the event of an American declaration of war. The American ambassador (allegedly) responded that in that case, there would surely be 500,001 lampposts in the United States; see Gerard, My Four Years in Germany, 173-174. 
of Americans of German descent. This was all the more the case during the war. At all times the question of 'German Americans' was not handled tactfully. In particular, expectations in them were too high." ${ }^{176}$ Throughout the war, many Germans cultivated a way of thinking about German Americans that was bound to raise unrealistic expectations - and American suspicion.

This German disregard for ethnic sensibilities unleashed a profound backlash against German influence. The sinking of the Lusitania added momentum to the U.S. preparedness campaign, which called for vigilance against the "German menace" at home and abroad. ${ }^{177}$ None other than former president Theodore Roosevelt, with an honorary doctorate from the University of Berlin, at one point told an audience that "Germany has habitually and as a matter of policy practiced the torture of men, the rape of women and the killing of children." ${ }^{178} \mathrm{~A}$ sensational exposé of Germany's covert activities in the New York World in the summer of 1915 only deepened American resentment. Though many of the activities it disclosed - such as the purchase of American newspapers - were not technically illegal, Americans did not regard them as legitimate for a friendly foreign power. ${ }^{179}$ Against the backdrop of German submarine warfare and acts of sabotage and terrorism on American soil (at Black Tom Terminal in New York in July 1916 and a New Jersey factory in January 1917), anti-German hysteria soared. ${ }^{180}$ In the process, Germany's clumsy opinion-shaping attempts came to be seen as a vast German plot and German Americans as imperial agents on American soil. ${ }^{181}$ In the escalating rhetoric of the 1916 presidential election, the "hyphen" in the identity of this group had already become tantamount to treason.

Though neither German hopes nor American fears about German-American disloyalty were justified, America's entry into the war on April 6, 1917, unleashed a crusade against "German Kultur" at home and abroad. While Pres-

176 Bernstorff, Deutschland und Amerika, 20.

177 According to Trommler, the sinking of the Lusitania set off three broader developments: 1) it led Americans to see Germany as a military threat; 2) it sparked an increasingly hysterical, violent reaction against German Americans; and 3) it was an important marker of American mobilization for national unity; Trommler, "The Lusitania Effect," 241-242.

178 Steward Halsey Ross, Propaganda for War: How the United States Was Conditioned to Fight the Great War of 1914-1918 (Jefferson, 1996), 177.

179 Fulwider, German Propaganda and U. S. Neutrality, 124.

180 Doerries, Berlin-Washington, 62.

181 British propaganda, for its part, fueled American hysteria with sensational publications like Frederic William Wile's "The German-American Plot," which depicted German propaganda as a vast, formidably organized conspiracy determined to use "hyphenated Americans" for its sinister plans; see Frederic William Wile, The German-American Plot: The Record of a Great Failure (London, 1915). 
ident Wilson had initially declared that he had "no quarrel with the German people," the tidy distinction between the government and the public, between politics and culture, soon collapsed. German Americans bore the brunt of American indignation. ${ }^{182}$ As the suspicion, distrust, and hostility that had begun to emerge in August 1914 came to the fore, German ethnic organizations and individuals that did not disavow their transatlantic connections quickly found themselves subject to boycotts, denunciations, and even violent attacks. Federal legislation censored or shut down the German-language press, and individual states forbade the teaching and even the public use of the German language. Most German ethnic clubs suspended their activity for the duration of the war, and often for good. Individually, German Americans sought to shed their cultural markers: they stopped using the German language, abandoned their associational life, and changed their names. While the war only accelerated an already far-advanced process of assimilation, the experience was traumatic, nonetheless.

But World War I also systematically rid the United States of nonethnic expressions of German Kultur. Universities purged their departments of alleged pro-Germans, public libraries removed the works of Johann Wolfgang von Goethe, Gerhart Hauptmann, and Friedrich Schiller, and concert halls no longer played German music. ${ }^{183}$ The Deutsches Haus at Columbia was fittingly re-dedicated as Columbia House, a center for Americanization. Americans seemed to be following the rule that "we disapprove of the Kaiser and his projects. Therefore we punish him by snubbing Beethoven [...]"; and although some recognized the absurdity of this position, the "eradication of German culture" in the United States could not be stopped. ${ }^{184}$ Indeed, this backlash was more severe in the U.S. than in other countries on account of the distinct menace German culture was believed to pose to America as a multiethnic society, the demands of mobilizing that reluctant society for war, and the widespread perception that the war constituted a moment of emancipation from German traditions. ${ }^{185}$ On this basis, George Creel's Committee for Public Information staffed with alumni of German universities - successfully recast Kultur as the

182 For German-American postwar frustrations about this development, see New Yorker Staats-Zeitung, Oct. 11, 1920, cited in Wiedemann-Citera, Die Auswirkungen des Ersten Weltkriegs auf die Deutsch-Amerikaner im Spiegel der New Yorker Staatszeitung, der New Yorker Volkszeitung und der New York Times 1914-1926 (Frankfurt, 1993), 243.

183 For a detailed summary of these measures, see Wüstenbecker, Deutsch-Amerikaner im Ersten Weltkrieg, 245-304.

184 Quoted in Trommler, "The Lusitania Effect," 251; for a dramatic account of these developments, see Erik Kirschbaum, Burning Beethoven: The Eradication of German Culture in the United States during World War I (New York, 2015).

185 See also Frank Trommler, "Inventing the Enemy: German-American Cultural Relations, 1900-1917," in Confrontation and Cooperation, ed. Hans-Jürgen Schröder, 99-126; comparative studies are still lacking; one recent exception is Panayi, ed., Germans as Minorities during the First World War. 
very antithesis of the American war effort. ${ }^{186}$ In the end, it was neither Germany nor the United Kingdom but rather the United States that proved to be the true master of World War I propaganda.

With the American entry into the war, Wilhelmine Amerikapolitik had ended in resounding failure. The campaign for American hearts and minds, which had begun fifteen years earlier, had not only failed to meet its objectives; it had clearly aggravated the situation. The alignment of cultural and military power and the attention paid to German Americans had amplified apprehensions about a German menace at home and abroad, ultimately unleashing a massive backlash against German Kultur, ethnic or otherwise. On both sides of the Atlantic, the period of U.S. neutrality left behind a trail of disappointments and injured feelings that would complicate cultural demobilizations in the 1920s. Above all, for perceptive observers, it demonstrated the futility of a German policy that was built on "gifts and gestures" but was unwilling to truly accommodate U.S. interests. All pronouncements of transatlantic respect aside, America remained little understood and esteemed in Berlin. Nowhere was this more apparent than in the decision to resume unrestricted submarine warfare (albeit against the massive opposition of the chancellor and German diplomats), as well as in the infamous Zimmermann Telegram shortly thereafter. ${ }^{187}$ As one American had already observed on the occasion of Prince Heinrich's visit fifteen years earlier, gestures of goodwill had a limited political effect because, in the end, "wars are not made or unmade by such things as personal visits." 188 As the Germans began to realize in 1917, it was not only German public diplomacy that needed reforming, but its foreign policy in general.

186 For the propaganda contribution of (German-educated) American academics, see George T. Blakey, Historians on the Homefront: American Propagandists for the Great War (Lexington, 1970); in the war's single most widely circulated propaganda pamphlet, "How the War Came to America," printed in a circulation of six million copies and eight languages, America's entry into the war was attributed to Germany's indefensible behavior, which had "with a fanatical faith in the destiny of German kultur as the system that must rule the world [...] through years of boasting, double dealing, and deceit tended toward aggression upon the rights of others," 15; on that particular publication, see George Creel, How We Advertised America (New York, 1920), 455. 187 There were, of course, also many voices that clearly saw the consequences of unrestricted submarine warfare. For a precise prediction of its consequences, see "Aufzeichnung Kurt Riezlers zur Frage des U-Bootkrieges," in Kurt Riezler, ed. Karl Dietrich Erdmann, 488-491.

188 "War Is Coming," Boston Daily Globe, Jan. 18, 1902, 6. 


\section{The German Propaganda Debate and the Foreign Ministry Reforms, 1917-1921}

From the history of our neighbors we can learn how well the art of disguising real political motivations beneath a cloak of smart words and beautiful appearances has been learned on the banks of the Seine, the Thames, even the Neva. As a wise Greek man once observed, people are moved less by the things themselves than by their opinions about these things. And often it is not truth that rules the world, but the appearance of truth. The Realpolitiker in particular knows of the great importance of emotions in international affairs, knows what great weight the imponderables have, which, as Count Bismarck remarked on February 6, 1888, weigh heavier, much heavier, than material things. ${ }^{189}$

(Bernhard von Bülow, Deutsche Politik, 1916)

Germany's botched propaganda campaign prompted a renewed public debate about the country's international representation. Beginning in late 1916 and lasting through the early 1920s, a series of internal memoranda and public pamphlets alike set out to reconfigure the place of public diplomacy in German foreign affairs in the face, first, of wartime failures, and then of defeat and of a humiliating peace. During the course of the debate, criticism of German propaganda operations converged with a more fundamental critique of how German foreign policy was conducted. The result was the most profound reform of the German Foreign Service in the twentieth century and a clear commitment to a concerted and state-directed public diplomacy even beyond the end of the war.

The debate on German public relations, which had gained momentum in the prewar years, resurfaced in 1916 when the endless Verdun campaign eroded patriotic self-censorship and raised broader questions about the German war effort. ${ }^{190}$ Trying to understand why Germany had lost the battle for international opinion, liberal publicists and politicians initially focused on prewar sins of omission. Most of these critics believed that Allied propaganda successes after 1914 were fostered by longer-standing German deficiencies. ${ }^{191}$ Whereas England and France had long prepared the ground with press and cultural policies, the German government, a German newspaper argued in late 1916, had

189 Bernhard von Bülow, Deutsche Politik (Berlin, 1916), 346.

190 On the development of German public opinion toward the war effort, see Wolfgang Mommsen, "Die Regierung Bethmann Hollweg und die öffentliche Meinung, 1914-1917," Vierteljahreshefte für Zeitgeschichte 17, no. 2 (Apr. 1969): 117-159.

191 "Auslandspresse und Auslandskorrespondenten," Süddeutsche Monatshefte (Nov. 1915): 268-70; Rohrbach, Memorandum to Foreign Ministry, June 1915, reprinted in Rohrbach, Woher es kam, 18-31. 
failed to advertise German traits and positions to the world and to cultivate that "predisposition of the heart" among foreign peoples that could translate into "commercial trust" and "diplomatic sympathies" in times of need. "The war," it concluded, had shown "that it was but a step from ignorance to mistrust, from mistrust to hostility." ${ }^{192}$ In a similar vein, National Liberal Party politician Gustav Stresemann would attribute the breakdown of diplomatic relations with the United States to this kind of public relations failure a few months later. ${ }^{193}$ After 1916, German isolation and even American belligerence were increasingly blamed on what Germany had failed to do in the field of public relations.

Importantly, those most intimately acquainted with German propaganda efforts doubted that the war had changed this state of affairs. While it was true that official and unofficial propaganda operations had grown by leaps and bounds, it was a different question altogether whether this had improved its quality. As early as March 1915, publicist Paul Rohrbach, a member of the Central Office for Foreign Services, had submitted a memorandum to the Foreign Ministry that characterized German efforts as "perfect disorganization." If someone had intended "to organize Germany's entire international opinion-shaping efforts $[\ldots]$ as inappropriately and as ineffectively as possible," Rohrbach concluded, he could hardly have done a better job. ${ }^{194}$ This situation only deteriorated as the war progressed. Private enterprise, interministerial turf battles, and rising tensions between the military and civilian leadership led to a duplication, even a contradiction, of efforts. By late 1916, Chancellor von Bethmann-Hollweg realized that the Foreign Ministry's approach to propaganda had to be reformed. Though crumbling domestic morale provided the initial impetus for reform, the deficiencies of Germany's international propaganda figured prominently in the ensuing reorganization process. In a detailed memorandum of December 1916, Erhard Deutelmoser, the director of the Foreign Ministry's news department, underlined the need to centralize all propaganda in the hands of the Foreign Ministry and called for a more comprehensive approach to German image-building. ${ }^{195}$ In line with public criticism, Deutelmoser also identified "the diligent cultivation of international cultural relations [as] the most influential diplomatic groundwork" for the enemies' wartime propaganda successes and, accordingly, as Germany's particular weakness. ${ }^{196}$

192 Clipping: "Ein Fortschritt deutscher Kulturpolitik," Weser Zeitung, Oct. 28, 1916, PA R 121333.

193 Gustav Stresemann, Verhandlungen des Deutschen Reichstags, Bd. 309, 85. Sitz. 2470B.

194 Rohrbach, Woher es kam, 17-18; scholars have agreed with this impression; see Grupp, "Vorraussetzungen und Praxis deutscher amtlicher Kulturpropaganda," 803.

195 Deutelmoser, "Über Nachrichten- u. Pressedienst des Auswärtigen Amtes," Dec. 3, 1916, partly reprinted in Vogel, "Die Organisation der amtlichen Presse und Propagandapolitik," 8891.

196 Grupp, "Vorraussetzungen und Praxis deutscher amtlicher Kulturpropaganda," 808. 
Based on Deutelmoser's suggestions, Foreign Secretary Arthur Zimmermann initiated a twofold reorganization process in early 1917. First, he introduced a division for cultural propaganda at the Central Office for Foreign Services to cultivate German cultural relations with otherwise propaganda-weary neutral audiences. Secondly, he centralized most of German public diplomacy - including the Central Office for Foreign Services - in the Foreign Ministry's news department, where newly opened geographical desks were to bring the processes of policymaking and policy communication into closer alignment. ${ }^{197}$ Unlike in other countries, the German Foreign Ministry thus defended its claim to leadership in this emerging policy field. ${ }^{198}$ While its control was by no means exclusive, it had concentrated a significant deal of authority and resources in its hands by $1918:{ }^{199}$ it was in charge of most international propaganda, including press matters, news agencies, telegraph and wireless communication, the distribution of film, pictorial, and print material, as well as economic and cultural propaganda. From around 1900 to 1918 , the news department increased its staff from about four to more than 400, clearly indicating the growing recognition that public opinion constituted a key factor in modern foreign relations. ${ }^{200}$

While these steps expressed new attention to the "imponderables of foreign relations," they did not placate more determined critics. Long-standing associates of official propaganda like Paul Rohrbach and Ernst Jäckh felt that such reforms failed to address its most fundamental problem, namely, that Germany simply engaged in the wrong kind of propaganda. By 1917, Germany's leadership had still not developed a compelling vision of its cause that would have allowed it to capture the hearts and minds of the neutrals. Whereas British propagandists had managed to turn the fate of "poor little Belgium" into an international cause célèbre, German officials had never understood foreign psychology or the power of ideas and emotions. As Rohrbach and Jäckh charged, they made arguments about encirclement and military necessity that had little emotional or moral sway over neutrals and failed to exploit prime "opportunities" to this end, like German civilian suffering under the British "hunger

197 It became the section on book, brochure, and cultural propaganda; see "Vorläufige Geschäftsordnung," BArch R 901/71001.

198 In Great Britain, the Ministry of Information was established in February 1918, and in the United States the Committee on Public Information was established in 1917; by contrast, German propaganda efforts were never united under one roof.

199 Ute Daniel, "Die Politik der Propaganda. Zur Praxis gouvernmentaler Selbstrepräsentation vom Kaiserreich bis zur Bundesrepublik," in Propaganda, ed. Ute Daniel and Wolfram Siemann, $44-82,55$.

200 These figures can be found in Hans Jürgen Müller, Auswärtige Pressepolitik und Propaganda zwischen Ruhrkampf und Locarno, 1923-1925. Eine Untersuchung über die Rolle der Öffentlichkeit in der Außenpolitik Stresemanns (Frankfurt, 1991), 32. 
blockade." ${ }^{201}$ Even as the impact of international opinion was duly recognized, Berlin seemed no closer to influencing it. Indeed, by tightening ministerial oversight, the reforms seemed only to aggravate earlier deficiencies by placing this line of work in the hands of men who lacked a feeling for mass psychology - and refused to listen to those who did have one. ${ }^{202}$ In the Foreign Ministry, experienced publicists like Rohrbach and Jäckh found themselves relegated to writing press digests. Their advice, like warning about the devastating impact that the resumption of unrestricted submarine warfare would have on American opinion, seemingly went unheard and unheeded by policymakers. For many involved, the ministerial reorganization of 1917 did not even begin to solve the true problem of German public relations. Consequently, both Jäckh and Rohrbach used the occasion to resign from the German propaganda effort.

By mid-1917, then, the debate over Germany's botched propaganda campaign was turning increasingly into a more profound critique of German foreign policymaking; it converged with debates on the democratization of German politics. Diplomatic blunders like the Zimmermann Telegram or the Luxburg Affair of a similar nature (which almost brought neutral Argentina into the war) in 1917 once again illustrated not just the deficiencies of "propaganda" in a narrow sense but also German leaders' ineptitude at gauging the international public repercussions of their actions. In the summer of 1917, when Germans' high hopes in unrestricted submarine warfare proved unfounded, liberal publicists, scholars, businessmen, and politicians began to call for more fundamental reforms. Faced with the disastrous results of a policy decision many of them had advised against, they demanded an overhaul of the institutions, individuals, and mentalities shaping German foreign policy. If German foreign policy seemed at times to go dangerously amiss, they argued, then German diplomats' traditional education and aristocratic background was, not least, to blame. As the free conservative Dr. Rewoldt concluded in the Prussian parliament: "the present war has shown appallingly just how grossly mistaken especially our leading circles have been about the assumptions and character of foreign peoples, namely England and America, so that we have exposed ourselves to very considerable and often far-reaching disappointment." ${ }^{203}$ The more America threw around its economic and military weight - that is, the

201 See Matthias Erzberger, Erlebnisse im Weltkrieg (Stuttgart, 1920), 8; and Bernstorff, My Three Years in America, 45-46.

202 Rohrbach to Ballin, Mar. 1915, cited in Kloosterhuis, Friedliche Imperialisten, 439n6; on these frustrations, see also Gärtner, Botschafterin des Guten Willens, 39-40; Moritz Julius Bonn, who was recruited into the press department for some time after his return from the United States, spent "the most useless months of my life" there; Bonn, So macht man Geschichte, 170.

203 See Dr. Rewoldt in "Die Auslandsstudien im preussischen Landtag," Internationale Monatsschrift für Wissenschaft, Kunst und Technik 11, no.7 (Apr. 1917): 769-820, 816-817; in a similar vein, Rohrbach later concluded that "of all our underestimations of our enemies, the underestimation of the Americans has been the most fateful. [...] That we did not realize how much of 
more flawed initial assumptions about American weakness turned out to be the more these voices gained currency.

By the last year of the war, this mounting criticism could no longer be ignored. ${ }^{204}$ In part to placate the growing number of critics, the Foreign Ministry's new state secretary Richard von Kühlmann solicited the suggestions of the Hanseatic shipping and export industry concerning the reorganization of the German foreign service. The "Hamburg Memorandum" of April 1918 bundled long-standing criticism and demands: that German diplomacy neglected "world economic policy"; that its organizational and conceptual principles were outmoded; and that an almost exclusive regard for "high politics" barred individuals with economic acumen from the ranks of the diplomatic corps and precipitated a dangerous disregard for the power of public sentiment. As the memorandum made clear, reform was urgently needed and would have to give greater weight to commercial relations, practical training of diplomats, and the reorganization of the Foreign Ministry along geographical lines; in short, the reforms had to adapt the foreign service to the needs of a globally operating nation in an age of worldwide trade and communications.

To this end, the Hanseatic elites, in the Hamburg Memorandum, also called for public diplomacy conducted by the government in order to offset the impact of Allied atrocity propaganda on Germany's commercial and political prospects. More widely traveled and globally invested than any other German group, they were painfully aware of this negative effect. Alongside other measures, a concerted "cultural propaganda," they argued, was needed to salvage Germany's international reputation and help recapture lost goodwill and markets. "The Foreign Ministry," the Hamburg Memorandum argued,

has to act on the assumption that it must not work on the governments of other countries alone, but on the sentiment of the peoples themselves. First and foremost, our government has to attach great importance to a German cultural propaganda [...] Only by familiarizing foreign countries with our culture time and again will we eliminate the delusion created by atrocity propaganda that to be German and to be barbarian is essentially the same. ${ }^{205}$

enemy strength relied on them fighting with the power of ideas, has cost us the victory." Rohrbach, Woher es kam, 10.

204 In the Reichstag the national liberals under Stresemann passed a resolution in June 1918 that a commission be appointed including diplomats, military representatives, and politicians, as well as representatives of the export industry, to ponder the reform of the Foreign Ministry; see Verhandlungen des Deutschen Reichstags Bd. 324, Antrag Nr. 1669; and Stresemann's explanation in Verhandlungen des Deutschen Reichstags, Bd. 180. Sitzung, June 25, 1918, 5657-5659. 205 Quoted in Düwell, Deutschlands auswärtige Kulturpolitik, 77; on the reorganization process, see also Kurt Doß, Das Auswärtige Amt im Übergang vom Kaiserreich zur Weimarer Republik. Die Schülersche Reform. (Düsseldorf, 1977). 
In May 1918, one month after the memorandum had been submitted, von Kühlmann tasked the director of the Foreign Ministry's personnel department, Edmund Schüler, with restructuring the German Foreign Service. ${ }^{206}$ Strongly supported by the Reichstag, the Hanseatic suggestions became the blueprint for the most profound reform of the German Foreign Service in the twentieth century.

That the reform actually took place, however, was due, above all, to German defeat. Just as German victory would have likely undermined the reform impetus, the situation after November 1918 made it even more urgent. ${ }^{207}$ The establishment of the Weimar Republic, the parliamentarization of foreign policy, the preparations for the peace negotiations, and President Wilson's call for what amounted to a "new diplomacy" all necessitated the reform of one of Germany's most conservative ministries. By late 1918, even the staunchest advocates of what was soon called "old diplomacy" recognized the imperative of at least a semblance of reform - if only to defend the traditional prerogatives of the Wilhelmstrasse. While this explains why these reforms took place, the exact shape they took and the significance they accorded to public diplomacy derived from how Germans came to understand the role of propaganda in their defeat and recovery.

The already substantial focus on the topic of propaganda during the war paled in comparison to the phenomenal influence ascribed to it thereafter. German defeat changed the entire premise of the debate. Within months of the armistice, a vast outpouring of scientific and popular treatises, articles, and memoirs by German journalists, professors, as well as military and civilian leaders, interpreted the propaganda from all sides in light of the war's outcome, only to declare it a major factor in Germany's defeat. Trying to explain why world opinion had been set against Germany during the war, they all concurred that the British had set up a giant propaganda machine within weeks of August 1914 and henceforth convinced a gullible world of both German war guilt and its atrocious warfare. ${ }^{208}$ It was foreign propaganda that had turned the Germans, a people once admired for their cultural and scientific achievements, into the "Huns." As one observer concluded as late as 1929, "the main weapon

206 See Sylvia Taschka, Diplomat ohne Eigenschaften. Die Karriere des Hans-Heinrich Dieckhoff (1884-1952) (Stuttgart, 2006), 56.

207 This is suggested by a comparison with the British Foreign Office; here, too, criticism had been mounting during the war years, but with British victory no truly substantial reforms were initiated; see Zara Steiner and M. L. Dockrill, "The Foreign Office Reforms, 1919-21," The Historical Journal 17, no. 1 (1974): 131-156.

208 Hans Thimme, Weltkrieg ohne Waffen (Stuttgart/Berlin, 1932), passim. 
with which our enemies defeated us [...] is and was the lie. The lie about our 'barbarism', which was used to drive nearly the entire world in war against us [...]."209

But it was not just the "entire world." German Conservatives in particular believed that Allied propaganda had also eroded the German home front's will to keep on fighting. This version of history, first popularized by former military leader Erich Ludendorff, construed the successes of enemy propaganda as the root of German defeat. His 1919 memoirs acknowledged the novel nature of the conflict as a "people's war" (Volkskrieg) where civilian and military involvement were never clearly demarcated. More than ever before, military success had depended on home-front morale, which the enemies, in turn, tried to "corrode and numb." 210 According to Ludendorff, it was only on this psychological battlefield that the Allies had been victorious. After years of warfare, he claimed, the Allies had abandoned their hope of defeating Germany by military might and shifted to psychological warfare as the "primary means" of defeating Germany. ${ }^{211}$ In the last years of the war, the effects of the Allied blockade and cleverly orchestrated enemy propaganda had begun to undermine Germany's "mental fitness to fight" and its belief in final victory. ${ }^{212}$ Eventually, external propaganda and socialist agitation from within had broken German spirits and roused the masses to revolution, making it impossible to continue the fighting on the Western front. ${ }^{213}$ Allied victory, in short, had not been a military but a propagandist one. ${ }^{214}$ Ludendorff's "propaganda legend," as the historian Wolfgang Schieder has observed, thus became an integral part of the "stab-in-the-back" myth. ${ }^{215}$

Of course, the debate was not without criticism of Germany's own prewar and wartime propaganda policies. Throughout the 1920s, a cacophony of voices once again lamented Imperial Germany's initial failure to recognize how essential propaganda abroad was, as well as its inability to later employ it rigorously enough, hence preparing the ground for Allied propaganda successes. ${ }^{216}$ Seeing propaganda as "unsophisticated" and "un-German"” the imperial

209 Hermann Leitz, Schlachtfelder im Westen, 1929, 55, cited in Susanne Brandt, "Versailles auf den ehemaligen Schlachtfeldern im Westen," in Versailles 1919, ed. Gerd Krumreich, 323-332, 328.

210 Ludendorff, Meine Kriegserinnungen, 1; English edition: My War Memoirs 1914-1918 (London, 1919), 2 vols., American edition: Ludendorff's Own Story (New York, 1920), 2 vols.

211 Ludendorff, Meine Kriegserinnerungen, 291.

212 Ibid., 285; on his assessment of enemy and German propaganda, see 285-303.

213 Ibid., 303.

214 Edgar Stern-Rubarth, Die Propaganda als politisches Instrument (Berlin, 1921), 3.

215 Wolfgang Schieder and Christoph Dipper, "Propaganda," in Geschichtliche Grundbegriffe, Vol. 5, Pro-Soz, ed. Otto Brunner, Werner Conze, and Reinhart Koselleck, 69-112 (Stuttgart, 1984).

216 Ludendorff, Meine Kriegserinnerungen, 300; Adolf Morsbach, "Die Deutsche Auslands-Kulturpolitik vor dem Kriege," Hochschule und Ausland 10, no. 6 (June 1932): 3; Paul Rühlmann, 
government, it was argued, had by and large stuck to the "truth" and never developed the type of striking emotive images that its less scrupulous enemies had skillfully used to sell the story of German atrocities to the world. While such lamentations rehashed long-standing criticism, German defeat cast these sins of omission in a much more dramatic light: German propaganda, virtually everyone agreed, had not just been a failure; it had been a key factor in Germany's defeat. Put differently, Germany had not just lost the propaganda war; its deficient propaganda had lost the war.

While such criticism of German propaganda was not unsubstantiated, such oft-repeated and exaggerated claims about its insufficient, ineffective, and haphazard nature - and the supreme efficacy of Allied propaganda - had a decidedly functional character. ${ }^{217}$ Military and civic leaders as different as Erich Ludendorff and Matthias Erzberger utilized their respective "propaganda myths" to exculpate and exonerate themselves. Moreover, the alleged lack of (the right sort of) German propaganda became an argument for securing financial and administrative support for a fledgling policy field. Not surprisingly, those with the strongest personal or professional interest in the expansion of public diplomacy argued most adamantly about its earlier deficiencies. ${ }^{218} \mathrm{Fi}$ nally, the "propaganda myth" defended against the idea that Germany's actual deeds - not their representation - were responsible for international opinion. It was much easier to claim that too little had been done too late than to wonder whether more done earlier might have yielded the same result, or to admit that even more effective German propaganda could not have changed the impression that Germany's treatment of Belgian civilians or the Lusitania had left. These "functions" of the German debate, to be sure, hardly undermined its influence. Quite the contrary, it was precisely because these claims served such salient psychological and political needs that they enjoyed the widest currency.

In itself, the German preoccupation with propaganda was hardly unique. In the aftermath of the war, the subject was critically debated and scientifically explored around the world, engendering a "propaganda boom" in the interwar period. ${ }^{219}$ The psychology of the masses, the techniques of how to manip-

Kulturpropaganda. Grundsätzliche Darlegungen und Auslandsbeobachtungen (Charlottenburg, 1919), 3; Heinrich Schnee in Verhandlungen des Deutschen Reichstags. 185. Sitzung, June $271930,5912 \mathrm{D}$.

217 For scholarly assessments of German propaganda, see Wilke, "Deutsche Auslandspropaganda im Ersten Weltkrieg," 121-125; Doerries, "Promoting Kaiser and Reich"; and Jörg Nagler, "German Imperial Propaganda and the American Homefront in World War I: A Response to Reinhard R. Doerries," in Confrontation and Cooperation, ed. Hans-Jürgen Schröder, 167-175.

218 Morsbach, "Die Deutsche Auslands-Kulturpolitik," claimed that "the beginnings of German cultural diplomacy before the war were correspondingly unimportant, fractured and chaotic"; scholars have not agreed; see vom Brocke, "Der Deutsch-Amerikanische Professorenaustausch," 169.

219 Philip M. Taylor, “The New Propaganda Boom,” International History Review 2, no. 3 (1980): $485-502,486$. 
ulate them, and the role of propaganda in the outcome of the Great War all came under scrutiny once the extent of wartime opinion-shaping attempts became known. ${ }^{220}$ But while all concurred that propaganda was a highly effective weapon in shaping public attitudes, the national debates differed significantly in the lessons they drew from this insight. In Britain and the United States, the two countries deemed most successful in their wartime efforts, the very term "propaganda" fell into disrepute, its practice was disavowed, and wartime institutions were quickly dismantled. ${ }^{221}$ However, Germany took a different path. Its wartime experiences led policymakers to overestimate the extent to which the masses could be manipulated and made them determined to use this hard-won lesson to Germany's advantage in the future. ${ }^{222}$ Liberals and conservatives alike advocated the brazen use of propaganda for the German cause and lobbied for German opinion-shaping efforts to be expanded, centralized, and institutionalized to meet the challenges ahead. As the guns fell silent, publicist Paul Rühlmann (a former member of the Central Office for Foreign Services) argued: "the battle for the minds will be continued all the more actively, especially for the masses, for the opinions and sentiments of wider parts of the public."223

The reality of the peace treaty only intensified this trend. Given worldwide anti-German sentiment, German observers soon realized that the Treaty of Versailles could not be revised without first revising negative opinions about Germany. Germany's recovery and return to great power status required more effective communication of its positions as well as a concerted effort to overturn wartime judgments and tap buried sympathies. Germany would have to persuade the international public of the untenable nature of Versailles while keeping the reproaches of German war guilt, the impact of territorial losses and occupation, the dire fate of German minorities, and the crippling economic effects of Allied reparations demands before the eyes of the world. Future foreign minister Gustav Stresemann gave voice to a broad public consensus when he demanded in 1920 "that the revision of the Versailles peace [be] made the

220 Stern-Rubarth, Die Propaganda als politisches Instrument; Wilhelm Bauer, Der Krieg und die öffentliche Meinung (Tübingen, 1915); Heber Blankenhorn, Adventures in Propaganda (New York and Boston, 1919); Campbell Stuart, The Secrets of Crewe House: The Story of a Famous Campaign (London, 1920); George Creel, How We Advertised America (New York, 1920).

221 For British developments, see Taylor, The Projection of Britain, 79.

222 Jeffrey Verhey, "Some Lessons of the War: The Discourse on the Propaganda and Public Opinion in Germany in the 1920s," in War, Violence and the Modern Condition, ed. Bernd Hüppauf, 99-118 (Berlin, 1997), 107; Corey Ross, "Mass Politics and the Techniques of Leadership: The Promise and Perils of Propaganda in Weimar Germany," German History 24, no. 2 (2006): 184-211.

223 Rühlmann, Kulturpropaganda, 10. 
center of a government propaganda, which hammers the injustice perpetrated on Germany home into the awareness of our people, into the awareness of the entire world." ${ }^{224}$ On a more positive note, Germany would have to rebuild trust and prestige abroad in order to exercise the little political and economic capital it still possessed. Isolated and ostracized, grappling with unexpected defeat and the consequences of the Versailles peace, Germans saw public diplomacy as a necessary tool even - in fact especially - in peacetime. If Germany was to rid itself of the dirt piled upon it by Allied propaganda, if it was to escape its isolation and push through its revisionist demands against competing Allied interests, it would have to learn to master the weapons of its enemies.

As the peace treaty went into effect, the constraints Germans encountered in most other fields of foreign policy reinforced this conviction. Though Versailles was nowhere near as devastating in the long run as German contemporaries liked to imagine, the Weimar Republic was forced to pursue its revisionist foreign policy from a tightly circumscribed position. ${ }^{225}$ Its military, political, and even (for the moment) its economic might had all been dismantled after the war, and the threat of Allied sanctions further limited its options in the postwar years. ${ }^{226}$ General-turned-minister Wilhelm Groener summarized contemporary frustration when he said, "foreign policy needs power, army, navy and money; we no longer have any of these."227 In this situation, Germany's intangible assets emerged as an alternative means of influence. As a wide cast of publicists, professors, Germandom enthusiasts, and tourist boosters pointed out, it was in the subtle influence exerted by German science and music, in the attractiveness of its historical sights and universities, and in the continued attachment of millions of ethnic Germans around the world that a defeated Germany still held considerable global assets. Germany needed to systematically manage these resources and include them in its arsenal of foreign policy tools, they argued, to escape the object role to which it was otherwise consigned and reclaim a field of active foreign policy. With the country bereft of other sources of power and influence, men as different as the former state secretary of foreign affairs Gottlieb von Jagow, the theologian and church historian Adolf von Harnack, and the liberal publicist Edgar Stern-Rubarth saw these intangible re-

224 Quoted in Freitag, Die Entwicklung der Amerikastudien in Berlin, 80.

225 The defeat had not been total enough to force a complete reorientation of foreign policy or forfeit the German position. In fact, Germany in the short-term would have to approach the question at stake with significantly fewer power tools in hand but could, in the long-run, hope to recapture its great power status, especially by recovering its economic position; see Andreas Hillgruber, "'Revisionismus': Kontinuität und Wandel in der Außenpolitik der Weimarer Republik," Historische Zeitschrift 237, no. 3 (Dec. 1983): 597-621, 600.

226 On this period, see Peter Grupp, Deutsche Außenpolitik im Schatten von Versailles, zur Politik des Auswärtigen Amts vom Ende des Ersten Weltkriegs und der Novemberrevolution bis zum Inkrafttreten des Versailler Vertrags, 1918-1920 (Paderborn, 1988).

227 Quoted in Düwell, Deutschlands Auswärtige Kulturpolitik, 32. 
sources as its "only remaining weapon."228 It was ultimately postwar Germany's restricted room to maneuver on the international stage that drove the German government to reorient itself toward alternate foreign policy tools. Collectively, the experiences of World War I and the realities of defeat and peace lent weight to the long-standing argument of Germany's peaceful imperialists: that effective foreign policy required effective public diplomacy.

\section{The Schüler Reforms and Public Diplomacy}

Based on these considerations, a broad public diplomacy infrastructure of departments, organizations, and individuals emerged in the years after Versailles. Since we will encounter organizations like the Association of German Universities (est. 1920), the German Tourism Promotion Bureau (est. 1920), and the Deutsche Akademie (est. 1923/25) in later chapters, it seems imperative first to take a closer look at the transformation of official structures, especially the Foreign Ministry, after World War I.

Going back to the "Hamburg memorandum" of Spring 1918, the Schüler reforms of 1919/1920 restructured the German Foreign Ministry, adapting it to the demands of modern diplomacy, in general, and German defeat, in particular. There were two major principles applied in pursuing this objective. The first was to integrate economic and political foreign policymaking along the lines of earlier French reforms. The formerly predominant "political department" - which had dealt exclusively with "high politics" - was dissolved into six (after 1926, three) geographical departments, which handled both politi$\mathrm{cal}$ and economic matters pertaining to distinct parts of the world. According to this set up, Department VI, and after 1926, Department III focused on the United States. In the same vein, the hitherto separate consular and diplomatic career paths were merged to allow more practically educated men to enter the diplomatic corps. For the first time in a generation, too, key diplomatic posts (including the ambassadorships in London and Washington) were opened up to "outsiders," mainly from the business world.

A second principle applied in the reform was according greater weight to public diplomacy. For one, the reform strengthened and professionalized the Foreign Ministry's news department, which was merged with the small press office of the Reich Chancellery in October 1919 to form the United Press Department of the German Government (Vereinigte Presseabteilung der Reichsregierung). While the Foreign Ministry provided its entire staff, apparatus, and

228 Stern-Rubarth, Propaganda, 3; Gottlieb von Jagow characteristically referred to propaganda "as the only feasible kind of foreign policy activity"; quoted in Friedrich Dahlhaus, Möglichkeiten und Grenzen auswärtiger Kultur- und Pressepolitik. Dargestellt am Beispiel der deutsch-türkischen Beziehungen 1914-1928 (Frankfurt, 1990), 243. 
funds, its director (the Pressechef) was appointed by and directly responsible to the German chancellor. Because the director presented a daily digest of the domestic and international press to the cabinet and Reich president and, in concert with them, formulated the central guidelines for Germany's information policy, this position linked the formation and communication of foreign policy for the first time. Though, in theory, the Pressechef was supposed to be a man (politically) close to the chancellor and appointed in line with party coalitions, in practice Weimar's frequent cabinet shifts soon made it expedient to appoint a civil servant, commonly the director of the Foreign Ministry's news department, to the post. ${ }^{229}$

The press department integrated domestic and international press policy. It handled routine political communication, including press communiqués and official statements, but also pursued "propaganda" in a narrower sense, that is, placing articles or creating brochures to exert indirect pressure on foreign governments. ${ }^{230}$ To this end, it relied heavily on the quasi-official German news agency Wolffs Telegraphisches Bureau (WTB), championed the development of wireless telegraphy to break into a global, as yet uncartelized market, and from the late 1920 s made increasing use of international radio broadcasting. ${ }^{231}$ For the most part, however, it focused on the major medium of the time, the press, which it supplied with mostly accurate, if generally pro-German, news. Specific postwar events, such as reparations conferences, the Upper Silesian plebiscite, and the Ruhr occupation, generated feverish activity in the press department. Importantly, this department, too, was organized according to the geographical principle. Much of the day-to-day work was handled by six newly created "country desks," which were often headed by men with long experience in the respective regions. In cooperation with the Foreign Ministry's new geographical departments, they worked to suppress or elicit domestic reporting, to encourage or deter private initiative, and to cultivate ties to foreign news correspondents. ${ }^{232}$ After late 1923, this work was aided by regular international press conferences, which aimed as much to explain German foreign policy to the world as they did to cultivate the sympathy and trust of the correspondents. ${ }^{233} \mathrm{All}$ in all, the reforms of 1919 addressed earlier shortcomings by linking the process of policy formation and policy communication and by allowing for a greater degree of intercultural expertise in selling policy decisions to international audiences.

229 On the job of the "press chief," see Walter Zechlin, Pressechef bei Ebert, Hindenburg und Kopf. Erlebnisse eines Pressechefs und Diplomaten (Hanover, 1956).

230 This useful distinction between "press policy" and "propaganda" is drawn by Müller, Auswärtige Pressepolitik, 19-20.

231 Evans, “"The Path to Freedom??"

232 Müller, Auswärtige Pressepolitik und Propaganda, 36.

233 On the importance of American news correspondents, see Müller, Weimar im Blick der USA, esp. 276-326. 
This part of the reform was already significant in itself, but it was complemented by a true novelty: the establishment of an independent cultural department (Kulturabteilung) to "cultivate personal and scholarly relations with foreign countries," especially with Germans abroad. ${ }^{234}$ This Kulturabteilung integrated the small and disjointed Foreign Ministry desks hitherto devoted to cultural matters, including the school desk (est. 1906) and the cultural propaganda desk (est. 1917), into a single department. Although it was the Foreign Ministry's smallest department with a staff of only forty-five (in 1930), it, too, answered only to the foreign minister. Charged with the systematic management of Germany's remaining cultural assets, it was set up into three sections in 1920: (i) Germans abroad, (ii) German schools abroad and (iii) international artistic and scholarly relations. This structure indicates the scope of its activity ${ }^{235}$ and the priority it gave to "Germans abroad." ${ }^{236}$ In fact, maintaining relations with Germans abroad - that is, Germandom policy - was the hallmark of German cultural diplomacy in the interwar period. Usually conducted through private or semiofficial groups, it aimed to keep alive the ethnic identity of millions of "Germans abroad" by funneling economic and cultural aid to German minorities. ${ }^{237}$ In many respects, German schools abroad, the Kulturabteilung's second section, was initially merely a subfield of Germandom policy. Since ethnic survival depended on language maintenance, the reconstruction of Germany's severely diminished international school system attracted a great deal of attention and funding. During the 1920s, half of the Kulturabteilung's budget was earmarked for this field. ${ }^{238}$ In contrast, the cultivation of artistic and scholarly relations, and nonethnic groups more broadly, initially remained underdeveloped.

234 See Kurt Düwell, "Die Gründung der Kulturpolitischen Abteilung im Auswärtigen Amt 1919/20 als Neuansatz," in Deutsche Auswärtige Kulturpolitik seit 1871, ed. Düwell and Link, 46-61.

235 The final set-up of 1926 reflected a greater attention to non-ethnic fields: Kult A Cultural Matters regarding Germans abroad and German minorities; Protestant churches and missions (...); Kult W General cultural policy; scientific relations; relations to the League of Nations, institutes, congresses, journeys, lectures abroad, student matters, German books abroad, medical matters, hospitals, doctors, Catholic churches and missions, budgetary matters (Terdenge); Kult

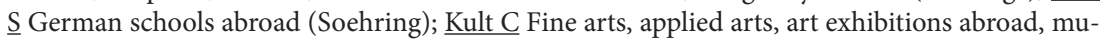
sic, theater, art congresses, film, sport (Sievers); Kult E emigration, inquiries about people and inheritances abroad.

236 Entwurf zu der Rede des Herrn Reichsministers betreffend die Aufgaben der Abteilung VI, June 10, 1930, PA R 61125.

237 Fritz von Twardowski, Anfänge deutscher Kulturpolitik zum Ausland (Bonn/Bad Godesberg, 1970), 15 .

$238 \mathrm{Zu}$ IIId 343 [Soehring] AA, R 64852; within ten years of the war, German schools were again frequented by 68,000 pupils and by 1933 the number of German schools had been almost doubled (to 1,60o) over prewar numbers. Entwurf zu der Rede des Herrn Reichsministers betreffend die Aufgaben der Abteilung VI, June 10, 1930, PA R 61125. 
While scholars have rightly seen the founding of the cultural department as a reorientation of German foreign policy, they have overstated contemporaries' readiness to decouple cultural policy from immediate political needs. ${ }^{239}$ It would take years for press and cultural policy to become more clearly demarcated, and throughout the 1920 s the Wilhelmstrasse's two public diplomacy departments worked closely together, with considerable overlap in both mission and personnel. ${ }^{240}$ Indeed, the Kulturabteilung was generally envisioned only as a longer-term and subtler complement to a news-oriented press policy. As the war had shown, specific German positions had only limited resonance without a larger sympathetic climate, that "predisposition of the heart." As the Foreign Ministry's state secretary perceptively noted in 1921, cultural relations had to be repaired before political relations could be improved: "As long as the boycott [of German science] persists, the intellectual elites of the former belligerents will never be able to leave the war psychosis behind; the war will be continued in the cultural field, and there will be no positive response to a policy of conciliation." ${ }^{241}$

Despite all that has been said, public diplomacy did not immediately emerge as a central field of foreign policy. As a relatively new field of state activity, cultural and even press policies were quite low down in the Wilhelmstrasse's internal pecking order. For a long time, the cultural department remained a "stepchild" of the Foreign Service, its existence a source of bewilderment rather than inspiration to German diplomats. ${ }^{242}$ This was partly due to the novelty of the field, its distance from prestigious "high politics," and its origins in the unloved Schüler reforms. ${ }^{243}$ But especially during the early 1920s, it also reflected the priorities of a foreign policy in dire need of immediate successes, which cultural diplomacy, in particular, could never deliver. This low regard was reflected in the Kulturabteilung's staff profiles. Unlike other Foreign Ministry departments, where up to 40 percent of staff still had an aristocratic background,

239 Volkhard Laitenberger, "Organisations- und Strukturprobleme der Auswärtigen Kulturpolitik und des akademischen Austauschs in den $20 e r$ und 3oer Jahren," in Deutsche Auswärtige Kulturpolitik seit 1871, ed. Düwell and Link, 73.

240 Friedrich Heilbron, for example, served as the director of the press and the cultural department in the 1920s.

241 AA to Nadolny (Stockholm), Apr. 28, 1921, PA R 64979.

242 Twardorski, Anfänge deutscher Kulturpolitik zum Ausland, 18.

243 Many diplomats were opposed to the reforms, especially because they were initiated from the outside; as Jagow complained to Bernstorff: "now they want to 'reform' the Foreign Service. As if that had been the problem. True, some things needed to change. But the parliamentarian smart-arses (Besserwisser) will just disorganize everything." Jagow to Bernstorff, Sep. 2, 1919; Bernstorff, Erinnerungen und Briefe, 120. 
the cultural and press departments were staffed almost exclusively with "bourgeois experts." ${ }^{244}$ This indicated their unattractiveness to young men with the strongest sense of professional prestige and the personal connections to avoid unappealing assignments. And while the 1920 did see bourgeois experts ascend into the highest echelons of the diplomatic corps, they usually came from other departments. ${ }^{245}$ Unsurprisingly, ambitious young diplomats were reluctant to serve in a department that seemed like a dead end to their careers and whose overall usefulness they may have doubted.

And still, no matter how poorly German diplomats regarded public diplomacy internally, they were determined to approach cultural and press matters with the same exclusivity they applied to foreign affairs more generally. By the end of the decade, the Foreign Ministry had won a series of interministerial turf wars and had slowly assumed responsibility for a field that had previously been the primary domain of the Prussian Ministry of Culture. ${ }^{246}$ In Foreign Minister Gustav Stresemann (1923-1929), public diplomacy, including its cultural variant, found a strong champion. Convinced of the importance of cultural power for German Weltgeltung, he helped nearly triple the Kulturabteilung's budget from 2,997,00o marks to 8,250,000 marks and felt it was the prerogative of the Foreign Ministry to "encourage the natural growth of Germany's cultural influence and make it useful to foreign policy." ${ }^{247}$ The following chapters will explore how this ambition was realized in the 1920 .

Since the turn of the century, the place of public opinion in foreign policymaking had changed profoundly - and this change accelerated dramatically during World War I. By demonstrating the impact of international perception on foreign affairs, the events of that period had precipitated a reorientation toward public diplomacy that inspired both substantial private initiative and the overhaul of the Foreign Service. Under the conditions of Germany's defeat, new attention was put into managing public relations to substitute for traditional means of conducting foreign policy that were not available at the time. It was

244 See Düwell, Deutschlands Auswärtige Kulturpolitik, 99.

245 See Peter Krüger, "Struktur, Organisation und außenpolitische Wirkungsmöglichkeiten der leitenden Beamten des Auswärtigen Dienstes 1921-33" in Das diplomatische Korps, ed. Klaus Schwabe, 101-169, 117.

246 On these administrative quarrels, see PA R 60795.

247 For an overview of funds, see Düwell, Deutschlands Auswärtige Kulturpolitik, 100; the budget figures for the years were as follows: $19217,200,000 ; 1922$ 142,300,000; $1923720,000,000$; 1924 2,997,000; 1925 3,300,000; 1926 4,700,000; 1927 6,000,000; 1928 6,000,000; 1929 8,250,000; 1930 7,244,000; 1931 6,484,000; its share of the Foreign Ministry's budget also grew: in 1925, it amounted to 7.7 percent of total funds, while in 1929, it was 12.2 percent; Stresemann Circular to Reich Ministers and State Governments, Jan. 16, 1929, PA R 61124. 
the combination of wartime failures and postwar imperatives that institutionalized state-funded public diplomacy. For the Weimar Republic - partly out of conviction, partly out of necessity - "soft power" became a proxy for "hard power" and, as we will see, this was nowhere more true than in the United States. 


\section{Chapter 3}

\section{Obstacles and New Beginnings, 1921-1924}

Fig. 5: Zeppelin over New York City, 1928, Bundesarchiv, Georg Pahl, Bild 102-06709
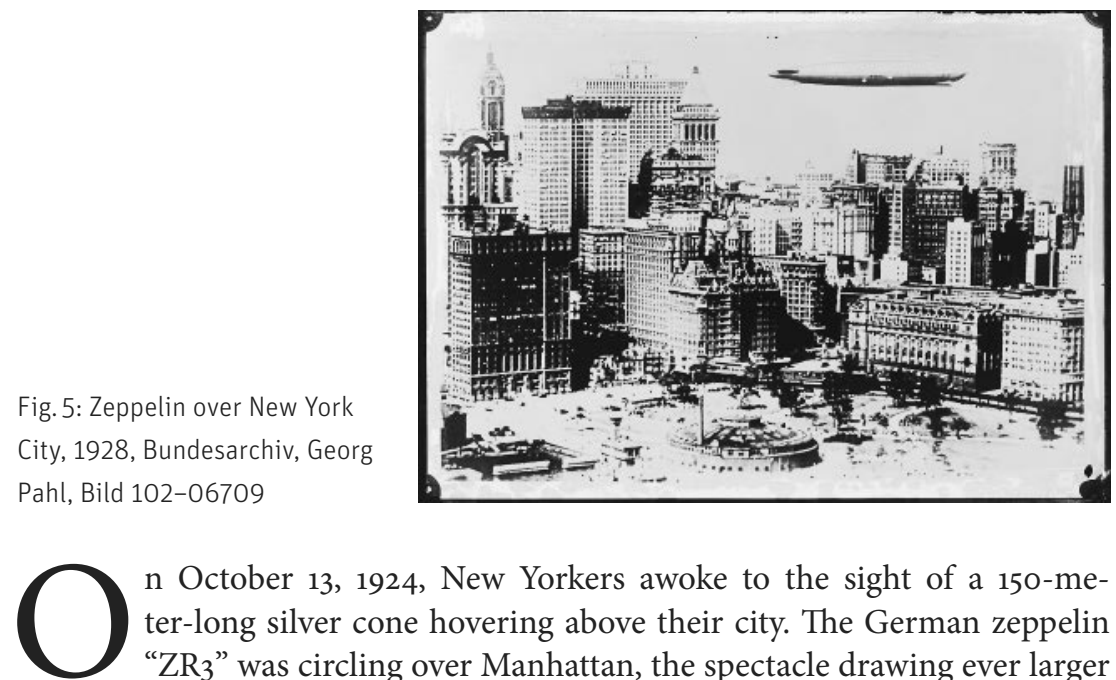

n October 13, 1924, New Yorkers awoke to the sight of a 150-meter-long silver cone hovering above their city. The German zeppelin "ZR3" was circling over Manhattan, the spectacle drawing ever larger crowds onto the streets. A masterpiece of engineering, it was not only among the largest airships ever built; it was also the first to cross the Atlantic. As befitted such a technological feat, its German crew was welcomed to New York City with a confetti parade and went on an extended tour across the United States. The American press, which for a decade had been reluctant to praise any German accomplishment, was full of stories about this transatlantic crossing's daring and technical ingenuity. Like Prince Heinrich two decades earlier, airship commander Hugo Eckener was enthusiastically fêted by American political and business elites across the country - so much so that it was rumored that he would become Germany's next ambassador to Washington. U.S. president Calvin Coolidge emphasized the event as a sign of the complete restoration of peaceful relations between the two countries; ${ }^{1}$ the German press hailed it as a day of national resurgence. The German consul general in Chicago declared it "an act of propaganda (for Germany) in the very best sense of the word."2 In popular imagination and public rhetoric, the flight of the zeppelin marked the end of the postwar period in German-American relations.

1 Content of telegram to Eckener as cited in German diplomatic correspondence, German Embassy Washington to AA, Oct. 16, 1924, PA R 80136.

2 Consulate General Chicago to AA, Nov. 13, 1924, "Betrifft Führer des ZR-3 Dr. Hugo Eckener," PA R 80136. 
This widespread impression was not entirely misplaced. The zeppelin's flight came at the tail end of a period of unprecedented distress for the German Republic. Only the previous year, French and Belgian troops had occupied the industrial Ruhr district to force Germany to make reparations payments, and Germany's subsequent policy of passive resistance as well as the ensuing hyperinflation had brought it to the brink of social, political, and economic disintegration. By the fall of 1923, the republic was under attack from radical forces on the left and right, its people hopeless and hungry, its currency worthless. One year later, however, things were looking up. Many of the issues that had overshadowed German-American relations in the five years after Versailles had, at least for the moment, been resolved. In early 1923, America had withdrawn its last occupation troops from the banks of the Rhine, and the U.S. Congress had released all confiscated German property valued at under \$10,0oo. More importantly, American involvement had brought the reparations conflict to a preliminary conclusion in early 1924. At the London Conference in August that year, American representatives had pushed for the adoption of a settlement that tied German reparations annuities to the country's ability to pay, which was to be determined by an independent American agent for reparations. This step helped depoliticize the reparations question, shielded Germany from French sanctions, and cleared the way for American loans. Though America's interest in an economically and politically stable Europe and not any special sympathy for Germany drove the country to get involved financially, this took place in a public climate that had lost much of its bitterness toward Germany. By the fall of 1924, while the cultural and moral blockade against Germany had not disappeared altogether, it had at least crumbled considerably.

German public diplomacy made only a modest contribution to this normalization of transatlantic relations. Though German representatives could be trusted to use occasions like the arrival of the airship to generate favorable publicity, they capitalized on random opportunities more than on systematic efforts. While Germany rediscovered softer forms of outreach as a valuable substitute for its failed wartime propaganda strategies, it struggled to develop, let alone implement, a constructive public diplomacy agenda in the postwar years. Nevertheless, as the next chapters of this book will illustrate, the mid1920 witnessed a veritable explosion of cultural initiatives directed at the United States. It is the purpose of this chapter then, to solve this apparent puzzle of why so little happened before 1924 and so much thereafter. With this in mind, I explain in this chapter (i) why and to what extent Germany committed to cultural diplomacy toward the United States, (ii) how it rebuilt transatlantic networks, and (iii) why these developments did not make themselves felt until the mid-1920s.

Many studies gloss over the developments of the early 1920s. They assert that Germany developed a new commitment to cultural diplomacy after the 
Great War but that it did not truly implement cultural diplomatic measures because the field was novel, there were tremendous political pressures at the time, and funds were lacking. Accordingly, the early 1920 s are often treated as a period that - apart from its retarding effect - had little long-term impact on how and why German cultural diplomacy programs developed as they did. But the opposite is true. The early 1920 s proved crucial to the form and organization of German policies after 1924, at least with regard to the United States. They generated interest in certain fields (and not others) and saw the emergence of new actors on both sides of the Atlantic. If we want to understand the development of German cultural diplomacy and the emergence of characteristics that have often remained seminal up to today, the early 1920 are of paramount importance.

\section{The United States and Public Diplomacy: The German "Propaganda Problem"}

In light of the foreign policy significance of American opinions on Germany (Chapter 1), Germans began to make observations about the state of U.S. sympathies and to debate how to influence U.S. attitudes almost immediately after the armistice. But whereas few doubted the necessity of winning over Americans, they did not know how to go about doing so. Consequently, an acrimonious and sometimes contradictory public discussion ensued in the early 1920 .

German difficulties in this field arose largely from postwar American sensitivity, "almost to the point of obsession" (as a British observer remarked) about all attempts to influence public opinion. ${ }^{3}$ Having been the primary target of German, British, French, and, in the end, their own government's wartime propaganda, Americans objected to the many real and imagined attempts to shape how they thought and felt about the world in the 1920s. Rather than subsiding, this opposition only grew stronger over the course of the decade because Americans began to question the role that propaganda had played in their attitudes toward the war. ${ }^{4}$ Subscribing to the widespread assumption that public opinion could be manipulated at will if only the right kind of technique were used, American isolationists eventually blamed Allied propagandists for

3 Taylor, The Projection of Britain, 68.

4 The many studies on the subject that appeared in the interwar period were especially influential in this regard. See, e. g., George Creel, How We Advertised America (1920); Walter Lippmann's trilogy on public opinion: Liberty and the News (1920), Public Opinion (1922), and The Phantom Public (1925); Edward Bernays's works Crystallizing Public Opinion (1923), and Propaganda (1928); Harold Laswell, Propaganda Technique in the World War (1927); Arthur Ponsonby, Falsehood in Wartime (1928); George Viereck, Spreading Germs of Hate (1930); J.D. Squires, British Propaganda at Home and in the U.S.1914-17 (1935); and H.C. Peterson, Propaganda for War: The Campaign against American Neutrality, 1914-1917 (1939). 
having "duped" Americans into the war..$^{5}$ In the United States, as Lee Huebner has remarked, "publicity, the hope of the Progressive Era, became propaganda, the scourge of the Twenties."

While Americans, in the end, were contemptuous of all propaganda, including Allied and American campaigns, they initially directed their ire most toward the former enemy. In contrast to Allied agitation efforts, which had relied strongly on the unobtrusive power of the British news empire and elite networks, Germany's clumsy propaganda had been highly visible. Moreover, long after German propaganda activities had ceased, American patriotic groups and official propagandists continued to draw on fears of German subversion to mobilize a reluctant, heterogeneous society for war.7 The bogeyman of "German propaganda" helped justify the suspension of civil liberties in the Espionage Act of 1917 as well as America's own comprehensive and successful propaganda operations. ${ }^{8}$ American paranoia about foreign influences continued after the armistice. As late as February 1919, the U.S. Congress conducted a sensational inquiry into the workings of German propaganda, which kept Germany's alleged conspiracies in the headlines just as the "Red Scare" once again heightened American fears of outside interference. Throughout the 1920s, even the most innocent German actions could-and would-rekindle American fears of German propaganda.

In this climate, all Germans who were well acquainted with the United States saw that any return to a more assertive German propaganda, such as the mass distribution of print material or agitation among German Americans, seemed out of the question. Based on wartime lessons and a realistic assessment of Germany's postwar position, Berlin's new "America experts," like Walther Drechsler (the wartime director of the Amerika-Institut, who joined the Foreign Ministry's press department in 1918) and Karl Alexander Fuehr (the former head of the German propaganda office in New York, who now worked in the new America department), strongly advised against any such agitation. German propaganda, they noted, had not only failed to sway Americans in Germany's favor but had heightened suspicions against it. As early as November 1920, the America desk of the press department referred to any "unauthorized propaganda" in the United States as "extremely unwelcome, if not outright dangerous." Given the high degree of American nativism in the

5 For an early example of that famous theory, see Philip Francis, The Poison in America's Cup (New York, 1919).

6 L. W. Huebner, quoted in Daniela Rossini, "Censorship in World War I: The Action of Wilson's Committee on Public Information," in Political Repression in U. S. History, ed. Cornelis van Minnen and Sylvia Hilton, 103-16 (Amsterdam, 2009), 114.

7 According to their portrayals, the "tentacles of the German octopus" reached into America's every nook and cranny; Earl E. Sperry, The Tentacles of the German Octopus in America (New York, 1917).

8 Creel, How We Advertised America, 9. 
postwar years, this applied especially to any political agitation among German Americans. Any "meddling in the domestic affairs of the Union," the report made clear, would alienate the American administration and public. ${ }^{9}$ In June 1921, the Foreign Ministry once more outlined the tight parameters governing all German opinion-shaping attempts in the United States to the Office of the Reich President: German propaganda could not be officially organized nor could it appear to aim to estrange the United States from its former Allies or at the political mobilization of German Americans. ${ }^{10}$ In other words, as the Foreign Ministry's "America experts" pointed out, any propaganda Berlin had hitherto considered worthwhile was more likely to arouse than to mitigate hostility toward Germany.

And yet, while wartime experience advised against German propaganda, the political reality seemed to require some attempts at shaping American opinion. Given the urgency of the reparations question, the "wait and see" approach many of Germany's "America experts" would have preferred was simply inadequate. If Germany's fate hinged on American public opinion, then how could Berlin forego what many contemporaries considered the "one weapon remaining to us"?

Two factors, in particular, called for something more than a hands-off approach. For one, Germany's key political rival, France, was undertaking an alarming number of opinion-shaping activities. Since France, too, was dependent on American goodwill and capital to rebuild its economy, avoid collection of its war debt, and enforce the peace treaty, French policymakers and private organizations had begun to think about how to retain America's fragile wartime sympathies as soon as the armistice was signed. ${ }^{11}$ To this end, they adopted what the historian Robert Young has called "a broadly cultural course of action." ${ }^{12}$ The resurgent interest in France as a tourist destination, the appeal of French universities to American students, and the frequent commemorations of wartime events offered such groups ample opportunity for promoting France and French culture to America's elites. Working primarily through bilateral friendship organizations like the France-America Society and Francophile Americans, like heiress Anne Morgan (the daughter of J. P. Morgan), they sought to remind Americans of their erstwhile brotherhood in arms, the sacrifices French people had made, and Germany's "unreconstructed" attitudes. With a curious mixture of admiration and alarm, the German embassy in Paris described French cultural propaganda as "a most elaborate network that spans

9 Note referring to VI A. V. 877 Nov. 3, 1920, PA R 80287.

10 AA to Office of the Reich President, June 10, 1921, PA R 80293.

11 William Keylor, "How They Advertised France. The French Propaganda Campaign in the United States During the Break Up of the Franco-American Entente, 1918-1923," Diplomatic History 17, no. 3 (July 1993): 351-373.

12 Young, Marketing Marianne, 102. 
the entire globe down to its remotest corners." ${ }^{13}$ And though the French themselves liked to describe their work as "intercultural interpretation," German observers thought of it as near-Machiavellian. "In the end," publicist Paul Rühlmann (a former member of the Central Office for Foreign Services) noted in 1919, "French cultural propaganda is not pure, real cultural propaganda, but power politics under the cloak of cultural policy, often so skillfully draped that its true purpose, global dominance, is hardly discernible."14 Indeed, observing French mastery in the field became something of a German obsession in the interwar years, serving as both a motivation and yardstick for Germany's own efforts in the United States.

Yet French competition was not the only factor. There was also a clear need for the German government to exert greater control over renegade German propagandists. Militant revisionist groups regularly ignored the official policy of caution and advocated a forceful propaganda campaign among Americans in general and German Americans in particular. ${ }^{15}$ German-American propagandists themselves, like poet and publicist George Sylvester Viereck, also resumed their work on behalf of the German cause shortly after the war, organizing mass rallies to protest German war guilt and the so-called Black Horror, i. e., the French use of colonial troops in the occupation of the Rhineland. ${ }^{16}$ Regardless of how German diplomats evaluated Viereck's overall objective, the methods he employed were clearly detrimental to the German cause because they kept alive fears of "German propaganda."17 As informed observers like Austrian professor Josef Redlich or Wilhelm Cuno, director of the HAPAG and future German chancellor, explained to German diplomats in the spring of 1921, "America wants no propaganda of that kind, at least no German

13 German Embassy, Paris to AA, Dec. 17, 1921, "Französische Propaganda," PA R 60430; German Embassy, Paris, to AA, No. 407, Mar. 21, 1925, "Französische Propaganda," PA R 60447; on the importance of French competition to the development of German cultural diplomacy in the United States, see Elisabeth Piller, "The Transatlantic Dynamics of European Cultural Diplomacy: Germany, France and the Battle for U.S. Affections In the 1920s," Contemporary European History, forthcoming 2021.

14 Rühlmann, Kulturpropaganda, 15.

15 “Zur Deutsch-Amerikanischen Annäherung," Der Reichsbote, Apr. 25, 1922; Edmund von Mach, "Eine politische Organisation von Amerikanern deutschen Stammes?," Der Auslanddeutsche 3, no. 16 (Aug. 1920): 481-482; Fritz Heinz Reimesch, "Erwachendes Deutsches Leben in Nordamerika," Germania, Nov. 10, 1921; "Die Deutsch-Amerikaner finden sich," Volk und Heimat 2, no. 6 (Apr. 1921): 64-65; Aufzeichnung (Noebel), VI A 263, Feb. 16, 1922, PA R 60104. 16 Niel M. Johnson, George Sylvester Viereck: German-American Propagandist (DeKalb, IL, 1972).

17 Throughout the early 1920s, German representatives in the United States repeatedly bore the brunt of the State Department's indignation as it complained about abrasive German propaganda arriving on American shores. German Embassy, Washington (Lang) to AA, Apr. 241922 , PA R 80294. 
propaganda." ${ }^{18}$ These developments reinforced the central lesson that German officials had drawn from the war: public diplomacy had to be carried out by "responsible" circles acquainted with foreign psychology and willing to work within the Foreign Ministry's "yet to be determined framework."19

This question of American sentiment came to a head in the spring of 1921. The gridlock in the reparations negotiations, the political threat of the French campaign, the problematic nature of renegade propaganda operations, and America's ever clearer political withdrawal from Europe necessitated a more constructive course of action to solve one basic dilemma: how to win American hearts and minds without arousing American suspicions. In this context, Germany began, tacitly at least, to consider cultural diplomacy a distinct policy option.

Before I delve into some of the efforts German authorities made toward this end, I must admit that their immediate response to the propaganda problem was not cultural diplomacy but to try and avoid the appearance of "German propaganda." In the spring of 1921, the Foreign Ministry established and funded several "front organizations" to coordinate and expand existing revisionist initiatives and reverse world opinion on the peace treaty. ${ }^{20}$ The most important of these, the Working Committee of German Associations (Arbeitsausschuß Deutscher Verbände) served as an umbrella organization for a vast number of revisionist groups (about 2,00o by 1930), which it used to channel German outrage over territorial losses, the war guilt verdict, the "Black Horror," and reparations payments into one effective "people's movement" against Versailles. Large demonstrations, publications, and lecture tours aimed to keep domestic indignation alive, thereby generating broad popular support - and hence democratic legitimacy - for Germany's revisionist demands abroad. ${ }^{21}$ Importantly, however, organizations like the Arbeitsauschuß did more than rehash Germany's wartime methods in the disguise of a nonstate actor. Aware of

18 German Embassy, London to AA, Apr. 27, 1921, "Deutschland und die Vereinigten Staaten," PA R 80132; and letter by Cuno to Dr. Hasselmann, May 25, 1921 (copy), PA R 80132.

19 Note referring to VI A. V. 87, Nov. 3, 1920, PA R 80287.

20 Addressing a range of revisionist issues, they were particularly active in the agitation against German war guilt, generally understood as the most significant stumbling block to Germany's moral rehabilitation. On the scientific Zentralstelle für die Erforschung der Kriegsschuldfrage (Center for the Study of the War Guilt Question) and the more popular Arbeitsausschuß deutscher Verbände (Working Committee of German Associations), see Herman Wittgens, "The German Foreign Office Campaign against the Versailles Treaty: An Examination of the Activities of the Kriegsschuldreferat in the United States" (PhD diss., University of Washington, 1970).

21 For a good overview of the recent literature and the tensions within the Black Horror-campaign, see Roos, "Nationalism, Racism and Propaganda in Early Weimar Germany." 
the deficiencies of previous propaganda efforts, the Arbeitsausschuß purposefully departed from the "old type of [brochure] propaganda." Instead, it systematically built ties with respectable interlocutors abroad, including church organizations, women's groups, and historians, especially in the United States, who would then serve as a "ferment" for Germany's revisionist ideas. ${ }^{22}$ This reorientation toward ostensibly private initiatives thus went hand in hand with an emphasis on quieter, less obtrusive contacts with multiplier groups. ${ }^{23} \mathrm{Be}-$ hind this shift stood the realization that overt propagandizing, even with no obvious state imprint, stood little chance of success with the American public. ${ }^{24}$

This explains, too, the growing official support for reestablishing cultural relations with the United States. The discussions on the fate of the Amerika-Institut in Berlin in 1921 provide a window onto the motives and ideas that shaped this debate. Founded in 1910 as a clearinghouse for transatlantic academic relations, the Amerika-Institut was almost the sole survivor of Wilhelmine Amerikapolitik. By mid-1921, the Institut's desolate financial situation made it necessary to clarify its future. Trying to garner Reich support, Karl Oscar Bertling, the Institut's Harvard-trained director since mid-1919, presented its publication exchange with the Library of Congress (which had been resumed in late 1920) as a stepping stone for the Institut's actual work: the cultivation of American academic elites in Germany's interest. Bertling submitted a memorandum to Foreign Minister Friedrich Rosen in July 1921, emphasizing that the Institut's cultural liaison work was particularly important because it accessed American opinion-shapers in a "politically unassailable way." ${ }^{25}$ Bernhard Dernburg, who had directed Germany's wartime propaganda office in New York until 1915, seconded the Amerika-Institut's interpretation and declared it a "very valuable cultural bridge (...) and a welcome opportunity to resume or establish - in a politically unassailable form - ties with influential circles in the United States." ${ }^{26}$ Bernstorff, the former ambassador to Washington, likewise stressed the Amerika-Institut's role as a "not to be underestimated substitute" for the "almost hopeless" endeavor of "open propaganda." ${ }^{27}$ More than any new

22 This strategy is outlined in "Erweiterung der deutschen Volksbewegung für die Revision von Versailles zur Weltbewegung," Arbeitsausschuß deutscher Verbände, May 1922, 14; BArch R 43I/227; on this reorientation, see also Gärtner, Botschafterin des Guten Willens, 72.

23 Wittgens, "The German Foreign Office Campaign," 49.

24 A mass rally against the black horror organized by George Sylvester Viereck in Madison Square Garden provoked the ire of the U.S. State Department and immediate counter-demonstrations by the American Legion. Even generally German-friendly, liberal magazines turned emphatically against German exaggerations; see Nelson, "Black Horror on the Rhine," 621.

25 Amerika-Institut, Arbeitsprogramm des Amerika-Instituts, July 28 1921, PA R 64997.

26 See the documents reprinted in Siegfried Grundmann, Einsteins Akte. Einsteins Jahre in Deutschland aus der Sicht der deutschen Politik (Berlin, 1998), 97.

27 IX D 2417 Schmidt-Ott to AA, May 4 1921, PA R 64997. 
institution, he believed, the Amerika-Institut could help re-establish for Germany a measure of trust and influence in the United States. ${ }^{28}$

The fact that two Reich ministries financially committed to the Amerika-Institut in November 1921 signaled their basic agreement with such ideas. Both the Foreign Ministry and the Ministry of the Interior agreed to support the Amerika-Institut for the next five years. While inflation soon rendered this financial arrangement meaningless, its true significance lay in the Reich's longterm commitment to advancing cultural relations with the United States. ${ }^{29}$ Though the Amerika-Institut officially remained under the aegis of the Prussian Ministry of Culture, its relations with the Foreign Ministry were close. The Foreign Ministry's Kulturabteilung was represented on the Amerika-Institut's board of trustees and in the early 1920 even "apprenticed" its attachés to the Amerika-Institut. ${ }^{30}$ After 1920, the Amerika-Institut's former director, Walther Drechsler, headed the America desk in the Foreign Ministry's press department, while Bertling, whom a friend later described as a "walking directory," informally advised the Wilhelmstrasse on American intellectual and cultural life. ${ }^{31}$ In hosting American scholars during their stay in Germany, the Amerika-Institut frequently assumed quasi-diplomatic functions that German officials would or could not undertake themselves. By supporting the Amerika-Institut in 1921, German officials took a clear step toward subtler, cultural means of influence in the United States.

Nevertheless, the importance of this step should not be overstated. For one, the support was not as emphatic as one might have expected given the broader lessons of the war. As noted above, the authorities paid the greatest attention, both materially and morally, to the groups that had a clear revisionist agenda. The Foreign Ministry and peaceful revisionists like Dernburg or Bernstorff did not believe that the Amerika-Institut and similar programs had value in themselves so much as they "substituted" for the "real" propaganda they could no longer engage in on account of American suspicions. Moreover, this reorientation toward cultural outreach was neither unique nor, seen in a wider European context, novel. In the propaganda-hostile climate of the United States in the 1920s, Britain and France settled on similar strategies to retain American elites' wartime sympathies. Aware of American sensitivity, the British, in particular, quickly dismantled their most overt wartime propaganda machinery only to

28 Amerika-Institut to Foreign Minister Rosen, July 27 1921, "Die Tätigkeit des Amerika-Institutes zu Berlin,” PA R 80516.

29 Abschrift zu UIK Nr. 2047.1. Niederschrift über das Ergebnis der Sitzung im Amerika-Institut v. 6. 10. 1921; R 64997 zu IX A 415, Abt VI, Feb. 4, 1921 [handwritten note].

30 For one example, see Amerika-Institut to AA, Tgb-Nr. 1453/23, June 8, 1923, PA R 65519.

31 Heinrich Albert to Ernst Hanfstaengl (ca. 1945/46), Ana 405 Nachlass Ernst Hanfstaengl, Box 45, Korrespondenz Bayerische Staatsbibliothek. 
replace them with subtler forms of cultural outreach and information policy. ${ }^{32}$ Arguably, the enthusiasm for transatlantic cultural exchanges in the interwar period primarily expressed Europeans' desire to shape American opinions, and the necessity of doing so in the least offensive way. And while such a "broadly cultural course" might have constituted a novelty in other countries, in German-American relations (as Chapter 2 has shown) it enjoyed a comparatively long tradition. Apart from greater diplomatic involvement, the early 1920 initially seemed more like a return to the subdued strategies of prewar days than an actual departure toward cultural diplomacy with different modes, actors, and objectives. Rather, as will be shown below, this actual departure took place only in response to the adversities of the postwar period.

\section{"A Particularly Menacing Piece of German Intrigue and Propaganda”: German Cultural Diplomacy and the Long Shadow of the War}

In the postwar years, German culture did not prove to be the valuable asset publicists and politicians had imagined it to be. While the Amerika-Institut, for example, resumed some of its basic functions, the German government's tacit commitment to a "cultural approach" in the United States translated into few concrete initiatives, let alone concerted ones. A lack of "energy and inspiration" among German officials and severe financial constraints were certainly to blame. ${ }^{33}$ But in the case of America, Germany also faced a unique set of constraints and obstacles to luring Americans back into its cultural domain: the relatively long period until a separate peace treaty was signed, American contempt for German Kultur and pervasive nativist paranoia, and, not least, the strong disappointment among many educated Germans concerning American wartime behavior.

32 Taylor, The Projection of Britain, 69; one example of this reorientation is the British Library of Information in New York, which opened in the fall of 1919. By providing reference material on Britain and keeping contacts with American journalists and academics, it tried to shape the British image in the United States while avoiding the semblance of propaganda for the next twenty years: David A. Lincove, "The British Library of Information in New York: A Tool of British Foreign Policy, 1919-42," Libraries and the Cultural Record 46, no. 2 (2011): 156-184, 159; on the British Library of Information's role as a monitoring tool for the British Foreign Office, see B. J. C. McKercher, "The British Diplomatic Service in the United States and the Chamberlain Foreign Office's Perceptions of Domestic America, 1924-1927: Images, Reality and Diplomacy," in Shadow and Substance in British Foreign Policy 1895-1939, ed. B. J. C. McKercher and D. J. Moss, 221-247 (Edmonton, 1984).

33 Schröder-Gudehus, Deutsche Wissenschaft und internationale Zusammenarbeit, 213; von Twardowski, Anfänge deutscher Kulturpolitik zum Ausland, 13; the Foreign Ministry limited itself to supporting more or less random opportunities such as occasional transatlantic trips, often calculated for short-term (propagandistic) gain. 
For one, Germany was quite simply unprepared. Because the few plans regading cultural diplomacy that it had developed during the war had all been premised on German victory, they now proved useless in the postwar reality. In the United States, moreover, efforts to salvage Germany's image were complicated by the lack of a peace treaty between the two nations. Not until July 1921 did President Harding officially end the state of war, and only on November 11,1921 - exactly three years after the armistice - did a separate peace treaty officially restore "friendly relations." The long period of uncertainty preceding this peace affected transatlantic relations on many levels. Though commercial relations were re-established relatively swiftly, many Americans still felt uneasy about visiting, studying or doing business in a country they were not officially at peace with yet. ${ }^{34}$ While Germans were not overly pessimistic about this development - hoping in vain that the delay might result in a separate, more lenient peace agreement - it effectively put the return to transatlantic "normalcy" on hold until late 1921.

The economic impact of inflation on German cultural endeavors was even more serious. Just when Germany decided to make more systematic use of its soft power assets, their foundation was crumbling. This was particularly noticeable in the academic and scientific fields, where inflation had eroded university and institute budgets to produce a much-discussed "distress of German science and scholarship" (Not der deutschen Wissenschaft). ${ }^{35}$ With inflation, chemicals, laboratory equipment, paper, and books became increasingly unaffordable, hampering scientists and scholars from conducting and publishing their research. Access to international publications, in particular, declined dramatically. ${ }^{36}$ Many students found it challenging just to continue their studies as their parents' wealth and income melted away. What gave the "distress of German science and scholarship" such resonance in postwar Germany was not that inflation affected universities and research institutions more than, say, museums, but that these cultural organizations had been assigned a crucial role in Germany's resurgence. Their prostration at the time of the fatherland's greatest need was widely seen as a national "tragedy." 37 The Foreign Ministry's Kulturabteilung summed up the situation in 1922: "Today, when we depend more than ever on righting wrong perceptions abroad, which lie at the bottom of all

34 Aufzeichnung, Oct. 31, 1922 [Abt B], PA R 65519.

35 On the "distress of German science and scholarship" and its various manifestations, see Eduard Wildhagen, "Die Not der deutschen Wissenschaft," Internationale Monatsschrift für Wissenschaft, Kunst und Technik 15, no. 1 (Oct. 1920): 1-33.

36 The Prussian State Library subscribed to 2,300 international publications before the war but subscribed to only 140 in 1920; Georg Schreiber, Die Not der deutschen Wissenschaft und der geistigen Arbeiter. Geschehnisse und Gedanken zur Kulturpolitik des Reiches (Leizpig, 1923), 20. 37 It was, as Schreiber noted, the "tragedy of German science that it experiences its greatest distress in the very moment when its greatest tasks are before it." Schreiber in Verhandlungen des Deutschen Reichstags Bd. 357, 267, Sitzung, Nov. 15, 1922, 8995 D. 
international measures against us, today, the German Wissenschaftler not only continuously reduces his everyday relations with neutral countries but is unable to regain ground in former enemy countries, where, after emotions quiet down, old doors are opening again." ${ }^{8}$ Though the German government and academic circles took steps to keep German science and scholarship afloat - such as founding the Emergency Society of German Science (Notgemeinschaft der deutschen Wissenschaft) in 1920 - German Wissenschaft had difficulty assuming its designated role for the time being. ${ }^{39}$

Similar financial constraints negatively affected all levels of Weimar's incipient cultural diplomacy. The funds available for cultural affairs in the Wilhelmstrasse were usually earmarked for a few important budget items (especially the maintenance of German schools abroad), making other measures difficult to finance and justify in light of the genuine material distress in Germany. ${ }^{40}$ The Amerika-Institut frankly admitted that it was regarded as a "luxury" of imperial days. ${ }^{41}$ Still, the lack of funds should not be overemphasized as the major retarding element, at least with regard to the United States. Up to about mid-1922, there was usually financial support for endeavors with a clear and promising strategy. Accordingly, the government distributed funds with relative largesse to German war guilt propagandists and for rebuilding the German school system abroad.

What most hampered German efforts was not a lack of funds but the experience of the war. Whereas German cultural diplomats could rely on prewar blueprints for rebuilding cultural infrastructures and influence in other countries, the war had so profoundly altered German-American relations that a return to Germany's earlier Amerikapolitik soon proved to be out of the question. France, for example, was able to build liberally on the momentum of wartime cooperation with the United States. By contrast, Germany was forced to fight an uphill battle against the long shadow of the war, which had left Americans with deep resentments and many unpleasant memories.

Only slowly did German officials realize just how difficult it would be to re-establish transatlantic relations in the field of culture. In the United States, the fight against the German enemy had ultimately turned into a fight against German culture, and the driving forces behind this cultural assault long out-

38 Aufzeichnung, Oct. 31, 1922 [Kult B], PA R 65519.

39 On the Notgemeinschaft, see Ulrich Marsch, Notgemeinschaft der Deutschen Wissenschaft. Gründung und frühe Geschichte 1920-1925 (Frankfurt, 1994); and Notker Hammerstein, Die Deutsche Forschungsgemeinschaft in der Weimarer Republik und im Dritten Reich. Wissenschaftspolitik in Republik und Diktatur, 1920-1945 (Munich, 1999); on students, see Michael H. Kater, "The Work Student: A Socio-Economic Phenomenon of Early Weimar Germany," Journal of Contemporary History 10, no. 1 (1975): 71-94.

40 Examples include a note related to VI A 1823 Dec. 16, 1922, PA R 60431; Aufzeichnung, Oct. 21, 1922, PA R 65519; AA to German Legation, Stockholm, Nov. 16, 1922, PA R 60430.

41 Bertling, "Das Amerika-Institut in Berlin," Hochschule und Ausland 7, no. 3 (Mar. 1929). 
lived the armistice. Nativist sentiment, for example, only peaked in the summer of 1919, with nationwide prohibition, the success of the revived Ku Klux Klan, and restrictive immigration legislation being visible tokens of its strength in the early $1920{ }^{42} .{ }^{22}$ As they had during the war, "100\% Americans" turned against both domestic and foreign expressions of German culture. ${ }^{43}$ When Ohio legislators banned teaching the German language below the eighth grade in May 1919, they claimed that German instruction was both a "distinct menace to Americanism" and "part of a plot by the German government to make school children loyal to it." 44 Amidst such paranoia, patriotic American groups, such as the newly founded American Legion, forcefully opposed attempts to normalize American treatment of German culture..$^{45}$ Efforts to restore German books to library circulation, German opera to concert halls, and German-language instruction to American schools all faced such resistance. ${ }^{46}$ In short, German cultural initiatives encountered just as much suspicion as any political propaganda, especially whenever German Americans were involved.

The pronouncements of American patriotic groups were just one indication of the more fundamental problem Germany faced: its lack of access to the American public. For the most part, neither the institutional infrastructures nor the personal networks of prewar days still existed. Those who still publicly supported Germany (such as George Sylvester Viereck) had been discredited by their wartime activity. ${ }^{47}$ In any case, what Germany needed were not militant champions but respectable, moderate advocates who enjoyed access to the American establishment and were willing to serve as cultural brokers between Germany and the United States. Yet the groups that had previously assumed this role, especially American academics, had either fallen silent or broken with Germany altogether. American Germanists, who had always felt most called to mediate between the two countries, had been personally and professionally devastated by the war. Under the impact of wartime suspicion and a drastic drop in enrollment numbers, they had found themselves ousted from

42 John Higham, Strangers in the Land: Patterns of American Nativism, 1860-1925 (New Brunswick, 1983).

43 Gustavus Ohlinger, The German Conspiracy in American Education (New York, 1919).

44 Ohio governor (and 1920 Democratic presidential candidate) James M. Cox in front of the Ohio General Assembly, quoted in Tolzmann, "The Survival of an Ethnic Community," 431.

45 In 1921, an official German report noted that "the through and through anti-German and pro-French character of the American Legion manifests itself on all occasions." Report on the American Legion, May 25, 1921, PA R 80293.

46 The American Legion declared German music "incompatible with 'one hundred per cent Americanism," New York Times, Sep. 24, 1919, cited in Barbara Wiedemann-Citera, Die Auswirkungen des Ersten Weltkrieges auf die Deutsch-Amerikaner im Spiegel der New Yorker Staatszeitung, der New Yorker Volkszeitung und der New York Times, 1914-1926 (Frankfurt, 1993), 224; see also clipping, "German Opera Ban Made Permanent; to Sing English," New York World, Oct. 28, 1919, BArch R 901/72721.

47 See Chapter 4. 
their positions, their departments closed down, and their subject slandered as part of a sinister German plot. As long as nativist sentiments ran high, few of them were likely to come out publicly for Germany again.

In hindsight, it is easy to see that America's continued hostility and Germany's lack of access were part of a realignment of U.S. cultural relations away from Germany. What is striking, however, is that even after the experiences of war and defeat, neither German officials nor German academics seem to have been prepared for the degree to which their cultural capital abroad had been lost. Not that there had been no warnings. As early as 1915 , farsighted observers like Paul Rohrbach had cautioned that "we have to face the embarrassing but irrefutable fact that our reputation as a Kulturnation [...] has been shaken, and that it will have to be re-established before we can once again interact with other nations on the basis of our common cultural background." ${ }^{8}$ Despite such premonitions and widespread German feelings of victimization, the true extent of the "cultural blockade" only sank in slowly after 1921. ${ }^{49}$

Just how difficult - indeed, impossible - it would be for Germany to fall back on established patterns to advance its interests became readily apparent with regard to Germany's academic and scholarly standing, which had long counted as its strongest asset in the United States.

Germans' initial hope in the nation's academic capital was perhaps most evident in the debate surrounding the first postwar ambassadorial appointment to Washington. In the spring of 1921, with a separate German-American peace treaty in sight, the delicate question of who should be appointed to this important Washington post garnered increasing attention. Given America's disdain for German officials (who were heavily implicated in wartime espionage, sabotage, and propaganda), former ambassador Bernstorff suggested not a trained diplomat, but a "political homo novus of world renown," namely, a German scholar. ${ }^{50}$ President Wilson's former advisor, Colonel Edward House, seconded the idea, recommending in April/May 1921 that the Wilhelmstrasse send someone unassociated with the war, whose primary job would be to influence public opinion, preferably a "distinguished and striking figure, perhaps a professor." ${ }^{1}$ At the request of Foreign Minister Walter Simons, Bernstorff then asked the eminent church historian Adolf von Harnack to accept the post, if

48 Rohrbach, Woher es kam, 28.

49 One example is Karl Kerkhof, "Die internationalen naturwissenschaftlichen Organisationen vor und nach dem Weltkriege," Internationale Monatsschrift für Wissenschaft, Kunst und Technik 15 , no. 3 (Jan. 1921): 225-242.

50 Bernstorff, Erinnerungen und Briefe, 203.

51 Aufzeichnung (Reichsminister Rosen) meeting with House, June 4, 1921, PA R 28487. 
only for a year. ${ }^{22}$ When Harnack declined, the Foreign Ministry unsuccessfully approached a number of other scholars with a liberal reputation, including the economist Lujo Brentano. ${ }^{53}$

In nations like the United States, France, and Great Britain, which all regularly appointed accomplished businessmen and scholars to diplomatic posts, the episode might have held little significance. But in Germany, matters were different. There, the Foreign Service had been a closed system for more than a generation, the preserve of aristocrats and trained professionals. Since 1871, not a single "outsider" had been appointed to a major diplomatic post, let alone one as important as Washington after the war. While the practice became slightly more common after 1919, almost only in the United States did the German government consider a scholar, and not a politician or a businessman, for an ambassadorial post. ${ }^{54}$ This extraordinary choice, then, clearly underscores the idea that Wissenschaft was one of Germany's remaining assets for rebuilding trust and prestige in the United States. Whereas a German diplomat or politician would arouse suspicion and disdain, Bernstorff explained, a German scholar might be less burdened by the "many unfortunate memories" of the war..$^{55}$ Even a man as familiar with American psychology as the former ambassador seems to have hoped that cultural relations could provide the needed common ground for a transatlantic rapprochement.

The outcome of this episode, however, only revealed how unrealistic such assessments were and how greatly German scholars really had been implicated in the "many unfortunate memories" of the war. Negotiations with both Harnack and Brentano stalled, not only because both of them felt ill-prepared to take on the post but also because the American press reacted unfavorably to the idea. When rumors (were) leaked that Brentano was being considered for the post, American journalists immediately pointed out that he - like Harnack had signed the Manifesto of the 93 and had never satisfactorily retracted his wartime statement. ${ }^{56}$ If such reservations applied to men as politically moderate as Brentano and Harnack, then almost any German academic of world renown, save Albert Einstein, could be ruled out.

52 Nottmeier, Harnack, 481; Bernstorff, Erinnerungen und Briefe, 204.

53 Lujo Brentano, Mein Leben im Kampf um die soziale Entwicklung Deutschlands (Jena, 1931), 477.

54 The only other case was that of Professor Wiedenfeld, who was appointed to Moscow in 1921. His case was different, however, because the appointment of a scholar was intended to "minimize the political significance of this diplomatic exchange in the eyes of the Western Powers"; see Hajo Holborn, "Diplomats and Diplomacy in the Early Weimar Republic," in The Diplomats, 19191939, ed. Gordan A. Craig and Felix Gilbert, 123-71 (Princeton, NJ, 1953), 153.

55 Bernstorff, Erinnerungen und Briefe, 203.

56 "Brentano Talked of as German Envoy Here: He was one of the Professors Who Signed the Famous Manifesto to the World," New York Times, July 2, 1921, 19. 
This experience was but one indication of the obstacles that had to be overcome to reconcile with American academics. Their moral indignation toward Germany survived the war unscathed, and even earlier advocates of close cultural relations took years to overcome their alienation. Columbia president Nicholas Murray Butler voiced the persistence of these sentiments in an open letter to the rector of Uppsala University in April 1919, speaking of the as yet unforgotten "amazing prostitution of [German] scholarship and science to national lust" in the Manifesto of the 93.57 Even when it became clear in the United States that many signatories had not known the content and wording of the manifesto, American contempt for German "self-prostitution" remained pronounced. ${ }^{58}$ Not only were individual educators like Butler at first unwilling to re-establish contact with Germany, but America's sprawling commitment to international education (spearheaded by the Carnegie Endowment under Butler) ignored Germany almost entirely until the mid-1920s. By the same token, prewar cultural programs were systematically discredited. For example, the professorial exchange, the Amerika-Institut reported, was seen as a "particularly menacing piece of German intrigue and propaganda." 59 With the American campus transformed from a beacon of German influence into a haven of anti-German sentiment, Germany had lost its most significant means of accessing American cultural elites. Only in 1921, it is fair to say, did the true extent of wartime devastation to Germany's cultural reputation sink in. In a memorandum of October 1922, the Foreign Ministry's Kulturabteilung astutely noted that the former Allies were well on their way to establishing a "cultural international against and without Germany."60

At this point, we must also acknowledge the more fundamental shift in transatlantic relations and American mentalities that underpinned this American position. The war provided Americans with a new sense of national pride that made them increasingly sensitive to the Old World's claims of cultural superiority. An American journalist conducted a survey among the famous "Ninety-Three" (the signatories of the 1914 manifesto) in 1920 and was not only dissatisfied with their generally unrepentant answers but was also quick to detect - and reject - "the old feeling of superiority to 'ignorant Americans."'61

57 "Butler Arraigns German Scholars," New York Times, Apr. 19, 1919.

58 See also "German Intellectuals Speak Up," The Literary Digest, Aug. 30, 1919, 32-33; "Kultur Manifesto Foisted on Signers: Many Germany Intellectuals Say They Were Misled by Vague Summary of Document," New York Times, Nov. 5, 1920. Yet while the manifesto itself had made front page news and was commonly reprinted and referred to, the story behind the manifesto was only reported on page 17 of the New York Times.

59 Amerika-Institut, Tgb.-Nr. 2053/23 to AA, Sep. 1, 1923, PA R 64998.

60 Aufzeichnung, Oct. 31, 1922 [Abt B], PA R 65519.

61 See Harvey M. Watts, "Present Attitude of the Ninety-Three German Professors," Public-Ledger Philadelphia, Jan. 25, 1920, reprinted in Ungern-Sternberg and Ungern-Sternberg, Der Aufruf 'An die Kulturwelt!', 296-306. 
Americans, well aware of the economically and ideologically decisive role their nation had played in the war and proud of their increasingly well-staffed and well-endowed universities, libraries, and concert halls, found this continued cultural conceit ever more irritating. ${ }^{62}$ As the German ambassador Otto Wiedfeldt would later observe about European lecturers in the United States, "the war has rightly made the Americans a self-confident people, who instinctively rebel against being given advice from foreigners in their own country." ${ }^{33}$ Even if Germans and Americans would one day bridge their differences, their relationship would never be the same.

Aside from all financial troubles, then, German leaders would find capitalizing on the prestige of German science and culture in mending relations with the United States more difficult than they had anticipated. Once they had realistically assessed the status of German culture in America, the major objective of the postwar years became maintaining rather than expanding cultural relations, and even this grew ever harder to accomplish. In the sober light of the postwar period, the ultimate aim of cultural diplomacy could no longer be a prewar version of "moral conquest" but rather moral redemption; ${ }^{64}$ not the establishment of wide-ranging German influence but the removal of the worst instances of the cultural blockade. In other words, constructive cultural diplomacy had to let go of earlier ideas of cultural imperialism and admit that merely re-establishing ties with America would be an uphill battle, a long and generally unpleasant experience. In short, German scholars - with caution, a measure of self-effacement, and the will to make a fresh start - would have to rebuild American contacts through slow and painstaking efforts. Unfortunately, few were willing to take on such an uninviting task.

\section{Reluctant Cultural Diplomats}

Indeed, if we turn to those who had previously been Germany's major cultural diplomats in the United States, especially German professors, it is apparent that it was very difficult for them to continue prewar efforts. For years after the war, many German scholars remained intransigent toward the international academic community and actively sabotaged the attempts of those (including the Foreign Ministry) trying to steer a more conciliatory course. Humiliated by the peace agreement and insulted by Allied charges of moral deficiency, they

62 Levine argues that it was only "during the 1920 and 1930 s that American schools of higher education moved into the mainstream of American economic, social and cultural life." See David Levine, The American College and the Culture of Aspiration, 1915-1940 (Ithaca, NY, 1998), 17.

63 German Embassy, Washington, to AA, Dec. 11, 1922, "Angebliche Vortragstour des ehemaligen Reichskanzler Wirth in Amerika," PA R80294.

64 See Rohrbach, Moralische Eroberungen. 
had strong reservations about such efforts and often rejected them outright. Once they recognized the extent of their exclusion from international scholarly organizations and networks - what German scholars would soon come to identify as the "boycott of German science" - the newly founded Association of German Universities (Verband deutscher Hochschulen, est. 1920) responded with a "counterboycott." In particular, it asked German scholars to abstain from attending international conferences or university jubilees until German scholarship once more received the acknowledgment it intellectually deserved. ${ }^{65}$ In the American case, academic resentment was only intensified by the great disappointment many German scholars felt toward their colleagues. They attributed the fact that their wartime appeals had found so little favor with American academics not to the deficiency of their own arguments but to American ill-will and ingratitude. Accordingly, they believed that any resumption of transatlantic relations would first require American academics to apologize. ${ }^{66}$

Rampant cultural and political anti-Americanism among Germany's conservative elites in the 1920 s further hindered the mending of transatlantic academic ties. In the face of America's rise to economic and financial pre-eminence, German cultural arrogance became even more pronounced. While the U.S. impressed Germans with its prosperity, they abhorred its allegedly mechanized, soulless, money-grabbing culture. Reducing the American image to the two poles of industrial greatness and cultural shallowness, even those with a liking for America regarded it as a country without culture or, at most, a culture in the making. ${ }^{67}$ Such cultural arrogance was, of course, not new, but it now affected transatlantic relations more than it had two decades earlier; not only had American elites grown less patient with it, but two important factors that had previously helped German professors overcome their opposition to America no longer existed: For one, the war had dashed their hope that they could gain a measure of influence in the United States through programs like the professorial exchange. Although German professors had previously agreed to participate in such endeavors to establish Germany's cultural pre-eminence

65 Schroeder-Gudehus, Deutsche Wissenschaft und internationale Zusammenarbeit, 181-211; see Declaration of German Professors in Mitteilungen des Verbandes der Deutschen Hochschulen 5, no. 1 (Jan. 1925): 50.

66 The sentiment of the more irreconcilable parts of German academia is embodied by Meyer, Die Vereinigten Staaten von Amerika.

67 Even those with good personal knowledge of the country could never entirely rid themselves of their cultural conceits. The counselor of embassy in Washington, Hans-Heinrich Dieckhoff, at first found "this country without history unappealing; the lack of culture, music and art is terrible." See Taschka, Diplomat ohne Eigenschaften, 88; This was repeated by the German ambassador to Washington as late as 1935: The Ambassador in the United States to the Foreign Ministry, June 28, 1935, Documents on German Foreign Policy (DGFP), Series C, Vol.4, Document No. 184 . 
in the United States, the war seemed to have demonstrated the faultiness of such assumptions, making them considerably less likely to take on similar tasks. ${ }^{68}$ Secondly, these academic initiatives no longer enjoyed the prestige of the Kaiser's interest in the 1920s. Whereas many German professors had previously been willing to go abroad as "Kaiser Wilhelm Professors" to enhance the reputation of imperial Germany, they often had no desire to serve the current government in the same way. Indeed, many of them had strong reservations about the new republic, if not outright hostility. Accordingly, they kept their distance from Germany's peace-burdened republic despite their loyalty to both state and nation as seemingly eternal entities. Though there were some notable exceptions (as we will see), most German professors were unwilling to swallow their pride and prejudice to help an unloved government re-establish itself internationally. The irreconcilable mentalities of Germany's foremost "exponents of culture" became a constant source of frustration to German ministries and semi-private organizations alike. ${ }^{69}$ In the early 1920 s, German mandarins turned out to be very reluctant cultural diplomats.

All in all, cultural, and especially academic, relations were not at first the muchneeded "neutral ground" that publicists and politicians had hoped. In practice, scarcely any other field was as burdened by wartime memories. A significant number of the individuals who had previously facilitated transatlantic cultural exchanges had defected from the cause, and the few who were still committed, like the Amerika-Institut, were hampered by financial constraints, a lack of overseas partners, and the general atmosphere of distrust. The psychological hurdles the war had erected proved to be much higher than initially anticipated. Partly for that reason, German diplomats tended to approach the subject with caution. Their standard response to private initiatives, like sending a German orchestra to the United States, was often dissuasion. When weighing the little good that cultural representations could do against the great harm they might cause, diplomats often deemed such endeavors a risk not worth taking. ${ }^{70}$

Moreover, with the London schedule of reparations payments in 1921 the German government set out on an economic course that appealed less to American sympathies than to America's self-interest in a politically and economically stable Europe. The German government argued that these repara-

68 See Chapter 5.

69 Amerika-Institut to AA [Heilbron], Mitteilungen des Amerika-Instituts an die Mitglieder des Kuratoriums, May 20 1922, PA R 64997.

70 German Embassy, Washington [Wiedfeldt], to AA, Sep. 23 1922, "Auf den Erlass vom 25 Okt. 1922 VI C 2071," PA R80294; German Embassy, Washington, to AA, Feb. 26, 1924, "Deutsche Amerikafahrer," PA R80297. 
tions payments overburdened Germany and - applying the logic of world economic interdependence - would ultimately undermine all of Europe's, as well as America's, prosperity. ${ }^{71}$ Thus, it was in America's own best interest to help Germany in adjusting the total reparations sum and the payment modalities. Accordingly, a businessman rather than a scholar was appointed ambassador to Washington. Assuming the post in March 1922, Otto Wiedfeldt, director of the Krupp Iron Works, was to use his economic acumen and contacts to "sell" the German version of the reparations problem and secure American involvement..$^{72}$ In the end, business, not culture, provided the needed common ground in the early 1920 .

Nevertheless, while this set of obstacles stifled German initiative in the short run, it also gradually led to a more realistic assessment of the means and ends of public diplomacy. Whatever German hopes had been, there could be no campaign to capitalize on the reputation of German culture, nor anything but the most tacit, most unassailable attempts to reach out to German Americans. Cultural diplomacy would primarily mean overcoming distrust and gaining access to an American public whose notions of German culture - or Kultur, as Americans still mockingly spelled it - were singularly negative. ${ }^{73}$ In concrete terms, this meant Germany needed to build a new stock of "cultural diplomats" willing and able to act in accordance with a more conciliatory foreign policy and to find alternate ways of reaching out to the American public. The first opportunity to this end arose not by design, but by chance - and across the Atlantic.

\section{Cracks in the Blockade: American Aid to Germany, 1919-1922}

A first major breach of German isolation immediately followed the Treaty of Versailles in the shape of American humanitarian aid for Germany. In the first few years after the war, relief work offered an important outlet for America's

71 For this argument, see Manfred Berg, "Germany and the United States: The Concept of World Economic Interdependence," in Genoa, Rapallo, and European Reconstruction in 1922, ed. Carole Fink, Axel Frohn et al., 77-93 (New York, 1991).

72 As the newly appointed Wiedfeldt explained to a German newspaper, Germans would have to "give our best to fulfill the conditions we have signed, and to show through our honest attempt at fulfillment, that they cannot be actually fulfilled." Rheinisch-Westfälische Zeitung, Mar. 23, 1922, in Otto Wiedfeldt als Politiker und Botschafter der Weimarer Republik, ed. Schröder, 159238 (Essen, 1971), 197; on the importance of Wiedfeldt's appointment, see also Document 42, Von Schubert to Krupp von Bohlen and Halbach, March 11, 1922, in Peter Krüger, ed., Carl von Schubert (1882-1947). Sein Beitrag zur internationalen Politik und europäischer Ordnung in der Ära der Weimarer Republik. Ausgewählte Dokumente, 199-201 (Berlin, 2017).

73 Aufzeichnung des Konsuls Dr. Kraske vom 10. Oktober 1924 (attachment to German Embassy report, Jan. 30, 1925), PA R 61130. 
internationalist impulses, constituting the most significant U.S. involvement with postwar Germany. ${ }^{74}$

German Americans spearheaded these American efforts. Affected by German appeals after the armistice and haunted by the idea of their kin suffering overseas, German Americans began to organize relief aid for Germany as early as the spring of 1919. Once the peace treaty had been signed and the sea blockade raised, German-American organizations and individuals devoted themselves almost entirely to alleviating the distress of an ever-growing number of German beneficiaries. By 1920, large fundraising campaigns for suffering children, students, and the middle classes were being organized across the country and millions of parcels dispatched to relatives and acquaintances overseas. ${ }^{75}$ German-American communities established their own children's homes, orphanages, and tubercular wards across Germany, formed knitting groups, and collected "quarters" for German children after every Sunday service. Overall, German-American donations to Germany in the first half of the 1920 are estimated at a staggering 150 million dollars. ${ }^{7}$ Relief work became the central ethnic occupation for German Americans of the postwar period, and, indeed, of the entire 1920s.

Yet, Anglo-Americans also grew more involved in aiding Germany. As in other countries, children served as universal symbols of innocent suffering, and their plight garnered a broad humanitarian response. ${ }^{77}$ As early as August 1919, the American Friends Service Committee (Quakers) established an emergency relief program for undernourished and tubercular German children. ${ }^{78}$ With the financial and logistical support of American "relief czar" Herbert

74 Ruth Rouse, Rebuilding Europe: The Student Chapter in Postwar Reconstruction (London, 1925), 10.

75 On U.S. aid to Germany, see Charles Strickland, "American Aid for the Relief of Germany 1919-1921" (M. A. thesis, University of Wisconsin, 1959); Elisabeth Piller, "German Child Distress, American Humanitarian Aid and Revisionist Politics, 1918-1924," Journal of Contemporary History 51, no. 3 (2016): 453-486.

76 Central Relief Committee to German Ministry of Labor, Nov. 1, 1921, BArch R 3901/9107; Hermann Stöhr, So half Amerika (Stettin, 1936), 122; the head of the New York Relief Committee Emanuel de Marnay-Baruch estimated in November 1923 that German Americans had donated a total of 350 million dollars; "Von unserer Arbeit. Vortragsabend," Der Auslanddeutsche 6, no. 21 (Nov. 1923): 623 .

77 On children and women in humanitarian campaigns, see R. Charli Carpenter, "Women, Children and Other Vulnerable Groups': Gender, Strategic Frames and the Protection of Civilians as a Transnational Issue," International Studies Quarterly 49, no. 2 (2005): 295-334; for the context of World War I, see Friederike Kind-Kovacs, "The Great War, the Child's Body and the American Red Cross," European Review of History 23 (2016): 33-62.

78 See Tammy M. Proctor, "An American Enterprise? British Participation in US Food Relief Programmes (1914-1923)," First World War Studies 5, no. 1 (2014): 29-42; Mary Elisabeth Cox, Hunger in War \& Peace: Women and Children in Germany, 1914-1924 (Oxford, 2019); Guy Aiken, "Feeding Germany: American Quakers in the Weimar Republic," Diplomatic History 43, no. 4 (2019): 597-617. 
Hoover, it soon grew into one of the largest aid programs on the continent. By mid-1921, the Quakers' feeding program for children (known as the Quäkerspeisung) provided a daily meal for one million children across Germany. In the following years, Americans would also be at the forefront of intellectual aid by trying to improve the living conditions of German students and supplying German libraries and universities with much-needed international publications. ${ }^{79}$ By the time a separate peace treaty between the two countries was signed, Americans had already delivered books, meals, and clothes valued at millions of dollars to Germany.

To be sure, the Americans groups involved used their relief work for widely different agendas. Perhaps the only conviction they shared was that German relief was not solely about alleviating physical or intellectual hardship. For the majority of German Americans, aiding Germany was deeply personal. After having been cut off from family and friends for more than two years, they saw relief work as a way to renew transatlantic connections and express affection for their former fatherland in a politically inoffensive manner. As one German American wrote to his German aunt: "even though no peace has been established between Germany and America, the circumstances are so good that one is allowed to have pity on one's kin without being persecuted or condemned."8o Many also saw German aid as a way to protest Germany's international isolation. German-American leaders, for their part, hoped that a humanitarian campaign could help them forge a common political platform against Versailles. ${ }^{81}$ While such hopes remained vain, German Americans did use relief work as a socially acceptable way to express their compassion, affection, and support for Germany in the first half of the 1920 .

While German-American aid was often personal and emotional, Herbert Hoover and his American Relief Administration pursued more pragmatic objectives. Following the simple and persuasive notion that "hunger breeds Bolshevism," Hoover systematically used American food to further a counter-revolutionary agenda and to stabilize a Central Europe under siege by "rad-

79 Germanistic Society, Appeal [late 1920], Franz Boas Papers, Box 31, American Philosophical Society (APS). In April 1921 the German program - like similar ones in Austria and Poland passed into the hands of the recently founded European Student Relief. A. Ruth Fry, A Quaker Adventure: The Story of Nine Years' Relief and Reconstruction (London, 1926), 333; on the European Student Relief, see Elisabeth Piller, "European Student Relief, Humanitarianism, and PostWorld War I Reconciliation," in Online Atlas on the History of Humanitarianism and Human Rights, ed. Fabian Klose, Marc Palen, Johannes Paulmann, and Andrew Thompson, urn: nbn:de:0159-2019042427; on intellectual aid in the postwar period more generally, see Tomás Irish, "The 'Moral Basis' of Reconstruction? Humanitarianism, Intellectual Relief and the League of Nations, 1918-1925," Modern Intellectual History 17, no. 3 (2020): 769-800.

80 Quoted in Wolfgang Helbich, ed., Amerika ist ein freies Land ... Auswanderer schreiben nach Deutschland (Darmstadt, 1985), 187.

81 Charles Strickland, "American Aid to Germany, 1919-1921," The Wisconsin Magazine of History 45 (1962): 256-270. 
ical" elements. Moreover, Hoover regarded American child relief as a prime image-building tool and made sure that European recipients knew their food was coming from a "beneficent America." ${ }^{82}$ In the specific case of Germany, Hoover's involvement was also an effort to wrest an emotional topic like child suffering from the hands of resentful ethnic leaders ${ }^{83}$ Reluctant to undertake the unpopular German work himself, however, he entrusted it to the politically reliable Quakers.

Between German Americans and Hoover, there were also American church, reform, and university circles. These were neither as emotional nor as pragmatic as the former, approaching German relief as a reform and peace-building project. Groups like the American Quakers set about their work to provide hope and sympathy to a German people who were "not only hungry, but discouraged and in despair." ${ }^{34}$ Where others saw only the unloved enemy, they saw an unprecedented opportunity to convert a resentful and militaristic society to the principles of peace and forgiveness. "There is a wonderful opening for us here," wrote one enthusiastic Quaker relief worker, "the philosophy of force has crumpled in our hands." ${ }^{85}$ For example, the YMCA-led European Student Relief, steeped in social gospel thinking, gave extensive aid to German students, considering its work part of a reform agenda to eradicate dangerous national chauvinism, stabilize the fledgling German republic, and draw Germany back into the family of nations. ${ }^{86}$ As Conrad Hoffmann, the American executive of the European Student Relief, explained in 1919, it was "high time, now that Germany had been defeated, that the hand of Christian helpfulness and fellowship be extended to the German people. They need encouragement in their efforts to become a democracy welcome in the society of nations." ${ }^{87}$ To be sure, behind this rhetoric of goodwill and solidarity American aid at times came close to a re-education program. For instance, the YMCA not only provided financial aid to German students but systematically encouraged American-style "work study," not least to promote democratic and

82 Costigliola, Awkward Dominion, 21; Americans served food only in canteens where an American flag was displayed; Franz Adlgasser, American Individualism Abroad: Herbert Hoover, die American Relief Administration und Österreich, 1919-1923 (Vienna, 1993), 95.

83 Strickland, "American Aid to Germany, 1919-1921."

84 Sidney Brooks, Germany and America, 1918-1925 (New York, 1925), 145.

85 Carolena Wood, quoted in Rufus Jones, A Service of Love in War Time: American Friends Relief Work in Europe, 1917-1919 (New York, 1920), 260.

86 Rouse, Rebuilding Europe, 129; Elisabeth Piller, "'Can the Science of the World Allow This?' German Academic Distress, Foreign Aid and Cultural Demobilization, 1919-1924," in The Academic World in the Era of the Great War, ed. Tomás Irish and Marie-Eve Chagnon, 189-211 (London, 2017).

87 Conrad Hoffmann, In the Prison Camps of Germany: A Narrative of 'Y' Service among Prisoners of War (New York, 1920), 265. 
egalitarian attitudes ${ }^{88}$ Above all, U.S. aid, wittingly or not, projected American efficiency, power, and prosperity overseas. Whatever its other qualities, American relief work was also a vehicle for American economic and cultural expansion in Europe. ${ }^{89}$

And yet, such observations still fail to capture the entire significance of American relief - at least in Germany. In fact, hardly any other activity was as important to redeveloping transatlantic cultural contacts in the long run. It did so in at least three ways. First, it rebuilt organizations. As an allegedly apolitical task, it helped German Americans, in particular, to restructure their defunct institutional life without running afoul of nativist sentiment. This is true both of the many ethnic Vereine and of high-brow cultural organizations like the Germanistic Society (est. 1904). Unable to resume its prewar transatlantic activities in the face of widespread hostility, the Germanistic Society, for example, had found a new purpose providing intellectual aid to Germany by 1920.90 This useful and generally unobtrusive work enabled it to recover its prewar membership of prominent bankers, editors, and professors relatively rapidly. ${ }^{91}$ Although the Germanistic Society wisely advertised its work as a way of spreading American influence in Europe, its fundraising appeals still aimed to elicit respect for German cultural accomplishments. By the time it officially resumed its work in 1925, it had already played an important transatlantic role for half a decade..$^{92}$ For the Germanistic Society, as for a large range of German-American organizations, relief work provided an important purpose and organizational focus that helped reinvigorate their work while steering clear of nativist suspicions. For Germany, the survival of these organizations and their tacit alliance with Anglo-Americans (especially in child and intellectual aid) would become significant.

88 See Elisabeth Piller, "Prelude to 'Re-Education': U.S. Internationalists, German Students and the Search for a New World Order, 1918-1948” (working paper).

89 On this point, see Costigliola, Awkward Dominion, 39-50; and Rosenberg, Spreading the American Dream, 74; for a more recent contribution, see Julia Irwin, "Sauvons Les Bébés: Child Health and U.S. Humanitarian Aid in the First World War Era”, Bulletin of the History of Medicine 86, no. 1 (2012): 37-65.

90 Emergency Society in Aid of European Science and Art, Special Meeting of the Society, Nov. 30, 1920, Franz Boas Papers, Box 24, APS.

91 By 1922 it again boasted a membership of 150 - compared to 200 before the war - made up of German-American academics, businessmen, and editors. Charles Nagel, the former U.S. Minister of Labor and Commerce and one of the most prominent German Americans of his time, served as president of the society. Scholars and intellectuals such as Camillo von Klenze of City College, F. W. J. Heuser of Columbia, Oswald Garrison Villard of the Nation, Victor Ridder of the New Yorker Staats-Zeitung, banker James Speyer, Henry Morgenthau, Paul Warburg, and anthropologist Franz Boas served as officers. Well-known philanthropists such as Henry Heide, Rudolf Pagenstecher, and Curt Reisinger supported its work.

92 By 1927 the Emergency Society for German and Austrian Art and Science, which the Germanistic Society had founded for that purpose, had administered more than $\$ 107,544$ in aid; Germanistic Society Report for the Year 1928. 
Second, American relief work improved transatlantic sentiment. For one, the fundraising drives communicated a German image to Americans that was at odds with the one created during the war. The focus on suffering German children once again humanized the German people, while intellectual aid reminded Americans of the important contributions German "culture" had made to civilization before it had become "Kultur." ${ }^{93}$ Although such representations elicited active sympathy among only a small group of Americans, they still reasserted the fundamental difference between German culture and politics and between the German people and the government, which the war had nearly erased. According to Schoenthal, relief work was one of the postwar factors that helped normalize American attitudes toward Germany. ${ }^{94}$ But in Germany, too, American aid softened sentiments toward the former enemy. While Germans were genuinely grateful for America's generous child aid, they also appreciated its intellectual and student relief as a token of ongoing regard for German science and universities. For some academics, at least, American aid made it psychologically easier to re-enter transatlantic relations.

Most importantly, American aid (re)built transatlantic networks. Personal "gifts of love" (Liebesgaben, charitable gifts) and large-scale child-feeding projects brought American ethnic, reform, church, and academic circles back into contact and cooperation with their German peers. Indeed, it would be wrong to conceive of aid as a unidirectional endeavor. In the field of intellectual aid, for example, the Germanistic Society partnered with the Notgemeinschaft der deutschen Wissenschaft to supply American publications to German libraries, thereby re-establishing intellectual exchange on the most basic level. In the field of student aid, too, the American-led European Student Relief developed such close ties with German student self-help organizations that, by 1923, it enjoyed perhaps its closest contacts not with former allies but with the former enemy. That the millions of individual "gifts of love" German Americans sent also profoundly strengthened transatlantic ties requires no special explanation. ${ }^{95}$ In terms of re-establishing institutional infrastructures, personal networks, and internationalist exchanges, no activity of the postwar period remotely matched America's multifarious relief operations. What is more, while historians have traditionally understood the role of aid operations as vehicles of American cultural and economic expansion in Europe, German students, professors, and officials could easily ignore these Americanizing undertones and see them also

93 See Elisabeth Piller, "Can the Science of the World Allow This?"

94 Schoenthal, "American Attitudes toward Germany," 89.

95 For one example of individual "gifts of love" and the substantial transatlantic correspondence accompanying them, see Princeton Special Collections, MCo34, Arthur von Briesen Papers, Box 11, Folders 35 and 41, Family Correspondence; von Briesen's many "gifts of love" to his family in Germany included caskets of eggs, milk, bacon, and cheese. 
as something else: cracks in the blockade. ${ }^{96}$ Not merely passive "recipients," they saw U.S. aid as a window of opportunity for redeveloping transatlantic contacts and eliciting sympathy among respectable Americans. In late 1922, the German Foreign Ministry's Kulturabteilung thus considered academic relief work the most promising development for the "re-establishment of a true universitas litterarum."97

\section{"The Average American Is Mad All the Time He Is in Germany": American Tourists and the Pathology of Inflation, 1922}

American relief offered a first opportunity to rekindle transatlantic contacts in the postwar period, yet the ratification of the separate peace treaty in late 1921 officially normalized transatlantic relations and broadened Germany's range of outreach options. Inflation uniquely aided this development. To be sure, currency devaluation had many disadvantages, but it also had its upsides. As it cheapened German services, living costs, and products, it facilitated cultural promotion. Due to inflation, for example, German books soon enjoyed worldwide demand, German universities saw an unprecedented increase in foreign (albeit not American) enrollment, and international tourism to Germany boomed, thereby giving Germany a chance to rectify its image and to fight wartime antipathies with the lure of a peacetime bargain. German psychology, however, made it difficult to capitalize on this opportunity. Nowhere was this more apparent than with regard to transatlantic tourism. Despite promising prospects, Germany suffered its most striking failure in this field. In the long run, however, the Foreign Ministry's new commitment to cultural diplomacy arose from these very difficulties.

It seems surprising at first that international tourism would be so fraught with problems. In fact, representatives of the German tourist trade had used the war to develop a coherent program of peacetime action that they had already presented to the Foreign Ministry in several memoranda in early 1919. The idea that travel promotion was not solely a commercial undertaking but also an unobtrusive way to shape how the world thought and felt about Germany was a key aspect of their vision. ${ }^{98}$ Personal impressions alone, they argued, could eradicate wartime prejudices and lead to a fairer assessment of Germany. The publicity director of the newly founded German Tourism Promotion Office

96 The German case confirms Emily's Rosenberg's contention of a "reciprocal agency that recipients could exercise upon the plans and strategies of donors." Emily Rosenberg, "Missions to the World: Philanthropy Abroad," in Charity, Philanthropy and Civility in American History, ed. Friedman and McGarvie, 241-257 (New York, 2003), 242.

97 VI A 1727 Aufzeichnung für den Herrn Reichsminister, Nov. 29, 1922, PA R60oo2.

98 See Chapter 6. 
(Reichszentrale für Verkehrswerbung, RDV, est. 1920) presented this argument as follows:

if we could with one stroke guide 100,000 educated and attentive foreigners through our Germany, show them our people at work, invite them from time to time to a friendly and contemplative stay, and if they then were to return home with lively memories, with memories of a country that looks so completely different than Northcliffe [Britain's main wartime propagandist] made it look, we could thereby do more for the revision of Versailles than all the diplomats in the world. ${ }^{99}$

Once Germany and the United States had re-established peaceful relations, prospects for tourism were indeed excellent. Thanks to inflation, the German tourist trade recovered by leaps and bounds and, by 1922, there were far more tourists than in the prewar period in those cities for which data are available. ${ }^{100}$ The low cost of a trip to Germany helped Americans overcome their prejudices against visiting Germany, especially as they were complaining of rising prices in other European countries. ${ }^{101}$ In 1922, during the first travel season after Germany had signed the separate peace with the United States and the first time the popular Oberammergau Passion Play planned to put on its performance in over a decade, up to 100,000 American tourists were expected to visit southern Germany. ${ }^{102}$ If the German Tourism Promotion Office held that 100,000 visitors could "do more for the revision of Versailles than all diplomats in the world," this marked a unique chance.

Germany almost completely passed up this chance, however. Rather than encountering a hospitable atmosphere in which their opinions on Germany might have softened, visitors found themselves harassed by inconvenient customs regulations and steep extra fees. By late 1921, travelers were no longer allowed to take even goods for daily usage out of the country and were subjected to harsh searches, heavy fines, and confiscation of unaccounted-for materials at the border. ${ }^{103}$ Hotels, theaters, restaurants, and shops often charged them several times the ticketed price, and newly introduced municipal taxes and so-

99 Maximilian Kraus, Die zukünftigen Aufgaben der deutschen Verkehrswerbung im In- und Auslande (Berlin, 1921), 10.

100 Instead of 140,000 foreign visitors in 1913, Munich hosted 230,000 in 1922. Whereas 40,000 foreigners visited the spa of Wiesbaden before the war, 100,000 did in 1922. In a trade fair city like Leipzig, the number of prewar visitors even increased five-fold to over 150,000 in 1922; the numbers are taken from Gerald Feldman, "Welcome to Germany? The Fremdenplage in the Weimar Inflation," in Geschichte als Aufgabe, ed. Wilhelm Treue, 629-49 (Berlin, 1988), 631.

101 "American Dollars Go Far in Germany," New York Times, July 31, 1921, 85; "Low Prices Big Surprise To Travelers in Germany," Washington Post, July 31, 1921, 50.

102 Its last prewar performance in 1910 had drawn about 200,000 visitors, of whom the single largest group had been Americans; "Liners Booked Up for Passion Play: One Hundred Thousand Americans Are Believed to Visit Oberammergau," New York Times, Apr. 9, 1922.

103 Reichsanzeiger, no. 257, Oct. 31, 1921. 
journ permits added to the inconvenience. Popular tourist destinations, like Bavaria, implemented a system of dual price scales (for foreigners and locals) across the board. Commenting on such practices, one U.S. citizen concluded in 1920: "the average American is mad all the time he is in Germany."104

There were many good reasons for such German measures. Given the immense purchasing power of foreign currency, strict customs regulations and dual price scales were primarily intended to dam the constant outflow of German valuables and hold German consumer prices in check. ${ }^{105}$ Accordingly, popular support for discriminatory measures rose and fell with the pace of inflation. But it was also influenced by postwar psychology. Having seen their own standards of living decline (and attributing it to the Treaty of Versailles), many Germans resented foreigners benefiting from their plight and being able to afford the luxuries Germans themselves could not. As one might expect, visitors from less prosperous regions, especially Eastern Europe, and those of the less affluent classes aroused the most resentment. Germans complained that many visitors who could barely afford a third-rate hotel at home were now taking advantage of the exchange rate to live in "undeserved" splendor in Germany. Concerning American tourists, the situation was slighty different. In this case, Germans' exaggerated sense of American prosperity and their notion that Americans "owed" Germany after President Wilson's "betrayal" at Versailles convinced them that Americans could afford to pay a little extra. At a time when the German public largely blamed the provisions of the peace treaty rather than the war itself for the country's malaise, it was not ready to be more welcoming of former enemies. As the American Consulate in Munich reported, Bavarian authorities tried to clamp down on the worst instances of extortion, but "in the face of the more or less pathological state of mind of the public it is going to be exceedingly difficult to keep charges within reasonable bounds ... travelers coming to Munich should be prepared to expect overcrowding, discrimination against foreigners, and regulations which at best will prove annoying." ${ }^{\prime 106}$

104 Parke Brown, "Rise in Marks Boosts Prices in all Germany," Chicago Daily Tribune, May 24, 1920,7 .

105 Particularly in tourist and border regions, foreigners seen wining and dining on the cheap aroused public resentment and fears about price increases for the local population; see Verhandlungen des Deutschen Reichstags, Bd. 351, 145. Sitzung, Nov. 17, 1921, 5019.

106 American Consulate, Munich, to State Dept, Apr. 5, 1922; "Tourist Travel at Munich; Attitude toward Foreigners," NARA RG 59 Box $9623862.111 / 154$. 
Fig. 6: The image captures German fears of a sell-out

Erich Schilling, "Kunstraubzug des Dollars [The Dollar's Art Pillage]," Simplicissimus, 1922

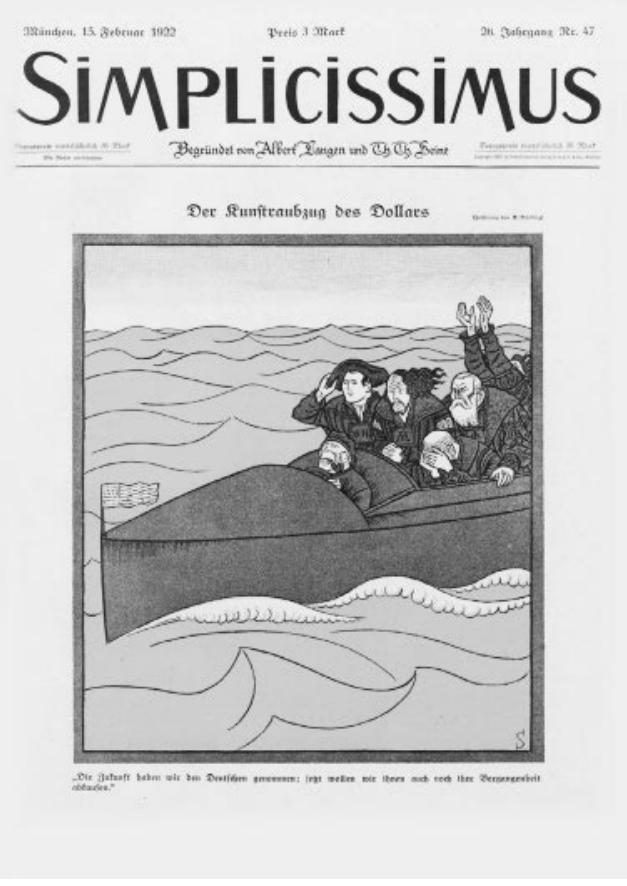

The consulate's predictions soon proved all too accurate. By mid-May 1922, throngs of American tourists left Germany with the distinct feeling of having been "ripped off." While indignation had flared up from time to time with regard to customs regulations or extra charges, now a veritable storm of unfavorable reporting erupted in the American press. American newspapers and their Paris editions gave extensive coverage to discriminatory practices and even called for a boycott of German (especially Bavarian) destinations. ${ }^{107}$ Reports that an American had been robbed in Berlin led the New York Times to quip that Americans were robbed every minute and "all over Germany."108 Though many Americans admitted that Germany remained a comparatively cheap travel destination, even with extra charges, they objected, on principle,

107 "Tourists Avoid Germany," New York Times, June 17, 1922; "Powers Protests to Reich over Extortions," Chicago Tribune, Paris Edition, May 25, 1922; "Pay \$10 to Leave Berlin," Chicago Tribune, Paris Edition, May 24, 1922; "American Women Outwit German Extortionists," Chicago Tribune, Paris Edition, May 24, 1922; "Prussians Seek to Tax Tourists," New York Herald, Paris Edition, May 23, 1922; "Bavarians Exact Exorbitant Fees from Americans," New York Herald, Paris Edition, May 23, 1922; "Trade Reports Show How Germans Fleece Tourists," Chicago Tribune, Paris Edition, May 22, 1922; American Consulate, Munich, to State Dept., June 1, 1922, "Tourist Travel at Munich," NARA RG 59 Box 9623 862.111/162; "Boycott of Munich Is in Full Swing," Amaroc News, June 8, 1922, 1.

108 "Robbing Americans All Over Germany," New York Times, May 19, 1922, 1. 
to being charged more for the same service. And while extortion was common to some degree in all tourist destinations, such practices easily reawakened the widespread antipathy toward Germany that tourists had grudgingly ignored for the promise of a cheap vacation. German Americans, the only group staunchly in favor of Germany at that point, who also comprised a very considerable share of American visitors to Germany in 1922, were particularly indignant about such maltreatment. Having just raised millions of dollars to alleviate German hardship, they were outraged at being treated like all other foreigners. ${ }^{109}$ For example, the director of the Germanistic Society Frederick Heuser wrote his friend Franz Boas that "[e]very ill in Germany is attributed to the foreigner and I am beginning to get very tired of this foolish agitation. The Germans are undoubtedly losing many sympathies by the annoying regulations which are enforced against foreigners without distinction." 110 The experiences of American tourists, in short, kept alive rather than eroded their wartime hostilities toward Germany. ${ }^{111}$ Instead of improving Germany's image, tourism confirmed Americans' preconceived notions.

To make matters worse, unfavorable tourist impressions easily reflected back on the ongoing reparations negotiations. American visitors and newspapers interpreted the behavior of German individuals and the crowdedness of cafés (often a result of inflation itself) as signs of German prosperity and applied these impressions to the larger economic questions at stake. One American business traveler was so outraged at being charged double or triple at hotels, restaurants, shops, and even the municipal police station that he concluded: "the Germans will not pay the reparations, but everyone has money [...] The Germans eat enormous and expensive meals and sit in the cafes drinking beer all day long and then say they cannot pay damages to France."112 This was exactly the sort of image that Germany needed to avoid carefully and that parts of the American press delighted in printing: a deceitful, unreconstructed nation in search of American money but without any warmth for or appreciation of the former enemy. The fact that this storm of publicity hit just as American bankers were gathering in Paris for informal talks with the Reparations Commission (from May 24 to June 9, 1922) made for a worst-case scenario. ${ }^{113}$ Germany had failed to use the unique chance tourism offered to mold American attitudes in its favor.

109 On German-American indignation, especially in the context of the relief program, see, for example, Clipping: "Eine Steuer auf amerikanische Gäste?" Chicago Abendpost, May 15, 1922, Abendausgabe, 34/114, German Consulate Chicago to German Embassy, Washington, PA Deutsche Botschaft, Washington, 1493.

110 Heuser to Boas, Jan. 20, 1923, Boas Papers, Box 39, APS.

111 Wendschuch to Reichszentrale für Verkehrswerbung, June 21, 1922, BArch R 901/25904.

112 “Robbing Americans All Over Germany," New York Times, May 19, 1921, 1.

113 On these talks, see Karl Dietrich Erdmann, "Deutschland, Rapallo und der Westen," Vierteljahreshefte für Zeitgeschichte 11, no. 2 (1963): 105-165, 155-63. 
These problems and their obvious repercussions for foreign affairs finally forced German officials out of their lethargy. Throughout May and June 1922 (on May 18, 23, 25, 27, and June 2), the German embassy in Washington reported the extent of American irritation. By late May, Ambassador Wiedfeldt warned that American complaints had come in at such a rate that he "feared for German-American relations." ${ }^{14}$ To him, these extortionate practices were nothing short of financial folly. With Germany's recovery dependent on American loans, he felt it was sheer lunacy to threaten these prospects for the "paper profits" of some Bavarian cities. ${ }^{115}$ As he admonished a few months later, "such odds and ends do not bring in significant amounts, but they damage us significantly with regard to the general opinion in this country. What good is the extra income of the Bavarian ... police force if it holds back American intervention in Europe even by some months[?]"116 He urged Berlin to critically rethink the treatment of American travelers in its foreign policy. If improving American opinion really was among Germany's primary foreign policy goals, Wiedfeldt noted, then the German authorities would have to address these discriminatory practices. ${ }^{117}$

In the following months, the Foreign Ministry pushed Germany's foreign policy interests with tourist groups, Bavarian officials, and the Reich Ministry of Finance. It prompted the nation's foremost tourist interest groups to agree to abandon discriminatory practices and adopt a public statement condemning discrimination against foreigners on July $22 .{ }^{118}$ While the dramatic drop in American tourist spending certainly helped to gain their cooperation, the crisis had also evoked greater concern for the German "image" among liberal circles. ${ }^{119}$ On June 22, 1922, the left-liberal Frankfurter Zeitung featured an editorial on the "sheer madness" of existing practices. It warned that German behavior was playing perfectly into the hands of its enemies, who were bent on cementing an unfavorable German image abroad:

114 German Embassy, Washington, to AA, May 27, 1922, PA Botschaft Washington, 1493.

115 German Embassy, Washington, to AA, "Politische Wirkung fremdenverkehrs-feindlicher Maßnahmen in Deutschland," May 18, 1922, PA R246958.

116 Report of the German Embassy, Washington, Oct. 4, 1922, PA Botschaft Washington, No. 1493, Vol. 1: 1921-25.

117 German Embassy, Washington, to AA "Politische Wirkung fremdenverkehrs-feindlicher Maßnahmen in Deutschland," May 18, 1922; PA R 246958; German Embassy, Washington, to AA, June 19, 1922, PA R 246958.

118 Circular AA to foreign missions, July 31, 1922, BArch, R 901/25904.

119 Whereas 30,000 foreigners visited Garmisch-Partenkirchen in June 1921, only 40,000 did the following year. By the end of the American travel season in late August, only 20,000 Americans were said to have attended the Oberammergau play; see "Greatest Season for the Passion Play," New York Times, Aug. 28, 1922; American Consulate, Munich, to State Dept., July 29, 1922, "Change of Attitude toward Foreigners in Bavaria," NARA RG 59 Box 9623 862.111/166. 
By our present attitude, we have seriously injured ourselves. And we have in this way done a great favor to our enemies. The Northcliffe press and the American yellow journals and all the other unfriendly organs have seized with avidity upon this material. We must ask our readers to look at the matter very seriously. .... The fact is that in North and South America, in Great Britain and in neutral countries there is a growing feeling against Germany on account of its improper treatment of foreigners. We should have learned from the experience of the war that politics frequently depend largely upon the feeling of the people. In our present political situation the most important article for export, which we have to offer foreigners is a good opinion about ourselves. We have not recognized this enough. It is time that we did. ${ }^{120}$

With this argument, the editorial laid its finger on the crucial problem of the postwar period. At a time when Germans liked to blame all ills on the "foreigner," the editorialist realized that negative opinions of Germany were not the product of a sinister enemy's machinations but were at least partly homemade. Germany was isolated, and it had isolated itself.

It was precisely this realization that drew the Foreign Ministry into fields that had long been outside its purview. More and more frequently, Germany's foreign missions reported on the negative repercussions of discriminatory practices, not only against tourists but also against foreign students (who were similarly subjected to steep extra fees). These reports increasingly focused the attention of German ministries, parliamentarians, and liberal publicists on issues like university admissions, the hospitable treatment of visitors, and the attitudes of German professors. ${ }^{121}$ In fact, in the same way that the Foreign Ministry began to push for a more accommodating stance toward tourists, it also began to champion more lenient admission criteria for international students at German universities and tried to effect more conciliatory attitudes among German professors. ${ }^{122}$ All these efforts attest to a growing sense among German officials of responsibility for public and cultural relations, a far cry from the lukewarm concern of even 1921. An internal memorandum of November 29, 1922, by the Kulturabteilung on Germany's international cultural relations illustrated this process. While the Kulturabteilung affirmed that maintaining ties with millions of Germans outside the Reich's borders was its priority, it also - for the first time since the war, it seems - underlined the importance of resuming the "cultural exchange with foreign peoples."123 To be sure, many official efforts to engender a more accommodating stance toward foreigners went nowhere, but it was precisely the ensuing frustrations that made these fields an

120 American Consulate, Frankfort-on-Main, to State Dept., June 22, 1922, "Paraphrase of Editorial in the Frankfurter Zeitung," NARA RG 59 Box $9623862.111 / 164$.

121 German Legation, Stockholm, to AA, Apr. 8, 1922, PA R64853.

122 Aufzeichnung (Kulturabteilung), Oct. 31, 1922, PA R65519.

123 Aufzeichnung (Kulturabteilung) für den Herrn Reichsminister, Nov. 29, 1922, PA R60oo2. 
official responsibility in the end. At the Wilhelmstrasse, every scientific conference German professors declined to attend, every pestered tourist, every rejected international student only hardened its resolve to establish a greater measure of official control once the opportunity arose.

Under the conditions of inflation, however, this was not going to happen. Of course, the Foreign Ministry did achieve some smaller successes from time to time, but it could not maintain them for long. Whenever a new phase of inflation came, any reductions in tourist surcharges or international student fees that it had painstakingly negotiated over months was immediately reversed. No appeal to patriotic service or invocation of French competition could make the German tourist industry or universities forfeit this source of extra income at a time when their financial foundations were rapidly being eroded. And no rational argument could overcome the "more or less pathological state of mind" of many Germans who blamed their malaise on foreign actions. In other words, the German public could not be convinced that foreigners needed to be cultivated at a time when foreigners were seen as Germany's very problem. Minor exceptions aside, the inflation provided neither the economic nor the psychological climate for systematic public diplomacy.

The situation in America clearly attests to this. By late 1922, four years after the armistice, German inroads in the United States were still remarkably modest. Efforts to regain a measure of trust and sympathy had hardly reached beyond German Americans and a very small group of American liberals. ${ }^{124}$ In early 1923, the Foreign Ministry's America Department prepared a list of "influential pro-German Americans" that shows just how little Germany diplomacy had accomplished. Of the only two dozen names on the list, all were German-American and none was truly "influential." ${ }^{25}$ Recurring bouts of nativism and wartime resentment, a lack of networks and sympathetic interlocutors, and the financial and psychological impact of inflation all stifled German endeavors. As Germany entered the period of hyperinflation in the early fall of 1922, American opinion seemed to have moved no closer to intervening in the reparations struggle on Germany's behalf.

124 This was also the basic conclusion Ambassador Wiedfeldt drew from the thoroughly pessimistic picture of American interests and attitudes he presented to Germany's leading industrialists in the summer of 1922; see Wiedfeldt in Schröder, Otto Wiedfeldt als Politiker und Botschafter der Weimarer Republik, 199.

125 Liste von einflussreichen pro-dt. Amerikanern [list of influential pro-German Americans], ca. 1923, PA R80295: the list included Prof. John A Mandel, Rudolph Pagenstecher, Fr. Professor von Klenze, Prof. Dr. Julius Hofmann, Otto L. Schmidt, Albert O Troetel, Ferdinand Thun, John D. Horst, Prof. John A Walz, Howard E Wurlitzer, Godfray Schirmer, and Charles Nagel. 


\section{"Propaganda Is Only Disadvantageous in this Country" Germany's Year of Crises and the Move toward Public Diplomacy, 1923-1924}

1923 has rightly been called Germany’s “year of crises.” On January 11, 1923, following a German default on coal and timber deliveries, French and Belgian troops occupied the industrial Ruhr as a "productive pledge" for German reparation payments. In response to this dramatic climax of the reparations struggle, the German government proclaimed a policy of passive resistance in the Ruhr. Intended to render the occupation economically futile, it only hastened Germany's financial breakdown. By November 1923, left- and right-wing coups shook the republic. Un- and underemployment numbers had soared to unprecedented heights. One dollar bought 4,210,500,000,00o marks.

Ironically, this time of profound crisis would bring Germany closer to a policy field as elusive as cultural diplomacy. The experiences of 1923 reaffirmed the German government's policy of caution toward the United States under conditions of extreme duress, underlined its need to reorganize international cultural relations, and, not least, occasioned the long anticipated reversal of American sentiment. It was during Germany's greatest trials in the fall of 1923 that the Foreign Ministry and private groups adopted a more coherent cultural approach distinct from the wartime legacy of propaganda. In the end, Germany would have a clearer idea of how to facilitate cultural rapprochement and a better chance of achieving it.

The Ruhr crisis brought the question of American public sentiment into sharp relief. With economic odds stacked against it, Berlin was determined to capitalize on what it considered an act of French aggression in the "midst of peace." As the chief press officer of the Foreign Ministry outlined in early 1923, Germany needed to use the French occupation to score a decisive moral victory in the eyes of the world, ${ }^{126}$ and especially in the United States, where this turn of events, it was hoped, would permit the U.S. administration to become involved in the reparations question. ${ }^{127}$ As the German ambassador to Washington explained in his report of January 7 , which he wrote in anticipation of the French advance into the Ruhr, Germany should broadcast all social and economic

126 W 236, Aufzeichnung, Jan. 15, 1923, PA W Ruhr, Propaganda, Die Besetzung des Ruhrgebiets, Propaganda, Vol.I, 1923. Reichskanzlei (Hamm) Circular, "Aufzeichnung des Pressechefs der Reichsregierung über die Aufklärungsarbeit im In- und Ausland," Apr. 18, 1923, in ADAP, Serie A, Band VII, 469-476.

127 Cuno to Leiter der Presseabteilung der Reichsregierung, Feb. 23, 1923, PA W Ruhr, Propaganda, Die Besetzung des Ruhrgebiets, Propaganda, Vol. I, 1923; see Stresemann's assessment in Berg, Stresemann und die Vereinigten Staaten, 130; Wiedfeldt to AA, "Graf Kesslers Unterredungen mit Hughes und Castle," July 31, 1923, ADAP, Serie A, Vol. 8, Document No. 89, 232-234. 
disturbances that developed during the occupation immediately, presenting France as an aggressive and militaristic power seeking not reparations but its former enemy's territorial dismemberment and long-term economic prostration. If Germany took this strategy, the Ruhr occupation could isolate France, place pressure on its currency, force it back into negotiations, and, finally, with U.S. support, settle the reparations question. ${ }^{128}$ In short, the Ruhr crisis, if portrayed in the right way, could facilitate America's "return" to Europe.

While the ends were clear, officials heatedly debated the means to adopt throughout the first half of 1923. Berlin's policy relied predominantly on the press. The Foreign Ministry's press department channeled information through German news agencies, encouraged prominent Germans to write articles in international periodicals, and distributed materials through private and ostensibly private organizations. ${ }^{129}$ But the most effective work, it believed, was to be done in the United States itself. Beginning in mid-January 1923, the press department sent daily news cables on French "atrocities" to Washington, which it expected the embassy to somehow place in the American press. ${ }^{130}$ Scholars have concluded that the Ruhr crisis in many regards meant a return to wartime mentalities - a cultural remobilization. This was certainly the case with regard to propaganda.

The German embassy in Washington, in contrast, advocated a low-profile approach. It was adamant that caution was needed more than ever as Americans were divided on the Ruhr occupation and the Republican Harding administration was taking a decidedly neutral stance. ${ }^{131}$ Though Secretary of State Charles Evans Hughes had already suggested that the United States could participate in a reparations conference of businessmen in late December 1922, he was convinced that Europe needed to enjoy its "own bit of chaos" before it would be ripe for American intervention. ${ }^{132}$ That Americans would, in the meantime, not respond well to European propaganda efforts became apparent when the otherwise so cautious French opened a public relations office in New York City in early 1923 that drew significant American criticism. ${ }^{133}$ "In this

128 Wiedfeldt to AA, "Politische Lage," Jan. 7, 1923, in ADAP, Serie A, Vol. 7, No. 14, 38-41.

129 German Embassy, Washington, to AA, June 18, 1923, PA R 80296; see the activities in PA R 121349 .

130 See the collection in PA Botschaft Washington, 1240, Telegramme betreffend: Wirkung der französischen Ruhraktion, 1922-1923.

131 Wiedfeldt to AA, July 20, 1923, "Propaganda in den Vereinigten Staaten," ADAP, Serie A, Vol. 8, No. 76, 185 .

132 Quoted in Berg, Gustav Stresemann und die Vereinigten Staaten, 134.

133 German Embassy, Washington, to AA, April 29, 1923, "Fremde Propaganda in den USA," PA R 80295 . 
country," Ambassador Wiedfeldt repeatedly proclaimed, "propaganda is only disadvantageous." 134

Although the embassy's advice was well-founded, it was hard to communicate to a "home front" that attributed America's lack of support to a lack of propaganda. Throughout the spring, zealous German and German-American visitors to the embassy believed they had found the solution to the alleged German propaganda problem. ${ }^{135}$ German publicists, politicians, and businessmen submitted detailed propaganda plans to the Wilhelmstrasse and even outfitted vanguard groups to scout out publicity opportunities in the United States. ${ }^{136}$ One business-funded propaganda hub submitted a confidential 16-page memorandum to Chancellor Wilhelm Cuno, outlining the establishment of a grand German propaganda apparatus in the United States at the phenomenal cost of $\$ 7$ million (the embassy's quarterly press fund at that time amounted to \$100). This plan envisioned movies, lecture tours, and brochures, all in the service of what it deemed the "urgent readjustment" of American public opinion. ${ }^{137}$

On July 20, 1923, with calls for propaganda and Berlin news cables arriving on the embassy's doorstep non-stop, Ambassador Wiedfeldt penned a 41page clarification about the situation for German and "enemy" propaganda in the United States that decisively shifted Germany's postwar debate. Wiedfeldt painted a pessimistic picture of the German situation, juxtaposing it with that of France. France, he lamented, still fed off a great amount of wartime sympathy and had gained the favor of large swaths of American elites and opinion-shaping circles. For one thing, American women were bedazzled by the fashion and charm of Paris, and, for another, American academics, the American Legion, most churches, and large foundations like the Carnegie Endowment were all sympathetic to France. Its strongest supporters were America's first families, who "annually go to do their shopping in Paris, whose daughters are brought up in French finishing schools, and who - if they served as nurses in the war now think back to this time with delight." A host of language schools, theaters, museums, and other cultural institutions, had helped the French succeed in maintaining and institutionalizing their favored wartime position. Ambassador Jules Jusserand, who had been in Washington for twenty years, generously bestowed French decorations upon Americans, "surely," Wiedfeldt commented bitterly, finding some words "for France and against Germany" in the process.

134 German Embassy, Washington, to AA, Mar. 15, 1923, PA R 121326; the advice he formulated throughout was to work on American news correspondents in Berlin, not through the embassy.

135 For Wiedfeldt's amusing account of these suggestions, see Wiedfeldt to AA, July 20, 1923, "Propaganda in den Vereinigten Staaten," ADAP, Serie A, Vol. 8, No. 76.

136 See the report by Haniel and Burgers (early 1923), PA R 80295.

137 Rhein-Ruhr, Freie Arbeitsgemeinschaft wirtschaftlicher Verbände, "Denkschrift über die Propaganda in den Vereinigten Staaten von Nordamerika," to Wilhelm Cuno, PA R 80296; the embassy's response: German Embassy, Washington, to AA, Sep. 6 1923, PA R80296. 
But the true core of France's propaganda, Wiedfeldt believed, was the special treatment and attention French officials accorded American news correspondents in Paris. In this way, the French had negatively influenced Germany's image, highlighting its instability, low tax rates, and flight of capital. In the "favorable context" of the postwar years, Wiedfeldt concluded, "the French propaganda has been able to play itself out at will." ${ }^{38}$

Germany's situation was starkly different. Germany, Wiedfeldt made clear, had neither the "means nor the opportunity" to do anything resembling the French campaign. No strong, usable economic ties currently existed between Germany and the United States. The churches, women's groups, and academic circles were mostly "anti-German," and German Americans still had no appreciable influence on mainstream opinion. Widespread suspicion, a lack of financial resources, and the absence of respectable American advocates for the German cause had hampered the embassy's previous efforts, leading to "meager" results. ${ }^{139}$ Given the generally hostile climate and the size and diversity of the United States, it was "a hopeless endeavor," Wiedfeldt argued, for German propaganda to try to reach even five percent of the population. Whereas France could rely on the remnants of inter-Allied infrastructure and goodwill, Germany was left with "nothing," the war having "cut all ties." "Every single thread," the ambassador wrote, "has to be knotted anew, has to be spun out and tightened bit by bit." 140

Wiedfeldt wrote his long report in the critical weeks of the Ruhr crisis, primarily as an attempt to tamp down expectations that the United States would immediately intervene, and to relieve pressure on the embassy. His admonitions went beyond calculated pessimism, however; above all, he pleaded for a more realistic assessment of the powers of propaganda. As a businessman, Wiedfeldt regarded the notion of propaganda as an effective weapon one could wield at will as absurd because, aside from the special constraints Germany was facing, the ultimate aim of German propaganda - American involvement in the reparations question - simply lay "beyond the reach of propaganda."141 Indeed, after half a year of German efforts, Americans seemed just as divided over and, generally, more apathetic about the European crisis than at the outset. This was not because there was not enough German propaganda, Wiedfeldt argued, but because propaganda was just not that powerful. To believe that a masterful stroke of public diplomacy could convince the United States to take immediate action, Wiedfeldt remarked, was tantamount to a mere "belief in miracles." What Germany needed was not more propaganda but a modern

138 Report of the German Embassy, Washington, July 20, 1923, "Propaganda in den Vereinigten Staaten," PA R 80296; parts of the report are printed in ADAP, Serie A, Vol. 8, No. 76, 183-196.

139 Ibid.

140 Ibid.

141 Ibid. 
press and information policy that influenced American news about Germany where it was actually made: in Berlin. Instead of sending press releases to the embassy in Washington, German officials needed to try and cultivate contacts with American news correspondents back in Berlin. Providing them with swift and accurate information, the ambassador believed, was the only way to generate more favorable coverage of Germany.

While paying attention to American news correspondents was certainly at the heart of Wiedfeldt's suggestions, he considered it just as necessary for Germany to systematically cultivate cultural and personal ties to the United States. This is clear from his substantial focus on French cultural influence as well as a number of discrete steps he took in that direction. Not only did he consistently highlight the political impact of angering U.S. tourists, as we have seen, but he also repeatedly asked for a German theologian to speak in front of American churches and universities. ${ }^{142}$ As he had already noted in late 1922: "One can only get at 115 million people by getting in touch with the intellectually leading forces; besides the press, these are the schools, the universities and church organizations [...] If a change in attitude can be effected among these circles, the impact will trickle down and broaden by itself." ${ }^{143}$ All in all, the ambassador argued, Germany had to let go of its short-term perspective and engage in more systematic image-building efforts. Only in this way could it "change the lack of information and one-sided sentiment [... and] prepare the ground for future events and decisions." ${ }^{144}$

While Wiedfeldt was not the first to formulate such recommendations, his advice carried considerably greater weight because it was packaged in a 41-page report at the very height of the Ruhr crisis. As scholars have shown, his report went on to serve as a blueprint for German public diplomacy in the United States in the $1920{ }^{145}$ It was no coincidence that Foreign Minister Stresemann, only a few months later, introduced regular press conferences for international news correspondents for the first time and convened the Foreign Ministry's Cultural Advisory Council, which had been dormant since $1921 .^{146}$ Ironically, the Foreign Ministry finally adopted a public relations approach more coherent and more neatly separated from the wartime legacy of propaganda at the

142 German Embassy, Washington, to AA, May 16, 1923, "Einladung eines deutschen Theologen nach Amerika," PA R 121326.

143 German Embassy, Washington, to AA, Dec. 27, 1922, PA R 80295.

144 German Embassy, Washington, to AA, July 20, 1923, "Propaganda in den Vereinigten Staaten," ADAP, Serie A, Vol. 8, No. 76.

145 Robert Gottwald, Die deutsch-amerikanischen Beziehungen in der Ära Stresemann (Berlin, 1965), 16.

146 The Foreign Ministry's "Cultural Advisory Council" was to secure public support for programs deemed politically useful and had been planned since 1921, but Stresemann was the one who reactivated the idea and arranged its very first meeting in early 1924; see Stresemann to Schenck (Reichsverband der Deutschen Hochschulen), Nov. 30, 1923, BArch R 8088/640. 
height of the German crisis in late 1923. In November 1923, the Kulturabteilung declared that its primary objective would henceforth be "the support and deepening of cultural relations [with foreign countries], that is, cultural propaganda in its very widest sense" in order to slowly re-establish Germany's moral standing in the world. ${ }^{147}$ It took the shock of the Ruhr occupation for Berlin to truly re-evaluate its approach to public relations in the United States.

Equally important, however, was the marked shift in some segments of German and American public opinion that Germany's year of crisis prompted. Detlev Peukert perceptively characterized late 1923 as Germany's "zero hour," the moment that laid bare the futility of its postwar approaches, precipitating a fundamental reappraisal. This was as true for official policy as it was for many of the peaceful revisionists we will encounter in the following chapters. The experiences of 1923 - the recurrence of war in the midst of peace - finally convinced a group of German liberals that the policy of intransigence was sure to end in disaster. While they had always disagreed with the tenets of the scientific "counterboycott," liberal professors like Alfred Weber at the University of Heidelberg and publicists like Ernst Jäckh in Berlin now realized that Germany's isolation, from within and without, might cost it its place among nations, paralyze its cultural development, and render a generation of young Germans provincial. ${ }^{148}$ At the peak of the Ruhr crisis, many of them demobilized culturally and began to push reconciliation with the West, primarily with the powerful United States. From 1923 onwards, a growing number of these peaceful revisionists resumed transatlantic contacts or encouraged their students to venture across the Atlantic. ${ }^{149}$ Whether this new interest in America could have withstood continued American apathy is impossible to say. Fortunately, it was never put to the test.

Indeed, in November and December of 1923, by all contemporary accounts, American opinion changed dramatically in Germany's favor. Whereas Americans had seemed largely apathetic, even hostile, toward Germany as late as August, Counselor of Embassy Hans-Heinrich Dieckhoff attested to a complete reversal of opinions just three months later: "Increasingly the idea that America entered the war against Germany with a wrong mindset is gaining

147 Aufzeichnung [betreffend "Urteile über Bedeutung der Pflege kult. Beziehungen," Kulturabteilung], Dec. 8, 1923, PA R60445.

148 Alfred Weber to Reichspräsident, Sep. 20, 1924, PA R63121.

149 For example, the Munich physicist Arnold Sommerfeld floated the idea of initiating an exchange of assistants with American universities; AA to Sommerfeld, VI B 2504 II, Apr. 5, 1924, NL 89 Arnold Sommerfeld, 030, Mappe Hochschulangelegenheiten, Archiv des Deutschen Museums, München. 
currency; ever greater is the discomfort that America was so involved in drafting the Versailles peace. I cannot stress just how strongly this turnabout in public opinion has begun to manifest itself recently." 150 This change was due less to any special American regard for Germany than to increasing concern about France's actions and their consequences for European stability. In the postwar years, the U.S. had gradually grown estranged from France over war debt and rearmament. In this context, France's military enforcement of the peace treaty, given its lack of positive results, truly alienated many Americans. ${ }^{151}$ In particular, the Stresemann government's decision to end passive resistance in September 1923 made the French look even more aggressive. At the same time, left- and right-wing coups, as well as the impending financial collapse and territorial disintegration of Germany, elicited widespread concern that the Weimar Republic might not survive. The developments of 1923, thus, ended the "one-sided moral indictment" of Germany that had prevailed since $1914 .{ }^{152}$ Instead, it provoked many Americans to return to their traditional view that power politics and militarism were more of a general European malaise than a specifically German problem. More importantly still, these events fed a growing conviction that only American common sense could solve Europe's seemingly endless squabbles. In late 1923, the Harding administration decided that Germany had now enjoyed enough of its "own bit of chaos." Bolstered by public sentiment, it used its creditor position to push France to accept a settlement of the reparations question under U.S. guidance. The Dawes expert committee, an international commission headed by American businessmen, would organize this American involvement in a deliberately nonstate way. Even so, Europeans widely (and rightly) saw this step as a U.S. "return" to Europe.

Nevertheless, America also "returned" in ways other than this economic and financial involvement. Changing American sentiments also entailed broader sympathetic concern for Germany for the first time since 1914. New relief drives for German children and students now gained wider Anglo-American interest, and American elites were more likely to welcome German clergymen and scholars back into their midst. ${ }^{153}$ Five years after the war, and faced

150 Dieckhoff to Bülow, Dec. 19, 1923, cited in Taschka, Diplomat ohne Eigenschaften, 81.

151 Keylor, "How They Advertised France," 371.

152 Müller, Auswärtige Pressepolitik und Propaganda, 139; Reuben Clarence Lang, "Die Meinung in den USA über Deutschland im Jahr des Ruhrkampfes und des Hitlerputsches," Saeculum 17 (1966): 402-416; Schoenthal, "American Attitudes Toward Germany," 145, concludes that the Ruhr invasion made Americans come closer to a pro-German viewpoint "not due to any particular enthusiasm for Germany, but rather to the widespread and bitter criticism of France."

153 In the winter of 1923/24, America's Protestant churches and even parts of the American Legion supported a large, nationwide relief drive for German children organized under the leadership of General Henry T. Allen, the former commander of American troops in the Rhineland. On the organization and the results of the campaign, see Henry T. Allen Papers, Box 29, American Committee for the Relief of German Children, LoC. 
with Germany's imminent collapse, American internationalists culturally demobilized. ${ }^{154}$ Nowhere was this change more visible than in the previously irreconcilable academic field. In the early months of 1924, an American relief campaign for German intellectuals and artists enlisted the support of several prominent university men, many of whom had carefully avoided involvement with Germany since 1914. ${ }^{155}$ In the face of the Ruhr occupation, even Nicholas Murray Butler gave up his decade-long presidency of the France-America Society and advocated American financial and moral support for Germany. By early 1924, the "cultural blockade" was rapidly breaking down.

Germany's incipient public diplomacy played only a modest role in paving the way for U.S. economic engagement with Germany. In mid-1924, when the Dawes Plan and the subsequent London Conference settled the reparations question and allowed for American capital to flow into Germany, cultural relations between the two nations were still tenuous and scant, especially compared to the prewar period. Actually, the ensuing economic cooperation hastened and deepened the rebuilding of cultural ties rather than the other way around. In fact, American investments in Germany placed transatlantic relations on a new psychological footing, giving American creditors a vested interest in Germany's future prosperity. Attributing the U.S. entry into the war at least partly to its financial entanglement with the Allies, Foreign Minister Stresemann was not alone in identifying American loans as Germany's most meaningful psychological asset in the United States. Once Americans were financially committed, he noted in September 1924, Germany could count on an "army of supporters" overseas that would not tolerate strong anti-German propaganda, foreign sanctions, or anything else imperiling their investment. ${ }^{156}$ This was the atmosphere in which the zeppelin took its transatlantic journey, giving rise to a new rhetoric of transatlantic cooperation. As Stresemann explained in a programmatic foreign policy speech on November 13, 1924, the recent entanglement of German and U.S. material interests had already positively affected the "friendly rapprochement" between the two nations:

The flight of the zeppelin to the United States, this masterpiece of German technology and German daring, has been met with the most cordial respect

154 In late 1922, the Rockefeller Foundation, for example, began to support German medical research; see Rockefeller Foundation, Annual Report 1922, 338-339.

155 Ludwig Bendix to Wiedfeldt, Jan. 31, 1924, PA Botschaft Washington, 1534 Ludwig Stein. 156 "Stresemann Rede auf dem Parteitag des Berliner Wahlkreisverbandes der DVP, Sep. 27 1924," in Gustav Stresemann. Reden der Kanzler- und Außenministerzeit (1923-1929), ed. Wolfgang Elz, 410-25, 414 https://neuestegeschichte.uni-mainz.de/files/2018/o7/Stresemann-Reden_1924.pdf (last acc. July 24, 2020). 
in the United States and has deepened both countries' conviction that they, in peaceful cooperation, are called to contribute to the solution of the cultural tasks (Kulturaufgaben) that face mankind. ${ }^{157}$

Political rhetoric aside, the flight of the zeppelin marked only the beginning of a long and arduous campaign to rewin American "hearts and minds." Germany had finally secured initial American engagement, yet its ambitions would continue to depend on American goodwill. In a few years' time, the provisions of the Dawes settlement would have to be renegotiated, and U.S. sentiment toward Germany would partly determine how favorable they would be. As Ambassador Wiedfeldt concluded in late 1924, "whether America wants to help us and in how far it can do so will depend on the attitudes of the American administration and public opinion." ${ }^{158}$ Although postwar animosity had abated, Germany enjoyed neither the particular interest nor the trust of the American public. And while German financial and political stabilization once again facilitated long-term planning and eased Germans' resentments towards their former enemies, the end of inflation also made German cultural and economic exports expensive. For the first time since the war, Germany's tourist destinations and universities, like its manufacturers, had to compete under market conditions. With the inflation over, the real work had just begun.

The early 1920 s turned out to be a transformative period. There were few concrete programs or accomplishments in this period, yet it set the course for much of what was to come. A brief review of why so little "happened" seems apt at this point. For one, the plans developed in anticipation of German victory were ill-suited to the psychological and financial realities of the postwar period. Pervasive American nativism, continuing anti-German sentiment, and the long absence of peaceful relations hampered the operations even of comparatively well-established actors like the Amerika-Institut. Arguably, however, the most significant hurdles lay in Germany itself. Germany's traditional "cultural diplomats" were reluctant to resume a transatlantic role after the profound disappointments of the war and inflation proved to be both a financial and psychological liability. Throughout the early 1920s, Germany was not just isolated: it isolated itself. Under these circumstances, Germany was not able to successfully utilize opportunities to improve its image, like American tourism.

Nevertheless, the very prevalence of these constraints fostered the expansion of public diplomacy after 1924. The specific frustrations of the postwar

157 "Rede in der Sitzung des Zentralvorstandes der DVP in Dortmund, Nov 13, 1924," in ibid., 438-55, 449 https://neuestegeschichte.uni-mainz.de/files/2018/o7/Stresemann-Reden_1924.pdf (last acc. July 24, 2020).

158 Wiedfeldt to AA, Nov. 15, 1924; cited in Schröder, ed., Otto Wiedfeldt, 232. 
period encouraged commitment to cultural undertakings among private and official groups. Paradoxically, the Foreign Ministry adopted a more coherent approach to public diplomacy, aiming to manage fields that had long been outside the purview of the traditionalist Foreign Service, during the crisis of late 1923. The experience of isolation and the resumed hostilities in the "midst of peace" prompted liberal German groups, too, to reappraise the German situation. Importantly, their cultural demobilization was mirrored across the Atlantic. Faced with the specter of unrest and disorder in Europe, Americans grew friendlier toward Germany - or at least less friendly toward France - after late 1923. When German currency stabilized in November 1923 and Americans invested in Germany after the fall of 1924, this forged tangible connections and a new psychological climate between the two nations. Collectively, these developments precipitated an explosion of cultural endeavors from 1924 onward. 

Part II

Peaceful Revision: Winning American Hearts and Minds, 1924-1929 

For the Weimar Republic, the years 1924 to 1929 were a period of "relative stabilization." Domestically, it enjoyed broader political support than ever before. Coalition governments included or were tolerated by parties ranging across almost the entire political spectrum, from the National Conservatives (DNVP) to the Social Democrats (SPD). At the same time, foreign investments, productivity, and the standard of living increased. Internationally, Foreign Minister Gustav Stresemann (1923-1929) and State Secretary Carl von Schubert (1924-1930) steered a policy course of "peaceful revision" and reconciliation with the West. By satisfying French security needs and integrating Germany more tightly in the European system, Stresemann aimed at achieving a gradual and consensual revision of the peace treaty's most odious terms: to throw off inter-Allied controls, decrease reparations payments, end the occupation of the Rhineland, and revise the eastern borders.

This policy of reconciliation, as many scholars have pointed out, differed from earlier approaches in its consensus-oriented means more than in its ultimate objectives. Stresemann, no less than most Germans of his age and education, desired first and foremost a return to German great power status and always thought in terms of Germany's national interest; ${ }^{1}$ yet he realized that cooperation, not confrontation, offered the most realistic and promising course to this end. Rather than harnessing Germany's controversial (and unavailable) military might, he relied on its more acceptable economic power to pursue Germany's national interests within the constraints of the postwar international order. ${ }^{2}$ As Karl Dietrich Erdmann poignantly put it, Stresemann pursued a "national policy of revision as [an] international policy of conciliation." ${ }^{3}$ However, historians continue to debate whether - and for how long - this amounted to a genuinely "Republican Foreign Policy," that is, a foreign policy different from its predecessor in both its means and its ends, as Peter Krüger has held. ${ }^{4}$ What is certain is that Stresemann's multilateral strategy was quite successful, at least in hindsight. The "economic peace" at the London reparations conference of 1924 was followed by the "political peace" at the Locarno Conference in 1925. Germany's admission to the League of Nations in 1926 signaled its return to the family of nations as an equal (if not entirely sovereign) power. To be sure, the inherent tension between revisionist ends and conciliatory means was never entirely resolved, and rightwing criticism of the policy of reconciliation never

1 Eberhard Kolb and Dirk Schumann, Die Weimarer Republik, $8^{\text {th }}$ edition (Munich, 2013), 251.

2 Gottfried Niedhart, Die Außenpolitik der Weimarer Republik (Munich, 2006), 39.

3 Erdmann, quoted in Impekoven, Die Alexander von Humboldt-Stiftung, 156.

4 Krüger, Die Außenpolitik der Republik von Weimar, 43. 
entirely subsided. 5 Still, Germany's international position improved notably in the mid-1920s, which, in turn, contributed to its domestic stabilization.

Though the United States never officially took part in these European developments, it played an important role in German foreign policy. Stresemann's pursuit of an economic foreign policy pivoted on the United States, and he was convinced, as he told the German ambassador to Washington Ago von Maltzan (1925-1927) in 1925, that "the determination of Europe's future depends in the last analysis on the United States." During his tenure as foreign minister, Stresemann pursued an accommodationist Amerikapolitik that courted the United States for financial and, tacitly, political support. This Amerikapolitik "paid" off, in the literal sense of the word. In the five years after 1924, U.S. financiers invested more than $\$ 3$ billion in German companies, municipalities, and state bonds, thereby underwriting Weimar's "relative" political and economic stabilization. ${ }^{7}$ Throughout the 1920 s, a strong mutuality of interests and methods undergirded German-American relations: the German policy of recapturing its international position by way of economic recovery aligned with the U.S. inclination to conduct world affairs through informal economic diplomacy; ${ }^{8}$ and Germany's desire for a peaceful revision of the new international order created at Versailles dovetailed with an American policy of consensual "peaceful change" in Europe. ${ }^{9}$ In the mid-1920s, both countries shared a commitment to Germany's economic reconstruction within a consolidated European system.

If the development and positive consequences of Germany's predominantly economic Amerikapolitik have been extensively researched, the next three chapters illuminate a lesser-known aspect of German peaceful revisionism in the United States. They explore German efforts to rebuild and strengthen transatlantic ties through a broader public relations campaign. As we will show, Weimar's Germandom policy (Chapter 4), academic diplomacy (Chapter 5), and travel promotion (Chapter 6) tied in closely with larger foreign policy objectives. Collectively, they leave no doubt that Germany's economic appeals were accompanied by a quite substantial, concerted cultural Amerikapolitik that

5 Detlef Peukert, The Weimar Republic: The Crisis of Classical Modernity (New York, 1993), 195. 6 Stresemann to Maltzan, Apr. 7, 1925, quoted in Andreas Dorpalen, "American Isolationism and German Foreign Policy During the Weimar Era," in Deutschland und die USA, 1918-1933, ed. Georg Eckert, 44-52 (Braunschweig, 1968), 44.

7 American financial investments in Germany were so substantial that Werner Link spoke of Germany as a "penetrated system." Link, Amerikanische Stabilisierungspolitik.

8 On U.S. informal diplomacy more generally, see Melvyn Leffler, The Elusive Quest: America's Pursuit of European Stability and French Security, 1919-1933 (Chapel Hill, NC, 1979); Rosenberg, Spreading the American Dream; Costigliola, Awkward Dominion.

9 Berg, Gustav Stresemann und die Vereinigten Staaten; Link, Amerikanische Stabilisierungspolitik; Frank Costigliola, "The United States and the Reconstruction of Germany in the 1920s," Business History Review 50, no. 4 (1976): 477-502. 
aimed to strengthen U.S. commitment to German reconstruction by building trust and sympathy across the Atlantic. Just as, in Detlev Peukert's words, "Stresemann mobilized Germany's economic potential as a way of enhancing her political weight in the world," so, too, did he - and certainly not he alone - systematically mobilize Germany's cultural potential to the same end. ${ }^{10}$

Identifying Stresemann's partners in this endeavor highlights a group that might best be characterized as peaceful revisionists. Werner Link showed that an "external foreign policy bureaucracy" of financial and business experts conducted most financial and economic relations with the United States, yet transatlantic cultural politics relied on informal cultural diplomats as well. These included academics, journalists, tourist organizers, businessmen, and the directors of semi-official "Amerika organizations," all of whom operated outside, albeit often in close touch with, the German foreign policy establishment. ${ }^{11}$ These men, and very few women, provided funds for transatlantic endeavors, sat on the boards of academic exchange programs, directed semiofficial organizations like the Amerika-Institut or the Vereinigung Carl Schurz (see Chapter 5), or assumed quasi-diplomatic functions at transatlantic events and conferences. Among them were financier Max Warburg, industrialists like Carl Duisberg and Robert Bosch, parliamentarians like Anton Erkelenz, publicists like Ernst Jäckh, and a wide set of educators including the economists Moritz Julius Bonn and Alfred Weber, the legal scholar Albrecht Mendelssohn Bartholdy, and the university/science administrators Reinhold Schairer and Adolf Morsbach. Former diplomats like Johann Heinrich von Bernstorff and liberal officials like Prussian Minister of Culture Carl Heinrich Becker may also be counted among this group. ${ }^{12}$

While these peaceful revisionists had no single club, journal, or party in common, and they certainly never self-identified under that epithet, they shared a number of characteristics and convictions that makes it possible to identify them as a more or less distinct group: For one, they generally belonged to Germany's educated urban bourgeoisie, the Bildungsbürgertum. They were products of Germany's elitist school and university system, and nearly all of them held a doctorate, then the prerogative of only 0.0001 percent of the German population. Their elite educational and bourgeois background endowed them with the sort of moral and cultural capital one acquired from mastering a

10 Peukert, The Weimar Republic, 198.

11 Link, Amerikanische Stabilisierungspolitik, 565, 572.

12 A particularly telling career is that of Carl Heinrich Becker, professor and Prussian Minister of Culture during the Weimar years; see Guido Müller, Weltpolitische Bildung und Akademische Reform. Carl Heinrich Beckers Wissenschafts- und Hochschulpolitik 1908-1930 (Cologne, 1991). 
rigorous canon of literature, classical languages, and advanced scholarly work. At the same time, it shaped their ideas of Kultur and Germany's position in the world. They self-identified as bearers of what they deemed a unique and in some respects superior German culture (Kulturträger), and though they were neither chauvinists, nor provincials, they felt that Germany had to recapture the prominent position in the world that it deserved from an intellectual and cultural standpoint.

Although they shared this background and outlook with large swaths of the German elite, they distinguished themselves by their generally positive attitude toward the republic. Among their ranks were a considerable number of "republicans by reason" (Vernunftrepublikaner), as well as some staunch democrats. Politically, most of them were associated with or leaned toward the left-liberal German Democratic Party (Deutsche Demokratische Partei, DDP) and, during the Stresemann years, the export-oriented wing of his liberal-conservative German People's Party (Deutsche Volkspartei, DVP). Most of them, like Stresemann himself, belonged to the generation born between 1860 and 1885 . Their formative experiences fell in the Kaiserreich years before 1900 , which were relatively calm on the international front, and they had already established successful careers when World War I broke out. This is true, for example, of Ernst Jäckh (b. 1875), who had been the editor-in-chief of several newspapers and journals before the war; of Alfred Weber (b. 1868), who had held the chair in economics at the University of Heidelberg since 1907; of Moritz Julius Bonn (b. 1873), who had been the founding director of Munich's Handelshochschule (commercial college), as well as an economics professor there, from 1910 onward; and of Carl Duisberg (b. 1861), who had directed one of the world's largest chemical companies, Bayer, since 1900. Whereas World War I largely shaped the "front generation" and the war child/youth generation, it was not the defining moment in the biographies of these men. ${ }^{13}$

In contrast to many others of their generation, however, these Vernunftrepublikaner had often been critics of certain aspects of Wilhelmine Germany, including its conduct of foreign policy. Indeed, many of them had championed a peaceful, liberal imperialism before the war and had advocated economic and cultural expansion as a more promising alternative - or at least a necessary complement - to Wilhelmine Weltpolitik. As Christoph Gusy showed, it was the combination of generational identity and the long-standing impetus for reform that determined their constructive stance toward the republic and,

13 On these defining generational features of Weimar's Vernunftrepublikaner, see Andreas Wirsching and Jürgen Eder, "Vernunftrepublikanismus' in der Weimarer Republik. Neue Analysen und offene Fragen," in Vernunftrepublikanismus in der Weimarer Republik. Politik, Literatur, Wissenschaft, ed. Andreas Wirsching and Jürgen Eder, 9-26 (Stuttgart, 2008), 18-20. 
arguably, their embrace of peaceful revision. ${ }^{14}$ To be sure, the group's generally liberal persuasion made its members neither less patriotic nor less revisionist. On the contrary, they all shared in the broad revisionist consensus of their class and time and were often among the earliest and most determined critics of the Versailles settlement, which they regarded as deeply unjust and ultimately "peaceless." 15 What distinguished them from their more conservative peers was not so much their ultimate objective - Germany's resurgence and recovery of its rightful place among nations - but the means they wished to adopt to this end. In keeping with their earlier ideas of "peaceful imperialism," they now championed a consensual revision of Versailles and embraced a foreign policy built on soft power. For them, the best option for regaining Germany's position in the world did not seem to be brooding intransigence, secret rearmament, or a spiteful orientation toward the East (as conservatives suggested), but détente and cooperation with the West.

The myriad initiatives they pursued toward the United States were one means toward that end. In their minds, a peaceful change of the Versailles order required first and foremost a better understanding of the German situation abroad and an end to Germany's "distorted image." Alongside their considerable agitation against German "war guilt," they thus devoted themselves to rebuilding Germany's international contacts and trust in it. ${ }^{16}$ Closer relations with the United States, an influential country outside of the European system, seemed particularly promising in this respect. Their ensuing cooperation with the United States and U.S. organizations like the Carnegie Endowment for International Peace and the Institute of International Education thus expressed both their longer-standing internationalist convictions as well as their clear revisionist agenda. As Katharina Rietzler, Peter Weber, and others recently suggested, men like Ernst Jäckh are best understood as "national internationalists." ${ }^{17}$ Like Stresemann himself, the group of peaceful revisionists believed in international cooperation in the national interest. This said, their special interest in the United States was sustained by ambitions other than international concerns: many German scholars looked to the prosperous United

14 Christoph Gusy, "Vernunftrepublikanismus' in der Staatsrechtswissenschaft der Weimarer Republik," in Vernunftrepublikanismus in der Weimarer Republik, ed. Wirsching and Eder, 195217.

15 Jürgen C. Heß, 'Das ganze Deutschland soll es sein'. Demokratischer Nationalismus in der Weimarer Republik am Beispiel der Deutschen Demokratischen Partei (Stuttgart, 1978), 15.

16 Sitzung des Vorstandes der Wirtschaftshilfe der Deutschen Studentenschaft, Jan. 1926; Allgemeiner Bericht Dr. Schairers über seine Amerika-Reise, BArch R149/235.

17 Peter Weber, "Ernst Jäckh and the National Internationalism of Interwar Germany," Central European History 52, no. 3 (2019): 402-423; Katharina Rietzler, "Philanthropy, Peace Research, and Revisionist Politics: Rockefeller and Carnegie Support for the Study of International Relations in Weimar Germany," GHI Bulletin Supplement 5 (2008): 61-79; Jan Stöckmann, "Studying the International, Serving the Nation: The Origins of International Relations Scholarship in Germany, 1912-1933," International History Review 38, no. 5 (2016): 1055-1080. 
States to sponsor their research, social reformers and businessmen sought to study Amerika as a potential solution to Germany's social and economic woes, and the German export industry - especially chemical, electrical, and shipping companies (IG Farben, AEG, Siemens, HAPAG, North German Lloyd) wished to improve transatlantic trade and facilitate the transfer of technological know-how. In short, the confluence of professional, political, and economic interests engendered their strong interest in the United States in the 1920 s.

These men's revisionist convictions and international contacts, as will become clear in the following chapters, made them key partners for Germany's official foreign policymakers in the 1920s. Their relations with Germany's foreign policy establishment tended to be close, and sometimes extraordinarily so: the law professor Albrecht Mendelssohn Bartholdy (Hamburg) was entrusted with the delicate task of editing and publishing the Foreign Ministry's prewar records, Ernst Jäckh and his Hochschule für Politik in Berlin trained the ministry's attachés, and the economist Moritz Julius Bonn (Berlin) served as a governmental advisor and envoy to various reparations conferences. Of course, individual and state interests were not always identical. For example, Reinhold Schairer, a passionate internationalist with close ties to the International Student Christian Movement (and a principal organizer of academic exchange: see Chapter 5), remained foreign, even suspect, to many within the Foreign Ministry. ${ }^{18}$ At the same time, German diplomats recognized the great appeal that internationalist enthusiasm like Schairer's had to Americans and the crucial role they could play in projecting an image of republican conviction and stability. ${ }^{19}$ Throughout the 1920s, the German Foreign Ministry was clearly willing to support internationalist initiatives for the sake of a common revisionist agenda.

This is not to suggest that there was no ambivalence in German attitudes toward the United States. Sharing neither the naïve enthusiasm for America of segments of the political Left nor the rabid anti-Americanism of the political Right, Germany's peaceful revisionists were both hopeful and apprehensive about what American power would mean for Germany. ${ }^{20}$ German companies desired America's cooperation just as they feared its competition; ${ }^{21}$ and the Bildungsbürgertum was far too steeped in German idealist thought not to ponder and dread the implications of "American" materialism, mechanization, and

18 See Aufzeichnung AA (Zimmermann), ca. July 1926, PA R 64793.

19 Maltzan reported that he had taken Erkelenz to Anglo-American circles in the summer of 1925 and he had "left the best of impressions everywhere"; German Embassy, Washington, to AA, Aug. 24, 1925, "Besuch des Reichstagsabgeordneten Erkelenz," PA R 80297.

20 This was the case for the left-liberal DDP; see Heß, 'Das ganze Deutschland soll es sein', 283.

21 Werner Link described this ambivalent relationship as "competition through cooperation"; see Link, Amerikanische Stabilisierungspolitik, 374-381. 
standardization for German culture. ${ }^{22}$ But even as they worried about America's ominous cultural and commercial expansion, Germany's peaceful revisionists always understood the opportunity that the United States presented: it was across the Atlantic that Germany's international position could be restored, and for this reason they set out to build a politically and economically desirable transatlantic "friendship." The following three chapters will detail this effort.

22 See, for example, the statement by Alfred Weber in Christian Jansen, "Auf dem Mittelweg von rechts. Akademische Ideologie und Politik zwischen 1914 und 1933," in Auch eine Geschichte der Universität Heidelberg, ed. Karin Buselmeier, Dietrich Harth, and Christian Jansen, 163-193 (Mannheim, 1985), 173. 



\section{Chapter 4 \\ German Cultural Diplomacy Between German Americans and Anglo-Americans}

W ith millions of Americans of German birth and descent, Germany's approaches to the United States differed fundamentally from those it took toward other Western countries. The large number of ethnic kin overseas was a defining feature of all German calculations, and the distinction between "Anglo-Americans" and "German Americans" was axiomatic to most contemporaries. However problematic or simplistic this distinction may appear in hindsight, it profoundly shaped how German diplomats, journalists, and politicians thought about the landscape of American public opinion, and it defined the scope, direction, and content of German outreach in the United States. They generally recognized German Americans as a group of Americans particularly sympathetic to Germany, and they understood that Germany's image was tightly bound to the standing of their ethnic brethren in American society. Just as Germany's status as a friendly or hostile power affected American attitudes toward German Americans, so, too, did the esteem in which German Americans were held affect Germany's standing overseas. This interdependence of the German and the German-American image rendered German Americans a particular concern: whether as potential targets, partners, or saboteurs of German ambitions, they always had to be factored in.

This situation was not peculiar to the 1920s. Since about 1900, as we have seen, Germany had treated German Americans as a potential pro-German pressure group, and in the last decade before the war transatlantic visits by naval cruisers and exchange professors had aimed to maintain their ties to the fatherland. During the war, unrealistic assumptions about their unity, ethnic loyalty, and political influence had led to redoubled German mobilization 
efforts - with disastrous results. As transatlantic relations soured, German Americans found themselves attacked as unreliable "hyphenates" and German agents on American soil. This process would repeat itself in a different guise after 1933, when Nazi agitators on both sides of the Atlantic once again cast doubt on the loyalty of parts of the German-American community. As it had during World War I, German agitation in the 1930s became the focus of public suspicion and congressional investigations. ${ }^{1}$

While this recurrence of German agitation and American suspicion may suggest a certain continuity from the Wilhelmine to the Nazi period, we lack a key piece of information crucial to evaluating the nature of this continuity, namely, information on Weimar's policy. Indeed, our extensive knowledge about pre-1917 and post-1933 initiatives has no counterpart in the historiography of Weimar's approaches. ${ }^{2}$ In particular, there are no studies that place German strategies in the larger context of Weimar-era "Germandom policies," on the one hand, and public diplomacy, on the other. This is lamentable not only because Germany's dealings with German Americans offers one of the best indicators for continuity and discontinuity in its Amerikapolitik, but because these dealings had a very significant impact on transatlantic relations.

This chapter assesses the shifts in the intricate relationship between Germans, German Americans and Anglo-Americans. Throughout, it employs the terms "Anglo-American" and "German-American" - not because they adequately express the complexity of ethnic identity in a multiethnic America but because this binary pervaded contemporary assessments. German representatives in the United States are placed at the heart of the story. While this obscures some of the private initiatives (which do not seem to have ever been substantial), it uncovers and highlights the pivotal role that ambassadors and consuls played both in implementing and in formulating Germandom policy. In a field in which policy often remained underarticulated, personal initiative and inclination could prove to be defining factors. All in all, the chapter suggests that a German disavowal of political agitation contributed markedly to reconciling German Americans and Anglo-Americans and, by extension,

1 See U.S. Congress, Brewing and Liquor Interests and German Propaganda: Hearing before a Subcommittee of the Committee on the Judiciary United States Senate, Sixty-Fifth Congress Second and Third Session Pursuant to German Americans. Res. 307 (Washington, 1919); and U.S. Congress, Investigation of Nazi Propaganda Activities and Investigation of Certain Other Propaganda Activities, Public Hearings before the Special Committee on Un-American Activities, House of Representatives, Seventy-Third Congress, Second Session (Washington, 1934).

2 See Wala, "Reviving Ethnic Identity," 326-341; and Hans-Werner Retterath, "Deutschamerikanertum und Volkstumsgedanke. Zur Ethnizitätskonstruktion durch die auslandsdeutsche Kulturarbeit zwischen 1918 und 1945" (PhD diss. Marburg University, 2000); most research has focused on the "disappearance" vs. the "ethnic survival" of German Americans as an ethnic group; see Tolzmann, "The Survival of an Ethnic Community"; Russell Kazal, "Becoming 'Old Stock': The Waning of German-American Identity in Philadelphia, 1900-1930" (Phd diss. University of Pennsylvania, 1998). 
Germany and America. By the late 1920s, German attention was increasingly shifting from German Americans to Anglo-Americans, just as wealthier, better-educated German Americans were once more assuming the role of mediators between the two countries.

\section{Germandom Policies in the Weimar Republic: A Short Introduction}

Before we delve into the intricacies of the American context, we must acknowledge the prominent role accorded to "Germandom policies" (contemporaries spoke of Volkstumspolitik or Deutschtumspolitik) in postwar Germany. Prewar efforts to organize the broad German diaspora paled in comparison to the wide-ranging undertakings of the postwar period. After 1919, the study and cultivation of "Germans abroad" (Auslandsdeutsche) grew phenomenally. By the mid-1930s, no less than seventy-six institutes and organizations - many of them founded or greatly expanded in the 1920 - were active in this field, attempting to strengthen the emotional and intellectual ties to ethnic Germans around the world. ${ }^{3}$ Long-standing member organizations such as the Verein für das Deutschtum im Ausland in Berlin (est. 1881), wartime establishments like the Deutsches Ausland-Institut in Stuttgart (est. 1917), and postwar associations like the Schutzbund in Berlin (est. 1919) and the Deutsche Akademie in Munich (est. 1925) were all devoted to various aspects of this project. On the ministerial level, the Foreign Ministry and the Ministry of the Interior set up richly funded Germandom sections, which helped to subsidize and coordinate the most important of these initiatives. ${ }^{4}$ With this broad ministerial, parliamentary and popular support, Germandom activists had the means to spend millions of marks and an inestimable amount of time and energy circulating German publications, keeping up correspondence, and supporting German schools abroad. Whether they belonged to newly emerging German minorities in the territories lost after the war or to long-standing German "colonies" in Latin America and elsewhere, Auslandsdeutsche became the focus of significant attention during the interwar period.

This commitment was fueled by a number of factors. For one, German ethnic nationalism had long facilitated the notion that collective cultural and ethnic (later, racial) attributes rather than national boundaries comprised the

3 Arthur L. Smith, The Deutschtum of Nazi Germany and the United States (The Hague, 1965), 3; the bibliographies published in Der Auslandsdeutsche, the magazine of the Deutsches Ausland-Institut in Stuttgart, provide a fairly comprehensive picture of the extensive scholarly and popular interest in the subject in the 1920 .

4 On this coordination effort in the Foreign Ministry, see Aufzeichnung, Jan. 5, 1923, PA R 60002 . 
German nation. ${ }^{5}$ Ethnic Germans' common experience of patriotic enthusiasm and anti-German resentment during World War I considerably deepened their sense of a worldwide German "community of fate." This was the connection that Germandom organizations set out to perpetuate beyond the end of the war. Similarly influential, however, were the immediate hardships that German minorities suffered in the postwar period. The territorial provisions of the peace treaty had trapped millions of ethnic Germans beyond the Reich's borders, giving rise to a broad political consensus that maintaining their livelihood and sense of ethnic belonging was a "right, duty and privilege" of the German nation. ${ }^{6}$ Notions of "Germans abroad" as a means of worldwide influence reinforced these emotional factors. After the peace treaty, it was estimated that more than 30 million Germans were living beyond Germany's national borders. Leading Germandom enthusiasts propagated the idea of a deterritorialized German nation of 100 million (Hundert-Millionen-Volk) ${ }^{7}$ and hoped that their active association could compensate for some of the hard power that Germany had lost. As German outposts in the world, they could promote trade relations, spread German culture, and lobby for political concessions. Thus, it was vital to the nation's future that these ethnic Germans continue to feel German. ${ }^{8}$ Gustav Stresemann, who commented frequently on the importance of Germans in the world, deemed the creation of a "cultural Volksgemeinschaft" a national task of prime importance. ${ }^{9}$ All postwar German governments considered Germandom and minority policies a major element of German foreign policy.

Nevertheless, the ultimate objectives, modes of operation, and degrees of official involvement in Germandom policies differed widely by region. In the lost territories, where about 10 million former German citizens now lived outside the Reich, Germandom policies tended to be richly funded, aggres-

5 It encompassed such positively connoted characteristics as industriousness and diligence, love of home, and "loyalty" (Treue), as well as negative ones like political naiveté and an excessive readiness to adapt to new circumstances at the expense of one's own cultural heritage.

6 Hans Steinacher, "Kulturpolitik als Gemeinschaftsaufgabe," Süddeutsche Monatshefte 28, no. 4 (Jan. 1931); Rogers Brubaker, for example, sees Weimar Germany as a particularly intriguing case study for the idea of external homeland nationalism, which viewed those Germans - also now belonging to a different state - as truly belonging to the German "homeland"; Rogers Brubaker, "Accidental Diasporas and External Homelands' in Central and Eastern Europe: Past and Present," in Transnationalism: Diasporas and the Advent of a New (Dis-)order, ed. Eliezer Ben - Rafael and Yitzhak Sternberg, 461-482 (Leiden, 2009).

7 Otto Boelitz, Das Grenz- und Auslanddeutschtum. Seine Geschichte und seine Bedeutung (Munich, 1930), 7 .

8 Boelitz, Das Grenz- und Auslanddeutschtum, 5.

9 Stresemann, "Aufgaben der Kulturpolitik," Dec. 13, 1925, in Gustav Stresemann: Vermächtnis, Vol. 2, ed. Henry Bernhard, 312-15 (Berlin, 1932), 313. 
sively pursued, and marked by a high degree of official involvement. ${ }^{10}$ Working through ostensibly private "front organizations," the German government supported ethnic parties, provided substantial economic grants, and bolstered cultural programs to offset the effects of economic discrimination, political marginalization, and forced acculturation that Germans in the lost territories experienced. ${ }^{11}$ By maintaining German settlements and a German sense of identity, they hoped to lay the foundation for German irredentism in the East. Their immediate distress and their designated role in territorial revision made these Germans a priority for all official and unofficial efforts. In contrast, interest in Germans overseas arose from "softer" revisionist objectives. In places with significant, economically secure ethnic "colonies" like Latin America, Germandom policies tended to be less aggressive in nature - working primarily through the German school system - and aimed to use ethnic Germans as cultural and economic assets. ${ }^{12}$ Ethnically conscious "Germans abroad" were to aid the rehabilitation of the fatherland by opening up markets for German products, conveying German cultural achievements, and guaranteeing a favorable public climate for revisionist ideas in their respective host countries. In late 1923, a Foreign Ministry memorandum noted that only if Germans abroad "actively contribute to building and maintaining the intellectual and moral bridges to the world can we successfully leave behind our hopeless isolation and replace the utter lack of understanding, which is the best breeding ground for all incendiary and deceitful propaganda of the other side, with an accurate impression of the German character."13

All in all, "Germandom policies" in their various guises became a defining feature of Weimar's foreign relations. The fate of "Germans abroad" galvanized public and parliamentary support for a number of international programs and produced, at least numerically, notable successes. The system of German schools abroad, for example, recovered and even expanded from 853 schools with 48 ,ooo students in 1913 to 1,600 schools with 80,000 students in $1933 .{ }^{14}$ In theory, it was hoped that these ties to ethnic Germans would facilitate con-

10 Germandom policies in Poland certainly offer the most extreme example: Norbert Krekeler, Revisionsanspruch und geheime Ostpolitik der Weimarer Republik. Die Subventionierung der deutschen Minderheit in Polen 1919-33 (Stuttgart, 1973); John Hiden, "The Weimar Republic and the Problem of the Auslandsdeutsche," Journal of Contemporary History 12 (1977): 273-289, 277.

11 Within just three years of the peace, for example, two-thirds of the 1.1 million Germans in the provinces of Poznan and West Prussia had left for the Reich; see Krekeler, Revisionsanspruch und geheime Ostpolitik, 48.

12 Rinke, Der Letzte Freie Kontinent, passim.

13 AA [Soehring] to Boelitz, Preuss. Ministerium für Wissenschaft, Kunst und Volksbildung, Dec. 7, 1923, "Skizze zu der Frage der geistigen Beziehungen zwischen Auslandsdeutschtum und Heimat," PA R 64853.

14 See Düwell, Deutschlands Auswärtige Kulturpolitik, 150. 
tacts with broader, non-German audiences, ${ }^{15}$ but in practice, the predominant focus on the former often meant that little attention was paid to the latter. ${ }^{16}$ This insight prompted the Foreign Ministry to separate the "school fund" from its general cultural diplomacy budget in 1929. Even then, however, "Germans abroad" remained the basic motivation for a substantial part of German cultural diplomacy. As Foreign Minister Julius Curtius explained to the Reichstag in 1930: if the Foreign Ministry's Kulturabteilung saw “Germany's rapprochement with foreign lands as its major task, the cultivation of Germandom [stood] as a leitmotif above all of its activities." ${ }^{17}$ In short, we cannot fully comprehend the contours of Weimar's public diplomacy without looking at Germandom policies.

\section{Germandom Policies in the United States}

As German Americans comprised the single largest group of ethnic Germans outside the Reich, the strategies German foreign policymakers and Germandom activists developed to engage with them are especially important. Was the expansion of Germandon activities also noticeable in the United States? What roles did Weimar's Amerikapolitik assign to German Americans, and were they actually willing and able to assume these roles? Did a focus on German Americans detract attention from Anglo-Americans?

German foreign policymakers and numerous private groups honed in on German Americans soon after the war, resuming detailed observations of German Americans, the state of their transatlantic sympathies, and their standing in American society as early as the summer of $1919 .{ }^{18}$ In particular, they noticed German Americans' large-scale charitable giving after July 1919, often perceiving it as a declaration of ethnic loyalty to and interest in the fatherland. ${ }^{19}$ In late 1920, the Foreign Ministry recruited Hermann Davidsen, formerly a professor of German at Cornell University, as a "German-America expert" for its press department. ${ }^{20}$ Davidsen joined the ranks of the Foreign Ministry's new "America experts" alongside Karl Alexander Fuehr at the America department and Walther Drechsler at the press department. Collectively, these men offered detailed and generally cautionary assessments of German Americans and postwar America. Once official relations resumed in late 1921, German

15 Ibid., 119.

16 Abelein, Die Kulturpolitik des Deutschen Reiches, 165.

17 Entwurf zu der Rede des Herrn Reichsministers betreffend die Aufgaben der Kulturabteilung, June 10, 1930, PA R 61125.

18 Fr. II963, Sep. 9, 1919, Aufzeichnung, BArch R901/80965.

19 Johannes Kreyenpoth, Die Auslandshilfe für das deutsche Reich (Stuttgart, 1932).

20 Amerika-Institut to Schmidt-Ott, Dec. 18, 1921, NL Schmidt-Ott 539, GSPK. 
consular and diplomatic personnel, too, were expected to re-establish contact with and report on German Americans as they had before the war.

This interest notwithstanding, German observers fully recognized the war's devastating impact on German Americans. Even though German Americans' wartime experiences differed significantly by region, religious belief, profession, and degree of acculturation, the social stigma attached to their ethnicity had clearly affected them. Individually, many had withdrawn from organized "German America" and "privatized" their ethnic maintenance. ${ }^{21}$ Ethnic associations, newspapers, and churches lay dormant and had shifted, often irreversibly, to English language use. To be sure, the war served as a catalyst for an already advanced Americanization process among German Americans, but it also reduced this browbeaten group considerably. Accordingly, its ethnic life re-emerged only slowly in the nativist postwar climate, ${ }^{22}$ and the nationwide implementation of Prohibition in 1920 deprived many ethnic clubs of a key element of revenue and, more importantly, sociability. ${ }^{23}$ For German Americans, the 1920 sould prove to be a period not of ethnic resurgence but of "ameliorated Americanization." ${ }^{24}$

And yet, while ethnic pride had reached a low point, the institutional structures of "German America" had not disappeared entirely. At least on paper, it still had formidable strength in numbers and organizational potential. The 1920 census identified 1.7 million German-born individuals and 5 million with at least one German parent, making them America's largest ethnic group of first- and second-generation immigrants. ${ }^{25}$ German estimates even reckoned that up to 25 million Americans - nearly a quarter of the population had German ancestry. Though half of all German-language publications had gone under during the war, about 500 remained, with the first postwar years even witnessing a "mild revival" of ethnic institutions. ${ }^{26}$ Millions of German Americans, moreover, still had relatives overseas, and the humanitarian relief they provided to them and German children often expressed not just a profound personal sympathy but a rejection of the peace treaty's underlying moral assumptions. ${ }^{27}$ While traditional factionalism soon resurfaced, many German

21 Don Heinrich Tolzmann, "The Survival of an Ethnic Community: The Cincinnati Germans, 1918 through 1932" (PhD diss., University of Cincinnati, 1983), 370.

22 James M. Bergquist, "German Americans," in Multiculturalism in the United States: A Comparative Guide to Acculturation and Ethnicity, ed. John D. Buenker and Lorman A. Ratner, 149172 (Santa Barbara, CA, 2005), 162.

23 The Cannstatter Volksfestverein may serve as an example: Mss 128 Cannstatter Volksfestverein, Historical Society of Pennsylvania (HSP).

24 LaVern. J. Rippley, “Ameliorated Americanization': The Effect of World War I on German-Americans in the 1920s," in America and the Germans, ed. Trommler and McVeigh, 2:217231.

25 Rippley, “Ameliorated Americanization," 222.

26 Bergquist, "German Americans," 162.

27 Strickland, "American Aid to Germany, 1919-1921." 
Americans did harbor common grievances - indignation about their wartime treatment, opposition to Prohibition, and the rejection of the Versailles Treaty which they vented at the ballot box. ${ }^{28}$ German foreign policymakers could certainly not afford to ignore this group of several million people, pro-German in orientation and settled in a country so crucial to Germany. How Germany should approach this group and how much - and what kind of - attention it should give it would occupy policymakers throughout the 1920 .

\section{"Not Simply Unwelcome, but Downright Dangerous" - German Officials and the Question of Political Agitation, 1919-1924}

It is possible to identify at least two distinct phases in this German debate, both of which are closely linked to wider domestic and international developments. During the first phase, which lasted until about 1924, the debate focused on whether and how German Americans could hasten the American intervention so urgently desired. Accordingly, discussions revolved around the degree of political influence German Americans had, the extent to which they were organized, and whether and how best to aid their ethnic mobilization from Germany. Eventually, the debate put to rest long-cherished myths and unrealistic expectations about the "German element" in the United States, paving the way for a more constructive "second phase" after 1925.

This German debate unfolded largely in step with German-American actions. While German Americans' charitable work first drew German attention to them once again, the founding of two German-American organizations, the Steuben Society and the German-American Citizens League, fed popular German impressions of a political awakening across the Atlantic. After the war, both of them vied to succeed the National German-American Alliance even as they addressed what they saw as its major shortcoming: its lack of political initiative. The abysmal treatment of German Americans during the war had only been possible, self-appointed ethnic leaders argued, because they had

28 For German-American hopes for and reactions to the peace treaty, see John B. Duff, "German-Americans and the Peace, 1918-20," American Jewish Historical Quarterly 59, no. 4 (June 1970): 424-444; the rejection of the Treaty of Versailles was not dependent on ethnic politics, even though a group of German as well as Irish Americans counted among its most outspoken opponents. As Ambrosius holds, Republicans organized the strongest opposition to the treaty, not mainstream German Americans or Irish Americans, though both groups were conveniently blamed by Wilson supporters; see Lloyd Ambrosius, "Ethnic Politics and German-American Relations after World War I: The Fight over the Versailles Treaty in the United States," in Germany and America: Essays on Problems of International Relations and Immigration, ed. Hans Trefousse, 29-40 (New York, 1980), 32. 
been too divided and politically apathetic in the prewar years; ${ }^{29}$ the only way to avoid future persecution and force concessions on issues that mattered to them (Prohibition, German language use, and a revision of Versailles) was to unify the German-American vote. The Chicago-based Citizen's League, founded in January 1919, saw itself as the direct heir of the National German-American Alliance and served as an umbrella organization for a range of ethnic Vereine, especially in the Midwest. The New York-based Steuben Society, on the other hand, founded a few months later, was more elitist in its self-understanding. ${ }^{30}$ It restricted membership to American citizens and adopted English as its official language. ${ }^{31}$ These tactical differences aside, both articulated a clear political leadership strategy that aimed, as the Steuben Society wrote, "to bring about the complete rehabilitation of the Germanic element in the United States, politically, socially and economically and its universal recognition as an integral part of our citizenry on the basis of absolute equality in all things." ${ }^{32}$

To a number of German observers, these new organizations appeared to be the harbingers of a German America that was unified and politically aware. The German press followed their activities attentively, often quoting their leaders' more militant speeches, which conveyed an impression of a German America on the cusp of successful political mobilization..$^{33}$ A 1921 article in Volk und Heimat (a publication of the Verein für das Deutschtum im Ausland) held that their wartime treatment had finally freed German Americans from their political lethargy and had even separated the wheat from the chaff. ${ }^{34}$ While many had passed straight into "Yankeedom," the article maintained, a hard core of politically minded German Americans now seemed ready to stand up for German interests in the United States. ${ }^{35}$ Exposed to wartime lies and discrimination, irritated by Prohibition, and incensed by the Versailles Treaty, German Americans were seen - and projected themselves - as having overcome their traditional factionalism and being ready to throw their united weight into the

29 Rudolf Loreck, "Die Zukunft des Deutschtums in Amerika" (New York, 1929), quoted in Hugo Grothe, Die Deutschen in Übersee. Eine Skizze ihres Werdens, ihrer Verbreitung und kulturellen Arbeit (Berlin, 1932), 186.

30 As Tolzmann notes the "League's aims were overtly political, its rhetoric abrasive, and the strategy one of demands and concessions." Tolzmann, "The Survival of an Ethnic Community," 286.

31 The Steuben Society was associated with Viereck's The American Monthly and Issues of Today; its rhetoric and idea was extremely close to many right-leaning German publications.

32 Rudolf Cronau, The Army of the American Revolution and its Organizer (Cronau, 1923), 149. 33 See, for example, "157. Stiftungsfest der ältesten deutschsprachigen Vereinigung in Amerika," Volk und Heimat 3, no. 2 (Feb. 1922): 38; "Die Deutsch-Amerikaner finden sich," Volk und Heimat 2, no. 6 (Apr. 1921): 64-65; "Die Zusammenschlussbewegung der Deutschen in Nordamerika," Volk und Heimat 2, nos. 15/16 (Aug 1921): 154.

34 "Die Deutsch-Amerikaner finden sich," Volk und Heimat 2, no. 6 (Apr. 1921): 64-65, 65.

35 Albert Bencke, "Das Deutschtum Chicagos," Der Auslanddeutsche 3, no. 23 (Dec. 1920): 705706; for a similar take, see Boelitz, Das Grenz- und Auslanddeutschtum, 173. 
political arena..$^{36}$ As a consequence, Germandom enthusiasts felt the time for a more forceful German propaganda to aid this political mobilization had come. Calls to action submitted to the Foreign Ministry portrayed this mobilization as the surest way to gain American concessions. ${ }^{37}$

The "America experts" at the Wilhelmstrasse emphatically disagreed. While they regularly commented on the activities of German Americans, they largely disavowed attempts at political mobilization due to both wartime experiences and postwar nativism. As early as November 1920, the Foreign Ministry's America Department penned a memorandum characterizing any unsanctioned attempt at politically mobilizing German Americans as "not simply unwelcome, but downright dangerous." ${ }^{38}$ External "America experts" like the Americanist Friedrich Schönemann or Karl Oscar Bertling, director of the Amerika-Institut, opposed even publicly discussing ethnic mobilization because it was bound to raise expectations that German Americans could never fulfill..$^{39}$ After German representatives arrived in the United States in early 1922, they strongly seconded these voices of caution. When Berlin wondered whether "ethnic committees" could not be loosely attached to German consulates, as had been done successfully in Spain, the embassy emphasized the entirely different nature of the American case: here, one was not dealing with a German "colony" but with a large U.S. citizenry of German descent whose political loyalties had to be exclusively American. ${ }^{40}$ The consul general in Chicago declared categorically: "We have to avoid even the semblance of wanting to influence German-American circles here." 41

Wartime lessons were most influential in this assessment as German involvement after 1914 had only served to harm German Americans and transatlantic relations in general. But it was also based on a sober calculation of German-American influence on the group that was of primary interest to German foreign policy: Anglo-Americans..$^{42}$ Germany would have to rebuild a measure of political trust and business confidence among this group, which led America

36 For German-American self-interpretations, see Edmund von Mach, "Eine politische Organisation von Amerikanern deutschen Stammes?," Der Auslanddeutsche 3, no. 16 (Aug. 1920): 481482; Amerika-Institut (Kartzke) to AA, Mar. 23, 1922, PA R 60104.

37 For German calls to action, see Abschrift VI A V 877, Oct. 28 1920, PA R 80287; Aufzeichnung (Noebel), VI A 263, Feb. 16, 1922, PA R 60104; newspaper articles discerned a political reawakening of Deutschtum in the United States and advocated support for its allegedly unifying forces; Clipping: Fritz Heinz Reimesch, "Erwachendes Deutsches Leben in Nordamerika," Germania, Nov. 10, 1921, PA R 60104; Clipping: "Zur Deutsch-Amerikanischen Annäherung," Der Reichsbote, Apr. 25, 1922, PA R 80293.

38 Aufz. zu VI A. V. 877 Nov. 3, 1920, PA R 80287.

39 Friedrich Schönemann, "Amerikanische Stimmungen," Vossische Zeitung, Sep. 30, 1920; and Amerika-Institut to AA (Heilbron), Jan. 12, 1922, PA 60104.

40 German Embassy, Washington, to AA, Jan. 30, 1923, PA R 60104.

41 German Consulate General, Chicago, to Embassy, Jan. 22, 1923, PA R 60104.

42 G. A., Oct. 19, 1920, PA 80131. 
politically, socially, and economically. As a consequence, German Americans were usually judged only on how well they could aid this process. Theoretically, at least, there were two ways German Americans could attain a measure of influence on American policy. First, they could champion a pro-German position in public debate, providing a much-needed corrective to prevalent anti-German views. Second, they could assert indirect influence on American foreign policies through a unified "German vote." Germany's "America experts" considered neither of these options very likely.

For one thing, at that point German Americans were a marginalized and disarrayed group, so they were ill-suited to being "multipliers" of a German-friendly position. Moreover, most of them did not want to be associated with the German cause at all. While they felt comfortable engaging in humanitarian work, they had no desire to open themselves up again to the sort of attacks they had endured during the war. The few that did, such as the publicist George Sylvester Viereck or art scholar Edmund von Mach, either lacked access to Anglo-American circles or were already heavily implicated by their wartime work. ${ }^{43}$ Despite initiatives like that of the Steuben Society, unified political action also appeared highly improbable. Having observed the fractured institutional landscape of German Americans, their religious divisions, social stratification, dispersed geographical settlement, and general apathy to national politics, German diplomats and "America experts" were skeptical that this group would be capable of united political action. ${ }^{44}$ Unlike the Irish, who carried considerable political weight through their allegiance to the Democratic Party, "German America" had never mustered a united ethnic vote in national elections - and probably never would. If anything, the war had only hardened the belief in German America's political impotence because, although the group had been relatively well organized at the time, it had not had any positive effect on general public opinion, let alone on the course of American foreign policy before 1917. Quite the contrary, their attempts at ethnic politicking had only heightened Anglo-American suspicion. Once the United States had entered the war, German Americans had not risen in defense of the fatherland but proved themselves the loyal American citizens they had been all along.45 This "failure" of German America sobered German expectations. ${ }^{46}$ In the end,

43 Amerika-Institut to AA, Dec. 8, 1920, Memorandum, PA R 121325. The advice of the Amerika-Institut was based on a memorandum by Führ and, thus, represented official opinion.

44 "America experts" such as Friedrich Schönemann and Karl Oscar Bertling warned publicly against misjudging the sympathies and influence of German Americans; see Friedrich Schönemann, "Amerikanische Stimmungen," Vossische Zeitung, Sep. 30, 1920; and Amerika-Institut to AA (Heilbron), Jan. 12, 1922, PA R 60104.

45 "Aus Zeitungen und Zeitschriften," Der Auslanddeutsche 8, no. 16 (Aug. 1925); 479.

46 Rolf Weber, "Deutschamerikanische Liebestätigkeit," Volk und Heimat 1, no. 4 (Feb. 1920): 51-52; on a particularly vicious German accusation about German-American "betrayal," see Kreuzzeitung, May 1917, quoted in Michael Singer, Jahrbuch der Deutschamerikaner für das Jahr 
the short-lived existence of the Citizens' League, the Steuben Society's general lack of influence, and the ineffective attempts at ethnic politicking during the national election campaigns of 1924 and 1928 proved that this skepticism was well-founded. ${ }^{47}$

In light of these pessimistic assessments, the negative trade-offs of any strategy of ethnic mobilization (at least wherever it stood any chance of detection) simply appeared too grave. German representatives repeatedly emphasized that all American administrations aimed to reintegrate the German element and further Americanize it, and that accusations of German agitation, even if unwarranted, would only precipitate a new wave of resentment against both Americans of German descent and Germany. ${ }^{48}$ As the America desk of the press department noted, "any sort of propaganda designed to further the political organization of Germans would also evoke the distrust of the American government, no matter whether Republican or Democrat, and would once more afford the American press the welcome opportunity to accuse us of meddling in the domestic affairs of the Union and of trying to create an anti-American movement on American soil."49 If Germany's primary goal was to win American support, it could not risk antagonizing Anglo-Americans for an outcome as unlikely as the political mobilization of German Americans. Weighing all factors, the Wilhelmstrasse found that the costs associated with a more assertive Germandom policy in the US clearly outweighed its potential benefits.

Based on such considerations, German objectives had to be altogether different. Rather than fueling ethnic separatism, they needed to facilitate German America's return to the fold of mainstream society. Indeed, only if they lost their stigma as "German propagandists" and regained the courage to speak out - and found an audience - could they ever be of any use to German interests. In other words, diminishing the rift between German America and Anglo-America had to be a primary objective of German foreign policy. This realization affected not only the appraisal of German actions, but shaped Germany's attitudes toward German Americans' own agitation. While German officials had previously welcomed ethnic organizers as potential champions of the German "cause," they now began to see them as extremist groups whose

1918 (Chicago, 1917), 162; the widespread disappointment among German Americans is also noted by Gerard, My Four Years in Germany, 230-231.

47 German Embassy, Washington, to AA, Nov. 15, 1924, PA R 80136; also Frederick C. Luebke, "German-American Leadership Strategies between the World Wars," in Germans in the New Worlds: Essays in the History of Immigration, ed. Luebke, 51-78 (Urbana and Chicago, IL, 1990). 48 German Embassy, Washington, to AA, Oct. 18, 1922, "Stimmung in den Vereinigten Staaten gegenüber Deutschland," PA R 80134. This caution was part of a larger policy; Hiden, "The Weimar Republic and the Problem of the Auslandsdeutsche," 281.

49 Aufzeichnung, Nov. 3, 1920, PA R 80287. Corresponding with the Bureau of the Reich President, the Foreign Ministry summed up its stance in June 1921: AA to Büro des Herrn Reichspräsidenten, June 10, 1921, PA R 80293. 
policy of demands and concessions perpetuated, rather than bridged, wartime divisions. ${ }^{50}$ Sworn to a "policy of reckoning" (Abrechnungspolitik), a number of professional German Americans engaged in loud agitation and abrasive language, typically merely provoking nativist backlashes that trapped German Americans in their marginalized position and ultimately contradicted both the average German American's craving for a quiet "return to normalcy" 51 and German interests..$^{2}$ In practice, then, German officials had to avoid the "semblance" of German meddling and keep their distance from German-American attempts at political mobilization as represented by the Steuben Society, the Citizens' League, and other self-appointed ethnic leaders. All the evidence suggests that this is precisely what they did..$^{53}$

This official restraint was profoundly aided by the lack of interest Germandom organizations showed in German Americans. While Germandom publications occasionally surveyed the American situation, at times even issuing calls to action, there seems to have been no more forceful agitation. It was true that organizations like the Deutsches Ausland-Institut in Stuttgart quietly built a network of subscribers for their publications, kept in contact with ethnic leaders, and collected funds in the United States, but these were neither particularly assertive nor visible. ${ }^{54}$ Given the ethnic emergencies and promising projects around the world, the attention these organizations paid to German Americans was relatively fleeting. If German America held a privileged place in Germandom policy, then only as a cautionary tale. Pertinent publications presented German Americans primarily as a group that had rapidly lost its ethnic identity. Comparing the large number of Americans of German descent to the small number of active German speakers, ${ }^{55}$ Germandom specialists like

50 For examples of this militant rhetoric and forceful calls for unity against Anglo-American insults, see the preface in Johannes Glaesser, Deutsch-Amerikanisches Vereins-Adressbuch für das Jahr 1921 (Milwaukee, 1921); and Edmund von Mach, "Deutsche, Heraus!" Viereck's American Monthly, Aug. 1, 1920, 167.

51 Frederick C. Luebke, "German-American Leadership Strategies between the World Wars," 52-53.

52 Especially the wealthier, better-educated, and thus more influential German Americans tended to steer clear of organizations accused of pro-German agitation. The strong responses of the Chicago Tribune to the third annual meeting of the Citizens' League on July 21, 1922, Steinbach believed, only reinforced the caution of the better elements in dealing with German-American organizations. German Consulate, Chicago, to AA, Aug. 5, 1922, "Deutsch-Amerikanisches Vereinswesen," PA R 80294.

53 Nowhere was this more apparent than with regard to George Sylvester Viereck, the wartime German propagandist; C. A. Vertraulich May 31, 1922 (Davidsen) PA R 80287.

54 DAI (Wanner) to Cronau, Jan. 7, 1928, Folder 5; DAI to Cronau, Sep. 1, 1927, Folder 7, Ms 1010 Rudolf Cronau Collection, Horner Memorial Library.

55 Germandom specialists, in particular, tended to inflate their numbers, calculating 25-30 million of "German blood"; Grothe, Die Deutschen in Übersee, 178; F. Schönemann estimated about 15-18 million Americans of German descent; Friedrich Schönemann, Die Vereinigten Staaten von Amerika. Vol. 1: Von der Kolonie zum Weltreich. (Stuttgart und Berlin, 1932), 303; Boelitz set 
Hugo Grothe calculated that 22 million had simply been "lost" to Germandom. 56 "Millions who could have been intermediaries and supporters of German culture, German prestige and German economy [in the United States]," declared the Verein für das Deutschtum im Ausland in 1921, "now serve Anglo-Saxondom." 57 From this perspective, German American "failure" during World War I seemed but the last in a long series of shortcomings. Though German Americans were clearly courted for their money, there were few attempts at any more forceful agitation. The commonly told story of German-American assimilation underlined past sins of omission in order to avoid them elsewhere, not to redress them across the Atlantic. For German diplomats, this defeatism about ethnic survival in the United States proved fortuitous. As they usually were unable to control or contain unwelcome Germandom efforts, it was primarily this widely accepted inevitability of German-American assimilation that allowed for a policy of restraint..$^{58}$

This is not to say that there were no attempts to mobilize German Americans. German "Black Horror" campaigners, for example, were especially active in the United States and found enthusiastic partners in men like Viereck. ${ }^{59}$ Nor is it to suggest that German officials had no contact with ethnic leaders. Both in Germany and the United States, informal connections and conversations were clearly re-established. But this never led German officials to abandon their general caution. Indeed, the opinions of the Foreign Ministry and its representatives abroad on this matter were more consensual than scholars have suggested. There is little evidence that German representatives in the United States had to resist "massive and repeated pressure from Berlin to mount propaganda efforts in the United States," ${ }^{\circ 0}$ at least not as far as German Americans were concerned. While there were numerous conflicts about the appropriate

the number of those of German descent between 15 and 20 million or about 25 percent of the white population, as compared to 32 percent English and Scottish; Boelitz, Das Grenz- und Auslanddeutschtum, 166.

56 The 25 to 30 million of German "blood" could be contrasted with only 8 million of German stock (of which 75 percent had been born in the United States) and only three million German speakers, producing a "deficit" of at least 22 million. Grothe, Die Deutschen in Übersee, 178.

57 “1881-1921. 40 Jahre Verein für das Deutschtum im Ausland," Volk und Heimat 2, nos. 7/8 (May 1921): 73-78, 75 .

58 This relative lack of control is exemplified in the ultimately futile efforts of German diplomats to keep Robert Treut - from the Verein für das Deutschtum im Ausland - from lecturing in the United States. Despite repeated efforts and despite the fact that the Verein für das Deutschtum im Ausland was heavily subsidized by the Foreign Ministry, all efforts to this end failed. See German Embassy, Washington, to AA, Jan. 30, 1926, "Sammlung und Vorträge des Studiendirektors Dr. Treut in den Vereinigten Staaten," PA R 60105. Aufzeichnung, July 16, 1928, PA R 60106.

59 The Wilhelmstrasse was repeatedly confronted with wide-ranging German plans on precisely how to organize successful propaganda campaigns among German Americans, e. g., VI B 9929, Abschrift Dr. Heinrich Brühl to Minister für Kunst, Wissenschaft und Volksbildung, July 9, 1923, PA R 64887.

60 Wala, "Reviving Ethnic Identity," 341. 
extent of agitation in the United States, there were few concerning the folly of ethnic politicking. Wartime experiences, postwar nativism, and the primacy of Anglo-American sympathy all too clearly advised against it.

Importantly, this points to a general professionalization of Germany's Amerikapolitik. By the early 1920s, long-standing tensions between cautious representatives abroad and more eager officials at home were largely resolved as men with an intimate knowledge of the United States rose to positions of responsibility in the Wilhelmstrasse. In stark contrast to the war years, the Press and America Departments were staffed with men who had often witnessed the negative effects of Germany's clumsy propaganda firsthand. ${ }^{61}$ While men like Walther Drechsler, Karl Alexander Fuehr and Hermann Davidsen did not hold particularly high-ranking positions, their superiors, such as the influential head of the America Department (and later secretary of state) Carl v. Schubert, seconded their calls for moderation. ${ }^{62}$ In this regard, the regional principle introduced during the Foreign Ministry's postwar reforms clearly fulfilled its intended purpose: to create expert knowledge attuned to foreign psychology. Accordingly, the more forceful Germandom policy practiced in other countries in the 1920 s never materialized in the United States. Heeding the lessons of the war, Berlin adopted a more realistic assessment of German Americans' position and influence.

\section{"To Strengthen Respect for Germany and Germandom": German Americans and Cultural Diplomacy, 1924-1929}

After 1924, the predominantly political discussion of the postwar years gave way to a broader, ultimately more constructive debate. This was clearly necessary. Given the imperative for caution, by the mid-1920s there was still nothing akin to a comprehensive strategy for approaching German Americans. While official representatives had always been expected to maintain informal contacts with ethnic clubs, businessmen, and editors in their districts, the overall place

61 At the America branch most matters pertaining to U.S. public opinion passed through the hands of Karl Alexander Fuehr, head of the German propaganda bureau in New York from 1915-1917. At the press branch Dr. Drechsler served as the "Amerika Referent." Educated in the United States, and director of the Amerika-Institut from 1910 to 1920, he also had an intimate knowledge of American affairs and psychology.

62 On support for caution by the head of the Kulturabteilung, see Abschrift No VI B 10304, (Heilbron) June/Aug. 1922, PA R 80294; on Schubert's support, zu III A 942, Mar. 13, 1922, PA 80133; on Schubert more generally, see Peter Krüger, Carl von Schubert. Außenpolitker aus Leidenschaft. Sein Beitrag zur internationalen Politik und europäischer Ordnung in der Ära der Weimarer Republik (Berlin, 2017); and Peter Krüger, ed., Carl von Schubert (1882-1947). Sein Beitrag zur internationalen Politik und europäischen Ordnung in der Ära der Weimarer Republik. Ausgewählte Dokumente (Berlin, 2017). 
of German Americans in German Amerikapolitik remained undefined. ${ }^{63}$ Not until 1925 was there a more systematic debate on the state of their emotional and cultural attachment to Germany, which led, in the end, to the adoption of a broadly cultural course.

Internal and external developments affected the timing and nature of this debate. For one, by 1925 ethnic life was once again becoming more visible, as in the increasingly public "German Day" celebrations, prompting a need for clarification of the German positions. ${ }^{64}$ Though ethnic associations emphasized their American character, German Americans still craved their old fatherland's attention. If Germany kept too great a distance, it would have unnecessarily offended a group of Americans who were often lovingly attached to their old Heimat and who, potentially at least, could act as purveyors of a more German-friendly feeling in the United States. ${ }^{65}$ By 1925 , too, nativist sentiment and patriotic scrutiny of ethnic groups had decreased, in part due to the strict Immigration Laws of 1924, thus allowing Germany to take a more active approach. Moreover, Germany's economic and political stabilization after the Dawes Plan improved transatlantic relations just as it provided some financial leeway in previously neglected fields of policy. Under these circumstances, whether and how to maintain at least German Americans' emotional and cultural affinities without antagonizing Anglo-Americans emerged as a major issue.

A new appointment at the Washington embassy in early 1925 provided a significant impulse in this regard. Indeed, the role of German representatives, ambassadors, and consuls, in implementing and even in formulating German public diplomacy is often underrated. The embassy and Germany's eight consulates were a natural focal point for German ethnic life in the United States. ${ }^{66}$ This was true both for obvious ethnic centers like Chicago, New York City, and St. Louis (which was re-opened in 1925 to maintain ties to German Americans), as well as for places that may initially seem less ethnically dominated, like San Francisco and New Orleans. ${ }^{67}$ The individual interest, initiative, and compe-

$63 \mathrm{Zu}$ III A 942, Mar. 13, 1922, PA 80133.

64 The German Day celebrations, for example, re-emerged from their often private, charity-focused existence of the postwar years into the public limelight after the mid-1920s. In Cincinnati, for example, the German Day celebrations resumed in 1926; Tolzmann, "The Survival of an Ethnic Community", 223.

$65 \mathrm{Zu}$ III A 942, Mar. 13, 1922, PA 80133.

66 German consulates were all closed in 1917 and reopened in early 1922: Boston, Chicago (consulate general), Cleveland (from 1926), New Orleans, New York City (consulate general), St. Louis (1922-1923, from 1925), San Francisco, Seattle (until 1923 and from 1925); an investigation of consular appointments would probably illustrate similar variations.

67 On St. Louis, see Mundt, "Wichtigkeit des Berufskonsulats in St. Louis," (ca. Feb. 1925), PA R 80238. On San Francisco, a consular district with more than 300,000 German-born, "the number of visitors would take no end. First, there came the prominent Germans, the directors of long-established, partly already strongly Americanized companies, then the presidents of the German 
tence of consuls and ambassadors greatly shaped public diplomacy. While a full investigation of consular activity lies beyond the scope of this study (and the scope of available archival material), Weimar's three ambassadors to Washington alone displayed marked variations in the direction and intensity of their public diplomacy during their tenures. For all their shared policy directives, they had three distinct "ambassadorial styles" for managing ethnic and public relations more generally.

The most marked shift in ambassadorial style occurred in early 1925 when Otto Wiedfeldt, the first postwar ambassador to Washington, left his post. Throughout his three years in Washington, the Krupp manager and economic expert never seemed particularly inclined to engage in public diplomacy. He did not share the enthusiasm for propaganda typical of the times and had always remained convinced that a sound economic plan, not public outreach, was the key to improving transatlantic relations. ${ }^{68}$ By temperament and training, Wiedfeldt felt much more comfortable discussing German problems with his Anglo-American peers behind closed doors than engaging in public speeches or hosting soirees. ${ }^{69}$ Under his watch, the embassy never exhausted its modest quarterly press fund of 100 dollars completely and also spent it exclusively on purchasing American periodicals. ${ }^{70}$ Not prone to Germandom romanticism anyway, Wiedfeldt was especially reserved concerning German Americans and had avoided public appearances, particularly at ethnic events. ${ }^{71} \mathrm{Al}-$ though postwar suspicions rendered this position sensible, for the most part, the "reclusive" ambassador was increasingly criticized, not the least by German Americans. After a bitter falling-out with Foreign Minister Stresemann, Wiedfeldt - who had originally taken on the difficult post only as a short-term favor - returned to Krupp in early 1925.

His successor, Adolf Georg Otto (called Ago) von Maltzan, essentially reversed Wiedfeldt's position on public diplomacy. ${ }^{72}$ Indeed, there may have been two major reasons why Maltzan - despite his lack of American experience and his rather problematic reputation as the principal "architect of [the treaty of] Rapallo" 73 - was assigned to the important Washington post. For one, after

Vereine, the editors of German newspapers, and last but not least the American press." See von Hentig, Mein Leben. Eine Dienstreise, 255.

68 German Embassy, Washington, to AA, Sep. 23, 1922, "Besprechungen mit führenden Amerikanern," PA R 80134.

69 German Embassy Washington, to AA Mar. 25, 1923, "Reise des Botschafters nach dem Süden der Vereinigten Staaten," PA R 80135.

70 See the correspondence and receipts in PA R 121070.

71 Informally, Wiedfeldt had indeed made some efforts to reach out to ethnic leaders; see what is left of the "top secret" report (probably early 1924) in PA R30641.

72 Aufzeichnung (AA), Aug. 18, 1925, BArch R 43-I/96.

73 Maltzan's name was primarily associated with the Rapallo Treaty between Germany and Russia, which had caused great unease in the West. Upon meeting Maltzan in Dec. 1922, William Castle, head of the State Department's Western European section, characterized him simply as "a bad 
the negative experience with the "outsider" Wiedfeldt, Berlin was determined to appoint an "insider," a type Maltzan epitomized..$^{74}$ Born into old nobility, trained in legal studies, and a member of the "right" sort of fraternity, Maltzan's social and educational background was typical of the traditional Foreign Service $^{75}$ - a fact that facilitated the meteoric rise of his career after 1906. By 1921 he had become head of the important Russian Department and by December 1922, at only 45 years of age, had risen to state secretary, the most influential diplomatic post in the Wilhelmstrasse. His undoubted competence, his shrewd commitment to German interests, and his (despite some differences in policy) mutually trusting relationship with Stresemann certainly helped to bring him into consideration for Washington. ${ }^{76}$ But so, too, did his strong interest in public affairs. Though Maltzan possessed all the trappings of the aristocratic career diplomat, he professed none of this "type's" alleged aversion to public relations. The new ambassador's very first action was to double the embassy's quarterly press fund to 200 dollars (he raised it again a year later to 500 dollars), and, unlike his predecessor, he always spent it completely.77 From the very first, too, he tried to establish good contacts with American newspapermen, who in turn described his demeanor as "affable and democratic."78 In the following years, he revived common practices of ambassadorial representation, keeping a busy social calendar, hosting German musical soirees, and modernizing the embassy building. ${ }^{79}$ His personal correspondence reveals a deep concern with restoring German standing and cultural influence in the United States. ${ }^{80}$

man. He alone was responsible for the Rapallo Treaty (...)." William Castle Diary, Oct. 23, 1922, cited from Niels Joeres, "Architekt von Rapallo, Der deutsche Diplomat Ago Maltzan im Kaiserreich und in der frühen Weimarer Republik" (PhD Diss. Universität Heidelberg, 2005), 586.

74 For another example of the German diplomatic corps wanting to appoint an "insider" over an "outsider," see the case of Harry Graf Kessler and the London ambassadorship in Peter Grupp, "Harry Graf Kessler und das Auswärtige Amt. Funktionselite und elitärer Außenseiter," in Eliten in Deutschland und Frankreich im 19. und 20 Jahrhundert. Strukturen und Beziehungen, Vol. 1, ed. Rainer Hudemann and Georges-Henri Soutou, 293-302 (Munich, 1994).

75 See Peter Krüger, "Struktur, Organisation und außenpolitische Wirkungsmöglichkeiten der leitenden Beamten des Auswärtigen Dienstes 1921-1933," in Das Diplomatische Korps 18711945, ed. Klaus Schwabe, 101-170 (Boppard am Rhein, 1985).

76 There has long been a discussion about whether Maltzan was placed in Washington to get an influential advocate of German East-orientation out of the way, but more recent studies generally highlight that the relationship between the ambassador and the foreign minister was a good and productive one and that Maltzan's appointment primarily underlined the importance of the Washington post; see Maltzan to Stresemann, May 1, 1925, Gustav Stresemann Vermächtnis II, $282-283$.

77 German Embassy, Washington, to AA, Mar. 8, 1927, "Antrag auf Erhöhung des Pressefonds," PA R 121070.

78 Clipping: The Boston Globe, June 23, 1925, "German Ambassador Popular at Magnolia: President's 'Neighbor' is Affable and Democratic in Manner," PA NL Maltzan, Vol. 48.

79 The ambassador's busy schedule is borne out by his social calendar held at the Politisches Archiv. PA NL Maltzan, Vol. 54, Tageskalender Botschafter Maltzan.

80 Maltzan to Bernhard (Voss. Zeitung), Dec. 16, 1925, PA NL Maltzan, Vol. 47. 
Maltzan was able to demonstrate his public relations skills just weeks into his ambassadorship when General von Hindenburg's election as Reich President on April 26, 1925, caused considerable unease among American investors and politicians. Denouncing him as a "place holder for the Kaiser," the American press called the war hero's election a "mental goosestep" on the part of the German people, tantamount to a rejection of Germany's agreed-upon obligations. ${ }^{{ }_{1}}$ To calm these prevalent fears, Maltzan assembled Wall Street investors and representatives of the nationally syndicated New York press and underlined Germany's continued commitment to fulfillment. This proactive press policy - if we are to believe Maltzan's own account - helped to defuse the situation and re-established America's trust in the Weimar Republic's stability. ${ }^{82}$ The "election of the field marshal," he reported on April 30, "will no longer be a liability to [our] political and economic relations with America." ${ }^{83}$ Following this early example, Maltzan gave public diplomacy new momentum until his untimely death in an airplane accident in September 1927.

Not long after his arrival in Washington, Maltzan began to take a more pronounced interest in German Americans. There is little doubt that the ambassador was concerned about the situation of German Americans in its own right as he shared the romantic notions of ethnic nationalism typical of his time. ${ }^{84}$ But this general disposition was reinforced by two events during the early summer of 1925 . For one, an invitation to Chicago by Vice-President Charles G. Dawes in July 1925 illustrated the crucial role that German Americans' continued interest and support could play in revising the peace treaty. Spending a pleasant afternoon at Dawes's sprawling estate and jointly presiding over a large German-American banquet, Maltzan was certain that his cordial reception was owed primarily to his host's political ambitions in the heavily German Midwest. Whatever its shortcomings, the "German vote," Maltzan concluded, still affected attitudes, perhaps even policies, toward Germany. ${ }^{85}$ This general insight coincided with conservative German criticism about the passivity of German authorities in the face of German-America's speedy Amer-

81 Clipping: "Faithful to the Old Masters," Saturday Evening Post, May 2, 1925, PA NL Maltzan, Vol. 48 .

82 German Embassy, Washington, to AA, Apr. 30, 1925, "Amerika vor den Hindenburgwahlen," PA R 80136 .

83 On Hindenburg's election and the considerable stir it created, see the clippings and reports in PA R 28490 .

84 Maltzan to Rudolf Cronau, Jan. 22, 1926, PA NL Maltzan, Vol. 47.

85 German Embassy, Washington, to AA, July 18, 1925, "Besuch des Botschafters Maltzan beim Vizepräsidenten Dawes in Chicago," PA R 80137. 
icanization. ${ }^{86}$ Unlike his predecessor, who had almost categorically objected to German involvement in this matter, Maltzan found it a "very grave problem" worthy of more careful consideration. On August 3, 1925, therefore, he asked all German consuls in the United States to report on the situation of German Americans and - within the boundaries of a general policy of political restraint - whether "cultural maintenance of their Germandom" was possible and desirable. ${ }^{87}$ The result was the decade's most comprehensive survey on the state of "German-America."

The German consuls clearly welcomed this opportunity to report on the state of German-American ethnic identity. Though their reports differed in some aspects, they first and foremost bade a resounding farewell to any concrete notion of "German-America." Germans in the United States, all of them agreed, assimilated more rapidly and completely than anywhere else. ${ }^{88}$ The majority of German immigrants integrated into American life completely within just a few years, leaving only a relatively small, mostly lower-class group to cultivate German traditions in a plethora of clubs and associations. The second generation, at the latest, which at that point made up more than two-thirds of German Americans, was sure to become "hopeless Vollamerikaner." dency to overadapt inherent in the German character, the substantial economic and social rewards for acculturation, and the generally low educational level of German immigrants were blamed for this process..$^{90}$ While wartime discrimination and postwar nativism had hastened this development, the restrictive immigration quota of 1924 sounded the death knell for ethnic survival. In one generation, there would be no more German Americans. ${ }^{91}$

These consular reports departed from prewar responses not so much in their general pessimism as in their prescriptions for how to deal with the situation. Even before the war, the notion of the United States as a "mass grave" of Germandom had achieved the status of conventional wisdom; ${ }^{22}$ but it was only in the 1920s that German authorities abandoned their anti-assimilationist

86 Clipping: Fritz Heinz Reimesch, "Vom Deutschtum in den Vereinigten Staaten," Deutsche Warte (Sonderbeilage zur Kreuzzeitung), PA R 60105.

87 German Embassy, Washington, to AA, Aug. 3, 1925, "Deutschtum in Amerika," PA R 60105.

88 Boelitz, Das Grenz- und Auslanddeutschtum, 168.

89 For this specific phrase, see an earlier characterization: German Consulate General, New York, to AA, Dec. 8, 1924, "Anfrage des Generalleutnants a. D. von Livonius, betreffend Organisation des Deutschtums," PA R 80287.

90 John Eiselmeier, "Die Deutsch-Amerikaner," Deutsche Arbeit 24, no. 4 (Jan. 1925): 98-101.

91 "The German-American element," wrote Consul General Steinbach from Chicago, "is shrinking rapidly and inevitably. The war has demolished the last connections. The great relief work on our behalf after the war will probably have been the last time that the German-Americans acted in a united fashion, and even then only non-politically." German Consulate General, Chicago (Steinbach), to Embassy, Sep. 29, 1925, PA R 60105.

92 Michael Ermath, "Hyphenation and Hyper-Americanization: Germans of the Wilhemine Reich View German-Americans, 1890-1914," Journal of American Ethnic History 21, no. 2 (2002): 
stance, deeming ethnic maintenance neither possible nor even politically expedient. On the contrary, since the highest political and social positions were reserved for those whose manners, education, and demeanor were entirely "American," the acculturation of German Americans was - from a purely political, if not necessarily from an emotional, perspective - only to be welcomed. ${ }^{93}$ What had to be ensured, however, was that even the fully assimilated American of German birth or descent retained a vague affinity, that "inclination of the heart," for his ancestral land. "Trying to counter the process of assimilation," Consul General Steinbach in Chicago concluded, "is a useless endeavor in my opinion. But our task is to ensure that the assimilated Germans do not lose all touch with and interest in the old Heimatland." 94 To this end, in their reports all the consuls advocated that the Foreign Ministry develop and direct, albeit covertly, a broadly cultural campaign that addressed German Americans not as Germans, but as Americans. ${ }^{95}$ A secure news supply to German-American newspapers, a focus on academic exchanges, concerted book promotions, and support for German language teaching, they hoped, could rekindle contacts even with those who had been completely Americanized. What was needed, Steinbach concluded, was "Kulturpropaganda in the best sense of the word [...] to strengthen respect for Germany and Germandom."96

\section{Balancing Acts, 1925-1927 \\ Between German and Anglo-Americans}

As Michael Wala has shown, these consular suggestions provided the blueprint for much of German outreach during the following years. It was through cultural - or at least not overtly political - measures that Berlin sought to revive a sense of ethnic identity and maintain German Americans' connection to their fatherland. To this end, consuls attended ethnic festivities, hosted German lecturers, and honored ethnic leaders. The Foreign Ministry and the German Naval Command organized visits of German cruisers to American ports, which often resulted in popular patriotic celebrations and an upsurge in ethnic pride. ${ }^{97}$ Such measures clearly attest to an effort to reach out to German Americans while avoiding the political entanglements that had harmed German and German-American interests in the past.

33-58, 49; for a contemporary assessment, see Julius Goebel, Das Deutschtum in den Vereinigten Staaten von Nord-Amerika (Munich, 1904).

93 German Consulate, Seattle, Oct. 7, 1925, PA R 60105.

94 German Consulate General, Chicago, Aug. 27, 1925, PA R 60105.

95 Aufzeichnung des Konsuls Dr. Kraske (German Consulate General, New York), Oct. 10, 1925, R 60105.

96 German Consulate General, Chicago, Aug. 27, 1925, PA R 60105.

97 Wala, "Reviving Ethnic Identity," 340. 
But the pursuit of such a "cultural course of action" took different priorities and contours during the tenures of ambassador Maltzan and his successor Friedrich Wilhelm von Prittwitz und Gaffron, which tells us something about the shifting fortunes of transatlantic relations as well as these men's individual preferences. The specific strategy Maltzan suggested (who assembled all consuls in Washington in November 1925 to discuss future Germandom policies, among other things) derived largely from a desire not only to steer clear of Anglo-American suspicions but at the same time to reconcile German Americans with postwar Germany.

Indeed, if German Americans have so far been presented as sympathizers of Germany, this requires an important qualification: To be sure, many of them were incensed about the Versailles Treaty, opposed the idea of German war guilt, and actively supported German economic, political, and moral rehabilitation. But their sympathy applied to the German people and a nostalgic version of the fatherland, not the Weimar Republic. German-born individuals, especially, found it difficult to come to terms with the end of the Wilhelmine Empire and had encountered few opportunities in the first half of the $1920 \mathrm{~s}$ to develop trust or confidence in the new Germany. ${ }^{98}$ For years after the war, German-language papers had focused on the economic distress, political instability, and international humiliations that had beset the old fatherland and frequently attributed the situation (which they often exaggerated to elicit funds and sympathy) not to Wilhelmine mistakes but Weimar's inaptitude. German Americans' traditional understanding of German politics also rendered them particularly susceptible to the "stab-in-the-back" myth. ${ }^{99}$ An ample number found Weimar's policy of reconciliation nothing short of dishonorable. ${ }^{100}$

By itself, this distance from the Weimar Republic's foreign policy might not have been especially disconcerting - after all, it hardly hindered German Americans' revisionist convictions - had it not increasingly hampered German ambitions to reconcile with Anglo-Americans. Indeed, German efforts to rebuild support and sympathy among influential but formerly critical Anglo-Americans caused considerable dismay among more conservative German Americans and repeatedly provoked vicious attacks on Ambassador Maltzan in the United States and, by extension, in Germany's right-leaning press and the Reichstag. ${ }^{101}$ At the same time, a bolder revisionist tone that might have recon-

98 This was Rohrbach's experience, for example; see Horst Bieber, Paul Rohrbach - Ein konservativer Publizist und Kritiker der Weimarer Republik (Berlin, 1972), 24; San Francisco Consul von Hentig, for example, remembers that one of the two major German papers in California, the California Journal, was more "patriotic" (vaterländisch) and headed by an editor "with connections to Imperial Germany"; von Hentig, Mein Leben, 265.

99 See Anton Erkelenz, “Der Amerikanische Deutsche," Berliner Tageblatt, Jan. 6, 1926.

100 See Clipping: Chicago Abendpost, Oct. 15, 1924, "Verbrüderungsduselei," PA R 80136.

101 German Embassy, Washington, to Stresemann, Sep. 6, 1925, PA NL Stresemann, Vol. 29; German Embassy, Washington, to Carl von Schubert, May 28, 1927, PA R 80143; Verhandlungen 
ciled German Americans with the republic was sure to alienate Anglo-Americans and awaken suspicions that had just been painstakingly calmed. German officials were thus forced to engage in a delicate balancing act: to convince German Americans that the republic deserved their support just as the monarchy had while avoiding playing into the hands of Americans who saw the republic as a place where monarchist convictions and militarist aspirations continued under a republican cloak. ${ }^{102}$ In other words, the challenge was to convince Anglo-Americans that Germany had fundamentally changed while assuring German Americans that it had remained essentially the same.

During his tenure from 1925 to 1927, Ambassador Maltzan tried to solve this dilemma by exercising formal restraint even as he engaged in nonpolitical, but quite deliberately traditional, forms of outreach. The ambassador himself employed a strategy of "Anglo-Americans first." Though everything suggests that he took a genuine interest in German Americans, during his first two years in Washington he focused nearly exclusively on winning the trust of the American press, Congress, and State Department. His busy social calendar, he privately admitted, aimed not least to establish a foundation of trust upon which to base outreach to German Americans. As he wrote to German-American author Rudolf Cronau, "It is especially to the American element of German descent that I have devoted my special interest, not to say love. You, as much as I, will recognize that I have so far not allowed myself to show this interest all too publicly [... I] have first to try to gain a firm foothold and win trust among government and congressional circles here before I can follow the voice of my heart." ${ }^{103}$ As a consequence, his few public interactions with German Americans were arranged in the least threatening way: to convey gratitude for ethnic charity, acting as the "ambassador of German children." ${ }^{104}$

In the meantime, the German consuls resumed active but relatively traditional non-political outreach, arranging events that managed to engender a sense of enthusiasm for and connection to Germany among attendees. The lecture tours of Felix Graf von Luckner and Hellmuth von Mücke, the captains of the famed World War I cruisers Emden and Seeadler, for example, conveyed the stories of adventure, heroism and German daring that German Americans delighted in hearing, ${ }^{105}$ while the visit of German cruisers to American

des Reichstag III. Wahlperiode 1924/26 Nr. 2681 Interpellation (v. Westarp und Fraktion), Nov. $13,1926$.

102 AA to all German missions abroad, Nov. 22, 1921, PA R 28039.

103 Maltzan to Rudolf Cronau, Jan. 22, 1926, PA NL Maltzan, Vol. 47.

104 German Consulate General, Chicago to AA, Tgb. Nr.261/27, May 2, 1927, "Besuch des Herrn Botschafters in Chicago," PA R 80299.

105 German Consulate General, Chicago, to AA, May 6, 1927, "Besuch Graf Luckner's in Chicago," PA R 80299; see all of PA Generalkonsulat San Francisco, Paket 48, Vortragsreise von Graf Felix von Luckner durch die USA 1927-28; on Luckner's impressions of America, see Felix Graf von Luckner, Seeteufel erobert Amerika (Leipzig, 1928). 
ports elicited pride in Germany's accomplishments and (persistent) worldwide reach. Such visits frequently celebrated bygone Imperial greatness more than present-day Germany - and spurred enthusiasm for the Reich rather than the republic - yet German representatives clearly tolerated this. After all, connections such as these kept alive German-American ethnic consciousness as well as convictions about the injustice of the Versailles Treaty, which, they still hoped would somehow impact the important congressional decisions of the coming years. ${ }^{106}$ While such events promoted the republic very little, German diplomats did try to use them to calm fears of German socialism. The visit of a number of Weimar parliamentarians in late 1925, Maltzan felt, had demonstrated "that the German Republic is not a Bolshevist state, but - especially under the leadership of President Hindenburg - a highly respectable and presentable institution. Especially for our German Americans, who used to be strongly in favor of a Republic in earlier days, and now that we have become one, have adopted a monarchist, or at least black-white-red attitude, this visit was very instructive."107

This approach, to be sure, was not without shortcomings. For one, ethnic festivities or visits of World War I heroes held only limited attraction to those outside the German-American community, be they Anglo-Americans or acculturated German Americans. ${ }^{108}$ More importantly, even the most nonpolitical activities could still arouse Anglo-American suspicion if "official Germany" was involved. While the arrival of German naval cruisers in American ports and their more or less open serving of alcohol generated great enthusiasm among German Americans, it hardly improved Germany's standing with the Anglo-American establishment. When the cruiser Hamburg visited Los Angeles in 1926, for example, federal Prohibition agents wound up investigating the event, and the embassy had to get involved. ${ }^{109}$ As counselor of embassy Hans-Heinrich Dieckhoff wrote to his mother: "I opposed the visit right from the outset (...). There is nearly always trouble if only one crew member leaves the boat (...) But that a German cruiser - the first since the war - can come to America, anchor in Los Angeles harbor for ten days and day in day out sell beer to American visitors, I still would not have deemed possible. The German cruiser, a swimming bar! And all of this in a country where the sale of alcohol

106 The next few years would bring significant political and economic decisions in the United States, including the settlement of war claims and the readjustment of reparations payments, for which the Reich had to secure American public and congressional goodwill. In this context and all non-political rhetoric notwithstanding - German Americans were to keep pressure for revising the treaty alive, even as Germany publicly proclaimed its every intention of fulfilling it. 107 Maltzan to Bertling, Jan. 7, 1926, PA NL Maltzan, Vol. 47.

108 Consul von Hentig only felt deeply saddened by festivities; see German Consulate General, San Francisco, to AA, Sep. 6, 1928, "Deutscher Tag in Los Angeles," PA R 60107.

109 Los Angeles Times, May 30, 1926, 5. 
is illegal! It is really unbelievable."110 That one and the same action proved appealing to German Americans and appalling to (at least some) Anglo-Americans spelled out a dilemma Germany was never entirely able to resolve.

Ultimately, such experiences revealed the clear limits of any official form of outreach, no matter how nonpolitical, and convinced German authorities that a more systematic campaign was best left to private groups. The German consul in Seattle had already come to this conclusion in October 1925: "in my opinion, there is little that can be done by the official representatives in the United States apart from a careful cultivation of relations to Germandom and a constant cordial exchange of ideas with its intellectual leaders. Yet in my opinion there is quite a lot that could be done through private activity from Germany, which could perhaps be arranged and controlled by the government." 11 It was no coincidence that Maltzan singled this report out for special praise. German officials realized that the Weimar Republic needed an ostensibly private organization to implement its moderate cultural approach without the restraints - and political scrutiny - that even the most harmless official undertaking would face.

\section{The Vereinigung Carl Schurz: An Instrument of German Cultural Diplomacy}

It was precisely to this end that the Vereinigung Carl Schurz (VCS), an ostensibly private, state-funded transatlantic friendship organization, was established in early 1926. Its origins went back to a private initiative in the fall of 1925 , when the Vereinigung's first director, Anton Erkelenz, a Reichstag delegate of the left-liberal German Democratic Party (DDP), toured the United States. As Erkelenz's biographer has shown, republican frustration was a strong motivating factor for his trip to America. ${ }^{112}$ By late 1924, the DDP, a major supporter of the republic, had already entered a long period of decline. In 1919, it had received 18 percent of the vote in the national elections, but its share had dwindled to only 6 percent at that point. All the while, some of its foremost concerns, such as the reconciliation of workers and employers and the civic education of the German people, remained unresolved. Consequently, Erkelenz traveled to the United States in search of models of democratic renewal and social reconstruction. After spending five months crisscrossing America, visiting factories, labor leaders, and educational reform projects, he returned convinced that American solutions could help "make over" German democracy and industry. Importantly, Erkelenz dismissed common notions of European cultural supe-

110 Dieckhoff to his mother, May 30, 1926, cited in Taschka, Diplomat ohne Eigenschaften, 84.

111 German Consulate, Seattle, Oct. 7, 1925, PA R 60105.

112 Brantz, "German-American Friendship," 232. 
riority, finding the United States to be not just a place of flat materialism and standardization but a country with its own, in many respects exemplary, culture. ${ }^{113}$ To facilitate the transfer of democratic ideas, to strengthen intellectual and personal contacts, and to improve German standing overseas, Erkelenz conceived of founding a transatlantic friendship organization and naming it after Carl Schurz, the champion of democratic reform in both countries. He aimed to base the organization on contacts with German Americans. ${ }^{114}$

Erkelenz's liberal agenda tied in closely with German officials' desire to maintain contact with German Americans while refraining from political and, if possible, official involvement. As Ambassador Maltzan intimated to Erkelenz in repeated conversations, a private organization committed to a moderate, nonpolitical course could count on official support as long as "the government and the Foreign Ministry will under no circumstances be publicly associated with the projected undertaking." ${ }^{15}$ Back in Berlin, Erkelenz thus approached the Foreign Ministry in January 1926 with a memorandum that echoed the moderate Germandom policy he had discussed with the ambassador. Although the war had irreversibly weakened the position of German Americans, the memorandum explained, they could still be a valuable resource for Germany in the long run if one fostered closer ties. However, such work could only proceed from several premises, including recognition of German Americans' full political Americanization and the abandonment of any designs to use them as a political pressure group in the United States in favor of a broadly cultural program to keep alive their interest in and sympathy for the old fatherland. This included academic exchange, lecture tours, and visitor hospitality. Above all, the entire endeavor had to be privately organized, its advisory board comprised of democratic politicians, professors, and businessmen, not officials. Unsurprisingly, the nonpolitical, ostensibly private nature of the Vereinigung Carl Schurz met with the Wilhelmstrasse's hearty approval. In early 1926 the Foreign Ministry provided an initial 5000 marks to "jump-start" the organization and was henceforth informally represented on its board. ${ }^{116}$

Importantly, Erkelenz also succeeded in gaining support from German industrial and parliamentary circles. Indeed, the Vereinigung Carl Schurz provides a unique window onto the economic and political interests that under-

113 Anton Erkelenz, Amerika von heute. Briefe von einer Reise (Berlin, 1926), 35-41, 79-80, 89. 114 Similar British organizations, he noted, had "for a hundred years - and quite deliberately abstained from the political thought of an American reunion with England. But all the more forcefully and all the more intelligently, it emphasizes and supports the cultural and intellectual relationship." Anton Erkelenz, "Der Amerikanische Deutsche," Berliner Tageblatt, Jan. 6, 1926.

115 Memorandum Abteilung III (Haas) to Heilbron, PA R 121328.

116 The Foreign Ministry was represented on the board through Edmund Schüler, the architect of the 1919/1920 reforms, who frequently undertook quasi-official missions, particularly where cultural affairs and the United States were concerned. On his cultural activities in the USA, see Edmund Schüler, Lebensbericht, PA NL Edmund Fritz Schüler. 
pinned peaceful revisionist alliances. The German export industry, especially the chemical industry (IG Farben) and the large shipping lines (HAPAG and NDL) generously supported the Vereinigung, hoping to strengthen ties with American customers and improve American opinion prior to the settlement of war claims ${ }^{117}$ Liberal industrialist Robert Bosch served as its president up until 1933, lending both his "international name" and "indisputable republicanism" to the endeavor, as Erkelenz noted. ${ }^{118}$ In the wake of Weimar's orientation to the West, the Vereinigung Carl Schurz also united representatives of all democratic parties from the Social Democrats to Stresemann's liberal-conservative DVP and in later years repeatedly underlined its Republican base by staging transatlantic celebrations in the Reichstag. The influence of the Foreign Ministry, too, remained strong and only increased over time. By the Vereinigung's second year of operation, the initial grant of 5,000 marks had already turned into 25,000 marks in annual subsidies, and by 1929 , the Vereinigung's annual budget had more than tripled to 85,000 marks, with more than half coming from official sources.

Throughout, the Vereinigung Carl Schurz assumed work that German officials would or could not undertake themselves. As an ostensibly private organization, it set out to rekindle ties with German Americans, focusing particularly on a hospitality agenda in Germany itself. By organizing teas and dinner banquets for German-American visitors or by inviting them to tour Germany, it engaged in a soft form of revisionism that tried to build personal contacts while raising sympathy for the republic's problems and accomplishments. In the summer of 1927, for example, it invited a dozen German-American journalists and editors to tour Germany, hoping to elicit more accurate and favorable coverage in the German-language press of "how we [Germans] bear and manage our hard fate."119 While the Vereinigung never enjoyed the elite support that would have turned it into a German equivalent of the English-Speaking Union, it still met a specific need in Germany's emerging public diplomacy. As German official representatives in the U.S. continued to cultivate the trust of Anglo-American circles, the Vereinigung offered an unobtrusive way to revi-

117 This was just one of many efforts in this direction; the North German Lloyd also strongly supported the transatlantic airplane flight of 1928 not only to market German aviation but to improve the German image among American customers. On hints of the NDL's involvement in marketing the transatlantic flight, see Inge Marszolek, "Der erste Nordatlantikflug von Europa nach Amerika. Transatlantische Aushandlungen über Helden, Ehre, Nation und Modernität," in Ehrregime, ed. von Reeken and Thiessen, 69-88, 86.

118 Heuss to Secretary of Robert Bosch, NL Erkelenz 37, BArch, Koblenz; German Embassy, Washington, to AA (De Haas), Mar. 27, 1926, Attachment Abschrift: Letter Erkelenz to Maltzan, Jan. 11, 1926, PA R 80298.

119 Pamphlet: Vereinigung Carl Schurz, Folder Allemagne - Divers- 1927, CEIP, Centre Europeen, Columbia University, Rare Book \& Manuscript Library Collections. 
talize the German-American "touch and interest in the old Heimatland." ${ }^{120}$ As such, it played a distinct and successful role in the German balancing acts of the mid-1920s.

By 1927, the general restraint practiced in cultural diplomacy since 1919 gradually allowed for more official steps to be taken. This was most apparent in Ambassador Maltzan's several month-long trips across the South and Midwest after March 1927. Even then, however, the trip was carefully curated to avoid even the semblance of ethnic outreach. For example, the ambassador only visited cities which Anglo-Americans had invited him to, and in the dozens of German clubs he visited, he emphasized emotional and cultural - never political - matters. Acting as the "ambassador of the children" once more, he highlighted how strongly German-American charity had helped to shape the image of a benevolent America and asked German Americans to support the republic in facilitating a transatlantic "friendship."121 Behind the scenes, to be sure, Maltzan lobbied ethnic and business leaders alike for a revision of the Dawes Plan, and did not hesitate to bring up more delicate questions such as German war guilt. ${ }^{122}$ In the end, the trip's most profound results likely derived not from anything Maltzan said or did but from his manner. His tactful, "democratic" demeanor calmed Anglo-American fears of a Germany "faithful to her old masters," just as his aristocratic background counteracted German-American trepidations concerning Weimar radicalism.

Certainly, the consular reports (to be taken with a pinch of salt, of course) claimed that the ambassadorial visit - to many locations the first in more than a decade - had had an overwhelmingly positive impact. They recorded both increased respect for Germany within influential Anglo-American circles and a heightened sense of ethnic pride among German Americans. "One can certainly claim," the consulate in St. Louis wrote, "that this outreach has been an enormous psychological help to the local Germans in overcoming their inferiority complex (...) at least as far as it was created by the calamitous war psychosis." ${ }^{123}$ Ambassador Maltzan himself was greatly pleased with his trip, which had allowed him to establish contacts with business and university elites across the country and had even earned him an honorary doctorate from Marquette University, the very first given to a German ambassador in a former

120 German Consulate General, Chicago, Aug. 27, 1925, PA R 60105.

121 German Consulate, St. Louis, Apr. 12, 1927, "Besuch des deutschen Botschafterpaares aus Washington in St. Louis und Kansas City," PA R 80141.

122 German Embassy, Washington, to AA, May 28, 1927, PA R 80141.

123 German Consulate, St. Louis, Apr. 12, 1927, "Besuch des deutschen Botschafterpaares aus Washington in St. Louis und Kansas City," PA R 80141. 
enemy nation. Still, he believed the major impact of his travels pertained to the "so far greatly neglected relations with the German-American element." 124 Having previously won a measure of trust among Anglo-American elites, he felt his outreach to German Americans had been "entirely successful, without arousing any suspicion among American authorities." ${ }^{225}$ Public accommodation and unobtrusive revision thus went hand in hand during this critical transitional period in transatlantic relations.

Arguably, this strategy of restraint in cultural relations abetted a threefold process of reconciliation: for one, it overcame some of the distance between German Americans and the Weimar Republic. Not that the republic or its colors ever came to inspire any greater degree of enthusiasm among German Americans (or that German officials tried to make it do so), ${ }^{126}$ but the visits of German politicians, diplomats, and cruisers, the awards and honors bestowed on ethnic leaders, and increasing travel to the old fatherland helped them to overcome at least some of their initial unease about the new Germany. Secondly, and at least as importantly, German restraint helped to decrease Anglo-American suspicions about ethnic separatism and facilitated German Americans' return into the American mainstream. By late 1927, prominent Americans like U.S. Ambassador to Germany Jacob Gould Schurman could once more attend ethnic festivities such as the Steuben celebration of 1927 and publicly praise the unique qualities and historical contributions of German Americans. ${ }^{127}$ Finally, German restraint helped to normalize transatlantic relations at large. Abstaining from political agitation among German Americans decreased American suspicions and increased trust in Germany's cordial intentions. On an official level, this normalization was visible in the release of German property in a congressional bill of 1928 and the German-American arbitration agreements signed shortly thereafter. By the spring of 1928, the new ambassador to Washington, Friedrich Wilhelm von Prittwitz und Gaffron (henceforth Prittwitz), found that "the psychosis of the immediate postwar years [had] given way to an atmosphere of which the Steuben speech of Ambassador Schurman has been a visible and fitting expression. The passing of the property bill in the

124 German Embassy, Washington, to AA, May 28, 1927, PA R 80141.

125 Ibid.

126 Even ten years after its founding, German representatives registered a notable skepticism toward the republic and a widespread popularity of the stab-in-the-back legend. German Consulate General, Chicago, to AA, June 25, 1928, “Dienstreise von Generalkonsul Dr. Simon,” PA R 80145 .

127 German Embassy, Washington, to AA, Nr. 1328, Dec. 8, 1927, “Steubenfeier,” PA R 80299. 
senate and its passing into law marks the appreciable end of this difficult phase of a first re-establishing of German-American relations." ${ }^{128}$

These reconciliations must be understood in relation to one another. As the developments of the Great War had shown, the standing of "Germans" in America and that of Germans across the Atlantic were closely intertwined. Just as earlier American suspicions of a "German threat" had had both a domestic and an international dimension, the transatlantic rapprochement of the later 1920 improved the image of both Germans and German Americans. At the same time, these two processes fed into each other in a number of ways: the rising esteem the Weimar Republic enjoyed among the general American public heightened its acceptance among German Americans, just as the increasingly German-friendly expressions of American elites reduced the chasm between them and German Americans. To be sure, these reconciliations were shaped by numerous external factors: The subsiding of American nativism after 1924, the notable decline of ethnic pride and visibility, and even the election of Paul von Hindenburg to the Reich presidency were relevant to these developments. But we need not entirely dismiss the notion that German policy contributed to this rapprochement. The restraint practiced by the German government shielded Germany from accusations of meddling in America's domestic affairs just as it shielded German Americans from accusations of ethnic separatism. While influence is always difficult to ascertain, post-1933 developments would once again demonstrate just how quickly and profoundly a more assertive "Germandom policy" could alienate a multiethnic America. ${ }^{129}$ Arguably, the most significant decision Weimar Germany ever made in its public diplomacy toward the United States lay not in anything it did but in something it did not do.

\section{Beyond “German Americans" and “Anglo-Americans”: Ambassador Prittwitz’s Take on Germandom Policy, 1928-1930}

Importantly, the friendlier climate of the late 1920 never tempted Weimar-era diplomats to return to a more assertive policy. When Maltzan's successor, Friedrich Wilhelm von Prittwitz und Gaffron, arrived in Washington in early 1928 he immediately renewed Maltzan's commitment to a restrained Germandom policy while introducing yet another "ambassadorial style" to public diplomacy. Only 43 years old at the time of his appointment, Prittwitz was a relatively rare species in the Foreign Ministry. It was not just his youth or his meteoric promotion - pushed through by Stresemann himself - from counselor of

128 Prittwitz to Carl von Schubert, May 29, 1928, PA NL Friedrich Wilhelm von Prittwitz und Gaffron, Vol. 4 .

129 See Chapter 8. 
embassy in Rome to ambassador in Washington that set him apart, but also his ideological convictions: Prittwitz was a staunch democrat. In late 1918 he had come out publicly in support of the republic and had even run for the Reichstag on a left-liberal DDP ticket. When Hitler came to power in 1933, Prittwitz tendered his resignation - the only high-ranking diplomat in all of the German Foreign Service to do so.

Like his predecessor, Prittwitz saw German Americans as an important factor in transatlantic relations, but he set quite different priorities. First, he redoubled efforts to promote the republic. Indeed, he was the diplomat who first developed a compelling narrative of the "New Germany" and repeatedly reminded his audiences that, in light of Germany's democratic movements in the nineteenth century, the revolution of 1918 was not an accident or an aberration but the logical result of German history. ${ }^{130}$ In 1929, for example, he embraced the celebration of Carl Schurz's one-hundredth birthday as a unique opportunity to underline the long history of democratic ideals shared by both Germany and the United States that had been expressed by the German revolutionaries of 1848 (Schurz among them) and fulfilled in 1918/1919. ${ }^{131}$ Celebrations were organized in New York, Washington, and Berlin (through the Vereinigung Carl Schurz), and Prittwitz felt the occasion had found an appreciable echo even beyond the German-American community. ${ }^{132}$

This points to the second aspect of Prittwitz's strategy: a reorientation of German public diplomacy away from German Americans. Even though the improved transatlantic climate would have allowed for greater leeway with regard to German Americans, Prittwitz avoided discrete ethnic appeals in favor of stressing a transatlantic mutuality of ideals - and not just for tactical reasons. While Maltzan's speeches, for example, had varied dramatically depending on whether he was speaking to a German American or an Anglo-American audience, Prittwitz's addresses betrayed no such distinction. Rather, he used a broadly cultural approach to appeal to Americans irrespective of their ethnic background. To Berlin he reported in late 1928 that "the more we continue to confine our American activities to the fields of cultural and economic cooperation and the less we openly bother them with European problems, the more surely we will maintain American sympathies and have decisive American public opinion on our side when particular problems crucial to Germany's future stand to be discussed or decided." 133

130 German Embassy, Washington, to AA, May 17, 1930, "Reise nach dem Mittelwesten der Vereinigten Staaten," PA R 80147; German Consulate General, Chicago, to AA, Jan. 31, 1929, "Botschafterbesuch in Chicago," PA R 80145.

131 German Embassy, Washington, to AA, Nov. 2, 1928, PA R 80288.

132 German Embassy, Washington, to AA, "Jahrhundertfeier des Geburtstages von Carl Schurz," Mar. 8, 1929, PA R 80289.

133 German Embassy, Washington, to AA, Oct. 30, 1928, "Stand der Beziehungen zwischen Deutschland und den Vereinigten Staaten," PA R 80145. 
Prittwitz's actions, I would argue, reflect a more general process of de-ethnicization of German public diplomacy in the United States. By the later 1920s, the Vereinigung Carl Schurz, to give one example, abandoned its discrete ethnic ambitions in favor of a broader American agenda. Having organized a German tour for German-American editors in 1927, it repeated the tour with Anglo-American journalists a year later. ${ }^{134}$ At the same time, the attention diplomats did pay to German Americans successively lost some of its ethnic imprint. Even though Germany's budding landscape of student exchange programs, holiday language courses, and tourist advertisements (to be explored in later chapters) was often intended to resonate specifically among Americans of German birth or descent, this was not readily apparent since they were marketed to an "American" audience more generally. Indeed, Berlin increasingly came to realize that the distinction between German Americans and Anglo-Americans was largely artificial - and not just in a political sense. Members of the second or third generation, in particular, balked at the idea that they should hold any special sympathy for Germany because of their family's emigration history. Certainly, outdated ethnic festivities or the flag-waving patriotism of a German cruiser visit held little sway over these Americans. This younger and better-educated generation often found a vacation or study abroad in Germany attractive, but only if it was advertised through commercial travel bureaus or universities, not ethnic organizations. Like their non-German peers, they proved receptive to Germany's allure - but only if it fit their tastes as American consumers, tourists or students, not as ethnic Germans. It was during the late 1920 s that Berlin began to realize fully that German Americans, while they could not be kept "German," constituted a reservoir of American citizens more favorably disposed to German appeals and advertisements if, and only if, they catered to their American predilections. Arguably, the best "Germandom policies" Weimar Germany ever mustered in the United States had, outwardly at least, nothing at all to do with "Germandom."

134 "[T]he [Vereingung Carl Schurz] does not at all limit itself to cultivate relations with German-Americans but tries - emphasizing the idea of cultural exchange between both countries to establish contacts also with Americans of non-German descent." See AA to German Embassy, Washington, Aug. 31, 1927, PA R 80299. 


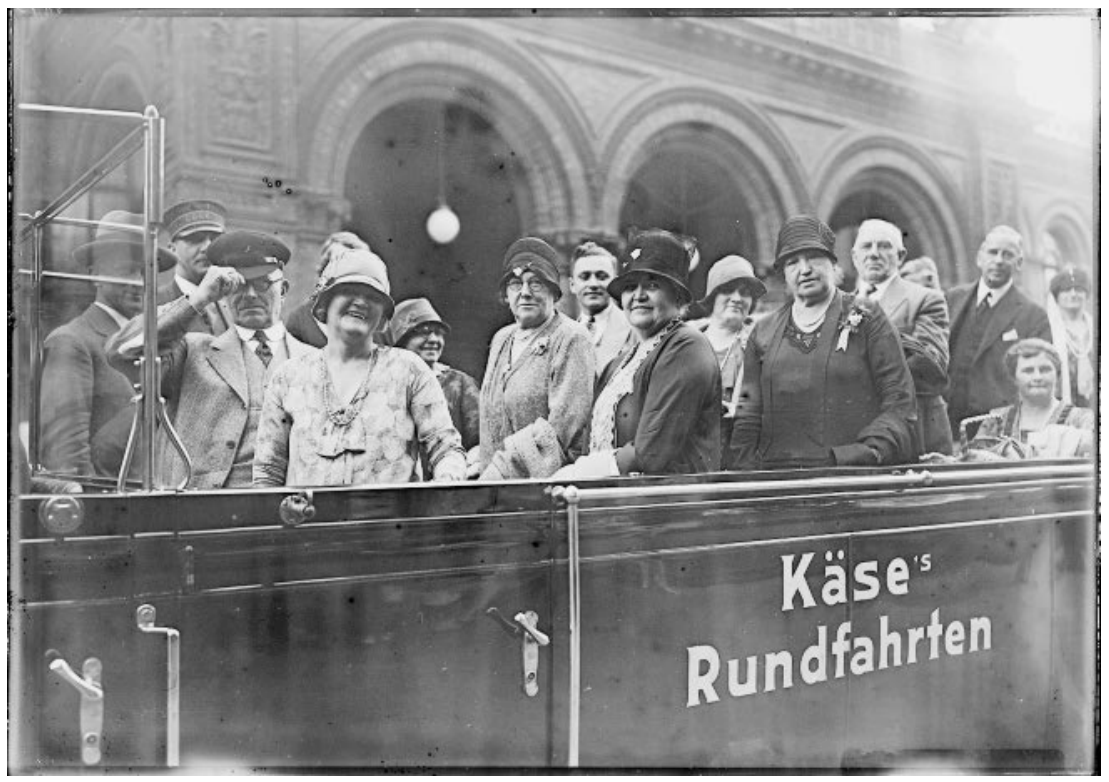

Fig. 7: The Steuben Club from New York touring Berlin, 1929, Bundesarchiv, Georg Pahl, Bild 102-08179

Over the course of the 1920s, then, the "German Americans as Americans" approach turned increasingly from theory into practice. Though more traditional ethnic outreach continued - not least to cater to the German-born - the reductionist binary of Anglo-Americans and German Americans gradually dissolved, albeit never entirely. Unlike in other countries, where Germandom policies stunted any more general outreach, the focus on German Americans never impeded the growth of broader public diplomacy in the United States but rather nourished its development. The prominence Germany gave to its cultural programs in the United States derived in part from officials' desire to reconnect with the large number of Americans of German birth or descent and the imperative of having to do so in a way that was not overtly ethnic. Much like this chapter within Part II of this study, ethnic considerations often stood at the beginning of more comprehensive German programs. As the New York consulate general had already concluded in 1925, "what really matters is that the greatest possible number of American citizens are - in a cultural sense on our side. This will predominantly be the case with those of our stock, but 
does not necessarily have to be limited to them.". ${ }^{\prime 35}$ It speaks to the new sense of realism in Germany's Amerikapolitik that when asking German-American questions, German diplomats arrived at American answers.

\section{German-American Partners: American Germanists and the Carl Schurz Memorial Foundation (CSMF), 1929-1930}

In this process, German Americans evolved from being "targets" of Germandom work to being, as the Deutsche Akademie in Munich put it, "trailblazers and intermediaries" in a policy designed to appeal to foreign elites. ${ }^{136}$ The idea of German Americans as well-nigh ideal intermediaries was, of course, a long-standing one. German programs had long built on the initiative and largesse of German Americans, and as early as 1925 the German consulate in New York City (which was home to a particularly well-organized and affluent group of German Americans) had identified them not only as "objects" but as "partners for German cultural diplomacy."137 But even the most optimistic proponents of this strategy acknowledged that it applied to only a small ethnic elite. Most German Americans, German diplomats agreed, could never be effective interpreters of Germany or German culture. While more successful and educated German Americans often swiftly abandoned their ethnic heritage, the lower middle classes, which clung to it most tightly, seemed particularly ill-suited to representing Germany: they neither enjoyed access to American opinion-shapers nor were they - in German diplomats' decidedly elitist views - worthy "carriers of German culture" (Kulturträger). On the contrary, German diplomats and visitors frequently commented on their low intellectual and educational level. Without recourse to a classical education and having left for a better life across the Atlantic long before, most of them had only a faint idea of German Kultur and present-day Germany. ${ }^{138}$ As the consul in San Francisco explained: "the vast majority of Germans who emigrate to this country have - as is well known - only an elementary school education. They are by all means honorable, respectable and hard-working people and they are, for the most part, lovingly attached to the old Heimat. Such attachment, however, is but of sentimental nature. They cannot be creative exponents of German Kul-

135 Aufzeichnung des Konsuls Dr. Kraske (German Consulate General, New York), Oct. 10, 1925, PA R 60105.

136 "Bericht über die fünfte Hauptversammlung der Deutschen Akademie in Berlin," Mitteilungen der Deutschen Akademie 2, no. 5 (Nov. 1930): 277-302, 288.

137 Aufzeichnung des Konsuls Dr. Kraske (German Consulate General, New York), Oct. 10, 1925, PA R 60105.

138 For this long-standing criticism, see also Reinhold Niebuhr, "The Failure of German-Americanism," Atlantic Monthly 118 (1916); Max Quadt, "Das Deutschtum in den Vereinigten Staaten von Amerika nach dem Kriege," Der Auslanddeutsche 13, no. 2 (Jan. 1930): 36-39, 38. 
tur in the United States. Not due to a lack of good intentions, but because they lack the qualities required for a Kulturträger." ${ }^{139}$ The consul general in Chicago even emphatically declared: "there is no more inappropriate use of the intellectual weapon that remains to us than to entrust it to the German Americans." ${ }^{140}$

Nevertheless, there was a small elite of respectable and highly educated German Americans who became increasingly visible and active after the mid1920s. Once nativist sentiment subsided, successful, fully Americanized men like the lawyer Charles Nagel (who was also former U.S. Secretary of Commerce and Labor in the Taft Administration), the bankers Paul Warburg and James Speyer, and the businessmen Julius Rosenwald (of Sears and Roebuck), Ferdinand Thun, Gustav Oberlaender, and Henry Janssen (all of the Textile Machine Works in Reading, Pennsylvania) redirected their generosity from alleviating overseas suffering to promoting German culture in the United States. ${ }^{141}$ Unlike the Steuben Society, which pursued a confrontational and political course, these men shared Germany's desire for a moderate cultural course of action to showcase German accomplishments and reconcile Anglo-Americans with Germany. ${ }^{142}$ To this end, they endowed university chairs in German language and culture, helped to reopen the Deutsches Haus at Columbia University (originally opened in 1911, closed in 1917), and donated money for German language contests.

While these men provided the funds, American Germanists, i.e., teachers and professors of German, provided the initiative. During the second half of the 1920s, this group resumed its transatlantic activity and traditional cultural leadership strategy. The reintroduction of German language teaching in American schools and universities - albeit never to the same extent as before the war - gave them new confidence, prestige, and professional opportunities. ${ }^{143}$ Prewar cultural infrastructures like the Germanistic Society or the Deutsches Haus at Columbia University were slowly rebuilt and new ones like the American Association of Teachers of German (est. 1926) founded. It was among American Germanists - men like John A. Walz and Kuno Franke (Harvard), Alexander Hohlfeld (Wisconsin), Camillo von Klenze (CUNY), Frederick Heuser and Robert Fife (Columbia), Adolph Busse (Hunter College), A. B. Faust (Cornell),

139 German Consulate General, San Francisco, Sep. 21, 1925 (Ziegler), PA R 60105.

140 German Consulate General, Chicago (Steinbach), Sep. 29, 1925, PA R 60105.

141 Charles Nagel had warned against ethnic politicking early on, noting that "German ambitions in America can only be cultural ambitions." Der Auslanddeutsche 4, no. 6 (March 1921): 174; Tolzmann calls Nagel "perhaps the most widely respected German-American involved in public affairs at the time." Tolzmann, "The Survival of an Ethnic Community," 205.

142 Luebke, "German-American Leadership Strategies," 68.

143 On the recovery of German language teaching, see The German Quarterly 1 (Jan. 1928); and for the positive interpretation of these developments by the Deutsche Akademie, see Franz Thierfelder, "Deutsch im Unterricht fremder Völker," Mitteilungen der Deutschen Akademie 28 (Aug./Sep. 1928): 1015-1055, 1037-1039. 
as well as Otto E. Lessing (Illinois) and William Alpha Cooper (Stanford) that the promotion of German culture and language found its single strongest ally in the United States.

German diplomats clearly recognized this. They carefully monitored and, whenever they could, aided the recovery of German language enrollments at high schools and universities, not least to support this valuable group of interlocutors. ${ }^{144}$ In most consular districts, professors of German were an integral part of the consulate's informal network, suggesting American students for German fellowships, arranging lectures for German visitors, and sharing information on academic and ethnic developments. This is not to suggest that they were German "agents," as wartime propaganda had claimed. Their relation to German officials was informal, and their activities often served their own professional advancement and academic prestige as much as Germany's cultural promotion. But it is true that the German side did try to keep their interest and sympathies alive: German universities invited them to give lectures, German shipping lines and publishers offered steep discounts, and Germandom organizations (often following official suggestions) honored their commitment to German culture through awards and medals. ${ }^{145}$ Much like France at the same time, Germany cultivated its valuable American intermediaries through sympathetic attention and small honors.

Their particular value to German public diplomacy derived from three factors. First and foremost, they self-identified as transatlantic mediators and often assumed this role with missionary zeal. Kuno Francke of Harvard University, for example, felt his profession was called to be the "heir and guardians of German culture in this country," ${ }^{146}$ while his colleague at the University of Wisconsin, Alexander Hohlfeld, saw his mission as "purposeful German-English mediation." ${ }^{147}$ To this end, Germanists possessed two unique qualities. For

144 German Embassy, Washington, to AA, May 17, 1930, "Reise nach dem Mittelwesten der Vereinigten Staaten," PA R 80147.

145 For example, A. B. Faust, the Cornell Germanist who had made a name for himself by writing the first comprehensive history of the German element, was invited to give the keynote address at the DAI's 1929 convention in Stuttgart. His reputation as an "ethnic leader" and pro-German academic secured him honors and banquets along the way, including an invitation to President von Hindenburg. Duly flattered by the immense attention, Faust communicated these honors to a large number of friends back home. A. B. Faust to Ferdinand Thun, Sep. 8, 1929, Faust Papers, Box 6, Correspondence, 1927-28 (actually contains Correspondence 1928-30), Division of Rare and Manuscript Collections, Cornell University Library.

146 Francke, German After War Problems, 1927, quoted in Tolzmann, "The Survival of an Ethnic Community", 290.

147 Quoted in Henry J. Schmidt, "Rhetoric of Survival: The Germanist in America from 1900 to 1925," America and the Germans, ed. Trommler and McVeigh, 2:204-16, 214. As Theodore Hewitt of the University of Buffalo summed up in 1930, "the most effective work (of mutual understanding) is to be done with the rising generation in our schools and colleges and a large part of this task by its very nature falls upon teachers of German [....] Thus America still retains the reputation of being devoid of a proper appreciation of art, music, literature and scholarship, and 
one, they maintained close ties with contemporary, educated Germany. After the war, they were among the first to visit Germany, and long semester breaks, sabbaticals, and exchange programs helped them to keep abreast of German developments. ${ }^{148}$ Second, they enjoyed ample access to educated Anglo-Americans, whether as colleagues, students, or through their social circles. Importantly, too, they felt called to mediate not so much between German-America and Anglo-America as between Germany and the United States. Unlike ethnic organizations, they celebrated not Steuben or Pastorius, but Beethoven, Goethe, and Schiller. Finally, as this group began to articulate a clearer cultural leadership strategy, they carefully avoided both the political agitation of the Steuben Society and the militant rhetoric of prewar cultural chauvinists. Kuno Francke summed up forty years of experience in 1927: Rather than closing themselves off in political groups, German Americans should cultivate the best of their cultural heritage, not by "boasting of German achievements" or by engaging in filiopietism, but through genuine cultural contributions, including financial endowments for German culture. Only in this way could he further "his own prestige as well as that of Germany."149

This cultural leadership strategy found its most ambitious expression in the Carl Schurz Memorial Foundation (CSMF). Established in 1929 to mark the one-hundredth birthday of the prominent German-American politician and diplomat, the Philadelphia-based foundation was the brainchild of a number of prominent German-American businessmen and educators, including Ferdinand Thun, Paul Warburg, Frederick Heuser, A. B. Faust, and Franz Boas. ${ }^{150}$ Through tireless campaigning they managed to raise a $\$ 500,000$ endowment, which allowed the foundation to undertake a number of German-American cultural initiatives including German lecture tours in the United States, student exchanges, and large-scale celebrations. Although its executive secretary,

in fact any form of idealism, while Germany is still regarded as unable to depart from a psychology that fails to understand the finer points of what in common parlance is termed "the spirit of good sport." Theodore Hewitt, "Friendlier Contacts," The German Quarterly 3, no. 4 (Nov. 1930): 139-141, 139 .

148 Already in 1923, Frederick Heuser of Columbia University informed the Amerika-Institut that German Americans would never play any other than a cultural role in the United States and that the Germanistic Society was still the most respectable German society in America, with the potentially best connections to Anglo-Saxondom. Amerika-Institut to AA, June 8, 1923; PA R 65519.

149 Kuno Francke, Deutsche Arbeit in Amerika (Leipzig, 1930), 91; Camillo von Klenze, for example, emphasized their mission to garner appreciation for German culture not "in hostile opposition to English traditions but as a fruitful addition to them." Camillo von Klenze, "Unsere Pflicht," Die Vereinigten Deutschen Gesellschaften der Stadt New York, Broschüre zum Deutschen Tag 1928; copy in PA R 80288.

150 businessmen like Paul Warburg, Ferdinand Thun, Henry Janssen, Gustav Oberlaender, Julius Rosenwald, James Speyer, editors like Victor Ridder and Oswald Garrison Villard, educators like Kuno Francke, Franz Boas, Heuser, Robert Herndon Fife and politicians like Charles Nagel. 
Wilbur K. Thomas (the former director of the Quaker child-feeding program) and a small number of its directors, such as former ambassador Jacob Gould Schurman, were not of German descent, the foundation was an almost exclusively German-American endeavor in terms of its endowment, planning, and self-understanding.

Its primary purpose, indeed, was to improve the public standing of German Americans. By increasing the esteem for German culture in the United States, its founders hoped to safeguard German Americans against any recurrence of wartime discrimination. How deeply the war experiences shaped the CSMF's founding members was revealed at the foundation's first annual meeting. Attributing the discrimination of a largely acculturated and productive part of society to a deep lack of "appreciation of the literary, artistic, and moral character of the German people," they agreed that "an effort should be made to infuse the whole of American life and thought so thoroughly with the best that the Germans have to offer that never again can they be singled out and persecuted because of a more or less remote 'foreign' origin." ${ }^{151}$ To the CSMF's leaders, this seemed to have been German-America's greatest sin of omission. Unlike other ethnic groups, which maintained active organizations like the English-Speaking Union, the American Scandinavian Foundation, the Alliance Française, the Kosciuszko Foundation, and the America-Italy Society, German Americans, despite their great number, had never mustered an organization to interpret German culture to Americans. ${ }^{152}$ Whereas British and French visitors to the United States had access to a nationwide network of upper-class contacts through the Alliance Française or the English-Speaking Union, German visitors were usually restricted to ethnic or, at best, academic audiences. As the historian Frederick Luebke concluded, the CSMF, in identifying the lack of a united cultural rather than political action as German Americans' greatest previous shortcoming, exemplified a new culture-based approach to ethnic leadership in the late 1920s. ${ }^{153}$

Ironically, a distinctive feature of this "ethnic leadership strategy" was to systematically de-emphasize its "ethnic" nature. Not only was the CSMF designed to appeal primarily to Anglo-American elites, but it steered clear of ethnic associations altogether for fear of being dragged into their "petty clubbiness" (Vereins-Meierei). ${ }^{154}$ Instead, it tried to methodically recruit prominent Anglo-American members to "ensure the integrity and neutrality of the fu-

151 First Annual Meeting of the Members of the Carl Schurz Memorial Foundation, May 4, 1931, Coll Mss 176 National Carl Schurz Association, Inc Records Box 33/5, HSP.

152 The files of the Carl Schurz Memorial Foundation illustrate the brainstorming process prior to and after its founding and the close attention paid to other cultural initiatives; see Coll Mss 176 National Carl Schurz Association, Inc, Box 2/6, HSP.

153 Luebke, "German-American Leadership Strategies," 68.

154 Eugene Hennigson to Hanns Gramm, Feb. 10, 1930. Instead, the CSMF addressed its appeals to those "high-minded, unselfish, cultured people in every nation who are constantly seek- 
ture Carl Schurz Memorial Foundation, which should not become known as one of the many German-American affairs." 155 Even though the foundation ultimately aimed to improve the standing of German Americans, its approach was indirect, trying to elicit regard not for German-American, but for German accomplishments. By early 1930, the CSMF was beginning to plan tours for German and American journalists overseas, to fund academic exchanges, and to establish local chapters across the United States. ${ }^{156}$ With time, it hoped to establish itself as the central clearinghouse for all American-German cultural relations. By the end of the postwar decade, German Americans seemed poised to assume the mediating role they had always shied away from - to their own and their old fatherland's detriment. ${ }^{157}$ As we will see in Chapter 7, with its nonpolitical, non-ethnic orientation, the CSMF was to become an ideal partner for German cultural diplomacy in the early 1930 .

Over the course of the 1920s, a unequivocal shift in German public diplomacy can be observed. While German Americans emerged as a matter of primary concern almost immediately after 1919, the war had shown clearly that German Americans had to be seen within the wider context of American opinion. The basic dilemma for Germany was how to reach out to German Americans without running afoul of (Anglo-)American sentiment. Weimar's three ambassadors approached this issue in different ways that reflected their own personal preferences and shifting transatlantic fortunes. While Otto Wiedfeldt employed the greatest possible restraint, keeping his distance from German Americans both formally and informally, Ago von Maltzan sought to reconcile the necessity of winning over Anglo-Americans with a desire to cultivate German Americans. The mid-1920s thus saw an approach that coupled official restraint with informal, non-political outreach that aimed tacitly to overcome the distance between the Weimar Republic and German Americans. This restraint, this chapter demonstrated, helped reconcile not only Germany and America but German Americans and Anglo-Americans. Weimar's last ambassador Prittwitz finally overcame the binary that had dominated assessments of German

ing fellowship with those of like spirit in other countries." CSMF - Circular, Aug. 20, 1934; Coll Mss 176 National Carl Schurz Association, Inc Records, HSP, Box 218.

155 Carl Schurz Memorial Foundation (Gramm) to Faust, Sep. 19, 1929, Albert B. Faust Papers, \#14-18-85. Box 6, Correspondence, 1927-28 (actually contains Correspondence 1928-30), Division of Rare and Manuscript Collections, Cornell University Library.

156 "Pamphlet: the Carl Schurz Memorial Foundation," Coll Mss176 National Carl Schurz Association, Inc Records, Box 26/6, HSP.

157 A. B. Faust to Carl E. Schmidt, Sep. 10, 1928; Albert B. Faust Papers, \#14-18-85. Box 6, Correspondence, 1927-28 (actually contains Correspondence 1928-30), Division of Rare and Manuscript Collections, Cornell University Library. 
Americans for so long. His increasing focus on the younger, completely Americanized generation led to a successive de-ethnicization of German public diplomacy in the United States. In the United States, the Weimar government never attempted a clearly structured Germandom policy of the kind it developed in Latin America because the U.S. had no tight-knit ethnic community of that sort. What distinguished Weimar's approaches from previous German administrations was that Weimar was realistic enough to truly recognize this fact, while the United States was too important for Weimar to fail to do so. Ultimately, German Americans emerged from the 1920s not so much as targets but as partners of German ambitions. Taken together, by 1930 these factors had brought German public diplomacy much closer to the "Kulturpropaganda in the best sense of the word, to strengthen respect for Germany and Germandom" that German consuls had suggested in 1925. With regard to German Americans, the lessons of World War I had thus occasioned a massive shift in German Amerikapolitik. 


\section{Chapter 5 \\ “The Best German Politics": Academic Diplomacy and the United States}

7 hroughout the nineteenth century, much of Germany's influence and prestige in the world had been bound up with its universities. But World War I fundamentally transformed international academic relations. It disrupted well-entrenched flows of communication, ideologically divided the international scientific community, and set in motion a process of intellectual dissociation from Germany. ${ }^{1}$ Arguably, this recalibration of the academic world was particularly visible in the United States, where the intellectual and moral movement away from Germany had begun already in 1914, years prior to the U.S. entry into the war. ${ }^{2}$ After 1917, America's own aspirations for moral leadership and Allied efforts to use Germany's absence to strengthen their toehold in the American educational landscape provided transatlantic alliance-building with a strong academic component. A steady flow of exchange professors, educational delegations, and honorary degrees between American, British, and French universities helped to forge a "cultural entente." In the process, the international academic world of prewar days was recast in an inter-Allied mold.

While much is known about how the international academic community broke apart after 1914, we know surprisingly little about how it grew together again. Indeed, some scholars have doubted it ever did. Neither the relatively tight-knit academic community of prewar days nor the belief in scientific universalism ever fully recovered. After the war, wartime rifts were cemented. New

1 Gruber, Mars and Minerva, 71-72.

2 Irish, The University at War, 5.

3 Tomás Irish, "From International to Interallied: Transatlantic University Relations in the Era of the First World War, 1905-1920," Journal of Transatlantic Studies 13, no. 4 (2015): 311-325. 
scientific and academic organizations were established along inter-Allied lines and excluded the erstwhile Central Powers from membership, conferences, and joint projects. German academics, for their part, responded to this international "boycott" with an equally self-righteous "counter-boycott," refusing to join these organizations even once they were asked to in the mid-1920s. ${ }^{4}$ The academic world thus remained split into "two hostile camps" long after peace had been re-established. ${ }^{5}$ Historians have even characterized the 1920 s as a "cold war in international scientific relations."' To be sure, this academic and scientific blockade of Germany was never airtight. In their private correspondence, many scholars took a more conciliatory, pragmatic position toward colleagues from former enemy nations, ${ }^{7}$ so the formal "cold war" was accompanied by informal research collaborations and sympathetic contacts - especially, it seems, between Germany and the United States. By the late 1920s, even otherwise critical German scholars and diplomats felt that transatlantic academic relations had been more or less restored.

But how were transatlantic divisions overcome, and who, if anyone, drove this rapprochement and for what reasons? The answers provided in this chapter are necessarily limited. No doubt, a great number of informal transatlantic contacts, as well as the passing of time, shaped this academic rapprochement. But the present chapter is concerned less with academic relations per se than with their strategic management in international politics, that is, academic diplomacy, ${ }^{8}$ so it focuses on the German ministries. Still, it should be clear that university administrators, professors, and students were never merely objects of official strategy but strong actors in their own right. While not every academic action ought to be classified as a quasi-diplomatic act and not every academic traveler as a "sub-diplomatic ambassador," the ambitions and activities of universities and their members have to be taken into account. ${ }^{9}$ By tracing the interplay of state and nonstate actors, the chapter aims to elucidate the origins of German academic diplomacy, assess the role of the United States, and

4 Schroeder-Gudehus, Deutsche Wissenschaft und internationale Zusammenarbeit, 181-211.

5 Daniel Kevles, “Into Hostile Political Camps': the Reorganization of International Science in World War I," Isis 62, no. 1 (1971): 47-60.

6 Paul Forman, "Scientific Internationalism and the Weimar Physicists: The Ideology and its Manipulation in Germany after World War I," Isis 64, no. 2 (1973): 150-180, 152.

7 For one such moderate voice see Max Planck in Gabriele Metzler, "WWelch ein deutscher Sieg!' Die Nobelpreise von 1919 im Spannungsfeld von Wissenschaft, Politik und Gesellschaft," Vierteljahreshefte für Zeitgeschichte 44, no. 2 (1996): 173-200.

8 There are, of course, many other definitions of academic diplomacy. Dorothee Bouquet, for example, has defined the term broadly as "any attempts or practices of international relationship through individuals who benefitted from an intellectual reputation or of an affiliation with a famous academic institution." Dorothee Bouquet, "French Academic Propaganda in the United States, 1930-39," in Teaching America to the World and the World to America, ed. Richard Garlitz and Lisa Jarvinen, 155-172 (New York, 2012), 169.

9 For this point in particular, see Lerg, "Uses and Abuses," 80; as well as Lerg, Universitätsdiplomatie. 
increase our understanding of the process of cultural demobilization on both sides of the Atlantic. ${ }^{10}$ In all, the chapter explores when, how, and why inter-Allied academic relations once again became international.

With this in mind, the chapter is divided into four parts. First, it briefly reviews the considerable problems German officials faced in returning to prewar traditions of academic diplomacy in a climate marked by German isolation and self-isolation. Second, it shows how this nonavailability of more traditional means of academic outreach refocused official attention on international student relations. In this context, America's importance in shaping German academic diplomacy is emphasized. It is in the transatlantic context of the 1920 s that we first observe a thorough "geopoliticization" of international students. ${ }^{11}$ The rapid expansion of this field was facilitated in particular by the mutual interests of German academics and American cultural internationalists. Third, the chapter looks at the difficult development of an academic rapprochement in the latter half of the 1920 and the more constructive role it allowed German universities to assume, albeit only for a brief period, on behalf of the Weimar Republic's foreign policy. Finally, the chapter critically examines the conditions of this "academic peace," revealing some of the deeper tensions that underlay transatlantic academic relations after World War I.

\title{
Weimar's Academic Diplomacy: Promises and Problems in the early 1920s
}

\begin{abstract}
One of the vital necessities of the state [is...] to maintain those great assets it still holds. Among these assets, German Wissenschaft assumes an outstanding position. It is the most important prerequisite not just for the maintenance of education in the country, for Germany's technology and industry, but also for its reputation and world position, on which in turn depend its standing and credit. These facts are so well known that they require no explanation. Before the war, Germany's standing rested on its military power, its industry (and commerce) and its Wissenschaft [...] But now our military power is destroyed, industry and commerce are profoundly weakened; but Wissenschaft, despite the loss of thousands of those working in and promoting it, still stands $[\ldots]^{12}$
\end{abstract}

10 If the United States is widely acknowledged as a major factor in such pioneering endeavors as the prewar professorial exchange, its impact in the 1920 is still underappreciated; Michael Wala, “'Gegen eine Vereinzelung Deutschlands'. Deutsche Kulturpolitik und akademischer Austausch mit den Vereinigten Staaten von Amerika in der Zwischenkriegszeit," in Deutschland und die USA in der internationalen Geschichte des 20. Jahrhunderts, ed. Manfred Berg and Philipp Gassert, 303-315 (Stuttgart, 2004), remains one of the only exceptions.

11 On this geopoliticization, see Paul Kramer, "Is the World Our Campus? International Students and U.S. Global Power in the Long Twentieth Century," Diplomatic History 33, no. 5 (2009): 775-806.

12 Harnack, February 1920, quoted in Notker Hammerstein, Die Deutsche Forschungsgemeinschaft in der Weimarer Republik und im Dritten Reich. Wissenschaftspolitik in Republik und Diktatur, 1920-1945 (Munich, 1999), 33. 
These words, which the eminent theologian and science organizer Adolf von Harnack spoke before the Reichstag just weeks after the Versailles Treaty had taken effect, eloquently expressed what was rapidly becoming a commonplace notion among German journalists, diplomats, and educators: that science and scholarship were of vital importance to Germany's international relations; that in the absence of its political, military, and (for a time) economic power, the cultural and symbolic capital bound up in Germany's universities - and its Wissenschaft more generally - was a "last remaining weapon" to re-establish the nation's standing and influence in the world. ${ }^{13}$ In the 1920s, Germans came to recognize, and often overestimate, the Weltgeltung deutscher Wissenschaft (the world influence of German science). ${ }^{14}$

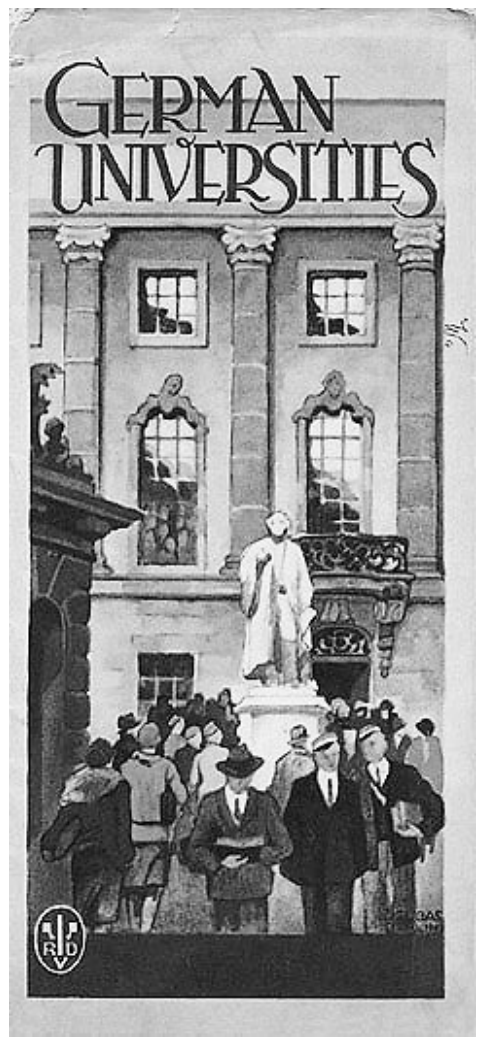

Fig. 8: This cover of a tourism brochure shows how important German universities were to promoting Germany more generally. Willi Dzubas, "German Universities," German Tourism Promotion Office, ca. 1930

13 A very similar assessment occurs in Max Planck's speech before the Prussian Academy of Sciences on November 14, 1918, quoted in Michael Grüttner, "Nachkriegszeit," in Geschichte der Universität unter den Linden, Vol. 2, eds. Grüttner and Heinz-Elmar Tenorth, 5-65 (Berlin, 2012), 59.

14 Sylvia Paletschek, "Was heißt 'Weltgeltung deutscher Wissenschaft?' Modernisierungsleistungen und -defizite der Universitäten im Kaiserreich," in Gebrochene Wissenschaftskulturen. Universität und Politik im 20. Jahrhundert, ed. Michael Grüttner et al., 29-54 (Göttingen, 2010). 
While Germany's educated elites did not doubt that the unique resource of German Wissenschaft had to be used to improve its global standing, tactical differences on how exactly to use it soon emerged. Although the Foreign Ministry's Kulturabteilung did not have a section solely devoted to academic and scientific matters until 1926 (but only a broader section on artistic and scientific relations), it expressed a clear desire to put German universities in the service of foreign policy and to replace the Prussian Ministry of Culture as the locus of German academic diplomacy. The need for academic diplomacy seemed pronounced in the United States, where substantial prewar traditions, the alarming academic activity of France, and U.S. political withdrawal from Europe all suggested it was a necessary and appropriate way of re-establishing German influence. ${ }^{15}$ Inter-elite channels of communication, German diplomats hoped, could be reopened on the "neutral ground" of international learning, thereby breaking down wartime resentments, arousing sympathetic consideration of German problems, and ultimately engendering a climate conducive to the revision of Versailles. ${ }^{16}$

To this end, the Foreign Ministry advocated an ambitious policy of international outreach early on. It never left any doubt that it regarded Germany's re-integration into the academic world as not a cultural but a political issue. "As long as the [scientific] boycott persists," the state secretary concluded in 1921, "the intellectual elites of the former enemy countries will never be able to leave the war psychosis behind; the war will be continued in the cultural field and there will be no positive response to a policy of conciliation., ${ }^{17}$ By serving as visiting professors, attending international conferences, attracting foreign students, or bestowing honorary doctorates on influential foreigners, German professors and German universities were to help re-establish Germany's influence vis-à-vis France. ${ }^{18}$ In light of the profound international challenges Germany faced - and the dearth of other available instruments - a more forceful academic diplomacy appeared imperative. ${ }^{19}$

As we have already seen in Chapter 3 , such convictions only slowly carried over into more concrete academic policy concerning the United States. While

15 On one French program, see Whitney Walton, "Internationalism and the Junior Year Abroad: American Students in France in the 1920 and 1930s," Diplomatic History 29, no. 2 (2005): 255278; for German observations in the early 1920s, see the various reports and memoranda in PA R 63382; and Bernhard Harms, Französische Kulturpropaganda in den Vereinigten Staaten von Amerika (Kiel, 1924).

16 Abschrift zu UIK Nr. 2047.1. Niederschrift über das Ergebnis der Sitzung im Amerika-Institut, Oct. 61921 , PA R 64997.

17 AA to Nadolny (Stockholm), Apr. 28, 1921, PA R 64979.

18 Aufzeichnung, Oct. 31, 1922, PA R 65519.

19 State and private groups alike deemed it clear that German universities would henceforth have to fight a "culture war" to recapture Germany's standing and liberate it from Versailles. A. Timpe, "Die Auslandsaufgaben der deutschen Akademiker und die deutschen Hochschulen," Deutsche Arbeit 24, no. 10 (July 1925) 256-261, 260. 
a certain lack of "energy and inspiration" and severe financial constraints were partly to blame, German efforts encountered structural and psychological obstacles on both sides of the Atlantic. ${ }^{20}$ In the United States, neither the institutional nor the personal infrastructure of the prewar period still existed: the professorial exchanges had been paused in 1915, German departments had been greatly weakened, and cultural bridgeheads, like the Deutsches Haus at Columbia University, had been closed. Still, the psychological hurdles to renewed understanding were even more problematic than the loss of organizational structures. The war had not personally affected American scholars as strongly as many of their French or Belgian colleagues, but anti-German sentiment still ran high among them, sustained by a moralistic understanding of the Great War that cast a once well-respected scholarly community as the cat's paw of a militaristic, autocratic state. Though not all American scholars shared such deep resentment of Germany, few had any desire to meet their German colleagues in the near future. Nowhere in America, a German embassy report noted as late as early 1923, were "expressions of German hatred still as common as in school and university circles."21 As long as the war's emotional and moral alliances prevailed, efforts to re-establish academic relations would likely falter across the Atlantic.

American resentments were not alone to blame for the slow re-establishment of academic exchange, however. German professors, in particular, quickly became an unmanageable group in the Foreign Ministry's efforts at reconciliation. Although professors were state employees and higher education was publicly funded, universities were self-governing institutions with a significant degree and sense of autonomy. Inviting international visitors, establishing exchange programs, or awarding honorary degrees required a (usually unanimous) faculty vote. And while German professors agreed that their universities had a crucial role to play in re-establishing German standing abroad, many of them saw a policy of active outreach as inappropriate..$^{22}$ The newly founded Association of German Universities (Verband der Deutschen Hochschulen, est. 1920), representing 41 institutions of higher learning, served as a lobby group for professorial interests and soon adopted a stance at odds with the Foreign Ministry. ${ }^{23}$ In particular, it promoted reserve toward the recent enemies in the West as a more effective and dignified means of re-establishing German prestige and influence. Once it became truly aware of the "scientific boycott" around 1921, it began to organize a "united line of defense" that asked German universities to abstain from attending international academic jubilees,

20 Schroeder-Gudehus, Deutsche Wissenschaft und internationale Zusammenarbeit, 213.

21 Geman Consulate General, New York (Kraske) to AA, Jan. 7, 1923, PA R 80295.

22 Schädel to Schenk, June 13, 1921, BArch R8o88/146.

23 On the early years of the Verband der deutschen Hochschulen, see Franz Bauer, Geschichte des Deutschen Hochschulverbandes (Munich, 2000), 14-19. 
and individual professors to reject personal invitations to international conferences, as long as German science in general remained excluded from international collaboration. ${ }^{24}$ Ultimately, association members believed, the very indispensability of German science - not German amends - would prompt the international community to readmit it in the equal (or more than equal, as some German scholars believed) position it intellectually deserved. For a time, at least, the German professoriate largely approved of this stance. ${ }^{25}$

To be sure, the question of how best to secure the prestige of German science in the United States - through active promotion or dignified reserve - had been discussed along similar lines even before $1914 \cdot{ }^{26}$ But the disappointments of war and peace gave the question an unprecedented emotional dimension. Embittered by foreign accusations, Germany's educated elites often understood their isolation as a studied insult and hence a matter of "national dignity." Although America was hardly as unpopular as France in the postwar years, Germans had taken its wartime rejections especially badly. The wartime behavior of the large number of German-trained American professors was considered nothing short of ingratitude, and the fact that it had followed upon a decade of lively academic exchange seemed only to suggest the futility of any further outreach. ${ }^{27}$ Anti-Americanism was also widespread among the generally conservative German professoriate, with President Wilson's perceived "betrayal" at Versailles only intensifying it. ${ }^{28}$ Moralistic accusations from Americans, which continued in the 1920 , also sustained a defensive mentality among German professors, initially complicating gestures of conciliation even among the small group of liberal German professors inclined to make them.

Moreover, in the postwar years, professorial intransigence also expressed a struggle within Germany about who would shape academic diplomacy. The Association of German Universities and many of its members viewed the Foreign Ministry's aspirations with suspicion, strongly doubting its competence in such delicate, intellectual matters - based not least on wartime experiences. ${ }^{29}$ It was

24 Schroeder-Gudehus, Deutsche Wissenschaft und internationale Zusammenarbeit, 181-211; see Declaration of German Professors in Mitteilungen des Verbandes der Deutschen Hochschulen 5, no. 1 (Jan. 1925), 50.

25 Many clearly rejected the tenets of the professorial counter-boycott; Prof. Dr. Weizsäcker (Heidelberg) to Schriftleitung des Verbandes der deutschen. Hochschulen, Jan. 2, 1924, BArch $8088 / 770$.

26 E. g., Bericht Clemen, May 15, 1908, NL Schmidt-Ott 480, GSPK.

27 Because a great number of those disappointed by American behavior, such as the historian Eduard Meyer (in the Hochschulverband) and Friedrich Schmidt-Ott (as president of the Notgemeinschaft), continued to occupy central positions in science, transatlantic reconciliation continued to face considerable hurdles in the 1920s: Meyer, Die Vereinigten Staaten von Amerika, 180-181; Schäfer, Mein Leben, 163.

28 Schäfer, Mein Leben, 238.

29 It was the association's declared aim to grow strong enough to counter the influence of the state ministries of culture and the Foreign Ministry in all international questions; Prof. Schenck 
precisely because they recognized, as one professor put it, that "international scientific relations are among the much-cited 'imponderables' of politics, in whose management we have lacked both enthusiasm and skill" that these relations seemed best left in the hands of those who embodied the highest ideals of the nation and remained above the fray of lowly (party) politics: German professors. ${ }^{30}$ In the 1920s, the distance professors kept to the republic reinforced this prevalent "mandarin ideology." ${ }^{11}$ While many professors had originally been willing to accept and adapt to the new government as long as it promised an honorable peace, the reality of Versailles placed them, often irreversibly, in opposition to the republic. ${ }^{32}$ The experience of inflation, the reformist impulses of the first republican governments, and the international humiliations of the early 1920 s only cemented their alienation from the Weimar "system," whose supporters they began to blame for Germany's defeat and the dishonorable peace. If Emperor Wilhelm II's interest in international outreach had often helped to overcome professorial opposition before the war, many professors were now unwilling to place their acumen, prestige, and networks in the service of the republic and its purportedly "dishonorable" policy of fulfillment. ${ }^{33}$

Still, it was not until late 1924 that the irreconcilable attitudes of Germany's conservative mandarins truly proved a liability to Weimar's foreign policy. Only when diplomatic relations with the Western powers grew friendlier after mid-1924 did the near absence of academic contacts and the belligerent tone of professorial pronouncements become a source of official embarrassment and a stumbling block to a policy of reconciliation. ${ }^{34}$ At a time when French and

to Prof. Seeberg, June 16, 1921, BArch R 8088/821; it even collected incriminating evidence to document the Foreign Ministry's wartime blunders; see materials in BArch 8088/821.

30 Prof. Dr. Gast, "Die Auslandsbeziehungen der deutschen Hochschulen," Mitteilungen des Verbandes der deutschen Hochschulen (2. Sonderheft), 17-24.

31 Fritz Ringer, The Decline of the German Mandarins: The German Academic Community, 1890-1933 (Cambridge, MA, 1969).

32 Herbert Döring, Der Weimarer Kreis. Studien zum politischen Bewusstsein verfassungstreuer Hochschullehrer in der Weimarer Republik (Meisenheim am Glan, 1975), 60; on the original arrangement of German universities with the Weimar Republic and their post-Versailles fallout, see Michael Grüttner, "Nachkriegszeit," 5-65.

33 Using the Kaiser's interest to circumvent professorial opposition and raise private funds was a practice perfected by the Prussian Ministry of Culture; see Bernhard vom Brocke, "Die Kaiser-Wilhelm-Gesellschaft im Kaiserreich," in Forschung im Spannungsfeld von Politik und Gesellschaft. Geschichte und Struktur der Kaiser-Wilhelm-/Max-Planck-Gesellschaft, ed. Rudolf Vierhaus and Bernhard vom Brocke, 17-160 (Stuttgart, 1990), 65.

34 Especially the opening of the League of Nation's Institute of Intellectual Cooperation in Paris in early 1925 (widely perceived as a French monopolization of cultural relations) notably increased public and parliamentary pressure for more forceful academic diplomacy. The Center Party issued a request for official commentary on the state of international scientific relations; see Abschrift III 754 II Ang Protokoll der Sitzung, betreffend Interpellation Nr. 375 Dr. Schreiber und Genossen im Reichsministerium des Innern am 17. Februar 1925, PA R 65521; this is shown also by Brigitte Schroeder-Gudehus, "Internationale Wissenschaftsbeziehungen und auswärtige Kulturpolitik 1919-1933. Vom Boykott und Gegen-Boykott zu ihrer Wiederaufnahme," in 
British universities, for example, were liberally awarding honorary degrees to American politicians, diplomats, and generals, the German Foreign Ministry had to expend considerable time and energy securing similar honors even for German-friendly Americans like ambassador Houghton. ${ }^{35}$

In order to resolve these issues, the Foreign Ministry's Kulturabteilung called a meeting with German professors in February 1925. In particular, it hoped to secure their cooperation on three matters that had proven to be sources of frustration during the previous years. For one, it tried to convince German professors that honorary degrees should be awarded in line with the nation's foreign policy interests; second, it asked to be informed directly (not through the state ministries of culture) of international conference invitations and professorial travels abroad; third, it hoped to get individual scholars to adopt a more lenient attitude toward attending international conferences, even when the groups issuing the invitations were associated with the "boycott organizations." In short, the meeting aimed to secure a basis of professorial cooperation and allow the Foreign Ministry to more actively "manage" international academic relations in line with its policy of peaceful revision. Given the controversial nature of these issues, the meeting had been prepared carefully. Rather than engaging in a futile discussion with the Association of German Universities, the Kulturabteilung sought to reach an agreement with a mix of influential professors and science organizers, who could thereafter make the decisions palatable to their peers. Though half of those assembled were right-leaning scholars, including historian Eduard Meyer and Otto Franke of the Association of German Universities, more liberal scholars, including the Heidelberg economist Alfred Weber and the Kiel geographer Albrecht Penck, were clearly overrepresented in light of the generally conservative professoriate. ${ }^{36}$

The careful preparation notwithstanding, the meeting failed to yield the desired results. All the professors present roundly rejected the use of honorary degrees as quasi-political instruments on the grounds that this was incompatible with university autonomy. Opinions were more diverse on the matter of

Forschung im Spannungsfeld von Politik und Gesellschaft, ed. Vierhaus and vom Brocke, 858-885, 872 .

35 The attempt to get an honorary degree for General Henry T. Allen, who had led a relief campaign for German children in early 1924, took several years and proved nearly impossible; German Embassy, Washington [Wiedfelt], to AA, May 18, 1924, BArch 3901/9111; Hans von Gwinner to v. Maltzan, Jan. 6, 1925, PA NL Maltzan, Vol. 47.

36 Liberals: the theologian Adolf Deissmann, the economist Alfred Weber, the geographer Albrecht Penck, and the physicist Arnold Sommerfeld (all of whom had strong connections to, or had recently visited, the United States). Right-leaning scholars included historian Eduard Meyer, the theologian Reinhold Seeberg, the sinologist (and head of the association's international committee) Otto Franke and Friedrich Schmidt-Ott, president of the Notgemeinschaft; on the meeting: Protokoll der Sitzung im Auswärtigen Amt vom 6. Februar 1925 betr. Verhalten der deutschen Gelehrtenwelt gegenüber dem Auslande, PA R 64981. 
conference attendance. Whereas right-leaning professors stressed the insulting nature of the "boycott" and demanded that international scholars make a "declaration of loyalty" prior to even the renewal of informal, personal contacts, liberals at least wanted to cultivate the goodwill of foreign scholars who had shown themselves willing to move on. Ultimately, they agreed that they should redevelop personal rather than institutional relations and avoid any behavior that could be misjudged as "pursuing" foreigners. Though the assembled professors made some minor concessions, such as expressing willingness to share official conference invitations with the Foreign Ministry (a concession that they then repeatedly failed to honor), the meeting had generated only negligible improvements from an official perspective. ${ }^{37}$ Certainly, the focus on personal rather than institutional relations hardly lent itself to ministerial management of academic affairs. Rather than paving the way for congenial cooperation, the meeting only made clear that the Foreign Ministry was getting nowhere with the German professoriate. Although some German professors were quite willing to lend themselves to war guilt agitation or anti-Western cooperation with the Soviet Union, many were decidedly more reserved when it came to reconciliation with the West.

By mid-1925, a number of things had become clear. For one, the foreign policy "uses" of German higher learning would depend on rebuilding a transatlantic infrastructure and overcoming the deep resentments the war had engendered; in addition, this policy would require winning a wider set of individual and institutional partners within German academia willing and able to support it. The success of academic diplomacy, in short, hinged on improving German professorial attitudes toward America and toward Berlin. This would be a slow and cumbersome process, however. For those interested in harnessing German universities to Germany's emerging Amerikapolitik, the prewar, professor-centered approach had, at least for the moment, proven a dead end.

\section{A New Academic Diplomacy: Geopoliticizing the Student, 1924-1929}

At this point in the 1920s, attention shifted dramatically toward other academic actors: students. With international scholarly relations an intractable issue, the Foreign Ministry and academic circles themselves refocused on questions of international education. In the five years after 1924, they would encourage and initiate international fellowship and exchange programs, set up summer and language courses, and create a broader student hospitality infrastructure. From

37 Later that year, the Senate of Berlin University advised its members not to attend international conferences under the auspices of the boycott organizations, and American scientists planning to work at the university hospital were asked to issue a public declaration denouncing the boycott; see Siebe, Germania Docet, 439. 
1924 to 1929 , Reich subsidies for international education increased more than tenfold, from 40,000 to 500,000 marks. ${ }^{38}$ By the late 1920s, no other cultural policy field had expanded at a faster pace or risen more in public recognition. While these undertakings remained comparatively limited in scope (at least when judged by any post-1945 standard), they still constituted a striking departure from earlier professor-focused efforts and laid the foundations for Germany's student-centered academic diplomacy of the twentieth century. This seminal development, I argue, cannot be adequately understood without considering Weimar's Amerikapolitik.

First, of course, it must be acknowledged that the reorientation toward students was not solely a German phenomenon. In the aftermath of the war, the question of international education acquired new urgency in many countries. The incipient support for international student exchanges that had existed before the war gave way to a large number of national, international, and transnational organizations devoted to facilitating student migrations. International bodies like the League of Nations and transnational actors like the World Student Christian Movement began to champion student exchange and travel as a key to international understanding. ${ }^{39}$ Likewise, individual countries established (often state-endowed) centers for that purpose, recognizing that the world's future elite offered an avenue for national influence. In 1919 alone, France enlarged its Office National des Universités et Écoles Françaises, Great Britain expanded its Universities Bureau of the British Empire, and American internationalists founded the Institute of International Education (IIE) in New York City. By the late 1920s a global network of information offices, student travel, and exchange opportunities catered to the more than 50,000 students then studying abroad. ${ }^{\circ}$ Whether in the name of peace or in the name of national interest - and most often, a combination thereof - the interwar years witnessed the "discovery" of students in international politics. ${ }^{41}$

In the German case, defeat and inflation - or more accurately, the economic and psychological conditions they created - delayed this discovery at first. During the first postwar years, German universities experienced a phe-

38 In 1931 the Foreign Ministry expended 515,000 RM on the DAAD and its branch offices in Paris and London; see Haushaltsplan 1931, PA R 64223.

39 See Daniel Laqua, "Activism in the 'Students' League of Nations' International Student Politics and the Confédération Internationale des Étudiants, 1919-1939," English Historical Review, 132, no. 556 (2017): 605-637.

40 Reinhold Schairer, "Ausländische Studenten an deutschen Hochschulen," in Das Akademische Deutschland III, ed. Michael Doeberl et al., 525-542 (Berlin, 1930), 529.

41 Siebe, Germania Docet, 375. Looking back in 1928, the League of Nation's Committee for International Intellectual Cooperation characterized the previous decade as a "typical founder's period" in international education; see University Exchanges in Europe: Handbook of the Institutions and Measures in all the European Countries to Facilitate the Work of Professors, Students and Teachers Abroad (Paris, 1928), 5. 
nomenal rise in international student numbers. At the height of inflation in 1923, 15,000 foreign students were studying in Germany, where they could gain an excellent education at bargain prices. However, since German universities already had to cope with two generations of German students (those returning from the war and those enrolling for the first time), international students were generally regarded as a liability, not an asset. The "foreigner question" (Ausländerfrage) - whether and under what conditions international students ought to be admitted to German universities - was bitterly discussed at the time and resulted in a number of discriminatory measures, in particular, the introduction of steep extra fees to ward off "currency profiteers." This applied especially to students from politically or racially "undesirable" backgrounds, including Jews, Poles, and in some cases, all former enemy nationals. ${ }^{22}$ As long as inflation and wartime mentalities prevailed, the Foreign Ministry and liberal university circles were unable to prompt more welcoming treatment, despite repeated attempts. ${ }^{43}$

A more constructive debate on international students only became possible following Germany's relative economic and political stabilization after 1924. Once living conditions and university finances improved, attitudes toward foreigners lost some (albeit never all) of their bitterness. At the same time, the end of the attractive valuta conditions led to a veritable exodus of foreign students from German universities. Their number plummeted from around 15,000 in 1923 to a mere 5,000 one year later. ${ }^{44}$ For the first time since the war, the reality of Germany's lost academic prestige was truly laid bare and suddenly gave weight to much longer-standing warnings about French advances in international education. From 1924 onwards, professorial and student organizations as well as federal and state ministries pondered how they could best re-establish the attractiveness of German universities.

The first step was to abandon the extra fees for international students. As early as January 1, 1924, just weeks into currency stabilization, the Foreign Ministry issued a circular to all state ministries of culture that (not for the first time) advocated a significant reduction of fees for international students. It emphatically underlined the absurdity of Germany's discriminatory measures at a time when Italy, France, and the USA were vying to attract foreign students to their universities and when "the cultivation of cultural relations is one of the few fields in which Germany can actively operate abroad." 45 The appeal was successful: Prussia, home to two-thirds of all German universities, removed international tuition rates the following year, with all other states fol-

42 Siebe, Germania Docet, 430.

43 By late 1922 the Foreign Ministry had arrived at a clear position to increase international scientific and academic contacts; Aufzeichnung, Oct. 31, 1922 [Abt B], PA R 65519.

44 Siebe, Germania Docet, 371.

45 AA to German State Ministries of Culture, Jan. 1, 1924, PA R 64853. 
lowing suit by $1927 .{ }^{46}$ While this resolved one of the most contentious academic issues of the early 1920s, it did not do much to address the larger problem of dwindling international enrollment. With advantageous currency conditions gone, German universities would not just have to remove artificial hurdles but actively compete for international students, matching the advertising, fellowship, exchange, and hospitality structures Germany's Western rivals had since created. The end of inflation, in short, necessitated a shift from passive to active academic diplomacy. ${ }^{47}$

Within just two years of 1925, these considerations gave rise to a number of complementary and competing private and official initiatives devoted to an ever more comprehensive "management" of international education in the national interest. One of the first and most important of these was the Academic Exchange Service (Akademischer Austauschdienst, AAD). Heidelberg student Carl Joachim Friedrich initiated the effort, helping to organize a small German-American student exchange program (later named the American-German Student Exchange) at the University of Heidelberg's Institute of Social and Political Science in 1923/24. From these modest origins, it soon evolved into a large and increasingly state-sponsored program. By its second year, the AAD had moved from Heidelberg to Berlin, and professors like Alfred Weber of Heidelberg had surrendered its administration to Prussian bureaucrats. Cooperating with the Institute of International Education in New York, the AAD steadily increased the volume of transatlantic exchanges, also expanding its program to Britain and France in the later 1920s. Under the directorship of Adolf Morsbach (1927-1934), a prewar Rhodes Scholar, it developed a clear profile and began to work more closely with the Foreign Ministry, which by 1930 provided a whopping 200,000 marks in annual subsidies. By 1931 the renamed and expanded German Academic Exchange Service (Deutscher Akademischer Austauschdienst, DAAD) had emerged as the German office for international academic affairs - which it remains to this day. ${ }^{48}$

The AAD, however, was only part of an emerging infrastructure of international education with close ties to German authorities. In June 1925, the Foreign Ministry founded the Alexander von Humboldt Foundation to serve as an instrument of its increasingly student-focused academic diplomacy. Its objective, as the Foreign Ministry noted, was to provide fellowships to promising international students based on political rather than charitable criteria and thereby to bring 80 to 100 "talented and German-friendly" students a year to

46 Laitenberger, "Organisations- und Strukturprobleme der Auswärtigen Kulturpolitik," 74.

47 See Impekoven, Die Alexander von Humboldt-Stiftung.

48 On the AAD/DAAD, see Laitenberger, Akademischer Austausch und Auswärtige Kulturpoli$t i k$; a recent exploration of the intellectual roots of the Heidelberg student exchange is Udi Greenberg, Weimar Century: German Emigres and the Ideological Foundations of the Cold War (Princeton, NJ, 2014), 41-44. 
Germany, of whom it "can be expected with some certainty that they will one day be politically and economically useful to us in their home country." 49 To avoid charges of "German propaganda," the foundation (as well as the AAD) systematically obscured the extent of official involvement, utilizing committees of professors and businessmen to represent them. Internally, of course, the Foreign Ministry never left any doubt that the Alexander von Humboldt Foundation was "to be seen as a part of the Kulturabteilung [... and that it carries that name for obvious reasons only to obscure the Foreign Ministry's financial involvement." 50 By late 1925, Berlin thus had access to two ostensibly private organizations that saw themselves clearly as "handmaidens of foreign policy." ${ }^{1}$ The founding of an independent section devoted solely to scientific and academic matters at the Foreign Ministry's Kulturabteilung in early 1926 signaled the beginning of a more constructive second phase in Weimar's academic diplomacy.

Such academic diplomacy, to be sure, was hardly the exclusive domain of German ministries. On the contrary, as the origins of the AAD demonstrate, academic circles were becoming decidedly more active in this regard. A more activist, war-influenced student generation played a key role in these developments. As early as 1921, the German Student Association had formulated its intention to develop a "student foreign policy" (studentische Außenpolitik), and once financial conditions allowed, it came up with a number of important initiatives, ${ }^{52}$ including the America Work Student Service (Amerika-Werkstudenten-Dienst, AWD, est. 1925), one of the decade's most successful programs. This transatlantic trainee service placed over 300 young German engineers in American companies between 1925 and 1930. Like the AAD, the AWD went back to the initiative of a handful of students who had first ventured to the United States in 1923 to "temp" in a hard-currency country, and who, by 1925, had managed - aided by German industrialists like Carl Duisberg, American groups like the YMCA, and the German embassy - to translate their individual experience as "student trainees" into an officially accredited industrial trainee program. Though the program relied on an official agreement between the German government and the American Department of Labor, it was administered by the Wirtschaftshilfe der deutschen Studentenschaft, the German Student Association's social service organization.

49 AA to v. Dirksen, Mar. 21, 1925, PA R 64794.

$50 \mathrm{Zu} \mathrm{I} \mathrm{D} 539$ 4/25 (Aufzeichnung), June 23, 1925, PA R 64794; on the founding and work of the Alexander von Humboldt Foundation more generally, see Impekoven, Die Alexander von Humboldt-Stiftung, 69-77.

51 Laitenberger, Akademischer Austausch und Auswärtige Kulturpolitik, 314.

52 This is expressed in Walter Zimmermann, "Deutsche Studentenschaft und Ausland," Der Auslanddeutsche 5, no. 2 (1922): 34; there is still no larger study on German student foreign policy. 
The AWD was only one expression of German universities' more comprehensive involvement in international education. The director of the AWD, Dr. Reinhold Schairer, played a crucial role in this regard. A left-liberal education manager with close ties to the international Student Christian Movement, Schairer emerged as one of Germany's foremost advocates of international education in the $1920 .{ }^{53} \mathrm{He}$ was convinced that only personal elite contacts could successfully counter Germany's "distorted image" abroad and create the trust and respect its international resurgence demanded. ${ }^{54}$ Following a six-month visit to the United States in 1925, he urged ministries and universities in a number of detailed memoranda to come together in a concerted academic campaign to be led by the Association of German Universities. The association, indeed - while maintaining its scientific counter-boycott - had also begun to discover international education as a more constructive, less controversial way to counter the decline of Germany's academic standing in the world and what it deemed "enormous French cultural propaganda." 55 Once negotiations on a joint approach with the Foreign Ministry failed, it established its own International Academic Office (Deutsche Akademische Auslandsstelle) in Dresden in early $1927 .^{56}$ Directed by Schairer, this office would in the coming years work closely with student and professorial circles to advertise German universities abroad, organize international student travel, and create a university-based hospitality structure for international students. ${ }^{57}$ In merely two years after 1925, the need for active academic diplomacy had thus created a novel network of competing and cooperating offices and organizations committed to managing academic relations in the German interest. Thus, in the mid-1920s, Germany laid the foundation for its modern academic diplomacy with the establishment of organizations like the AAD and the Alexander von Humboldt Foundation.

53 On Schairer, see Malcolm Richardson, "Reinhold Schairer and the Revival of the German Philanthropic Tradition from Weimar to the Federal Republic," in German Philanthropy in Transatlantic Perspective, ed. Gregory Witkowski and Arndt Bauernkämpfer, 143-153 (Cham: 2016).

54 Sitzung des Vorstandes der Wirtschaftshilfe der Deutschen Studentenschaft (Jan. 1926); Allgemeiner Bericht Dr. Schairers über seine Amerika-Reise, BArch R 149/235.

55 Akademische Auslandsstelle to Herren Rektoren der angeschlossenen Hochschulen (early 1927), BArch R 8088/80o; see also Prof. Schlink, "Zur Frage der Betreuung ausländischer Studenten," Mitteilungen des Verbandes der Deutschen Hochschulen (1927): 141-153.

56 The Foreign Ministry disliked both the idea of placing the work in the hands of the Association of German Universities and Schairer's overly internationalist approach to student migrations, and especially any connection with the world student movement that Schairer was part of; see Aufzeichnung AA (Zimmermann), ca. July 1926, PA R 64793.

57 On the planning process, see Protokoll der vom Verband der Deutschen Hochschulen einberufenen Besprechung über die Fragen der Förderung der Auslandsbeziehungen und Auslandsbeziehungen der deutschen Hochschulen, Nov. 9, 1926 BArch R 8088/1221; Entwurf für den Aufbau und die praktischen Arbeiten der Deutschen Akademischen Auslandsstelle, Dec. 1926, BArch R8088/799. 
This emerging network directed its attention overwhelmingly across the Atlantic - a fact all too often ignored. Though scholars rightly point out that German cultural diplomacy of the 1930s focused on southeastern Europe, where Germany hoped to build an "informal empire," they often fail to note that it concentrated on the United States during the 1920s: $:^{58}$ The America-Workstudent Service operated exclusively in the United States; the numerically largest group of exchange students in Germany was comprised of Americans (and in the United States of Germans);59 and of the fellowships that the Humboldt Foundation had awarded by 1930, the second largest number had gone to American students as well. ${ }^{60}$ In addition, the rapidly expanding number of summer and language courses at German universities often catered primarily to Americans, and special academic programs like the Junior Year in Munich (est. 1930) did so exclusively. ${ }^{61}$ There can be no doubt: in the 1920 no other country figured as prominently in Germany's international educational efforts as did the United States. But how can this predominant focus on the United States be explained?

Seldom have scholars attributed this focus on the United States to foreign policy concerns. The most comprehensive study on German academic diplomacy in the interwar period, Volkhard Laitenberger's 1976 monograph on the $\mathrm{AAD}$, concluded, and more recent studies have repeated, that the initial geographical focus on the United States "was not the result of cultural diplomatic considerations but largely coincidental." ${ }^{2}$ While Laitenberger was right to note that student initiative first determined this focus on the United States, his conclusion still falls short in two repects. For one, he ignored the question of why students like Carl Joachim Friedrich of Heidelberg University and the student trainees went to the United States and not elsewhere in the first

58 See Stephen G. Gross, Export Empire: German Soft Power in Southeastern Europe, 189o-1945 (Cambridge, UK, 2015).

59 Düwell, Deutschlands auswärtige Kulturpolitik, 175; as Paulus shows of the 1,219 German exchange students that studied in 21 countries from 1924 to 1938,616 ( $51 \%$ ) went to the United States; of the 1,179 international exchange students in Germany, 566 (48\%) came from the United States. By comparison, only 182 (15\%) came from Great Britain, 131 (11\%) from France, and 106 (9\%) from Italy; see Stefan Paulus, Vorbild USA? Amerikanisierung von Universität und Wissenschaft in Westdeutschland 1945-1976 (Munich, 2010), 89.

60 See Impekoven, Die Alexander von Humboldt-Stiftung, 226.

61 See the numbers of the Heidelberg summer courses in Alexander David Tutt, "Ausländerbetreuung an der Universität Heidelberg, 1928-1938. Das Akademische Auslandsamt und die Vergangenheit" (BA thesis University of Heidelberg, 2012), 22.

62 Laitenberger, Akademischer Austausch und auswärtige Kulturpolitik, 175: Holger Impekoven explicitly notes that foreign policy aspects played a greater role than emphasized by Laitenberger, albeit not in the United States. With regard to the United States, he fully agrees with Laitenberger that "its strong position" was due not to foreign policy concerns but to "the tradition of American study in Germany"; Impekoven, Die Alexander von Humboldt-Stiftung, 118. 
place. Indeed, looking more carefully at the origins of this orientation toward the United States, one finds that informal transatlantic ties (developed through U.S. postwar student relief) usually provided the opportunity, while a deep curiosity about living, working, and studying in the United States provided the motivation. ${ }^{63}$ In other words, to see the early focus on the United States as a result of the more or less accidental journeys of a few students across the Atlantic is to neglect what drove these students overseas in the first place: the desire to get to know a powerful and prosperous America.

More importantly, however, Laitenberger failed to explain why these America-focused student initiatives, and not others, received the critical support that eventually turned small, private educational endeavors into large, official organizations and ultimately into the bedrock of Germany's cultural diplomacy today. In this, political and economic reasons were paramount. Indeed, the student exchanges constituted first and foremost an alternative effort to break the inter-Allied hold on Americans. They aimed to reverse the recalibration of academic relations in a country where German losses appeared to be particularly dramatic and politically detrimental. A widely circulated memorandum penned by Reinhold Schairer in 1927 detailed this decline: in 1895 Americans had accounted for 20 percent of all international students (445) in Germany, only to drop to 4 percent (163) by 1911 and 0.7 percent (53) by 1925. At that point only 53 Americans were enrolled at German universities, while 419 were studying in Britain and 5,000 in France. ${ }^{64}$ Even though French numbers were inflated by the inclusion of summer students, the trend could not have been clearer. ${ }^{65}$ At the same time, Schairer and others were confident that Germany could still tap a considerable reservoir of academic prestige in the United States. Americans displayed continued respect for German Wissenschaft and a growing disenchantment with wartime propaganda, suggesting that they could be drawn back to German universities if only an appropriate effort were made. ${ }^{66}$ America, as Schairer repeatedly put it, was "ripe" for a systematic German campaign. ${ }^{67}$

63 Especially the close contacts with the American YMCA helped implement the Amerika-Work-Student Service; Herbert Krippendorf, Die Entstehung der Carl Duisberg Gesellschaft, 1982, Abt. 352 Carl Duisberg-Gesellschaft, Rheinisch-Westfälisches Wirtschaftsarchiv.

64 "Auslanddeutsche Studierende an deutschen Hochschulen," Der Auslanddeutsche 8, no. 23 (Dec. 1925): 667-677, 669 .

65 In late 1923, the German embassy in Washington forwarded a Washington Post article that reported that many more Americans studied in France than studied in Germany since the war and that interest in the French language had risen. German Embassy, Washington, to AA, Dec. 2, 1923, PA R 65520.

66 Denkschrift (vertraulich) über die Fragen der Ausländischen Studenten in Deutschland, Apr. 7, 1927, BArch R8088/804; also Bericht über meinen Studienaufenthalt in den Vereinigten Staaten (written by Remme or Picht), PA R80287.

67 Reinhold Schairer, Deutsche Akademische Auslandsstelle des Verbandes der Deutschen Hochschulen. Bericht über die Zeit vom April bis September 1927 sowie Vorschläge für die Weiterführung der Arbeit, BArch R8088/802. 
This feeling of opportunity was complemented by a desire to build a pool of experts on the United States. Groups of German businessmen, politicians, and professors had long worried about the lack of international education Germany's future elites were receiving, and a decade of propaganda and limited travel opportunities had only intensified their trepidations. Liberal professors like Alfred Weber in Heidelberg supported student exchange programs early on because they saw the need to deprovincialize German youths, whose international experience was only marginal compared to previous generations. ${ }^{68}$ And while German elites often remained convinced that American education was generally inferior, they regarded the opportunity to study the United States (rather than to study at its universities), now that it had newly become so important, as highly valuable. ${ }^{69}$ In this way, students could also work on their language skills and develop a grasp of American psychology - facilities Germany had sorely lacked before and during the war. ${ }^{\circ}$ Unsurprisingly, such utilitarian considerations were especially pronounced in the case of industrial trainee programs like the AWD, which operated in a field of undisputed American predominance. By training young German engineers in successful American companies like Ford or General Motors, German industry hoped to facilitate the transfer of American technical and industrial know-how in order to modernize its own production. ${ }^{71}$ Little wonder that ambassador Wiedfeldt, a former Krupp manager, regarded the trainee program as a "particularly useful program.".72

Finally, and no less importantly, this focus on the United States expressed the distinct needs of German foreign policy after 1924. At a time when Germany was having to rebuild trust in its intentions and confidence in its industry, intelligent German youths, who had often "worked their way through college," seemed to be the most appropriate ambassadors. At the same time, it was hoped that young Americans visiting German universities could develop a greater sympathy for Germany's "hard fate."73 By facilitating and mul-

68 Alfred Weber to Reichspräsident, Sep. 20, 1924, PA R 63121.

69 Bericht über meinen Studienaufenthalt in den Vereinigten Staaten (written by Remme or Picht), BArch, R80287, 8.

70 In the early 1920s, publicists argued that a lack of understanding for American mentalities was, not least, to blame for the thwarted wartime efforts. Schönemann noted, "it is hardly an exaggeration to say that we eventually lost the war because we did not know the United States enough. We even lost the Versailles peace because we had no clear grasp of Wilson's position toward his people." Friedrich Schönemann, "Amerikakunde. Eine zeitgemäße Forderung," Die Grenzboten 80 (1921): 189-192, 191.

71 On these larger efforts, see Mary Nolan, Visions of Modernity: American Business and the Modernization of Germany (New York, 1994).

72 German Embassy, Washington, to AA, Sep. 15, 1924, "Deutsche Amerikafahrer," PA R 80297; German Embassy, Washington, to AA, July 28, 1924, "Studium Deutscher auf amerikanischen Universitäten," PA R 63121.

73 Siebe, Germania Docet, 383. 
tiplying elite contacts, German educators and officials thus hoped to overturn transatlantic misperceptions and to foster a climate in which Germany could peacefully undo the Versailles Treaty. Whereas professorial exchanges had previously appeared to be promising trust- and prestige-building measures, wartime experiences now suggested students - at a more impressionable age and less burdened by wartime memories - as a much better long-term investment. ${ }^{74}$ To Adolf Morsbach, the director of the AAD, the German task in the United States was not to conduct propaganda, but, given the opinion-shaping power of American universities, "to enter into relations with America's intellectual leaders of today, and especially of tomorrow, and to carefully cultivate these relations and to cautiously and unerringly use them for Germany's cultural and political interests." 75 The American orientation of German academic diplomacy during the 1920 s was thus very far from "largely a coincidence." Quite the contrary, it followed directly from academic tradition, economic interests, and discrete foreign policy priorities. Germany's academic Amerikapolitik speaks to the "geopoliticization" of international students, long before the Cold War.

\section{American Interests: Cultural Internationalism}

This process of geopoliticization was not exclusive to Germany, however. In fact, to understand these developments we need to acknowledge that the establishment of German educational programs unfolded in step with American sentiments and ambitions toward Germany. Americans were the targets of German public diplomacy as much as they themselves were pursuing a program of cultural and ideological expansion in Europe. The receptive climate for educational exchange that Germans found in the United States by 1924/1925 was yet another reason their efforts focused so heavily on the United States. Without the support of prominent Americans like Stephen P. Duggan, the director of the Institute of International Education, the German-American banker Paul Warburg, and Columbia philosopher John Dewey, who all offered their influence and contacts to secure the cooperation of American institutes, companies, and universities, German ambitions could never have been realized. ${ }^{76}$ But what were American motivations and objectives at the time? And why did Americans decide to support German initiatives when they did?

74 German Embassy, Washington, to AA, Sep. 15, 1924, "Deutsche Amerikafahrer," PA R 80297. 75 Bericht des Oberregierungsrat a. D. Dr. Morsbach über seine Reisen nach Amerika JanuarMai 1929; März-Juli 1930, PA R 64236.

76 The AWD Advisory Board in the United States included German Consul General von Lewinski, Magnus T. Alexander, president of the National Industrial Conference, David R. Porter of the Student Department of the YMCA, financier Paul Warburg, and Stephen P. Duggan of the Institute of International Education; the American advisory board for American-German Student Exchange attached to the IIE included Edwin M. Borchard, professor of law, Yale; Joseph P. 
These questions call for a brief review of the American situation. In the United States, World War I and its aftermath had brought about a phenomenal expansion of organizations devoted to aspects of international education. When the United States entered into the war, it had led to a centralization of university interests in the American Council on Education, which also oversaw the emerging "cultural alliances" with England and France. With the deployment of American soldiers, American educational offices, too, went abroad. In 1917, an American University Union was established in Paris to support American college alumni stationed in France, while organizations like the YMCA and the American Library Association provided education and information services to American doughboys overseas. After the war, these organizations often continued their international work and expanded their European presence. They were joined by myriad - a 1925 survey listed no less than 117 - new societies, institutes, lecture programs, and round table conferences devoted to aspects of international education. ${ }^{77}$ Of these, the Institute of International Education (IIE, est. 1919) in New York City was arguably the most important. Established on February 1, 1919, through a $\$ 30$,0oo-grant from the Carnegie Endowment for International Peace, it soon established itself as a clearinghouse for the management of America's intellectual and educational relations with the world..$^{7}$ In addition to coordinating student exchanges (about 250 fellowships by 1929) and organizing lecture tours, it published reference works on studying abroad and lobbied Congress for student visas and transatlantic shipping lines for student rates. ${ }^{79} \mathrm{~A}$ working agreement with the American Council on Education connected it domestically to hundreds of American universities, while the American University Union provided it with an overseas presence in Paris, London, and Rome. An untiring advocate of international education, the IIE's director, CUNY professor Stephen P. Duggan, systematically expanded its field of operation and would become a key figure in German-American academic relations. ${ }^{80}$

Chamberlain, professor of law, Columbia; John Dewey, professor of philosophy, Columbia; Stephen P. Duggan; Livingston Farrand, president, Cornell; Irving Fisher, professor of economics, Yale; Frank J. Goodnow, president, John Hopkins; Henry Goddard Leach, editor, The Forum; W. A. Neilson, president, Smith; Ellen F. Pendleton, president, Wellesley; Henry Suzzalo, president, Washington; Frank W. Taussig, professor of economics, Harvard; Ray Lyman Wilbur, Stanford.

77 See David A. Robertson, "International Educational Relations of the United States," Educational Record, 91-150.

78 See Stephen Mark Halpern, "The Institute of International Education: A History" (PhD diss., Columbia University, 1969), 65; fourteen large national educational organizations were represented on the IIE's Administrative Board; News Bulletin of the Institute of Pacific Relations (April 1928): $3-8,4$.

79 See the Institute of International Education, Annual Bulletins.

80 See his considerable attention to his German experiences in Stephen Duggan, Professor at Large (New York, 1943), passim. 
Behind this expansion of international education stood a liberal internationalist agenda. ${ }^{81}$ Searching for a viable postwar settlement, American internationalists sought ways to apply themselves meaningfully to overseas reconstruction and the creation of a stable world order. Guided by the belief that wars arose principally from international "misunderstandings" and applying the progressive idea that education bred peace and progress, they discovered international education as a particularly important peace-building field. If leaders around the world could just learn to understand and respect each other's positions and idiosyncrasies, they felt, conflicts could be resolved in a peaceful fashion or avoided altogether. ${ }^{82}$ Paul Monroe, a professor at Columbia University and a trustee of the Institute of International Education, made precisely this argument:

Nations come into contact with nations through commerce, through travel, through politics, through religion, through cultural activities and interest. Each of these has its advantages and disadvantages in connection with the development of international good will. But of them all, that contact which we call education - i.e. the cultural and intellectual contact - is the one which has the fewest disadvantages and the greatest advantage, from the point of view of those who are interested in cultivating international understanding and good will..$^{83}$

After the war, both the Carnegie Endowment for International Peace (CEIP, est. 1910) and the Rockefeller Foundation (RF, est. 1913) abandoned prewar agendas of legal internationalism in favor of a cultural and education-based approach. Throughout the interwar period, their largesse funded many of these

81 These included the Carnegie Union, the Carnegie Endowment for International Peace, the Carnegie Foundation for the Advancement of Teaching, the Rockefeller Foundation, and the Laura Spelman Rockefeller Memorial. By 1934 they had allocated \$18 million for social sciences and \$15 million for academic exchanges; see Pells, Not Like Us, 23.

82 Nicholas Murray Butler, an officer of the Carnegie Endowment for International Peace, had already summed up this ideology as the "International Mind" in 1912. According to Ninkovich, this "international mind ... which, given the adoption of a universal set of values, would function as an international superego. To a large degree, moral transformation would be achieved through transnational contacts, with cultural relations serving as the vehicle of reeducation," Ninkovich, Diplomacy of Ideas, 11; as Duggan summed up, "The Institute believes that it is essential for Americans to know of the difficulties and problems of other countries as for the people of other countries to know something about us, in order that international good-will may be realized," Stephen P. Duggan, "The Institute of International Education," School and Society 12 (1920): 642 .

83 Quoted in Liping Bu, "Education and International Cultural Understanding: The American Elite Approach, 1920-1937," in Teaching America to the World, ed. Garlitz and Jarvinen, 111133,112 . 
international education initiatives, which they deemed a more effective means of building a stable and peaceful world order. ${ }^{84}$

This more peaceful world, to be sure, was clearly conceived under the moral leadership, at least, of the United States. American internationalism was strongly underpinned by notions of American exceptionalism and the belief that American economic and cultural models could reform and uplift the world. Foreign countries, too, could alight on the road to peace and prosperity if they were introduced to American values and standards - from hygiene to individualism. While such reform sentiments had long informed American attitudes toward less developed countries, a devastated, essentially bellicose Europe seemed no less in need of American solutions. ${ }^{85}$ An early memorandum on the IIE noted that "no other land, for obvious reasons [emphasis added], is so well fitted as the United States to take the initiative in such an enterprise. No time could be more suited than the present to start the movement, for all the Allied countries are eager to cement the spiritual bond created by the War and all recognize that by education more than by any other force mutual understanding (not understandings) can be brought about." ${ }^{86}$ Certainly, American programs also pursued a clearly anti-Bolshevist agenda. By integrating Central and Eastern European students into the "West," U.S. internationalists aimed to secure a tighter ideological and emotional grip on Europe's future leaders, combating both a "narrow nationalism" on the right and rivaling forms of internationalism on the left. Finally, by sending American students overseas, business leaders hoped not only to generate international goodwill but to train future elites for their increasingly global role in the "American century." ${ }^{87}$

So how did the politics of American cultural internationalists relate to official American foreign policy? American foundations and their subsidiaries were, in fact, America's foremost public diplomacy actors during the interwar period. While most European countries inaugurated government-sponsored cultural programs in the 1920s, the U.S. administration remained relatively aloof from these matters. After the war, the federal government abandoned the Committee on Public Information, which had espoused American ideas and

84 See Kramer, "Is the World Our Campus?", 788; on the work of American foundations in supporting political science and international studies as a way to reform international politics, see Katharina Rietzler, "American Foundations and the 'Scientific Study' of International Relations in Europe, 1910-1940" (PhD University College London, 2009).

85 As Emily Rosenberg argues, cultural internationalism was closely "associated with liberal expansionism" and "the globalization of the American liberal tenets of private enterprise, the open door, and free flow"; Rosenberg, Spreading the American Dream, 115.

86 Memorandum for the Carnegie Endowment for International Peace Concerning the Establishment of an American Institute of Education, Sep. 27, 1918, Box 486 Vol. 154, CEIP, Columbia University, Rare Book \& Manuscript Library Collections.

87 Marcus M. Mars, "International Travel and Study - An Official College Extension," The Educational Record 5, no. 1 (Jan. 1, 1924): 40-43, 40. 
values at home and abroad, and it was not until 1938 that it established a culture and information section at the State Department in response to Nazi expansion in Latin America ${ }^{88}$ Meanwhile, the U.S. erected what historian Frank Ninkovich has characterized as a "half-way house" with American philanthropies undertaking public diplomacy, largely in line with and in lieu of official foreign policy agendas. This alignment between private and official foreign policy was not usually the product of formal agreements - though foundation officers often had close ties to the Foreign Service - but of a shared educational and ideological background. ${ }^{89}$ Convinced of America's moral authority, disdainful of European power politics, and driven by anti-Bolshevism, these groups shared the vision of a peaceful, liberal, capitalist world order organized along American lines. But where American officials were constrained by congressional mandates and public opinion, American foundations had the international clout, political independence, and financial resources to pursue their ideological convictions. During the 1920s, foundation officers held fast to the notion that America had a profound role to play in European reconstruction and even sought to deliberately compensate for America's largely inactive official foreign policy. ${ }^{90}$

For America's cultural internationalists, Germany at first played a secondary role. Their sprawling commitment to the organization of international education focused overwhelmingly on France, Britain, and Italy, ignoring Germany almost entirely until the mid-1920s. This was the product of wartime resentments but it was also based on the assumption that strengthening the wartime cultural alliances with the Western Allies was the best guarantee of European stability. Especially when inter-Allied tensions rose after 1919, U.S. internationalists felt called to maintain Franco-American amity. ${ }^{91}$ Amidst bitter public debates over U.S. nonratification of the peace treaty and French debt payments, they instituted large-scale study abroad programs like the American Field Service Fellowships and the Junior Year Abroad to memorialize and

88 Justin Hart, Empire of Ideas: The Origins of Public Diplomacy and the Transformation of U.S. Foreign Policy (New York, 2013), 21.

89 On these issues, see Katharina Rietzler, "Before the Cultural Cold Wars: American Philanthropy and Cultural Diplomacy in the Inter-War Years," Historical Research 84, no. 223 (Feb. 2011): 148-164, 153-155.

90 Joseph W. Winn, "Nicholas Murray Butler, The Carnegie Endowment for International Peace, and the Search for Reconciliation in Europe, 1919-1933," Peace and Change 31, no. 4 (2006): 555-584, 560; Ninkovich concludes that "the liberal internationalist outlook, in cultural affairs and foreign policy as a whole, solved a basic riddle of American foreign policy by promoting American global interests without involving the nation in Weltpolitik or resorting to an undesirable reliance on state power"; Ninkovich, The Diplomacy of Ideas, 23.

91 The CEIP decided to help rebuild the libraries of Louvain (Belgium) and Rheims shortly after the war and provided funds for medical aid to France and to the Societé France-Amerique; likewise the Rockefeller Foundation gave millions for the rebuilding of France. 
perpetuate the two countries' brotherhood in arms on a cultural level..$^{92}$ In the same vein, wartime bodies like the American University Union were refitted as "educational embassies" to represent the United States in Paris, London, and Rome. ${ }^{93}$ For years after the war, educational and cultural exchanges with Europe primarily served to bridge the political and economic divides in the inter-Allied world.

In contrast, Germany remained largely excluded from America's cultural internationalist forays. Judging by the Institute of International Education's 1922 annual report, for example, Germany was truly a nonentity in America's educational landscape. The report's twenty pages, packed tightly with descriptions of academic exchanges with France, England, and Italy, left Germany essentially unmentioned. ${ }^{94}$ And though some of the Carnegie Endowment's large-scale postwar projects such as the Economic and Social History of the War and the international inquiry into school textbooks did involve a very select number of German scholars, the endowment's pro-Allied bias often perpetuated the hostile sentiments it officially sought to overcome. ${ }^{95}$ Its two "special correspondents" on Germany (after 1922, the pacifists Hellmut von Gerlach and Wilhelm Foerster) were so far removed from the German mainstream that their widely circulated reports merely reinforced prevailing views of an essentially unreconstructed nation. ${ }^{96}$ With a few exceptions, postwar Germany remained more an object of study than a subject of international cooperation for U.S. cultural internationalists.

This only changed following Germany's year of crises in 1923. The Ruhr occupation cooled American internationalists' pro-French sentiment, just as Germany's near social, economic, and political breakdown during the fall and its potentially grave ramifications for all of Europe caused serious concern. As Germany's postwar isolation seemed bound to topple the Weimar Republic,

92 Walton, "Internationalism and the Junior Year Abroad," 257.

93 Report: American University Union in Europe, Jan. 1921, 18; American Council on Education, Box 28 Folder 6, Hoover Institution Archives.

94 Germany was only mentioned once but in a different context; see IIE, Annual Report 1922, 11.

95 On these ambivalences, see Tomás Irish, "Peace through History? The Carnegie Endowment for International Peace's Inquiry into European Schoolbooks, 1921-24," History of Education 45, no. 1 (2016): $38-56$.

96 Gerlach, for example, was convinced of German war guilt, a position taken by only an exceedingly small number of German professors. The German Foreign Ministry believed that Gerlach's reports seriously damaged Germany. The German embassy in Washington wrote Berlin that "You cannot imagine the effect of these reports. One carries them to the President, to Congress, to the Administration and takes them to be the gospel"; quoted in Rietzler, "Before the Cultural Cold Wars," 162; the editors of Gerlach's letters emphasize, in contrast, that Gerlach might have painted a more positive picture of Germany than actually existed to maintain Germany's credit abroad; Karl Holl and Adolf Wild, ed. Ein Demokrat kommentiert Weimar. Die Berichte Hellmut von Gerlachs an die Carnegie-Friedensstiftung in New York, 1922-193o (Bremen, 1973), 47 . 
however imperfect it might be, American internationalists moved to reintegrate Germany, not least in the field of international education (see Chapter 3). When German students like Carl Joachim Friedrich visited the United States in late 1923, they thus encountered American professors and foundation officers who had already begun to define renewed cooperation with Germany as an American interest. Announcing the establishment of the American-German Student Exchange in July 1924, Stephen Duggan of the IIE concluded "that the antagonism of the war has sufficiently passed away to [...] bring about educational relations in higher education with Germany again." Still, he felt the need to assure his audience that the German students it would bring to the United States "will probably come chiefly from Heidelberg, which has always been liberal and has established an institute primarily for the study of Anglo-American history and institutions."97 With this emphasis on Heidelberg's liberal, pro-American tendencies, Duggan apparently intended to quiet any remaining apprehensions among America's educated classes while also holding out the promise of German "democratization."

Indeed, the student exchange program between Germany and the United States differed from inter-Allied ones in some telling ways. From the very first, it clearly aimed not only to overcome Germany's potentially dangerous isolation but to integrate it more tightly into a "Western" system by encouraging and strengthening its fledgling democratic institutions. American cultural internationalists hoped to use German student contacts with America as a way to democratize and pacify future German leaders. ${ }^{98}$ By attracting young engineers and social scientists to American companies and universities, they aspired to facilitate the transmission of both American industrial and educational models and the more democratic, egalitarian mindset they believed underpinned them. They likewise hoped that introducing American business and cultural practices would stabilize Germany economically as well as politically. ${ }^{99}$ Decidedly, the intention of these nonstate efforts foreshadowed the much larger and state-sponsored "re-education" programs after 1945.

One cannot help but notice how closely American cultural initiatives paralleled the larger course of transatlantic politics. The Franco-German confrontation, Germany's financial breakdown, and the implications of both for European stability led American foreign policymakers to "return" to Europe in 1923/24. Constrained in their formal actions by American isolationist currents, they worked informally through American businessmen and financiers to help settle the reparations dispute. Henceforth, the United States - mostly exerting financial pressure - furthered a consensual revision of the peace treaty in

97 “The Institute of International Education," The Educational Record 5, no. 3 (July 1924): 190.

98 Duggan, Professor at Large, 53.

99 Ninkovich, The Diplomacy of Ideas, 13; Costigliola, Awkward Dominion, 167-183. 
exchange for guarantees of French security, a policy that facilitated the recovery of Germany within a consolidated European system in the end. ${ }^{100}$ America's cultural expansion into Germany constituted another, equally informal way to stabilize Europe in line with America's policy interests. While scholars have long emphasized America's economic intervention of 1923/24, it is worth stressing the cultural intervention that followed tightly on its heels. Like America's economic "linkage groups," its cultural "linkage groups" set out to stabilize Germany in response to its year of crises in 1923. The educational exchanges of the coming years reflected America's commitment to "peaceful change" in Europe no less than its involvement in the Dawes settlement did.

\section{Geopoliticizing the Student}

For Germany's peaceful revisionists, the American cultural internationalists were well-nigh ideal partners. Their ambition to reintegrate Germany into "the West" matched Germany's desire to overcome its isolation in step with a powerful America. After 1924, America's policy of "peaceful change" and Germany's policy of "peaceful revisionism" dovetailed not just in the economic but also in the cultural field. One consequence of these overlapping interests was the rapid development of educational exchanges. In the five years after 1925, the number of German fellowships at the IIE more than tripled from 14 to 50, while the American fellowships at the AAD quintupled from 9 to 47 . During the same time, the AWD placed more than 310 student trainees in American companies. Toward the end of the 1920s, hundreds of American students began to attend summer and language courses at German universities. Though overall numbers are modest by any Cold War standard, they were quite substantial for the time. For both the DAAD and the American IIE, the American-German Student Exchange was the single largest and most successful exchange program. ${ }^{101}$

Nevertheless, one must acknowledge that the two countries differed quite significantly in their ultimate objectives. Unlike many Americans, most Germans saw international understanding not as a value in and of itself but as

100 Patrick Cohrs put it this way: America (and Britain) sought to find a solution to "the epicentre of Europe's disorder: the problem of how the vanquished Germany, the burdened Weimar Republic, could be reintegrated into a viable international order without jeopardising the security of France"; Patrick O. Cohrs, "The First 'Real' Peace Settlement after the First World War: Britain, the United States and the Accords of London and Locarno 1923-1925," Contemporary European History 12, no.1 (2003): 1-31, 2; a similar take can be found in Arnold Offner, "Research on American-German Relations: A Critical View," in America and the Germans, ed. Trommler and McVeigh, 2:168-182, 170 .

101 See Stephen P. Duggan, "Der deutsche Einfluss auf die amerikanische Erziehung," Hochschule und Ausland 9, no. 1 (Jan. 1931): 7. 
a vehicle for a peaceful revision of Versailles. They fostered cordial relations with the United States primarily to help them realize their interests vis-à-vis competing French ambitions. Americans, by contrast, always saw relations with Germany embedded in a larger European strategy that sought to balance French and German demands. ${ }^{102}$ In short, whereas Americans imagined a stable, peaceful Europe under America's (moral) leadership, German elites envisioned a transatlantic partnership that would allow them to regain their semihegemonic position in Europe. Their shared interest in a peaceful change of the status quo proved mutually beneficial at a time when Germany was just beginning to escape its isolation, yet it was bound to create tensions once Germany tried to unseat French influence more forcefully. Ultimately, American involvement helped realize German interests in the short run, but would circumscribe them in crucial ways later on. In the meantime, both sides aimed to organize educational programs in a way that minimized their potential drawbacks and maximized their potential benefits.

\section{"Geopoliticization" in Practice: The German Student as Ambassador}

A consideration of how abstract political ambitions were translated into concrete practices seems appropriate at this point. By what means exactly were German objectives, in particular, to be achieved? ${ }^{103}$ To answer this question it is necessary to distinguish between the different roles assigned, and mechanisms applied, to outgoing German and incoming American students. German students going abroad were generally perceived as informal ambassadors of Germany and expected to represent an attractive national image to Americans, most of whom had not come into contact with Germans in over a decade. Reinhold Schairer summed up the importance of choosing the right students for this function: AWD students would have to demonstrate their abilities "as workers, as students, and first and foremost as human beings. The failure even of only a small part of these students - especially where their personal side, their character, is concerned - would heavily damage the trust gained and shown. The selection of the right personalities will be an especially difficult and responsible task."104

102 German Embassy, Paris, to AA, May 29 1926, PA R 28491.

103 For a study of this "geopoliticization" that focuses not predominantly on the German side but also explores American infrastructure and ambitions based on the records of the Institute of International Education, see Elisabeth Piller, "Eradicating Misunderstanding? The Institute of International Education, Student Exchanges \& Transatlantic Relations in the 1920s," Rockefeller Archive Research Report, Sleepy Hollow, NY (Nov. 2018) http://rockarch.issuelab.org/resources/33683/33683.pdf

104 Vorläufiger Bericht über den Aufenthalt Dr. Schairers in den Vereinigten Staaten von Nord-Amerika, Dec. 24, 1925, BArch R149/234. 
To this end, both the AAD and the AWD developed intricate screening processes overseen by committees of liberal professors, ministerial representatives, and, in the case of the AWD students, prominent industrialists and engineers. ${ }^{105}$ Their selection criteria reflected their desire to identify future elites who would later occupy the sort of political, educational, or business positions in which they could make the best use of their American education and connections. In looking for indicators of future success, professional and scholarly merit (based on grades and references) played a strong role, but so, too, did the candidates' social and family background. ${ }^{106}$ The considerable number of exchange students coming from well-known ministerial and professorial families reflected the relatively rigid German class structure, a degree of favoritism, as well as the selection committee's essential conviction that their own class, the Bildungsbürgertum, constituted the most "qualified representative(s) of the German people abroad." ${ }^{107}$ Under Adolf Morsbach's directorship after 1927 , the AAD began placing more emphasis on certain ambassadorial qualities, including an attractive personality, open-mindedness, social skills, and even good looks. ${ }^{108}$ An active interest in sports, for example, was considered highly beneficial for developing friendships in the United States. In short, the selection process generated a pool of candidates that struck a balance between those most likely to advance in the German system (by way of grades, field of study, political orientation, and family background) and those most likely to represent Germany in a way that appealed to Americans (by way of personality, social skills, or hobbies).

At the same time, there was a clear emphasis on national "reliability." Only students of a certain age and with a solid sense of national identity were considered suited to representing Germany abroad, not least as they would be able to withstand the not-to-be-underestimated dangers of "Americanization." 109

105 In the case of the AWD these included: Geheimrat Dr. (Carl) Bosch (BASF), Dr. Robert Bosch, Dr. Buecher, Dr. Cuno (HAPAG), Deutsch (AEG), Duisberg (Bayer), Dr. Eckener, Dr. Einstein, Dr. Fehling (Rockefeller Foundation), Dr. Haber, Dr. Harnack, Klingenberg (AEG), Dr. Heinecken (Norddt. Lloyd), Dr. ing. Köttgen (Siemens), Prof. Matschoss (engineer), Exc. von Miller (Dt. Museum), Prof. Naegel (engineer), Dr. Penck (Prof., Kiel), Dr. Petersen (Hamburg), Max Planck, Dr. Schacht (Reichsbank), Dr. Schairer (Studienstiftung, Wirtschaftshilfe der dt. Studentenschaft), Schmidt-Ott (Notgemeinschaft der dt. Wissenschaft), Carl Friedrich von Siemens, Prof. Dr. Sommerfeld (Munich; first Carl-Schurz-Professor in Wisconsin after the war), Prof. Spranger (Berlin), Dr. von Stauss, Dr. Edmund Stinnes (Dr. Ing; Stinnes AG, son of Hugo Stinnes), Prof. Dr. Stumpf, Generaldirektor Vögler (Ver. Stahlwerke), Max Warburg.

106 The selection of Friedrich Franz von Papen (son of Franz von Papen, German Chancellor, 1930-1932), Anneliese von Halle (daughter of Professor Ernst von Halle), Eduard Baumgarten (nephew of Max Weber), and Reimer Koch-Weser and Volker Koch-Weser (sons of minister Koch-Weser) attest to this.

107 Quoted in Laitenberger, Akademischer Austausch und auswärtige Kulturpolitik, 187.

108 Laitenberger, Akademischer Austausch und auswärtige Kulturpolitik, 187.

109 German Consulate General, New York, to AA, July 2, 1925, PA R 63122. 
The AAD's selection committee thus prioritized older applicants, many of whom had already earned a doctorate. The 1928 cohort of exchange students, for example, was $271 / 2$ years old on average. ${ }^{110}$ This preference was also evident with regard to the AWD students, all of whom were actually postgraduate engineers. From the German perspective, in fact, sending "students" actually made very little sense because it only delayed the transfer of valuable American know-how to German industry. Careful selection, in short, aimed to maximize the programs' political and economic gains.

This screening process was soon complemented by a measure of instruction to outgoing students. A "departure camp" close to Berlin and an "arrival camp" in New York familiarized German exchange students with each other, explained American idiosyncrasies, and briefed them on current political, social, and economic topics. ${ }^{111}$ These camps stressed a German image suited to the overall revisionist objective: a country united in a heroic fight against the injustices of Versailles. At the same time, students were advised to carefully abstain from any sort of partisan propaganda. National issues like the German youth movement, rearmament, the war guilt question, or reparations were deemed appropriate topics of discussion, but domestic politics was not. In the United States, exchange students were not to act as though they were "representative of a party or an ideology, but of Germany abroad." ${ }^{12}$ Above all, these instructions were to imbue German students with a sense of national mission and raise awareness about the political implications of their behavior. The AWD student, for example, was reminded that "through his entire demeanor on and off the job, he is obligated to increase the esteem in which the German name is held as a representative of Germanness in most difficult surroundings. He is to do so by way of maximum fulfillment of duties, a superb work ethic and tactfully restrained behavior. Every breach of this self-evident duty could damage the German reputation most severely" 113

110 Bericht des Oberregierungsrat a. D. Dr. Morsbach über seine Reisen nach Amerika JanuarMai 1929; März-Juli 1930, 45, PA R 64236.

111 These were usually equipped with recent summaries on reparations and disarmament.

112 Quoted in Laitenberger, Akademischer Austausch und auswärtige Kulturpolitik, 210.

113 Soziale und Wirtschaftliche Lage; Mitteilungen über die Möglichkeit von Werkarbeit in den Vereinigten Staaten (streng vertraulich), BArch R149/217. 


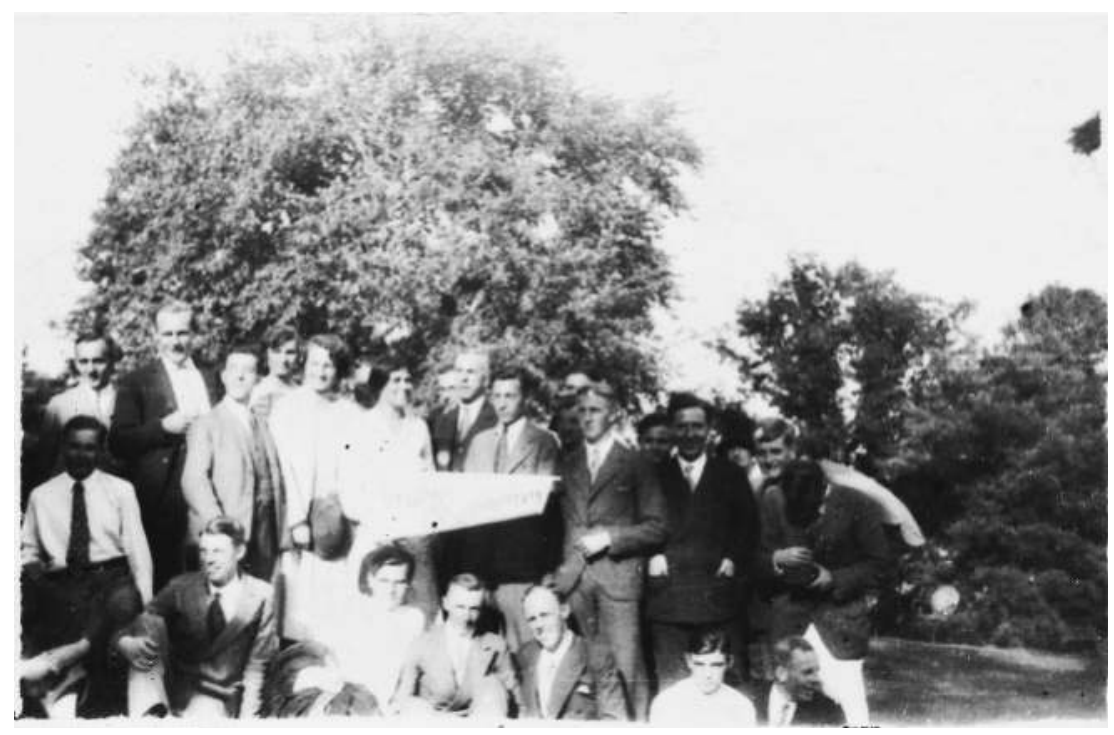

Fig. 9: German Exchange Students at the Arrival Camp at Storm King, 1930, Rockefeller Archive Center, Collection: IIE RG 4 Series 1, Photographic Files FA\#1288 Box 35 Folder 284

According to all available evidence, these selection and instruction mechanisms procured an attractive, politically conscious, and articulate group of German students in the United States. The first cohorts included a disproportionate number of future publicists, professors, diplomats, and pastors, including the journalist Klaus Mehnert, the historian Alfred Vagts, the theologian Dietrich Bonhoeffer, as well as, in the 1930s, the founder of German public opinion research Elisabeth Noelle-Neumann. Their internal communication reveals a set of young men and women proud and eager to represent Germany abroad. ${ }^{114}$ Among themselves, they exchanged advice on what topics to mention or to avoid and on how best to explain German developments (disarmament, reparations, war guilt, "what about Hitler?") to a frequently uninformed American audience. ${ }^{115}$ Their activities show that they very much wished to use the many outlets for nuanced political debate available on the American campus. Many of them joined the university's international relations societies, shared their insights with friends, local newspapers, churches, and rotary clubs, and served as college delegates to model League of Nations conferences. ${ }^{116}$ Above all, they had internalized the idea that their bearing on and off campus was an integral

114 Anneliese von Halle to F. Schmidt-Ott, June 9, 1926, PA R 64211.

115 See the exchange student letters in RDA, Rundbrief Deutscher Austauschstudenten; copies for 1931-33 in HML, German-American Collections, Uncataloged Pamphlets, Box 12.

116 See the reports in RDA, Rundbrief Deutscher Austauschstudenten in Amerika, no. 2 (Dec. 1931/32). 
part of Germany's image-building endeavors. It is as "living propaganda," one exchange student remarked in 1932, that "we can best do justice to our task." ${ }^{117}$ That same year, the obvious zeal of German exchange students prompted the French ambassador Paul Claudel to share his fears with the Quai d'Orsay that the Germans were better-trained propagandists for their nation than their French peers. ${ }^{118}$

Despite their relative success, German organizations soon found themselves confronted with an issue they had not anticipated: how to maintain the link between German students and their fatherland during their extended stays abroad. Especially in larger cities, this "retention" work often fell to German consulates, which sponsored regular gatherings and festivities. ${ }^{119}$ Students who lived further away from official representatives received regular newsletters and, in the case of the AWD students, visits from a delegate of the New York office. ${ }^{120}$ Collectively, these measures aimed to keep them in touch with German developments and to remind them of their duty both to be "informal" ambassadors and, no less importantly, to leave behind the promising American job market and help rebuild the struggling fatherland. The AWD frankly admitted that "one main function of the New York headquarters is to keep the contact with the AWD students so lively that they remain emotionally invested in Germany and do not stay in America for good." ${ }^{121}$

These and similar initiatives highlight an unpleasant truth that German diplomats and educators alike experienced: the "pull" of the United States in the 1920s. Germany's young engineers, in particular, showed an unabashed enthusiasm for the United States. For a generation that had grown up under the shadow of war, defeat, hunger, inflation, and national humiliation, the United States did, indeed, seem much like the Promised Land. ${ }^{122}$ Besides their access to cars and adventure, the trainees marveled at the immense optimism that

117 Dr. Hermann Schnitzler, "Wenn ich Dr. Morsbach wäre ...," RDA, Rundbrief Deutscher Austauschstudenten, No. 5 (Mar. 1932).

118 Whitney Walton, "National Interests and Cultural Exchange in French and American Educational Travel, 1914-1970," Journal of Transatlantic Studies 13, no. 4 (2015): 344-357, 346; Stephen Duggan also later remembered that "no foreign students were so popular in our colleges as the Germans, who were attractive young men and women as well as good scholars"; Duggan, Professor at Large, 176.

119 German Embassy, Washington, to AA, Sep. 15, 1924, "Deutsche Amerikafahrer," PA R 80297. In San Francisco, Consul Werner Otto v. Hentig used German students as something of a cultural attaché squad; they helped him organize social gatherings and chauffeured the consulate's intoxicated party guests home; see Klaus Mehnert, Ein Deutscher in der Welt. Erinnerungen 1906-1981 (Stuttgart, 1981), 141.

120 Fritz Weidner, Der Bericht [des Reiseonkels] Sommer 1929 Abt. 352 Carl DuisbergGesellschaft, 352-14-7, Rheinisch-Westfälisches Wirtschaftsarchiv.

121 Reisebericht Dr. Schairer, Berlin, Sep. 13, 1929, BArch R149/91.

122 For the profound impression made by the beautiful, well-fed, and well-clad Americans on the Berkeley campus on one German exchange student: Mehnert, Ein Deutscher in der Welt, 127. 
prevailed in American industry and the nation at large. ${ }^{123}$ Whereas German universities and shop floors appeared to be places of anxiety, political confrontation, and class strife, they found American companies pervaded by a liveand-let-live mentality, friendly competition, and boundless confidence. Several advisors to the AWD, steeped in the bourgeois conceit of their time, were unable to suppress just how uneasy they felt finding the returned work-students "impressively attach [ed] to the advantages of the American character, [...] vocal defenders and fiery apologists of the youthful continent." ${ }^{124}$ A significant number of the German trainees stayed on for a second or third year, and some stayed for good. To the German organizers, America at times seemed like a "gigantic magnetic mountain that draws in ships and merchandise shipments and the war debts of nations [...] sounding the siren calls of prosperity, of happiness, of contentment and of [a high] living standard."125 In its sons and daughters' responses to Amerika, the German Bildungsbürgertum caught yet another disconcerting glimpse of the "irresistible empire."126

123 This was encapsulated in a frequently related anecdote: A German professor had visited a large American industrial plant and, inspecting American machinery, diligently jotted down his impressions in his notebook. When approached by one of the American engineers, the German professor - afraid of being taken for an industrial spy - entered into a long-winded defense assuring the engineer that his sketches served purely academic purposes. The American then departed from the scene, leaving the professor behind in anguish, only to return a few minutes later with a set of engineering blueprints, which he handed the startled German. Asked whether he did not fear that Germany could copy his machines, the engineer asserted, "by the time you Germans have rebuilt the machine, we'll have built something even better." Apocryphal or not, the anecdote encapsulated many a German work student's experience of American confidence.

124 Georg Schreiber, "Amerika-Werkstudenten-Dienst der Wirtschaftshilfe der Deutschen Studentenschaft," Der Arbeitgeber, Aug. 1, 1928, Clipping: BArch R149/52.

125 Georg Schreiber, "Amerika-Werkstudenten-Dienst der Wirtschaftshilfe der Deutschen Studentenschaft," Der Arbeitgeber, Aug. 1, 1928, Clipping: BArch R149/52.

126 Victoria de Grazia, Irresistible Empire: America's Advance through Twentieth-Century Europe (Cambridge, MA, 2005). 
Fig. 10: This photograph of exchange student Inge von Müller at Bates College captures some of the excitement of studying in the United States. Rockefeller Archive Center, Collection: IIE RG 4 Series 1, Photographic Files FA\#1288 Box 34 Folder 283

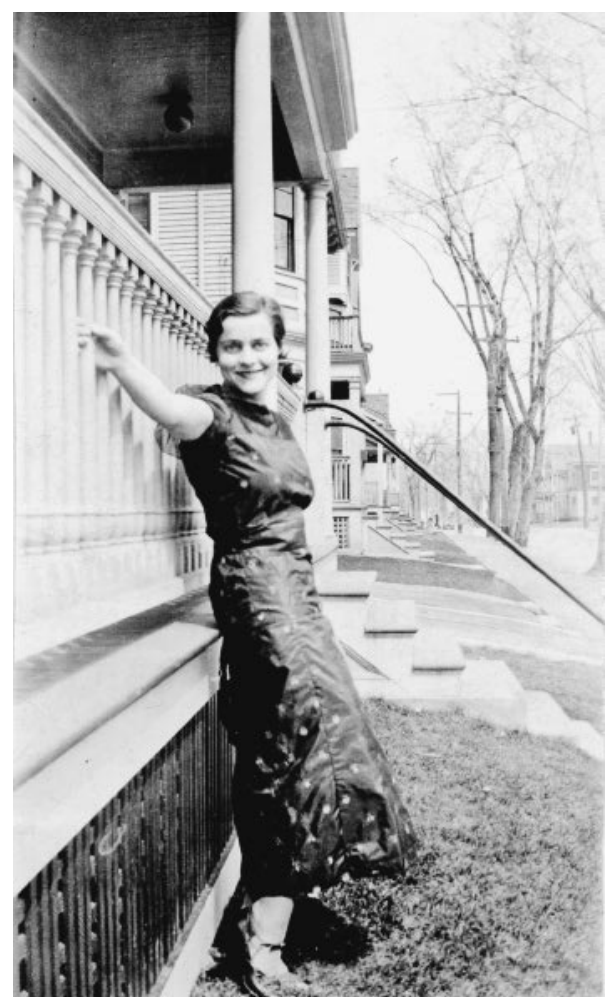

\section{"Geopoliticization" in Practice: Creating the Hospitable University}

It was not least the German students' manifest enthusiasm for America that reminded German professors and officials that the successful "geopoliticization" of students hinged on American experiences in Germany. In this regard, the key was not usually selection - American students were mainly selected by American institutions like the Institute of International Education ${ }^{127}$ - but cultivation. Perhaps the most important lesson liberal university groups had

127 A glimpse into the American selection process can be gleaned from the Minutes of the Sixth Meeting of the Advisory Board American-German Student Exchange of the Institute of International Education, May 3, 1926, Samuel McCune Lindsay Papers Box 32/Folder: American-German Student Exchange, Columbia University Libraries, Rare Book \& Manuscript Library Collections. The only exception was the relatively small number (18) of American Humboldt fellows, who were suggested by German consulates in the United States. These suggestions (as far as they are still available) indicated a clear preference for students of the humanities and of German descent; see, for example, the case of Harold John Grimm (who would go on to become a famous American Renaissance scholar), German Consulate, Cleveland, to AA, "Bewerbung um ein Stipendium bei der Alexander von Humboldt-Stiftung," Dec. 21, 1928, PA R 64211. 
taken from the war was that affection was not a quasi-automatic result of studying in Germany. Rather, study abroad could result in affection or alienation, depending not so much on academic but on personal experiences. This personal factor, they felt, was what they had previously neglected. International students had been largely left to their own devices without recourse to systematic language preparation, excursions, let alone "international houses." While this had already seemed inadequate before the war, it was even less appropriate in the 1920s, when many students were rather less fluent in German and stayed for shorter periods of time. Rescuing them from isolation, bringing them into contact with German culture and people, and affording them the opportunity to build friendships with their German peers - in short, creating a "hospitable university" - was now a serious goal.

Although state offices increasingly organized student exchanges, the question of hospitality fell primarily to the German universities and student circles themselves. After 1927, Reinhold Schairer and his International Academic Office began to systematically build international clubs, offices, and houses at German universities based on American or French models like the Rockefeller International House in New York City (est. 1924) or the Cité Internationale Universitaire in Paris (est. 1925). ${ }^{128}$ These international institutions were intended to help international students with admissions, language courses, and suitable accommodation. ${ }^{129}$ Most importantly, Schairer emphasized, they were to provide "active hospitality to pierce the personal and social isolation often present [for international students]."130 By organizing dinners and excursions, by offering a meeting place for German and international students, they hoped, as Schairer acknowledged, to foster the "personal connections that can be of

128 On these initiatives, see Guillaume Tronchet, "Diplomatie universitaire ou diplomatie culturelle? La Cité internationale universitaire de Paris entre deux rives (1920-1940)," in La Babel étudiante. La Cité internationale universitaire de Paris (1920-1950), ed. Dzovinar Kévonian and Guillaume Tronchet, 59-88 (Rennes, 2013); and Liping Bu, Making the World Like Us, chapter 3. 129 In this development, America served as an important point of reference. Though France, with its wide hospitality structure, remained both a model and motivation for German initiatives, German hospitality advocates were no less impressed by the American system. Visiting America in 1925, Reinhold Schairer admired the YMCA-organized welcome committees at American universities and was so impressed by the Rockefeller-funded International House in New York City (est. 1924) that he secured its architectural blueprints and sought to win first Rockefeller, then (and more successfully) industrialist Carl Duisberg for similar projects in Germany. Friedrich Beck, who ran the international office at Munich University, felt that the popularity of American universities were due to the fact that "barriers between American and foreign students are hardly noticeable and there exists a free, happy fellowship among students." See Friedrich Beck, "Ausländerstudium im Ausland und in Deutschland," Süddeutsche Monatshefte 28, no. 4 (Jan. 1931): 246-253, 250; on French influences, see American Institute in Munich to AA [Terdenge], Aug. 20, 1929, "Zuschuss für das Amerikanische Institut München," PA R 65788 a.

130 Schairer, Denkschrift (streng vertraulich) Gedanken zu der Frage des Ausländerstudiums in Deutschland - ca. Juni 1926, BArch R8088/799. 
great import in human, cultural and political terms, especially to Germany in its current situation." ${ }^{131}$ Though Schairer rejected the idea of subjecting foreign students to anything resembling political propaganda, he was still convinced of the political, even short-term, benefits of this work: a greater familiarity with postwar Germany, for instance, would quite naturally dispel the myth of German prosperity and challenge the nation's capacity to pay reparations. ${ }^{132}$

In institutional and quantitative terms, at least, this strategy was remarkably successful. The network of international offices at German universities grew rapidly from a handful in 1920 to 23 in 1930 and assumed an ever more comprehensive role in organizing international educational relations. By the end of the decade, many of them were arranging summer courses for foreign students and hosting numerous (usually American) student travel groups, often in cooperation with international organizations like the League of Nations or the International Student Service. ${ }^{133}$ At Munich University, the director of the international office Friedrich (Fritz) Beck used his substantial local and international network to systematically develop global student relations. ${ }^{134}$ In line with an international club (also headed by Beck) and an international student house, funded by industrialist Carl Duisberg, the Munich office offered a wide range of social activities to international students, organized highly successful summer courses, and helped to turn Munich into a hub of German cultural diplomatic activity in the 1920s. ${ }^{135}$ The aim of his "concerted hospitality," Beck explained to his benefactors at the Wilhelmstrasse, was "to conduct a German cultural propaganda in the very best sense of that word."136

It is difficult to assess with any certainty how study in Germany affected American students. Without access to a large and reliable sample of student impressions, no conclusive analysis is possible. Yet, published impressions suggest that their experiences were overwhelmingly positive. While German efforts never succeeded in creating a tight-knit American college atmosphere, a considerable number of American students expressed great enthusiasm for

131 Sitzung des Vorstandes der Wirtschaftshilfe der Deutschen Studentenschaft, Jan. 1926; Allgemeiner Bericht Dr. Schairers über seine Amerika-Reise, BArch R 149/235.

132 Reinhold Schairer, Die Studenten im Internationalen Kulturleben. Beiträge zur Frage des Studiums in einem Fremden Lande (Münster, 1927), 112.

133 The Munich International Office served as an official branch of the International Student Service.

134 On Beck and the early years of the Munich office, see Veronika Diem, "Friedrich Beck (1889-1934) und die Gründungsgeschichte des Münchener Studentenwerks," in Die Universität München im Dritten Reich, ed. Elisabeth Kraus, 1:43-71 (Munich, 2006).

135 Duisberg's involvement in this regard is little researched. Indeed, he sponsored a number of such student houses. On the occasion of the 400-year university jubilee in Marburg, for example, he donated a Carl Duisberg House to bring together a select group of German and international students; on Duisberg's role in student affairs, see Werner Plumpe, Carl Duisberg, 1861-1935. Anatomie eines Industriellen (Munich, 2016), 651-660.

136 Studentenhaus München to AA (Terdenge), Oct. 11, 1927, PA R 64011. 
the independence of the German system. They found Germany clean and orderly and appreciated Berlin's art and music scene as much as quaint university towns. Though they were increasingly proud of America's own traditions, American students professed little of the patriotic zeal of their German counterparts. Indeed, while German students in the United States frequently complained about the widespread complacency about international affairs on the American campus, Americans were shocked by the politicization of German university life. Many left with a much deeper appreciation of the war's impact on Germany, at times taking away just the sort of lessons Germans hoped they would: "There is an excellent friendly feeling everywhere for all Americans," one American student wrote to his parents from Berlin in August 1927, "[o]ur alliance with France in the war was only temporary and accidental, whereas with Germany we have a much closer actual connection and kinship."137 At least in some instances, then, the efforts to geopoliticize the student were quite successful.

\section{National Interest and International Understanding(s)}

Before we continue to other elements of German academic diplomacy, we must emphasize the remarkable and remarkably rapid re-interpretation of international students, which made this expansion of student exchanges possible in the first place. Within just a very few years, the spies, profiteers, and competitors of the early 1920 came to be seen as informal envoys and long-term friends of Germany. To be sure, this was a selective, never entirely uncontroversial, process. Attitudes toward international students continued to depend on their national and increasingly also on their racial background. ${ }^{138}$ As late as October 1929, Schairer observed "a seclusion of wide circles of academic life, especially of students, from the foreigner." At the same time, advocates of international understanding like himself often found themselves maligned as nationally unreliable "pacifists." ${ }^{39}$ Still, by the late 1920s, German politicians, professors, and

137 Quoted in James Colwell, “The American Experience in Berlin during the Weimar Republic” (PhD Diss., Yale University, 1961), 217; see also the experiences of Shepard Stone in Volker Berghahn, America and the Intellectual Cold Wars in Europe: Shepard Stone between Philanthropy, Academy, and Diplomacy (Princeton, 2001), 8-10.

138 As one liberal German professor remarked with regard to the rampant anti-Semitism at German universities: "the entire mentality, if I may use this modern expression, at German universities does not lend itself to exert any force of attraction to the foreigner"; Julius Michelsohn to Dr. Schlink, Jan. 8, 1928, BArch R 8088/810.

139 Tätigkeitsbericht der Deutschen Akademischen Auslandsstelle des Verbandes der Deutschen Hochschulen (Feb. 15 to Oct. 1929), BArch R8088/804; student leaders had reacted to plans regarding international students by the Hochschulverband in late 1926 with the announcement that they would respond with "iron opposition"; Schairer to Scheel, Dec. 14, 1926, BArch R 8088/799. 
diplomats, sometimes even in conservative circles, had come to accept the international student as a national asset, not a liability. ${ }^{10}$ Even someone as critical of international reconciliation as Sinologist Otto Franke of the University of Berlin, the architect of the Association of German University's scientific "counter-boycott", welcomed international students. He later remarked in his autobiography, "It is only a small step from studying the language, literature, the weltanschauung of a people to a political and economic inclination [toward that people]; a step so small that it will always be taken." ${ }^{141}$

As Franke's words illustrate, Germany's embrace of international students aligned international outreach and national ambitions. Whereas German organizations like the DAAD duly stressed aspects of reconciliation in addressing American audiences, they cast their work almost exclusively in terms of national advantage in a German context. ${ }^{142}$ In developing a meaningful "cultural encounter" between nationally minded elites, the DAAD aimed not at "international understanding" and the national self-denial this might have entailed, but at "international understandings" that could engender mutual recognition of national traits and differences. ${ }^{143}$ For many Germans, in short, the objective of international education was not world peace but a just peace for Germany. It was Foreign Minister Gustav Stresemann - unrivaled in reconciling national interest with international understanding - who exemplified this increasingly prevalent way of thinking about international students in a 1929 Reichstag speech. Countering nationalist criticism that German universities ought to be for Germans only, he asserted:

How untrue is the idea that somehow spots are taken from German students! How wrong it is not to appropriate the funds, if one can, to give these visiting students comfortable gathering places and to make everything easier for them. This will in the end only benefit future German generations. Why are there so many people in the world affectionate toward Germany? Because they have been here before, because they have taken in the German spirit, because that spirit has tied itself to their soul and because this has created an affinity for our country. And thus, no matter how difficult the entire financial situation will become, please think of one thing: This [support for international education] is not,

140 E. g., "Bericht über die fünfte Hauptversammlung der Deutschen Akademie in Berlin," Mitteilungen der Deutschen Akademie 2, no. 5 (Nov. 1930): 277-302, 291; Heinrich Schnee in Verhandlungen des Deutschen Reichstags. 185. Sitzung, June 27, 1930, 5912C.

141 Otto Franke, Erinnerungen aus Zwei Welten (Berlin, 1954), 119-120.

142 It was, for example, very specific that it was not a "center for the brotherhood of mankind" (a Menschheitsverbrüderungszentrale), quoted in Paul G. Graham, "American German Student Exchange," Monatshefte für deutschen Unterricht 20, no. 7 (1928): 218-220, 220.

143 On this doctrine of "cultural encounter," see Volkhard Laitenberger, "Theorie und Praxis der 'Kulturellen Begegnung zwischen den Nationen' in der deutschen auswärtigen Kulturpolitik der 3oer Jahre," Zeitschrift für Kulturaustausch 31, no. 2 (1981): 196-206. 
as one often says in quotation marks, an "internationalizing politics", this is the best German politics, a politics of international understanding in the German interest. ${ }^{144}$

To sum up, the 1920 s witnessed a clear trend toward institutionalizing and instrumentalizing student migrations. By the late 1920s, a comprehensive system of organizations and committees had come to manage crucial parts of international education in order to render them politically useful. In carefully selecting German students as informal ambassadors and in providing active hospitality to American students, these actors had established the major contours of a student-oriented academic diplomacy. In just a few years, international educational relations had developed into one of the most dynamic fields of German public diplomacy. In the context of Germany's desire to break the inter-Allied hold over the United States, this "geopoliticization" of the student played a critical role that is too often neglected in the historical scholarship.

\section{Academic Diplomacy and “Academic Peace": Transatlantic Network-Building, Cultural Demobilization and Diplomacy on Campus, 1924-1930}

Students, however, were never the sole target of German academic diplomacy. No matter how wise an investment, these programs would not bear political fruit for years, even decades to come (if at all). Though international education was to provide a basis for future transatlantic influence, German policymakers also wished to harness the prestige and contacts of German professors and universities for more immediate objectives. Despite the sobering experiences of the postwar years, they never relinquished the notion that German academia had an important role to play in reconnecting and representing Germany across the Atlantic. But whereas educational relations were redeveloped in an increasingly formalized, institutionalized, and state-organized manner, broader academic contacts largely continued to elude systematic management. ${ }^{145}$ Accordingly, German diplomats beat a tactical retreat from an institutional and multilateral approach toward developing bilateral and informal ties with the United States. The larger-scale objective, of course, remained unchanged: to rebuild academic networks, to demobilize minds, and, ultimately, to use Germany's academic prestige to improve its image and influence abroad.

144 Stresemann in Verhandlungen des Deutschen Reichstags, Bd. 425, June 24, 1929, 2881D.

145 For a glimpse of some of the vitriolic professorial rhetoric prevailing even in the mid-1920s, see Georg Karo, "Deutsche Wissenschaft und Ausland," Mitteilungen der deutschen Akademie 7 (Sep. 1926): 231-39, 231. 
To this end, Berlin systematically cultivated academic partners on both sides of the Atlantic. To be sure, as academic lines of communication and cooperation were successively reopened in the mid-1920s, there was usually little opportunity or need for official involvement. Nevertheless, German ministries and semiofficial bodies like the Amerika-Institut became remarkably involved in rebuilding transatlantic connections, especially wherever these connections promised to generate a broader, quasi-diplomatic impact. Here, too, American cultural internationalists were identified as the most important transatlantic partners. The international relations round tables, lecture tours, visiting professorships, and research programs of organizations like the Carnegie Endowment for International Peace, the Foreign Policy Association, the Council on Foreign Relations, the Institute of Politics at Williams College, and the many international-minded American universities promised unique access to influential Americans and a pulpit for Germany's revisionist message. ${ }^{146}$

In Germany, official efforts to rebuild transatlantic ties and promote German positions also relied on a distinct group of liberal German educators. While the German professoriate as a whole only reluctantly lent itself to a German policy of reconciliation, the Foreign Ministry found strategic partners in men like the Prussian Minister of Culture Carl Heinrich Becker; economists like Moritz Julius Bonn (Handelshochschule Berlin), Gerhart von Schulze-Gaevernitz (Freiburg), and Alfred Weber (Heidelberg); theologians like Adolf Deissmann (Berlin) and Adolf von Harnack (Berlin); geographers like Albrecht Penck (Kiel); Anglicists like Johannes Hoops (Heidelberg); historians like Hermann Oncken (Berlin) and Otto Hoetzsch (Berlin); the political scientist Ernst Jäckh (Berlin); legal scholars like Albrecht Mendelssohn Bartholdy (Hamburg) and Walther Schüking (Kiel); and scientists like Albert Einstein (Berlin), Max Planck (Berlin), Fritz Haber (Berlin), and Arnold Sommerfeld (Munich). Collectively, their names feature prominently in the files of the Foreign Ministry as those to approach when an important article needed to be written, an international conference or round table attended, a lecture held, a visiting professorship assumed, a position on an international committee filled, or a favor (like an honorary degree) secured from a university faculty. ${ }^{147}$ Throughout the 1920s, they were the people who could be trusted to use their

146 The way that German officials thought about U.S. internationalists is exemplified by their interest in the Williamstown Conference, an international relations conference held annually at the Institute of Politics at Williams College. In 1925, for example, the German embassy attested that Williamstown had a "great and steadily growing importance - despite its not always very high (intellectual) level - as a means of propaganda." German Embassy, Washington, to AA, Oct. 11, 1925, "Diesjährige Tagung des Institute of Politics in Williamstown," PA R 80297.

147 See, for example: AA to German Embassy, Washington, Feb. 7, 1923, PA R 80295; Sommerfeld to AA, Report, May 5, 1923, PA R 63383; Einberufung einer Sitzung im AA zur Klärung des Verhältnisses zw. deutscher Wissenschaft und Ausland am Feb. 61925 , PA R 64981; on Einstein alone, see PA R 64677 and PA R 64678; on Jäckh, see his files at the Botschaft Washington, 1527; 
academic authority to articulate German revisionist positions for an American public.

These liberal professors epitomized the type of the peaceful revisionist described above. For all their individual and professional differences, they shared a number of common convictions that set them apart from their professorial peers. Ideologically, most of them belonged to what Fritz Ringer has identified as the "modernist camp" of German professors, taking a progressive stance on domestic and international affairs. ${ }^{148}$ Though their patriotism and missionary self-understanding had prompted many of them to place themselves in the service of wartime propaganda after 1914, they had soon begun to clash with their "orthodox" peers over German war aims, submarine warfare, and parliamentary reform. ${ }^{149}$ Few had any special enthusiasm for mass democracy, yet they usually belonged, as the historian Herbert Döring has phrased it, to "that small minority of German professors who came out publicly in support of the Weimar constitution" - and its conciliatory foreign policy. ${ }^{150}$ The experience of 1923, in particular, convinced many of them that the continuation of an intransigent policy course - in cultural as in political affairs - was bound only to further isolate Germany. Whereas many of their "orthodox" peers now sought closer ties to Russia as a counterweight to Western reconciliation, personal, professional, and ideological reasons spurred them to support the republic's pro-Western orientation, especially with regard to the United States and Great Britain. ${ }^{151}$ Needless to say, even the most international-minded of them understood their American networking and lecturing work as a distinct step toward the revision of Versailles. As the economist Schulze-Gaevernitz remarked after his American lecture tour in 1924, "after all, I consider the influencing of [American] universities - given the lack of any other aristocratic class - a more important field for the formation of public opinion in the long run; it is likely that from them a reversal in favor of a just reorganization of Europe (in terms of the armistice) will emanate and assert itself." ${ }^{152}$ Individually, as well as

German Embassy, Washington, to AA, April 23, 1926, PA R 64709; AA to German Embassy, Washington, June 1925, PA R 64266.

148 Ringer, The Decline of the German Mandarins.

149 Klaus Schwabe, "Zur politischen Haltung der deutschen Professoren im 1. Weltkrieg," Historische Zeitschrift 193 (1961): 601-634.

150 Döring, Der Weimarer Kreis, 6.

151 After the war, to be sure, this longer-standing interest was often reinforced by professional ambition: many of them worked in the fledgling fields of international studies and political science, which tended to be further developed, more greatly appreciated, and much more richly funded in the United States. For close ties of a number of these scholars to the Rockefeller Foundation(s), see Rietzler, "Philanthropy, Peace Research, and Revisionist Politics"; Martin Bulmer and Joan Bulmer, "Philanthropy and Social Science in the 1920s: Beardsley Ruml and the Laura Spelman Rockefeller Memorial, 1922-1929," Minerva 19, no. 3 (1981): 347-407, esp. 388.

152 Letter Schulze-Gaevernitz [1924], PA R 64708. See also the instructive report written by Professor Hoetzsch after his lectures at the Williamstown Conference: "Aufzeichnung von Prof. 
through the handful of internationally oriented institutions many of them were connected to - such as Alfred Weber's Institute for Social and Political Sciences (est. 1922) at Heidelberg University or Ernst Jäckh's Hochschule für Politik in Berlin (est. 1920) - they set out to rebuild Germany's transatlantic academic networks. ${ }^{153}$

\section{Building Alternative Networks: President Butler in Berlin}

The interplay of private and official German interests in this endeavor is best illustrated by the German effort to reconnect with the Carnegie Endowment for International Peace (CEIP) in 1925/26. Unlike the Rockefeller Foundation, which had begun funding German medical (and later also social science) research from late 1922, the Carnegie Endowment had remained more reserved toward Germany. ${ }^{154}$ At the same time, its heavily publicity-oriented work appealed particularly to German policymakers with their revisionist objectives. True to its mission to "multiply contacts and circulate knowledge," the CEIP funded and organized internationally minded institutes, conferences, lecture tours, libraries, and magazines to educate Americans on and connect them to foreign affairs. In the aftermath of the war, it also significantly expanded its European operations, rebuilding its Paris-based Centre Européen into an influential transatlantic knowledge hub. ${ }^{155}$ By fall 1925, Germany's ambassador in Washington, Ago von Maltzan, advocated building closer relations with the CEIP because it offered "very remarkable opportunities to influence public opinion, especially the intellectual circles, in all countries." According to Maltzan: "We cannot pass up the chance to work toward an attitude favorable to Germany."156

Dr. Otto Hoetzsch, M.d.R über seine Teilnahme am 'Institute of Politics' in Williamstown im August 1928 und verwandte Fragen (Dec. 1928)," BArch Koblenz, NL Morsbach, 11.

153 These included Bernhard Harms's Institut für Weltwirtschaft and Seeverkehr (est. 1914) at Kiel University, Ernst Jäckh's Hochschule für Politik (est. 1920) in Berlin, Mendelssohn Bartholdy's Institut für Auswärtige Politik (est. 1923) at Hamburg University, and Alfred Weber's Institute for Social and Political Sciences (est. 1922) at Heidelberg University.

154 On the activities of the Rockefeller Foundation in Germany, see Helke Rausch, "US-amerikanische 'Scientific Philanthropy' in Frankreich, Deutschland und Großbritannien zwischen den Weltkriegen," Geschichte und Gesellschaft 33, no. 1 (2007): 73-98; Rietzler, "Philanthropy, Peace Research and Revisionist Politics"; Judith Syga-Dubois, Wissenschaftliche Philanthropie und transatlantischer Austausch in der Zwischenkriegszeit. Die sozialwissenschaftlichen Förderprogramme der Rockefeller Stiftungen in Deutschland (Cologne, 2019).

155 German Embassy, Washington, to AA, "Jahresbericht des Carnegie Endowment for International Peace, 1924," Apr. 23, 1925, PA Botschaft Washington, 1548.

156 German Embassy to AA, "Carnegie Endowment for International Peace," Sep. 11, 1925, PA Botschaft Washington, 1548. 
At that point, a number of German institutions were already seeking closer ties with the Carnegie Endowment. The Hochschule für Politik in Berlin, in particular, sought to gain access to Carnegie funds and networks. Founded in 1920 by a group of liberal professors, publicists, and officials, the reform-oriented Hochschule aimed to educate Germans on democratic government and international relations, and by the mid-1920s had also been tasked with training the attachés of the German Foreign Service. Its director, journalist-turned-professor Ernst Jäckh, had already championed an alternative foreign policy during the Wilhelmine Era, and the ineptness of German politics after 1914 had only convinced him that Germans needed to be acquainted with foreign, and not least American, psychology. After the war, Jäckh, previously an expert on the Ottoman Empire, thus turned his attention to the United States. After 1924, he went on annual lecture, networking, and fundraising trips across the Atlantic, where he rigorously promoted a "new Germany" and a cultural alliance between the two "sister republics," quickly establishing a reputation as one of the republic's foremost representatives. ${ }^{157}$ Appealing masterfully to American desires to help a democratic and peaceful Germany, Jäckh ultimately secured substantial support for the Hochschule and by 1925 had prepared the ground for closer cooperation with the Carnegie Endowment under its new president Nicholas Murray Butler. ${ }^{158}$

The time for closer cooperation seemed to have come in early 1926 when Butler announced a visit to Berlin on his European summer tour. The visit was not an informal sojourn but a carefully orchestrated affair with the aim of renewing Butler's German contacts (he had not been to Germany since 1912) to prepare for the expansion of the Carnegie Endowment's European program. There can be no doubt that both sides had a strong interest in renewed cooperation. In light of the Locarno treaties and Germany's impending admission to the League of Nations, the CEIP's essentially nonexistent relationship with German leaders had become an embarrassment and a hindrance to its peace-building agenda. ${ }^{159}$ Already a year earlier the American trustees had laid the foundation for closer relations with Germany when they had tightened American control over the Centre Européen in Paris and shifted the focus from

157 Ernst Jäckh, Amerika und Wir. Amerikanisch-Deutsches Ideenbündnis (Stuttgart, 1929); on his reception in the United States, see Rose C. Feld, "New University Trains Germans for Politics; Dr. Jäckh, Its President, Comes to Urge Cooperation between Americans and Future Leaders in this Country. His Hope Is for Youth," New York Times, Dec. 20, 1925, XX8.

158 Copy: Ernst Jäckh, American Cooperation for the support of Democratic Organization in Germany ca. Dec. 1924, PA 80297; already during the spring of 1926 he went on a Carnegie-sponsored lecture tour through the United States speaking on the Weimar Republic.

159 Jens Wegener, "An Organization, European in Character' - European Agency and American Control at the Centre Européen, 1925-1940," in American Foundations and the Coproduction of World Order in the Twentieth Century, ed. John Krige and Helke Rausch, 37-60 (Göttingen, 2012), 55-56. 
cooperation with pacifist groups to getting in touch with liberal circles closer to European decision-making elites. ${ }^{160}$ From the official German perspective, too, contacts with the CEIP seemed highly desirable, especially since it had recently reorganized, providing a promising opportunity to end France's alleged monopolizing of American sympathy and money. ${ }^{161}$ As Butler was one of the most prominent Americans of his time, reintroducing him to postwar Germany would contribute greatly toward recalibrating the academic world. ${ }^{162}$

The entire episode, however, revealed the significant psychological hurdles still in place. German officials and professors alike scrutinized Butler's wartime behavior and found it - to put it mildly - wanting. Although Butler, in 1919, had declared that he had not forgotten the "amazing self-prostitution" of German scholars during the war, his own anti-German pronouncements had not been forgotten either. The fact that Butler had been educated in Germany and highly honored by the Imperial government rendered his wartime behavior only all the more offensive. Even the conciliatory Amerika-Institut had to admit that Butler epitomized the "disloyal type."163 The first letter Butler had addressed to Foreign Minister Stresemann in April 1925 had been "purposefully left unanswered" (as an internal memorandum made clear) by the Wilhelmstrasse for more than six months, and it was only at the repeated instigation of Ambassador Maltzan that it was eventually answered at all. ${ }^{164}$ The full psychological ambivalence of transatlantic relations thus came to the fore in the extensive planning that preceded Butler's visit to Berlin. The treatment of this influential but "disloyal" American would be a litmus test for Germany's willingness to subordinate its injured pride to realpolitik.

The vehemence of opposition to Butler's visit is perhaps best discerned by how intensely interested circles pleaded that his wartime behavior should be ignored. Shortly before Butler's visit, the Amerika-Institut, for example, submitted two long memoranda to the German ministries, essentially asking them to overlook his wartime "disloyalty" to make way for a transatlantic intellectual rapprochement. ${ }^{165}$ At that point (mid-1926), the Foreign Ministry had already arrived at similar conclusions. Aside from Butler's recognized importance, two

160 Wegener, "An Organization, European in Character," 42-44.

161 Erich von Prittwitz und Gaffron, first German member of the new European advisory council, characterized the American director Dr. Earle Babcock as "personally very pleasant and with an appreciable understanding of German interests"; Amerika-Institut to AA, Nov. 14, 1925, PA R 64999.

162 A detailed description of German aims in Aufzeichnung (Fuehr), June 21, 1926, AA, R 80299; see also Stresemann to German Embassy, Washington, May 10, 1926; and German Embassy, Washington, to AA, May 18, 1926, in PA Botschaft Washington, 1551.

163 Amerika-Institut [Dr. Bertling] Memorandum II, May 26, 1926, PA R 64909.

164 German Embassy, Washington, to AA, Oct. 14, 1925, PA Botschaft Washington, 1548.

165 K. O. Bertling penned a long memorandum that sought to relativize Butler's wartime behavior and underline his importance in American education; Amerika-Institut [Dr. Bertling] Memorandum II, May 26, 1926, PA R 64909. 
other factors played a decisive role. For one, Butler had provided a token of his goodwill by appointing Erich von Prittwitz und Gaffron (a brother of the later German ambassador to Washington) to the Carnegie Endowment's European advisory board and had sidelined the CEIP's pacifist "special correspondents," who had always been critical of the German government. ${ }^{166}$ In addition to this behind-the-scenes confidence-building measure, Butler had also grown more vocal about his renewed sympathy for Germany and had publicly underlined his admiration and appreciation for German learning and culture on several occasions during $1925{ }^{167}$ At a time when the political Right was always quick to attack German gestures of conciliation as undignified attempts at ingratiation, Butler's gestures cleared the Foreign Ministry of any such motive. ${ }^{168}$ Weighing in on Butler's visit, the America department advised that "given his great standing in the United States as well as in Paris and London, we only stand to benefit from having good, or at least, normal relations with Dr. Butler. It is thus politically important that his upcoming visit to Berlin - where he can expect no less and no more than what is commensurate with his standing and importance - proceed in an entirely harmonious way."169

Realpolitik gained the upper hand, indeed. The dinners and receptions given in Butler's honor in Berlin in June 1926 brought together the top tier of German bureaucracy, business, and science. Stresemann met him for an hour-long conversation, which apparently impressed Butler deeply. ${ }^{170}$ The visit, clearly a rather delicate affair for all involved, proved a wise investment because it opened the doors of the institutions managed, formally or informally, by the Carnegie enterprise, to Germany. In the coming years, the CEIP would introduce author Thomas Mann, Prussian Minister of Culture C. H. Becker, and Reichsbank president Hjalmar Schacht to American audiences and invite groups of American journalists and academics to visit Germany. Just one month after Butler's visit, Moritz Julius Bonn, an economics professor and German government advisor on reparations, was added to the CEIP's European advisory board, thus granting Germany the same number of seats as Great Britain. ${ }^{71}$

166 AA to German Embassy, Washington, July 27, 1925, PA Botschaft Washington, 1548.

167 Evidence of Butler's goodwill was also presented in K.O. Bertling's memorandum; see Amerika-Institut [Dr. Bertling] Memorandum II, May 26, 1926, PA R 64909.

168 Aufzeichnung (Fuehr), June 21, 1926, PA R 80299.

169 Ibid.

170 In 1930, Butler would initiate a Stresemann Memorial, a peace academy in Berlin, in Stresemann's honor; see CEIP, Box 324 Folder Stresemann Memorial, Columbia University, Rare Book \& Manuscript Library Collections.

171 Statement by the President of the Carnegie Endowment regarding the new work of the Endowment in Europe, Aug. 23, 1926, CEIP, 67 Box 97, Report, Butler, Columbia University, Rare Book \& Manuscript Library Collections. Bonn's liberal persuasion, pro-American orientation, and close ties to Weimar governments made him an attractive choice for both sides. Bonn himself experienced his work on the European Advisory Council as "little satisfying"; Bonn, So macht man Geschichte, 295-296. 
Back in the United States, Butler also announced the establishment of a Carnegie Chair at the Hochschule für Politik, which was to bring American and European professors to Berlin to lecture on international relations. Only the second Carnegie Chair ever to be established, this step symbolized the Carnegie Endowment's new commitment to including Germany in its network-building and knowledge-sharing endeavors. As Butler put it, this chair would show that "Germany once again has the rightful place in American public life that she has had for more than 100 years." ${ }^{172}$

The episode illustrates the systematic private and official attempts on the part of Germans to reconnect with America; at the same time, it once more underlines the often profound obstacles they first had to surmount. ${ }^{173}$ Butler's visit, despite the prevalent rhetoric of goodwill surrounding it, succeeded primarily in building alternative, at best semi-academic, networks - however influential they were. It is notable, for example, that Butler's reception took place at the Hochschule für Politik, an institution outside mainstream academia, not at the University of Berlin. Butler also gave no academic speeches, nor did he receive any particular academic attention, let alone honors. To be sure, this had never been his primary intention. He visited Germany not as the president of Columbia University but as president of the Carnegie Endowment; not to familiarize himself with academics but with Weimar leaders. Yet Butler's dual roles as university president and Carnegie officer were not usually separated so very neatly. ${ }^{174}$ The truth of the matter was that Weimar's strategy of peaceful revisionism, especially when it involved "disloyal types" like Butler, was still struggling to find support among the academic establishment. As late as 1929, the historian Eduard Meyer (admittedly a particularly irreconcilable character) felt America, "with its inner dishonesty and moralistic arrogance" - clearly Butler's America - to be "the most disgusting of our enemies."175

On the American side, too, distrust concerning the actual degree of democratization among German academics remained pronounced. ${ }^{176}$ It was telling that the Carnegie Endowment chose to base its German networks not on mainstream universities or even prewar bodies like the Amerika-Institut

172 Clipping: “Eine Unterredung mit Präsident Butler," Berliner Tageblatt, June 24, 1926, PA Botschaft Washington, 1548.

173 On questions of German psychology and foreign policy toward the United States in the 1920 more generally, see Berg, Gustav Stresemann, 233-240.

174 Butler was, after all, a man who routinely fashioned himself America's cultural ambassador to Europe and received honorary degrees wherever he went.

175 Alexander Demandt, "Eduard Meyer und Oswald Spengler," in Eduard Meyer. Leben und Leistung eines Universalhistorikers, ed. William M. Calder III and Alexander Demandt, 159-181 (Leiden, 1990), 169.

176 See Duggan to Nicholas Murray Butler, Oct. 3, 1925, Attachment: Report on European Visit, Oct. 1925, CEIP, Box 231 3-5 Folder: Institute of International Education, Columbia University, Rare Book \& Manuscript Library Collections. 
but on the reformist Hochschule für Politik, one of the Weimar Republic's typical "outsider institutions." ${ }^{177}$ Although the Hochschule's agenda and its unique access to (future) diplomats rendered it especially suitable for the endowment's plans to reform international politics, America's cultural internationalists doubtlessly preferred to support institutions akin to their own democratizing agenda, few of which could be found in the German university landscape. ${ }^{178}$ While Butler's visit can thus be understood as a symbolic step in transatlantic "network-building," it bypassed a considerable part of Germany's still irreconcilable academic establishment. As a result, this episode tells us a great deal about how the Foreign Ministry and its professorial partners rebuilt alternative transatlantic ties to loosen the inter-Allied hold on America, yet we need to look elsewhere to understand how a broader "academic peace" actually developed.

\section{Cultural Demobilization and the Academic World}

As much as German authorities sought to aid the transatlantic academic rapprochement (as evidenced by Butler's visit), there was an undeniable demobilization of academic minds by the late 1920s. The causes for this ran much deeper than any official or private effort.

On the American side, this demobilization first became apparent in the context of the Ruhr occupation and accelerated thereafter. Wider political and economic developments, including the London Reparations Conference of 1924, the "spirit of Locarno" of 1925, and Germany's admission to the League of Nations in 1926, certainly had a marked impact on the normalization of sentiments toward Germany both in academia and among the general American public. ${ }^{179}$ Yet growing American disenchantment with the outcome of the war in general and American involvement in particular, also aided this process. Harold Laswell's groundbreaking 1927 study on wartime propaganda, the publication of wartime memoirs, and the research of a group of revisionist American historians who challenged common notions of German war guilt all contributed to a re-evaluation of U.S. intervention. ${ }^{180}$ By the late 1920s, a greater number of publicists and academics were beginning to wonder whether Amer-

177 See Peter Gay, Die Republik der Außenseiter. Geist und Kultur in der Weimarer Zeit, 19181933 (Frankfurt, 1970), 63-65.

178 Just two years later the Rockefeller Foundation would go a similar, if decidedly less public, way by funding the Lincoln Foundation; Malcolm Richardson, ed., Weimars transatlantischer Mäzen: Die Lincoln-Stiftung 1927-1934. Ein Versuch demokratischer Elitenförderung in der Weimarer Republik (Essen, 2008).

179 See Müller, Weimar im Blick, 253-275; and Schoenthal, "American Attitudes toward Germany," $182-215$.

180 Adler, “The War Guilt Question and American Disillusionment, 1918-1928," 1-28. 
ica had not actually been lured into the war, whether its cause had really been so noble, and, correspondingly, whether German motives had been so vile. According to the German ambassador to Washington, the tenth anniversary of America's entry into the war in April 1927 was marked by "strong disillusionment." 181

These increasing doubts about America's intervention in and Germany's responsibility for the war mitigated some of the harsher sentiments of the postwar years. In some American academic circles, it also set off a process of soul-searching concerning their own wartime behavior. Serious German blunders such as the "Manifesto of the 93" lost some of their sting as a younger generation of left-leaning American scholars critically analyzed American academia's own wartime overreactions. ${ }^{182}$ Though the desire for critical self-reflection among American academics should not be overstated, the general disillusion certainly worked in Germany's favor. As Americans returned to imagining all of Europe as a cesspool of power politics, Germany - in contrast to the former Allies - stood only to gain. In this climate, American scholars like Butler were given to adopting a more conciliatory stance toward Germany: many began to remember their happy student days and encouraged younger colleagues to visit. ${ }^{183}$

On the German side, the process of cultural demobilization proved to be considerably more difficult, slower, and more uneven in consequence. German academics were regularly confronted with the real and imagined consequences of Germany's defeat, which thwarted them in their efforts to develop a more conciliatory attitude. But their resentment clearly began to break down in the mid-1920s, especially toward American scholars. While the absence of real political grievances between the two nations favored this development, American gestures of goodwill proved equally important. For German scholars, who carefully registered any international niceties or insults, American postwar aid (Chapter 3 ) had already served to justify closer transatlantic relations. ${ }^{184}$ The first cohort of German academics to return from visits to the United States also reported that their American colleagues overwhelmingly received them in a

181 German Embassy, Washington, to AA, Apr. 7, 1927, “10. Jahrestag des Kriegseintrittes Amerikas," PA R 80141.

182 Charles Angoff, "The Higher Learning Goes to War," The American Mercury, June 1927; C. Hartley Grattan, "The Historians Cut Loose," American Mercury, Aug. 1927.

183 Prof. Dr. Julius Richter, Bericht über meine Vortragsreise an den Universitäten, Colleges und Theologischen Seminaren der Vereinigten Staaten vom 25. Oktober 1924 bis 5 April 1925, PA R 64708; on Butler, see Anlage zum Bericht der Botschaft zu Washington vom 18. November 1925 (Dieckhoff), PA Botschaft Washington, 1548.

184 At a meeting between professors and the Foreign Ministry in February 1925, they agreed to pursue closer relations with the United States, in part because American scholars had been particularly generous and accommodating; Protokoll der Sitzung im Auswärtigen Amt vom 6. Februar 1925 betr. Verhalten der deutschen Gelehrtenwelt gegenüber dem Auslande, PA R 64981. 
friendly and courteous manner. One Königsberg philosopher stated in early 1925: "I have sensed nothing of boycott tendencies in America [...] The respect for German Wissenschaft, its prestige and a recognition of its importance for the big picture continue unimpaired in the United States, in my opinion, and with it the will and desire to develop closer ties. [...] I never [encountered] any sign of rejection, distrust, hostility or affront." 185 The American debate on German war guilt - followed more attentively in Germany than in the United States itself - likewise led Germans to believe that American scholars were moving decidedly toward a more "objective," i. e., pro-German, assessment of this critical issue. ${ }^{186}$ Not infrequently, Germans also (mis)interpreted American disillusionment with the war as a sign of remorse or even recognition of the injustice done to Germany. ${ }^{187}$ It was precisely because German scholars thought in binary categories of "friend or foe" that they increasingly perceived Americans as on "our side." 188

Arguably the most important factor, however, was American pronouncements of renewed intellectual appreciation and gratitude. All militant rhetoric aside, German professors positively ached for international recognition. In this context, the role of Jacob Gould Schurman, the U.S. ambassador to Berlin from 1925 to 1929, cannot be overemphasized. Schurman was one of those educator-diplomats that American history is so rich with. Like the generation of ambassadors before him, the Canadian-born philosopher of Dutch descent had been educated in Göttingen and Heidelberg before becoming a professor and (at age 37) president of Cornell University, a post he held until 1920. At that point, his close affiliation with the Republican Party secured his appointment as ambassador to China and subsequently his "promotion" to Berlin in 1925. The precise reasons for Schurman's appointment to the important Berlin post are not clear. Originally, at least, the Coolidge administration seems to have favored sending yet another businessman. Perhaps Parker Gilbert, the U.S. agent for reparations, and his staff already provided sufficient American economic and financial expertise in Berlin; perhaps no suitable candidate was found. In any case, there is little to suggest that Washington sent a former university president to complement the "economic peace" of 1924 with an "academic peace." But intentions aside, Schurman's appointment had just that result.

185 Beobachtungen und Erfahrungen während eines Aufenthaltes in den Vereinigten Staaten von Amerika, Juni bis Oktober 1924, von Herbert Kraus, PA NL Maltzan, Vol. 47.

186 Günter Moltmann, "Revisionist Historiography in the United States and its Importance for German-American Relations in the Weimar Period," in Deutschland und die USA, 1918-1933, ed. Georg Eckert, 89-101 (Braunschweig, 1968).

187 Stresemann strategically used this argument when he tried to secure an honorary degree for Schurman; see Stresemann to Johannes Hoops, July 22, 1927, PA NL Stresemann, Vol. 56.

188 Entschließungen des 6. Deutschen Hochschultages vom 7 bis 9. März 1929 in München "Zur Kriegsschuldthese," Mitteilungen des Verbandes der Deutschen Hochschulen (1929): 104105. 
Indeed, Schurman understood his German appointment as a mission of cultural reconciliation. ${ }^{189}$ Though he, too, had taken a stance against Germany during the war, the 71-year-old philosopher was obviously delighted in the prospect of settling in Berlin and prepared himself carefully for the post. ${ }^{190}$ Once in Germany, Schurman applied all his public relations skills from his years as an American university president to launching an unprecedented goodwill campaign targeting the German public in general and his academic peers in particular. ${ }^{191}$ Schurman's regular recourse to the "nonpolitical" field of culture is remarkable in this regard. Just as the first postwar ambassadors Alanson B. Houghton (director of Corning Glass) and Otto Wiedfeldt (director of Krupp) had used their economic backgrounds to "talk business" with their German and American peers, so the German-trained professor appealed to Germany's educated elites primarily as a scholar and former German student, as part of the universitas litterarum. While his excellent German language skills and academic credentials already afforded him unrivaled access to German academic life, Schurman combined this advantage of a shared academic background with a masterful grasp of German psychology. He instinctively understood what Germans craved most: outside recognition. ${ }^{192}$

From the very first, Schurman flaunted his high regard for German science and thought. He cited Goethe, Kant, and Luther with ease, took quasi-pilgrimages to the shrines of German classical culture like Königsberg, and praised the profound impact German learning had made on world progress. Above all, Schurman was ready to profess his own personal and America's national debt to German education. In speech after speech, he underlined the influence of German university training on his own and his country's national development and used it to construct a "special relationship" between the two nations. In one of his very first German addresses, which he gave to an American audience

189 See Detlef Junker, "Jacob Gould Schurman, die Universität Heidelberg und die deutsch-amerikanischen Beziehungen," in Semper Apertus. Sechshundert Jahre Ruprecht-Karls-Universität Heidelberg, 1386-1986, ed. Wilhelm Doerr (Berlin, 1985), 3:328-358; see also Maynard Moser, "Jacob Gould Schurman" (PhD Diss., University of California, Santa Barbara, 1976).

190 Upon his return from China, for example, he approached the members of Cornell's German department for information and advice on the state of German culture and academia. A. B. Faust to Harry Elmer Barnes, Mar. 2, 1926, Albert B. Faust Papers, \#14-18-85, Box 4, Correspondence 1920-26, Division of Rare and Manuscript Collections, Cornell University Library.

191 His tenure witnessed the first transatlantic radio communication, the first transatlantic airplane flight, and the first postwar speed records for Germany's transatlantic ocean liner.

192 Schurman to Dwight W. Morrow, Oct. 22, 1925, 3/4/6 Jacob Gould Schurman Papers, Folder 4.2 Cornell University Library, Division of Rare and Manuscript Collections: "There is another thing to be considered. Nobody since 1914 has shown any gratitude to Germany for anything. The German people feel keenly this moral and intellectual isolation. An expression of gratitude from the American people for help given them in the greatest crisis in their history by the greatest of German philosophers [Kant during the Revolutionary War] will, as Stresemann said, produce a quite extraordinary effect upon the mind and feeling of the German people." 
at the Hotel Adlon in July 1925, he set the tone for the quintessential "Schurman speech" of the coming four and a half years. Focusing almost exclusively on his happy student days in Germany, Schurman concluded that the German people were so talented that they would soon rise to international eminence once more. "The war is over!" he closed, "whoever still feels and thinks and speaks in terms of war, such a person is an anachronism and has no place in the world of today. If there ever were two nations that are destined, nay predestined, to be friends - to be close friends - it surely is the U.S. and Germany." The Foreign Ministry found the speech simply "remarkable."193

Schurman's strategy - and a strategy it was ${ }^{194}$ - proved exceptionally successful. Ignoring his long involvement with the Republican Party, German scholars chose to see him as an educator who, like themselves, essentially stood above party politics. The Prussian Minister of Culture, orientalist C. H. Becker, for example, paid tribute to Schurman as a "scholar amongst scholars." $195 \mathrm{By}$ the late 1920s, hardly any academic festivity passed without Schurman in the front row, and there was scarcely any honor he did not receive. ${ }^{196}$ In 1929, he was made an honorary member of the Prussian Academy of Sciences - only the second American ever and the first (enemy) foreigner after the war so honored. ${ }^{197}$ As philosophy professor Eugen Kühnemann wrote upon Schurman's return to the United States in December 1929: "You have been the wonderful representative of all that is best in the spiritual life of your country and have been an ambassador of goodwill and real friendship in our great distress. We all know that in you we have gained a friend who understands us and who will do all in his power to work for a new world in which mankind will do us justice." ${ }^{198}$ Reading contemporary files, one is tempted to give in to the impression that Schurman, more than any other single person, helped to demobilize German academics.

193 Aufzeichnung, July 14, 1925, PA R 80136, Hermann Davidsen, a former Cornell professor and now a member of the Foreign Ministry's America division, was more critical in his personal assessment: see H. Davidsen to A. B. Faust, July 12, 1925, Albert B. Faust Papers, \#14-18-85, Box 4, Correspondence 1920-26, Cornell University Library, Division of Rare and Manuscript Collections.

194 Schurman to Dwight W. Morrow, Oct. 22, 1925, 3/4/6 Jacob Gould Schurman Papers, Folder 4.2 Cornell University Library, Division of Rare and Manuscript Collections.

195 American Embassy, Berlin, to State Dept., Aug. 4, 1927, NARA RG 59 Box 1640 [Schurman] $123 /$ Sch $87 / 210$.

196 At the opening of the Kaiser-Wilhelm-Gesellschaft's Harnack House in 1929, hailed as the rebirth of German science, Schurman not only sat in the front row next to Harnack and Stresemann but was also the only foreigner to address the audience.

197 See the lists of members in http://www.bbaw.de/MitgliederderVorgaengerakademien/chronologisch.html?zeitraum $=1900-1950$

198 Eugen Kühnemann to Schurman, Dec. 28, 1929, 3/4/6 Jacob Gould Schurman Papers, Division of Rare and Manuscript Collections, Cornell University Library. 
By the late 1920s, informal contacts and public declarations of goodwill had gone a long way toward reconciling German scholars with America and vice versa. This matters for the subject at hand because this more cordial climate increasingly paved the way for academic diplomacy that went beyond individual students, scholars, and institutes. As a consequence, it also restored a more representative, quasi-diplomatic function to German universities that finally allowed Weimar to conduct broader academic diplomacy. Nothing illustrates this development more than the honorary degrees awarded to Foreign Minister Stresemann and U.S. Ambassador Schurman in 1928.

\section{Diplomacy on Campus: The Case of Heidelberg, $1928^{199}$}

Not surprisingly, German foreign policymakers had always been interested in the quasi-diplomatic, representative aspects of academic relations. The Foreign Ministry carefully recorded the establishment of international visiting professorships, the bestowal of honorary degrees, and the celebration of academic jubilees in its files. As scholars have recently shown - and as 1920 s diplomats knew well - such academic practices were significant acts of communication and representation, invoking and confirming not only the Weltgeltung deutscher Wissenschaft (world influence of German science) but also serving discrete national interests. ${ }^{200}$ By showcasing German intellectual traditions and their international esteem, they advanced Germany's position in the peaceful competition for prestige and influence. But while the Wilhelmstrasse never tired of analyzing the political benefits other countries reaped from the quasi-diplomatic practices of their universities, Berlin itself had benefited little. Professors and students eagerly celebrated the allegedly "apolitical" traditions of the Reich (the day of the proclamation of the Wilhelmine Reich, January 18, was declared a dies academicus in 1921), yet they decidedly lacked enthusiasm for the "political" celebrations of the Weimar Republic and its black-red-gold

199 I borrow that phrase from Thomas Adam and Charlotte Lerg, "Diplomacy on Campus: The Political Dimensions of Academic Exchange in the North Atlantic," Journal of Transatlantic Studies 13, no. 4 (2015): 299-310.

200 See Charlotte Lerg, "Die Ehrendoktorwürde im Dienste der transatlantischen Diplomatie. Politische Dimensionen einer akademischen Praxis im 20. Jahrhundert," in Akademische Wissenskulturen. Praktiken des Lehrens und Forschens vom Mittelalter bis zur Moderne, ed. Martin Kintzinger and Sita Seckel, 301-322 (Basel, 2015); Pieter Dhondt, "Introduction. University History Writing: More than a History of Jubilees?" in University Jubilees and University History Writing. A Challenging Relationship, ed. Pieter Dhondt, 1-17 (Leiden, 2015), esp. 14. 
colors. ${ }^{201}$ Although individual professors and institutes would at times cooperate, German universities in general rarely lent their cultural capital or even their venerable space to republican ambitions.

This was most keenly felt with regard to honorary degrees. Since the republic had abolished all state decorations, doctoral degrees seemed to offer one of the few truly prestigious instruments available for gaining, rewarding, or strengthening international sympathies. ${ }^{202}$ Efforts in this direction, however, often met with the determined opposition of academic circles and, even where successful, hardly ever involved a politically desirable public ceremony. During the 1920s, foreigners (from former enemy nations) were rarely honored "on campus," thus depriving the honorees - and German foreign policy - of the performative act, which tends to be even more important than the degree itself. ${ }^{203}$ In part, to be sure, this reluctance was due to German academic tradition. Unlike in the United States, where universities had long used honorary doctorates to acknowledge the exemplary public service of domestic and foreign statesmen, German universities generally treated them as nonpublic, academic acts dependent on scholarly merit. ${ }^{204}$ While wartime patriotism and postwar distress had already undermined this principle, German universities were now doubly careful not to "taint" the prestige of their honorary degrees further by subjecting them to political (that is, republican) considerations. ${ }^{205}$ They also insisted that the honoree have a proven past and present pro-German attitude, which seriously limited the political usefulness of this instrument. Here as elsewhere, German universities only reluctantly assumed a constructive role in Weimar's policy of reconciliation with the West.

This changed notably, albeit never entirely, only toward the late 1920s. In the transatlantic case, this development found its most remarkable expression at the University of Heidelberg, which awarded an honorary doctorate first to U.S. Ambassador Schurman, then to Foreign Minister Stresemann, and finally decided to bestow the degrees in a joint and public ceremony on May 5 , 1928. This extraordinary event provides a unique window onto the increasingly

201 Observance of republican holidays was so lukewarm and the use of republican colors so uncommon that they eventually had to be legislated; Preuss. Minist. für Wissenschaft, Kunst und Volksbildung, Zu UI Nr 21895, 1929 Flaggenerlasse, BArch R 8088/662: "On the occasion of all university festivities the festival room is to contain a dignified symbol of the Republican form of state."

202 Bonn, So macht man Geschichte, 329-330.

203 Dietmar von Reeken and Malte Thiessen, "Ehrregime. Perspektiven, Potenziale und Befunde eines Forschungskonzepts," in Ehrregime. Akteure, Praktiken und Medien lokaler Ehrrungen in der Moderne, ed. von Reecken and Thiessen, 11-29 (Göttingen, 2016), 25.

204 Lerg, "Die Ehrendoktorwürde," 305.

205 Reinhold Seeberg, "Der Doktor ehrenhalber und die Ehre der deutschen. Hochschulen," Mitteilungen des Verbandes der Deutschen Hochschulen (1930), 177-180; see also the public discussion of some honorary degrees awarded to benefactors of the university in Anne Nagel, ed., Die Philipps-Universität Marburg im Nationalsozialismus (Stuttgart, 2000), 87-93. 
fruitful interplay of academic and political interests and, I would argue, the emergence of an "academic peace" in the late 1920 .

The Heidelberg honorary doctorates were a political and diplomatic matter from the beginning. Indeed, it was none other than Foreign Minister Stresemann who "arranged" Schurman's honorary degree during the spring of 1927 in order to recognize and maintain his goodwill and, it seems, demonstrate Germany's pro-American sentiment just as the U.S. Congress was debating the release of former German property seized during the war. Despite the decline of wartime resentment in Germany, Stresemann fully realized the difficulty of the task. A first approach to the University of Göttingen, though carefully prepared through informal channels, failed due to faculty reservations. Even Stresemann's strategic emphasis on the liberal degree policies practiced at Allied universities to illustrate "by what means [universities] in other countries support the foreign policy of their governments" proved to be of little avail. ${ }^{206}$ Though Göttingen officially - and quite ironically - based its rejection on the former Cornell University president's lack of academic merit (thereby also rejecting Stresemann's idea of an honorary degree as a quasi-diplomatic tool), it seems that rumors of Schurman's anti-German utterances during the war were actually to blame. ${ }^{207}$ In his second, successful attempt at the University of Heidelberg, Stresemann thus made sure to vouch personally for Schurman's "unconditional friendliness toward Germany." Attuned to conservative psychology, he also highlighted a recent American honorary degree to German ambassador Maltzan as a "sign that insightful American circles are beginning not just to forget the war, but to express through such salient honors that we are owed amends. We are thus not taking the first step in this direction, but are following the United States." ${ }^{208}$ Although Stresemann plainly misrepresented American motives here, it seems to have helped convince the remaining skeptics at Heidelberg's Faculty of Philosophy. In late July 1927, Schurman was awarded the title of doctor of philosophy in honor of his commitment to transatlantic reconciliation. ${ }^{209}$ The ambassador himself was delighted, and Stresemann anticipated "the very best effect, domestically and internationally, from the award ceremony itself." 210

206 Stresemann to Senator Hobelmann, May 24, 1927; Stresemann to Meinardus, May 31, 1927, PA NL Stresemann, Vol. 54.

207 Meinardus, Rektor Universität Göttingen to Stresemann, May 14, 1927; Professor Hoops to Stresemann, July 15, 1927, PA NL Stresemann, Vol. 54.

208 Stresemann to Johannes Hoops, July 22, 1927, PA NL Stresemann, Vol. 56.

209 The award is cited in Universitätsarchiv Heidelberg, B-1523/1a, Verleihung der Ehrendoktorwürde an Jakob Gould Schurman und Gustav Stresemann.

210 Stresemann to Badensian Minister of Culture, Leers, July 30, 1927, PA NL Stresemann, Vol. 56. 
At the time, even Stresemann could not have foreseen just how good this "effect" would eventually be. Certainly, the relatively swift award conferred by one of Germany's best-known universities would have constituted a significant success in its own right. But a number of Heidelberg professors now took two steps that would turn Schurman's honorary degree into a much larger transatlantic affair. First, merely a few months later, Heidelberg's Institute for Social and Political Science, directed by Alfred Weber, awarded an honorary doctorate in political science to Foreign Minister Stresemann for his service to the fatherland. ${ }^{211}$ In addition, the university administration agreed (at the suggestion of the Foreign Ministry, it seems) to confer the two degrees in a joint and public ceremony. These actions were remarkably consequential. If we recall just how unwilling German universities were to award honorary degrees whenever they seemed to serve political (i. e., republican) considerations, Heidelberg honoring the American ambassador for his role in transatlantic reconciliation and the republican foreign minister for his national service - was going far beyond common academic practice. By holding a joint public ceremony, moreover, it turned an academic act into what Stresemann rightly identified as "an act of international reconciliation politics." ${ }^{212}$

This exceptional action was certainly a product of the liberalism of some parts of Heidelberg University. The Faculty of Law and Alfred Weber's Institute for Social and Political Sciences (Institut für Sozial- und Staatswissenschaften, InSoSta), in particular, were strongholds of democratic thought and American connections in the Weimar years. ${ }^{213}$ But there is also reason to see the ceremony as a marketing coup for Heidelberg on the part of town and gown alike. Academic ceremonies, scholars have noted, often aimed to strengthen the public role of universities and to establish them as actors in international affairs. ${ }^{214}$ The extraordinary attention the university administration paid to the national and international publicity of this event (as reflected in the university archives) suggests that it deliberately used the occasion to raise and sharpen

211 Addresses at the Ceremony of Conferring Honorary degrees upon Dr. Stresemann and Dr. Schurman, in the Convocation Hall of Heidelberg University, May 5, 1928, translated from the German (Heidelberg, 1928).

212 Stresemann to Rochus von Rheinbaben, Feb. 20, 1928, PA NL Stresemann, Vol. 64.

213 The fact that a small number of left-liberal professors at the InSoSta independently administered the political science doctorate enabled them to honor candidates who would have stood little chance at other faculties - an advantage they used to the fullest. A Heidelberg University statistic showed that its faculties on average awarded 2.3 honorary doctorates a year through the 1920s, while the InSoSta awarded 4.4; see Universitätsarchiv Heidelberg, B-1522, Ehrenpromotionen, Allgemeines, 1918-1949 Ehrenpromotionen in Heidelberg; for a critical appraisal of Heidelberg's alleged liberalism, see Christian Jansen, "Auf dem Mittelweg von rechts. Akademische Ideologie und Politik zwischen 1914 und 1933," in Auch eine Geschichte der Universität Heidelberg, ed. Karin Buselmeier, Dietrich Harth, and Christian Jansen, 163-193 (Mannheim, 1985), 185-187.

214 Lerg, "Die Ehrendoktorwürde," 313. 
its public profile in a certain way. ${ }^{215}$ Whereas the University of Marburg, for example, cultivated the image of a distinctly "German" institution during the 1920s, ${ }^{216}$ Heidelberg used the ceremony to increase its transatlantic visibility and project itself as a haven of liberal cosmopolitanism. ${ }^{217}$ By linking Germany's prestigious academic traditions to republican foreign policy, it deliberately made itself a stage for the academic and political rapprochement between the United States and Germany.

Fig. 11: Stresemann and Schurman receiving honorary doctorates in Heidelberg, May 1928, Bundesarchiv, Robert Senneck, Bild 1461978-029-05 A

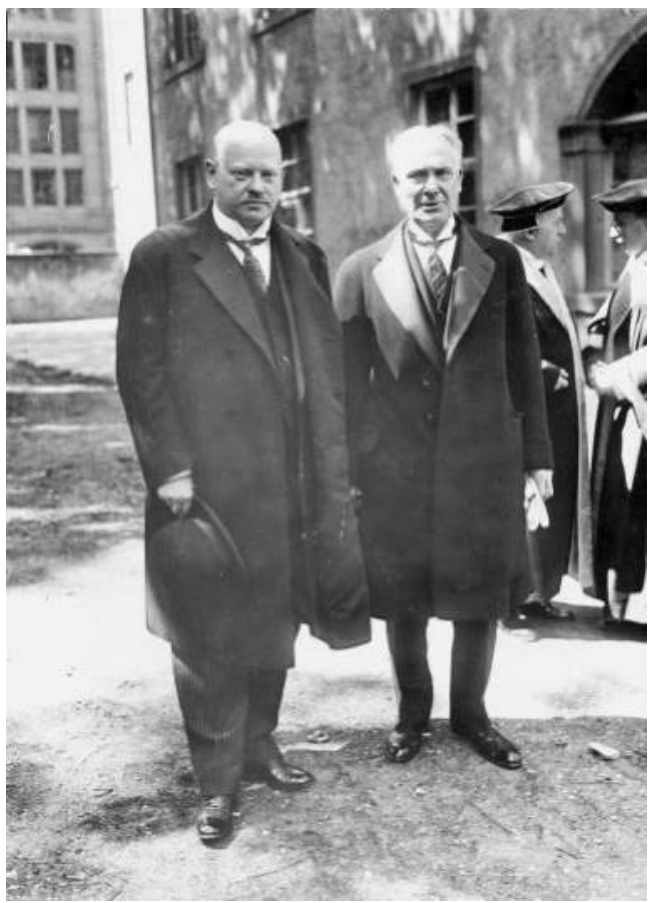

The joint ceremony on May 5, 1928, was a diplomatic and academic act of the first order, as Heidelberg Rector Martin Dibelius stressed in his opening re-

215 See especially Universitätsarchiv Heidelberg, B-1523/2a, Generalia, Feierlichkeiten: Paramount News, Bruno Stindt, to University Heidelberg, Mar. 21, 1928; Universität Heidelberg, Rektorat an Mitglieder der Akademischen Korporation, Apr. 14, 1928; Reichszentrale für deutsche Verkehrswerbung to Prof. Andreas, Apr. 18, 1928.

216 On Marburg's public profile, see Siebe, Germania Docet, 491; on the increasingly public role of universities in the 1920s, see Mathias Kotowski, Die öffentliche Universität. Veranstaltungskultur der Eberhard-Karls-Universität Tübingen in der Weimarer Republik (Stuttgart, 1999).

217 Concerning questions of war guilt, Heidelberg University was just as "national" as other universities. Just one month after the award ceremony, American professor and CEIP director James Brown Scott was disinvited from a lecture in Heidelberg when he failed to guarantee not to repeat the idea of German war guilt; Wegener, "An Organization, European in Character," 37. 
marks. ${ }^{218}$ The idyllic Heidelberg setting, the quality of the speeches, and the phenomenal media interest (including an American newsreel team and more than a dozen American news correspondents) set the stage for a ceremony that combined the pomp of academic tradition with the urgency of international politics. Schurman was in his element. In a particularly exuberant version of the "Schurman speech," he used his reminiscences of his Heidelberg student days (underlined by his own English-language rendition of the poem "Old Heidelberg") to proclaim a cultural alliance between Germany and the United States. Based on "the similarity of the fundamental international ideals of the Governments and peoples of our countries," he saw, "Germany and the United States $[\ldots]$ marching forward in a great and noble adventure in the cause of human civilization." ${ }^{219}$ Stresemann, in contrast, used the significant national and international attention to lay out the tenets of German foreign policy. Coming on the eve of the Briand-Kellogg Pact to outlaw war and on the heels of a Reichstag debate in which his accommodating foreign policy had been bitterly attacked for its lack of results, Stresemann's "grand speech," as Detlef Junker called it, underlined Germany's commitment to reconciliation but also emphasized its dependence on revisionist concessions in front of a world audience. ${ }^{220}$ At the same time, Stresemann cautioned the student body "not to get carried away by old rallying cries. The maintenance of peace and efforts to this end are not cowardice, are not weakness; they are the true political recognition of our own national interests." 221

This moment of "Weltpolitik in Heidelberg," as the liberal Vossische Zeitung termed it, made headlines in all the major German and a significant number of international newspapers. ${ }^{222}$ It was not that declarations of transatlantic friendship had been absent from public debate. Yet since 1914, no American ambassador had championed intellectual cooperation between the two nations so warmly - nor had one so clearly challenged the war's recalibration of academic relations. And rarely, indeed, did a German university seem to have taken such a clear stance in support of republican foreign policy, as contem-

218 On the speeches, see Reden bei dem Akt der Ehrenpromotion des Reichsministers Stresemann und des Botschafter der Vereinigten Staaten Dr. Schurman, in der Aula der Universität Heidelberg, 5. Mai 1928 (Heidelberg, 1928); this publication was arranged and paid for by the German Foreign Ministry - as was the English translation: Addresses at the Ceremony of Conferring Honorary Degrees upon Dr. Stresemann and Dr. Schurman.

219 American Embassy, Berlin, to State Dept., May 8, 1928, NARA RG 59 Box 1640 [Schurman] $123 / \operatorname{Sch} 87 / 229$.

220 Junker, "Jacob Gould Schurman, die Universität Heidelberg und die deutsch-amerikanischen Beziehungen," 328-358.

221 Reden bei dem Akt der Ehrenpromotion.

222 "Weltpolitik in Heidelberg," May 6, 1928, Nr. 108, Vossische Zeitung (Beilage); see the collected clippings in Universitätsarchiv Heidelberg, B-1523/2a-e, Ehrenpromotionen Stresemann-Schurman Zeitungsberichte, 1928. 
poraries pointed out. ${ }^{223}$ These same contemporaries felt the ceremony was a symbolic departure from wartime cultural alliances toward a closer political and academic partnership between Germany and America. Not surprisingly, the enthusiasm of the liberal German press was matched only by French dismay. ${ }^{224}$ Doubtlessly, the Heidelberg ceremony revealed an increasingly fruitful interplay of academic and political interests in the late 1920 s and underscored German academia's reconciliation with both Berlin and the United States during the period of relative stabilization, however selective that reconciliation may have been. Looking back a few years later, the German ambassador to Washington Friedrich von Prittwitz und Gaffron considered the Heidelberg ceremony to have been of "symbolic significance for the entire second phase of German-American relations after the war."225

\section{Toward an Academic Peace?}

It was arguably with regard to academic relations, not international politics, that the ceremony's most positive effect unfolded. This was true for Heidelberg itself, which re-established itself as a mecca for international and especially American attention. American newspapers and newsreels alike praised the unique charm of Germany's oldest and - as many now held - foremost university. ${ }^{226}$ Moreover, Schurman's honorary degree enjoyed a stunning aftermath as the American ambassador expressed his gratitude by raising the enormous sum of $\$ 500,000$ for a new university hall in the heart of the city. This generous American gift not only allowed the university to open a grand modern building in the midst of the Great Depression but yielded yet another string of heavily publicized, quasi-diplomatic celebrations of transatlantic "friendship"

223 See especially Dr. E. C., "Die Heidelberger Ehrenpromotion," Vossische Zeitung, May 6, 1928, 2. According to the Vossische Zeitung, the true historical significance of the award ceremony lay not in Stresemann's and Schurman's commitment to peace but the fact that "finally a German university has the courage to commit itself to (sich bekennen) the state, as it is."

224 Temps and Figaro reminded Schurman that Americans had not yet forgotten the sinking of the Lusitania or the occupation of Belgium; Clipping: "Die Heidelberger Reden Stresemann und Schurmans. Französische Pressestimmen," Frankfurter Zeitung, May 7, 1928, Universitätsarchiv Heidelberg, B-1523/2e.

225 Friedrich Wilhelm von Prittwitz und Gaffron, "Deutschland und die Vereinigten Staaten seit dem Weltkrieg," 20.

226 As Lincoln Eyre of the New York Times realized, Heidelberg profited greatly from the honorary degrees: "This 'intellectual sister act' as an irreverent onlooker dubbed the impressive ceremony, not only added to Heidelberg's cultural renown but was also mighty good publicity for the city's claim to be the hub of the touristic cycle in Southern and Western Germany. The statesmen's visit, Heidelbergers affirm, is bound to stimulate international interest in a spot already famed for its historical treasures and educational eminence"; Lincoln Eyre, "Germans Allure American Tourists," New York Times, May 13, 1929, 47. 
over the next two years. ${ }^{27}$ Even more remarkable was that this set off a kind of chain reaction, leading other German universities to orient themselves toward the United States, too. The University of Munich, for instance, established a chair in American History and Culture in 1928 and initiated an American "Junior Year in Munich" shortly thereafter. By the late 1920s, interuniversity rivalry for American connections and funds led German universities - not "outsider institutions" like the Hochschule für Politik - to actively cultivate transatlantic relations once more.

Importantly, similar trends were visible across the Atlantic. Harvard University established the Kuno Francke-Professorship in German Language and Culture in 1927 and concurrently worked toward resuming its professorial exchange with German universities. This effectively rekindled the prewar competition for German connections. ${ }^{228}$ Columbia's Nicholas Murray Butler responded to Harvard's actions almost immediately. In January 1929, he welcomed the German ambassador von Prittwitz und Gaffron on campus, where the two men jointly reopened the Deutsches Haus (closed in 1917) in yet another quasi-diplomatic act. ${ }^{229}$ Shortly thereafter, Butler took an even more monumental step: he re-established the Roosevelt Professorship at the University of Berlin after a 15-year hiatus. These highly symbolic actions not only restored the institutional infrastructure of prewar days; they also reflected renewed interuniversity competition on the American side as well. German academic contacts were considered "valuable" once again, just as German academics sought to reconnect with Americans. Arguably, it was this resumption of the dynamics of competition for transatlantic contacts both in Germany and the United States that marked the true return to academic normalcy. Even though German scholars never joined the scientific "boycott organizations," the bilateral strategy pursued by German diplomats, students and professors had to some degree overturned the recalibration of the academic world. By October 1929, Ambassador Prittwitz concluded that "German science is once more accorded the position within American universities it intellectually deserves." ${ }_{230}$ In the transatlantic context, the long-awaited "academic peace" seemed to have arrived at last.

227 See Junker, "Jacob Gould Schurman, die Universität Heidelberg und die deutsch-amerikanischen Beziehungen," 328-358.

228 This time it strove to establish the exchange with the liberal University of Hamburg and Mendelssohn Bartholdy; Aufzeichnung, zu VI W 6046, July 18, 1928, PA R 64079.

229 The Foreign Ministry helped the Haus secure a significant part of its library as well as a large number of welcome telegrams by prominent Germans. (Heuser) Deutsches Haus Columbia University to AA (Freytag), Oct. 1928; and Erich von Prittwitz u. Gaffron to AA (Terdenge), Jan. 8, 1929, "Gründung des 'Deutschen Hauses' in New York," PA R 64080.

230 German Embassy, Washington, to AA, Nov. 4, 1929, "175jährige Jubiläumsfeier der Universität Columbia in New York," BArch R8088/147. A similar assessment can be found in Stephen P. 


\section{German Universities and the American Century}

Despite these developments, it would be naive to interpret German efforts as wholly successful. To be sure, substantial strides had been made compared to 1919. After 1924, transatlantic academic relations resumed at an astonishing pace. Especially where student relations were concerned, the following five years created institutional structures that outlasted the twentieth century. While most initiatives certainly unfolded without any official involvement, many did profit from the new interest that German foreign policymakers and America's cultural internationalists took in international education. As the climate grew less poisonous in the late 1920s, transatlantic academic and diplomatic interests were able to align once more. By that point, inter-Allied academic relations had quite clearly become international academic relations again.

It is tempting to see this development as a promising trajectory that could have restored German academic prestige and influence had it not been for the transatlantic estrangement following 1933. But this was not how German contemporaries perceived the situation. Although transatlantic relations had come a long way since the war, we must not lose sight of the fact that contemporaries measured their successes not against 1919, but 1913. German aspirations - be they political, economical, or cultural - aimed at the status quo ante. From this perspective, the outcomes of this decade-long effort in international education were unsatisfactory to say the least. The global expansion of study abroad in the 1920s had largely passed Germany by. Of the 70,000 international students worldwide in 1930, only every tenth decided to study in Germany, a number hardly commensurate with the reputation German science still enjoyed. And while France and the United States registered a steadily rising share of international students among their student bodies, in Germany these relative numbers kept falling, too. ${ }^{231}$ Of the 130 ,ooo students at Germany's universities, only 7,600 , or about 5 percent, hailed from beyond its borders, and of those about half were ethnic Germans. ${ }^{232}$ While more international students had sought to study in the German educational system than anywhere else in the world in 1900, three decades later, France and the United States had both overtaken Germany.

In the United States, in particular, the focal point of Germany's high hopes and efforts, it had not even remotely recovered its prewar position. While exchange programs and summer courses brought a significant number of Americans to German universities, regular enrollment did not keep pace. By 1929

Duggan, "Der deutsche Einfluss auf die amerikanische Erziehung," Hochschule und Ausland 9, no. 1 (Jan. 1931): 7.

231 Beck, "Ausländerstudium im Ausland und in Deutschland," 248.

232 Reinhold Schairer, "Ausländische Studenten an deutschen Hochschulen," in Das Akademische Deutschland III, ed. Doeberl et al., 525-542 (Berlin, 1930), 526. 
only about 260 of America's more than half a million students were regular degree students at German universities (by contrast, 360 of Germany's 130,000 students were enrolled at American universities). ${ }^{233}$ The reservoir of American cultural affinity left over from a generation of German-trained American scholars would predictably run dry in the very near future; men like Butler or Schurman were already of retirement age, and Germany had not managed to produce a new cohort of Germanophile academics to take their place. Prewar warnings about the decline of German influence in American education seemed to have come true. These developments were readily apparent to contemporaries, and, after 1928, sparked concerned debate in the press, university halls, and the Reichstag. ${ }^{234}$ Different political camps agreed that international enrollment fell far short of German scientific Weltgeltung and there were many calls "that Germany can by no means resign itself to the standstill, if not the decline of international students at German universities." 235 The situation was deeply frustrating, especially to those most committed to international education. By 1930, Reinhold Schairer felt that Germany had fallen so far behind other countries and considered "its foreign policy implications" so grave that he resigned from the directorship of the International Academic Office. ${ }^{236}$

The reasons German universities had lost international favor are multifaceted and difficult to pinpoint. But even contemporaries realized that placing all the blame on the war was only a convenient answer to a more complex and partly homemade problem. Some scholars have evoked Germany's relatively strict admissions and equivalency standards to explain this decline, yet this was only a minor factor in the American case. ${ }^{237}$ More important, it seems, was the fact that Germans remained vested in the ideal of the Wissenschaft-driven degree student instead of refocusing on "cultural students," who were far greater in number. They failed to recognize that, a few exceptions aside, the American graduate student no longer had much reason to study in Germany while the freedom of the German system did not meet many an undergraduate's need for college "credit." The rapid growth of summer courses in the late 1920 illustrated just how receptive American students were to more flexible, culturally oriented German programs. ${ }^{238}$ Ministerial turf battles also stalled a

233 Christian Fleck, Transatlantische Bereicherungen. Zur Erfindung der empirischen Sozialforschung (Berlin, 2007), 92.

234 Isaac Marcosson, “The New Germany," Saturday Evening Post, Nov. 16, 1929.

235 Beck, "Ausländerstudium im Ausland und in Deutschland," 250.

236 Schairer to Prof. Dr. Tillmann, Mar. 4, 1930, BArch 8088/804.

237 For the argument of strict equivalencies as restricting international student numbers, see Peter Drewek, "Limits of Educational Internationalism - Foreign Students at German Universities between 1890 and 1930," Bulletin of the German Historical Institute 27 (2000): 39-63.

238 Alexander David Tutt, "Ausländerbetreuung an der Universität Heidelberg, 1928-1938. Das Akademische Auslandsamt und die Vergangenheit” (BA Thesis, University of Heidelberg, 2012), 22. 
more concerted German academic campaign because the Foreign Ministry, in particular, was clearly willing to sacrifice short-term expansion for longterm control. ${ }^{239}$ But this alone does not fully account for the frustrations many Germans felt, particularly with regard to the United States. Here, the failure to raise student numbers revealed a deeper and more troubling transformation of transatlantic (academic) relations.

This can be shown with regard to German efforts to raise the number of American students, especially the hand-picked American exchange students. Apparently, this had been foremost on the agenda of German academic diplomacy since 1925. And while the number of American exchange students did increase continuously through the 1920s (up to 50 in 1929), Germans always believed that a more concerted effort to win additional fellowships for Germans at American universities (and then subsequently to increase the fellowships for Americans at German universities) could easily raise that number by several hundred. These German ambitions, however, were hampered by the institutional cooperations Germany had entered in the United States in the early 1920s. In particular, Germans felt that their American partner institution, the Institute of International Education (IIE), was inefficient. Although Germans greatly appreciated the IIE's director Stephen P. Duggan, who had supported Germany soon after the war, the IIE's staff seemed to lack the competence and interest to advertise German universities more forcefully. In fact, managing America's educational relations with foreign countries from Hungary to China, the IIE often answered American inquiries about Germany unsatisfactorily and, Germans felt, directed U.S. attention to more familiar and better-advertised French and British universities. ${ }^{20}$ That France operated its very own French Universities Bureau in New York City only heightened Germans' frustration with the IIE's apparent priorities. Compared to the skillful efforts of its rivals, Adolf Morsbach of the AAD felt, "Germany lack[ed] any opportunity to

239 This policy was clearly very frustrating for those most interested in the field, like Reinhold Schairer, who resigned in March 1930. In a letter to the president of the Hochschulverband, he noted, "It is my duty (... again) to point to the world political implications of the problem of international student migrations. Other countries are paying ever more heed to these implications by ever new measures and programs. Every month that passes increases only the advance these countries have over the German measures and programs and makes it ever harder for us to catch up. The cultural political and foreign policy impact of these developments are so serious that I can no longer stand for them." Schairer to Prof. Dr. Tillmann, Mar. 4, 1930, BArch 8088/804. 240 Bericht des Oberregierungsrat a. D. Dr. Morsbach über seine Reisen nach Amerika JanuarMai 1929; März-Juli 1930, PA R 64236. 
deepen American universities' strong and steadily rising interest and to guide it into the right sort of channels." ${ }^{241}$

Morsbach visited the United States twice, in 1929 and 1930, respectively, for a 5-month period to resolve this situation. Traveling throughout the United States, he sought not only to increase the number of fellowships for German students at American universities but also to improve the administration of the student exchange in the United States. His plan was twofold: first, to place a German secretary at the IIE, then to establish a German University Office in New York City to systematically advertise German universities, assist with matters of admission and accreditation, and systematically expand student and professorial exchanges. ${ }^{242}$ This office was supposed to be similar to the AAD's bureaus in London (est. 1926) and Paris (est. 1929) in some ways, yet it was to operate on a much grander scale befitting the more developed nature of academic exchanges with the United States. Funded and run exclusively by Berlin, this "educational embassy" would pursue German interests in the United States more rigorously, while an Anglo-American board of trustees under Duggan would shield it from accusations of engaging in "German propaganda." 243

In the end, however, nothing ever came of the plan. Though Duggan initially supported the idea of appointing a German secretary, the IIE's trustees balked at the idea of setting such an unwelcome precedent for the many other nationalities the IIE represented. Germans, in turn, shrank from severing all ties with the IIE for fear of alienating Duggan and the Anglo-American support they needed. ${ }^{244}$ The outcome of this episode, which effectively stunted more forceful academic diplomacy in the United States, revealed the deeper contradiction between German and American ambitions. Whereas Germany had always treated its transatlantic relations as a lever to advance its interest vis-à-vis its European rivals, American cultural internationalists cultivated relations to Germany (alongside relations to a host of other countries) to pacify and consolidate Europe. Although they supported German recovery, academic or otherwise, they would not do so at the marked expense of other countries. In this way - at least this was how Germany began to see it - they effectively perpetuated the status quo post bellum.

241 Foreign Ministry to Embassy, Washington, Nov. 18, 1929, Attachment: Morsbach, Abschrift zu VI W 9136 (Nov. 1929), PA R 64081.

242 Morsbach to AA, Mar. 5, 1930; and Morsbach, Meine zweite Reise in die Vereinigten Staaten Mai bis Juli 1930, PA R 64236; on his personal thoughts and experiences, see Bundesarchiv Koblenz, NL Morsbach, Boxes 11 and 12.

243 Foreign Ministry to Embassy, Washington, Nov. 18, 1929, Attachment: Morsbach, Abschrift zu VI W 9136 (Nov 1929), PA R 64081.

244 Niederschrift über die Sitzung des Kuratoriums und der Mitgliederversammlung des Akademischen Austauschdienstes am 24. Februar 1931 in Berlin; this meeting once more reiterated the entire development and its major setbacks and defined the founding of an independent German University Office in New York as a long-term goal; PA R 64223. 
In consequence, by 1930 Germany's cooperation with U.S. cultural internationalists had, at least in some respects, outlived its initial usefulness. A major asset as long as Germany was devoid of support and influence, by the late 1920 s it had begun to constrain the country's larger ambitions. As in transatlantic relations in general, the early 1930 os would bring underlying differences to the fore as Germany's demand for peaceful revision began to outpace America's commitment to peaceful change. ${ }^{245}$ Ultimately, the situation was part and parcel of a larger shift in transatlantic relations, which all appeals to friendship or intellectual gratitude could never entirely mask. There could simply be no return to the status quo ante - not politically, economically, or culturally - because the war had changed the texture of transatlantic power and shifted it dramatically in America's favor. And for all the support American foundations and universities provided, they had no desire to restore Germany to its earlier position. On the contrary, international student numbers already foreshadowed the coming inversion of academic and scientific fortune that both American and German observers - hidden behind almost ritualistic expressions of intellectual gratitude on the one side and cultural arrogance on the other - were growing more and more aware of. ${ }^{246}$ As Charles Thwing, the former president of Western Reserve University, concluded in a 1928 study, Germany's dominant influence in education had passed irrevocably, but science and learning, now carried by other countries (not least the United States), would "go forward and upward." ${ }^{247}$ As the German century in education was drawing to a close, the American century was just beginning.

245 Heinrich Schnee and Hans Draeger, eds., Zehn Jahre Versailles (Berlin, 1929), 1:viii.

246 As Ludwig Stein of the Vossische Zeitung had written already in 1924: "We have to get used to reminting our academic coins. In academic things, too, we will have to relinquish some of German leadership to maiden America. Especially the hard sciences, which rely on laboratories and observatories, and demand enormous funds, will with time emigrate from the old world to the new. [...] The American universities are beginning to export technology, science and art to the old world"; Clipping: Ludwig Stein. "Amerikanische Universitäten" (1924) Nicholas Murray Butler Papers, Box 394/Stein, Ludwig, Columbia University, Rare Book \& Manuscript Library Collections; also Prof. Fuelleborn, "Der Wiederaufbau und die deutsche Wissenschaft," Beilage $z u$ den Mitteilungen des Verbandes der Deutschen Hochschulen (ca. 1924): 15.

247 See Charles Franklin Thwing, The American and the German University: One Hundred Years of History (New York, 1928), 228. 



\title{
Chapter 6 \\ “Germany Invites You!”: Tourism Promotion as Public Diplomacy
}

\author{
"You didn't go to Berlin? Why everybody goes to Berlin now. Only tourists go to Paris any \\ more." The returning vacationists speak thus enthusiastically of the new Welthauptstadt. Gayer, \\ brighter, faster, more cosmopolitan and cheaper - Berlin, the throbbing city an der Spree has \\ suddenly supplanted Paris in the affection of the Americans. ${ }^{1}$
}

7 hese words from a 1931 article in Vanity Fair praised Berlin - and Germany more generally - as the new European darling of America's traveling upper crust. The piece is emblematic of a large number of articles in American society and travel magazines in the late 1920 and early 1930 s that described Germany's growing popularity among America's traveling and travel-minded public. Few would have been able to predict this development a decade earlier. After the war, the idea of vacationing in Germany would have appeared quite absurd to many of Vanity Fair's readers. Ten years later, however, the picture had changed dramatically. While Germany was establishing itself as America's "junior partner" in Europe, it had also re-emerged as a major tourist destination. But how did this happen? And was there a connection between the broader transatlantic rapprochement and Germany's rehabilitation as a tourist destination?

This chapter will focus on one aspect of German-American relations that has received scant scholarly attention thus far: transatlantic travel. It will trace Weimar's efforts to promote Germany as a travel destination in the United States and try to assess whether and how increased transatlantic travel affected Germany's image in the 1920s. Tourism promotion, the chapter will show, often doubled as public diplomacy, and by the end of the decade was seen as a legitimate instrument of Weimar foreign policy. While previous chapters have highlighted two fields with a relatively long tradition in German Amerikapolitik - ethnic politics and academic diplomacy - the "management" of American

1 “Berlin - A French Artist looks at a rival capital," Vanity Fair (Sep. 1931). 
tourism was genuinely new to the 1920s. In the decade after World War I, a field that had long remained outside of foreign policy considerations turned into an increasingly accepted and, indeed, central image-building tool. Advancing chronologically, the chapter explores why Germans came to identify tourism as a potential foreign policy tool, how they tried to attract American tourists to Germany, and, at least tentatively, it suggests what effects this had on transatlantic relations. As it turns out, Germany's popularity was neither as "sudden" as Vanity Fair would have it, nor was it entirely devoid of state calculation.

\section{“A Country Worth Knowing - Despite It All!”: Tourism Promotion and Public Diplomacy in the Wake of Versailles, 1919-1921}

Whatever isolationism existed in America in the 1920s was not evident in American travel patterns. The 1920 s became the first era of American mass tourism, and Europe was its major overseas destination. Between 1924 and 1930, the number of Americans crossing the Atlantic annually doubled. ${ }^{2}$ By the end of the decade, it had reached 300,000 - a volume not reached again until the 1950s. This increase continued a long-standing trend. Tourist numbers had risen steadily throughout the latter half of the nineteenth century, but after World War I new leisure and consumption patterns propelled these numbers further upward. The increasing commodification of travel through package tours, traveler's checks, and travel bureaus and the heightened speed and safety of transatlantic voyages made European trips ever more convenient. American postwar affluence gave greater numbers of white-collar workers access to paid vacations and raised disposable incomes at the same time that favorable exchange rates rendered Europe more affordable. After the introduction of "Tourist Third Class" on transatlantic liners in 1923, round-trip fares went for as little as $\$ 180$ (at a time when the average American earned \$1303 a year), making a journey to Europe more accessible to members of America's burgeoning middle classes in search of adventure and cultural distinction. ${ }^{3}$ These individuals joined recent immigrants to America reuniting with their families, affluent Americans returning to vacationing "normalcy," and businessmen get-

2 U.S. Department of Commerce. Bureau of Foreign and Domestic Commerce, Oversea Travel and Travel Expenditures in the Balance of International Payments of the United States, 1919-38. (Washington, 1939).

3 For the average income of an American, see https://www.gilderlehrman.org/history-by-era/ roaring-twenties/resources/american-economy-during-1920s; of course, a transatlantic journey remained expensive: by comparison a Model T at the same time cost $\$ 280$. On Tourist Third, see “The White Collar Goes Abroad," American Review of Reviews (Apr. 1929): 145-146. Popular travel books offered to take Americans through Europe on just two dollars a day; see Frank Schoonmaker, Through Europe on Two Dollars a Day (New York, 1927). 
ting back into the European market. ${ }^{4}$ As the United States officially withdrew from Europe after the Great War, the "great tourist invasion" began. ${ }^{5}$

From the first, the German tourist trade was determined to profit economically and politically from this "invasion." Tourism promoters agreed that Americans, who had made up a rising share of visitors to Germany before the war, needed to come and spend their dollars in the Reich once more. During the war, rationing measures, the general shortage of transportation, special taxes, and patriotic self-restraint had weighed heavily on the German tourist industry, while the postwar impoverishment of the German middle classes left little hope for a swift recovery. The North German Lloyd (Norddeutscher Lloyd, NDL) and the HAPAG, previously the largest shipping lines in the world, had lost almost their entire fleets in the peace treaty and were struggling to rebuild transatlantic business at a time of ailing commerce and (after the introduction of American immigration quotas) flagging business from emigrants. In this situation, the prosperous American tourist seemed a solution to the woes of the German tourist trade, as Hugo Stangen ("the German Thomas Cook") summed up in a memorandum shortly after the war:

in the United States in particular, we have yet to develop an appropriate propaganda to rekindle the interest of the American traveling public in Germany, an interest that previously was so very great. American tourists in particular were an important factor in our travel business before the war, and for the hotel business were at times of nearly indispensable importance; to win them back has to be our keenest desire. ${ }^{6}$

These salient commercial agendas dovetailed with larger national interests. Winning back the American tourist, the German tourist industry argued, would also serve Germany's foreign policy needs. As early as February 1919, the League of German Tourism Associations (Bund deutscher Verkehrsvereine, est. 1902), the largest German tourist body, had submitted a strategy paper to the Foreign Ministry, underlining tourism promotion as a valuable complement to Germany's political and economic propaganda. ${ }^{7}$ By presenting a coherent and attractive national image, tourism promotion could not only draw tourists once more but overcome German isolation. While this insistence on the foreign policy benefits of tourism primarily aimed to elicit financial support from German ministries, it still had a point. Exposure to German cul-

4 Between 1920 and 1922, American travel numbers rose proportionally to a greater extent than thereafter; U.S. Department of Commerce, Oversea Travel and Travel Expenditures, 20.

5 Daniel Boorstin, The Image: A Guide to Pseudo-Events in America (New York, 1962), 90.

6 Hugo Stangen was a long-time director of Stangen's travel agency, which became the travel agency of the HAPAG after 1905; Hugo Stangen, "Die Wiederherstellung des Fremdenverkehrs nach dem Kriege," 9, BArch R5/6481.

7 Bund deutscher Verkehrsvereine to AA, Feb. 10, 1919, "Vorschläge für die Zusammenarbeit des Auswärtigen Amtes mit dem Bund Deutscher Verkehrs-Vereine," BArch R 901/801. 
ture and lifestyles, to Germany's hardworking, hospitable, and clean people, it was hoped, would engender a more nuanced understanding of its postwar situation, eradicate misperceptions, and cast doubt on the veracity of wartime atrocity stories. As Maximillian Kraus, the publicity director of the German Tourism Promotion Bureau (Reichszentrale für Deutsche Verkehrswerbung, RDV, est. 1920), noted in 1921:

if we could with one stroke guide 100,00o educated and attentive foreigners through our Germany, show them our people at work, invite them from time to time to a friendly and contemplative stay, and if they then were to return home with lively memories, with memories of a country that looks so completely different than Northcliffe [Britain's chief propagandist] made it look, we could, through this process, do more for the revision of Versailles than all the diplomats in the world. ${ }^{8}$

The obstacles, however, appeared formidable. Regular passports to Germany were not even issued until November 1919, and, thereafter, rationing measures, economic chaos, and social upheaval made for less than ideal touring conditions. Besides, many Americans balked at the idea of taking a German ship, let alone vacationing among the erstwhile enemy, especially as long as the two countries were not yet officially at peace. European competition for American tourists, moreover, would be stiff, and German tourist bodies had no doubt that other countries would seize on postwar US sentiment to crowd Germany out of the market. As the German Hotel League informed the Foreign Ministry a few months after the armistice: "our enemies [plan] to cut Germany off from world travel" and "annihilate" the German tourist trade. ${ }^{9}$ If Germany were to profit from the American tourist invasion at all, whether economically or politically, its tourist trade would have to adopt decisive countermeasures.

The German tourist trade's lobby efforts to this end were partly successful. While substantial state subsidies - such as those received by the French Office National du Tourisme (est. 1910) - never materialized, longer-standing demands for a national tourism body were finally heeded. On February 20, 1920, the German Tourism Promotion Bureau (Reichszentrale für Deutsche Verkehrswerbung, RDV) was founded at an interministerial conference. Though officially under the auspices of the German Ministry of Transportation, the RDV brought together federal and state ministries, the Foreign Ministry among

8 Maximilian Kraus, Die zukünftigen Aufgaben der deutschen Verkehrswerbung im In- und Auslande (Berlin: RDV, 1921), 10.

9 French spas, the German Hotel League noted, were trying to replace the superior international position of German "world spas," which had generated revenues of 800 million marks before the war; Verband der Hotelbesitzervereins Deutschlands to AA, Mar. 13, 1919, "Wiederaufrichtung des Fremdenverkehrs," BArch R 901/801. This observation was well-founded: see Harvey Levenstein, Seductive Journey: American Tourists in France from Jefferson to the Jazz Age (Chicago, 1998), 217. 
them, and a wide array of interest groups including the German Municipal League (Städtetag), the League of German Spas (Deutscher Bäderverband), the German Railways (Reichsbahn), the shipping lines, and regional tourist associations. ${ }^{10}$ By pooling the resources of all interested parties, it hoped to initiate a concerted campaign to "sell" Germany abroad. ${ }^{11}$

Circumstances indicate that the Foreign Ministry broadly agreed with the economic and political desirability of international tourism. It was a founding member of the RDV, made modest annual contributions, and distributed some of the RDV's promotional materials abroad. ${ }^{12}$ But its involvement ended there. It clearly had neither the funds nor the intention to subsidize the economic self-interest of hotels, spas, and shipping lines, and there is little to suggest that it developed a more comprehensive understanding of tourism's role in German foreign affairs. Although the Wilhelmstrasse briefly contemplated establishing a tourism desk in 1919, it did not do so; moreover, it was represented on the RDV's board only by the politically marginal passport division. Of course, such unprecedented official involvement did not appear necessary at first because it seemed likely that transatlantic travel, driven as it was by salient business interests, would normalize by itself. Subscribing to a classic understanding of diplomacy as "high politics," Germany's traditionalist foreign service only slowly took on responsibility for allegedly mundane aspects of modern life like tourism. It was only during the early 1920 s that its benign disinterest gave way to more substantial engagement with matters of tourism.

While the immediate reason for this shift will be discussed below, we must keep two overarching factors in mind that played an important role in this process throughout the 1920s. The first was French competition. In the immediate postwar years, France emerged as Germany's main rival for American diplomatic support and capital; the ensuing "Franco-German struggle for the affections of Americans" that Robert Young observed played out in the field of tourism. ${ }^{13}$ As in other fields of competition, France enjoyed a highly advantageous position. Not only had it long been America's favorite overseas destination, but its promotional efforts were far better organized. Almost as soon as the war was over, the Office National du Tourisme, alongside French companies and tourist associations, began to convert America's wartime sympathies into tourist revenue and political capital at Germany's economic and

10 Reichszentrale für deutsche Verkehrswerbung to AA, Mar. 14, 1924, PA R 121352.

11 Christine Keitz, Reisen als Leitbild. Die Entstehung des modernen Massentourismus in Deutschland (Munich, 1997), 59-60.

12 Note (Sievers), Mar. 1919, BArch R 901/801; for examples of cooperation, see RDV to AA, Sep. 15, 1921, PA R 65088; Reichszentrale für deutsche Verkehrswerbung to AA, Mar. 14, 1924, PA R 121352.

13 Young, Marketing Marianne, xviii. 
political expense. ${ }^{14}$ Trips to the battlefields and the destroyed provinces (the major tourist attraction of the interwar years) provided a particularly powerful instrument for perpetuating anti-German sentiment. By mid-1919, the Guide Michelin had already published a three-volume battlefield guidebook devoted to "Americans in the Great War," and Thomas Cook \& Son offered near daily outings to the major sites of destruction, which were generally presented as proof of "Teutonic aggression."15 The German embassy in Paris lamented that American visitors were not only showered with attention in Paris but were also "invariably" taken to the battlefields. ${ }^{16}$ The scenes of destruction they encountered often had a pronounced impact. ${ }^{17}$ Prominent American travel writer Clara Laughlin, for instance, left the devastated regions with a feeling of admiration for the French and a "black blinding rage against the barbarism of the bestial invaders." "We came back," she recounted in a letter, "feeling that there is but one transcendent virtue ... killing Germans! Ridding the world of their noxious presence." ${ }^{18}$ In part, the strong French bid for American tourists and the political implications thereof pushed the Foreign Ministry into taking a more active interest in this question.

Two other closely connected factors also came to suggest tourism promotion as a suitable public diplomacy instrument. First, the American traveling public belonged qua wealth or social position to just the kind of opinion-shaping segment Germany was most eagerly and often unsuccessfully trying to reach. The fact that transatlantic travel became accessible to larger parts of American society in the 1920 did not fundamentally alter the exclusive nature of transatlantic tourism. Although contemporaries vocally bemoaned the social decline (or hailed the democratization) of transatlantic travel, a trip

14 Patrick Young, “'A Place Like Any Other?': Publicity, Hotels and the Search for a French Path to Tourism," in Touring Beyond the Nation: A Transnational Approach to European Tourism History, ed. Eric Zuelow, 127-149 (London, 2011), 137. By the end of the war, more than two million American soldiers had been stationed in France, and though their presence had aroused ill feelings on both sides, it had once more whetted American tastes for France as a touring destination. As American troops waited to return across the Atlantic, their strong presence in France sowed seeds of discord. American drunkenness, French lack of hygiene, and price-gouging came under increased scrutiny in this long waiting period. Many American doughboys came away from France with unfavorable attitudes - and certainly did not leave a stellar impression on their hosts, either. Officers stationed in Paris, especially found that their stay had reaffirmed the notion that Paris, indeed, was the 'pleasure capital of the world'; Levenstein, Seductive Journey, $217 \mathrm{ff}$..

15 "The world must see what the German did," was how one newspaper article explained why American visitors had to see the battlefields; quoted in Levenstein, Seductive Journey, 225.

16 German Embassy, Paris, to AA, Aug. 19, 1924, PA R 60447; Karl Remme and Margarete Esch, Die Französische Kulturpropaganda. Auf der Grundlage französischen Quellenmaterials und eigener Beobachtungen im Ausland (Berlin, 1927), 5.

17 See, for example, Hughes Black, "Peace and Pessimism," The Atlantic Monthly (Feb. 1921): 261-267.

18 Cited in Levenstein, Seductive Journey, 228. 
to Europe was never readily available to the vast majority of Americans with middling incomes. Even at the interwar height of transatlantic travel, only a little more than 0.2 percent of the American population traveled to Europe. ${ }^{19}$ Rather than making transatlantic travel available to most Americans, the interwar period gave the educated middle classes access to what formerly had been the privilege of America's moneyed elite. College professors and teachers, the editors of small-town journals and newspapers, church, professional, and women's groups all discovered Europe in the 1920s. While these groups were less affluent than prewar tourists, they were people of local prominence and likely-perhaps more likely even-to communicate their experiences through church journals, regional newspapers, or school and college events. Even if they did not constitute America's upper crust, they were undoubtedly valuable multipliers with an impact on American public opinion.

Tourism, moreover-and this would become successively clearer-provided access to an American society that was otherwise growing weary and suspicious of Europe. While Europe's economic and political situation might meet with only limited interest, travel books, travel talks, and travel magazines found a rapidly growing American audience. ${ }^{20}$ Tourism promotion, moreover, was able to develop in the United States without encountering strong opposition. Although fears of allegedly ubiquitous "German propaganda" hampered most German efforts at public diplomacy, Americans generally considered tourism advertising an unobjectionable business proposition. ${ }^{21}$ As Maximilian Kraus, the RDV's publicity director, laid out in a programmatic speech of 1921, "especially tourism promotion abroad can, in the least conspicuous way, say what has to be said in the near future, and said again and again, namely: that Germany is a country of ancient Kultur that is worth knowing - despite it all!"22 It was in the unpolitical field of travel that influential Americans - otherwise so disinterested in European affairs - could be won for Germany.

Alongside these overarching considerations, the experience of the early 1920 imbued tourism promotion with a larger, political meaning. Indeed, despite prominent postwar plans, broader tourism advertising did not commence until the mid-1920s. The conditions of inflation, as we have already seen in Chapter 3, were conducive neither to organized promotion of tourism nor to more hospitable treatment of American visitors. Rising consumer prices and fears of a "sell-out" (Ausverkauf) of Germany induced restrictive customs regulations, extra taxes, and dual price scales that resulted in a wave of unfavora-

19 There were 280,000 American tourists to Europe in 1930 out of a population of 123 million. 20 On the rise of the travel magazine and travel advertising, see Richard K. Popp, The Holiday Makers: Magazines, Advertising and Mass Tourism (Baton Rouge, LA, 2012).

21 Bund deutscher Verkehrsvereine to AA, Feb. 10, 1919, "Vorschläge für die Zusammenarbeit des Auswärtigen Amtes mit dem Bund Deutscher Verkehrs-Vereine," BArch R 901/801.

22 Kraus, Die zukünftigen Aufgaben der deutschen Verkehrswerbung im In-und Auslande, 14. 
ble American newspaper reporting about German extortion and harassment. Rather than improving the German image, American tourism in the early 1920 largely reinforced negative stereotypes. The onset of hyperinflation only made matters worse. In February 1923, the U.S. Department of State issued an official warning about German practices, and by June 1923, it advised against visits to Germany altogether - advice that American tourists mostly heeded. ${ }^{23}$ Germany, the New York Times drily remarked in June 1923, had killed "her Golden Goose."24 Inflation, in short, provided neither the psychological nor the financial foundations to enable German diplomats to successfully utilize tourism.

However, it was precisely this situation that helped transform German foreign policymakers' notions about American travel. As Germany's treatment of American tourists soured transatlantic relations and undermined talks on reparations, the Foreign Ministry decided it needed to become more actively involved in the field. Beginning in 1922, it reprimanded customs officials, coaxed local and regional tourist bodies to abandon extra fees, and convinced them to publicly condemn discriminatory practices. ${ }^{25}$ Although every new burst of inflation immediately reversed all painstakingly negotiated improvements, the postwar years transformed the very idea of the American tourist. Because tourist experiences had such detrimental repercussions on American published opinion, German officials began to recognize the American tourist as a unique asset whose personal impressions informed American opinion more than any German propaganda ever could. By 1923, they had become convinced that they needed to facilitate American travel by any and all means. ${ }^{26}$ "It is the aim of the Entente," Ambassador Wiedfeldt summed up in early 1923, "to keep [American] travelers from Germany, because most of those that return are no longer friends of the Entente. For this political reason, we should do everything

23 From February 1923, the U.S. Department of State attached a note to the passport applications of potential travelers to Germany, which informed them "that travelers to Germany are subjected in many cases to especially high charges by hotels, theatres, shops etc, and that at Frankfort they are subjected to a visitor's tax of from 15-40 percent of the price charged Germans from rooms in hotels and inns." Department of State, Division of Passport Control, Concerning the Use of Passports, Feb. 21, 1923, BArch R 901/25905.

24 See T. R. Ybarra, "Germany Kills Her Golden Goose: Dismay in the Fatherland Because the Postwar Grouch Has Driven Away American Travel," New York Times, June 10, 1923, SM 5.

25 Circular, AA to foreign missions, July 31, 1922, BArch R 901/25904.

26 German Embassy, Washington, to Consulate General, San Francisco, Mar. 29, 1923, Attachment: AA, V Pa 1330/259o Mar. 31, 1923, PA Botschaft Washington, 1493. See, for example, the entire series of reports by Frank C. Carpenter presented in his Carpenter's World Travels during 1923. Spending weeks in Germany, he detailed conditions as he saw them, concluding, "there is one truth, however, that stands out like a boil on one's nose and this is that these Germans are in a terrible condition. A very few of the people may be making money, but tens of millions have lost every cent of their savings, millions have not enough to buy a scrap of new clothing, and hundreds of thousands in every district are practically on the edge of starvation"; see Carpenter, "The Truth about Germany," Los Angeles Times, March 11, 1923, XI 6. 
in our power to attract foreigners." ${ }^{27}$ During 1922/23, American officials' constant complaints, the notable impact on American published opinion, and the admonitions of the otherwise propaganda-averse German ambassador in Washington went a long way toward establishing tourism as a legitimate field for state monitoring and intervention. By the mid-1920s, the Foreign Ministry's benign disinterest of 1920 had given way to manifest involvement. From this time onward, it saw American tourism as a field of foreign relations in dire need of tighter official "management" once conditions allowed.

\section{Marketing Germany in the United States, 1924-1930}

This was increasingly the case after mid-1924. Once the German currency had been stabilized, Germany was ready and able to launch a concerted effort to promote tourism. But in a striking reversal of its earlier role, the Foreign Ministry now took the lead. ${ }^{28}$ Within just a year, it had removed most of the bureaucratic hurdles that war and inflation had created, particularly wherever they pertained to coveted American visitors. ${ }^{29}$ Border searches were abandoned, customs formalities and visa applications simplified, and cumbersome foreigner registrations transferred from police stations to hotel desks. Visa fees were first substantially reduced and soon discarded altogether. These determined steps, widely publicized at the time, ${ }^{30}$ illustrated that the Foreign Ministry had come to a more comprehensive understanding of American tourists' role in restoring transatlantic contact, trust, and cooperation. As the Foreign Ministry's Press Department declared programmatically in October 1924, "all questions pertaining to tourism promotion have more or less the character of foreign policy." ${ }^{11}$

Importantly, too, these official German efforts tied in with the ideas of American officials and reformers who encouraged American tourism to Europe as an informal aid and goodwill program. Herbert Hoover's Department of Commerce realized even before the Europeans did that the hundreds of

27 German Embassy, Washington, to AA, May 11, 1923, "Fremdenbesteuerung in Deutschland," PA Botschaft Washington 1493. A few months later the German embassy in Paris concurred: "almost in all cases, where an Englishman or an American has traveled to Germany and received opportunity to get to know conditions in Germany as they really are, we have won friends ... [these visitors] return home with a friendly attitude toward Germany and anti-French." Letter Dufour-Feronce, Dec. 19, 1923, quoted in Müller, Auswärtige Pressepolitik, 98.

28 Niederschrift über die Sitzung des Verwaltungsrats der Reichszentrale für Deutsche Verkehrswerbung, Feb. 15, 1924, BArch R 901/25905.

29 See, for example, Reichskanzler to Ambassador Houghton, Apr. 1925, PA R 246958.

30 Consulate General, New York, to AA, Mar. 24, 1924, PA R 121327; Stresemann to Reichsverband der deutschen Hotels, Restaurants und verwandter Betriebe e. V., July 1925, BArch R $901 / 25656$.

31 Aufzeichnung, Oct. 25, 1924, PA R 121262. 
millions of dollars American tourists spent overseas each summer were crucial to transatlantic financial flows and allowed Americans to pacify Europe and solve its balance-of-payments problem - without lowering tariffs. ${ }^{32}$ In France, for instance, the \$137 million American tourists spent in 1929 went a long way toward paying French debt interest. While travel to Germany was less fiscally vital, it nevertheless promised, as the U.S. government put it, a "normal resumption of relations" between the two countries. ${ }^{33}$ Indeed, much of American public debate linked international travel to the cause of peace, with travel promoters and internationalists alike depicting it as the surest path to international understanding. ${ }^{34}$ In mid-1924, the Department of State removed the official warning about travel to Germany from passport applications, and American ambassadors to Germany repeatedly championed transatlantic tourism. ${ }^{35}$ In early 1925, U. S. Ambassador Alanson B. Houghton, for example, expressed his hope that Americans might once more visit Germany to "realize for themselves what a hearty, generous welcome awaits them at the hands of the German people." 36

Even with American support, however, re-establishing Germany as a tourist destination would prove no easy feat. Rumors about the nation's hostile treatment of foreigners and price-gouging practices subsided only slowly and were often, German officials believed, kept alive by political and commercial rivals. ${ }^{37}$ And while the currency stabilization created a more favorable psychological climate for welcoming foreigners, it also made Germany a relatively expensive travel destination. ${ }^{38}$ For the first time since the war, Germany had to compete under normal market conditions - a situation for which it was not particularly well prepared. Not only had the conditions of the postwar years stunted more comprehensive promotional efforts, but by 1924, the considerable rivalry between German cities, spas, and regions had also impeded joint action. Instead of banding together to advertise in the quality and quantity the American market demanded, individual hotels and spas liked to take out

32 For an exceptional account of the economic and political role of the American tourist, see Hiram Motherwell, “The American Tourist Makes History," Harper's Magazine (Dec. 1929): 7076.

33 Quoted in Costigliola, Awkward Dominion, 173.

34 “The Tourist Season Begins," Christian Science Monitor, May 5, 1928, 18.

35 Statement Wiedfeldt, K. Nr. 581, June 16, 1924, BArch R 901/25905.

36 T. R. Ybarra, "Houghton Praises New German Envoy," New York Times, Jan. 30, 1925, 4.

37 Circular AA to German missions in the United States, June 30, 1924, BArch R 901/25905. Travel bureaus in the American West, the German Consul General in New York reported, still advised against a trip to Germany as "unsafe and partly dangerous." See Consulate General, New York, to AA, Mar. 24, 1924, PA R 121327.

38 "Foreigners Shun German High Prices," New York Times, Aug. 6, 1924, 14; Report Wiedfeldt, Mar. 1924, "Reisen von Amerika nach Deutschland"; BArch R 901/25905. 
(naturally smaller and less widely circulated) advertisements of their own. ${ }^{39}$ The result was a considerable lapse in tourist numbers..$^{40}$ By 1924 only 40,000 Americans visited Germany.

Thus, German officials and tourist boosters would have to complement the removal of inconveniences - that is, passive tourism promotion - with an active advertising campaign. Following Ambassador Wiedfeldt's lead, the Foreign Ministry impressed German tourist bodies with the need to raise the number of American visitors and join in a coordinated push for their hearts, minds, and pocketbooks..$^{41}$ In particular, it urged them to follow the French and Swiss example by adopting more sophisticated American marketing techniques and establishing a promotional office in America's business and advertising capital, New York City. At least in the case of the German Tourism Promotion Bureau (RDV) these suggestions fell on fertile ground: eight months later, it opened its first overseas bureau, the German Tourist Information Office, in New York City.

\section{The German Tourist Information Office in New York}

The opening of the German Tourist Information Office (GTIO) on June 16, 1925 , heralded a second and considerably more productive phase of German tourism promotion. Located in beautiful rooms on New York's Fifth Avenue close to major travel agencies - its main mandate was to advertise an attractive image of Germany that would draw Americans to the fatherland once more. This task was far from easy. Though anti-German sentiment was clearly on the wane by 1925 , Germany had only a rudimentary advertising infrastructure. Unlike France, for example, it had never operated a tourist office in the United States before and had made few inroads since the war as a travel destination. In the summer of 1925, Bennett's Tours, one of America's largest travel companies, offered 24 package tours to Europe, but only 3 of them toured Germany whereas all of them toured France. ${ }^{42}$ In travel and society magazines, Germany

39 As long as such "shortsighted parochialism" prevailed, Ambassador Wiedfeldt concluded in August 1924, there would be no use complaining about a lack of American tourists. Wiedfeldt, Aug. 1924, "Reklame zur Hebung des deutschen Reiseverkehrs," BArch R 901/25905.

40 As late as March 1924, the North German Lloyd reported that some of its ships were only $25 \%$ booked for the coming travel season; North German Lloyd to AA, Mar. 10, 1924, PA R 121327.

41 III A 1393, Circular, Oct. 15, 1924, PA R 246898.

42 See the advertisement in Journeys Beautiful (May 1925); Bennett's did, however, offer two extension tours to Germany; Cook's tours was very similar; for the entire early 1920 s they scrupulously avoided the word "German" in their advertisements. While they did go to "Oberammergau (Bavaria)" and "the Rhine," Germany was not mentioned in any advertisements until December 1922; even by 1924 only 1 in 30 of Cook's tours visited Germany; by 1925, however, 
was a nonentity. As late as March 1927, three elite magazines important to travel promotion (Spur, Vogue and Harper's Bazaar) featured 117 international hotel advertisements, of which 61 were Italian, 32 French, 24 Swiss, and 3 German. To make matters worse, these three were directly translated from German and had little appeal to the marketing-savvy American tourist-consumer. The last comprehensive travel guidebook on Germany had appeared in 1912, placing Germany behind Tibet, Siam and Persia in terms of available travel literature. ${ }^{43}$ As a modern travel destination, well-known travel writer Medill McBride concluded, Germany was almost terra incognita to the American tourist. ${ }^{44}$

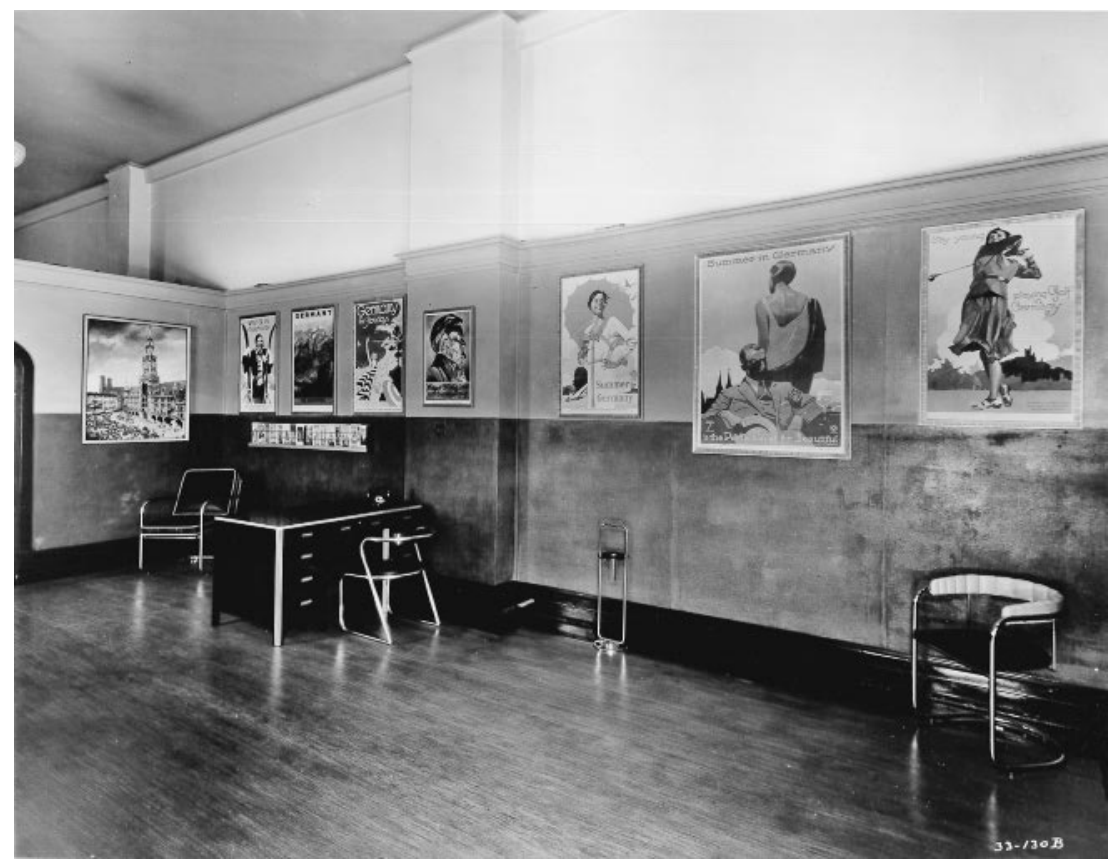

Fig. 12: Interior of the German Tourist Information Office in New York City, ca.1931, NARA RG 131/65, Folder 131-GR-273 Window Displays

Nevertheless, the prospects for systematic tourism promotion in the United States were not altogether discouraging. The Dawes reparations settlement

about $50 \%$ did; see the advertisements in The American Traveller's Gazette: An Illustrated Journal Devoted to Travel (published monthly by Thos. Cook \& Son in New York from 1920 to 1925).

43 RDV, Werbemaßnahmen der Reichsbahnzentrale für den Deutschen Reiseverkehr. Januar bis September 1928, 17, Entry UD 338, Printed Material Concerning German Technology Seized from the German Railroad Information Office, 1927-41, Box 3, Folder: Industry and Technology: General.

44 Robert McBride, Towns and People of Modern Germany (New York, 1927), vii. 
(1924), the Locarno Treaties (1925) and Germany's admission to the League of Nations (1926) readied many Americans for a return to transatlantic normalcy. Not strong antipathy but a lack of information, the GTIO concluded, was keeping Americans from visiting Germany. A skillful marketing campaign thus stood some chance of success. In this regard, Ernst Schmitz, the founding director of the New York office, was German tourism's single greatest asset in the United States. As the former Berlin correspondent of the New Yorker Staatszeitung, the most prestigious German-language newspaper in the United States, Schmitz had an equally excellent command of English and German and a sound grasp of American psychology, unlike most German contemporaries. As a newspaperman, he also understood the tenets of the American advertising business and embraced his role as an advertiser. Schmitz was a member of various professional advertising organizations and advocated the adoption of modern marketing techniques tailored to the mentality and predilections of American audiences. ${ }^{45}$ Indeed, Schmitz proved to be so skillful (and ideologically flexible) in his publicity work that he retained his New York post until June 1941, when the Roosevelt administration shut down all German propaganda offices in America. ${ }^{46}$

Beginning in 1925, the GTIO's concerted campaign reintroduced Germany to the American travel market with astonishing swiftness. Over the following years, it systematically created suitable promotional materials, developed a widespread distribution network in the United States, and built up up-to-date travel literature on Germany by subsidizing, covertly hiring, or simply inviting American travel writers to enjoy lavish trips there. One can gauge the extent of the GTIO's promotional work from the example of the 1928 season: ${ }^{47}$ in the first nine months of that year, the New York office distributed 200,000 of its own German Guide Books, 160,00o booklets by German spas, hotel, and cities, and gave away more than 42,000 leaflets and 6,00o posters. It placed more than 241 English-language and 297 German-language articles in American print media and provided publications with more than 1,100 images. Its almost daily news releases resulted in at least 1,416 English-language and 333 German-language news items. A staggered advertising campaign in 45 upper-class magazines, 30 daily papers, and 100 German-language publications encouraged Americans to visit Germany. A new travel film on Germany was shown in American movie

45 On Schmitz's memberships, see NARA Entry\# UD 336, General Administrative Records Seized from the GTIO 1926-41, Box 2, Folder 1.

46 This occurred due to repeated congressional investigations of the Tourism Office as a part of the German propaganda infrastructure in the United States. When the offices were closed, their records were seized by the United States. Together with the records of a number of other German and German-American bodies, they are today part of the Records of the Office of Alien Property at the National Archives, College Park, Maryland.

47 See RDV, Werbemaßnahmen der Reichsbahnzentrale für den Deutschen Reiseverkehr. Januar bis September 1928. 
theaters, and, in the run-up to the travel season, almost 40 American travel agencies highlighted Germany in their window displays (which included, for example, large-scale reproductions of Neuschwanstein Castle). An agreement between the GTIO and Thomas Cook \& Son made sure that 61 of its 76 package tours to Europe that summer included Germany. Meanwhile, reputable travel speaker John Bucher (hired by the German embassy) portrayed Germany to 30,000 Americans in some 40 cities, and revered travel writer E.M. Newman had just - following a contract with the RDV - traveled the Reich in preparation for a new book on Germany to be published by the prestigious and reputedly still anti-German publishing house of Funk \& Wagnalls. In fact, the postwar travel literature on Germany grew from zero books in 1925 to more than a dozen just five years later. By tapping into the entire marketing repertoire of its time, the GTIO successfully re-established a German presence in American journals, newspapers, package tours, bookstores, radio broadcasts, lecture halls, and movie theaters across the country.

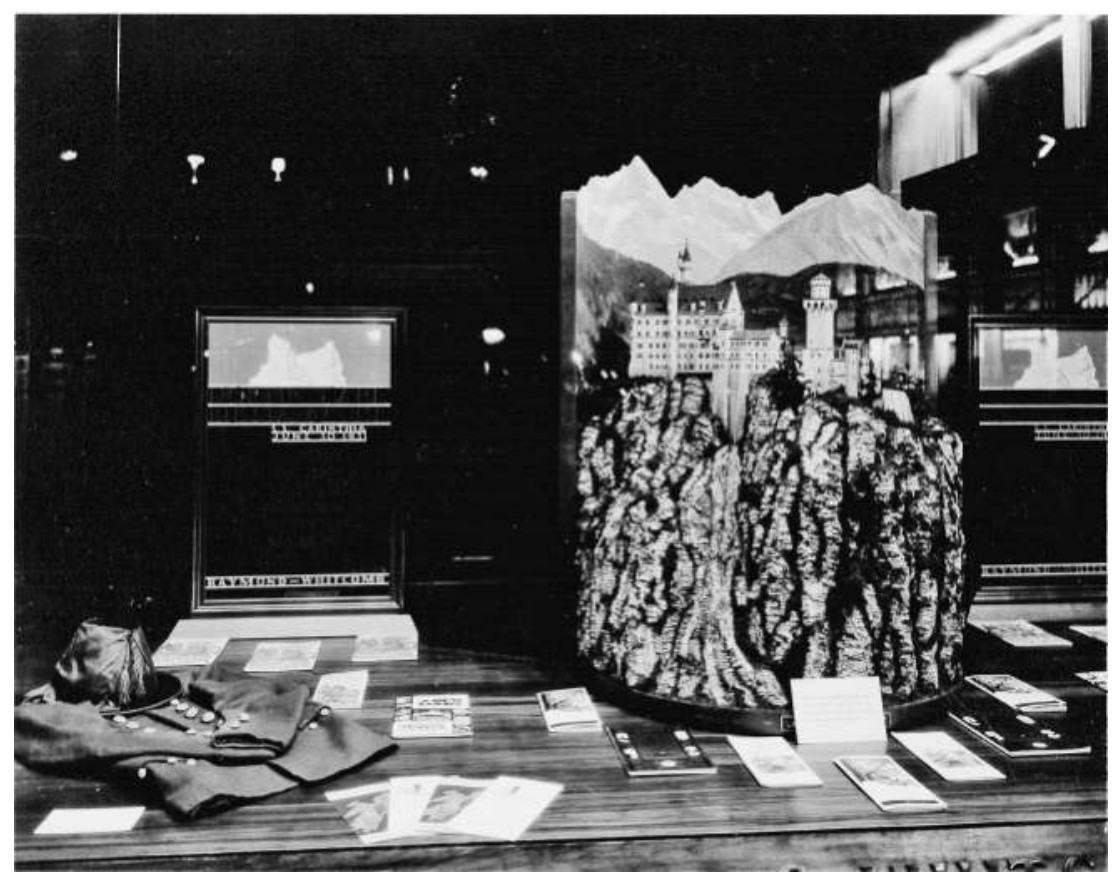

Fig. 13: Window Display of Neuschwanstein Castle at Whitcomb Travel Agency in New York, NARA, RG 131, Box 65, Folder 131-GR-273, Window Displays

The GTIO owed its success to a number of factors. First, Schmitz understood the workings of the American travel market. He recognized that effective promotion depended on the support of American travel agencies, which gladly 
accepted well-designed and informative promotional materials from an advertising bureau but would have rejected them from a commercial rival. This was why the GTIO always remained purely a promotional office, despite the obvious commercial interests involved. All its materials were free of charge, and, as Schmitz once put it, there was nothing at all for sale at its office. The second, equally important precondition was its willingness to adopt sophisticated American marketing practices. The GTIO readily embraced concepts of market research, target audiences, and consumer psychology that were already entrenched in the American market but only just beginning to gain a foothold in Europe.$^{48}$ Within a year of embarking on its transatlantic activity, for example, the GTIO no longer distributed materials that were created indiscriminately for the entire English-speaking world but catered to predilections and cultural understandings believed to be distinctly American. As a result, brochures began to feature catchy slogans, avoid unnecessary detail, include brilliant images, and explain the German land and people in ways deemed intelligible to Americans. The 1931 brochure Germany - Visit the Heart of Europe is a case in point. Designed and written solely for the U.S. market, it explained Germany's size and geography in terms of American states ("Germany is about the size of California"), illustrated Germany's beauty using quotes from wellknown American authors (Mark Twain, Walt Whitman), and highlighted the famous Americans who had once attended various German universities to point to their renown. ${ }^{49}$ Finally, the RDV not only rigorously applied these standards to its own work but imposed them on all its member organizations..$^{50}$ As it refused to forward any material that failed to meet its strict advertising guidelines, only a fraction of German materials ever qualified for the American market. This generated both considerable resentment among regional tourism bodies and coherent and well-designed German tourism propaganda. ${ }^{51}$

48 See Alexander Schug, "Missionare der globalen Konsumkultur. Corporate Identity und Absatzstrategien amerikanischer Unternehmen in Deutschland im frühen 20. Jahrhundert," in Politische Kulturgeschichte der Zwischenkriegszeit 1918-1939, ed. Wolfgang Hardtwig, 307-339, (Göttingen, 2005).

49 RDV, Germany: Visit the Heart of Europe, 1931.

50 On the RDV's guidelines, see Ernst Schmitz, Werbespiegel. Increasing competition within Germany led many municipalities, hotels, and touring associations to adopt their own publicity plans. Between 1908 and 1928, the average advertising funds of German cities rose from an annual 2,000 marks to 19,000 marks. By the late 1920 s there was hardly a German city that did not advertise itself as a tourist destination. The city of Berchtesgaden alone raised the number of city brochures it printed from 20,000 to 160,000 after the war. See Christine Keitz, "Grundzüge einer Sozialgeschichte des Tourismus in der Zwischenkriegszeit," in Reisekultur in Deutschland. Von der Weimarer Republik zum 'Dritten Reich', ed. Peter Brenner, 49-71 (Tübingen, 1997), 68.

51 While almost $20 \%$ of the RDV's own brochures were sent across the Atlantic, only $10 \%$ of those of its member associations were deemed good enough for the American market; see RDV, Werbemaßnahmen der Reichszentrale für Deutsche Verkehrswerbung April bis Dezember 1927, PA R 121266. 

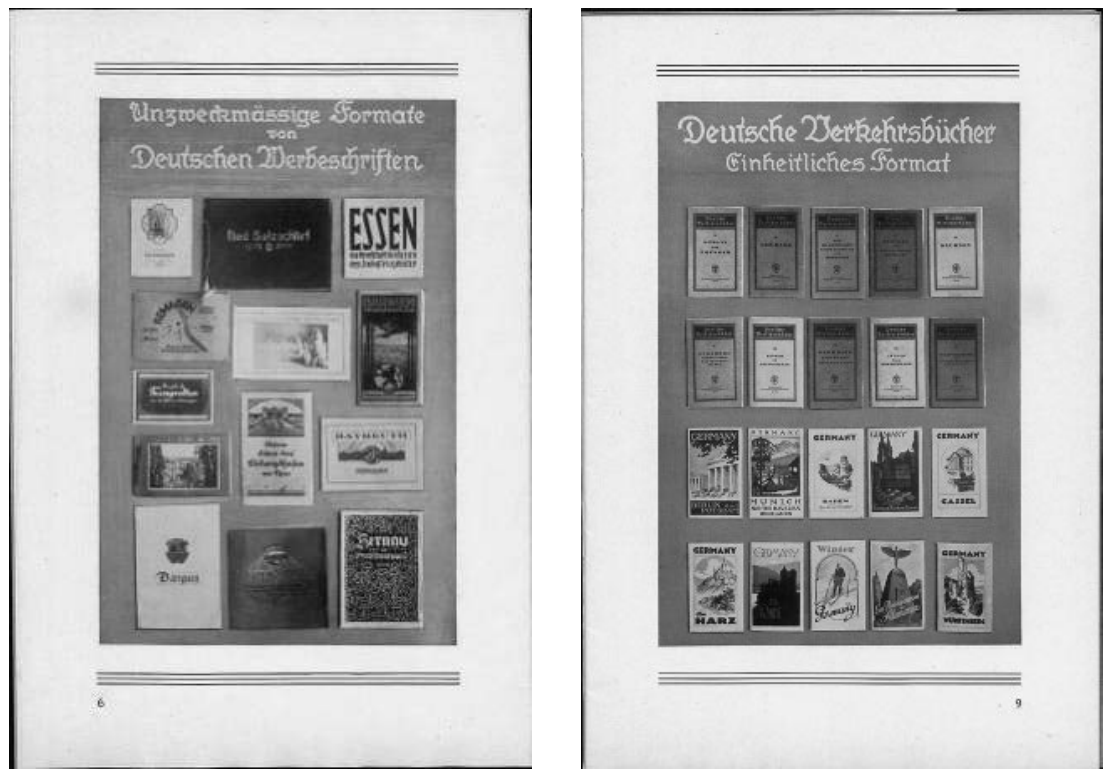

Fig. 14: Streamlining German Tourism Advertising - Before and After: Ernst Schmitz, Werbespiegel, 1926, Politisches Archiv des Auswärtigen Amts, R 65090

Importantly, too, the RDV appealed to American tourists around the world. Much of its marketing budget - which increased dramatically from 178,000 marks in 1924 to 2.8 million marks in 1927 - went toward establishing a network of international offices in Zurich, Rotterdam, Stockholm, Paris, and London, not least to reach American tourists. ${ }^{52}$ The RDV's Parisian office on the Champs-Élysées, for instance, catered predominantly (70\%) to an American clientele, working diligently to reroute the stream of American tourists from France to Germany. ${ }^{53}$ In the same vein, the RDV opened its second overseas bureau in Havana in 1929 not to appeal to Cubans but to American vacationers. The RDV's ambition to reach solvent and politically influential American tourists wherever they roamed was largely what gave rise to an international infrastructure of German promotional offices over the course of the 1920 s.

52 Niederschrift über die Sitzung des Verwaltungsrats der Reichszentrale für deutsche Verkehrswerbung, Berlin, June 12, 1925, BArch R 8132/13; Jahresrechnung Reichszentrale für Deutsche Verkehrswerbung, 1927, PA R 246900; the exchange rate was fixed at one dollar to 4.2 Reichsmarks.

$53 \mathrm{RDV}$, Werbemaßnahmen der Reichszentrale für Deutsche Verkehrswerbung April bis Dezember $1927,18$. 


\section{"The New Old World" - German Image-Building and Tourism Promotion}

With German tourism promotion swiftly establishing a foothold in the United States, what image of Germany did it advertise, and how, if at all, did it serve larger national interests?

It is important to note that the very premise of the GTIO's advertising was selling all of "Germany." Whereas German health resorts, for instance, sought to promote the curative effects of a certain German spa, or German shipping lines sought to sell a trip to Europe on a German carrier, the GTIO operated under one slogan only: Germany. Its advertising lines ran: Germany wants to see you! - Germany invites you! - See Germany next! - Going to Europe means going to Germany! All of its travel booklets, posters, and brochures, regardless of the region, city or event they advertised, invariably featured "Germany" on their title page; no promotional materials designed by cities, spas, or trade fairs had a hope of being distributed in the United States if they did not adhere to this principle. As Schmitz explained to the representatives of German tourist organizations, "the promotion of Germany in America has to be not only active but aggressive. It has to struggle and fight, has to be taken onto the streets and to the people, and again and again in spoken and written word, on images and posters, in brochures and lectures it has to proclaim but a single word, a single name, and this name is: Germany." 54

This broad publicity for Germany evolved from a combination of structural and political factors. Representing a wide array of organizations and funded primarily by the German Railroads, the RDV was invested in promoting all of Germany as a travel destination rather than focusing on a certain city or region. This broader publicity, in part, also reflected the significant European competition for American tourists. Competing with equally broad French, Swiss, and Italian publicity, only such general promotion of Germany would have enough of a "ring" to draw larger tourist numbers. Americans, the RDV realized, did not travel halfway around the world to visit Bordeaux, Genoa or Bayreuth, nor were they lured by the Nouvelle-Aquitaine, Liguria or Bavaria; their desire was to see France, Italy, or Germany as a whole. As all advertising experts and the embassy in Washington repeatedly imparted to disgruntled regional tourist bodies, advertising a single city or region was simply doomed to failure. ${ }^{55}$ This premise also arose from the pragmatic insight that Americans had relatively limited geographic knowledge. Schmitz often encountered American customers who, planning to travel from Cologne to Düsseldorf (a

54 Amerika-Propaganda und amerikanischer Reiseverkehr (Schmitz, 1926), 6, NARA Entry UD 328: Seized Promotional Materials of the German Railroad Information Office, 1932-1941, Box 36, Folder: Tourism: Promotion.

55 III A 1393, Circular by the AA (to all bodies interested in American tourism), Oct. 15, 1924, PA R 246898. 
12-mile trip), wanted to stop over in Venice or Budapest. Despite such gaps in Americans' knowledge of Europe, Schmitz noted that "there is one thing that the American knows all too well; that there is a Germany in Europe. Therefore everyone who wants to promote a single German city or region in the United States, again and again has to advertise Germany. The name 'Germany' will be his best advertising slogan and only with this slogan will he prevail." ${ }^{36}$ Lastly, political considerations played into these commercial reasons. If travel advertisements were to improve Germany's transatlantic standing, then a focus on "Germany" was an essential prerequisite. Advertisers like Schmitz and diplomats like Ambassador Prittwitz concurred that "Germany" itself was the very brand name they were seeking to re-establish among the American public.

Still the RDV advertisements catered first and foremost to the demands of the American tourist, emphasizing the convenience, value, and hospitality of travel in Germany. They depicted Germany as a country where customs formalities were negligible, the train system punctual, the cities safe and impeccably kept - a place where, due to the variety of German landscapes, customs, and history, money traveled further and a friendly, hospitable population welcomed Americans. In fact, a significant proportion of German advertisements emphasized the absence of hard feelings, and even Germany's great appreciation for its former enemy. ${ }^{57}$ While such depictions are the stock-in-trade of all modern tourism promotion, they took on added meaning against the backdrop of the war. Cultural representations of German hospitality and docility deliberately countered wartime images of German aggression and frequently played out directly vis-à-vis Germany's European rivals. Germany's oft-cited cleanliness, for example, was more or less a direct stab at France's alleged lack thereof; it was likely no coincidence that advertising pro-American feeling in Germany peaked just as reporting on anti-American feeling in France soared after 1926. All in all, the picture of the clean, hardworking, efficient and hospitable German (who allegedly loved to speak English and appreciated Americans for more than just their dollars) aimed to whittle away at prevalent enemy images.

Naturally, the GTIO did not sell the same image of Germany to everyone and its advertisements diversified noticeably over time. For example, it emphasized a nostalgic, romantic version of Germany to German Americans..$^{8}$ So-

56 Amerika-Propaganda und amerikanischer Reiseverkehr (Schmitz, ca.1926), NARA Entry UD 328: Seized Promotional Materials of the German Railroad Information Office, 1932-1941, Box 36, Folder: Tourism: Promotion.

57 Donald Douglas, "Travel, New Style: Recipes, from a Modern Traveler, on How to Discover Germany and Have a Mighty Good Time Doing It," Nomad (March 1929), NARA Entry UD 328 , Box 9, Germany: General I.

58 Originally, it seems the GTIO did not set out to promote tourism among German Americans because if they traveled to Europe, they made sure to visit Germany anyway. Moreover, $98 \%$ of all travel agencies were owned by Anglo-Americans, and the RDV saw little use in German-lan- 
called Heimatbilder ("images of the homeland"), vignettes of certain regions or folk traditions, struck an emotional tone and offered idealized pictures of quaint German towns. Another highly coveted target audience was universities, to which the GTIO emphasized Germany as a land of culture with special brochures on German universities, Goethe, and music; Schmitz fostered this effort by maintaining a mailing list with the addresses of more than 800 professors and teachers with an interest in Germany. ${ }^{59}$ In this context, the GTIO also supplied hundreds of classrooms with splendid posters of Germany and provided its brochures and popular films as classroom materials to German teachers free of charge. Finally, it sold Germany to affluent Anglo-Americans as a convenient, well-kept, and hospitable country inhabited by slender, alluring Fräuleins, chic boutiques, technological marvels, sublime music, and high(and low-)brow entertainment. In the very late 1920 in in particular, trips to Germany were packaged as part of an upper-class lifestyle, with poster campaigns featuring beautiful people engaged in leisure pursuits. ${ }^{60}$

guage materials. See "Vertraulich! Tätigkeits-Bericht der German Railroads Information Office New York. Vom 15. Juni-15. Dezember 1925," PA R 65090.

59 RDV, Werbemaßnahmen der Reichszentrale für Deutsche Verkehrswerbung April bis Dezember 1927, PA R 121266; this reached a high point during the 1932 Goethe celebrations, which will be covered in more detail in Chapter 7.

60 See, for example, the advertisement: "Germany: Land of Beauty and Sports," Travel (Mar. 1930): 3; Henry Albert Phillips, "Winter Sports in the Bavarian Alps," Travel (Jan. 1932): 14-17; RDV, Germany: Land of Varied Attractions (brochure), 1931. 


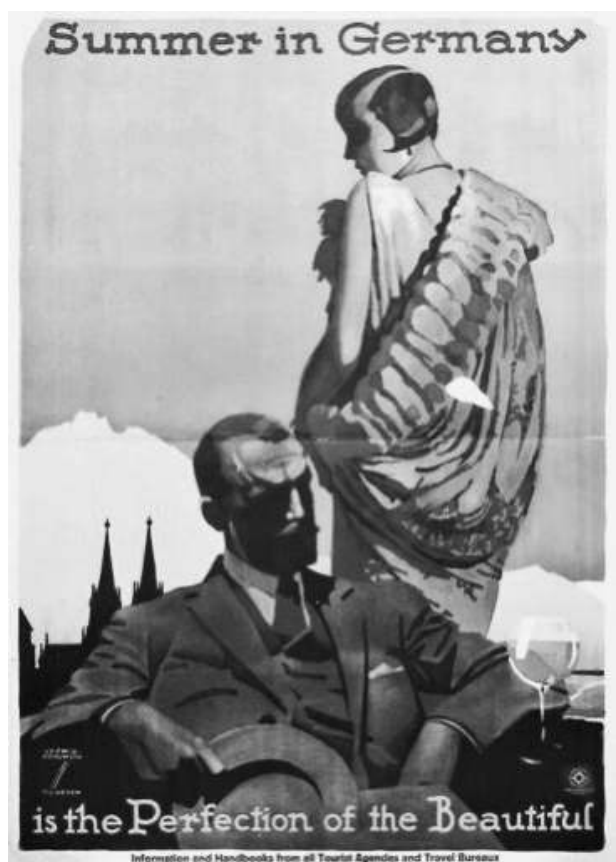

Fig. 15: Ludwig Hohlwein, "Summer in Germany,” Poster, German Tourism Promotion Office, 1928

These advertisements served Germany's quest for cultural rehabilitation in a dual sense. For one, promotional materials re-established Germany as a land of ancient and enthralling history, a land (to echo one of Schmitz's favorite phrases) that "was old when Columbus discovered America." Showcasing its rich cultural heritage and its prominent position in the worlds of classical music and higher education, this campaign reclaimed Germany's status as a civilized nation. At the same time, however, its strong focus on German modernity signaled a clear break with the days of old. It presented Germany as the most modern and advanced nation in Europe, replete with technological ingenuity, modern industry, and contemporary architecture. "Our modern age," wrote Schmitz (posing as an American observer) in obvious hyperbole,

has created the most impressive achievements in Germany. Let a traveler see the sparkling great cities with their stirring business, spotless cleanliness and efficient administration. Let him wonder at the modern architecture and city planning in the suburb and small city and let him visit the roaring workshops of industry. He will then experience the marvel of German invention and German technology, learn the great projects of recovery and business and acknowledge without envy the rightful eminence of the German people as the most progressive and modern in Europe. ${ }^{61}$

61 Schmitz, The Land of Wanderlust, ca.1932, NARA Entry UD 336, Box 2, Folder: Ernst Schmitz Personal Papers. Writings on German travel, n.d. 
The RDV visualizations of Germany often emphasized the traditional and modern aspects of Germany side by side (e.g., by depicting a car in front of a cathedral), arguably reminding viewers of Germany's rich contributions to civilization while distancing it from its suspect Wilhelmine past.

Fig. 16: Jupp Wiertz, "Germany Wants to See You," Poster, German Tourism Promotion Office, ca.1926

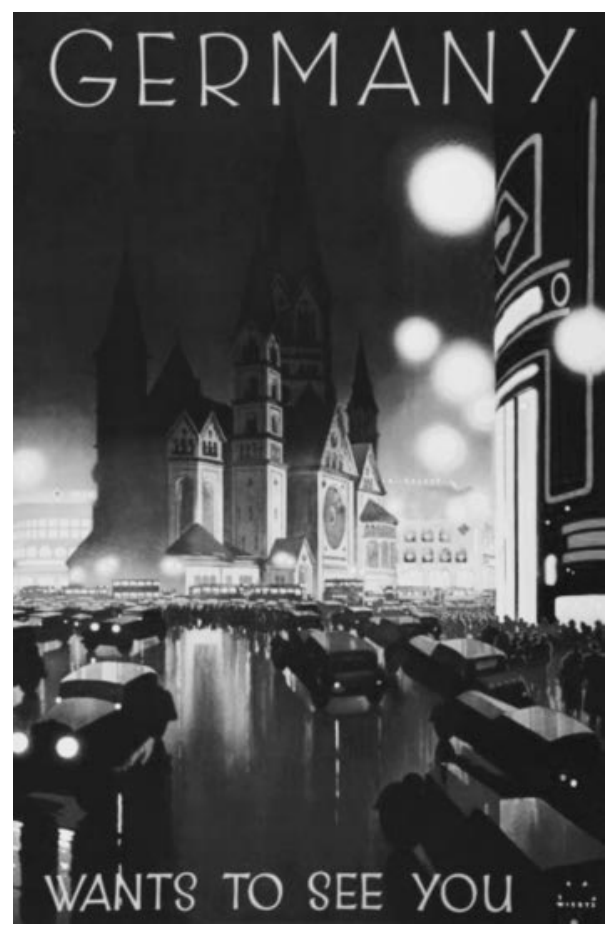

Such advertisements quite deliberately suggested that Germany was not simply the most modern but also the most American country in Europe - terms, to be sure, that Europeans used virtually interchangeably at the time. Many of the advertisements sought to establish a specific likeness between Germany and America or at least emphasize Germany's particular affinity for the United States. Schmitz, for example, often highlighted that American developments and mass culture generated a broad interest in Germany and, passing as an impartial American observer in a travel magazine, he hailed Germany as the "new old world" replete not only with old-world charms but a new-world mindset. ${ }^{62}$ Strikingly, these visions of an "Americanized" Germany remained mostly apolitical. Germany's modernity and affinity for America were expressed through

62 E. S. Crayfield (= Ernst Schmitz from Krefeld), "The New and the Old in Germany," Nomad 3/4 (Mar. 1927). 
shared leisure pursuits, sanitary conditions, and technological achievements, not the fact that both countries were republics. ${ }^{63}$ While the RDV's emphasis on a "modern Germany" seemed to signal a clear break from its monarchical past, it did not mean an emphatic embrace of the republican present. Consequently, Nazi Germany was able to almost seamlessly adopt the touristic images and slogans developed during the 1920 after 1933.

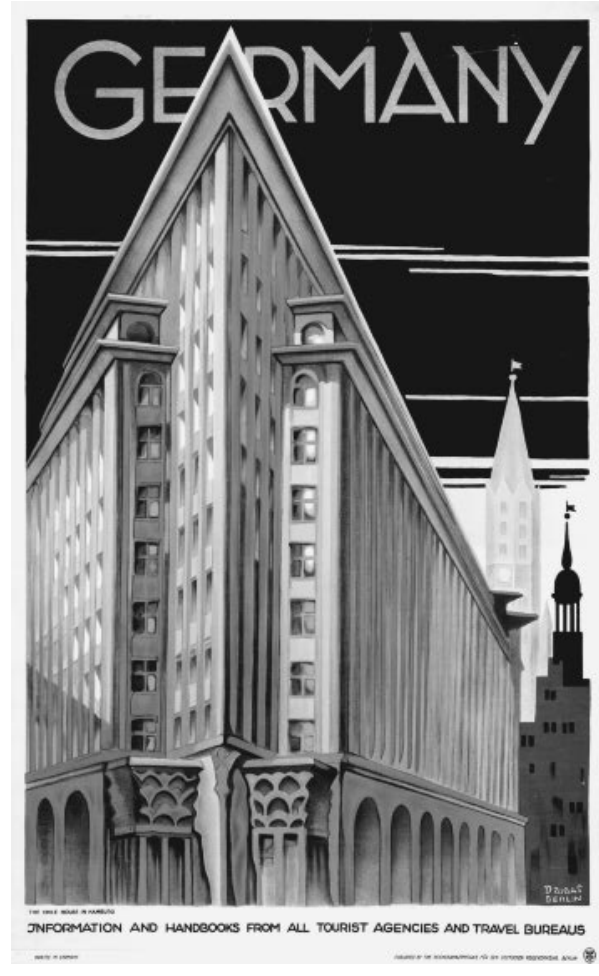

Fig. 17: Willi Dzubas, “Germany,” Poster, German Tourism Promotion Office, ca. 1930

Nevertheless, tourism promotion tied in closely with Weimar's foreign policy objectives at the time, becoming a legitimate, even coveted, part of German public diplomacy over the course of the 1920s. German diplomats at home and abroad recognized its unrivaled potential to revise Germany's "distorted image" while at the same time avoiding accusations of "German propaganda." 64

63 An exception is the March 1927 issue of Nomad, a travel journal, whose editorial seems to have been penned by Ernst Schmitz; he surmised that there was no reason "the Republic of Germany should not become even more popular among American travelers than was the German Empire”; see Anon., “The Contributing Editors Keyboard," Nomad (Mar. 1927): 5

64 Travel advertisements, the German consul general in New York judged, were "beyond their actual objective, valuable general advertising media for Germany [and ...] the beneficial side ef- 
The GTIO worked closely with German representatives in the United States, submitting regular circulars on its undertakings, sharing information on prominent visitors to Germany, and usually accommodating official suggestions concerning the content or distribution of its materials. ${ }^{65}$ In 1932, when the Foreign Ministry commissioned reports on the effectiveness and suitability of German tourism promotion abroad, German missions in the U.S. offered an overwhelmingly positive assessment, commending the GTIO's work as "extraordinarily skillful und effective" (Chicago), "well-rounded and suited to national conditions and [...] target audiences" (New York), and even altogether "exemplary" (St. Louis). ${ }^{66}$ Importantly, as the New York Consulate stressed, Americans, who were "generally highly trained in advertising matters," widely shared this impression. ${ }^{67}$ The German Consulate in St. Louis praised the GTIO highly, explicitly connecting its work to the consulate's own:

[... the GTIO's] advertising work guarantees something much greater [than tourist revenue], namely, depending on the individual, the awakening, strengthening or deepening of interest, of understanding and of recognition of German cultural values. Its advertising work offers an entirely indispensable support and resource for the consulate's cultural political work. $^{68}$

German tourism promotion in the United States, then, clearly doubled as public diplomacy. Its depictions of Germany sought to free the nation's history and culture from wartime misrepresentations and strengthened its claims to a great and powerful status based on its sophisticated past and accomplished present. American tourism featured prominently in Germany's pursuit of a transatlantic partnership as the GTIO portrayed it as a stable, peaceful, and productive region of Europe, extending a warm welcome to American visitors and investors alike. As Weimar's single largest advertising endeavor in the United States (and indeed the world), tourism promotion played a key role in reshaping Germany's image in line with its strategic interests. Representations of Germany and the ensuing trips they prompted, theoretically at least, were well suited to evoking new interest, sympathy, and respect - but did they actually do so?

fects of tourism promotion are to be evaluated as pretty high." German Consulate General, New York, to AA, Mar. 23, 1932, "Fremdenverkehrswerbung," PA R 246918.

65 German Embassy, Washington, to AA, Apr. 27, 1928, "Vortragstätigkeit Mr. Buchers," PA R 80300.

66 Reports in PA R 246918; these files also hold a very interesting survey of German missions worldwide: "Beobachtungen der deutschen Auslandsvertretungen über die im Ausland betriebene deutsche Fremdenverkehrswerbung und Anregungen für ihre Ausgestaltung."

67 German Consulate General, New York, to AA, Mar. 23, 1932, "Fremdenverkehrswerbung," PA R 246918.

68 German Consulate, St. Louis, to AA, Mar. 14, 1932, "Fremdenverkehrswerbung im Ausland," PA R 246919. 


\section{American Travelers in Weimar Germany}

Without a doubt, international travel affected how elite Americans imagined and discussed world affairs and their own nation's role in them. As scholars have shown, it was often through impressions gained abroad that Americans "articulated visions of how the United States and its citizens should behave in the world." 69 Even tourism, long dismissed as a particularly trivial form of travel, is now increasingly recognized as a "communication between Self and Other,"70 as a modern practice that produced "images not only of tourists, but of the nations tourists consumed." ${ }^{11}$ Importantly, I would posit, this was to some degree true even of those many travel-minded Americans who never left North America. Travel, one should recall, was everywhere in 1920 s America: travel magazines and talks, travel editorials and advertisements, travel accounts and books all enjoyed unprecedented popularity during this decade. Newspapers informed their readers of who had arrived from or departed for Europe, colorful tourism advertisements adorned train stations and shop windows across the country, and fashion and lifestyle magazines - as well as novels and short stories, of course - covered the splendid outings of America's rich and famous extensively. ${ }^{72}$ Collectively, all these images generated a mental map of the world not just for the actual but for the potential, or vicarious, traveling public. ${ }^{73}$ Whereas interest in foreign politics proper was at a low ebb, interest in travel was at high tide. This is not to suggest that Americans uncritically believed travel accounts, let alone advertisements, nor that travelers (armchair or actual) arrived at similar conclusions. ${ }^{74}$ Travel to Europe could enthrall or repel; it could heighten or deflate notions of American exceptionalism; or it could suggest isolation or intervention, and everything in between. But it did have an impact.

69 Endy, "Travel and Power," 590-575.

70 Rudy Koshar, “What Ought to Be Seen': Tourists' Guidebooks and National Identities in Modern Germany and Europe," Journal of Contemporary History 33, no. 3 (1998): 323-340, 329. 71 Koshar, "What Ought to be Seen," 339; this is certainly most pronounced with regard to the attacks on tourists in France in 1926. For a brief description of the general climate in which these attacks took place, see Brooke Blower, Becoming Americans in Paris. Transatlantic Politics and Culture between the World Wars (New York, 2011), 69-70.

72 Many of them even ran their own international travel bureaus for the convenience of their travel-minded readership. For example, Vanity Fair's International Travel Bureau advertised that "No matter where you want to go, the Travel Bureau will tell you how to get there, what to see and when to see it"; see Vanity Fair (Jan. 1921): 12.

73 Scholars have long drawn on travel literature to explain the cognitive and discursive construction, the "mental mapping," of the "Orient," the "West," or the British Empire; see Robert F. Hunter, "Tourism Empire': The Thomas Cook \& Son Enterprise on the Nile, 1868-1914," Middle Eastern Studies 40, no. 5 (2004): 28-54.

74 Frank Schoonmaker ridiculed tourism advertisements as "obvious hyperbole," but felt them to be "very effective. To laugh at it is to laugh at the whole principle of advertising." See Frank Schoonmaker, “The Tourist's Dollar," Outlook and Independent (July 23, 1930): 460-61. 
Before we can assess this impact for the case of Germany, however, we must first explore American travel patterns to Germany. This is seriously complicated by a lack of comprehensive and reliable statistics. ${ }^{75}$ That American travel to Europe grew significantly during the 1920 s is abundantly clear: the American statistics on American travel and overseas expenditure, compiled after 1922 by the U.S. Department of Commerce, show that American tourism doubled from 6o,0oo in 1919 to 125,000 in 1920 and again to 245,000 in 1927 before reaching an all-time high in 1930, when about 280,000 Americans traveled to Europe. After this, numbers dropped rapidly, reaching a low of 144,000 in $1933 .{ }^{76}$ It is more difficult to find out how many of these Americans went to Germany, however. Only in 1935 did American statistics begin to specify exact European destinations. ${ }^{77}$ German statistics, too, are problematic, as national tourism statistics were only introduced in the early 1930s, and the municipal data available for the 1920 s neither followed standardized guidelines nor covered all (or even all larger) German cities..$^{78}$

As a result, estimates varied dramatically. For instance, while the RDV estimated that 185,000 Americans had visited Germany in 1929, the Foreign Ministry estimated that as few as 70,00o had done so. ${ }^{79}$ Neither of these estimates, however, seems very reliable. While the RDV systematically overstated the number of American visitors to highlight the effectiveness of its work, the Foreign Ministry (at this point engulfed in a power struggle with the RDV, described later in this chapter) aimed to depreciate these numbers to underline the need for a tourism reform under its aegis. Similar problems apply to American tourist expenditure. According to American statistics, American expenditure in Europe peaked at $\$ 303$ million in 1929, with Americans spending \$137 million in France, $\$ 45$ million in Germany, and $\$ 40$ million in Great Britain. ${ }^{80}$

75 Also useful for data on the long-term rise of American travel to Europe is Dupont, Ghandi and Weiss, "The American Invasion of Europe: The Long Term Rise in Overseas Travel, 18202000," National Bureau of Economic Research, Working Paper 13977 www.nber.org/papers/ w13977. Looking at a period of 180 years, the authors explain the long-term rise of American tourism to Europe primarily through two factors: population growth and GDP/capita, though they, of course, recognize that travel patterns have been affected by a multitude of other, less measurable, factors.

76 The progression was as follows: 1919: 60,000; 1920: 125,000; 1921: 150,000; 1922: 160,000; 1923: 140,000; 1924: 170,000; 1925: 205,000; 1926: 215,000; 1927: 245,000; 1928: 260,000; 1929: 265,000; 1930: 279,000; 1931: 220,000; 1932: 211,000; 1933: 144,000.

77 However, they do allow interesting insights into why Americans traveled to Europe: a 1929 study by the U.S. Dept of Commerce found that almost $50 \%$ traveled for pleasure, while the second largest group (35\%) cited family affairs, $7 \%$ educational, and $8 \%$ commercial reasons for going overseas. Department of Commerce, Oversea Travel and Expenditures 47, Table 24.

78 Some cities asked travelers to list their country of origin; others simply their home continent. 79 Davidsen, "Schätzung der Ausgaben amerikanischer Reisender in Deutschland" (ca. 1932), PA R 105542; GTIO to German Embassy, Washington, Apr. 1930, PA R 246905.

80 Total expenditures by U.S. citizens visiting Europe and the Mediterranean in millions of dollars amounted to 59 in 1919, 122.9 in $1920,148.2$ in $1921,180.4$ in 1922, 171.1 in $1923,195.4$ in 
But since it was believed that the U.S. Department of Commerce inflated these numbers to appease Europeans complaining about U.S. tariffs, the Foreign Ministry adjusted them downward to only $\$ 20$ million in $1928 .^{81}$

Bearing these distortions - and their self-serving motivations - in mind, we may still arrive at more reliable estimates. One way to do so is to deduce the figures for the 1920 s from the destination information available in U.S. statistics from the 1930s. According to the U.S. Department of Commerce, $38 \%$ of all U.S. citizens going to Europe visited Germany in 1935 and $48 \%$ did so in 1936. During the same time, $51 \%$ and $40 \%$, respectively, visited France, while $57 \%$ and $52 \%$ visited Great Britain. While these numbers were clearly affected by the 1935 Crown Jubilee in England and the 1936 German Olympics, they average out to $43 \%$ for Germany, $55 \%$ for Britain (where transatlantic liners docked), and $46 \%$ for France. Assuming that Nazi Germany was neither less nor more attractive to American visitors than the Weimar Republic, it is fair to conclude that 110,000 Americans at the very least visited Germany in 1930. The 130,000 visas that German missions issued to Americans in the United States and Europe during that year roughly corroborate this number. ${ }^{82}$

If we assume that only 40,000 Americans visited Germany in 1924, then American travel to Germany did not just keep pace with but outperformed overall European increases, especially after 1928. While general travel to Europe stagnated during that year, American visitors to Germany seem to have increased by about $15-20 \% .{ }^{83}$ Certainly, the relative impact of American tourism was pronounced in terms of numbers and expenditure. In German cities for which data is available, Americans were the single largest - and the single most profitable - group of foreign tourists. ${ }^{84}$ And even if we accept the Foreign Ministry's lowered estimate of American expenditure at \$20 million in 1928, this still amounted to half of all revenue generated by international tourism in the German balance of payments. ${ }^{85}$ Even though there is a lack of precise data,

$1924,227.1$ in $1925,237.3$ in $1926,262.4$ in 1927,287 in $1928,302.9$ in $1929,283.8$ in 1930 , 174.7 in $1931,127.3$ in 1932, and 91.5 in 1933; see Historical Statistical Abstract of the United States, 404; U.S. Department of Commerce. Bureau of Foreign and Domestic Commerce. Trade Promotion Series - No. 113, "The Promotion of Tourist Travel by Foreign Countries" (Washington, 1931), 2; copy in Folder: Tourism: Promotion, NARA Entry UD 328: Seized Promotional Materials of the German Railroad Information Office, 1932-1941 Box 36.

81 Davidsen, "Der ausländische Fremdenverkehr in Deutschland," 1929, PA R 246903.

82 AA to Reichsbahnzentrale für den deutschen Reiseverkehr, Apr. 22 1931, PA R 246917.

83 RDV, Werbemaßnahmen der Reichsbahnzentrale für den Deutschen Reiseverkehr. Januar bis September 1928, 18.

$8412.3 \%$ of all tourists in ten German cities were American. Davidsen, "Der ausländische Fremdenverkehr in Deutschland," PA R 246903.

85 Länderrat des Amerikanischen Besatzungsgebiets, Statistisches Handbuch von Deutschland 1928-1944 (Munich, 1949), 602-603; the assets from international tourism stood at 180 million marks in 1929; the liabilities (created by Germans traveling abroad) at 300 million marks. 
American tourist numbers and expenditure rose very significantly through the 1920 s, both in absolute and relative terms.

To be sure, this development was hardly due to German efforts alone. In part, it resulted from tourists resuming earlier travel patterns as the war faded into memory and Germany re-entered the family of nations. It also stemmed from developments in competing tourist destinations, especially the emergence of hostility toward American tourists in France in 1926, which was heavily publicized at the time, as well as the strengthening of the franc the following year. Tellingly, Paris had its worst postwar season in 1929, just as Germany had its best. ${ }^{86}$ Still, we cannot dismiss German efforts, either. If we recall Germany's near absence from contemporary materials, magazine advertisements, and package tours as late as 1925, we can reasonably assume that the German government's incentives (waiving visa fees and abandoning customs regulations), combined with the GTIO's extensive promotional efforts, accelerated this process. Many German, American, and French contemporaries, at least, attributed the rise of Germany in American tourist favor to its marketing offensive. ${ }^{87}$ One decade after the war, Germany had, indeed, recaptured a considerable segment of the American travel market.

It is also fair to assume that rising tourist numbers themselves expressed a normalization of American sentiment toward Germany. But it is considerably more challenging to assess precisely how American travelers experienced Germany and what they took away from a trip there. Since it is impossible to create a truly representative sample of tourist impressions, any assessment has to rely on published accounts, especially in travel-oriented, upper-class American magazines. ${ }^{88}$ Using published over archival material allows us to follow a broader public debate, yet it also poses distinct methodological challenges. For one, we have to distinguish actual travel accounts from the widespread (and unlabeled) "advertorials." In other words, we have to distinguish how Americans saw Germany from how Germany wanted to be seen. Moreover, articulate published accounts are not likely to reflect the opinion of the average American "tourist." While little can be done about this latter fact, the following discussion excludes all placed articles as far as possible, even if they were not

86 Clipping: "Tourists Snub Paris and Its Leaping prices,“ Daily News, Aug. 7 1929, PA R 246903. 87 "Dark Horse in the Tourist Trade," The Atlanta Constitution, June 29, 1930.

88 These included Atlantic Monthly, Harper's Monthly, Literary Digest, North American Review, Outlook, Scribner's Magazine, World's Work, Literary Digest, Saturday Evening Post, National Travel Club, Travel, Travel Talks, National Geographic, Journeys Beautiful, Town and Country, The Spur, Current History, Business Survey, Railway Life, Cook's American Traveler's Gazette, Cook's Excursionist and Tourist Adviser, Ladies' Home Journal, Paris Tribune, Variety, New York Times Magazine, New Republic, and The Nation. 
readily recognizable as such to contemporary readers. On this basis, it tries to show how American travel shaped discussions on Germany.

Two more general observations are in order at this point. The first concerns the frequency of American travel reporting on Germany. As American tourism to Germany rose, so did coverage of Germany in American publications. While American reporting on Germany in the postwar years had concentrated on economic or political factors, the later 1920 s saw a notable increase in travel-related matters. Still, German observers perceived a slight, but significant, time lag between American tourists' return to Germany and any corresponding public discussion. For example, by 1927 the German consul general in San Francisco regularly provided upper-class American families with summer visas to Germany and recommendations for German schools only to find that these families, in their official travel announcements in the newspapers, admitted only to staying in Paris, the South of France, "perhaps even Italy or Egypt, but never Germany." ${ }^{99}$ Even though Americans were once more interested in visiting Germany, the consul concluded, they were - "under the spell of French society" - not yet ready to admit to traveling in Germany. ${ }^{\circ 0}$ This changed noticeably after about 1928, however, when prominent magazines such as Town and Country, Good Housekeeping, the Living Age, Vogue, Harper's Bazaar, and Vanity Fair opened their pages first to large-scale German travel advertisements, then to more detailed articles. As part of this trend, the consciously elitist Town and Country reintroduced a regular "Berlin Letter" (in addition to a "London Letter" and a "Paris Letter") by correspondent Lilian T. Mowrer, which chronicled modern German design, carnival celebrations, and Berlin nightlife, often employing the "breathless," exuberant tone otherwise reserved for Paris..$^{11}$ Since the prestige of elite journals depended partly on what they chose to market, their successively greater willingness to associate themselves with "Germany" as a product indicates the country's more positive public associations. At the same time, such coverage helped Germany recover an attractive, lighter image in public discussion.

A second general observation is that American travel impressions need to be understood in light of preconceived notions about Germany. For one, Americans approached their trip with a cache of distinct images and expectations of what postwar Germany would look like. Tourists measured the country and its people against common notions of, for example, retrenched monarchism or economic prostration. Their impressions, moreover, were strongly compar-

89 Consulate General, San Francisco [Wiehl], to AA, Dec. 6, 1927, "Französische Kulturpropaganda in San Francisco," PA R 61130.

90 Ibid.

91 See, for example, "Modern Houses as Germany Builds Them," American Vogue (Aug. 3, 1929): 62-63; Lilian Mowrer, "Our Berlin Letter," May 1928 on the Bauhaus; Ernst Schmitz, "Neue amerikanische Reise- und Lehrbücher über Deutschland," PA Botschaft Washington, 1497. 
ative. In particular, they perceived their erstwhile enemy alongside their erstwhile allies, primarily France. Finally, many Americans crossed into Germany with exceptional curiosity about the state of mind of its people, their feelings toward Americans, and the nature of its transition from a monarchy to a republic: how reconstructed were the German people, had they truly disavowed their militarist past, and could the Kaiser ever return? In light of the country's postwar transformations, a trip to Germany seemed to many an educated traveler half vacation, half expedition. "It is this mystery, this shadow, this enigma [of its recent transformation]," bestselling travel author Frank Schoonmaker noted in 1930, "which makes Germany more than ever attractive to the travelers of to-day." 92

Given this surfeit of expectations, American travelers commented more on their impression of the astonishing degree to which Germany had recovered than on anything else. Postwar reporting had conjured up visions of an impoverished and prostrate land, but traveling abroad presented an altogether different picture. As tourists were uniquely preoccupied with matters of transportation, it was usually in this field rather than, say, the Ruhr's smoking chimneys, that they noticed German recovery. For example, they frequently understood the resurgence of German transatlantic liners as a resurgence of Germany more generally. Despite having lost almost their entire fleet after the war, the NDL and the HAPAG had recaptured about $25 \%$ of American passenger business to Europe by 1930; moreover, the NDL's Europa and Bremen (launched in May 1928) were the world's fastest and most modern ships, conveying German recovery even to American tourists who disembarked in England or France. ${ }^{93}$

92 Frank Schoonmaker, Come with Me through Germany (New York, 1930), 5; for an earlier example of this inquiring mentality, see Louis Graves, "The American Soldier and the German Mind," Atlantic Monthly (June 1919): 811-817, 811.

93 Though British lines by 1931 still held the largest market segment, the two German lines came in a very close second. The NDL, in particular, experienced a steep increase, making it the leading line in all passenger categories in American westbound business by 1930 . If only 4.5 of American transatlantic travelers took a NDL liner in 1927, $17 \%$ percent did four years later. Even more astounding were the gains in the luxury segment of the market, where the share of American first-class passengers rose from $4.5 \%$ to $20 \%$ in only three years. Where every tenth second-class passenger had taken the NDL, nearly every third did three years later. See Norddeutscher Lloyd (Stadtländer) to Davidsen, "Anteil der deutschen Reedereien am Nordamerika-Verkehr," Sep. 18, 1931, PA R 246918; the NDL was also especially successful in repositioning itself in the deluxe class of liners; according to contemporaries, there were only three ships in this category: the Bremen, the Europa, and the Ile de France; see Howard Sternau, "Problems in the Transatlantic Passenger Service," Harvard Business Review (1930): 359-365, 359; for American reporting, see "What Makes the Bremen Speedy," American Review of Reviews (Dec. 1929), Clipping: T. R. Ybarra, "Europa (or Bremen) Ueber Alles!," Outlook and Independent (Apr. 30, 1930), Entry UD 328: Seized Promotional Materials of the German Railroad Information Office, 1932-1941, Box 32, Folder: Opinions on Germany. It is important to note that for Americans the tangible European experience usually began when they set foot on one of these "floating palaces"; in terms of cultural exposure, it mattered a great deal whether one took the White Star Line, the French Line, or the North German Lloyd; see Mark Rennella and Whitney 
In Germany itself, Lufthansa, with its extensive and competitively priced network of commercial flights and aircraft, left a similar impression, engendering respect for the technological strides that the defeated nation had made in just a few years' time.${ }^{94}$ By 1929 , too, the heavily publicized launching of a German airship service that could cross the Atlantic in just over two days, captivated America's travel-minded public. ${ }^{95}$ Collectively, these observations, clearly shaped by a traveler's lens, suggested one thing: at a time when Americans often saw Europe as teeming with resentment and self-pity, they saw Germany as pulling itself up by its bootstraps. ${ }^{96}$

Technological advances aside, American travelers by the later 1920 s found what they felt to be an increasingly contented and reconstructed Germany. Indeed, many emphasized how little in Germany still reminded them of the war. The absence of battlefields, which had worked to Germany's detriment in the early 1920s, increasingly helped German image-building efforts because it disassociated it from the war experience that many Americans were trying to leave behind. American travelers would visit Germany - perhaps with initial trepidation - only to find a people largely uninterested in the war. Whereas mentioning the war had still precipitated considerable, and usually uncongenial, debate in the early 1920 , a few years later it usually prompted a mere shrugging of shoulders and a determined statement to close the discussion: "the war is over."97 The German people, many found, were not looking for a war of revenge but for entertainment. As one American visitor reported, "if you talk about the past war or the chance for a new war they find you a terrible bore and go on drinking beer and listening to Strauss waltzes."98 After visiting in 1926, American journalist Frank H. Simonds felt that "more than any Eu-

Walton, "Planned Serendipity: American Travelers and the Transatlantic Voyage in the Nineteenth and Twentieth Centuries," Journal of Social History 38, no. 2 (2004): 365-383, 366 ff..

94 The Lufthansa operated the most comprehensive passenger service in the world at the time, with prices so competitive that many Americans took their very first flight when visiting Germany.

95 Lady Drummond-Hay, "Gossip of the World," World Traveler (Nov. 1928): 20-21, 40 [her account of the maiden voyage of the transatlantic Zeppelin service]; "Count Zeppelin's Successor," American Review of Reviews (Oct. 1929): 142.

96 Basil Woon, "The Story of Hapag," World Traveler (Feb. 1929), 17-19, 19: "When the war took away from the Hamburg-American Line its biggest, finest vessels they did not sit down under the blow and cry their woes to the world. I think the story of the Hamburg-American Line's extraordinary ten-year comeback is the finest episode of business sportsmanship I have ever investigated."

97 Donald Douglas, "Germany at Peace: War is Out - Down and Out - in Germany," New York Tribune, Sep. 16, 1928; Oswald Garrison Villard, "Germany Revisited," Nation 123, no. 32 (Nov. 3, 1926): 447-449.

98 Douglas, "Germany at Peace." 
ropean country which I have visited, Germany seems to have liquidated the war." 99

In this regard, Berlin, the heart of the empire and the seat of the Hohenzollerns, was always subject to special scrutiny. "Most Americans," Frank Schoonmaker remarked in his 1927 guidebook, "prefer to think of Berlin rather as the city of Wilhelm II than as the city of von Hindenburg and Stresemann." A fleeting visit did little to change that. Baedeker and Cook's tours continued to center on imperial Berlin, leaving the tourist with the impression of a city replete with the sights of the Hohenzollerns, not the republic. But those who stayed longer or strayed from the main sights soon learned that Berliners mocked the pomposity of the Wilhelmine monuments and dispensed with stiff formality in their city's nightlife. The modern architectural boom was also widely interpreted as a deliberate ideological departure from the bombast of old, while the widely noted absence of uniforms in German public life and the courteous, "democratic" demeanor of its police officers led many Americans to conclude that German militarism was gone for good. ${ }^{101}$ By the late 1920s, Berlin epitomized the transition from empire to republic for many Americans. ${ }^{102}$ The empty royal castles, they now concluded, were waiting not for the return of their former owners, but for the next tourist bus.

Perhaps most surprisingly, American tourists usually found Germans to be particularly friendly and hospitable toward them, especially when compared to their erstwhile allies. ${ }^{103}$ The highly volatile relations between the United States and France, in particular, affected American impressions of Germany. From their high point in 1919, Franco-American relations had steadily deteriorated, reaching a low point after the Dawes reparations settlement because America seemed to have relieved Germany of much of the payments due to France while simultaneously insisting on full repayment of the French debt. Resentment against the U.S. ("Uncle Shylock") erupted in a number of sensational attacks on American tourists in the summer of 1926 and 1927, seriously impact-

99 Frank H. Simonds, "New Germany, in New Europe," American Review of Reviews (Nov. 1926): 491-495, 493.

100 Schoonmaker, "Come with Me through Germany," 8.

101 Modern German architecture was featured relatively widely toward the late 1920s; see, for example, Robert Allerton Parker, "Seeing a New Europe," Travel (Oct. 1928): 7-12; Lawrence Gilman, "Poundergood Visits Berlin," New York Herold Tribune, Sep. 30, 1928; Lincoln Eyre, "Renascent Germany," National Geographic (Dec. 1928): 639-718, 644-645; such an image of Germany was also systematically promoted by the GTIO; see E. S. Crayfield (Ernst Schmitz), "The City of Never-Ending Day" (on Berlin), Nomad (Mar. 1928).

102 Sydney A. Clark, "The New Spirit in Germany's Capital: How Republican Berlin Faces the Future - Some Achievements of Democracy - Aspects of Europe's Greatest City," Travel (Oct. 1930): 12-16, 54 cont.

103 Raoul Martini, "A Picture of Present-Day Germany," Christian Science Monitor, Sep. 22, 1925, 18; Bruce Reynolds, "A Warm Welcome and a Cold Drink Await - in Berlin," Nomad (Mar. 1929). 
ing France's image and balance of payments. ${ }^{104}$ Conversely, Germany benefited morally and economically from this anti-French sentiment. Frank Schoonmaker, for example, found Germans "friendly, not with the surface courtesy of the French, but with a true hospitality that asks nothing in return." ${ }^{105}$ In the field of tourism, too, wartime alliances were slowly being recalibrated.

Finally, Americans experienced Germany and Germans as particularly familiar. To be sure, Bavarian peasant dresses, folk celebrations, and medieval myths "exoticized" Germans to a degree, but this was not the general trend. Rather, American travelers observed Germans' enthusiasm for American forms of leisure, including the wide popularity of American sports, jazz, and movies, ${ }^{106}$ and often felt Germans to be most "like us" - an observation they applied to everything from dating practices and drinking preferences to physique. German youths, one American visitor noted, had substituted beer with cocktails, and the stout German girl of prewar days had given way to the slender "American" type. ${ }^{107}$ Such observations not only helped overcome the distance between Germans and Americans - that "Otherness" the war had attached to Germans - but also, since Americans understood their own forms of leisure as deeply democratic, reinforced the notion of Germany's democratic conversion. By the mid-1920s, repeat visitors, in particular, believed they could discern the contours of a truly new, "spiritually disarmed" Germany. ${ }^{108}$ As one of them remarked in 1925: "The Germany through which I traveled in 1913 was impressively militaristic. The Germany I saw three years ago was a people in social, political and mental chaos. The Germany of today is neither chauvinistic nor helplessly befuddled. It is a Germany chastened in spirit, democratically inclined, thinking clearly and constructively." ${ }^{109}$ American tourists, it seemed, were taking away just the impressions Germany had hoped they would.

104 Clipping: "If France Wants Tourists," New York Evening Post, Mar. 5, 1930. Already in 1928, American tourists had spent a whopping $\$ 40$ million less in France than in the previous year. This was not primarily the result of rival tourist efforts but French prices; France, as American newspapers noted, had simply become too expensive for the standards it provided, PA R 246905; Davidsen, Entscheidende Ereignisse in der Organisation des frz. Fremdenverkehrs, PA R 105542. 105 Schoonmaker, Through Europe on Two Dollars a Day, 140.

106 Donald Douglas, "Travel, New Style: Recipes, from a Modern Traveler, on How to Discover Germany and Have a Mighty Good Time Doing It," Nomad (March 1929); Grace Z. Brown, "Neoteric Germany," Nomad (Mar. 1930): 13; NARA Entry UD 328, Box 9, Germany: General I. 107 Lawrence Gilman, "Poundergood Visits Berlin"; see especially Frank H. Simonds, "New Germany, in New Europe," American Review of Reviews (Nov. 1926): 491-495, 494.

108 Villard, "Germany Revisited."

109 Martini,"A Picture of Present-Day Germany." 


\section{Turning Tourists into Ambassadors?}

That such impressions aligned closely with German hopes was due, to some extent, to the increasing attention Germany itself had begun to pay to visitor hospitality. While enticing Americans to return to Germany was an important step, making sure that their impressions would be commercially and politically useful was yet another. This seemed especially necessary because the large number of leisure tourists were ever less likely to study the country they visited in any depth and proved "only all too ready", as one German observer remarked, to draw broad, general conclusions about Germany from chance encounters. ${ }^{110}$ It was precisely because American impressions hinged on all sorts of vagaries that German officials and private groups increasingly turned their attention to the American experience in Germany. The ultimate value of American travel, German tourism promoters and diplomats agreed, depended on turning the American visitor into "a friend of Germany and a living propagandist" for its cause, as Schmitz put it. "11 "If [American visitors] are welcomed in a friendly manner and receive a favorable impression of the land and people," echoed the German consul in Boston, "a more just and sympathetic assessment of our country cannot fail to take root here, too."112

To this end, the Foreign Ministry began to support a hospitality infrastructure for American travelers in the 1920s. The idea, of course, was not entirely new. Bodies like the Amerika-Institut had long hosted select groups of American visitors, especially academics. But after the war a much more comprehensive hospitality framework evolved. As early as 1922, the Krupp Iron Works had funded the "Economic Policy Association" (Wirtschaftspolitische Gesellschaft, WPG) to guide anglophone visitors through the Ruhr district and improve British and American opinions on Germany. After 1924, the WPG moved closer to the Foreign Ministry and engaged in a concerted program of revisionist hospitality work by introducing visitors to Germany's "bleeding borders" in the East. After 1926, the Foreign Ministry also supported the Vereinigung Carl Schurz and a number of social hospitality organizations that were modeled on

110 Fritz Gerathewohl, "Münchner Deutschkurse für Ausländer," Mitteilungen der Deutschen Akademie 23 (Oct./Nov. 1928) 1101-1105, 1102.

111 Amerika-Propaganda und amerikanischer Reiseverkehr (Schmitz, ca. 1926), 28, NARA Entry UD 328: Seized Promotional Materials of the German Railroad Information Office, 19321941, Box 36, Folder: Tourism: Promotion; "The Foreigner, especially the American," added the director of the Reichsbahn, Dorpmueller, "who has been in Berlin and has been satisfied with his visit, will always return and successfully promote us in his home country." Clipping: "Germany Wants to See You." Berliner Tageblatt, Dec. 15, 1928, PA R 246900.

112 German Consulate, Boston, to AA, Aug. 18 1927, PA R 80299. 
the French Société Bienvenue. ${ }^{113}$ All these organizations formed an interlocked, fairly sophisticated hospitality system: the New York tourist office, consulates, shipping lines, and individual hotels would inform the Foreign Ministry about prominent visitors, and the ministry, in turn, passed the information on to the pertinent organization: American scholars to the Amerika-Institut, German Americans to the Vereinigung Carl Schurz, and those with an interest in territorial or economic aspects of the peace treaty to the WPG and a number of other organizations. ${ }^{114} \mathrm{By}$ the late 1920 s, there was a relatively tight-knit, government-sponsored network of German hospitality organizations to wine, dine, and unobtrusively cultivate American visitors.

Importantly, German hospitality infrastructure followed the French model, not the Soviet one. ${ }^{115}$ Even during the Nazi period, social hosting remained an offer that American visitors could, but did not have to, avail themselves of. Aiming to convey a politically and economically desirable image of Germany to visitors, hospitality organizations relied on social attention and information, not outright propagandizing. Breakfasts, teas, and banquets were intended primarily to provide the opportunity for a "real encounter with Germans" and lay the foundation for a deeper understanding of Germany. Even organizations with a relatively narrow revisionist purpose, such as the WPG, aimed to persuade, not preach. By taking Americans to see the idiosyncrasies of the Eastern borders for themselves, the WPG aspired, as its long-time director Margarete Gärtner explained, to open Germany "like a book" for foreign visitors to "read in and study its problems." ${ }^{116}$

Though German attention could at times feel overwhelming for American visitors, it arguably still paid its dividends. During these visits, Germany was able to secure substantial - and usually favorable - American news coverage. ${ }^{117}$ In the case of the American Seminar, a YMCA-organized annual study tour of 150 journalists, clerical social reformers, and college professors who all enjoyed

113 These included the Deutsche Willkommensgesellschaft (German Welcome Society), directed by Ada Schnee, the wife of former Colonial Minister Heinrich Schnee, and the Willkommensclub (Welcome Club) under Anna Schultze-Fryhse.

114 On the agreement between the GTIO and the AA, see German Embassy, Washington, to all German Missions in the United States, Aug. 4, 1925, PA Botschaft Washington, Nr.1500 V 6d; The division of labor between these various organizations is explained in Margarete Gärtner, Botschafterin des Guten Willens, 135.

115 On the Soviet model, see Michael David-Fox, Showcasing the Great Experiment: Cultural Diplomacy and Western Visitors to Soviet Russia, 1921-1941 (New York, 2011), esp. chapter 3, 98-141.

116 Gärtner, Botschafterin des Guten Willens, 73.

117 The Foreign Ministry sought to multiply information via the press coverage of events; important speeches, such as those the German chancellor gave before the American Seminar on July 29, 1925, were forwarded by the press department to all major American newspapers. Sherwood Eddy Party, July 25-31, 1925, PA R 121327; for the American response, see "Hindenburg Smiled at Yankee German," New York Times, Aug. 2, 1925. 
the special attention of the German government, the participants themselves later commented on their German impressions in numerous interviews, lectures, and articles. ${ }^{118}$ In light of their hospitable welcome, they often felt obliged to emphasize the positive aspects of their stay. Having just been wined and dined by a group of obviously well-meaning Germans, they felt it would have been impolite to voice excessive criticism. ${ }^{119}$ The Boston consul was thus optimistic that tourist impressions "may, if repeatedly won and confirmed, play no insignificant role in restoring Germany's old standing." 120 Some tourists, he was confident, could indeed be turned into ambassadors.

The history of American tourism in Germany in the 1920 provides an intriguing window onto transatlantic normalization. The very fact that Americans were traveling to Germany again and that American magazines were featuring their experiences already indicates as much. Moreover, the image of a democratically chastened and industrious Germany tied in well with ideas of transatlantic partnership. Germany's obvious recovery and the democratic conversion many Americans believed they had witnessed strengthened America's commitment to the Weimar Republic. Still, it should be acknowledged that the generally positive assessment of German developments hinged primarily on Germany's continued willingness and ability to play its role in the cycle of war debts and reparations, its democratic sentiment, and its peaceable foreign policy. It takes little imagination to predict that Germany's impressive recovery, inspiring respect and goodwill when it seemed to serve European stability and peace, would awaken suspicion, even resentment, once this was no longer the case. As the 1930s would show, in a changed global political context, it would be but a small step from praising German efficiency to fearing it.

\section{Tourism Promotion and its Discontents}

Let us briefly return to official involvement in tourism promotion. As we have already seen, the postwar years inspired ever greater official interest in

118 In 1925, for example, Sherwood Eddy published an article in the Christian Century on contemporary Germany: WPG to AA, Oct. 3, 1925, PA R 122406. The Chicago consulate reported on a very pro-German lecture given by one of the 1930 group, German Consulate General, Chicago, to AA, Nov. 19, 1930, "Vortragsabend des Rev. MacPherson in Joliet," PA R 80303.

119 Brantz, "German-American Friendship," 247.

120 German Consulate, Boston, to AA, Aug. 18, 1927, PA R 80299; Ambassador Prittwitz later attributed much of American sympathy for Germany to the fact that American travelers had come in regular contact with Germans and realized that they were not "Huns"; Prittwitz to v. Bülow, Dec. 27, 1930, PA NL von Prittwitz u. Gaffron, Vol. 4. 
this field, which had long lain outside of ministerial competence and concern. Throughout the 1920s, German diplomats had cooperated in a fruitful and mutually beneficial way with the German Tourism Promotion Bureau (RDV). However, the increasing attention the Foreign Ministry paid to "hospitality" already signaled its ambition to use tourism to facilitate a deeper understanding of Germany's history, culture, and people - with a clearly revisionist spin - and to take this new field of public diplomacy under its own wing. This desire elicited increasing conflicts with the RDV and inspired official efforts to establish considerably greater control over the field. While these efforts would not be successful until after 1931, they illustrate the larger significance that tourism management had acquired within foreign policy and, as will be shown, laid bare some of the underlying frictions between diplomats and tourist boosters.

Irrespective of the RDV's many merits, its tourism promotion did not meet with blanket acclaim in Germany. In fact, in the later 1920s serious grievances about national representation emerged, both between the RDV and other tourist bodies and between the RDV and the Foreign Ministry. Questions about what kind of Germany should be advertised abroad lay at the heart of these disputes.

Criticism of the RDV's work initially came from German tourist associations, which felt that it only inadequately represented their interests. Though the founding of the RDV as a promotional office in 1920 had been a marked step toward centralizing the German tourism industry, the balance of different economic and political, regional and national interests grew more difficult to maintain. As the RDV tightened its hold on German tourism promotion after 1925, regional businesses and touring associations began to object to its broad "Germany advertising," feeling that individual cities or regions were not advertised in accordance with their perceived cultural importance. ${ }^{121}$ These grievances were exacerbated by the fact that the RDV betrayed its original purpose as an umbrella organization to serve the interests of its single largest stakeholder: the Reichsbahn. Contributing more than $90 \%$ of the RDV's funds by 1927 , the Reichsbahn was not particularly inclined to mollify regional tourist bodies, which, in turn, came to question the RDV's very legitimacy in representing German tourist interests. ${ }^{122}$ The immediate consequence was that tourist promotion efforts once again became fragmented. In 1927, the disgruntled tourist bodies broke away from the RDV and founded the Working Association for German Tourism Promotion (Arbeitsgemeinschaft für deutsche Verkehrsförderung). The Reichsbahn, too, abandoned all pretense and re-established

121 The Leipzig Trade Fair, for example, generally agreed with the need to centralize all German tourist promotion in one place, but at the same time demanded that it should enjoy preeminence over the fairs held in Frankfurt or Cologne.

122 RDV, Der Ausbau der Reichszentrale für Deutsche Verkehrswerbung, Berlin, 1927, PA R 65090. 
the RDV, with all its holdings, as a company-run advertising branch, in April 1928. That its aims, offices, and advertising remained essentially unchanged only illustrates the degree to which the Reichsbahn had already dominated the endeavor. Meanwhile, long-standing industry groups like the League of German Spas (Deutscher Bäderverband) and the League of German Tourism Associations (Bund deutscher Verkehrsvereine) lobbied for a new "National Tourism Council" ("Reichsausschuss für Fremdenverkehr"), where heavier financial state involvement was to help mutualize the Reichsbahn's considerable resources while curtailing its influence.

The idea fell on fertile ground at the Foreign Ministry, which by then was entertaining its own grievances over the RDV's work and attitude - grievances that illustrate a larger rift between public diplomacy and tourism promotion. The immediate occasion of the conflict between the Foreign Ministry and the RDV was their different assessment of the work of the Terramare Office (T. O.), a small publishing bureau founded in 1924 on the private initiative of Berlin lawyer Karl Kiesel. Its primary objective was to improve relations with the United States by helping Americans to understand Germany better principally through (rather text-heavy) publications on Germany distributed to American visitors. According to the T. O., its mission was "to arouse and deepen interest and understanding for German living conditions and the German character and to overcome all prejudices against Germany in the Anglo-Saxon world in North America, in England and wherever English is spoken."123 Beginning in 1924 and annually thereafter, the T. O. published Passing through Germany, a collection of essays on German life, cultural achievements, and history, as well as recent social and cultural developments. ${ }^{124}$ While its director Karl Kiesel had run the T.O. as something of a hobby, rising circulation numbers prompted him to turn to the Foreign Ministry for financial support in 1926. There, responses were widely positive. Ambassador Maltzan emphatically declared Passing through Germany an "excellent" publication, deserving of much wider distribution in the United States. ${ }^{125}$ The Wilhelmstrasse's America Department seconded this assessment and felt that tourism promotion, "if carried out in the form of Herr Kiesel's work, is of great cultural propagandist importance."126

The RDV and its New York office, however, were of a fundamentally different opinion. In fact, the GTIO's assessment of Passing through Germany was

123 Terramare Office (Résumé of Purpose) 1930, National Carl Schurz Association, Inc. Records, Series 1 General Historical and Office Materials Box 44 Folder 2, HSP.

124 The first two editions actually went under the name "In Honour of our American Guests." Passing through Germany was published annually until 1936.

125 German Embassy, Washington, to AA, Aug. 31, 1926, "Verbreitung der deutschen Werbeschrift 'Passing through Germany," PA R 65090.

126 Aufzeichnung, Aug. 19, 1927, PA R 65090; this was repeatedly voiced, for example, in Aufzeichnung betr. Terramare-Office, Feb. 7, 1929, PA R 246901; and emphatically in AA to Ministry of the Interior, Aug. 13, 1928, PA R 246899. 
nothing short of devastating. Schmitz deemed the booklet suitable neither as promotional material nor as a guidebook, dismissing its treatment of Germany as incoherent and impressionistic. Some of the major tourist attractions like the Rhine or Nuremberg were not even featured in its pages. Moreover, "whoever glances through this brochure must get the impression that Germany has no East, no Baltic Sea area, no spas at all, because there is little or no mention of these things." All in all, Schmitz failed to understand what "the actual objective of such a sort of booklet should even be." Accordingly, the RDV refused to help fund or distribute Terramare products, treating it as it did all publications it deemed subpar. A meeting in late February of 1927 between representatives of the Foreign Ministry, the RDV, and the Terramare Office did little to clear the air. Rather, the RDV once more refused to cooperate, deprecated Passing through Germany, and doubted the competence of the German ambassador who had recommended it so emphatically. To the representative of the Foreign Ministry, this was final proof of "the narrow-minded and autocratic operations of this organization." As a consequence, it cut its modest subsidies to the RDV, channeling them into the Terramare Office instead. ${ }^{127}$

On the most basic level, this episode amounted to a struggle over authority with regard to foreign representation. The Foreign Ministry had, indeed, approached the meeting as a testing ground for the RDV's general willingness to support outside work and, more importantly, to "comply with the suggestions of the Foreign Ministry." ${ }^{128}$ Seeing itself as superordinate in all foreign affairs, the Wilhelmstrasse interpreted the RDV's unwillingness to accommodate its suggestions as nothing short of an impudent challenge to its authority. This was especially the case because Ambassador Ago von Maltzan, the career diplomat and former state secretary whose competence the RDV had openly questioned, was the very embodiment of the German Foreign Service. Accusing him of poor judgment was tantamount to deriding the Foreign Ministry in general; hence, it incited determined reactions. Not only was the RDV deprived of Foreign Ministry subsidies; it was also asked to submit an official apology to the ambassador. In addition, the Foreign Ministry henceforth threw its weight behind reorganizing tourist interests in a way that would effectively rein in the Reichsbahn.

While this power struggle itself testifies to Germany's growing official interest in international tourism, the diametrically opposed assessments of the work of the T. O. reflect a more fundamental conceptual disagreement over the means and ends of German tourism promotion. As shown above, the RDV did understand its work as a form of national service, or at least advertised it

127 Aufzeichnung (Schmidt-Rolke), Mar. 9, 1927, PA R 65090.

128 Memorandum Davidsen, Nov. 16, 1926, PA R 65090. 
as such. ${ }^{129}$ It agreed with the Foreign Ministry that a greater number of Americans had to visit Germany and worked tirelessly to project an attractive image of Germany in the United States. Still, the two bodies' ultimate motivations differed. The GTIO was willing enough to accommodate diplomatic interests as far as they fit into its general framework, yet it was, after all, a business operation. Its primary aim was to "sell" its image of Germany abroad, even if this meant peddling a more trivial form of national representation. It operated on the premise that has guided tourism promotion ever since, namely, that German realities and traditions first and foremost have to meet tourist desires and occasionally have to be repackaged, even reinvented, for the tourist gaze. ${ }^{130}$ In other words, the degree of "marketability," not the degree of authenticity, determined how it represented Germany.

This commodification of the German experience, however, clashed with the Foreign Ministry's own emerging ideal of "intellectual tourism" ("vergeistigte Touristik"), which aimed to facilitate foreign elites experiencing a meaningful intellectual encounter and engender in them a deeper understanding of German Kultur, heritage, and history. The official primarily responsible for this conceptual elaboration was Hermann Davidsen, who had taught German at Cornell University for more than a decade. Having returned to Germany in 1919 and originally recruited as the Foreign Ministry's advisor on German Americans, he had taken charge of all tourist matters in 1924. In this role, he established himself as an expert on tourism and foreign policy not only in lengthy internal memoranda, but in public lectures, articles, and radio interviews. ${ }^{131}$ Though Davidsen, a former professor, was also among the very first to underline the macroeconomic impact of international tourism, the more profound value of travel always remained educational for him. It was during the general meeting of the League of German Tourism Associations in August 1928 that Davidsen articulated the Foreign Ministry's first coherent theory of tourism's foreign policy function. ${ }^{132}$ His speech forcefully underscored tourism as a foreign policy question that belonged within the purview of the Foreign Ministry. A foreigner seeing Germany for himself, he stated,

129 Dorpmüller in Clipping: "Germany Wants to See You."

130 When meeting with German journalists, Schmitz instructed them and local tourist bodies on the picture material to be taken. Many of the pictures he received, for example, he saw as unfit to advertise Germany abroad. Pictures of traditional folk festivals, he noted, frequently captured an old toothless woman sporting the most traditional of dirndls - an image little suited to selling Germany abroad. Instead, Schmitz noted, photographs primarily had to "capture (Germany's) flourishing youth," even if the costumes were less authentic; "Werbe-Spiegel aufgestellt in der Ersten und Zweiten verkehrspolitischen Konferenz von der RDV," NARA Entry UD 328: Seized Promotional Materials of the German Railroad Information Office, 1932-1941 Box 36 Folder: Tourism: Promotion.

131 See Davidsen's reference files in PA R 105542.

132 Hermann Davidsen, "Fremdenverkehr und Außenpolitik," Monatliche Mitteilung des Bundes deutscher Verkehrsvereine (Nov. 1928), PA R 246900. 
will then find - and thousands have done so since the war - that the aspects that united us are stronger than those that divide us, and he will happily correct the image of Germany he has formed as a result of the insufficient or even deliberately misguiding reporting of his press. The misunderstandings that cloud the relations of nations, this much should be clear, rest not on an actual clash of economic or political interests, but to a large part on ignorance of the facts $[\ldots]$ and every foreigner who travels Germany with open eyes and ears and an honest will to see the things as they are will return home a small advertising center from which the $[\ldots]$ truth about Germany will radiate. ${ }^{133}$

While he acknowledged that various organizations were already working to create that "favorable atmosphere and good weather" between Germany and the United States, he stated that the greatest "cultural diplomatic importance" lay in an "intellectual tourism" that neither overaccommodated American tastes (such as offering golf courses) nor staged traditions (like folk dances) solely for tourists' sake; rather, it offered an "authentic" presentation of German life, "revealing the connection between Kulturvolk and landscape." "Whatever is not real has not grown in Germany," Davidsen asserted, "will not have an effect [on the foreigner] in the long run." In other words, tourism should not offer American tourists whatever sold best, as the RDV did, but whatever was most representative of German culture. Once the tourist trade had been reunited, Davidsen noted, a general meeting, involving not just the tourist trade but "artists, scholars and politicians" would have to develop "large, well-thoughtout, general guidelines for tourism promotion" to forge a truly representative cultural image of Germany. As Davidsen summed up the Foreign Ministry's conclusions: "tourism promotion has to be pursued as cultural promotion."134

On a deeper level, Davidsen, with his ideal of "intellectual tourism," was giving expression to contemporary unease with mass tourism increasingly aimed at recreation, not education. Davidsen, like many of his class and education, clearly yearned for an allegedly older kind of tourism that had aimed at gratifying intellectual curiosity, not consumer desires. ${ }^{135}$ Based on the common notion that American-style advertising somehow corrupted German Kultur, this group found the commodification of national representation deeply disquieting. By the same token, they regarded shallow, easily comprehensible slogans and attractive images as singularly ill-equipped to convey the depth of German "national character." Even though the GTIO's Americanized image of Germany admittedly helped the government to achieve foreign policy goals, it still contradicted educated bourgeois notions of how Germany ought to be represented. This was the deeper significance of Davidsen's telling remark that

133 Ibid.

134 Ibid.

135 On the changed nature of tourism in the 1920s, see Levenstein, Seductive Journey, 233-244. 
the RDV's criticism of Passing through Germany relied on altogether "faulty premises." Schmitz's failure to comprehend the function of a publication like Passing through Germany, Davidsen felt, spoke not to the booklet's inadequacy for tourism promotion but to "how little Schmitz is suited for his post." ${ }^{36}$ If Passing through Germany was a profound introduction to contemporary German issues, then the GTIO efforts to "sell" Germany at all cost threatened to turn a profound Kultur into a soulless product.

But the episode was about more than the offended sensibilities of the Bildungsbürgertum. Rather, it also expressed the government's prevalent desire to wield tourism promotion as a foreign policy tool just as international competition for American tourists was noticeably increasing once more. Not only had most major European countries established tourist bureaus in New York by 1928, but France had also initiated a major campaign to defend its once undisputed position as America's preferred vacation spot. ${ }^{137}$ Responding to the alleged "German threat" in the United States, the French parliament had allocated 30 million francs to the Office National du Tourisme in 1929, appointing an undersecretary for tourism a year later. ${ }^{138}$ The very same year, the Maison de France, a central tourist information bureau, opened its doors in Paris, ${ }^{139}$ and the German embassy in Paris reported on plans to establish a massive Palais de France in New York City to house touristic, cultural propaganda and business offices. Designed from top to bottom to recapture French prestige visà-vis German efforts, it was to be a celebration of French tastes, with every floor named after a famous Great War battle. The German embassy was unable to hide its admiration in the face of this new example of France's sweeping cultural diplomatic vision, stating: "tourism promotion through brochures is as far from this form of advertisement as a primitive cart from the most modern of Mercedes cars or as an oil lamp from the sea of electronic light in a modern metropolis." ${ }^{140}$ In light of these developments, German tourism promotion

136 Memorandum Davidsen, Nov. 16, 1926, PA R 65090.

137 By April 1927, New York City boasted British, Swiss, Norwegian, Swedish, Dutch, Italian, French, Spanish, Austrian, and German tourist offices. Für die Direktion der Reichszentrale für Deutsche Verkehrswerbung, Berlin zusammengestellt von der German Railroads Information Office in New York, April 1927, Entry UD 336 General Administrative Records Seized from the German Railroad Information Office, 1926-41 Folder: RDV Travel Statistics, 1927-38; for German observations, see German Embassy, Paris, to AA, Oct. 15, 1929, "Bestrebungen zur Erweiterung der französischen Verkehrswerbung," PA R 246903; Hermann Davidsen, "Französische Verkehrspropaganda. Abwehr und Angriff," 1930, PA R 105542; Hermann Davidsen, "Französische Sorgen" (1931/32), PA R 105542; in general, see Young, "A Place Like Any Other?" 139. 138 German Embassy, Paris, to AA, Jan. 18, 1929, "Fremdenverkehrsförderung in Frankreich," PA R 246901.

139 German Embassy, Paris, to AA, Dec. 27, 1928, "Bestrebungen zur Hebung des Fremdenverkehrs in Frankreich," PA R 246900.

140 III A 5328 (Embassy Paris), "La Maison de France in Paris und Le Palais de France in New York," Dec. 18, 1929, PA R 246904. The Palais de France eventually became the Maison Française at the Rockefeller Center. 
that was generic and inauthentic was not only intellectually unsatisfying; it was also unable to compete.

Above all, the conflict with the RDV signaled the Foreign Ministry's determination to use tourism promotion as an instrument of foreign policy. It clearly conceived the need for a governmental tourism strategy to reconcile modern marketing with cultural distinctiveness or whatever else was politically opportune. This was nowhere clearer than in the founding of the Foreign Ministry's first ever tourism desk, headed by Davidsen, in January 1928. While its attachment to the America Department attests to the undisputed primacy of American tourists, that it was realized at all underlines the Foreign Ministry's desire to subject international tourism to official policy formation. ${ }^{141}$ Henceforth, German missions abroad were asked to report regularly on the development of international tourism, and Berlin energetically pushed to increase its own influence on the newly founded German Tourism Council. ${ }^{142}$ It did not achieve its objective until 1931, and then only incompletely, yet the determination with which it championed the reorganization of this council according to the French (state-governed) model signaled its new understanding of international travel as a policy field. The 1920s, in short, had alerted German foreign policymakers to the considerable political and economic possibilities of international tourism.

By 1930, tourism promotion and hospitality had emerged as a legitimate and quite successful field of German public diplomacy, and German efforts arguably paid off in terms of revenue and goodwill. They helped to entrench the image of a stable, peaceful, and hardworking Germany, a country most "like us" to Americans, which was important for attracting loans and gaining political concessions alike. It is, therefore, fair to assume that tourism was part and parcel of the German-American rapprochement in the postwar decade. The abundant funds provided by the Reichsbahn and its early adoption of American marketing techniques contributed greatly to this success and notably strengthened the German position vis-à-vis its main competitor, France. This said, this analysis of German tourism promotion also indicates some of the shortcomings of German efforts. Most notably, neither German officials nor tourism organizations ever used tourism promotion to advertise Germany

141 As de Haas, the head of the America Department, explained, this was especially "to draw a greater amount of the about $\$ 700$ million, which American tourists (according to official American statements) expend every year abroad, to Germany." VIII A Nr 631/28, Jan. 1928 (de Haas), PA R 246898; the decision was made official in February 1928: I A 280 Internal Circular, Feb. 22, 1928, PA R 246898.

142 AA to German missions in the United States, June 4, 1928, PA R 246899. 
as a republic. The Foreign Ministry's criticism that the GTIO "sold" a rather nondescript version of Germany was true in so far as the GTIO advertised a timeless, albeit modern, Germany, not the Weimar Republic. At the same time, this lack of focus on the form of government, as such, was never the reason for official criticism. When German officials pondered ways to integrate tourism promotion into larger policy agendas, they aimed to open it up to revisionist agitation and broader cultural promotion, not representations of the republic. As we shall see, it was precisely this state of affairs that would facilitate an almost seamless transition from Weimar to Nazi tourism promotion after 1933. 

During the years of Weimar's "relative stabilization" (1924-1929), its public diplomacy grew by leaps and bounds. The half decade after 1924 saw the proliferation of organizations, committees, and programs directed toward cultivating public and cultural relations with the United States. These included transatlantic friendship and intermediary organizations like the Vereinigung Carl Schurz (Chapter 4) and the German Academic Exchange Service (Chapter 5), as well as promotional bureaus like the German Tourist Information Office in New York (Chapter 6). Although the Foreign Ministry subsidized all of these and many smaller ones - they relied on the initiative of a group of peaceful revisionists, including parliamentarians like Anton Erkelenz (founder of the Vereinigung Carl Schurz), tourist promoters like Ernst Schmitz (director of the German Tourist Information Office), professors like Ernst Jäckh (head of the Hochschule für Politik) and Alfred Weber (founder of the Academic Exchange Service), as well as education managers like Reinhold Schairer (of the America Work Student Service), Adolf Morsbach (of the Academic Exchange Service) and Fritz Beck (of the Munich International Student House). Convinced that Germany's "distorted image" was partly to blame for its postwar predicament, this group of men (and a few women) sought to rebuild ties with the United States and thus opportunities to get to know the "real" Germany.

This dimension of Weimar's Amerikapolitik, it stands to argue, had a distinct impact on the transatlantic rapprochement of the 1920s. At this point, it seems apt to recall once more the tremendous change that German-American relations underwent in the 1920s. Following World War I, relations between the two countries were clearly at a low point. Although the conflict had not affected many Americans as immediately as other belligerents, they had developed a strongly anti-German sentiment and rhetoric during the war. This had emerged from their nation's dual need to mobilize a reluctant society for war and to police a large German-American population, which the government identified as a potential "enemy within." Although U.S. opinions on Germany diversified after the armistice and the peace treaty, anti-German attitudes remained common. In the early 1920s, even an action as seemingly inoffensive as aiding German children could easily draw public criticism. Contacts between German and American society remained fairly scarce until the mid-1920s and, wherever they existed, they were often complicated by memories of wartime "offenses" and postwar grievances. Five years after the war, a mix of indifference, antipathy, and caution still characterized U. S. attitudes towards Germany.

This changed profoundly in the years after 1924. By the late 1920s, journalists, academics, and diplomats celebrated a new-found transatlantic friendship. U.S. Ambassador Schurman, for example, even saw the two nations "marching 
forward in a great and noble adventure in the cause of human civilization."1 And while official statements of this sort must be taken with a grain of salt, the preceding three chapters of the present volume clearly documented the normalization of German-American relations. By the end of the decade, German Americans (whose standing was often closely bound to the state of transatlantic relations) once more enjoyed a respected presence in the United States, and their endeavors, such as the Carl Schurz Memorial Foundation, gained the support of prominent Anglo-Americans. The number of American students in Germany, especially those taking holiday courses, had also risen notably, and events like the joint honorary degree ceremony for U.S. Ambassador Schurman and foreign minister Stresemann at Heidelberg or the re-opening of the Deutsches Haus at Columbia University expressed the amiable societal contacts that had once more developed. Moreover, these symbolic acts were but an outward expression of the cultural demobilization of German and American elites like Nicholas Murray Butler (see Chapter 5), who once again worked to renew and strengthen connections between the two countries. The ever greater number of U.S. tourists traveling to Germany, which peaked at about 110,000 in 1930, as well as the increasingly positive presentation of Germany in U.S. periodicals, were two further tangible indicators of how far U.S. attitudes toward Germany had improved. Considering the vitality and cordiality of the German-American relationship in the late 1920s, one is tempted to agree with Ambassador Prittwitz's contention that German-American relations had "never been better." ${ }^{2}$

Yet, this renewal of cultural entanglements across the Atlantic not only expressed but also shaped the German-American rapprochement. This is not to say, of course, that the normalization of German-American relations was solely or even primarily due to either German (or American) public diplomacy. Many of the previously discussed initiatives were never designed to have immediate results. ${ }^{3}$ In addition, as historians have shown, the transatlantic rapprochement was influenced by a wide range of factors that, more often than not, fell well beyond the reach of official policies. For one, the postwar situation itself favored the rapprochement of the two countries, which, by virtue of wartime and postwar constellations, had no real territorial, financial, commercial, or military disputes with one another. The United States intervention in the repa-

1 See the translation of Schurman's Heidelberg speech, which he submitted to the State Department: American Embassy, Berlin to State Dept, May 8, 1928, NARA RG 59 Box 1640 [Schur$\operatorname{man}] 123 /$ Sch $87 / 229$.

2 Friedrich Wilhelm von Prittwitz und Gaffron, Deutschland und die Vereinigten Staaten seit dem Weltkrieg (Berlin, 1934), 25.

3 With regard to student exchanges, for example, contemporaries recognized that even if they ultimately succeeded in fostering pro-German (or pro-American) sentiments, it would be at least a decade until the former exchange students reached the sort of professional positions from which they could hope to influence transatlantic relations. 
rations settlement in 1924 and its subsequent $\$ 3$ billion financial investment in Germany also underwrote this process of reconciliation. Moreover, rising U.S. tensions with France and Great Britain in the later 1920s suggested Germany, now stabilized and peaceful, as a more reliable and like-minded partner across the Atlantic. Finally, growing disillusionment among Americans with the nation's participation in World War I was perhaps the single most powerful factor in American cultural demobilization. As Americans began to question the motives of their involvement and as they grew ever more aware and resentful of the role that Allied propaganda had allegedly played in the U.S. entry into the war, they began to call old "truths" about German "war guilt" and atrocities in Belgium into question. ${ }^{4}$

But one cannot dismiss the impact of German public diplomacy altogether. Although it is notoriously difficult to establish "influence," especially when it concerns as intangible a concept as public sentiment, chapters 4, 5, and 6 offered some evidence to that effect. This is perhaps most notable with regard to German efforts to facilitate the visits of tourists and students. Their stay in Germany, as chapters 5 and 6 showed, often forced them to correct preconceived notions about Germany and led them to develop a generally positive attitude towards the hospitable, docile, and, in many respects, "Americanized" Germans they encountered. At least some of these American visitors came away with the idea that Germany was much more like them than the former Allies. One American student, for example, wrote from Berlin in 1927 that "[o] ur alliance with France in the war was only temporary and accidental, whereas with Germany we have a much closer actual connection and kinship."5 In the United States, too, the carefully selected German exchange students often left a positive impression, entirely at odds with the propaganda depictions of the Great War. Whereas their numbers remained relatively small, their presence on campus had a disproportionately large impact, precisely because they were often the first German visitors Americans had experienced in over a decade. Encounters with likeable, modest and considerate German students must have gone a long way toward undermining prevalent enemy images. ${ }^{6}$ In this way, German efforts at tourism promotion and academic exchange aided the process of transatlantic cultural demobilization.

4 See Adler, "The War Guilt Question"; and Horne and Kramer, German Atrocities, 1914, 366367.

5 Quoted in James Colwell, "The American Experience in Berlin during the Weimar Republic" ( $\mathrm{PhD}$ diss., Yale University, 1961), 217; see also the experiences of Shepard Stone in Volker Berghahn, America and the Intellectual Cold Wars in Europe: Shepard Stone between Philanthropy, Academy, and Diplomacy (Princeton, 2001), 8-10.

6 This is even true for the late 1930s; see, for example, Rockefeller Archives Center, IIE Records, Alumni and Historical Files, RG 1, Reel 6 HF, Side 2 \# 19, Comment on German Students, 193638. 
In fact, these examples point to a key feature of cultural diplomacy: the power of the personal encounter. As John Horne has noted, the most difficult aspect of cultural demobilization was "the personal encounter, the finding of gestures, words and practices of reconciliation;"7 and it was precisely such "personal encounters" that German public diplomats systematically facilitated. Whether in tourism advertisements, in reminding Americans of their happy student days, or in hosting American visitors, they always sought to overcome the "Otherness" that the war had attached to Germany and to generate situations that would allow for such "gestures, words and practices of reconciliation." For German (public) diplomats, this commitment to personal encounters sometimes involved considerable personal discomfort (as when they had to welcome Nicholas Murray Butler to Berlin in 1926). That they ultimately maintained this commitment speaks to the significance they attached to it. While the surviving records do not allow us to quantify the myriad individual experiences on both sides of the Atlantic, they nonetheless suggest that such personal encounters had a particularly marked influence in the 1920 s because (i) the German image had been so extremely "distorted" during the war, and (ii) the experience of wartime propaganda had prompted Americans to valorize their personal observations. More than anything else, Ambassador Prittwitz concluded, it was their sojourn across the Atlantic that had finally convinced Americans that Germans were not "Huns" after all. ${ }^{8}$

For an assessment of the influence of German cultural diplomacy it is also helpful to entertain for a moment a counterfactual scenario, i. e., to ponder what might have happened had German cultural diplomats not taken such prevalent interest in improving relations with the United States. Arguably, the discriminatory practices against foreign tourists and students (such as extra fees and bureacratic red tape) that had existed in the early 1920 s would not have been removed as quickly and would have continued to cause considerable transatlantic ill-will. A significant number of Americans might never have visited Germany. Certainly, some of the most celebrated transatlantic events, such as the Schurman/Stresemann honorary degree ceremony at Heidelberg, would never have taken place. Even if the passing of time and financial entanglements alone likely would still have normalized transatlantic relations, the process of cultural demobilization would have been slower still. Above all, there is plenty of evidence to suggest that Germany would have once more committed the types of blunders that had always marred Wilhelmine Amerikapolitik. Nowhere is this more visible than in Berlin's clear policy of restraint toward German Americans. It was only because German cultural diplomats

7 John Horne, "Kulturelle Demobilmachung 1919-1939. Ein sinnvoller historischer Begriff?," in Politische Kulturgeschichte der Zwischenkriegszeit 1918-1939, ed. Wolfgang Hardtwig, 129-150 (Göttingen, 2005), 142.

8 Prittwitz to Bülow, Dec. 27, 1930, PA NL von Prittwitz und Gaffron, Vol. 4. 
abstained from political agitation among German Americans that a reconciliation with "Anglo-Americans" became possible. Certainly, an active German Volkstumspolitik would have become a most serious liability to transatlantic relations, as it did before 1917 and again after 1933. Consequently, the determined cultural diplomacy of Weimar, both in the things it did and those it did not do, contributed to the U.S.-German rapprochement of the 1920 .

This said, it is important to note that these cultural initiatives were only part of much broader German efforts at public diplomacy. As Carmen Müller has shown, the Foreign Ministry went to considerable lengths to cultivate the goodwill of American news correspondents in Berlin. Not only did it try to minimize their personal discomfort (i. e., by helping them with accommodation and police registration), but it also sought to develop closer relations with them so that it could call in a favor from time to time. ${ }^{9}$ Whenever possible, the Foreign Ministry's press department also sought to preempt any overly anti-American reporting in the German press. ${ }^{10}$ In Washington, too, as Chapter 4 showed, ambassadors like Ago von Maltzan pursued a proactive press policy. Still, the most effective part of German public diplomacy lay in Stresemann's weekly international news conferences (and his general availability to U.S. news correspondents), which allowed him to build relations with the correspondents and to clarify the German position on important international developments. American journalists themselves credited Weimar's successes in the United States to Stresemann's abundant public relations skills. In his obituary of the German foreign minister, U.S. journalist Frank H. Simonds felt that "certainly no American official from the President down to the last cabinet minister of the present day meets the press as Stresemann did. And as a result not only did the foreign secretary have a "good press," but his country's politics, purposes and interests were always certain of accurate and friendly presentation." ${ }^{11}$ Unlike in the Wilhelmine era, then, public diplomacy was not at the margins but at the center of Weimar's foreign policy towards the United States.

9 Müller, Weimar im Blick, esp. chapter 3; as she notes, Berlin's main line during the 1920s was "tactical caution within the United States one the one hand and privileged treatment of American news correspondents in Berlin on the other hand," 102.

10 However, given the different social worlds that German diplomats and U.S. journalists inhabited, as well as the stark polarization of Weimar politics, these efforts were often not very successful. As Dominik Geppert and others have shown, German press policy was always hampered by the limited social interaction between diplomats and journalists; see Dominik Geppert, Pressekriege: Öffentlichkeit und Diplomatie in den deutsch-britischen Beziehungen (Munich, 2007); and Andreas Rose, "Der politische Raum Londons und die öffentlichen Beziehungen zwischen England und Deutschland vor 1914," in Außenpolitik im Medienzeitalter, ed. Bösch and Hoeres, 95123.

11 Frank H. Simonds, “Stresemann's Death," American Review of Reviews, Nov. 1929, 71; in his biography of Stresemann, Kurt Koszyk notes that "Stresemann was in his habitus and in his thinking a journalist and a publicist, whose expertise was economic questions and who [...] be- 
Ultimately, German public diplomacy's positive impact derived from its close alignment with a much larger accommodationist Amerikapolitik. Unlike in the Wilhelmine period, when Germany's disregard for the Monroe Doctrine had made its public diplomacy appear to be little more than empty "gifts and gestures," Weimar's public campaign was an integral part of its overall policy. After 1924, at least, German policy decisions, whether large or small, obviously reflected deference to perceived American wishes and general consideration of the "optics" of German actions in the United States. For example, Germany ratified the Kellogg-Briand Pact extremely rapidly in 1928, it diligently avoided the appearance of forming part of a debtors' coalition against the United States, and even chose not to appoint a naval attaché to the embassy in Washington, all with an eye to how the American public would react. ${ }^{12}$ As Lord d'Abernon, the British ambassador to Germany, noted in 1929, "in all the more important developments in Germany during the post-war years, American influence has been decisive. Eliminate action taken on American advice, or in assumed agreement with American opinion, or in anticipation of American approval, and the whole course of policy would be altered."13 More than anything else, this steady consideration of American psychology was what fundamentally distinguished Weimar's Amerikapolitik from its Wilhelmine predecessor. ${ }^{14}$ Only in this much larger context of accommodating U.S. sentiments did Weimar's much narrower public diplomacy attain its significance.

Importantly for Weimar Germany, this strategic orientation toward the United States - while not unanimously supported - had proven rewarding. From the perspective of 1919, indeed, Germany had fared rather well as America’s "junior partner" in Europe. By late 1929, modest prosperity had been restored, the Young reparations plan (lowering German payments) had just been accepted, and the French had agreed to evacuate the Rhineland by mid-1930, five years ahead of schedule. A dispassionate stocktaking would have confirmed what Bernstorff, the former ambassador to Washington, had predicted in 1918: that it was with American support that Germany would recapture its place in the world. ${ }^{15}$

came a foreign policymaker"; see Kurt Koszyk, Gustav Stresemann. Der kaisertreue Demokrat. Eine Biographie (Cologne, 1989), 17.

12 On this issue, see German Embassy, Washington, to AA, Feb. 191926 , PA R 28491; in the case of the decision not to send a naval attaché, the embassy had noted that America's positive opinion of Germany depended on "Germany's unwavering peacefulness"; for further examples, see Jonas, The United States and Germany, 166.

13 Edgar Vincent d'Abernon, An Ambassador of Peace (London, 1929), 1:18.

14 One of the only exceptions happened upon Wilson's death; on this episode, see Berg, Gustav Stresemann, 237-240.

15 "Aufzeichnung des Leiters der vorbereitenden Maßnahmen für die Friedensverhandlungen Graf von Bernstorff," Nov. 24, 1918, ADAP Series A, Vol. 1, no. 36, p. 55. 
But the late 1920 s were not a dispassionate time. After all, many Germans measured foreign policy "success" not in relation to 1919 but to 1914. From that perspective, they seemed unsatisfactory to say the least: ten years after the war, Germany had failed to truly gain any economic, military, or territorial revision and the German public was growing frustrated with a policy of reconciliation that bore fruit too slowly. ${ }^{16}$ Rightwing parties campaigned increasingly vigorously against a policy that seemed to demand constant German concessions for little in return. Restraining such calls for a more assertive foreign policy required extraordinary political skill. From his deathbed, Foreign Minister Stresemann saw the Young Reparations Plan of 1929 through the Reichstag, and it already faced a vicious protest campaign spearheaded by the National Socialists. His death in October 1929 was, as U.S. journalist Simonds presciently noted, "nothing less than a disaster" for Europe. ${ }^{17}$ When the American stock market crashed just weeks later, perceptive observers on both sides of the Atlantic were already able to see the fissures in German-American relations, with Germany's desire for revision beginning to outpace America's desire for peaceful change. In the early 1930s, this constellation would profoundly affect the much lauded "transatlantic friendship" and bring longer-standing grievances to the fore.

16 This was even frustrating to the left liberal DDP; see He $\beta$, "Das ganze Deutschland soll es sein," 174 .

17 Simonds, "Stresemann's Death," 71. 



\section{Part III}

Maintaining Transatlantic “Friendship"?, 1930-1937 



\section{Chapter 7 \\ Public Diplomacy, the Great Depression, and the Intrusion of German Politics, 1930-1932}

7 he onset of the Great Depression dealt a heavy blow to the cordial transatlantic relations that had emerged in the 1920s. It undercut concrete initiatives, drained budgets, and deflated notions of American prosperity, which had defined German attitudes toward America. Because Germany's relationship with the United States was heavily financial in nature, the Depression transformed it more than its relationships toward other countries. As Germany grew more politically radicalized and began to campaign more forcefully for revision, the mutuality of interest that had underpinned the transatlantic relationship was increasingly strained. In this situation, public diplomacy offered a chance to counteract Germany's deteriorating image and obscure the profound changes that were actually taking place in German-American relations. This chapter will explore a number of heavily publicized transatlantic celebrations in the early 1930 s to illustrate German attempts to maintain a German-American "friendship" at a time when the political, economic, and social fabric of the Weimar Republic was beginning to unravel.

The Impact of the Depression on Cultural Diplomacy and Transatlantic Relations

The beginning of the Depression dealt an undeniable blow to transatlantic cultural relations. Funds available for cultural and public relations dwindled in both the United States and Germany. Within a year, the Foreign Ministry's cultural affairs budget dropped by $17 \%$, prompting keenly felt cuts in a field 
that had just begun to expand in previous years. ${ }^{1}$ The semi-official Vereinigung Carl Schurz, for example, saw its budget shrivel from 85,000 marks in 1928 to 25,000 marks four years later. If the Depression seriously affected German activities around the world, it doubly affected transatlantic programs because they often relied on American generosity. A number of projected undertakings - such as the Carnegie Endowment's idea of establishing a Stresemann Memorial/Peace Academy in Berlin - had to be shelved for lack of funds. Even relatively well-entrenched initiatives, such as the America Work Student Service (AWD, est. 1925) collapsed early on. Already on February 19, 1930, the Department of Labor informed the AWD that the economic crisis had forced it to terminate the program. While the German embassy was able to postpone implementation, by November 1931, the department ultimately determined that most of the German trainees were "holding drafting jobs in this country which could be very properly filled by American employees." ${ }^{\prime 2}$ The end of the AWD illustrates that for U.S. industry and authorities, the generous programs of the mid-1920s had outlived their usefulness.

At the same time, many initiatives of the 1920 continued nearly unaffected or came to fruition in the early 1930s. The Carl Schurz Memorial Foundation (CMSF), which Germans and German Americans had been planning since 1928, for instance, took up its work only in 1930. A year later, Gustav Oberlaender, a German-born self-made millionaire, endowed it with a $\$ 1$ million trust to support the study trips of Anglo-American "multipliers" to Germany. ${ }^{3}$ Working closely with German officials, the CSMF would facilitate the transatlantic visits of several hundred American journalists, educators, and social reformers as Oberlaender Fellows in the coming decade, as well as maintain and even expand German-American academic exchanges, with its financial resources. ${ }^{4}$ In 1930, too, the University of Munich welcomed the first cohort of

1 Überblick über die Kürzungen der kulturpolitischen Fonds des Auswärtigen Amts, PA R 61125; Pöppinghaus, Moralische Eroberungen, 121.

2 Memorandum by the Assistant Secretary of State (Carr), Nov. 12, 1931, FRUS 1931, Vol. 2 , 333-334; on the German Embassy's repeated interventions, see German Embassy to the Department of State, Jan. 30, 1931, FRUS 1931, Vol. 2, 329-330; German Embassy to the Department of State, Memorandum, June 28, 1930, FRUS 1930, 112-113; Secretary of State to the German Ambassador (von Prittwitz), Mar. 26, 1931, FRUS 1931, Vol. 2.

3 On Oberlaender and his philanthropic endeavors, see Gregory Kupsky, "Gustav Oberlaender," in Immigrant Entrepreneurship: German-American Business Biographies, 1720 to the Present, Vol. 4, 1918-1945: The Age of the World Wars, ed. Jeffrey Fear, available online at German Historical Institute, http://www.immigrantentrepreneurship.org/entry.php?rec=56; see also Clipping: "Gustav Oberländer, ein deutsch-amerikanischer Mäzen," Germania, May 2, 1931, PA R 80304.

4 While they carefully avoided any public involvement, German officials informally cooperated with the foundation from the very beginning. During the fundraising process, they offered advice on potential donors and, later on, suggested German lecturers. In 1931, German diplomats also precluded independent CSMF representation in Berlin, which would have weakened German influence and convinced the foundation to employ two German representatives with exceptionally close ties to German officialdom: Karl von Lewinski (a former German consul general in 
American participants to the Junior Year in Munich; not until mid-1931 did the University of Heidelberg open its new, American-donated building, and only shortly thereafter did the first postwar "Roosevelt Professor" hold his inaugural lecture in Berlin. In this respect, many of the efforts and initiatives of the 1920 s clearly paid their dividends long past Black Tuesday.

And still, the Depression doubtlessly eroded transatlantic contacts on a deeper and often less visible level, as the example of tourism may illustrate. American tourism to Europe reached its interwar peak at 300,000 in the summer of 1930 only to plummet to 130,000 in 1933. It would be more than two decades before American transatlantic travel would recover to its 1930 volume. In the 1930s, a powerful "See America first" campaign suited both economic realities and national sentiment. Importantly, however, even Americans who still ventured overseas now saw Germany with different, decidedly less benevolent eyes. For example, whereas they had often understood modern German architecture as a symbol of Germany's democratic conversion in the prosperous 1920s, they now viewed it with some skepticism, raising unpleasant questions about German municipal spending habits. Given the billion-dollar US loans to German cities, a 1931 article in the widely read Saturday Evening Post was not alone in wondering whether German cities had not been squandering "other people's money" on modern architecture. ${ }^{5}$ In light of these developments, the embassy even asked German tourism promoters to pull the tourism brochure "Modern Style" devoted to modern German architecture from the American market. ${ }^{6}$ As these and other instances show, American generosity - long a foundation of transatlantic relations - had run dry. Ambassador Prittwitz drily analyzed the situation in December 1930, noting that in times of crisis, "charity begins at home."

These developments were only part and parcel of a deeper estrangement between the two countries. Though reparations and disarmament conferences repeatedly brought European issues into sharp relief, many Americans were preoccupied with the unprecedented crisis unfolding at home. Europe's repudiation of war debt payments in 1932 only strengthened powerful isolation-

New York) and Georg Kartzke (a former director of the Amerika-Institut). On the strategic distance that German officials kept from the CSMF, see German Embassy, Washington, to consulates, Jan. 3, 1929, "Carl Schurz Memorial Foundation," PA Konsulat New Orleans, Paket 24. One of the CSMF's concrete measures was defraying the annual administrative costs of the German-American student exchange at the Institute of International Education $(\$ 10,000)$ after 1930, thus allowing the student exchanges to continue during the Depression; German Embassy, Washington, to AA, May 20, 1930, "Carl Schurz Memorial Foundation," PA R 64173.

5 See Garet Garret, "The Rescue of Germany"; and "As Noble Lenders," Sep. 26 and Oct. 17, 1931, Saturday Evening Post; reprinted in Garet Garret, Other People's Money (New York, 1932).

6 See German Consulate General, New York, to AA, Mar. 23, 1932, "Fremdenverkehrswerbung," PA R 246919.

7 Prittwitz to Arnold Brecht, Dec. 12, 1930, PA NL von Prittwitz u. Gaffron, Vol. 4. 
ist currents in US society. ${ }^{8}$ In Germany, too, the extremely lively debate on Amerika and Amerikanisierung lost much of its vigor. Though American music and movies remained widely popular in the Weimar Republic, the Great Depression removed an important basis of Germans' fascination with America: its prosperity. ${ }^{9}$ As the United States deflated as an industrial and social model, its influence and prestige notably declined in the early 1930 os. $^{10}$ The restrictive Smoot-Hawley tariff of June 1930 only exacerbated America's loss of importance in the commercial sector. In December 1930, when the German consul in St. Louis, Georg Ahrens, was back in Berlin for the first time in two years, he was struck by "how little one talks in Germany of America when compared to two years ago. In my opinion this is a very bad sign." contacts and initiatives continued, the overall atmosphere and quality of transatlantic relations changed after 1930. The two countries grew apart.

\section{Consolidating Germany's Cultural Amerikapolitik}

Politically and financially, of course, the United States at first remained important. During the early 1930s, German attention turned once more to the reparations question. The right-centrist minority cabinet under Chancellor Heinrich Brüning, which succeeded Weimar's last majority cabinet in March 1930, adopted a more assertive revisionist policy, with finding a solution to the reparations question being its absolute priority. ${ }^{12}$ The objective, to be sure, was not to broker yet another modification of the recently adopted Young Plan but to use the German crisis to shake off reparation payments once and for all. ${ }^{13}$ Chancellor Heinrich Brüning's deflationary policies of the coming years brought Germany to the brink of economic and political collapse - not least to demonstrate its inability to pay. ${ }^{14}$ Once relieved of its financial burden, Brüning anticipated, the government could more actively pursue the military and territorial revisions of the peace treaty. The French withdrawal from the Rhineland in June 1930 sparked a wave of German nationalist sentiment and launched

8 According to Selig Adler, the Depression gave rise to an "isolationist tornado"; Adler, The Isolationist Impulse, 219.

9 Klautke, Unbegrenzte Möglichkeiten, 315.

10 Nolan, Visions of Modernity, 228; and Gassert, Amerika im Dritten Reich, 78; this is not to say that Germany did not observe and learn from American practices in the 1930 os and vice versa; see, for example, Kiran Patel, Soldiers of Labor: Labor Service in Nazi Germany and New Deal America, 1933-1945 (New York, 2005).

11 Ahrens to Charles Nagel, Dec. 18, 1930, PA NL Georg Ahrens, Package 1/Correspondence Nagel.

12 Kolb, Weimarer Republik, 262.

13 Hermann Graml, Bernhard von Bülow und die deutsche Außenpolitik (Munich, 2012), 82.

14 Kolb, Weimarer Republik, 261. 
the Brüning government on its more confrontational course. At the Wilhelmstrasse, this reorientation found expression in an important shift as State Secretary Carl von Schubert, the co-architect of Stresemann's policy of reconciliation, was replaced with his long-time critic, Bernhard Wilhelm von Bülow. ${ }^{15}$ Though historians continue to debate the nature of the caesura, they uniformly emphasize the substantial transformation of German foreign policy after 1930. As Peter Krüger concluded, "the Locarno policy, a policy of constant efforts at reconciliation and closer international cooperation and entanglements, gave way to a great-power politics of the 'free hand,' avoiding or casting off international shackles. Thus ended in March 1930 a 'Weimar foreign policy' in the real sense of the word." 16

At the time, this reorientation was not immediately apparent abroad. Indeed, the German government tried hard to hide it. This was especially true in the United States, on which German revisionist politics, especially in the reparations and armament question, still depended. ${ }^{17}$ While Brüning identified America's $\$ 3$ billion in German investments and its fears of political radicalization (and subsequent debt refutation) as a discrete German asset early on, the importance of concerted public diplomacy only increased. ${ }^{18}$ In light of the anticipated renegotiations of reparations, the United States not only had to be convinced of the impossibility of German payments but also had to retain its basic trust in German intentions. ${ }^{19}$ Since the Brüning government was aware that only a relatively stable and peaceable Germany could count on American support, it had to publicly emphasize continuity, common ideals, and peaceful intentions to ameliorate the impact of its more assertive policy. Above all, this was the case because Germany's political radicalization, in particular, the landslide gains of the National Socialists from 12 to 107 seats in the September 1930 Reichstag elections, shook American business and political confidence in Germany and occasioned a withdrawal of American loans. ${ }^{20}$ With rising nationalist sentiment at home leaving little room for concessions abroad (a fact the German government made sure to emphasize in conversation with their American partners), efforts to improve the transatlantic climate by means of

15 Graml, Bernhard von Bülow, 85.

16 Krüger, "Struktur, Organisation und außenpolitische Wirkungsmöglichkeiten," 158; also Krüger, Die Außenpolitik der Republik von Weimar, 521-522.

17 Link, Die amerikanische Stabilisierungspolitik, 494.

18 In Berlin, the new American ambassador, businessman Frederic Sackett, left no doubt that America would support the Brüning government to avoid either a Bolshevist experiment or a right-wing coup, and the financial chaos either might cause; Bernard Burke, Ambassador Frederic Sackett and the Collapse of the Weimar Republic, 1930-33: The United States and Hitler's Rise to Power (New York, 1995).

19 Graml, Zwischen Stresemann und Hitler, 126.

20 Prittwitz to Arnold Brecht, Dec. 12, 1930, PA NL von Prittwitz u. Gaffron, Vol. 4. 
public relations measures appeared all the more necessary. ${ }^{21}$ As Ambassador Prittwitz concluded after the Reichstag elections, "if we do not squander American sympathy by political or diplomatic adventures and if we show our good will in accordance with the government's program, the American support of past years will surely not be missing in critical moments in the future."22 Foreshadowing the post-1933 period, public diplomacy after 1930/31 would serve not least to obscure the profound changes taking place in Germany. In this respect, the years 1930-1932 already differed markedly from the mid-1920s.

In the early 1930s, German public diplomacy took a wide variety of forms. In keeping with practices developed during the 1920s, Berlin made routine use of the quasi-official news agency, the Wolff Telegraphic Bureau, and worked hard to keep American press correspondents informed and happy. In moments of crisis, like the National Socialist electoral gains of September 1930 or the dissolution of the Reichstag, interviews with Reich President Hindenburg and Chancellor Brüning were readily arranged and, as scholars have shown, had a decidedly positive effect. In the American mind, the two men appeared to be stalwarts of republican stability. ${ }^{23}$ Stresemann's successor, Foreign Minister Julius Curtius, too, maintained the regular international press conferences introduced in 1923 and used new opportunities to address Americans directly via radio. ${ }^{24}$ In addition, German official representatives like Reichsbank President Hjalmar Schacht, former Foreign Secretary Richard von Kühlmann, and, after his dismissal in October 1931, Curtius himself went on lecture tours in the United States, where they stressed the stability of the current government, Allied responsibility for German problems, and the need for revision. ${ }^{25}$ On a diplomatic level, Berlin avidly cultivated the trust and sympathy of the new American ambassador to Germany, businessman Frederic Sackett, and encouraged his tours of Germany, especially to the Eastern borders - with appreciable results. Like his predecessors Alanson B. Houghton and Jacob G. Schurman,

21 Krüger, Die Außenpolitik der Republik von Weimar, 517.

22 German Embassy, Washington, to AA, Nov. 3, 1930, PA R 80149.

23 Müller, Weimar im Blick, 350.

24 A transatlantic radio address Curtius gave in June 1930 was reprinted in the Congressional Record; see Congressional Record, Seventy-First Congress, Third Session, Dec. 4, 1930, "Our Relations with Germany: Address by Dr. Julius Curtius and Letter of Nicholas Murray Butler," PA R 80304 .

25 On Curtius's account of his American tour, see Julius Curtius, Sechs Jahre Minister der deutschen Republik (Heidelberg, 1947), 249-256. In mid-1931, the cabinet also raised the Foreign Ministry's secret funds to initiate a press campaign for a revision of the reparations questions; see Graml, Zwischen Stresemann und Hitler, 126. 
Sackett soon emerged as a valuable champion of German positions in American government and public circles. ${ }^{26}$

In addition, Berlin continued its cultural course of action to mollify lingering differences, allay growing distrust, and rival French forays. ${ }^{27}$ Indeed, the financial distress of the early 1930 s resulted in a rather beneficial consolidation and centralization of the many overlapping and competing initiatives created in previous years. In January 1931, different academic exchange, fellowship, and hospitality programs were merged in the German Academic Exchange Service (Deutscher Akademischer Austauschdienst, DAAD). This established the Foreign Ministry's predominance in matters of international education and gave it control over one of the best-endowed and best-connected cultural diplomacy instruments of its time..$^{28}$ Moreover, in late 1930 a National Tourism Council was finally established, which provided some of the greater coordination and diplomatic influence that the Foreign Ministry had sought since 1928. ${ }^{29} \mathrm{Fi}-$ nally, financial duress forced the various America organizations (there were six in Berlin alone) to coordinate their work and align themselves more closely with official directives. The Vereinigung Carl Schurz in Berlin and the increasingly active Deutsche Akademie in Munich (the forerunner of the Goethe-Institut) provided the Foreign Ministry with nationwide support for its cultural Amerikapolitik. ${ }^{30}$ By the early 1930s, longer-standing official efforts and financial pressures conspired to concentrate the comparatively loose public-private cooperation of the 1920 s into centralized, state-driven cultural diplomacy. The Foreign Ministry's self-definition as a "guiding hand" in cultural matters turned increasingly from theory into practice. In contrast to other fields of foreign policy, its responsibilities and influence expanded in matters of public diplomacy in the early 1930 .

26 Burke, Ambassador Frederic Sackett, passim.

27 On January 2, 1930, Foreign Minister Curtius asked German missions to submit a detailed "cultural policy plan" for the coming year and assured them that "questions regarding effective and systematic cultural diplomacy are to be accorded special attention also this coming year"; Curtius to all missions, Jan. 2, 1930, PA R 76922.

28 Laitenberger, Akademischer Austausch und Auswärtige Kulturpolitik, 309; at that point the DAAD had a budget of 300,000 marks and a network of 23 domestic and 12 international offices. 29 It was through a smaller excecutive council that the Foreign Ministry gained at least some advisory influence on the Reichbahn's annual advertising plan. AA [Dieckhoff] to all missions abroad, June 16, 1931, "Reichsausschuss und Hauptausschuss für Fremdenverkehr," PA R 61125. 30 The Deutsche Akademie established a Committee on Cultural Relations between Germany and America in 1931. Headed by Camillo von Klenze, a Germanist who had long taught in the United States, it included (by 1933) a number of German and American professors including Harry Garfield, Frederick Heuser, William F. Ros, William Sheperd, and William Alpha Cooper, as well as, Moritz Julius Bonn, Erich von Prittwitz und Gaffron, Carl Duisberg, and former Ambassador Schurman. Bundesarchiv, Berlin, R51 Deutsche Akademie, 51/14 (Junior Year Abroad); on the ongoing differences with the VCS, see Aufzeichnung betr. Die Vereinigung Carl Schurz, zu III A 656 (Fuehr, Feb. 18, 1931), PA R 80327. 
Importantly, this consolidating process also went hand in hand with a conservative reorientation that matched the general trend in German foreign policy. The DAAD, for instance, was centralized under the leadership of "young conservative" Adolf Morsbach, not the left-liberal Reinhold Schairer, whom the Foreign Ministry had always treated with some reserve. ${ }^{31}$ In the same vein, the founder of the Vereinigung Carl Schurz, left-liberal parliamentarian Anton Erkelenz, was replaced by Hans Draeger, the long-time director of the Foreign Ministry's war-guilt campaign, in early 1930. While Erkelenz's failing health was one factor in this shift, his political reorientation from the left-liberal German Democratic Party to the Social Democrats in 1930 - a party not in high standing with the Vereinigung's diplomatic and industrial backers - was yet another. The more conservative Draeger, by contrast, had long been a reliable partner in the fight against Versailles and could be trusted to steer the Vereinigung in closer cooperation with the Foreign Ministry. ${ }^{32}$ In the coming years, Draeger would notably broaden the Vereinigung's base of support to the right of the political spectrum and harness its networks for more overtly revisionist agitation. ${ }^{33}$ In all, the concurrent shifts from Erkelenz to Draeger and from Schairer to Morsbach signaled a conservative and more assertively revisionist turn in Germany's cultural Amerikapolitik.

\section{Performing "Transatlantic Friendship"}

In the early 1930s, this consolidated cultural-diplomacy apparatus pivoted on transatlantic celebrations. A rapid succession of prominent anniversaries, including the $100^{\text {th }}$ birthday of Carl Schurz (1929), the $200^{\text {th }}$ birthday of General Friedrich Wilhelm von Steuben (1930), as well as the bi-centennial of the birth of George Washington along with the centenary of the death of Johann Wolfgang von Goethe (1932), provided visible and cost-effective opportunities to communicate cultural affinity, construct a useable transatlantic past, and celebrate German-American friendship.

Festivities had long held a central place in transatlantic public diplomacy. Quite apart from the extraordinarily rich festive culture of German Americans in the nineteenth century, transatlantic banquets and celebrations had been a prevalent part of Germany's prewar policy of "gifts and gestures." It was precisely

31 Aufzeichnung AA (Zimmermann), ca. July 1926, PA R 64793.

32 On the Foreign Ministry's payroll since 1922, Draeger joined the ministry in 1933 as a "special advisor" on how to counter "anti-German" propaganda; on how close relations were, see PA Personalakte Draeger, 2955, esp. Aufzeichnung, Geh I 138g, June 17, 1936; Draeger also sought to involve the VCS more in the fight against the "war guilt lie"; see Arbeitsausschuss deutscher Verbände (Draeger) to AA, Feb. 12, 1931, PA R 26206.

33 Brantz, "German-American Friendship," 240. 
this tradition, however, that fostered German reluctance in this regard in the 1920s. Although German clubs in the United States routinely commemorated the birthdays of Schiller, Goethe, and Beethoven, these occasions received no significant attention from Berlin. ${ }^{34}$ It was only the Steuben celebration of December of 1927 that seems to have reminded German officials of how effectively they could use such events for transatlantic communication. The Steuben Society organized this event in honor of the $150^{\text {th }}$ anniversary of Steuben's arrival in the United States, scheduling speeches by American Ambassador Schurman in New York City and Foreign Minister Stresemann in Berlin. These speeches, as the German embassy repeatedly emphasized, had "an extraordinarily great impact." ${ }^{35}$ As a consequence, the festivities in honor of the $100^{\text {th }}$ birthday of Carl Schurz on March 2, 1929, were already much more comprehensively organized. ${ }^{36}$ The Vereinigung Carl Schurz staged a number of celebrations in Berlin, Munich, Stuttgart, Frankfurt, and Liblar (Schurz's hometown) with significant official and scholarly involvement. ${ }^{37}$ All of them used the occasion to stress German contributions to American history, celebrate the two nations' shared ideals, and honor a man who had faithfully served America without forgetting his cultural ties to Germany. ${ }^{38}$ This set a pattern that would define German cultural diplomacy in the early 1930s, as can be seen from the transatlantic celebrations of Steuben, Washington, and Goethe.

34 Despite the high regard for German music in the United States, the $100^{\text {th }}$ anniversary of Beethoven's death in 1927 seems to have gone largely unnoticed. See, for example, German Consulate General, Chicago, to AA, Nov. 14, 1927, "Vortrag von Herrn Generalkonsul Dr. Simon vor der Deutschen Gesellschaft der Northwestern University in Evanston," PA R 80299.

35 German Embassy, Washington, to AA, Nov. 2, 1928, PA R 80288; German Embassy, Washington, to AA, Dec. 8, 1927, "Steubenfeier," PA R 80299.

36 German Embassy, Washington, to AA, Nov. 2, 1928, PA R 80288.

37 The Reichstag celebration took place on March 3 and was attended by German dignitaries like Reichstag president Paul Löbe, historian Hermann Oncken, American historian A. B. Faust, and Ambassador Schurman to commemorate Schurz's life in front of packed ranks. Clipping: "Carl Schurz-Feier im Reichstags-Gebäude," New Yorker Staats-Zeitung, Mar. 18, 1929, Series 1, General Historical and Office Materials Box 27 Folder 9, National Carl Schurz Association, Inc., Records (Collection Mss 176) HSP; the proceedings were later published with a foreword by Foreign Minister Stresemann and Ambassador Prittwitz; see Anton Erkelenz and Franz Mittelmann, eds., Carl Schurz, der Deutsche und der Amerikaner (Berlin, 1929).

38 See Hermann Oncken in his Reichstag speech, "Zum Gedächtnis von Carl Schurz. Rede bei der von der Deutschen Akademie und der Carl-Schurz-Vereinigung im Deutschen Reichstag am 3. März veranstalteten Feier," Mitteilungen der Akademie zur Wissenschaftlichen Erforschung und zur Pflege des Deutschtums/Deutsche Akademie 2, no. 3 (May/June 1929): 199-208; on Schurz as a model for German Americans, see Retterath, "Deutschamerikanertum und Volkstumsgedanke," 350 . 


\section{The Steuben Celebration}

Almost immediately on the heels of the Schurz celebrations of 1929, the Vereinigung Carl Schurz spearheaded preparations for the 1930 commemoration of the $200^{\text {th }}$ birthday of Friedrich Wilhelm von Steuben, the Prussian general who had helped fight and win the American War of Independence. From March 1930 onward, it presided over an organizational committee made up of myriad Germandom and America organizations from Berlin, Munich, Stuttgart and Hamburg. Together, they coordinated a series of Germany-wide celebrations, including a joint event at the Reichstag. For the first time, the planners also established an honorary committee that included Foreign Minister Curtius, U.S. Ambassador Frederic Sackett, President of the Reichstag Paul Löbe, and President Hindenburg. ${ }^{39}$

The special prominence the Steuben celebrations enjoyed was due to a number of factors. First and foremost, the Prussian general appealed to conservative elements, including President Hindenburg, whose patronage, in turn, greatly enhanced the attractiveness and visibility of the festivities. More importantly, the historical figure of von Steuben allowed Germans to insert themselves into a seminal moment of American history. According to the German version, Steuben's reorganization of George Washington's desolate army at Valley Forge had been indispensable to America's victory. ${ }^{40}$ This narrative that the American Revolution had hinged on the devotion, skill, and discipline of a single German was highly welcome as it seemed to rehabilitate not only certain German character traits ("diligence, industriousness, honesty" 41 ) but also Prussia's much-maligned "militarism." ${ }^{22}$ In particular, Steuben's story gave Germany a convenient opportunity to challenge the unique role traditionally assigned to the Marquis de Lafayette and thereby also France's narrative of the two "sister republics." 43 In light of the renewed Franco-German battle for American affections in the context of the reparations and rearmament debates of the early 1930s, the Foreign Ministry had a very strong interest in heightening Steuben's stature. ${ }^{44}$ Behind the scenes, it went to considerable lengths to

39 Vereinigung Carl Schurz to AA, Mar. 25, 1930, PA R 80147.

40 Walter Bloem, "Das Steuben-Jahr," Hochschule und Ausland (April 1930): 7-10.

41 Kühnemann in Vereinigung Carl Schurz, Zum zweihundertsten Geburtstag von Friedrich Wilhelm von Steuben (Berlin, 1930), 16.

42 See, for example, Rudolf Cronau, The Army of the American Revolution and Its Organizer (New York, 1923).

43 See also Retterath, "Deutschamerikanertum und Volkstumsgedanke," 359.

44 As early as January 1930, Ambassador Prittwitz had reported that "the more Germany's political and cultural position in the United States is re-won, the more intense grow third-party efforts to influence American sentiment and make sure that the peace will continue to be interpreted according to the one-sided sense of the victors; German Embassy, Washington, to AA, Jan. 27, 1930, “Deutsch-amerikanische Beziehungen," PA R 80146. 
maintain the name and reputation of a man it characterized as a distinct "asset to our Amerikapolitik." 45

Above all, the Steuben celebrations appealed to German Americans. While Steuben was not well known among the broader public, German Americans had discovered him as a forgotten "cultural hero" at about the turn of the century. ${ }^{46}$ From 1900 onward, celebrations of Steuben had helped them lay claim to the most significant event in American history, thereby underlining their status as an "old" immigrant group. Berlin celebrated Steuben not least to support this German-American agenda. To be sure, this ethnic dimension also complicated the Steuben celebrations. In particular, the New York-based Steuben Society's decision to organize a "Steuben pilgrimage" to Germany during the summer months of 1930 gave German officials numerous headaches. While they had always kept their distance from the political Steuben Society, they clearly recognized the need to receive the 300 Steubenites in a suitable manner. It was highly characteristic of the German government that it sought to solve this dilemma with recourse to semi-official organizations. It quietly tasked the Vereinigung Carl Schurz and the Deutsche Akademie with arranging a set of special courtesies, ceremonies, and receptions for the group that would signal German appreciation to German Americans without implicating German officials or arousing (Anglo-)American suspicion. Just how much the Foreign Ministry appreciated this informal set-up became evident shortly thereafter when it emphatically disapproved of the Vereinigung Carl Schurz's desire to change its name to Steuben. As the Wilhelmstrasse made clear, it had no use for a German organization that signaled any closer association with the political Steuben Society. ${ }^{47}$ For political - if not ideological - reasons, the Foreign Ministry preferred for the organization to be named after a German revolutionary, not a Prussian general.

No such political scruples applied to the public Steuben celebration in the Reichstag on October 19, 1930. With American diplomats in attendance, the celebration offered only a welcome occasion to propound German-American friendship and stimulate positive press coverage of Germany shortly after the disconcerting results of the September elections. ${ }^{48}$ French expressions of dismay about such celebrations are perhaps the best indicators that they were at

45 Such efforts included pressure on historians and archivists who questioned Steuben's heroic narrative or his aristrocratic background; see AA to Reichsarchivrat Schäfer, Nov. 1931, PA R 80168.

46 "Steuben: An Address by Hon. Richard Bartholdt, Delivered at Chicago (1927)," German-American Historical Review 30 (Dec. 1930): 16-27, 24.

47 Aufzeichnung zu III A 787 (Fuehr), March 12, 1931, PA R 80327.

48 See the proceedings of the celebration in Vereinigung Carl Schurz, Zum zweihundertsten Geburtstag von Friedrich Wilhelm von Steuben (Berlin, 1930). In its official press declaration, the Vereinigung Carl Schurz emphasized its purpose was "[to] highlight $[. .$.$] the part the German$ element played in the becoming and prospering of the United States to strengthen cordial rela- 
least partially successful in this. When a representative of the Steuben family was invited to attend the official Yorktown Sesquicentennial in 1931 (the French sent an entire military delegation under Marshal Philippe Pétain), the Journal des Débats dismissed Steuben as little more than an elaborate German fiction invented as propaganda to soil the unique role that France had played in the American Revolution. ${ }^{49}$ For German diplomats, such French reactions were as worrying as they were gratifying. France's long-standing monopoly on transatlantic celebrations, they felt, was rapidly coming to an end.

\section{Washington and Goethe, 1932}

The set of transatlantic festivities reached its climax in 1932 when the two countries concurrently celebrated two towering historical figures: George Washington and Johann Wolfgang von Goethe.

German planning for the Washington celebrations began early. Already in February 1931, Ambassador Prittwitz reported on the large-scale American preparations for the Washington Bi-Centennial. As early as 1924, Congress had appointed an official Bi-Centennial Commission chaired by US Representative Sol Bloom, a former entertainment entrepreneur and a "public relations genius." 50 Bloom planned a host of pageants, parades, and every other conceivable form of publicity to fuel a year-long celebration. ${ }^{51}$ For Germany, the importance of the bicentennial was two-fold. For one, it was yet another opportunity to honor General Steuben because the Bi-Cenntenial Commission had expressed its desire to celebrate Washington's "foreign partners" in order to strengthen the bicentennial's appeal to ethnic groups. In addition, the bicentennial's observance was a major national event so that, as Ambassador Prittwitz noted, suitable German participation in it provided a "good opportunity to revive [America's] friendly feelings for Germany."52

When the ambassador wrote his initial report in February 1931, he could not have anticipated how much such a show of Germany's good faith would be needed a year later. The Washington celebrations, indeed, came on the heels

tions between Germany and the United States." Vereinigung Carl Schurz, Oct. 8, 1930, PA R 121330 .

49 German Embassy, Paris, to AA, "Steuben und die Steuben-Gesellschaft," Apr. 17, 1931; Clipping: General du Cugnac, "La legende Steuben aux États-Unis," Journal des Débats, Apr. 10, 1931, PA R 80168.

50 On Bloom, see Karal Ann Marling, George Washington Slept Here: Colonial Revivals and American Culture, 1876-1986 (Cambridge, MA, 1988), 325-326.

51 Some aspects of this publicity are described in Marling, George Washington Slept Here, 325364 .

52 German Embassy, Washington, to AA, Feb. 5, 1931, "Washington Bicentennial 1932," PA R 80167 . 
of a tumultuous year that witnessed not only President Herbert Hoover's oneyear moratorium on the payment of war debts and reparations but also increasing American annoyance with the Brüning government, which, hoping to terminate rather than pause reparations payments, cooperated only reluctantly. In this situation, the German celebration of Washington seemed to be an economically and politically affordable gesture that could express German appreciation for American support and help maintain American goodwill for the summer of 1932, when the Brüning government hoped to shake off reparations and armament restrictions once and for all. These immediate political ambitions explain the Foreign Ministry's repeated interventions in the bicentennial planning process, which it had once more entrusted to the Vereinigung Carl Schurz: For example, the Foreign Ministry insisted that Washington and Goethe be celebrated separately (not in a joint event) so as not to reduce the diplomatic impact of either jubilee. Moreover, it pushed for one visible and well-organized German celebration in Berlin rather than a number of smaller celebrations like the Steuben year had had. Finally, it convinced President Hindenburg to assume the honorary presidency of the German Bi-Centennial Committee and even to attend the event at the Reichstag in order to "make the celebration as impressive as possible."53

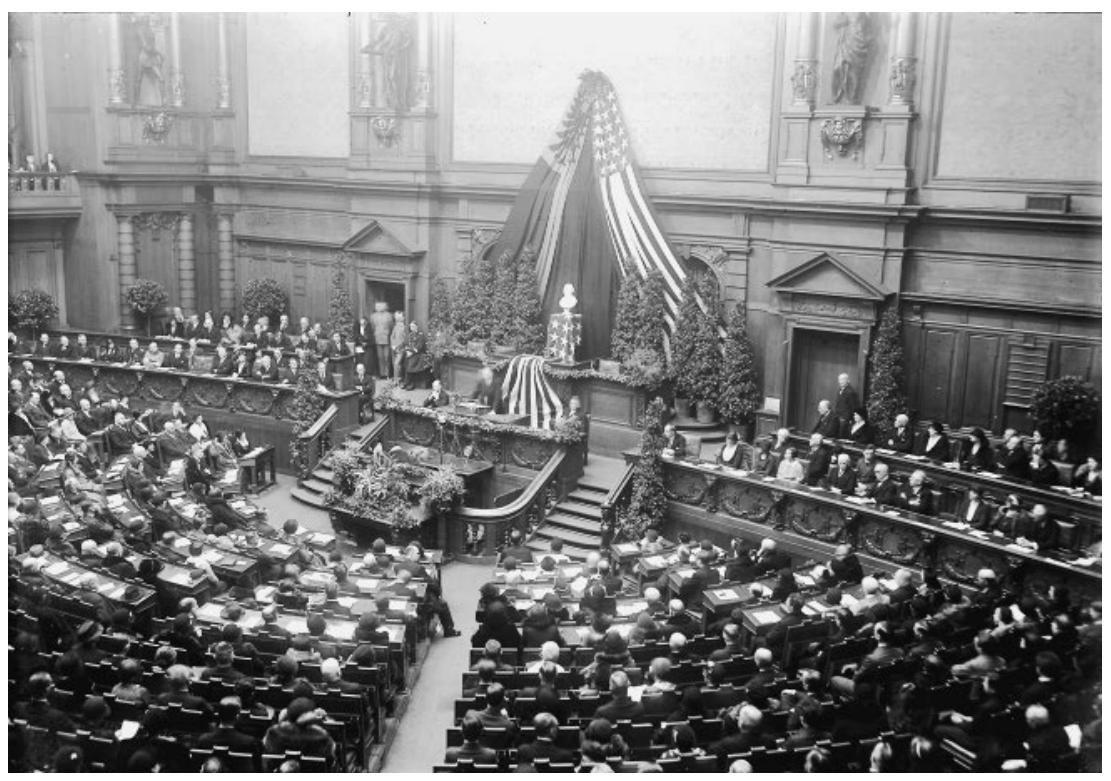

Fig. 18: The Reichstag draped in American and German flags during the Washington Bi-Cenntenial, 1932, Bundesarchiv, Georg Pahl, Bild-102-13208 A

53 AA to Büro des Reichspräsidenten (zu III A 1673), June 23, 1931, PA R 80167. 
The celebrations themselves also unfolded with significant official involvement. At the U.S. embassy's banquet on February 22, 1932, Berlin authorities were heavily represented and the addresses by Ambassador Sackett, "Roosevelt Professor" Frederick Woodbridge (1931-1932), and German economist Moritz Julius Bonn were broadcast via radio to the United States. The Foreign Ministry also used the media attention for a number of well-timed goodwill gestures including the christening of a "Washington-Platz" in downtown Berlin (which still exists in front of Berlin Central Station) and the announcement of an honorary doctorate from the University of Tübingen for the American ambassador. ${ }^{54}$ At the German-organized celebration two weeks later, Chancellor Brüning's address at the Reichstag adorned with American and German flags emphasized Washington's universal acclaim and the historical roots of German-American friendship. ${ }^{55}$ In Bremen, Breslau, Cologne, Dresden, Frankfurt, Hamburg, Munich, Leipzig, and Stuttgart, the American consulates and colonies organized celebrations, often with substantial support from German organizations. The Deutsche Akademie in Munich, for example, invited the German-American historian Carl Wittke to hold a series of lectures on "Washington and his time," which greatly enhanced the intellectual quality of these events. ${ }^{56}$ Throughout, all leading German newspapers honored George Washington's memory with detailed portraits and - against the backdrop of the upcoming German presidential election - often drew parallels between Washington and von Hindenburg. Both of these men, they argued, had been "the first in war, the first in peace, the first in the hearts of [their] countrymen." ${ }^{57}$

This is not to say that German celebrations were particularly exceptional on the world stage. The American Bi-Centennial Commission made sure that the celebrations would be observed internationally, and Washington events were thus held in 259 cities in 81 countries around the world. Yet this lack of exceptionality was precisely what made these German celebrations remarkable. Even if German celebrations might not have matched the vigor and elegance of similar British or French events, special inter-Allied ties were no longer in evidence. The official American report on the international Washington festivities gave no less room to German celebrations than to those in France. On a world map of Washington observances prepared by the Bi-Centennial Commission, Germany even came in first with 16 separate events, whereas France had 11

54 Some files on this honorary doctorate can be found in BArch R 43-I/99; see also Kotowski, Die öffentliche Universität, 149; the degree was publicly bestowed on Sackett on April 25, 1932, but seems to have evoked no response similar to that of the degrees for Schurman and Stresemann in 1928.

55 See Eugen Kühnemann, George Washington. Sein Leben und Werk (Bremen, 1932).

56 See Carl F. Wittke, George Washington und seine Zeit (Bremen/Leipzig, 1933).

57 See the clippings in PA R 80167. 
and England 10. ${ }^{58}$ Clearly satisfied with the international response to the Washington Year, the Bi-Centennial Commission declared that "never before did a foreign hero receive such universal and enthusiastic acclaim. To judge by the spirit of the bicentennial ceremonies which took place in all parts of Germany, Washington is a name which is cherished and revered by the German people."59 The German celebrations, in short, had left just the desired impression.

Understandably, in Germany preparations for this American celebration paled in comparison to what Germans considered the real event of 1932: the Goethe Year. Planning for the occasion had begun in the late 1920 and involved a wide cast of actors including the (rivaling) cities of Frankfurt and Weimar, tourist offices, state ministries, and the Reichskunstwart (the office in charge of state representation in the Weimar Republic). Though the publicity for Goethe celebrations was hardly as comprehensively organized as the U.S. Washington events, such festivities took place in nearly every German town, university, museum, and theater. Official German planners were able to utilize these occasions to appeal to German unity, underline a cosmopolitan German tradition, and bolster the government's prestige at a time of political street fighting and unprecedented economic distress. ${ }^{60}$ The official "Reich Goethe Week," which took place in Weimar in March of 1932, had many of the highest government representatives in attendance; and the week-long Goethe celebrations in Frankfurt in August of 1932 pivoted around the republican constitution day at the Paulskirche, the seat of the first German parliament in 1848. Quite obviously, the Goethe Year, as scholars have concluded, was "the last great self-presentation of the Weimar Republic before its demise." ${ }^{61}$

If the domestic organization of the Goethe commemorations is relatively well known, its international arrangement has garnered less attention; and while scholars attribute the global resonance of the Goethe Year to local initiative and enthusiasm, this was only part of the story. Indeed, just as the American government did with celebrations of Washington, the German government clearly encouraged the worldwide observance of the Goethe Year. In December 1931, the Foreign Ministry informed its foreign missions of the official schedule of events in Germany and suggested that celebrations be arranged in all larger cities in their districts via German clubs, schools, or university departments. To this end, the ministry spurred the missions to spend their entire 1932 cultural diplomacy funds on the Goethe Centenary. To simplify the task, Berlin sent a

58 For the global observance and corresponding maps of the bicenntenial, see History of the George Washington Bicentennial Celebration, Vol 4: Foreign Participation (Washington, 1932).

59 Ibid., 114.

60 On efforts to celebrate Goethe as a cosmopolitan and the limits thereof, see Christian Welzbacher, Edwin Redslob. Biografie eines unverbesserlichen Idealisten (Berlin, 2009), 222.

61 Joachim Seng, "Das Goethe-Jahr 1932," in Der Reichskunstwart. Kulturpolitik und Staatsinszenierung in der Weimarer Republik 1918-1933, ed. Christian Welzbacher, 196-216 (Weimar, 2010), 214. 
number of attachments, including a blueprint on how to organize a successful Goethe celebration, a template of a suitable Goethe speech, and a list of German professors and authors who could be "booked" for the occasion. ${ }^{62}$ As the Foreign Ministry explained, the "festivities at home and abroad are primarily to express the cultural affinities between all Germans, even those living beyond the Reich's border; but it is also to encourage all foreign populations to take part." " 3 A few weeks later, the German government invited foreign dignitaries and "Germandom leaders" to attend the official celebration in Weimar. ${ }^{64}$

At that point, the Goethe Year in the United States was already fully planned. While official records on the Goethe commemorations in the United States have not survived, there can be no doubt that the official preparations were substantial. In particular, German officials supported the Carl Schurz Memorial Foundation, the Goethe Society of America (founded by educator-diplomats like Nicholas Murray Butler and Jacob Gould Schurman) and a large number of German departments at U.S. universities in preparing banquets, lecture tours, publications, and German-language essay contests. ${ }^{65}$ The German Tourist Information Office (GTIO) in New York City unleashed a veritable flood of Goethe publicity (including Goethe films) through commercial and educational channels. ${ }^{66}$ The consulate in St. Louis, for example, could not praise the GTIO's Goethe campaign enough. Its English-language Goethe pamphlet, the consulate reported, was "the delight of all university professors, and, indeed, all educated circles that it reached. It thereby creates an intellectual atmosphere in which alone friendship between the best of both peoples can grow." 67

Based on these preparations, early 1932 witnessed a string of Goethe ceremonies at the U.S. House of Representatives, Carnegie Hall, the Waldorf Astoria in New York, and innumerable German clubs, classrooms, and university auditoriums across the country. What gave the American Goethe Year special flair was the visit of German dramatist and Nobel laureate Gerhart Hauptmann. Not only was Hauptmann one of Germany's most revered authors, but he was also, nearing his seventieth birthday, said to bear a striking resemblance

62 AA Circular, Dec. 22, 1931, PA RAV Bukarest - Gesandtschaft Bukarest, 147 Goethejahr.

63 Ibid.

64 AA Circular, Jan. 15, 1932, PA RAV Bukarest - Gesandtschaft Bukarest, 147 Goethejahr.

65 E. g., the Goethe Society published "Goethe in Amerika," the University of Wisconsin published a Goethe memorial volume, the Monatshefte für deutschen Unterricht published a special Goethe issue, and the Carl Schurz Memorial Foundation initiated a Goethe essay contest.

66 The GTIO lent out a Goethe film series to German clubs and teachers at low cost and with great success; it included Germany in the Goethe Year 1932 (1 reel), Goethe and Frankfurt (1 reel), Goethe and Weimar (1 reel), and Creative Hands (1 reel).

67 German Consulate, St. Louis, to AA, Mar. 14, 1932, "Fremdenverkehrswerbung im Ausland," PA R 246919. 
to Goethe himself. ${ }^{68}$ Though Hauptmann's visit, arranged by Columbia Germanist Frederick Heuser and the Carnegie Endowment, included only a handful of German-language lectures at prestigious universities, his fame generated abundant American press coverage. ${ }^{69}$ The coordinated character of the Goethe campaign in the United States is suggested by the actions of Ambassador Prittwitz, who balanced out Hauptmann's focus on the Northeast by personally attending the large Goethe celebration at the University of Wisconsin. The Carl Schurz Memorial Foundation, too, flanked Hauptmann's exclusive tour by sending none other than Eugen Kühnemann (former Wilhelmine exchange professor and wartime propagandist) on a five-month tour across the United States, during which he gave almost one hundred Goethe speeches. ${ }^{70}$ Still the cultural missionary of earlier days, Kühnemann felt elated by the task and repeatedly emphasized the stroke of fate that Germany and the United States would be celebrating their greatest historical figures (Washington and Goethe) within just a month of each other. "In their great memorial days," Kühnemann imagined, "the two nations, America and Germany, have come as close to each other as if they were called to a new spiritual community." 71

A review of the rapid succession of transatlantic celebrations after 1929 evokes a number of observations. For one, the celebrations throw light on the transatlantic cultural infrastructure that had developed after the war. The events commemorating Schurz, Steuben, and Washington involved about a dozen intermediary organizations interested in transatlantic cultural relations, including the Amerika-Institut, the Vereinigung Carl Schurz, the Society of Friends of the USA (Hamburg), the Deutsche Akademie (Munich), and the Deutsches Ausland-Institut (Stuttgart). ${ }^{72}$ These organizations allowed the Foreign Min-

68 On the organization of Hauptmann's visit and general impressions, see the personal report by Frederick Heuser, Heuser Papers, Box 2: Misc. Correspondence, Manuscript Collections, Columbia University Libraries.

69 To Ambassador Prittwitz, Hauptmann “was the best 'good will ambassador' his country could have sent across the ocean for that occasion"; Prittwitz, Zwischen Petersburg und Washington, 180; Nicholas Murray Butler also found that “Dr. Hauptmann's visit which comes to an end today has been remarkable, and his reception most enthusiastic. His oration of Goethe on Tuesday last was one of the finest things of the kind I have ever heard"; Butler to Woodbridge, Mar. 3, 1932, Frederick James Eugene Woodbridge Papers, Box 1, Correspondence, Folder: Butler/ Woodbridge, 1931, Columbia University, Rare Book \& Manuscript Library Collections.

70 For a list of American ceremonies, see Mitteilungen der Deutschen Akademie (Dec. 1932).

71 Eugen Kühnemann, "Auf Goethefahrt in Amerika (Eindrücke meiner letzten Amerikareise)," 6, NL Eugen Kühnemann, Box 2, Universitätsbibliothek Marburg.

72 The Washington banquet, for example, was hosted by the Vereinigung Carl Schurz, the Amerika-Institut, and the Gesellschaft der Freunde der USA (Hamburg), as well as Germandom organizations, including the Bund der Auslandsdeutschen, the Deutsche Akademie, the 
istry to conduct highly coordinated but unobtrusive cultural diplomacy, of which transatlantic celebrations were but one element. The Goethe Year, too, illustrated how effectively Germany could mount a significant cultural campaign across the Atlantic by 1932. In particular, it showed the astonishing degree to which Germany had restored reliable partnerships with American universities, German Americans and cultural internationalist groups like the Carnegie Endowment. Compared to the near complete absence of such connections as late as 1923 (Chapter 3), this abundance of cooperation speaks clearly to the effectiveness of Germany's network- and sympathy-building efforts in the 1920s. The transatlantic celebrations in the early 1930 only deepened the ties and coordination among and between cultural diplomats on both sides of the Atlantic.

Secondly, the introduction of the Goethe medal in the context of the Goethe Year in 1932 finally resolved one of the gravest problems of Weimar public diplomacy: a lack of state honorary decorations. ${ }^{73}$ Throughout the 1920s, Weimar's constitutional ban on official decorations had frustrated German diplomats, who felt deprived of a key foreign policy tool. While Germandom organizations, the German Red Cross, and German universities offered some alternative decorations, they lacked the wide applicability and/or the prestige of state medals. ${ }^{74}$ Given the widely accepted (and expected) function of decorations in expressing appreciation and allocating prestige, they were, as the Kulturabteilung noted in 1932, "urgently necessary" as an instrument for maintaining goodwill abroad, not least in the United States. ${ }^{75}$ As early as 1923, the German ambassador to Washington, Otto Wiedfeldt, had pointed out that "one can hardly overestimate the craving for medals in this democratic country; by abolishing any decorations [...] we have deliberately deprived ourselves of an effective tool abroad." ${ }^{76}$ President Hindenburg's introduction of the Goethe Medal for Art and Science in 1932, then, at least partly addressed these concerns. The three Americans who received the Goethe Medal in 1932 also once more underlined Germany's most important bases of support in the United States: German Americans (Gustav Oberlaender), cultural internation-

Deutsches Ausland-Institut, and the Verein für das Deutschtum im Ausland; see "Feier des 200. Geburtstages von George Washington 1932," PA R 60108.

73 On Hindenburg's initial response to the suggestion of the Reichskunstwart, see Edwin Redslob, Von Weimar nach Europa, 206-207.

74 In October 1930, the Deutsche Akademie introduced three awards to be given to individuals who had increased German prestige in the world and improved its international cultural relations: the Großes Ehrenzeichen, the Ehrenzeichen, and the Silberne Medaille. The first recipient of the most prestigious category was President von Hindenburg.

75 VI W 9956 Aufzeichnung, Nov. 17, 1932, PA R 61125.

76 Wiedfeldt to AA, July 20, 1923, "Propaganda in den Vereinigten Staaten," ADAP, Serie A, Vol. 8, No. 76, 183-196. 
alists (Nicholas Murray Butler), and American professors of German (Frederick Heuser).

Finally, the remarkable international resonance of the Goethe Year (the list of global Goethe celebrations prepared by the Deutsche Akademie filled 34 pages in very small print) was widely felt to have finally redressed the cultural losses of the Great War. Such feelings were as prevalent among German Americans as they were among parts of the German Bildungsbürgertum. ${ }^{77}$ As Frank Thierfelder, the executive secretary of the Deutsche Akademie, noted, the Goethe celebrations "meant that the disparagement of the German name during the war has been rescinded in a form that will make it easier for us to forget some things ... for stronger than the loss of two million on the battlefields, stronger than the losses in land and property, stronger than the nameless plight of the postwar period, the German people have suffered from the soiling of their honor."78 In his opinion, the "Goethe World Festival" had thus "broken a spell that has weighed on us like a nightmare."79 To Thierfelder and many of his peers, the Goethe Year had finally rehabilitated Germany in the world.

\section{German Politics and Transatlantic Relations}

Still, the impact of these celebrations on transatlantic relations themselves must not be overstated. If diplomats like Ambassador Prittwitz naturally hailed the wide participation in these events as evidence of transatlantic "rapprochement," few of these celebrations were of a truly popular nature. ${ }^{80}$ The commemoration of Carl Schurz in 1929 had already suffered from widespread disinterest on both sides of the Atlantic, and even the "promotional extravaganza" that preceded the Washington Bi-Centennial had been no guarantee for public enthusiasm in dire times. ${ }^{{ }^{8}}$ The repeated Steuben festivities, for their part, left hardly any impression on a larger American audience, with Steuben remaining even afterward a little known and little appreciated historical figure

77 Kazal, "Becoming 'Old Stock", 486.

78 Franz Thierfelder, "Die Goethe-Welt-Feier 1932," Mitteilungen der Deutschen Akademie 3, no. 1 (April 1933): 21-59, 21.

79 Ibid., 23.

80 Prittwitz, "Deutschland und die Vereinigten Staaten seit dem Weltkrieg," 22.

81 In New York, Carnegie Hall was not sold out, and in Stuttgart and San Francisco, "disinterest and weather" resulted in a relatively meager turnout; see the respective clippings "Ein letzter Appell zur Schurz-Feier," New Yorker Staats-Zeitung, Mar. 20, 1929; and "Schurz-Feier im Deutschen Ausland-Institut, Stuttgart," New Yorker Herold, Mar. 15, 1929, both in National Carl Schurz Association, Inc., Records, Series 1 General Historical and Office Materials Box 27 Folder 9, HSP. 
in comparison to the Marquis de Lafayette. ${ }^{82}$ Moreover, as much as the United States and Germany liked to attribute honoring their historical icons to honest appreciation and spontaneous enthusiasm, they were - more often than not carefully orchestrated products of transatlantic cultural politics. The American Germanist Camillo von Klenze cautioned against placing too much store in these events as indicators of true cultural awareness:

all this wonderful evidence of an honest Goethe interest [in the United States in 1932] should not blind us to the fact that Goethe is nearly exclusively known to the literary educated in America - a circle that is much smaller in a young country than in an old cultural nation like Germany - [and] that the wider public knows almost nothing of him, and that there is absolutely no appreciable influence of Goethe on American literature to speak of. ${ }^{83}$

More serious than the limited impact these celebrations had was the notable tendency for entirely different versions of these "heroes" to be on display at the various events This was already in evidence with the Carl Schurz events. Whereas democrats like Ambassador Prittwitz celebrated Schurz as the epitome of the German republican tradition and a man who had "fought for the same ideals on both continents," ${ }^{84}$ Germandom organizations honored the 1848 revolutionary as a virtuous German man with "conservative common sense and a great respect for law and order." ${ }^{\text {"s }}$ And while Americans lauded Schurz's American sense of civic duty, some German circles considered him "Germany's greatest gift to America." In the same vein, when Americans thought of Steuben at all, it was as one among George Washington's Polish, French, Irish, and Jewish "helpers," yet German rhetoric cast him as the father of the U.S. Army and the real savior of the American Revolution. ${ }^{86}$ Finally, one cannot help noticing that many Germans, in their embrace of George Washington, were celebrating not the American hero and first president of the American republic but the idealized version of a strong leader whom they themselves longed for in the early 1930s. To be sure, such diverging interpretations are common to all celebrations at all times; nevertheless, they still laid bare the underlying fault lines of German-American relations.

82 Outside of German-America, his name seems to have been mostly unknown. A 1927 bibliography on Steuben reveals hardly any literature outside of German-American publications; Heinz Kloss, "Friedrich Wilhelm von Steubens Bedeutung," Der Auslanddeutsche 10, no. 23 (Dec. 1927): $788-789$.

83 Camillo von Klenze, "Das amerikanische Goethebild," Mitteilungen der Deutschen Akademie (July 1933): 184-210, 210.

84 Prittwitz, Zwischen Petersburg und Washington, 214.

85 "Carl-Schurz-Feiern der Deutschen Akademie in Berlin und München," Mitteilungen der Deutschen Akademie (May/Jun 1929): 240-242.

86 Bloem, "Das Steuben-Jahr," 7-10. 
Indeed, as Frank Trommler and Joseph McVeigh remarked in another context, "symbolic celebrations generally conceal problem areas," ${ }^{87}$ and there was no shortage of these in the early 1930s. Despite the prevalent rhetoric of transatlantic friendship, these years did not mark a high point of transatlantic amity. In hindsight, Ambassador Prittwitz identified an "atmospheric" shift in German-American relations in 1931, when German revisionist demands began to alienate and concern an increasing number of Americans. ${ }^{88}$ In fact, all gestures of goodwill aside, the Brüning cabinet had already moved a long way from the deference, accommodation, and proactive communication that had built transatlantic trust during the Stresemann years. ${ }^{89}$ Instead, Germany's foreign policy began to be characterized once more by rash, isolated, and impatient actions and more or less openly used Germany's political instability and financial debt to blackmail the United States into supporting its revisionist demands. That Germany would stress its dire financial straits at every turn but insist, for instance, on building new armored cruisers irritated American diplomats and an attentive public alike..$^{90}$ Above all, such actions signaled Germans' withering regard for American psychology, which had so clearly distinguished Weimar from Wilhelmine foreign policy. "The Germans," American economic advisor Herbert Feis presciently noted in mid-June 1932, "grow more and more hysterically conscious of their own grievances and less and less aware of the judgment of the rest of the world."91 From this perspective, the transatlantic celebrations looked suspiciously like a return to the prewar policy of "gifts and gestures."

Ultimately, these differences only reflected how increasingly radicalized domestic politics intruded ever more forcefully into transatlantic relations. From mid-1932 onward, the U.S. State Department received complaints about German exchange students in the United States engaging in Nazi propaganda, while American tourists of Jewish faith reported instances of harassment in Germany..$^{92}$ At that point, German students had already radicalized

87 Trommler and McVeigh, "Introduction," in America and the Germans, ed. Trommler and McVeigh, 2:xi.

88 Prittwitz, Zwischen Petersburg und Washington, 195-196.

89 For an example of the change in transatlantic relations, see Burke, Ambassador Frederic Sackett, 134-137; in general on this, see Krüger, Die Außenpolitik der Republik von Weimar, 514-515. 90 Burke, Ambassador Frederic Sackett, 146.

91 Feis, quoted in Burke, Ambassador Frederic Sackett, 238.

92 On the experiences of allegedly "Jewish looking" American students in Germany in the summer of 1932, see Edward Murrow to Professor G. R. Walther Thomas, Nov. 29, 1933, Roll 7, Rockefeller Archives Center, IIE Records, Grantee Files. "The closer the 3oth of January 1933 came," remembered Ambassador Prittwitz, "the more often the propagandistic emissaries of the Völkische Beobachter [the Nazi paper] showed themselves." Prittwitz, Zwischen Petersburg und Washington, 221. 
and turned German universities into National Socialist strongholds. ${ }^{93}$ When in mid-1931 Ambassador Schurman returned to Heidelberg to open the new university building, which he and American friends had endowed in 1928, the "liberal Heidelberg" of Weimar days had already crumbled under right-wing agitation. ${ }^{94}$ The National Socialist student organization greeted the university's distinguished alumni, generous benefactor, and honorary doctor in its very own way: with anti-Semitic and anti-American slurs. ${ }^{95}$ Perhaps no one saw more clearly than Germany's democratic ambassador in Washington just how profoundly Germany's domestic radicalization would come to alienate Americans. In numerous reports and private correspondence, Prittwitz stressed the grave danger to Germany of straying too far from its reliable peaceful policy. ${ }^{96}$ American goodwill, he warned Berlin, depended "to a great extent on the trust in the basic direction of German domestic and foreign policy."97

93 Long before the National Socialists' general political success, a majority of the German student body voted for them. In the student elections of January 1932, the National Socialist group received almost two-thirds of all votes at the University of Berlin. Michael Grüttner, "Studentenschaft in Demokratie und Diktatur," in Geschichte der Universität unter den Linden, ed. Grüttner et al., 2:187-294 (Berlin, 2012), 220; on Berlin University as an ideological battleground, see ibid., 239-249.

94 The subsequent student campaign against one well-known pacifist professor was so vicious that one German magazine concluded in July 1932 that "liberal Heidelberg has thus opened the era of the Third Reich in the sphere of academia!" Quoted in Steven P. Remy, "We Are No Longer the University of the Liberal Age': The Humanities and National Socialism in Heidelberg," in Nazi Germany and the Humanities: How German Academics Embraced Nazism, ed. Wolfgang Bialas and Anson Rabinbach, 21-49, 23.

95 Buselmeier, Harth, and Jansen, eds., Auch eine Geschichte der Universität Heidelberg, 155.

96 See, for example, Prittwitz's letter to Bülow, reprinted in Prittwitz, Zwischen Petersburg und Washington, 219-221.

97 German Embassy, Washington, to AA, May 9, 1931, PA R 80150. 
Fig. 19: National Socialist Student Organization, "Die Juden bringen den lebendigen Geist [The Jews bring the living spirit]," Pamphlet circulated upon the opening of the American-financed new university building, June 1931, Heidelberg University Archive, B-5135/7

\section{Die Guben bringen Den , "rebendigen Geift"

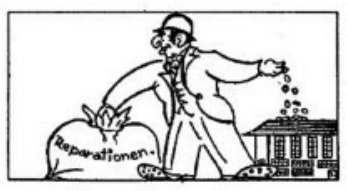 \\ Geitichrift

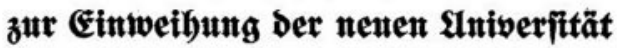

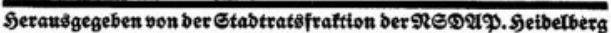
Frete 10 \%Feunig

Hetzschrift der Stadtratsfraktion der NSDAP anläßtich der Eimweihung der Neuen Universität im Juni 1931 (Universitätsarchiv Heidelberg B-5135/7)

With the privilege of hindsight, then, the Goethe commemorations of 1932 appear only as a stage on which the agony of Germany's first republic played out. Taking place in the critical weeks of the German presidential election, the celebrations were pervaded by political strife: Gerhart Hauptmann and Eugen Kühnemann, for example, used their American sojourns to champion the candidates for Reich president, Hindenburg and Hitler, respectively; ${ }^{98}$ and the German commemorations of Goethe were characterized by a widespread ideological clash between "Goethe as a [... cosmopolitan" and "Goethe as a German." 99 The momentum was certainly on the side of the latter interpretation, however. If the official festivities at Weimar, held in March 1932, had already been disturbed by parading Brownshirts, by the time of the official Frankfurt

98 On Hauptmann, see George Sylvester Viereck, "Gerhart Hauptmann, Deutschlands berühmtester lebender Dramatiker und Literat, Gewinner des Nobelpreises 1912, in einem Gespräch," Detroit Sunday Times, Mar. 20, 1932, reprinted in H. D. Tschörtner, Gespräche und Interviews mit Gerhart Hauptmann (1894-1946) (Berlin, 1994), 137-139; on Kühnemann and his endorsement of Hitler, see Kühnemann, Interview with Harvard Crimson, Feb. 10, 1932, NL Eugen Kühnemann, Box 6, Universitätsbibliothek Marburg.

99 Welzbacher, Edwin Redslob, 220. 
event five months later, the Nazis were the strongest party in the Reichstag. ${ }^{100}$ When a depressed-looking Brüning led the black-clad official delegation to Goethe's grave, one onlooker could not shake the premonition that "we are burying the Republic."101

For German-American relations, June 1932 proved a turning point. ${ }^{102}$ Hindenburg's dismissal of Chancellor Brüning came as a shock to Americans, who had come to regard both Hindenburg and Brüning as stalwarts of republican stability. The appointment of Brüning's successor, Franz von Papen, and his aristocratic "monocle cabinet" was widely considered a reactionary takeover. Given Papen's notorious American past (the former military attaché in Washington had been forced to leave the United States in 1915 on espionage and sabotage charges), the appointment clearly undermined US confidence and trust in Germany. ${ }^{103}$ As if to prove Americans' fears correct, German representatives walked out of the world disarmament conference in Geneva shortly thereafter. Though the United States continued to support Germany in casting off its reparations burden (July 1932) and attaining armament equality (December 1932), there was no denying the qualitative change in the relationship between the two countries. No transatlantic celebration could long hide what many American observers, including Secretary of State Henry L. Stimson, deemed a "reawakening of the Prussian spirit." ${ }^{104}$ As Ambassador Prittwitz once more reminded Berlin in November 1932, the crux of transatlantic relations lay not in Germany's foreign but in its domestic politics. ${ }^{105}$

100 Manfred Müller, "Nationalsozialistische Einflüsse auf die Vorbereitung und den Ablauf der Reichsgedächtnisfeier für Goethe 1932 in Weimar," Zeitschrift für Germanistik 14, no. 3 (2004): 608-613.

101 Redslob, Von Weimar nach Europa, 207; less involved observers, like Roosevelt Professor Woodbridge, however, remarked that "the ceremony at the time when the wreaths were laid upon Goethe's tomb was particularly impressive"; see Woodbridge to Butler, Apr. 14, 1932, Frederick James Eugene Woodbridge Papers, Box 1, Correspondence, Folder: Butler/Woodbridge, 1931, Columbia University, Rare Book \& Manuscript Library Collections.

102 Link, Amerikanische Stabilisierungspolitik, 523.

103 German Embassy, Washington, to AA, June 6, 1932, "Deutscher Kabinettswechsel," PA R 80151; Prittwitz analyzed the situation as follows: "Generally, the Americans do not care in what way other peoples want to pursue their happiness or damnation. But they do have a certain fundamental attitude that could be best summarized as an aversion to radicalism, on the one hand, and a disdain for military preponderance in politics, on the other hand."

104 Link, Amerikanische Stabilisierungspolitik, 531.

105 German Embassy, Washington, to AA, Nov. 10, 1932, "Stand der deutsch-amerikanischen Beziehungen," PA R 80151. 


\section{Chapter 8}

\section{"Submerged Under a Nazi Wave"? Continuity and Change in German Public Diplomacy, 1933-1937}

7 he Nazi Party's rise to power transformed German-American relations. While American officials refrained from public criticism of Germany's domestic politics, the American public registered and at times protested the changes taking place overseas. Germany reacted to these challenges with new efforts to ease American apprehensions, not always successfully. Alternately heeding or ignoring the lessons of previous decades, public diplomats would continue to play a discrete, if ambivalent, role in transatlantic relations. While the historiography on Nazi public diplomacy and propaganda is voluminous, the following chapter briefly traces developments after 1933 with special attention to continuities and ruptures in the fields of action explored in the previous chapters. In so doing, it illuminates some of the unique strengths and shortcomings of Weimar's public relations.

Americans followed the Nazis' rise to power apprehensively, if not usually very closely. Beginning in mid-1932, discerning American news correspondents in Berlin like Edgar Ansel Mowrer had sought to alert the American public to the dangers of National Socialist agitation and Germany's attempt, as Mowrer's book title called it, to "put the clock back." Still, relatively few Americans paid significant attention to such journalistic predictions. More than the appointment of the Hitler cabinet itself, the establishment of dictatorial controls over 
legislative and executive powers and the accompanying violence and suspension of civil liberties in February and March was what first caused American alarm. The critical reports of American journalists on these events impressively confirmed many an American's lingering suspicions about the depth of Germany's democratic conversion. ${ }^{2}$ Even before the Reichstag self-abdicated by passing the "Enabling Act" on March 23, American Ambassador Sackett reported that "[d]emocracy in Germany has received a blow from which it may never recover. Germany has been submerged under a huge Nazi wave. The much heralded Third Reich has become a reality."3

Throughout the spring of 1933, anti-Semitic outbursts in Germany fed American concern and indignation. The official German boycott of Jewish businesses (April 1), the dismissal of Jewish and left-leaning civil servants, including world-famous scientists like Albert Einstein (April 7), and the nationwide book burnings one month later evoked strong American reactions. ${ }^{4}$ As the persistent and state-driven nature of discrimination and terror in Germany became apparent, American protest, too, settled into more organized forms. With some Catholic and Protestant support, Jewish groups in the United States mounted large-scale protest rallies and called for a boycott of German products, tourist destinations, and universities. American diplomats frequently warned their German interlocutors of the adverse effects of antisemitism on U.S. opinion. ${ }^{5}$ Although many Americans long remained remarkably ambivalent about the nature of Nazi rule, the degree of its popular support and its ultimate intentions, disdain for, and suspicion of Nazi Germany never entirely subsided during the 1930s. ${ }^{6}$ After January 1933, American attitudes toward Germany took a decided turn for the worse. ${ }^{7}$

German observers were clearly distressed by American responses and began to focus their attention on American public opinion more than they had in nearly a decade. From March 1933 onward, the Foreign Ministry was inundated

2 Müller, Weimar im Blick, 374. For a consular report on the similarities between the Italian fascist takeover and National Socialism, see Consul General at Stuttgart (Dominian) to the Secretary of State, Feb. 21, 1933, FRUS, Vol. II 1933, 193-198.

3 The Ambassador in Germany (Sackett) to the Secretary of State, Mar. 9, 1933, FRUS, Vol.II 1933, 206-209, 209.

4 See the reports in PA R 80152 and R 80153.

5 Memorandum by the Secretary of State of a Conversation with the German Ambassador (Luther), May 3, 1933, FRUS 1933, Vol. II, 352-354.

6 On this ambivalence, see Hoenicke-Moore, Know Your Enemy, esp. Chapter 2, 41-77. Offner notes that "the boycott probably made its greatest impact in 1933-34, when Germany's exports to the United States declined proportionately over twice as much as its exports to the rest of the world." See Arnold A. Offner, American Appeasement: United States Foreign Policy and Germany, 1933-1938 (Cambridge, MA, 1969), 63.

7 In a frank report in 1935, Ambassador Luther characterized the United States as "one of the main centres of anti-German agitation"; The Ambassador in the United States to the Foreign Ministry, June 28, 1935, DGFP, Series C/Vol. 4, Document No. 184. 
with diplomatic, commercial, academic, and press accounts commenting on the depth and extent of American indignation. German shipping lines, export companies, and the tourist trade feared the American boycott movement for the impact it could have on commerce, while diplomats and German Americans dreaded its implications for Germany's standing in the United States. ${ }^{8}$ Indeed, a vast number of German and German-American observers were reminded of 1914 and voiced their concerns that antisemitism could turn into a new public relations disaster, a "new Belgium." George Sylvester Viereck warned that Germany might once more "find herself morally isolated as she did in the World War," unless decisive countermeasures were adopted. ${ }^{9}$ A cable the German Tourist Information Office in New York sent Germany in late March 1933 gave concise expression to these fears, along with recommendations for immediate action:

flood of agitation grows especially in the churches of all confessions, reminds of 1914 atrocity propaganda but much more comprehensively organized - stop - Hearst press, even [New Yorker] Staats-Zeitung, agitate, which were neutral or sympathizing then stop [...] most forceful intervention necessary (interviews with church leaders etc) [...] flood of anti-German material floods all press outlets here[.] Counter-flood has to be set in motion there immediately. ${ }^{10}$

Before we turn to the contours of this German "counter-flood" it must be acknowledged that despite the constant invocations of 1914, the United States was not nearly as crucial to German foreign policy in 1933 as it had been then. The final settlement of the reparations question in November 1932, Germany's unilateral withdrawal from the disarmament talks in late 1933, and manifest US political isolationism - underlined by the neutrality legislation of the mid1930 - further decreased American weight in Berlin. In contrast to Great Britain or France, the United States posed no serious (i. e., military) threat to Nazi Germany's revisionist course and, thus, played no important role in Hitler's immediate foreign policy conceptions. ${ }^{11}$ For much of the 1930s, Detlef Junker has noted, Hitler would consider "American good will [...] useful but relatively

8 See Max Ilgner to AA, Mar. 29, 1933, PA R 80152; Meeting, Mar. 30, 1933, PA R 80152.

9 George Sylvester Viereck to AA (Dieckhoff), Mar. 16, 1933, PA R 80153.

10 Telegram (GTIO), Mar. 23, 1933, PA R 246920.

11 There is some disagreement about how important the United States was to Germany. Hans-Jürgen Schröder emphasizes that the United States was not at all a "quantité negligeable" for Hitler's foreign policy and that especially during the first few years after 1933, he accommodated the United States in a number of ways; see Hans-Jürgen Schröder, "Das Dritte Reich und die USA," in Die USA und Deutschland, 1918-1975, ed. Knapp et al., 107-152 (Munich, 1978), 115. 
insignificant."12 Nevertheless, it was clearly in Germany's interest to maintain basically friendly relations with the United States. Not only did the foreign currency-starved Reich wish to maintain American trade and tourism; it had no desire to further increase American suspicions. As it did elsewhere, Germany would, hence, try to obscure its forceful revisionist and, ultimately, expansionist agenda by emphasizing its peaceful intentions and the continuity of earlier foreign policy aspirations. ${ }^{13}$ In its basic intention then - to camouflage the changes taking place in Germany - the "Third Reich" in its public diplomacy had more in common with the policies of Germany's presidential cabinets from 1930 to 1932 than it did with those of the mid-1920s.

Like Nazi rule more generally, German public diplomacy after 1933 was characterized by a strong duality of traditional and revolutionary elements. Long-standing, conservative state bureaucracies like the Foreign Ministry increasingly competed with a host of party offices. ${ }^{14}$ The result of this polycratic structure was notorious infighting that made for the unique dynamism - and unique problems - of the Nazi state. In questions of public diplomacy, as in foreign relations overall, German diplomats by and large maintained the caution of the previous decade. ${ }^{15}$ While American opposition to the new government prompted it to immediately increase publicity efforts, this was more a change in pace than in basic direction. For example, O.C. Kiep, the German consul general in New York, decided to hire World War I propagandist George Sylvester Viereck as the consulate's press liaison in 1933 - a move that might suggest a German "relapse" to the policies of 1914 - but Kiep's most ambitious project, a book with portraits of Nazi leaders published by an American publisher, was far from radical. ${ }^{16}$ The American public relations firms German companies like the chemical trust IG Farben hired to help them improve Germany's image only seconded this cautious approach: They advised the German companies to (i) engage in a policy of "come and see" that would beckon Americans to visit the new Germany, and (ii) pay more attention to American news correspond-

12 Detlef Junker, "Continuity of Ambivalence: German Views of America," in Transatlantic Images and Perceptions, ed. Barclay and Glaser, 243-263, 244.

13 Herbert Sirois, Zwischen Illusion und Krieg. Deutschland und die USA 1933-1941 (Paderborn, 2000), 45; a prime example of this strategy is the German proclamation on leaving the disarmament conference and the League of Nations; see Proclamation of the German Government to the German Nation, Oct. 14, 1933, DGFP, Series C, Vol. 2, Document No. 1.

14 Hans-Adolf Jacobsen, Nationalsozialistische Außenpolitik, 1933-38 (Frankfurt, 1968).

15 Already on January 30, 1933, the Foreign Ministry had issued a circular to its missions to calm fears about the Hitler cabinet by stressing its continuity in personnel. Circular of the State Secretary, Jan. 30, 1933, DGFP Series C, Vol. 1, Document No. 1.

16 German Embassy, Washington, to AA, Mar. 29, 1933, "Antideutsche Stimmung in den Vereinigten Staaten," PA R 80153. 
ents in Berlin, essentially reiterating policies Germany had already practiced for a decade. ${ }^{17}$

But already during the spring of 1933, new party-affiliated offices began to challenge more traditional ministerial conceptions of public diplomacy. Germandom policies and political propaganda, in particular, enjoyed great attention among Nazi Party leaders. ${ }^{18}$ Hitler himself, whose understanding of propaganda had been shaped by his experience of the world war, was deeply interested in this field and would remain so up to 1945 . Still, his ideas on the subject stood out not for their originality - Mein Kampf only repeated the widely held assumption that skillful British agitation had precipitated German defeat - but for their radical conclusions: ${ }^{19}$ Already in the early 1920s, the National Socialists had developed a "propaganda doctrine," according to which repetitive, catchword-oriented mass agitation, especially when coupled with violence, could have almost unlimited influence on people. ${ }^{20}$ In the coming years, the Nazis substituted propaganda for politics, stabilizing their rule once they came into power using ideological appeals to the Volksgemeinschaft and attacks against outside enemies (Jews, Bolsheviks). The party's long preoccupation with the subject logically resulted in the establishment of the Ministry of Propaganda (Ministerium für Volksaufklärung und Propaganda) under Joseph Goebbels on March 13, 1933.

Although the Ministry of Propaganda initially focused on domestic matters, it soon relieved the Foreign Ministry of much of its authority over representing Germany to the world. In an inter-ministerial meeting of May 24, 1933. Hitler underlined the importance of a forceful, well-funded campaign to overcome Germany's international isolation..$^{21}$ To this end, the Ministry of Propaganda was to take over all official instruments suitable for more "active" and "aggressive propaganda," leaving the Foreign Ministry with only a small press division to tend to routine, official information work. The Foreign Ministry weakly protested that public diplomacy must not be regarded (nor openly identified) as propaganda and ought to be closely coordinated with foreign pol-

17 On the hiring process, see Max Ilgner to Ivy Lee, Mar. 29, 1933, PA R 80152; Investigation of Nazi propaganda activities and investigation of certain other propaganda activities, Public Hearings before the Special Committee on Un-American Activities, House of Representatives, Seventy-Third Congress, Second Session (Washington DC, 1934-35), 178.

18 Laitenberger, Akademischer Austausch und auswärtige Kulturpolitik, 38.

19 Peter Longerich, Propagandisten im Krieg. Die Presseabteilung des Auswärtigen Amtes unter Ribbentrop (Munich, 1987), 60.

20 Longerich, Propagandisten im Krieg, 71-72; for a brief introduction, see David Welch, "Introduction," in Nazi Propaganda: The Power and the Limitations, ed. David Welch, 1-9 (Totowa, NJ, 1983).

21 Minutes of the Conference of Heads of Departments, May 24, 1933, "Propaganda Abroad," DGFP, Series C, Vol. 1, Document No. 261. 
icy, but this proved of little avail. ${ }^{22}$ By the summer of 1933 , Goebbels's ministry had gained control over the bulk of political, economic, commercial, and tourist propaganda as well as matters pertaining to exhibitions, film, sports, and fairs. ${ }^{23}$ Abroad, Goebbels appointed and deployed a network of press attachés at German missions, which allowed him to use traditional infrastructures (and diplomatic immunity) while largely cutting the Foreign Ministry out of fields it had previously managed.

Similar challenges to the Wilhelmstrasse's authority arose in the field of Germandom policies, which was similarly embedded in Nazi ideology. Notions of the Volksgemeinschaft, albeit racially rather than culturally defined, shaped the Nazi Party's domestic and international politics. In this context, $\mathrm{Na}-$ zis regarded Germans abroad (Auslandsdeutsche) - whether citizens or not increasingly as targets, conduits, and fertile ground for spreading National Socialist ideals or, at the very least, creating a favorable climate of opinion toward the Third Reich. Alongside a number of other offices, the National Socialist Party's Foreign Section (Auslandsorganisation/AO) devoted itself to these matters. Founded in 1931 to collect dues and keep in touch with the growing number of National Socialist Party members abroad, it sought to wrest the wider field of Germandom work from the allegedly lackluster, ideologically unreliable older Germandom organizations and the Foreign Ministry after $1933 .{ }^{24}$ While it did not immediately succeed, its leader Ernst Wilhelm Bohle tapped into the international network of Nazi enthusiasts to try and turn Germans abroad into a distinct asset for the new Germany. ${ }^{25}$

In both cases - political propaganda and Volkstumspolitik - this reorganization of international representation ultimately undermined the Foreign Ministry's policy of caution in the United States. Indeed, these new offices, which entertained - like Hitler himself - a notoriously low opinion of diplomats, brushed aside diplomatic warnings about the ill effects of forceful agitation in the United States. ${ }^{26}$ This is not to suggest that the cautious traditional diplomats and assertive National Socialists were always at odds - doubtlessly,

22 Memorandum/Sievers about work of VI C, Feb. 24, 1933; and Memorandum "Kulturpolitik," Mar. 1, 1933, PA R 60798.

23 Alton Frye, Nazi Germany and the American Hemisphere (New Haven, 1967), 21: "For the next six years this divorce of foreign propaganda from the control of the Foreign Ministry and its officers in other countries worked havoc with the efficient functioning of the Reich's official foreign service."

24 Traditional Germandom organizations retained a certain degree of autonomy until 1937; see Frank-Rutger Hausmann, Ernst Wilhelm Bohle. Gauleiter im Dienst von Partei und Staat (Berlin, 2009), 54; on the competition between traditional and National Socialist Germandom work, see Tammo Luther, Volkstumspolitik des deutschen Reiches, 1933-38. Die Auslandsdeutschen im Spannungsfeld zwischen Traditionalisten und Nationalsozialisten (Stuttgart, 2004).

25 Hans-Adolf Jacobsen and Arthur L. Smith, The Nazi Party and the Foreign Office (New York, 2007), 34 .

26 Hausmann, Ernst Wilhlem Bohle, 57. 
Hitler excelled at peaceable posturing - but to emphasize that the Foreign Ministry's loss of influence left Germany's Amerikapolitik in the hands of men with limited knowledge of the United States once again. ${ }^{27}$ Hitler himself had never been to an English-speaking country, and most of his ambivalent and inconsistent assumptions about the United States derived from popular Amerikaliteratur, which was notoriously distorted. ${ }^{28}$ In general, he tended to prefer unreliable, but ideologically compatible, accounts of the United States over cautious diplomatic reports. ${ }^{29}$ As a result, the Nazi government generally (i) blamed American opposition to National Socialism only on Jewish influences, and (ii) misinterpreted German Americans as a readily accessible asset. ${ }^{30}$ Whereas German diplomats generally held on to the basic lessons of the previous decades, Nazi offices tended at first to fall back-with different ideological emphases, to be sure-on the notions of 1914.

\section{Boggling Its Propaganda Again: Nazi Germany and the Case of Volkstumspolitik}

This was nowhere clearer than in Nazi Germany's approaches to German Americans, a subject that has received bountiful scholarly attention. ${ }^{31}$ Already by the summer of 1933, both the Ministry of Propaganda and the Auslandsorganisation had departed notably from the caution that had characterized Weimar policies toward German Americans. Instead, they sought to activate this ethnic group for German interests and use them to spread National Socialist ideas abroad. Their main partners in this agitation were not traditional German-American Vereine but a number of Nazi groups that had developed in the United States since 1924 with memberships comprised largely of postwar German immigrants. Many in this cadre of about 600,000 immigrants

27 Jacobsen, Nationalsozialistische Außenpolitik, 329, labeled Hitler's talent "grandiose Selbstverharmlosung" (grandiose playing down of his true intentions).

28 While Hitler admired America’s rigid racial hierarchies, business efficiency, and territorial expansion (which fueled his own dreams of autarky and Lebensraum), he despised its alleged material excesses and undue Jewish influences. Gerhard L. Weinberg, "Hitler's Image of the United States," American Historical Review 69, no. 4 (1964): 1006-1021.

29 Sirois, Zwischen Illusion und Krieg, 144.

30 Gassert, Amerika im Dritten Reich, 199-208.

31 Arthur L. Smith, The Deutschtum of Nazi Germany and the United States (The Hague, 1965); Cornelia Wilhelm, Bewegung oder Verein. Nationalsozialistische Volkstumspolitik in den USA (Stuttgart, 1998); Jacobsen, Nationalsozialistische Außenpolitik, 528-549; G.H.W. Graessner, "Deutschland und die Nationalsozialisten in den Vereinigten Staaten von Amerika 1933 bis 1939. Ein Beitrag zur Deutschtumspolitik des Dritten Reiches" (PhD Diss. Universität Bonn, 1973); Klaus Kipphan, Deutsche Propaganda in den Vereinigten Staaten 1933-1941 (Heidelberg, 1971); Joachim Remak, “'Friends of the New Germany': The Bund and German-American Relations," Journal of Modern History 29, no. 1 (1957): 38-41; a concise overview of the American situation is offered in Jacobsen and Smith, The Nazi Party and the Foreign Office, 119-128. 
were unable to identify with U.S. society or traditional ethnic associations. ${ }^{32}$ From about 1931 the Auslandsorganisation maintained closer contact with Nazi activists in the United States and encouraged them to found the Friends of the New Germany as the National Socialist organization in North America in July $1933 .{ }^{33}$ This organization, which originally included party members and sympathizers, as well as German and American citizens, soon coordinated its operations along German lines: it divided North America into four Gaue (Nazi administrative regions), founded an equivalent to the storm troopers and Nazi youth organizations, and adopted somewhat similar uniforms. Set up in this way, the Friends of the New Germany aimed to unite all "Germans" in North America around National Socialist ideals, to fight the "distortions" of the Jewish press, and to enlighten Americans about the "real" Third Reich. ${ }^{34}$ Fairly close ties to the Auslandsorganisation, the Ministry of Propaganda, and the embassy's propaganda attaché facilitated its agitation.

While this attempt to organize German Americans clearly broke with the official practices of the 1920s, German diplomats remained remarkably consistent in their assessment. As their predecessors had during the 1920s, the German ambassadors to Washington Hans Luther (1933-1937) and Hans-Heinrich Dieckhoff (1937-1938) deemed aggressive and visible agitation among German Americans to be only counterproductive. Not only was it extremely unlikely to meet its objective, but it was also bound to provoke resolute American opposition because it would give the impression of a foreign government organizing a political movement on American soil. ${ }^{35}$ Unlike in the 1920s, however, when widespread disinterest in German Americans had facilitated such restraint, the newfound enthusiasm for (and among) German Americans and the "polycratic" structures of Germandom work rendered caution impossible. Even as American protests repeatedly led party offices to deny, loosen, or shift their contacts with American Nazis, they never entirely broke off relations with them. ${ }^{36}$ Moreover, American Nazis themselves regularly undermined Germany's efforts to distance itself from these groups because they liked to boast of their access and ties to Nazi leaders. ${ }^{37}$ Despite their small numbers (they

32 Wilhelm, Bewegung oder Verein, 23.

33 Ibid., 47.

34 Ibid., 63.

35 Offner, American Appeasement, 86.

36 American criticism led the Auslandsorganisation to forbid party members to proselytize among Americans or to belong to "American organizations" like the Friends of the New Germany in February 1934; Director of Department III to the Embassy in the United States, Feb. 16, 1934, DGFP, Series C, Vol. 2, Document No. 259; relations were often kept up informally; see Jacobsen, Nationalsozialistische Außenpolitik, 543.

37 Jacobsen and Smith, The Nazi Party and the Foreign Office, 125. 
probably never had more than 20,000 members), Nazi groups in the United States eventually became a serious liability for transatlantic relations. ${ }^{88}$

Indeed, as German diplomats had predicted, Nazi agitation almost immediately alienated Americans and gave them a welcome opportunity to indict the "new Germany." By late 1933, American district attorneys were investigating the Friends' leaders, customs authorities were searching German ships for propaganda literature, and U.S. politicians were calling for a congressional "Investigation of Nazi Propaganda Activities." Launched in early 1934, this long, drawn-out investigation ultimately had little legal consequence, having found little evidence of a larger subversive German plot, but it generated plentiful adverse publicity. ${ }^{39}$ Like its 1919 forerunner, the congressional investigation left many Americans with the impression that their country was crawling with German agents. ${ }^{40}$ As the historian Charles A. Beard concluded in December 1933: "The Germans horribly boggled their propaganda during the World War and they are in a fair way to do it again." ${ }^{41}$ It was in American reactions after 1933 , then, that the wisdom of Weimar's policy of restraint was fully borne out.

\section{"There is nothing disconcerting at all [...] going on in Germany" - Cultural Diplomacy and the Projection of Normality}

Still, in retelling this familiar story of Nazi blunders, we must not lose sight of the fact that some elements of the German campaign were successful, having built skillfully on Weimar-era approaches and achievements. Indeed, one defining characteristic of Nazi foreign policy was its careful attention to the public image of the Nazi regime, and despite all of its preference for an "active" and "aggressive" propaganda, it also engaged in decidedly less controversial means of promoting the nation. ${ }^{42}$ In early July 1933 , for example, the Ministry of Prop-

38 Scholars have noted that American reactions to pro-Nazi groups in the United States were entirely "unrelated to the small size of these formations. The repercussions of a movement looking to foreign political models on a country of immigrants would be hard to exaggerate"; see Gerhard L. Weinberg, "From Confrontation to Cooperation: Germany and the United States, 1933," in America and the Germans, ed. Trommler and McVeigh, 2:45-58, 46.

39 Director of Division III to the Embassy in the United States, Feb. 16, 1934, DGFP, Series C, Vol. 2, Document No. 259; Investigation of Nazi Propaganda Activities and Investigation of Certain Other Propaganda Activities: Public Hearings before the Special Committee on Un-American Activities, House of Representatives, Seventy-Third Congress, Second Session (Washington, DC, 1934-35).

40 Memorandum by an Official of Department III, DGFP, Series C, Vol. 2, Document No.139, DGFP, Series C, Vol. 2, Document No. 337.

41 Charles A. Beard, "Spooks - Made in Germany," New Republic 77 (Dec. 16, 1933), 97, cited in Kipphan, Deutsche Propaganda, 200.

42 Friedrich Kießling, "Zur Einführung: Nationalsozialistische Außendarstellung und der fremde Blick. Die internationale Dimension der Reichsparteitage," in Bilder für die Welt. Die 
aganda instructed the coordinated German press to abstain from "attacks on America, the government of the United States and President Roosevelt at all costs." ${ }^{3}$ The government also made notable efforts to maintain Weimar-era cultural programs, leading to numerous deliberate continuities. For Nazi Germany, educational exchanges and tourism promotion became convenient ways to normalize and trivialize the nature of the Third Reich abroad.

As the U.S. reacted adversely to Germany's renewed forceful activities in 1933/34, in particular, Nazi Germany, in close analogy to the developments after World War I, once more focused attention on subtler means of influence. Ambassador Luther commented in great detail on the shape and pace of "German cultural policy in the United States." 44 Repeating entrenched ideas about the United States as a culture in the making, he felt a non-political, broadly cultural campaign was best suited to winning American sympathy and preventing Great War configurations from recurring: "Apart from the growing respect for Germany's recovering health and strength, cultural ways and means are practically all that remains open to us. Therefore, increased cultural work in the United States is imperative in view of the peculiar political situation prevailing at the moment." 45 Even the propaganda attaché at the Washington embassy (appointed against the will of the Foreign Ministry) concluded in August 1934 that a non-political and non-ethnic approach was probably Germany's best option in the United States. Moving away from a focus on German Americans, he explained, "we can only hope to overcome propaganda carried on against us by Jewry infiltrated with the international Spirit if we succeed in establishing clear relations of mutual esteem and respect with the mass of patriotic Americans." 46

In this endeavor, Nazi Germany controlled cultural efforts to a far greater degree than a pluralistic democracy like Weimar ever could have. The Nazification and coordination (Gleichschaltung) of German cultural life had set in almost immediately upon the Nazis' rise to power. Many Jewish and left-leaning professors were dismissed from universities, and German students, teachers, professors, artists, and writers were organized into professional, National Socialist organizations. Newly established Kulturkammern began to coordinate

Reichsparteitage der NSDAP im Spiegel der ausländischen Presse, ed. Friedrich Kießling and Gregor Schöllgen, 1-23 (Cologne, 2006), 7.

43 Hans-Jürgen Schröder, Deutschland und die Vereinigten Staaten, 1933-1939. Wirtschaft und Politik in der Entwicklung des Deutsch-Amerikanischen Gegensatzes (Wiesbaden, 1970), 95.

44 Ambassador in the United States to the Foreign Ministry, June 28, 1935, DGFP Series C/ Vol. 4, Document No. 184.

45 The ambassador noted that "A young nation of more or less recent immigrants, the United States possess a culture of their own only in embryonic form [...] in terms of culture the United States are still substantially a colony of Europe"; ibid.

46 An Official of the Embassy (Sallet) in the United States to the Ministry of Propaganda, Aug. 3, 1934, DGFP (Series C) Vol. 3, Document No. 569. 
the German press, art, music, and literature following the directives of the Ministry of Propaganda and other offices. ${ }^{47}$ These chambers of culture, in concert with festivities, mass rallies, and social programs, were intended to help structure German society around the key propagandist concept of the time, the Volksgemeinschaft. ${ }^{48}$ All of this cultural organization also impacted the way Germany presented itself to the wider world. The more than two dozen international offices at German universities were swiftly Nazified;49 the German Tourism Council was subordinated to the Ministry of Propaganda; and the German Academic Exchange Service's (DAAD) advisory board was packed with party members..$^{\circ}$

That such a process of Gleichschaltung proceeded rapidly and smoothly was due to the accommodation and "self-coordination" of a large number of Germany's cultural, business, and diplomatic elites. If conservatives found the transition easier on account of their widespread illiberalism and anti-republican feeling, many liberals, too, had been losing confidence in democratic governance because of their experiences since 1930. ${ }^{51}$ Historians have underlined the "partial identity of interests" between Nazis and traditional elites, particularly with regard to more assertive foreign policy. Especially during the first few months of Nazi rule, even a number of those who opposed the Nazis felt no need to threaten their life's work to take a principled stance against a government that might prove as short-lived as its many Weimar predecessors. Contrary to his later depictions, the publicist, educator, and champion of democratic Germany in the 1920s, Ernst Jäckh, for example, initially accommodated the new rulers to such an extent that the Rockefeller Foundation marveled at his "extraordinary capacity of adaptation." ${ }^{2}$ For Germany's professional pub-

47 Trommler, Kulturmacht ohne Kompass, 439-441; on the broader European conception of Nazi cultural order, see Benjamin Martin, The Nazi-Facist New Order for European Culture (Cambridge, MA, 2016).

48 On the Volksgemeinschaft and propaganda, see Bernd Sösemann, Propaganda. Medien und Öffentlichkeit in der NS-Diktatur (Stuttgart, 2011), li-lvii.

49 Ambassador in Germany (Dodd) to the Acting Secretary of State, Dec. 4, 1933, FRUS (1933) Vol. II, 268-269, provides one American diplomatic report on this: "through this control over all culture in Germany, the Minister for Propaganda will be able to regiment and mold public opinion to an extent inconceivable in the United States and many other countries. That the effect will be stimulating to the artist, the author or the composer seems extremely doubtful."

50 Adolf Morsbach of the DAAD, for example, strategically recruited (moderate) National Socialist supporters to serve on its board to shield it from the influence of the (much more radical) National Socialist Student Body. Laitenberger, Akademischer Austausch und auswärtige Kulturpolitik, 54-55.

51 Christian Jansen, "Auf dem Mittelweg von rechts. Akademische Ideologie und Politik zwischen 1914 und 1933," in Auch eine Geschichte der Universität Heidelberg, ed. Karin Buselmeier, Dietrich Harth, and Christian Jansen, 163-193 (Mannheim, 1985), 187; Jansen speaks of a "breakdown of liberalism" among German professors in the crisis years of the early 1930 .

52 Steven D. Korenblat, "A School for the Republic? Cosmopolitans and Their Enemies at the Deutsche Hochschule für Politik, 1920-1933" Central European History 39 (2006): 394-430, 
lic diplomats - men like Adolf Morsbach of the DAAD, Karl Oscar Bertling of the Amerika-Institut, and Hans Draeger of the Vereinigung Carl Schurz pre-emptive self-coordination also promised to give them an opportunity to realize longer-standing ambitions. ${ }^{53}$ After a meeting with Nazi representatives in mid-May 1933, the notoriously disgruntled Bertling felt that "the new gentlemen have a way of doing business that allows me, the outsider, to hope once more for an appreciation of the Amerika-Institut's work." ${ }^{4}$

While such hopes were not always fulfilled, the new government did have the momentum, interest, funds, and, not least, repressive instruments to centralize cultural activities, as many of these cultural diplomats had long desired. In December 1933, all organizations cultivating cultural relations with the United States were brought together into an informal "America Committee" (Deutscher Amerikaausschuß), which was to formulate and coordinate a joint cultural Amerikapolitik. From March 1934 onward, the representatives of the Amerika-Institut, the Terramare Office, the Former America Work Students (an alumni organization of the America Work Student Service, AWD), the American Committee of the Deutsche Akademie, the DAAD, the German Tourism Council, and others were organized into four sub-committees dealing respectively with (1) scientific and academic questions, (2) travel and tourism, (3) publications, and (4) economic matters.55 The leadership and official representation of Nazi Germany's cultural relations with the United States fell to the Vereinigung Carl Schurz. That its director Hans Draeger had never visited the United States and apparently spoke little English mattered less than his long involvement in revisionist propaganda and his outspoken allegiance to the new regime..$^{56}$ The opening of the Vereinigung Carl Schurz's Carl Schurz Haus, an industry-financed mansion in Berlin's posh Tiergarten neighborhood, ended the first phase of restructuring in May 1934.

412; on a similarly "adaptive" response at Heidelberg's famously "liberal" Institut für Sozial- und Staatswissenschaft (InSoSta), see Carsten Klingemann, "Das 'Institut für Sozial- und Staatswissenschaften' an der Universität Heidelberg zum Ende der Weimarer Republik und während des Nationalsozialismus," Jahrbuch für Soziologiegeschichte (1990): 79-120.

53 Through 1933-1934, almost all of these individuals advocated a wide-ranging restructuring of German cultural diplomacy under their own leadership. The DAAD's restructuring plan would have transferred the academic programs of the Deutsche Akademie, the Amerika-Institut, the Vereinigung Carl Schurz, and even the Prussian Ministry of Culture to the DAAD, making it a comprehensive center for Germany's academic-scientific relations with the world; see Adolf Morsbach, "Aufzeichnung über die Neorganisation der dt. Kulturpolitik nach dem Auslande," Mar. 1933, BArch Koblenz, NL Morsbach/14.

54 Amerika-Institut to Schmidt-Ott, May 23, 1933, NL Schmidt-Ott/540, GSPK.

55 Freitag, Die Entwicklung der Amerikastudien in Berlin, 159.

56 His lack of English fluency is noted in Brantz, "German-American Friendship," 237. During the first meeting of the America Committee, Draeger emphatically proclaimed that all private organizations "serve the will of the Führer." Erste Sitzung des Deutschen Amerika-Ausschusses, Dec. 4, 1933, PA R 803278; on Draeger's close relationship with the Foreign Ministry, see his personal file, PA Personalakte 2955 Hans Draeger, esp. Aufzeichnung, Geh I 138g, June 17, 1936. 
This restructuring doubtlessly affected the ideological tenets of Germany's cultural Amerikapolitik. As Waldemar Hartmann, the America Committee's party liaison, explained in late 1933, the only remedy for Germany's distorted image abroad was to continue earlier "personal intercourse and reciprocal cultural exchange," albeit on very different terms. Contacts with American pacifist circles such as YMCA Secretary Sherwood Eddy (long courted by the Weimar Republic) were to be abandoned in favor of facilitating an encounter between Germans and Americans who were "truly representative, both in blood and spirit." 57 The field of international education, especially, was quickly transformed along these lines because the DAAD's principle of "cultural encounter" between national(ist) elites proved readily adaptable to National Socialist ideology..$^{58}$ Already by late 1933, potential exchange students were asked for evidence of Aryan descent and commitment to the National Socialist state..$^{59}$ Publicly, too, Adolf Morsbach, the director of the DAAD since 1927, sought vigorously to distance the organization from its very recent past. Only ten months after Weimar's demise, he saw the need to blame the "current misunderstandings" between Germany and the United States on the republic. According to Morsbach, Weimar (which he characterized as "deeply un-German") had systematically misled Americans into believing in a mutuality of republican commitment and "forcefully veiled" the German people's actual attitude toward "democracy, which has been forced upon it." ${ }^{\circ 0}$ Once the German people had been able to return to their true nature in January 1933, he said, Americans had simply not known what to make of it. In short, if Americans were opposed to Nazi Germany, this was due not least to Weimar's strategic misrepresentations. Such statements reveal not only the new direction of Nazi cultural diplomacy; they also highlight the lack of deeper democratic commitment among some of the men who had been responsible for representing Weimar Germany abroad.

Despite such real and rhetorical departures, there were, nevertheless, plenty of undeniable personal and institutional continuities between Weimar and Nazi cultural diplomacy. To be sure, Weimar's hard-core peaceful revisionists were forced into early retirement or exile, but professional public diplomats stayed on and often even remained wedded to the concepts they had developed in previous decades: ${ }^{61}$ the German Tourist Information Office in New

57 Waldemar Hartmann, "Deutschland und die USA. Wege zu gegenseitigem Verstehen," $\mathrm{Na}$ tionalsozialistische Monatshefte 44 (Nov. 1933): 2.

58 Adolf Morsbach, "Die kulturellen Beziehungen zwischen den Vereinigten Staaten und Deutschland," Nationalsozialistische Monatshefte 44 (Nov. 1933): 30.

59 Laitenberger, Akademischer Austausch und auswärtige Kulturpolitik, 196.

60 Morsbach, "Die kulturellen Beziehungen," 32.

61 E. g., Amerika-Institut [Grossmann], Dec. 1934, "Gedanken zu dem Problem gemeinsamer Amerika-Arbeit, Amerika-Institut Files [1910-1946], Freie Universität Berlin. 
York City continued under the directorship of Ernst Schmitz (1925-1941), the DAAD under Adolf Morsbach (1927-1934), the Vereinigung Carl Schurz under Hans Draeger (1930-1942), the Amerika-Institut under Karl Oscar Bertling (1911-1945), and the Wirtschaftspolitische Vereinigung under Margarete Gärtner (1922-1945). This was doubtlessly a strategy. Indeed, as in foreign relations more generally, Nazi leaders appreciated the mollifying qualities of continuities in personnel. ${ }^{62}$ For example, long after the actual leadership of the Amerika-Institut had passed into the hands of men closer to National Socialism, Bertling outwardly remained its director. His transatlantic networks, knowledge, and, above all, bourgeois respectability were simply too valuable to dispense with. ${ }^{63}$ While Nazi Germany's attention to German Americans signaled a disconcerting departure from Weimar traditions, the following pages will show that many of its cultural representations - especially with regard to tourism and international education - displayed a reassuring (and deliberate) continuity. They were, as Kristin Semmens has noted, a "crucial part of the attempt to convince other nations of the supposed normality of life in the Third Reich." ${ }^{64}$

It is important to remember that this strategy of sugarcoating German developments had already begun before Hitler ever came to power. For example, as street violence and antisemitic assaults had awakened American concerns during 1932, the German Tourist Information Office (GTIO) in New York had taken discrete publicity steps to allay American fears. ${ }^{65}$ After 1933, it vastly expanded these efforts. Following its conversations with American public relations specialists, the GTIO pursued a proactive course: its summer 1933 adver-

62 See Laitenberger, Akademischer Austausch und auswärtige Kulturpolitik, 38. In 1933 Hitler also expressed satisfaction at having Neurath stay on, judging that it was "his benevolent appearance that is of most use to me. You can't imagine a man like that going in for a revolutionary policy"; quoted in Offner, American Appeasement, 30. Offner takes this Hermann Rauschning's Conversations with Hitler, which have to be approached with caution.

63 The same holds true for Margarete Gärtner, the director of the Wirtschaftspolitische Gesellschaft, who had a wide and valuable network of contacts. Through the 1930s, both Bertling and Gärtner were sent on repeated goodwill tours to the United States; as late as 1939/40, they still tried to explain German positions; see K. O. Bertling, Amerika-Institut, to Nicholas Murray Butler, Oct. 30, 1939, CEIP Box 222, Folder 9 Amerika-Institut, Columbia University, Rare Book \& Manuscript Library Collections.

64 Kristin Semmens, Seeing Hitler's Germany: Tourism in the Third Reich (Houndmills, 2005), 131.

65 The German Tourism Promotion Office had asked the American journalist Miles Bouton, one of its contributors, to send a cable to the United States that reported "All Quiet in Germany" and quoted a prominent American claiming that everything was calm and pleasant in Bad Nauheim, "tranquil and peaceful as it was two years ago ... no tenseness of public feeling ... no slightest indication that there is danger of any such eventuality in the future"; see RDV to AA, Aug. 9, 1932, R 246920; on the mid-1932 situation in general, see German Consulate General, New York, to AA, Aug. 26, 1932, "Beunruhigung amerikanischer Reisender durch innenpolitische Vorgänge in Deutschland," R 246920. 
tising campaign sold the "national revolution" as the not-to-be-missed event of the season:

to all of Germany's famous tourist attractions there is now added the fascinating spectacle of the rebirth of a nation. Germany bids you welcome to the land, which now even more wins the distinction of being Europe's most interesting country ... perfect order is continuously maintained, assuring security and comfort. Germany, this summer, is again the center of Europe's music and art ... The thrill of traveling in this new-born land gives you undying memories endlessly renewed to imperishable beauty.

Finally, the advertisement concluded that there was "nothing disconcerting at all ... going on in Germany." 66

This, indeed, would become the main argument of Germany's public diplomacy efforts. Throughout the 1930s, the GTIO in New York would play a paramount role in "normalizing" the Third Reich. With its budget rising from $\$ 153,000$ in 1933 to at the least $\$ 208$, ooo in 1936 , it used its wide marketing repertoire of films, brochures, posters, radio shows, and news releases to advertise Germany's eternal beauty and its new government's accomplishments alike. ${ }^{67}$ It skillfully marketed specific events, such as the 1934 Oberammergau Passion Play and the 1936 Olympics, just as it used its inconspicuous advertising structures to present a (visually) attractive Germany. Whereas American newspaper audiences read about a repressive and xenophobic regime, the GTIO portrayed a contented, healthy, and smiling nation, ready to welcome Americans. Above all, it beckoned Americans to "come and see" for themselves, a strategy that proved especially attuned to postwar Americans' notorious suspicion of atrocity stories and their correspondingly high regard for firsthand knowledge and eyewitness accounts. The GTIO's strategy was soon echoed in the highest levels of government. In July 1933, Propaganda Minister Goebbels, with the United States and Great Britain in mind, invited "the people of all nations to come and convince themselves of the untruth" being spread about Germans' treatment of foreigners. ${ }^{68}$

The DAAD, too, sought to maintain its American connections and counter the precipitous drop in student enrollment and fellowship numbers in

66 Clipping: NY Herald Tribune, GTIO Advertisement, Apr. 28, 1933, "Witness the Rebirth of a Nation - New Germany," PA R 246920.

67 Investigation of Un-American Propaganda Activities in the United States: Special Committee on Un-American Activities, House of Representatives Seventy-Sixth Congress, Third Session on H.R. 282 Appendix-Par II (Washington, 1940), 1060-1061.

68 Clipping: Roanoke News, July 4, 1933, "Germany to Try to Lure Tourists," NARA Entry UD 328: Seized Promotional Materials of the German Railroad Information Office, 1932-1941 Box 36 Folder: Tourism: Promotion. 
$1933 .{ }^{69}$ In the spring of 1933 , its director Adolf Morsbach wrote personally to his American acquaintances to calm prevalent safety concerns, while the German embassy issued a public statement to the same effect. ${ }^{70}$ With its budget doubled from $1933 / 34$ to $1934 / 35$, the DAAD entered upon a broader campaign, developing branch offices in Madrid, Barcelona, and Budapest and restructuring those in London and Paris into "cultural embassies." ${ }^{11}$ In the United States, it continued to partner with the Institute of International Education (IIE), provided new fellowships for the Junior Year in Munich, and advertised German universities and their summer courses. Its efforts to bring American academics over to Germany, if only for a shorter period of time, was greatly aided by new initiatives like the Vereinigung Carl Schurz's Carl Schurz tour, which offered a four-week trip to Germany to one hundred American professors and students annually beginning in 1934 . German universities, too, sought to maintain their international contacts and lent their prestige to the "new Germany." Heidelberg's 550-year university jubilee in 1936 was even declared a "reichswichtig" event (important for the Reich), with the Ministry of Propaganda managing its entire organization..$^{72}$ As Heidelberg Rector Wilhelm Groh wrote, "since the National Socialist Revolution, no German university has had the opportunity to conduct such effective propaganda for the prestige of German scholarship in the world, nor can any be as certain as Heidelberg that the intellectual world will truly send its prominent representatives."73 German universities, which had generally kept their distance from the republic, placed themselves readily, if not always enthusiastically, "at the service of the regime." ${ }^{4}$

Importantly, the German campaign in the United States allowed plenty of room for ideological leeway. Antisemitic polemics and symbols of Nazism were notably absent from German tourist advertising. ${ }^{75}$ Similarly, while German exchange students going abroad were screened for their National Socialist convictions after 1933, they were still instructed to be courteous and tactful and not to propagandize but to offer explanations when asked..$^{76}$ For all the DAAD's desire to send those who were "representative in blood and spirit" abroad, it re-

69 For example, offering five fellowships to Junior Year in Munich students in July 1933 kept the incipient program from collapse. DAAD to AA, June 19, 1933, "Erlass VI W 4294/33 vom 27. 5.33," PA R 64237.

70 German Consulate General, New York, to AA, Apr. 22, 1933, "Rückwirkungen der anti-semitischen Bewegung in Deutschland auf kulturellem Gebiet," PA R 64237.

71 Laitenberger, Akademischer Austausch und auswärtige Kulturpolitik, 72.

72 Meinhold Lurz, "Die 550 Jahrfeier der Universität Heidelberg als nationalsozialistische Selbstdarstellung von Reich und Universität," Ruperto Carola 57 (1976): 35-41, 35.

73 Gassert, Amerika im Dritten Reich, 195.

74 Stephen P. Remy, The Heidelberg Myth: The Nazification and Denazification of a German University (Cambridge, MA, 2002), 3 .

75 Semmens, Seeing Hitler's Germany, 145.

76 On the changes after 1933, see Laitenberger, Akademischer Austausch und Auswärtige Kulturpolitik, 193-203. 
alized that ideological zealots were more likely to discredit the "new Germany" than to advertise it. ${ }^{77}$ Indeed, even though Americans often accused German exchange students of being Nazi propagandists or spies, a confidential 1938 survey undertaken by the IIE found that most of them behaved just like all other exchange students. ${ }^{78}$ In Germany, too, the German campaign remained relatively subtle: American tourists were always able to avail themselves of the many "hospitality" measures offered by local tourist bureaus (now controlled by the Ministry of Propaganda), but they never had to. ${ }^{79}$ Even Americans who visited Germany on a sponsored tour were often allowed to set out on their own for a while. ${ }^{80}$ Nazi organizers realized that it was far more valuable for them to forego making any discrete ideological points and allow Americans to have a generally pleasant time, gaining firsthand impressions of German cleanliness, orderliness, and relative freedom. After all, Nazi Germany was not trying to convert Americans but to convince them of its peaceable intentions. As such, American travel and study in Germany during this period must be seen as prime examples of Nazi Germany's "managed normality." ${ }^{11}$

If student and tourist numbers are any indication, this policy was remarkably successful. In hindsight, the degree to which Americans continued to study and vacation in the Third Reich is nothing short of astonishing. After an initial drop in 1933/34, student and tourist numbers rose steadily through 1936/37. Between 1934 and 1937, American overnight visits doubled and American attendance at German university summer courses rose steeply. ${ }^{82}$ At Heidelberg alone the number of American attendees rose from 31 in 1933 to 161 in 1936. This development was certainly due to more comprehensive advertising strat-

77 One such case was a German student in Cincinnati who was called to the dean's office and asked to abstain from any public talks; DAAD to Members of Präsidium, Jan. 24, 1934, PA R 64237. Discontent about the strongly revisionist orientation of German exchange students had been brewing since the early 1930s; see the letters by Albert Gerberich to Assistant Secretary of State Wilbur Carr through 1932 and 1933 in NARA RG 59, General Records of the Department of State; Visa Division. General Visa Correspondence 1914-1940, Box 13 Folder: Colleges 62, 811.111 .

78 In a 1938 IIE survey of 55 institutions, 47 stated that German exchange students behaved like any other exchange students, while 8 others qualified their replies. See IIE, Annual Report, 1938, 28; Frank-Rutger Hausmann, Anglistik und Amerikanistik im Dritten Reich (Frankfurt, 2003), 192.

79 Der Reichsminister für Volksaufklärung und Propaganda to Reichspropagandaämter, July 16, 1938, "Ausländerbetreuung"; Attachment: Deutscher-Ausländerdienst e. V. BayHStA, MHIG 9244 .

80 K. O. Bertling, Amerika-Institut, to Henry S. Haskell, Carnegie Endowment, Division of Intercourse and Education, May 17, 1934, Box 222, Folder 9, Amerika-Institut, CEIP, Columbia University, Rare Book \& Manuscript Library Collections.

81 Semmens, Seeing Hitler's Germany, 94.

82 Ibid., 149; on the University of Heidelberg, see Tutt, "Ausländerbetreuung an der Universität Heidelberg," esp. statistics on p. 22; and Werner Moritz, "Außenbeziehungen der Universität," in Die Universität Heidelberg im Nationalsozialismus, ed. Wolfgang Eckard, Volker Sellin, and Eike Wolgast, 147-172 (Heidelberg, 2006). 
egies, but there is no denying that all these initiatives profited tremendously from the transatlantic networks, expertise, and goodwill that Weimar had painstakingly (re-)built. In particular, they continued to rely on longer-standing partners in the United States, including the IIE, the Carl Schurz Memorial Foundation (CSMF), and many individual universities and ethnic organizations. But why did these Americans cooperate so willingly? Why did they seemingly lend themselves to a German dictatorship as readily as they had to the Weimar Republic?

\section{The Attitude of American Partners}

Despite clear American disdain for the illiberalism of the German government, the two countries maintained cultural interactions and programs to an impressive degree. Just as tens of thousands of Americans individually continued to vacation and study in the Third Reich, American universities, as well as traditional ethnic and educational organizations, accommodated the new Germany. ${ }^{83}$ Most of the presidents and professors of America's leading Northeastern universities not only failed to join student protests against the Third Reich but also welcomed and honored its unofficial and official representatives on campus, continued German student exchanges, attended German university jubilees, and continued to travel on German ships flying the swastika flag. ${ }^{84}$ By the same token, the CSMF continued to send its influential "Oberlaender fellows" to study and write about Nazi Germany.

This accommodation was not due to ignorance about the repressive nature of Nazi rule. The regime's brutality and the lack of academic and personal freedom were well known. ${ }^{85}$ To explain these lukewarm responses to Nazism, it is certainly correct to point to widespread American antisemitism, as Norwood has done. Indeed, in the organizations that debated their position toward Germany most intensively, like the CSMF, the fault lines usually ran between Jewish and Gentile members. ${ }^{86}$ But this alone is a reductive explanation of Americans' complex responses to Nazism. Americans like Nicholas Murray Butler, Frederick Heuser, Wilbur K. Thomas, and Stephen P. Duggan pondered

83 AA to Hauptausschuss für Fremdenverkehr, Aug. 4, 1932, PA R 246920.

84 See the substantial evidence in Stephen H. Norwood, The Third Reich in the Ivory Tower: Complicity and Conflict on American Campuses (New York, 2009), passim.

85 Norwood, Third Reich in the Ivory Tower, 79.

86 Speyer to Thun, Dec. 13, 1933, Mss 176, National Carl Schurz Association, Inc., Records, Series 1, Box 23/3, HSP; see also Dodd to Charles R. Crane, Sep. 16, 1933, Dodd Papers, Box 40, 1933, LoC: "the Jews had held a great many more of the key positions in Germany than their numbers or their talents entitled them to. This cannot be corrected, however in the way that Mr. Goebbels recommends." 
various possible responses to Nazism critically and repeatedly. ${ }^{87}$ Although they ultimately settled on a policy of accommodation, this derived from factors other than antisemitism alone: Apart from their often plentiful professional reasons to maintain transatlantic programs, it was simply not clear at first whether the Nazi government would stay in power. Considering the short lives of many Weimar governments, it seemed ill-advised to sacrifice successful and hard-won projects on the spur of the moment. Moreover, for all their disdain for Nazism, many Americans had come to sympathize with the German situation by the early 1930 s and were likely to attribute German developments, at least in part, to Allied mistakes at Versailles. ${ }^{88}$ The former Secretary of War and well-known internationalist Newton D. Baker, for example, expressed this view dramatically in a letter to the U.S. ambassador to Germany, William Dodd, in June 1933:

Germany has seemed to me to have a certain pathetic dignity as she has waded her way through tragedy since 1918 and while she has done much to forfeit the respect of the world by her book burning and other incantations, I am not very sure that I would not have burned all the books I could have laid my hands on, including the Bible, if I had been ground under the heel of adverse fate to the extent she has. ${ }^{89}$

Moreover, cutting all ties with Germany would have contradicted the very principles of cultural internationalism that these connections had been built on during the 1920s. If elite contacts were the best guarantee for peace, were they not more needed than ever?90 As Stephen Duggan, the IIE director, wrote Henry Pritchett, a Carnegie trustee, in late 1933, "I am wholly opposed to isolating Germany. On the contrary I believe the Germans are now in particular need of contact, and personal contact, of the right kind."91 The longer Nazi rule lasted, the more such thinking was complemented by the idea that one could perhaps exert a moderating influence on Germany or provide encouragement to remaining liberal circles by maintaining relations..$^{92}$ In the case

87 The correspondence of Chicago historian and America's newly appointed Ambassador in Berlin, William Dodd with Nicholas Murray Butler and Stephen P. Duggan, for example, suggests that these men repeatedly and critically considered the questions at stake.

88 Raymond Leslie Buell (Foreign Policy Association) to Dodd, July 27, 1933, Dodd Papers, Box 40, 1933, LoC.

89 Newton D. Baker to Dodd, June 30, 1933, Dodd Papers, Box 40, 1933, LoC.

90 See, "Extract from the Minutes of the Meeting of the Board of Directors of the Carl Schurz Memorial Foundation of May 6, 1933," Mss 176, National Carl Schurz Association, Inc., Records, Series 1 General Historical and Office Materials Box 23/3, HSP.

91 Duggan to Pritchett, Nov. 20, 1933, quoted in Halpern, "The Institute of International Education," 156.

92 See the considerations of the Rockefeller Foundation in Malcolm Richardson, "Philanthropy and the Internationality of Learning: The Rockefeller Foundation and National Socialist Germany," Minerva 28 (1990): 21-58, 39. 
of student exchanges, one also saw continued academic relations with Nazi Germany as a way to provide an experience of American freedom to German youth growing up under a dictatorship..$^{93}$

Finally, men like Butler, Duggan, and Thomas had no desire to repeat the rift of World War I. Historians have failed to adequately appreciate the extent to which these men's decisions were informed by what they now regarded as the mistakes of 1914. But men like Butler, who had spent the entire 1920 s painstakingly mending the divisions of 1914, were determined to avoid such disruptions in the future. Even as the permanence of the Nazi regime became clear, American academics and moderate German-American organizations like the CSMF tried to stay above political controversy lest cultural relations be once more tainted by politics. Their position, not least, helped them shape an "American debate on Nazism" that diligently distinguished Nazis from Germans and German culture from politics. ${ }^{94}$ And it was precisely in this context that personal continuities in Germany played a paramount role. The fact that their longterm German partners, educated bourgeois men like themselves, would serve Nazi Germany as they had the republic was often crucial to their decision to maintain relations, if only after bitter debate. ${ }^{95}$ As a consequence, the German Consulate General in New York City noted in July 1933 that Stephen Duggan and Wilbur Thomas had an "utterly objective stance toward the German politics of today, entirely unaffected by pro-Semitic tendencies ... Rather, they see it as their task to step up their mediating capacity in this time when relations are tarnished by polemics and to maintain the valuable institutions of cultural exchange throughout this crisis." 96

To be sure, their positions were not as sympathetic as the consulate made them out to be. In reality, organizations like the CSMF or the IIE pursued a dual strategy from the very beginning: while they withstood pressure to discontinue and denounce their connections to Germany, they likewise engaged in tremendous efforts to aid displaced German scholars. ${ }^{97}$ Rather than aim-

93 IIE, Annual Report 1938, 9; see also Duggan, Professor at Large, 177.

94 As Arnold Offner has noted, "The Third Reich's domestic and foreign policies often horrified Americans, but they retained basic respect for German (as distinct from Nazi) culture and productive capacities"; Arnold A. Offner, "The United States and National Socialist Germany," in The Fascist Challenge and the Policy of Appeasement, ed. Wolfgang Mommsen and Lothar Kettenacker, 413-427 (London, 1983), 414; ironically, this development was aided by German emigrants, like Thomas Mann and Albert Einstein, who perpetuated notions of an "other Germany." 95 On the debate within the CSMF, see Gregory Kupsky, "The True Spirit of the German People': German Americans and National Socialism, 1919-1955” (PhD diss., Ohio State University, 2010), 203-221.

96 German Consulate General, New York, to AA, June 15, 1933, "Kulturpolitische Rückwirkungen der Vorgänge in Deutschland," PA R 64237.

97 Beginning in mid-1933, both the CSMF and Stephen Duggan's Emergency Committee in Aid of Displaced Scholars would count among America's most significant refugee aid organizations. The CSMF, for example, provided shorter-term grants to almost 300 refugees from Germany and 
ing to support Nazi Germany, then, these organizations attempted quite deliberately to keep in touch with German culture as they steered clear of Nazi politics..$^{98}$ After the purges of June 30, 1934 - which led to the imprisonment of DAAD director Adolf Morsbach and the murder of Fritz Beck, the wellknown head of the Munich International House - such convictions developed a logic of their own. While these violent events were indeed a breaking point for many, the IIE, the CSMF, and many American universities upheld their German contacts. ${ }^{99}$ Personal conversations with trusted Germans proved to be one factor in this decision, but the belief that it would be possible - and even necessary - to ignore a country's current political state to keep "in touch with the more permanent cultural achievement of a nation and a people" was yet another. ${ }^{100}$ In defending its acceptance of the invitation to Heidelberg's 1936 jubilee, Harvard University, for example, asserted, "that the ancient ties by which the universities of the world are united [...] are independent of the political conditions existing in a country at any particular time." ${ }^{101}$ For U.S. cultural internationalists like Butler, such arguments were not just a convenient answer to a moral dilemma; they were the hard-won lessons of the Great War era. ${ }^{102}$ Only slowly did it dawn on them that culture and politics could not be so neatly separated in a totalitarian regime.

Austria just as it funded German lecturers, who, like K. O. Bertling in 1937, were clearly traveling on behalf of their government; "List of Grants made by the Carl Schurz Memorial Foundation to Institutions," Mss 176, National Carl Schurz Association, Inc., Records, Series 1 Box 23/3, HSP. 98 When the former ambassador Jacob Gould Schurman, for example, visited Germany in 1935, he was glad to see his German friends but insisted that no one associated with the new party be invited to his banquet. "Tea for former Ambassador Jacob Gould Schurman, Thursday, October 24, 1935 (List of Persons invited)," Dodd Papers, Box 6o/Reception and Dinner Lists, $1934+35$, LoC.

99 "Fritz Beck, Familiar Figure to American Students at Munich. 'Clean Up' Victim," New York Tribune, July 4, 1934; "Killing of Beck, Academic Foreign Bureau Head, Attributed to 'Terrible Accident", New York Times, July 4, 1934. Morsbach was supposed to host the group of forty American professors coming over on the "Carl Schurz Tour," so his ouster considerably deepened U.S. apprehensions. In response, Oswald Garrison Villard, long a warm supporter of Germany, wrote: "I am absolutely opposed to any intellectual relationship with the Germany of Hitler or any National Socialist Government." Oswald Garrison Villard to CSMF, July 11, 1934, Mss 176, National Carl Schurz Association, Inc., Records, Series 1 Box 2/11, HSP.

100 After conversing with DAAD representative Gerhard Neumann in London, Duggan was sufficiently convinced of German stability to continue the student exchange; see Gerhard Neumann, Anglo-German Academic Bureau, London to Ewald von Massow, DAAD, July 20, 1934, "Deutsch-Amerikanischer Austausch," PA R 64236; CSMF, Circular, Aug. 20, 1934, Mss 176, National Carl Schurz Association, Inc., Records, Series 4 Box 218, HSP.

101 Quoted in Norwood, Third Reich in the Ivory Tower, 94; the original statement was issued by the presidents of Harvard, Yale, and Columbia: "Statement about University of Heidelberg Celebration," University Central Files, Box 549/Heidelberg, Columbia University Archives.

102 Nicholas Murray Butler to Beck, May 29, 1936, University Central Files, Box 549/Heidelberg, Columbia University Archives. 
American accommodation doubtlessly helped normalize and legitimize Nazi Germany. If not all American tourists or students returned from their trip more sympathetic to Germany, their visit itself provided the currency of international legitimacy to the Third Reich. American attendance at Heidelberg's $550^{\text {th }}$ jubilee in June 1936 and at the Berlin Olympics one month later lent these events a coveted international flair, which first and foremost bolstered the regime's prestige at home. ${ }^{103}$ At the same time, American participation, as Norwood has noted, helped "Nazi Germany present itself to the American public as a civilized nation, unfairly maligned in the press." ${ }^{\prime 104}$ Moreover, these Nazi self-presentations were often echoed by American tourists and students, who commented favorably on the clean, orderly, not at all unpleasant impression they had gained of German life, particularly when compared to the prevalent American news coverage of Germany. ${ }^{105}$ Their reports resonated with a wider American public, who in the 1930s, as Michaela Hoenicke-Moore has shown, often "more readily trusted [tourist impressions] than the professional pessimists in the press and diplomatic community." ${ }^{106}$ In 1935, one American Oberlaender fellow found Munich "filled with young Americans. All the girls in dirndl dresses and the boys in leather shorts. All adore Germany and when they get a little older and have something to say, there won't be much of a Deutschfeind attitude left in America." "107 These American descriptions certainly gave the impression that there was "nothing disconcerting going on" in Germany.

Such impressions arguably affected transatlantic relations at large. Even as American press coverage was usually critical, the State Department remained reluctant to get involved in German domestic politics and never openly condemned the suspension of civil liberties. Apart from general diplomatic courtesy, this "American appeasement" (Offner) expressed widespread uncertainty about the National Socialists' nature and intentions. ${ }^{108}$ Government officials long believed that the Nazi government was basically animated by the same revisionist objectives - and would adopt the same peaceful means - as its Weimar predecessors. In any case, they regarded the German people as basically

103 On efforts Germany adopted with regard to American participation in the Olympics and the Heidelberg ceremony, see Gassert, Amerika im Dritten Reich, 189-198.

104 Norwood, Third Reich in the Ivory Tower, 34.

105 "Regular tourists, there for a week or two at most, usually returned only with positive impressions of a peaceful, pleasant land"; see Semmens, Seeing Hitler's Germany, 151.

106 Hoenicke-Moore, Know Your Enemy, 71-72.

107 Appleton Read to Dr. Thomas, late 1935, Mss 176, National Carl Schurz Association, Inc., Records, Series 1 Box 23/3, HSP.

108 Offner, American Appeasement. 
peaceful. ${ }^{109}$ This assessment was clearly strengthened by tourist and educational contacts, which did not give the impression of a country radically different from the 1920s. It was precisely because Nazi Germany's broader cultural campaign built on Weimar's longer-standing initiatives that it was relatively successful. Ironically, Weimar's stringent efforts to rewin American hearts and minds in the 1920 s paid their dividends long past 1933.

\section{Alienation}

But even if Nazi Germany profited greatly from Weimar's efforts and there were numerous continuities in methods, infrastructure, and personnel, there was no denying the deeper transformation of German Amerikapolitik and transatlantic relations. In spite of the carefully maintained veneer of normality, this change became ever more visible. It is difficult to determine a particular moment or reason for alienation between the two nations. What can be said with relative certainty - thanks to the introduction of the Gallup poll in 1935 - is that Americans were largely not in sympathy with Nazi Germany after the mid1930s. ${ }^{110}$ As could be expected, German antisemitism figured prominently in this. In fact, the only time German representatives recorded an improvement in American sentiment in the 1930s - in June of 1935, following the Anglo-German naval accord - this gain was almost immediately undone by antisemitic outbursts in Germany, which even sparked rumors of an imminent break in diplomatic relations. ${ }^{11}$ The pogroms of November 1938 then marked a caesura: the Roosevelt administration recalled Ambassador Hugh Wilson to Washington for "talks," and Ambassador Dieckhoff went back to Berlin soon thereafter. Neither of them would return to his post.

But a look at contemporary transatlantic cultural relations also suggests that 1937 was already a turning point. Notably, the American universities that had still accepted the invitation to the University of Heidelberg's jubilee in 1936 declined that of the University of Göttingen one year later. ${ }^{112}$ The number of American students at German universities, which had been steadily rising for years, dropped off. ${ }^{113}$ Even the CSMF, having continued its German activities seemingly unfazed by internal and external criticism, had "essentially ceas[ed]

109 Ibid., 58.

110 See the overview of Gallup data on Germany in Detlef Junker, Kampf um die Weltmacht. Die USA und das Dritte Reich, 1933-1945 (Düsseldorf, 1988), 70-78.

111 The Charge d'Affaires in the United States to the Foreign Ministry, July 31, 1935, DGFP Series C/Vol. 4, Document No. 237.

112 See Stephen H. Norwood, "Legitimating Nazism: Harvard University and the Hitler Regime, 1933-1937," American Jewish History 92, no. 2 (2004): 189-223, 220.

113 Tutt, "Ausländerbetreuung an der Universität Heidelberg," 22. 
international work" by $1937 .{ }^{114}$ In September 1937, Nicholas Murray Butler opened Columbia University's academic year by condemning "the three military dictatorships of Japan, Italy and Germany" as a serious threat to world peace. ${ }^{115}$ Just one month later, President Roosevelt famously echoed this sentiment in his "quarantine speech." At the same time, Germany's coordinated press moved from "skeptical ambivalence" to "open hostility" in its reporting on the United States. ${ }^{116}$

To be sure, suspicion about Germany's course in Europe had been present since 1933, but German rearmament, and especially the announcement of the Four-Year Plan, seems to have truly changed American sentiment. ${ }^{117}$ As German Ambassador Luther summed up in early 1937, "it must regrettably be said that [the possibility of a German war of aggression] is not only a matter of press and public opinion but that authoritative quarters [...] also doubt the Fuehrer's desire for peace." ${ }^{118}$ Perhaps, too, American observers finally realized that the substance and function of Nazi cultural diplomacy differed fundamentally from its Weimar predecessor, despite the similarities in form. While the latter had been embedded in a larger accommodationist Amerikapolitik, there was no such thing in the 1930s. Certainly, the days when there had been a genuine desire for an "alliance of ideas" between Germany and the United States had long since passed: its most sincere advocates had been dismissed, retired, or exiled. ${ }^{119}$ Instead, the long-standing champions of an anti-Western, German-dominated "new order for Europe" - an order without and in fact against the United States - had been elevated to positions of influence. ${ }^{120}$ In the end, there appeared to be no possibility of reconciliation between the two nations, as the head of the Foreign Ministry's America Department Hans-Heinrich Dieckhoff argued in late 1936: "the fundamental antithesis between the two [German and American] ideologies seems to be unbridgeable."121

All in all, the 1930s brought the much longer-standing rivalry between the two countries to the fore. Their increasingly divergent trade policies, especially the sharp opposition between Germany's autarky-focused, bilateral approach and America's multilateral, open door policy, spurred sharp competition. In Latin America, in particular, Nazi Germany directly challenged America’s

114 Kupsky, “The True Spirit," 210.

115 Norwood, Third Reich in the Ivory Tower, 101.

116 Gassert, Amerika im Dritten Reich, 247.

117 Offner, "The United States and National Socialist Germany," 417; see Stephen P. Duggan (IIE) to Dodd, Jan. 8, 1937, Dodd Papers, Box 44, LoC.

118 The Ambassador in the United States to the Foreign Ministry, Feb. 15, 1937, DGFP, Series C, Vol. 6, Document No. 207.

119 This is true for Jäckh, Bonn, Prittwitz, Weber, and others.

120 See the career of Karl Kerkhof in Martin, The Nazi-Facist New Order, 158-159.

121 Memorandum by the head of Political Division IX, Nov. 16, 1936, DGFP, Series C/Vol. 6, Document No. 37 . 
open-door empire with an aggressive, decidedly anti-American, and relatively successful trade and propaganda campaign. ${ }^{122}$ As trade competition thus widened into a more fundamental ideological conflict, Germany was increasingly perceived as a hemispheric threat to the United States - a development that gave rise, not least, to America's own, state-sponsored public diplomacy. ${ }^{123}$ In light of these developments, German diplomats in the United States warned Berlin ever more frequently about the possibility that the constellations of 1917 could recur. In case of war, they held, America would not remain aloof - for all its neutralist convictions. Such diplomatic warnings, however, went unheard and unheeded.

122 On this competition, see Schröder, Deutschland und die Vereinigten Staaten, 203-261. This competition had already begun in the 1920s; see Rinke, Der letzte freie Kontinent, 2:419.

123 Sirois, Zwischen Illusion und Krieg, 98; on the ideological dimensions of America's idea of an "open door empire" and tensions with Germany, see also Detlef Junker, Der unteilbare Weltmarkt. Das ökonomische Interesse in der Außenpolitik der USA 1933-1941 (Stuttgart, 1975), esp. 93-104; on the emergence of U.S. public diplomacy as a response to the Nazi threat, see Justin Hart, Empire of Ideas: The Origins of Public Diplomacy and the Transformation of U.S. Foreign Policy (New York, 2013), 21. 



\section{Conclusions \\ German Public Diplomacy and the United States}

$\mathrm{I}$ n analyzing German Amerikapolitik in the 1920s, many scholars have emphasized economic and financial matters. They have shown that the United States - emerging from World War I as the world's creditor and, as contemporary sources put it, as "world victor" - stood at the center of Germany's efforts to undo the Versailles Treaty by way of its economic recovery. In trying to secure America's political and financial support, Germany appealed strategically and successfully to American interests in a stable and prosperous Germany as both a bulwark against Bolshevism and a market for American goods. This study has complemented this predominantly economic perspective with a focus on German public diplomacy in the postwar United States. It has shown that the management of cultural relations, in particular, became a legitimate field of Amerikapolitik with its own discrete infrastructures, strategies, and funds. Whereas abrasive campaigns like the agitation against the "Black Horror" (the stationing of North African troops in the French-occupied Rhineland) still dominate our perception of German "propaganda" in the 1920s, there was also a much subtler approach to re-establishing trust and sympathy in the newly important United States. Germany launched systematic cultural appeals alongside its economic appeals to rebuild an economically and politically desirable "friendship" across the Atlantic.

After World War I, this approach played out in three phases. The first phase, 1919-1924, was characterized by limited activity. Though the experiences of the Great War had convinced Weimar Germany of the need for a far more comprehensive public diplomacy, financial troubles, lack of expertise, and German isolation and self-isolation precluded any active or effective out- 
reach. At the same time, the distinct frustrations of the postwar years shifted official attention from the war's fruitless propagandist concepts onto fields such as international education or tourism that had long lain outside the purview of traditional foreign policy. The breakdown of American resentments toward Germany during and after the Ruhr crisis in 1923 made way for a much more constructive second phase of German public diplomacy.

This second phase, 1924-1929, was in many regards the founders' period of German public diplomacy. It led to a comparatively sophisticated public-private infrastructure of committees, organizations, and programs devoted to cultivating American trust and sympathy. During this time, the Foreign Ministry's policy of reconciliation with the West found unique support among a group of peaceful revisionists whose professional, political, or commercial interests focused their attention across the Atlantic. Together, they systematically rebuilt relations with Americans of German descent, with American academics, and with American tourists. What they shared was a desire to correct the "distorted image" of Germany that the war had created, and, ultimately, to secure American financial and moral support in overturning the provisions of the Versailles peace treaty. It was in the mid-1920s that public diplomacy truly became a distinct part of German Amerikapolitik.

A third phase after 1930 consolidated and further politicized these structures. The establishment of large-scale national organizations, such as the German Academic Exchange Service (1931) and the German Tourism Council (1931), considerably increased the influence of the German Foreign Ministry in these fields and aligned them more closely with an assertive revisionist foreign policy. The aim of German public diplomacy during this period was to convince Americans that the transatlantic "friendship" still existed even as tensions between the United States and Germany, now increasingly radicalized, became ever more visible. After 1933, the Nazi government adopted and coopted many of the programs and organizations created in the 1920s, often deliberately and, for a time, quite successfully cultivating these continuities to veil the profound changes taking place in Germany. In the following years, it also applied many of the programs and measures initially designed for the United States to other countries.

\section{German Cultural Diplomacy in the United States: the European Context}

It seems apt at this point to reflect on German public diplomacy in the United States in a wider European context. This involves two related questions: First, how did Germany's cultural diplomacy toward the United States differ from its cultural diplomacy toward other countries? And, second, how did it differ from the cultural diplomacy pursued by other countries? In combination, the an- 
swers elucidate the role that the United States played in the making of German and European public diplomacy.

First, we must acknowledge that German public diplomacy toward the United States was part and parcel of a much larger reorientation of German and European diplomatic practice from about the 1890 os to the 1930s. The new public dimension of foreign policy was a reaction to an increasingly connected and democratic world that diplomats became ever more aware of from the late nineteenth century. While public opinion had long played a prominent role in foreign relations, the rise of the mass press, the ever faster and cheaper dissemination of (international) news, the greater affordability of international travel, and the concurrent rise of mass politics gave it a more significant place than ever before. ${ }^{1}$ Spurred by Germany's worldwide commercial ambitions, the idea that successful foreign policy required effective communication not only with ministers and princes but also with a global public gained traction around the turn of the century. By adopting more concerted press, information, and cultural policies, German foreign policymakers tried to adapt traditional statecraft to the exigencies of a new major factor in international relations. ${ }^{2}$ But it was World War I and its outcome that truly illustrated the power of public sentiment and subsequently transformed German diplomatic practice. Based on the belief that deficient public diplomacy was at least partly responsible for Germany's defeat, the Foreign Ministry reforms of 1919/1920 sought to adjust German foreign policy to the necessities of the modern age and German defeat alike. As a consequence, the 1920 s witnessed not only the establishment of a great array of private and semi-official organizations committed to public outreach but also the substantial expansion of official interest and competence in this field. The creation of the Foreign Ministry's Kulturabteilung in 1919/2O, the founding of a separate academic diplomacy section in 1926, and of a tourism desk within the America Department in 1928 signal its embrace of new policy fields. As the previous chapters have shown, it was in the 1920s that groups like ethnic Germans, students, and tourists were first systematically "geopoliticized." If by 1900 few diplomats had thought of them as discrete political assets, by 1930 they thought of them as little else.

This development shaped German foreign policy in many countries, not just in the United States. All over the world, Germany began to pay attention to public diplomacy around the turn of the century, accelerated this development during the war, and usually expanded and professionalized it in the 1920s. As Kurt Düwell has shown, the idea that German culture could be a "substitute"

1 A good summary can be found in Frank Bösch and Peter Hoeres, "Im Bann der Öffentlichkeit? Der Wandel der Außenpolitik im Medienzeitalter," in Außenpolitik im Medienzeitalter, ed. Bösch and Hoeres, 7-35.

2 On the development of German information policy at the time, see Heidi Tworek, News from Germany: The Competition to Control World Communications (Cambridge, MA, 2019). 
for lost hard power provided a key impetus for cultural diplomacy in the 1920 . In the postwar decade, the Kulturabteilung's budget nearly tripled from less than 3 million marks in 1924 to 8,250,000 marks in 1929 - funds that were sometimes spent quite successfully. The system of German schools abroad, for example, recovered and even expanded from 853 schools with 48 ,ooo students in 1913 to 1,600 schools with 80,000 students in 1933. ${ }^{3}$ In Latin America and southeastern Europe, especially, Germany systematically employed cultural means to facilitate its commercial expansion. ${ }^{4}$ At the same time, cultural diplomacy also began to play a greater role in repairing relations with great powers like France, Great Britain, and even Soviet Russia. Much as it did in the United States, for example, Berlin began to appeal strategically to British tourists and students in the mid-1920s. ${ }^{5}$ With regard to France, too, cultural interchange proved to be a powerful tool for bridging the two countries' differences and allowing German and French youth, in particular, to develop a more cordial relationship. ${ }^{6}$ In short, in trying to find new avenues for establishing German influence abroad as well as for reconciling with former enemies, or at least finding a modus vivendi, Weimar Germany increasingly harnessed its remaining soft power and cultural capital.

Even though the cultural focus on the United States is not extraordinary in itself, it still stands out in a number of respects. For one, the attention Germany paid to the United States was particularly strong in the 1920s. By the end of the decade, there were six organizations that were exclusively or predominantly committed to cultivating cultural relations with the United States in Berlin alone - more than toward any other country. More notably still, Germany first pioneered methods and concepts now among its standard repertoire of soft power approaches in relation to the United States: it was in the United States that Germany first installed professorial exchanges (1905), founded one of the first semi-official intercultural institutes (Amerika-Institut, 1910), and intro-

3 See Düwell, Deutschlands Auswärtige Kulturpolitik, 150.

4 On Latin America, for example, see Rinke, Der Letzte Freie Kontinent; and Michael Goebel, "Decentering the German Spirit: The Weimar Republic's Cultural Relations with Latin America," Journal of Contemporary History 44, no. 2 (2009): 221-245, since Spain was often seen as a "springboard" to Latin America; see also Pöppinghaus, Moralische Eroberungen. In southeastern Europe, for example, interwar Germany used trade fairs, German language training, and ethnic networks to establish an informal "export empire"; see Gross, Export Empire; on the early days of the Goethe-Institut and its focus on southeastern Europe, see Eckard Michels, "Deutsch als Weltsprache? Franz Thierfelder, the Deutsche Akademie in Munich and the Promotion of the German Language Abroad, 1923-1945," German History 22, no. 2 (2004): 206-228.

5 Tara Windsor, "Rekindling Contact: Anglo-German Academic Exchange after the First World War," in Anglo-German Scholarly Networks in the Long Nineteenth Century, ed. Heather Ellis and Ulrike Kirchberger, 212-231 (Leiden, 2014); and Angela Schwarz, Die Reise ins Dritte Reich. Britische Augenzeugen im nationalsozialistischen Deutschland (1933-39) (Göttingen, 1993).

6 Hans Manfred Bock, ed., Französische Kultur im Berlin der Weimarer Republik. Kultureller Austausch und diplomatische Beziehungen (Tübingen, 2005). 
duced large-scale student exchanges (1924), an international trainee program (1925), and systematic, state-supported tourism promotion (1925). The U. S. - a country with a sizeable "German" population - was also where Weimar diplomats first abandoned their focus on ethnic audiences in favor of a general appeal to elites. Finally, it was also in the United States that Germany began in the 1920 s to consider the "optics" of its actions abroad carefully and to elevate cultural politics (alongside economic relations) to a central place in its foreign policy. It may have been a "coincidence," as Laitenberger holds, that student exchanges initially began with the United States, but their almost immediate conversion into large-scale, semi-official organizations was not. Rather, these developments show that Germany's cultural initiatives in the United States perhaps more so than in any other Western country - became part of its larger foreign policy agenda. There is no denying it: the United States was one crucial place where modern German public diplomacy was made.

This study has offered several explanations for this development. Certainly, it was at least partly the product of historical timing, i. e., Germany's new focus on public diplomacy coincided with the U.S. rise to international importance. And yet, German public diplomacy was shaped less by the fact that the United States became a great power than by the fact that it became (or at least considered itself) an unorthodox great power. German observers were well aware that the United States, a country that refused to play by traditional European rules, required a different and more public-oriented foreign policy approach. Already before the war, many German officials harbored the belief that public opinion was more powerful in the United States than anywhere else, due to America's democratic politics and its sensational, mass-circulated press. That many Germans in the 1920 attributed the U.S. entry into World War I to British propaganda successes - and German propaganda failures - further elevated American public opinion to a position of unique prominence. The innovative character of Germany's public diplomacy toward the United States, then, was, in part, a response to the extraordinary influence it attributed to the American public.

Even more interesting, however, is the fact that cultural diplomacy, i.e., the cultural variant of public diplomacy, was especially prominent in the United States. This derived from a number of particularly instructive factors. First, Germans held long-standing and enduring assumptions about the lack of American (high) culture and its corresponding openness to European influences. In 1914, Ambassador Bernstorff concluded that "today an American culture does not yet exist. After a short acquaintance with any American, it is soon clear whether his culture is of English, German or French origin."

7 Abschrift A 1380 Imperial German Embassy Washington to Reichskanzler von Bethmann-Hollweg, Jan. 8, 1914, PA Botschaft Washington, 1523, Bernstorff. 
than twenty years later, and despite the phenomenal strides the United States had made in the meantime, Ambassador Luther once again regretted that the United States "possesses a culture of its own only in embryonic form ... in terms of culture the United States is still substantially a colony of Europe." Such cultural conceits, coupled with a belief in the unique qualities of German culture, explain why Germany pursued a policy toward the United States that it otherwise pursued most avidly in semi-colonial and allegedly backward zones of influence. The idea that Americans were particularly susceptible to, and in dire need of, European high culture proved remarkably durable from 1890 to 1940 - and beyond.

Yet Germany's cultural diplomacy toward America was also due to specific interwar constellations. The fact that postwar Germany understood cultural capital as a substitute for its lost hard power rendered cultural diplomacy especially prominent in German foreign policy, and all the more so in relation to newly important United States. French competition strongly reinforced this trend. The two rivaling countries competed in a great number of different fields: as tourist and student destinations, in terms of high school language enrollment, and regarding the celebrations of "national heroes" such of Steuben and LaFayette. More often than not, French actions determined German approaches to the United States, and vice versa. The French Tourism Office in New York City served as a model for the German Tourist Information Office in the same city; and the opening of the Cité Universitaire in Paris in 1925 prompted Germany's interest in establishing international houses at its own universities. As Holger Impekoven has rightly noted, the interwar Franco-German competition for American favor offers a perfect example of the cultural transfers and dynamics that arise from "learning from the enemy"9 That cultural diplomats in both countries tended to exaggerate the malice, danger, and success of the other's efforts partly explains the vitality of the field..$^{10}$ And yet, while French mastery in the field of cultural diplomacy informed German approaches, German diplomats also recognized that a cultural course was simply the only viable option with regard to the United States. In fact, America's prevalent fears of any "political propaganda" severely limited Germany's policy alternatives. This affected previous allies like France and Great Britain, but

8 The Ambassador in the United States to the Foreign Ministry, June 28, 1935 (DGFP), Series C, Vol. 4, Document No. 184.

9 The concept of "learning through emnity" is explored in Martin Aust and Daniel Schönpflug, eds., Vom Gegner Lernen: Feindschaften und Kulturtransfers im Europa des 19. und 2o. Jahrhunderts (Frankfurt, 2007); for its use regarding Weimar cultural diplomacy, see Impekoven, Die Alexander von Humboldt-Stiftung, 156.

10 For a more systematic analysis of this Franco-German competition for favor in the United States, see Elisabeth Piller, "The Transatlantic Dynamics of European Cultural Diplomacy: Germany, France and the Battle for U.S. Affections in the 1920s," Contemporary European History, forthcoming 2021. 
it applied especially to Germany and its allegedly ubiquitous "German propaganda." In the 1920s, Americans objected strongly to many real and even more imagined efforts to shape how they thought and felt about the world. As a consequence, German Ambassador Wiedfeldt recognized early on that propaganda was harmful rather than beneficial in America. ${ }^{11}$ For all of these reasons, Germany's seemingly unobtrusive cultivation of cultural relations enjoyed much greater attention in the United States than in other Western countries.

The final factor in Germany's cultural choice was the notable economic and cultural presence of the United States in postwar Europe just as the nation's politics grew increasingly isolationist. In fact, many Americans were oblivious to political developments in interwar Europe, yet they devoured travel literature, adored European art and music, or dreamt of a Junior Year Abroad. Moreover, while U.S. Congress and the State Department had to maintain utmost caution in their dealings with Europe, U.S. internationalists poured their enthusiasm and considerable resources into cultural interchange with Europe; whatever isolationism there was in the 1920s, it was not manifest in U.S. tourism, or in study abroad, or in the many transatlantic programs pioneered by U.S. foundations. Quite the contrary, the allegedly isolationist 1920 arguably witnessed upper- and middle-class Americans engaging more extensively with Europe than they ever had before. As a consequence, educational exchanges, tourism, and other cultural initiatives first emerged as legitimate policy fields because they offered a rare chance to reach a politically withdrawn and suspicious American public. In other words, the American disdain for, and German lack of, hard power conspired to make soft power, both in its cultural and economic variants, a particularly vital field of transatlantic interaction in the 1920 .

Importantly, these factors shaped not only German but also European cultural diplomacy. In the 1920s, the United States - courted across Europe for its (continued) financial support - evolved into a major target of European, often state-sponsored, cultural diplomacy. Between the wars, European countries opened "libraries of information," sent a never-ending stream of "informal ambassadors" (from professors and artists to generals) across the Atlantic, established academic exchange programs, and, where possible, cultivated close relations with U.S. bilateral and ethnic organizations. This manifest enthusiasm for transatlantic cultural exchange expressed European countries' desire to shape American opinions and the imperative to do so in the least offensive way. Moreover, this cultural courtship of the United States was by no means limited to European great powers. Just like Spain, Germany, and Great Britain, the Czechoslovak, Hungarian, and Romanian governments, too, competed for 
U.S. sympathy and support, as Zsolt Nagy has shown. ${ }^{12}$ Europe's widespread interest speaks clearly to the new position the United States occupied in the postwar world. To be sure, the considerable activities and funds of U.S. cultural internationalists only intensified this European interest. The international relations think tanks that the Rockefeller Foundation established across Europe - from Paris and Geneva to Oslo and Berlin - were many things at once: a welcome opportunity for transatlantic intellectual dialogue, an avenue of U.S. influence in Europe, and a chance for European cultural diplomats to cultivate U.S. attention and affinity. In the interwar period, the United States was as much a partner as it was a target of European cultural diplomacy.

In all, I would argue that this competition for American hearts and minds was one factor that led European countries to adopt a set of new and fairly uniform tools and approaches in the 1920s. For example, while only two European countries, France and Switzerland, had maintained a government-funded tourist information office in New York City in 1920, more than a dozen did a decade later. ${ }^{13}$ By the same token, a large number of European countries had developed a student exchange with the United States by 1930, often the first in their history. ${ }^{14}$ Indeed, while the establishment of such cultural diplomacy programs was clearly part of a broader development - one also visible in relation to other European and Commonwealth countries - European activities were often particularly early and extensive in the United States for all of the reasons mentioned above. In this and many other ways, the role of the U.S. as an elusive great power contributed to the "transformation of diplomacy" across Europe in the decades after 1900. ${ }^{15}$ Quite apart from the well-researched activities of America's own cultural diplomats and from President Woodrow Wilson's call for a "new diplomacy," the politically withdrawn and culturally involved United States hastened Europe's embrace of public diplomacy as a legitimate field of foreign policy.

\section{German Public Diplomacy and German-American Relations}

This cultural Amerikapolitik also played a distinct role in German-American relations. During the 1920s, as previous chapters detailed, it contributed to the remarkably swift rapprochement between the two countries. This is not

12 Zsolt Nagy, "National Identities for Export: East European Cultural Diplomacy in Inter-War Pittsburgh," Contemporary European History 20, no. 4 (2011): 435-453.

13 U.S. Department of Commerce, The Promotion of Tourist Travel by Foreign Countries U.S. Department of Commerce, Trade Promotion Series - No. 113 (Washington, DC, 1931), 63.

14 See, for example, Institute of International Education, Annual Report 1935, 20.

15 Zara Steiner, "Foreign Ministries Old and New," International Journal 37, no. 3 (1982): 349$377,351$. 
to suggest that Weimar public diplomacy made Germany uniquely popular with Americans. American society as a whole paid relatively little attention to Germany during the 1920s; those interested in Europe typically preferred France and (to a lesser extent) Great Britain for traveling, studying, and shopping abroad, or simply boasting about back home. Clearly, Americans never came close to paying as much attention to German culture in the United States as Germans did to American lifestyles and mass cultural products in Germany. Nevertheless, Germany made substantial relative gains and reestablished American networks, interest, and sympathy to an astonishing degree. If the early 1920 s had effectively undermined the cultural blockade, the later 1920 s rapidly turned inter-Allied into international cultural relations again - at least as far as the United States was concerned. To be fair, American cultural internationalists, in their search for a stable and peaceful world order, tremendously aided Germany's peaceful revisionists. Often acting in accordance with or in lieu of U.S. administrations, organizations like the Institute of International Education and the Carnegie Endowment for International Peace contributed greatly to reintegrating and rehabilitating Germany. While Germany's ambition for a revision of the peace treaty soon outpaced America's desire for change, their mutual interest in peacefully transforming the status quo generated a unique dynamic in German-American relations in the 1920s - both in the cultural and the economic field.

In the long run, the cultural diplomatic programs begun in the 1920 s had a significant legacy in German-American relations. For one, there were myriad organizational continuities. After the Second World War, the Institute of International Education and the (refounded) German Academic Exchange Service organized and facilitated the two countries' academic relations once again - and on a much grander scale. Modeled on interwar student programs, they have since brought about the exchange of tens of thousands of students. Moreover, some of Weimar's cultural diplomats who had emigrated to the United States, including Ernst Jäckh, Carl Joachim Friedrich, Werner Richter, and Reinhold Schairer, used their Weimar-era expertise to help build Cold War Atlanticism after 1945. Recently, Udi Greenberg spoke of a "Weimar Century" - i. e., the long shadow of the lessons learned from Weimar - with the transatlantic careers of Weimar intellectuals (like Friedrich) in mind; this certainly holds true for transatlantic cultural diplomacy as well. But the legacies of interwar initiatives extend far beyond those relatively few cultural diplomats. In fact, many of the interwar exchange students and trainees seem to have developed an enduring affinity for the other country. In 1949, one of the former America work students - at that point a manager in West Germany - admitted that "when I have beautiful dreams, I always dream of my time in Ameri- 
ka."16 Alongside other former America work students, he helped reestablish a German-American trainee program in the late 1940 s and 1950s. In a similar vein, Shepard Stone, who received his PhD in Berlin in 1932, after 1945 became one of the major architects of German-American cultural relations, in particular, and the cultural cold war, in general, first as an officer of the U.S. High Commissioner in Germany, then of the Ford Foundation. ${ }^{17}$ In this way, the cultural initiatives of the 1920 s formed a part of the much longer arc of what Mary Nolan called the "transatlantic century." 18

In the short run, to be sure, Weimar-era programs primarily benefited Nazi Germany. In fact, post-1933 developments clearly show how much Americans had come to sympathize with the German position. Although Germans liked to equate their isolation in 1933 with that of 1914, Americans actually understood (or made an effort to understand) German grievances far more at the later date than they had in 1914. Weimar's efforts at sympathy-gathering and network-building certainly deserve some credit for this development. In fact, as Michaela Hoenicke-Moore has shown, Americans who saw Nazi Germany as a threat in the 1930s struggled to convince the larger American public of their fears as so many had grown accustomed to thinking of Germans as essentially "like us" once more. ${ }^{19}$ Ironically, it was the Nazi government that profited most immediately from Weimar's untiring revisionist advocacy across the Atlantic.

\section{Continuity and Discontinuity: Republican Foreign Policy?}

This brings us to a question that has long preoccupied scholars of German history: the question of foreign policy continuity from Wilhelmine to Nazi Germany. Flipped on its head, the question boils down to whether Weimar's foreign policy actually was unique. Did the Weimar Republic, as Peter Krüger holds, develop a "republican foreign policy" (republikanische Außenpolitik) that truly differed from Wilhelmine approaches, not just in its necessarily different means but also in its ultimate ends? ${ }^{20}$

I would, indeed, argue that it did. From about 1923 to 1930, Weimar's Amerikapolitik did differ fundamentally from that of Wilhelmine Germany. For one, the systematic attention the republic paid to public diplomacy - alongside economic relations - in the 1920 s already constituted a marked departure from

16 "Ehemalige AWD-ler erinnern sich" (ca. 1949), Abt. 352 Carl Duisberg-Gesellschaft, 35214-26, Rheinisch-Westfälisches Wirtschaftsarchiv.

17 Berghahn, America and the Intellectual Cold Wars in Europe.

18 Mary Nolan, The Transatlantic Century: Europe and America, 1890-2010 (New York, 2012).

19 Hoenicke-Moore, Know Your Enemy, 8.

20 Krüger, Die Außenpolitik der Republik von Weimar, 43. 
pre-1914 efforts, even if it was, admittedly, often applied toward relatively traditional ends. The true difference, however, lay in the fact that public diplomacy was embedded in a larger accommodationist and realistic policy toward the United States. Unlike in the Wilhelmine period, when Germany's disregard for the Monroe Doctrine had made its public diplomacy appear to be little more than an empty gesture, Weimar's public campaign was closely aligned with its overall policy. At least after 1924, German policy decisions, both large and small, readily reflected deference to American wishes and general consideration of the "optics" of German actions in the United States. Several factors - the profound learning processes of World War I, the much greater international weight of the United States, and the presence of a group of bourgeois "America experts" in the Foreign Ministry - combined to generate a better Amerikapolitik and ensured that Weimar that would not suffer from the problems of its predecessors, namely, a dissonance between its words and deeds. The decision not to mobilize German Americans (Chapter 4) exemplifies Weimar's much more considerate and realistic approach. More than anything else, it was this steady consideration of American psychology that fundamentally distinguished Weimar's foreign policy toward the United States from that of both Wilhelmine and Nazi Germany.

Still, one should not unduly romanticize these developments. German (public) diplomats always held on to notions of German cultural superiority and generally preferred bilateral to multilateral relations. After all, one of the reasons they were eager to cooperate with organizations like the Carnegie Endowment was that these structures provided them with international networks without multilateral oversight and afforded them a much better opportunity to re-establish German influence than, say, the scientific "boycott organizations." In addition, German caution with regard to the important United States was not necessarily representative of German foreign policy. Toward lesser powers, as Peter Grupp has shown, Germany tended to act much as it had before the war. ${ }^{21}$ Moreover, it is important to acknowledge that this Amerikapolitik lasted a comparatively short period of time. The policies of the Brüning cabinet after 1930, for example, already had more in common with the policies before 1914 and after 1933 than those of the mid-1920s. After 1930, the peaceful revisionists, especially the left-leaning ones, were increasingly marginalized as Weimar's foreign policymakers abandoned persistent deference to American psychology for a quasi-Wilhelmine "free-hand" approach. German attention shifted increasingly toward southeastern Europe and Latin America, where moral conquests seemed more readily attainable.

21 Peter Grupp, Deutsche Außenpolitik im Schatten von Versailles: Zur Politik des Auswärtigen Amts vom Ende des Ersten Weltkriegs und der Novemberrevolution bis zum Inkrafttreten des Versailler Vertrags, 1918-1920 (Paderborn, 1988). 
Finally, even if I agree that toward a specific country - the United States and for a very specific period of time - from 1923 to 1930 - German public diplomacy in the United States was indeed part of a "republican foreign policy," there was still no "republican" public diplomacy, i.e., a systematic effort to promote a democratic Germany in the United States. Of course, some of Germany's "peaceful revisionists” like Ernst Jäckh, Anton Erkelenz, Reinhold Schairer, and Ambassador Prittwitz did emphasize the deep historical roots of German democracy and sought to underline the values and ideals it shared with the United States. But their individual emphasis did not make a larger policy. Despite the fact that Germany's democratic status was widely acknowledged as a distinct asset in the United States, the Foreign Ministry's records provide little indication of any systematic championing of a democratic Germany. ${ }^{22}$ For example, Berlin's criticism of German tourism promotion (Chapter 6) revolved around the reluctance to promote a (high) cultural Germany, not the equally obvious reluctance to promote a democratic Germany. In the same vein, the Wilhelmstrasse rejected the Vereinigung Carl Schurz's request to change its name to honor Friedrich Wilhelm von Steuben (a Prussian general) rather than Carl Schurz (a 1848 revolutionary) on the political grounds that it was best to avoid any association with the German-American Steuben Society, not on the ideological grounds that Schurz might more appropriately represent the Weimar Republic. The absurdity of the situation was perhaps best recognized by U.S. Ambassador Schurman, who always wondered why Germans would keenly promote the role a relatively obscure historical figure like Steuben played in the American Revolution while making no serious effort to emphasize the role of Enlightenment thinkers like Immanuel Kant. Even though Germany had a notable tradition of democratic thought and action, the Foreign Ministry seems to have made no concerted attempt to capitalize on it. What is more, Weimar Germany failed to require even basic democratic convictions of those it sent abroad as "informal ambassadors." Whereas Nazi Germany carefully screened its exchange students for their National Socialist beliefs, Weimar never even asked whether they had a basic commitment to democratic government. As a consequence, Germany sent National Socialist exchange students to the United States long before $1933 .{ }^{23}$

These realities reveal a deeper dilemma of German foreign policy after World War I: the commitment to revision usually trumped the commitment to democratic government. Especially when faced with the decision to promote either the republic or to make discrete revisionist gains, German elites almost invariably chose the latter. It was symptomatic that German exchange students,

22 Taschka, Diplomat ohne Eigenschaften, 86.

23 One example is Ulrich von Gienanth, who joined the NSDAP in 1930 and was sent abroad as an exchange student in 1931. After 1937 he served as the Ministry of Propaganda's "propaganda attaché" at the German Embassy in Washington. 
before leaving for the United States were sworn in on a common revisionist agenda, not a common democratic one. This is not to repeat old claims that Weimar was a democracy (entirely) without democrats but to emphasize that allegiance to the Reich and the recovery of its former glory were usually vastly more important to German elites. Weimar governments, as scholars have shown, strongly encouraged revisionism in the hope that it would hold a divided postwar German society together; in the end, the ever louder, ever more violent calls for revision only contributed to its downfall. ${ }^{24}$

That many Americans still came to see the Weimar Republic in a decidedly democratic light arguably owed more to American hopes and assumptions than to any large-scale German projection. After the mid-1920s, American investors, politicians, and journalists often desired to see the new-born republic in a certain way, reflecting their ambitions to boost German loans, to aid in its recovery, or simply to find their hopes in a peaceful and stable Europe fulfilled. Not least, such impressions of a democratic Germany revealed an American disposition to regard the transition from monarchy to republic as a progressive and irreversible act. Many Americans were eager to hear men like Prittwitz or Jäckh paint the picture of a "new Germany," and American tourists were quick to confuse an "Americanized" Germany with a democratic one. Despite some more critical voices, many Americans did not - or did not want to - see that Germany's embrace of American-style sports was no indicator of democratic conversion or that the German professors the Carnegie Endowment circulated in the United States - for all their excellent connections - were actually "outsiders," as Peter Gay called them, in the German system.. Without reading history backwards - there was certainly nothing foreordained about Weimar's collapse - a significant part of America's enthusiasm for a democratic Germany rested on wishful thinking. In the end, Weimar shone much brighter abroad than it did at home.

24 Heinemann, Die verdrängte Niederlage, 72.

25 Peter Gay, Weimar Culture: The Outsider as Insider (New York, 1968). 



\section{Bibliography}

\section{Archival Material}

Politisches Archiv des Auswärtigen Amts (PA)

Abteilung III Nordamerika

Abteilung VI Kultur

Abteilung P Presse

Büro Reichsminister

Büro Staatssekretär

Botschaft Washington

Botschaft Paris

Konsulat New Orleans

Generalkonsulat San Francisco

Gesandtschaft Bukarest

NL (Nachlass, Personal Papers) Gustav Stresemann

NL Johannes Sievers

NL Friedrich Wilhelm von Prittwitz und Gaffron

NL Fritz von Twardowski

NL Adolf Georg Otto von Maltzan

NL Edmund Schüler

NL Georg Ahrens

Personalakten: Draeger, Fuehr, Bertling, Terdenge 


\section{Bundesarchiv, Berlin (BArch)}

R 43-I Reichskanzlei

R 51 Deutsche Akademie

R 57 Deutsches Ausland-Institut

$R 73$ Notgemeinschaft der deutschen Wissenschaft

R 149 Wirtschaftshilfe der deutschen Studentenschaft

R 901 Auswärtiges Amt

R 4323 Reichsbahnzentrale für deutsche Verkehrswerbung

R 8039 Deutscher Schutzbund

R 8056 Volksbund für das Deutschtum im Ausland

R 8088 Reichsverband der deutschen Hochschulen

R 8132 Mitropa

R 9368 Vereinigung Carl Schurz e. V.

\section{Bundesarchiv, Koblenz (BArch Koblenz)}

N 1072 NL Anton Erkelenz

N 1238 NL Adolf Morsbach

N 1106 NL August Wilhelm Fehling

N 1082 NL Moritz Julius Bonn

N 1139 NL Erich Kraske

\section{Geheimes Staatsarchiv Preußischer Kulturbesitz (GSPK)}

VI HA Rep 92 NL Heinrich Schnee

VI HA Rep 92 NL Margarete Gärtner

VI HA Rep 92 NL Carl Heinrich Becker

VI HA Rep 92 NL Friedrich Schmidt-Ott

Rep 76 Reichs- und Preußisches Ministerium für Wissenschaft, Erziehung und Volksbildung

I. HA Rep 151 IC 7110 Amerika-Institut in Berlin

I. HA Rep 8913367 Förderung der geistigen Beziehungen zu Amerika, Vol.3

\section{Bayerisches Hauptstaatsarchiv}

MHIG 227 Fremdenverkehr, 1920-22 Handakt des Herrn Ministers Hamm MHIG 9244 Fremdenverkehr, Ausländerbetreuung, Auslandspropaganda, $1937-42$

\section{Bayerische Staatsbibliothek}

Ana 405 Nachlass Ernst Hanfstaengl, Box 45, Correspondence

Archiv des Deutschen Museums, München.

NL 89 Arnold Sommerfeld 


\section{Universitätsarchiv Heidelberg}

Rep H-VI 178/1-2 Staatswissenschaftliche Kommission, Ehrenpromotionen 1922-34

B-2740/1-2 Generalia, Akademische Auslandsstelle

B-7046/1-3 Generalia, Ausland, Ferienkurse für Ausländer

B-0670/1-2 Ausland, Beziehungen zum Ausland Verhältnis zu ausl.

Universitäten

B-0678/2 Feierlichkeiten, Die Einladung der Universität zu Festlichkeiten außerdeutscher Hochschulen und gelehrter Gesellschaften, 1927-1930 B-0680/2 Das Studium Deutscher im Ausland und von Ausländern in Deutschland, 1930-1941

B-1522 Ehrenpromotionen, allgemeines, 1918-1949

B-1523/1-7, Ehrendoktorwürde

B-6680/1-2 InSoSta

\section{Freie Universität Berlin, JFK Institut für Nordamerikastudien}

Handakten Amerika-Institut, Berlin (1910-1942)

\section{Universitätsbibliothek Marburg}

NL Eugen Kühnemann

\section{Rheinisch-Westfälisches Wirtschaftsarchiv}

Abt 352 Carl Duisberg Gesellschaft e. V. /Amerika-Werkstudentendienst

\section{Krupp Archiv}

WA 3/222-241 NL Otto Wiedfeldt

WA 4/2741-46 Wirtschaftspolitische Gesellschaft

\section{Bayer AG Archiv}

NL Carl Duisberg

\section{Columbia University Libraries, Rare Book \& Manuscript Library Collections}

Frederick Heuser Papers

Nicholas M. Butler Papers

Frederick James Eugene Woodbridge Papers

Samuel McCune Lindsay Papers

James T. Shotwell Papers

Carnegie Endowment for International Peace

Carnegie Endowment for International Peace, Centre Européen

Deutsches Haus Records 


\section{Columbia University Archives}

Historical Subject Files, 1870s to Present

Columbia Central Files

Cornell University Library, Division of Rare and Manuscript Collections Jacob Gould Schurman Papers

Albert B. Faust Papers

Princeton University Library, Special Collections

MCo34 Arthur von Briesen Papers

Library of Congress (LoC)

William E. Dodd Papers

Henry T. Allen Papers

\section{National Archives and Records Administration (NARA)}

RG 84 Records of the Foreign Service Posts of the Department of State RG131/87550 German Tourist Information Office

M 355 United States. Records of the Department of State Relating to Political Relations Between the United States and Germany. 1910-1929.

M 336 United States. Records of the Department of State Relating to Internal Affairs of Germany, 1910-1929.

\section{German Society of Pennsylvania, Joseph B. Horner Memorial Library} (HML)

Ms. Coll. 28 Hilfsfond Records

Ms. Coll. 29 Relief for German Children of the Lost Provinces of Germany and Austria Records

Ms. Coll 1010 Rudolf Cronau Collection

Historical Society of Pennsylvania (HSP)

MSS 167 National Carl Schurz Association

MSS 128 Cannstatter Volksfestverein

MSS 81 Rudolf Cronau Collection, 1858-1930

New York Public Library, Special Collections (NYPL)

Raymond T. Rich Papers

American Philosophical Society (APS)

Franz Boas Papers 


\section{Hoover Institution Archives (HIA)}

91002 American Council on Education Records

\section{Rockefeller Archive Center}

Institute of International Education Records

\section{Published Sources}

Akten der Reichskanzlei, Weimarer Republik, 1918-1933, https://www.bundesarchiv.de/aktenreichskanzlei/1919-1933/oooo/index.html Verhandlungen des Deutschen Reichstags, 1905-1933 http://www.reichstagsprotokolle.de Akten zur Deutschen Auswärtigen Politik, 1918-1938. 50 vols. Göttingen, 1950-1995.

Documents on German Foreign Policy, 1918-1945. Series C (1933-1937)

The Third Reich: First Phase. 6 vols. London, 1962.

Henry Bernhard, ed., Gustav Stresemann Vermächtnis. 3 vols. Berlin, 1932/33. Wolfgang Elz, Gustav Stresemann. Reden der Kanzler- und Außenministerzeit (1923-1929)

www.geschichte.uni-mainz.de/neuestegeschichte/795.php

Statistisches Jahrbuch für das deutsche Reich. Berlin, 1919-1940.

Foreign Relations of the United States, 1917-1937. 86 vols. Washington, DC, 1926-1954.

\section{Newspapers}

Boston Daily Globe

Chicago Tribune (+ Paris Edition)

The Christian Science Monitor

Los Angeles Times

New York Times

New York Tribune

New York Herald Tribune

Washington Post

\section{Annual Reports}

Germanistic Society of America, Annual Reports, 1910-1913; 1920-1943

Institute of International Education, Annual Reports, 1920-1938

Rockefeller Foundation, Annual Reports, 1920-1934 


\section{Magazines [affiliation], dates consulted}

Amaroc News, 1922

American Review of Reviews, 1919-1929

Atlantic Monthly, 1919-1927

Auslandswarte [Bund der Auslandsdeutschen], 1920-1936

Der Auslanddeutsche [Deutsches Ausland-Institut], 1919-1932

Deutsche Arbeit [Verein für das Deutschtum im Ausland], 1923-29

Deutsche Welt [Verein für das Deutschtum im Ausland], 1924

France-États-Unis, [Comité France-Amérique], 1919-1924

Educational Record [American Council on Education], 1920-1928

The Fatherland, 1914-1917

Germanistic Society Quarterly, 1914-1917

German Quarterly, 1928-1934

German-American Historical Review

Harper's Magazine, 1919-1934

Heimat und Volk [Verein für das Deutschtum im Ausland], 1920-1922

Hochschule und Ausland, [German Academic Exchange Service], 1930-1934

Internationale Wochenschrift für Wissenschaft, Kunst und Technik, 1907-1921

Journeys Beautiful/Nomad, 1924-1931

Literary Digest, 1919-1934

Mitteilungen der Deutschen Akademie, 1925-1934

Mitteilungen des Verbandes der deutschen Hochschulen, 1921-1934

Monatshefte für Deutschen Unterricht, 1928 [Successor of Monatshefte für

deutsche Sprache und Pädagogik]

National Geographic, 1919-1934

The Nation, 1919-1933

Nationalsozialistische Monatshefte, 1933

The New Republic, 1919-1933

Rundbrief deutscher Austauschstudenten in den USA, 1932-1933

Süddeutsche Monatshefte, 1914-1933

The American Traveller's Gazette [Thos. Cook \& Son], 1920-1925

Travel, 1926-1934

Town and Country, 1920-1932

Viereck's American Monthly, 1919-1920

World Traveler, 1928-1930

\section{Contemporary Literature}

Akademischer Austauschdienst. Der akademische Austauschdienst 1924-1930. Berlin, 1930. Akademischer Austauschdienst. Deutsche Austauschstudenten in den Vereinigten Staaten. Berlin, 1928. 
Academic Exchange Service. German Universities: A Manual for Foreign Scholars and Students. Berlin, 1932.

Baden, Max von. Die Moralische Offensive. Deutschlands Kampf um sein Recht. Hamburg, 2011, orig. 1921.

Becker, Carl Heinrich. Kulturpolitische Aufgaben des Reiches. Leipzig, 1919.

Brooks, Sidney. Germany and America, 1918-1925. New York, 1925.

Bonn, Moritz Julius. Amerika als Feind. Munich, 1917.

Boelitz, Otto and Franz Schmidt, eds. Aus deutscher Bildungsarbeit im Auslande. Langensalza, 1928.

Boelitz, Otto. Das Grenz- und Auslanddeutschtum. Seine Geschichte und seine Bedeutung. $2^{\text {nd }}$ edition. Munich, 1930.

Bülow, Bernhard von. Deutsche Politik. Berlin, 1916.

Bryce, James. The American Commonwealth. Philadelphia, 1906.

Church, Samuel Harden. Kultur and the War. Sixty American Opinions On the War. London, 1915.

Committee on the Judiciary. Brewing and Liquor Interests and German Propaganda. Hearing before a Subcommittee of the Committee on the Judiciary United States Senate. Sixty-Fifth Congress, Second and Third Session Pursuant to S.Res. 307. Washington, 1919.

Creel, George. How We Advertised America. New York, 1920.

Cronau, Rudolf. The Army of the American Revolution and Its Organizer. New York, 1923.

Draeger, Hans, ed. Arbeitsauschuß Deutscher Verbände. 1921-1931. Berlin, 1932.

-, and Heinrich Schnee, eds. Zehn Jahre Versailles. Vol II. Berlin, 1929.

Elzbacher, Paul. Die Presse als Werkzeug der auswärtigen Politik. Jena, 1918.

Erkelenz, Anton and Fritz Mittelmann, eds. Carl Schurz. Der Deutsche und Amerikaner. Zu seinem 100. Geburtstage. Berlin, 1929.

Erkelenz, Anton. Amerika von heute: Briefe von einer Reise. Berlin, 1926.

Falcke, Horst P. Vor dem Eintritt Amerikas in den Weltkrieg. Deutsche Propaganda in den Vereinigten Staaten. 1914/15. Dresden, 1928.

Francis, Philip. The Poison in America's Cup. New York, 1919.

Fry, A. Ruth. A Quaker Adventure: The Story of Nine Year's Relief and Reconstruction. London, 1926.

Fulda, Ludwig. Amerika und Deutschland während des Weltkrieges. Leipzig, 1916.

Fittbogen, Gottfried. Was jeder Deutsche vom Grenz- und Auslanddeutschtum wissen muss. Munich, 1926.

George Washington Bicentennial Commission. History of the George Washington Bicentennial Celebration. Vol. 4, Foreign Participation. Washington, 1932.

Germanistic Society. Activities of the Germanistic Society of the United States, 1904-1910. New York, 1911.

Glaesser, Johannes. Deutsch-Amerikanisches Vereins-Adressbuch für das Jahr 1921. Milwaukee, 1921.

Grothe, Hugo. Die Deutschen in Übersee: Eine Skizze ihres Werdens, ihrer Verbreitung und kulturellen Arbeit. Berlin, 1932.

Haenisch, Konrad. Die Not der geistigen Arbeiter. Ein Alarmruf. Leipzig, 1920.

Harms, Bernhard. Französische Kulturpropaganda in den Vereinigten Staaten von Amerika. An die Freunde des Instituts für Weltwirtschaft und Seeverkehr an der Universität Kiel. Kiel, 1924.

Hoffmann, Conrad. In the Prison Camps of Germany: A Narrative of ' $Y$ ' Service among Prisoners of War. New York, 1920.

House Committee on Un-American Activities. Investigation of Nazi Propaganda Activities and Investigation of Certain Other Propaganda Activities: Public Hearings before the Special Committee on Un-American Activities, House of Representatives, Seventy-Third Congress, Second Session. Washington, 1934-1935. 
House Committee on Un-American Activities. Investigation of Un-American Propaganda Activities in the United States. Special Committee on Un-American Activities, House of Representatives Seventy-Sixth Congress, Third Session on H.R. 282, Appendix-Part II. Washington, 1940.

Institute of Intellectual Cooperation. Holiday Courses in Europe, 1928-1929. Paris, 1928.

Institute of Intellectual Cooperation. University Exchanges in Europe. Paris, 1928.

Institute of International Education. Directory of American Fellows Studying under the Auspices of the American German Student Exchange 1925-1935. New York, 1936.

Jäckh, Ernst. Amerika und wir. Amerikanisch-deutsches Ideenbündnis. Stuttgart, 1929.

-. The New Germany. New York, 1929.

-, and Paul Rohrbach et al. Truth about Germany: Facts about the War. New York, 1914.

Jones, Rufus M. A Service of Love in War Time: American Friends Relief Work in Europe, 19171919. New York, 1920.

Jünger, Karl. Deutsch-Amerika mobil. Leipzig, 1915.

Gerloff, Helmut. Die Ausländerfrage an den deutschen Hochschulen. Göttingen, 1920.

Goebel, Julius. Das Deutschtum in den Vereinigten Staaten von Nord-Amerika. Munich, 1904.

Goverts, Henry et al., eds. Der Student im Auslande. Heidelberg, 1930.

Harley, John Eugene. International Understanding: Agencies Educating for a New World. Stanford, 1931.

Kraus, Maximilian. Die zukünftigen Aufgaben der deutschen Verkehrswerbung im In- und Auslande. Berlin, 1921.

Kreyenpoth, Johannes. Die Auslandshilfe für das deutsche Reich. Stuttgart, 1932.

Kühnemann, Eugen. Vom Weltreich des deutschen Geistes. Reden und Aufsätze. Munich, 1914.

-. Deutschland und Amerika. Briefe an einen deutsch-amerikanischen Freund. Munich, 1917.

-. George Washington. Sein Leben und Werk. Bremen, 1932.

Karo, Heinrich. Der geistige Krieg gegen Deutschland. Halle, 1925.

Kellermann, Hermann. Der Krieg der Geister 1914. Weimar, 1915.

Kiesel, Karl. Passing through Germany. Berlin, 1926.

Knesebeck, Ludolf Gottschalk. Die Wahrheit über den Propagandafeldzug und Deutschlands Zusammenbruch. Der Kampf der Publizistik im Weltkriege. Munich, 1927.

Konen, Heinrich, ed. Volkstum und Kulturpolitik. Cologne, 1932.

Langewiesche, Wolfgang. Das amerikanische Abenteuer. Deutscher Werkstudent in USA. Stuttgart, 1933.

Laswell, Harold. Propaganda Technique in the World War. New York, 1938, orig. 1927.

Luckner, Felix von. Seeteufel erobert Amerika. Leipzig, 1928.

McBride, Robert. Towns and People of Modern Germany. New York, 1927.

Mehnert, Klaus. Ein deutscher Austauschstudent in Kalifornien. Stuttgart, 1930.

Meyer, Eduard. Nordamerika und Deutschland. Berlin, 1915.

-. Amerika und unser Krieg. Flugschriften des unabhängigen Ausschusses. Berlin, 1916.

-. Die Vereinigten Staaten von Amerika. Geschichte, Kultur, Verfassung und Politik. Frankfurt a. M., 1920.

Mowrer, Edgar Ansel. Germany Puts the Clock Back. New York, 1933.

Münsterberg, Hugo. The War and America. New York, 1914.

Münsterberg, Margaret. Hugo Münsterberg, His Life and Work. New York, 1922.

Niessen, Ludwig. Der Lebensraum für den geistigen Arbeiter. Münster, 1931.

Ohlinger, Gustavus. The German Conspiracy in American Education. New York, 1919.

Oncken, Hermann. Deutschlands Weltkrieg und die Deutschamerikaner: Ein Gruß des Vaterlandes über den Ozean. Stuttgart, 1914.

Peterson, Horace. Propaganda for War: The Campaign against American Neutrality, 19141917. Norman, OK, 1939.

Powys, John Cowper. The Menace of German Culture: A Reply to Professor Muensterberg. London, 1915.

Ponsonby, Arthur. Falsehood in Wartime. London, 1928. 
Prittwitz und Gaffron, Friedrich Wilhelm von. Deutschland und die Vereinigten Staaten seit dem Weltkrieg. Berlin, 1934.

Remme, Karl, and Margarete Esch. Die französische Kulturpropaganda. Auf der Grundlage französischen Quellenmaterials und eigener Beobachtungen im Ausland. Berlin, 1927.

Rohrbach, Paul. Der deutsche Gedanke in der Welt. Leipzig, 1920, orig. 1912.

-. Woher es kam. Stuttgart, 1919.

Rouse, Ruth. Rebuilding Europe: The Student Chapter in Postwar Reconstruction. London, 1925.

Ruedorffer, J. J. (=Kurt Riezler) Grundzüge der Weltpolitik in der Gegenwart. Stuttgart, 1914.

Rühlmann, Paul. Kulturpropaganda. Grundsätzliche Darlegungen und Auslandsbeobachtungen. Charlottenburg, 1919.

Schairer, Reinhold. Die Studenten im internationalen Kulturleben. Beiträge zur Frage des Studiums in einem fremden Lande. Münster, 1927.

Schieber, Clara Eve. "The Transformation of American Sentiment toward Germany, 18701914." The Journal of International Relations 12, no. 1 (1921): 50-74.

Schoonmaker, Frank. Through Europe on Two Dollars a Day. New York, 1927.

-. Come with Me Through Germany. New York, 1930.

Schönemann, Friedrich. Die Kunst der Massenbeeinflussung in den Vereinigten Staaten von Amerika. Berlin/Leipzig, 1924.

-. Die Vereinigten Staaten von Amerika. Vol. 1, Von der Kolonie zum Weltreich. Stuttgart, 1932.

Schrader, Frederick Franklin. 1683-1920. New York, 1920.

Schreiber, Georg. Die Not der deutschen Wissenschaft und der geistigen Arbeiter. Geschehnisse und Gedanken zur Kulturpolitik des Reiches. Leipzig, 1923.

Sperry, Earl E. The Tentacles of the German Octopus in America. New York, 1917.

Squires, James. British Propaganda at Home and in the U. S. 1914-17. Cambridge, MA, 1935.

Stern-Rubarth, Edgar. Die Propaganda als politisches Instrument. Berlin, 1921.

Stöhr, Hermann. So half Amerika. Stettin, 1936.

Stuart, Campbell. The Secrets of Crewe House: The Story of a Famous Campaign. London, 1920.

Stolper, Ernst. Werkstudent im wilden Westen: Aus dem Tagebuch eines jungen Deutschen. Leipzig, 1933.

Thimme, Hans. Weltkrieg ohne Waffen. Die Propaganda der Westmächte gegen Deutschland, ihre Wirkung und ihre Abwehr. Stuttgart/Berlin, 1932.

Thwing, Charles Franklin. The American and the German University: One Hundred Years of History. New York, 1928.

Vereinigung Carl Schurz. Zum zweihundertsten Geburtstag von Friedrich Wilhelm von Steuben. Berlin, 1930.

U.S. Department of Commerce, Bureau of Foreign and Domestic Commerce. Oversea Travel and Travel Expenditures in the Balance of International Payments of the United States, 1919-1938. Washington, 1939.

Verein für das Deutschtum im Ausland, ed. Deutschtumsarbeit in den Vereinigten Staaten von Nordamerika. Berlin, 1925.

Viereck, Louis. Die Vereinigung alter deutscher Studenten in Amerika. New York, 1902.

Viereck, George Sylvester. Spreading Germs of Hate. London, 1931.

Weber, Alfred. Die Not der geistigen Arbeiter. Leipzig, 1923.

Weis, Erwin. Die Propaganda der Vereinigten Staaten gegen Deutschland im ersten Weltkrieg. Essen, 1943.

Vogel, Walter. "Die Organisation der amtlichen Presse- und Propagandapolitik des Deutschen Reiches von den Anfängen unter Bismarck bis zum Beginn des Jahres 1933." Zeitungswissenschaft 16 (Aug./Sep. 1941).

Wile, Frederic William. The German-American Plot: The Record of a Great Failure. London, 1915.

Witte, Emil. Aus einer deutschen Botschaft. Zehn Jahre deutsch-amerikanischer Diplomatie. Leipzig, 1907.

Wittke, Carl. George Washington und seine Zeit. Bremen, 1933. 


\section{Memoirs and Published Diaries}

Allen, Henry T. Mein Rheinlandtagebuch. Berlin, 1923.

Bonn, Moritz Julius. So macht man Geschichte. Munich, 1953.

Butler, Nicholas Murray. Across the Busy Years: Recollections and Reflections. 2 vols. New York, 1939.

Brentano, Lujo. Mein Leben im Kampf um die soziale Entwicklung Deutschlands. Jena, 1931.

Bartholdt, Richard. From Steerage to Congress. Philadelphia, 1930.

Bernstoff, Johann Heinrich von. My Three Years in America. London, 1920.

-. Deutschland und Amerika. Erinnerungen aus dem fünfährigen Kriege. Berlin, 1920.

-. Erinnerungen und Briefe. Hamburg, 2010, orig. Zurich, 1936.

Curtius, Julius. Sechs Jahre Minister der Deutschen Republik. Heidelberg, 1947.

d'Abernon, Edgar Vincent. An Ambassador of Peace. 3 vols. London, 1929.

Dodd, William E. Ambassador Dodd's Diary, 1933-1938. New York, 1941.

Duggan, Stephen. Professor at Large. New York, 1943.

Erzberger, Matthias. Erlebnisse im Weltkrieg. Stuttgart, 1920.

Erdmann, Karl Dietrich, ed. Kurt Riezler - Tagebücher - Aufsätze - Dokumente. Göttingen, 1972.

Francke, Kuno. Deutsche Arbeit in Amerika. Erinnerungen. Leipzig, 1930.

Franke, Otto. Erinnerungen aus zwei Welten. Berlin, 1954.

Gärtner, Margarete. Botschafterin des Guten Willens. Außenpolitische Arbeit 1914-1950. Bonn, 1955.

Gerard, James. My Four Years in Germany. New York, 1917.

Gerlach, Hellmut von. Von rechts nach links. Frankfurt, 1987, orig. 1937.

Hentig, Werner Otto von. Mein Leben. Eine Dienstreise. Göttingen, 1962.

Holl, Karl, and Adolf Wild, eds. Ein Demokrat kommentiert Weimar. Die Berichte Hellmut von Gerlachs an die Carnegie-Friedensstiftung in New York, 1922-1930. Bremen, 1973.

Jäckh, Ernst. Der goldene Pflug, Lebensernte eines Weltbürgers. Stuttgart, 1954.

-. Weltsaat. Erlebtes und Erstrebtes. Stuttgart, 1960.

Kühnemann, Eugen. Mit unbefangener Stirn. Mein Lebensbuch. Heilbronn, 1937.

Ludendorff, Erich. Meine Kriegserinnerungen, 1914-1918. Berlin, 1919.

Mehnert, Klaus. Ein Deutscher in der Welt. Erinnerungen 1906-1981, Stuttgart, 1981.

Penck, Albrecht. US-Amerika. Gedanken und Erinnerungen eines Austauschprofessors. Stuttgart, 1917.

Prittwitz und Gaffron, Friedrich Wilhelm von. Zwischen Petersburg und Washington. Ein Diplomatenleben. Munich, 1952.

Rohrbach, Paul. Um des Teufels Handschrift. Hamburg, 1953.

Redslob, Edwin. Von Weimar nach Europa. Erlebtes und Durchdachtes. Berlin, 1972.

Rheinbaben, Werner von. Viermal Deutschland: Aus dem Erleben eines Seemanns, Diplomaten und Politikers, 1895-1954. Berlin, 1954.

Schäfer, Dietrich. Mein Leben. Berlin, 1926.

Schmidt-Ott, Friedrich. Erlebtes und Erstrebtes, 1860-1950. Wiesbaden, 1952.

Schreiber, Georg. Zwischen Demokratie und Diktatur. Persönliche Erinnerungen an die Politik und Kultur des Reiches von 1919-1944. Münster, 1949.

Shuster, George. Amerika und Deutschland. Erinnerungen eines amerikanischen College-Präsidenten. Frankfurt, 1965.

Warburg, Max M. Aus meinen Aufzeichnungen. New York, 1952.

Zechlin, Walter. Pressechef bei Ebert, Hindenburg und Kopf. Erlebnisse eines Pressechefs und Diplomaten. Hanover, 1956. 


\section{Secondary Sources}

Abelein, Manfred. Die Kulturpolitik des Deutschen Reiches und der Bundesrepublik Deutschland. Ihre Verfassungsgeschichtliche Entwicklung und ihre verfassungsrechtlichen Probleme. Cologne, 1968.

Adam, Thomas, and Charlotte Lerg. "Diplomacy on Campus: the Political Dimensions of Academic Exchange in the North Atlantic." Journal of Transatlantic Studies 13, no. 4 (2015): 299-310.

Adams, Willi Paul. "Die Geschichte Nordamerikas in Berlin." In Geschichtswissenschaften in Berlin im 19. und 20. Jahrhundert, edited by Reimar Hansen and Wolfgang Ribbe, 595631. Berlin, 1989.

Adler, Selig. "The War-Guilt Question and American Disillusionment, 1918-1928." Journal of Modern History 23 (1951): 1-28.

-. The Isolationist Impulse: Its Twentieth Century Reaction. New York, 1966.

Adlgasser, Franz. American Individualism Abroad: Herbert Hoover, die American Relief Administration und Österreich, 1919-1923. Vienna, 1993.

Aguilar, Manuela. Cultural Diplomacy and Foreign Policy: German-American Relations, 19551968. New York, 1996.

Aiken, Guy, "Feeding Germany: American Quakers in the Weimar Republic." Diplomatic History 43, no. 4 (2019): 597-617.

Ambrosius, Lloyd. "Ethnic Politics and German-American Relations after World War I: The Fight over the Versailles Treaty in the United States." In Germany and America: Essays on Problems of International Relations and Immigration, edited by Hans Trefousse, 29-40. Brooklyn, 1980.

Aust, Martin and Daniel Schönpflug, eds. Vom Gegner Lernen: Feindschaften und Kulturtransfers im Europa des 19. und 20. Jahrhunderts. Frankfurt, 2007.

Badash, Lawrence. "British and American Views of the German Menace in World War I." Notes and Records of the Royal Society of London 34, no. 1 (1979): 91-121.

Barclay, David E., and Elisabeth Glaser-Schmidt, eds. Transatlantic Images and Perceptions: Germany and America since 1776. New York, 1997.

Becker, Frank, and Elke Reinhardt-Becker, eds. Mythos USA. "Amerikanisierung" in Deutschland seit 1900. Frankfurt, 2006.

Berg, Manfred. Gustav Stresemann und die Vereinigten Staaten von Amerika. Weltwirtschaftliche Verflechtung und Revisionspolitik. Baden-Baden, 1990.

-. "Germany and the United States: The Concept of World Economic Interdependence." In Genoa, Rapallo, and European Reconstruction in 1922, edited by Carole Fink, Axel Frohn, et al., 77-93. New York, 1991.

Berg, Peter. Deutschland und Amerika 1918-1929. Über das deutsche Amerikabild der zwanziger Jahre. Lübeck, 1963.

Berghahn, Volker. "Philanthropy and Diplomacy in the American Century." Diplomatic History 23, no. 3 (1999): 393-419.

-. America and the Intellectual Cold Wars in Europe. Shepard Stone between Philanthropy, Academy, and Diplomacy. Princeton NJ, 2001.

Bergquist, James M. "German Americans." In Multiculturalism in the United States: A Comparative Guide to Acculturation and Ethnicity, edited by John D. Buenker and Lorman A. Ratner, 149-172. Santa Barbara, 2005.

Besier, Gerhard. Krieg - Frieden - Abrüstung. Die Haltung der europäischen und amerikanischen Kirchen zur Frage der deutschen Kriegsschuld 1914-1933. Göttingen, 1982.

Bickelmann, Hartmut. Die deutsche Überseewanderung in der Weimarer Zeit. Stuttgart, 1980.

Biskup, Thomas, ed. Selling Berlin. Imagebildung und Stadtmarketing von der preußischen Residenz bis zur Bundeshauptstadt. Stuttgart, 2008.

Blakey, George. T. Historians on the Homefront: American Propagandists for the Great War. Lexington, KY, 1970. 
Bock, Hans Manfred, ed. Französische Kultur im Berlin der Weimarer Republik. Kultureller Austausch und diplomatische Beziehungen. Tübingen, 2005.

Bösch, Frank, and Peter Hoeres, eds. Außenpolitik im Medienzeitalter. Vom späten 19. Jahrhundert bis zur Gegenwart. Göttingen, 2013.

Bösch, Frank, and Peter Hoeres. "Im Bann der Öffentlichkeit? Der Wandel der Außenpolitik im Medienzeitalter." In Außenpolitik im Medienzeitalter, edited by Bösch and Hoeres, 7-35.

Bouquet, Dorothee. "French Academic Propaganda in the United States, 1930-1939." In Teaching America to the World and the World to America, edited by Richard Garlitz and Lisa Jarvinen, 155-172. London, 2012.

Brandt, Susanne. "Versailles auf den ehemaligen Schlachtfeldern im Westen." In Versailles 1919. Ziele - Wirkung - Wahrnehmung, edited by Gerd Krumreich, 323-332. Essen, 2001.

Brantz, Rennie. "German-American Friendship: The Carl Schurz Vereinigung, 1926-1942." International History Review 11, no. 2 (1989): 229-251.

Brocke, Bernhard vom. "'Wissenschaft und Militarismus'. Der Aufruf der 93 'An die Kulturwelt!' und der Zusammenbruch der internationalen Gelehrtenrepublik im Ersten Weltkrieg." In Wilamowitz nach 50 Jahren, edited by William M. Calder III, Hellmut Flashar, Theodor Linken, 649-719. Darmstadt, 1985.

-. "Der Deutsch-Amerikanische Professorenaustausch. Preußische Wissenschaftspolitik, internationale Wissenschaftsbeziehungen und die Anfänge einer deutschen auswärtigen Kulturpolitik vor dem Ersten Weltkrieg." Zeitschrift für Kulturaustausch 31, no. 2 (1981): $128-182$.

-, and Peter Krüger, eds. Hochschulpolitik im Föderalismus. Die Protokolle der Hochschulkonferenzen der deutschen Bundesstaaten und Österreichs 1898 bis 1918. Berlin, 1994.

-. "Die Kaiser-Wilhelm-Gesellschaft im Kaiserreich." In Forschung im Spannungsfeld von Politik und Gesellschaft. Geschichte und Struktur der Kaiser-Wilhelm-/ Max-Planck-Gesellschaft, edited by Rudolf Vierhaus and Bernhard vom Brocke, 17-160. Stuttgart, 1990.

Brubaker, Rogers. "Accidental Diasporas and External 'Homelands' in Central and Eastern Europe: Past and Present." In Transnationalism: Diasporas and the Advent of a New (Dis-) order, edited by Eliezer Ben-Rafael and Yitzhak Sternberg, 461-482. Leiden, 2009.

Bruch, Rüdiger vom. Weltpolitik als Kulturmission. Auswärtige Kulturpolitik und Bildungsbürgertum in Deutschland am Vorabend des Ersten Weltkrieges. Paderborn, 1982.

-. "Gesellschaftliche Initiativen in den auswärtigen Kulturbeziehungen Deutschlands vor 1914. Der Beitrag des deutschen Bildungsbürgertums." Zeitschrift für Kulturaustausch 31 (1981): 43-67.

Bruziere, Maurice. L'Alliance française: Historie d'une institution. 1883-1983. Paris, 1983.

$\mathrm{Bu}$, Liping. Making the World Like Us: Education, Cultural Expansion and the American Century. Westport, CT, 2003.

-. "Education and International Cultural Understanding: The American Elite Approach, 1920-1937." In Teaching America to the World \& The World to America: Education and Foreign Relations since 1870, edited by Richard Garlitz and Lisa Jarvinen, 111-133. London, 2012.

Buitenhuis, Peter. Great War of Words. British, American and Canadian Propaganda and Fiction, 1914-1933. Vancouver, 1987.

Bulmer, Martin, and Joan Bulmer. "Philanthropy and Social Science in the 1920s: Beardsley Ruml and the Laura Spelman Rockefeller Memorial, 1922-1929." Minerva 19, no. 3 (1981): 347-407.

Bungert, Heike. Festkultur und Gedächtnis. Die Konstruktion einer deutsch-amerikanischen Ethnizität. Paderborn, 2015.

-. "Demonstrating the Values of 'Gemüthlichkeit' and 'Cultur': The Festivals of German-Americans in Milwaukee, 1870-1910." In Celebrating Ethnicity and Nation: American Festive Culture from the Revolution to the Early Twentieth Century, edited by Geneviève Fabre, Jürgen Heideking and Kai Dreisbach, 175-193. New York, 2001. 
-. "Migration und Internationale Beziehungen im Kaiserreich: Wilhelm II., das Auswärtige Amt und ihr Interesse an den Deutschamerikanern." Zeitschrift für Geschichtswissenschaft 63, no. 5 (2015): 413-434.

Burke, Bernard. Ambassador Frederic Sackett and the Collapse of the Weimar Republic, 19301933: The United States and Hitler's Rise to Power. New York, 1995.

Carpenter, R. Charli. "'Women, Children and Other Vulnerable Groups': Gender, Strategic Frames and the Protection of Civilians as a Transnational Issue." International Studies Quarterly 49, no.2 (2005): 295-334.

Carruth, Joseph. "World War I Propaganda and its Effects in Arkansas." The Arkansas Historical Quarterly 56, no. 4 (Winter 1997): 385-398.

Chickering, Roger. Imperial Germany and the Great War, 1914-1918. $2^{\text {nd }}$ ed. Cambridge, 2004.

Cohrs, Patrick O. "The First 'Real' Peace Settlement after the First World War: Britain, the United States and the Accords of London and Locarno 1923-1925." Contemporary European History 12, no. 1 (2003): 1-31.

Colwell, James. "The American Experience in Berlin during the Weimar Republic." PhD diss., Yale University, 1961.

Costigliola, Frank. Awkward Dominion: American Political, Economic and Cultural Relations with Europe, 1919-1933. Ithaca, NY, 1984.

-. "The United States and the Reconstruction of Germany in the 1920s." The Business History Review 50, no. 4 (1976): 477-502.

Cox, Mary Elisabeth. "'Hunger Games' or How the Allied Blockade in the First World War Deprived German Children of Nutrition, and Allied Food Aid Subsequently Saved Them." Economic History Review 68 (2015): 600-631.

-. Hunger in War \& Peace: Women and Children in Germany, 1914-1924. Oxford, 2019.

Crawford, Elisabeth. Nationalism and Internationalism in Science, 1880-1939: Four Studies of the Nobel Population. New York, 1992.

Cronenberg, Allen Thomson. "The Volksbund für das Deutschtum im Ausland: Völkisch Ideology and German Foreign Policy, 1881-1939." PhD diss., Stanford University, 1970.

Curti, Merle. American Philanthropy Abroad: A History. New Brunswick, 1963.

Dahlhaus, Friedrich. Möglichkeiten und Grenzen auswärtiger Kultur- und Pressepolitik. Dargestellt am Beispiel der deutsch-türkischen Beziehungen 1914-1928. Frankfurt am Main, 1990.

Daniel, Ute. "Die Politik der Propaganda. Zur Praxis gouvernmentaler Selbstrepräsentation vom Kaiserreich bis zur Bundesrepublik." In Propaganda. Meinungskampf, Verführung und politische Sinnstiftung 1789-1989, edited by Ute Daniel and Wolfram Siemann, 4482. Frankfurt, 1994.

David-Fox, Michael. Showcasing the Great Experiment: Cultural Diplomacy and Western Visitors to Soviet Russia, 1921-1941. New York, 2011.

Deist, Wilhelm. Flottenpolitik und Flottenpropaganda. Das Nachrichtenbureau des Reichsmarineamtes, 1897-1914. Stuttgart, 1976.

de Grazia, Victoria. Irresistible Empire: America's Advance through Twentieth-Century Europe. Cambridge, MA, 2005.

Deist, Wilhelm. Flottenpolitik und Flottenpropaganda. Das Nachrichtenbureau des Reichsmarineamtes, 1897-1914. Stuttgart, 1976.

Demm, Eberhard. "Propaganda and Caricature in the First World War." Journal of Contemporary History 28, no. 1 (1993): 163-192.

Dexheimer, Wolfgang. "Die Deutsch-amerikanischen Kulturbeziehungen seit den zwanziger Jahren." In Deutsche auswärtige Kulturpolitik seit 1871, edited by Düwell and Link, 121140.

Diem, Veronika. "Friedrich Beck (1889-1934) und die Gründungsgeschichte des Münchner Studentenwerks." In Die Universität München im Dritten Reich, edited by Elisabeth Kraus, 1:43-71. Munich, 2006. 
Dockrill, M.L. "Britain, the United States, and France and the German Settlement 19181920." In Shadow and Substance in British Foreign Policy 1895-1939, edited by B. J.C. McKercher and D. J. Moss, 203-220. Edmonton, 1984.

Döring, Herbert. Der Weimarer Kreis. Studien zum politischen Bewusstsein verfassungstreuer Hochschullehrer in der Weimarer Republik. Meisenheim am Glan, 1975.

Doerries, Reinhard. Washington, Berlin 1908/1917. Die Tätigkeit des Botschafters Johann Heinrich Graf von Bernstorff in Washington vor dem Eintritt der Vereinigten Staaten von Amerika in den Ersten Weltkrieg. Düsseldorf, 1975.

-. "Promoting Kaiser and Reich: Imperial German Propaganda in the United States during World War I." In Confrontation and Cooperation, edited by Schröder, 135-166.

-. "Imperial Berlin and Washington: New Light on Germany's Foreign Policy and America's Entry into World War I." Central European History 11, no. 1 (March 1978): 23-49.

Dhondt, Pieter. "Introduction. University History Writing: More than a History of Jubilees?" In University Jubilees and University History Writing. A Challenging Relationship, edited by Pieter Dhondt, 1-17. Leiden, 2015.

Dorpalen, Andreas. "American Isolationism and German Foreign Policy During the Weimar Era." In Deutschland und die USA, 1918-1933, 44-52. Braunschweig, 1968.

Doß, Kurt. Das deutsche Auswärtige Amt im Übergang vom Kaiserreich zur Weimarer Republik. Die Schülersche Reform. Düsseldorf, 1977.

-. "Vom Kaiserreich zur Weimarer Republik. Das deutsche diplomatische Korps in einer Epoche des Umbruchs." In Das Diplomatische Korps 1871-1945, edited by Klaus Schwabe, 81-100. Boppard am Rhein, 1982.

Dubosclard, Alain. "Diplomatie culturelle et propagande françaises aux États-Unis pendant le premier vingtième siècle." Revue d'Histoire Moderne et Contemporaine 48 (2001): 102119.

Drewek, Peter. "Limits of Educational Internationalism - Foreign Students at German Universities Between 1890 and 1930." Bulletin of the German Historical Institute 27 (2000): $39-63$.

Duff, John B. "German-Americans and the Peace, 1918-1920." American Jewish Historical Quarterly 59, no.4 (June 1970): 424-444.

Düwell, Kurt. Deutschlands auswärtige Kulturpolitik, 1918-1932. Grundlinien und Dokumente. Cologne, 1976.

Düwell, Kurt, and Werner Link, eds. Deutsche auswärtige Kulturpolitik seit 1871. Cologne, 1981.

-. "Der Einfluss des deutschen technischen Schul- und Hochschulwesens auf das Ausland (1870-1930)." Zeitschrift für Kulturaustausch 31 (1981): 80-95.

-. "Die Gründung der Kulturpolitischen Abteilung im Auswärtigen Amt 1919/20 als Neuansatz." In Deutsche auswärtige Kulturpolitik seit 1871, edited by Düwell and Link, 46-61.

Elz, Wolfgang. "Die Weimarer Republik und ihre Außenpolitik: Ein Forschungs- und Literaturbericht." Historisches Jahrbuch 119 (1999): 307-375.

Endy, Christopher. “Travel and Power: Americans in Europe, 1890-1917." Diplomatic History 22 (Fall 1998): 565-594.

-. Cold War Holidays: American Tourism in France. Chapel Hill, NC, 2003.

Erdmann, Karl Dietrich. "Deutschland, Rapallo und der Westen." Vierteljahreshefte für Zeitgeschichte 11, no. 2 (1963): 105-165.

Ermarth, Michael. "Hyphenation and Hyper-Americanization: Germans of the Wilhemine Reich View German-Americans, 1890-1914." Journal of American Ethnic History 21, no. 2 (2002): 33-58.

Etheridge, Brian C. Enemies to Allies: Cold War Germany and American Memory. Lexington, KY, 2016.

Evans (=Tworek), Heidi. “'The Path to Freedom' Transocean and German Wireless Telegraphy, 1914-1922." Historical Social Research 35, no. 1 (2010): 209-233. 
Eversdijk, Nicole. Kultur als politisches Werbemittel. Ein Beitrag zur deutschen kultur- und pressepolitischen Arbeit in den Niederlanden während des 1. Weltkrieges. Münster, 2010.

Fahlbusch, Michael. "Wo der Deutsche ist, ist Deutschland!" Die Stiftung für deutsche Volksund Kulturbodenforschung in Leipzig 1920-1933. Bochum, 1994.

Feldman, Gerald D. "Welcome to Germany? The Fremdenplage in the Weimar Inflation." In Geschichte als Aufgabe, edited by Wilhelm Treue, 629-650. Berlin, 1988.

Fiebig-von Hase, Ragnhild. Lateinamerika als Konfliktherd der deutsch-amerikanischen Beziehungen, 1890-1903. 2 vols. Göttingen, 1986.

-. "Die politische Funktionalisierung der Kultur: Der deutsch-amerikanische Professorenaustausch 1904-1914." In Zwei Wege in die Moderne: Aspekte der deutsch-amerikanischen Beziehungen 1900-1918, edited by Ragnhild Fiebig-von Hase and Jürgen Heideking, 45-88. Trier, 1997.

Finkelmann, Paul. “The War on German Language and Culture, 1917-1925.” In Confrontation and Cooperation, edited by Schröder, 177-206.

Fleck, Christian. Transatlantische Bereicherungen. Zur Erfindung der empirischen Sozialforschung. Berlin, 2007.

Forman, Paul. "Scientific Internationalism and the Weimar Physicists: The Ideology and Its Manipulation in Germany after World War I." Isis 64, no. 2 (1973): 150-180.

Fraenkel, Ernst, ed. Amerika im Spiegel des deutschen politischen Denkens. Cologne, 1959.

Freitag, Christian. "Die Entwicklung der Amerikastudien in Berlin bis 1945 unter Berücksichtigung der Amerikaarbeit staatlicher und privater Organisationen." PhD diss., Free University Berlin, 1977.

Friedman, Lawrence J., and Mark D. McGarvie, eds. Charity, Philanthropy and Civility in American History. Cambridge, 2003.

Frye, Alton. Nazi Germany and the American Hemisphere. New Haven, CT, 1967.

Fuchs, Eckhardt. "Schriftenaustausch, Copyright und Dokumentation: Das Buch als Medium der internationalen Wissenschaftskommunikation vor dem Ersten Weltkrieg unter besonderer Berücksichtigung Deutschlands und der Vereinigten Staaten von Amerika." Leipziger Jahrbuch zur Buchgeschichte 7 (1997): 125-168.

-. "Wissenschaftsinternationalismus in Kriegs- und Krisenzeiten: Zur Rolle der USA bei der Reorganisation der internationalen scientific community, 1914-1925." In Wissenschaft und Nation in der europäischen Geschichte. Universalistischer Anspruch und nationale Identitätsbildung im europäischen Vergleich, edited by Ralph Jessen and Jakob Vogel, 263-284. Frankfurt, 2002.

-. "Das Deutsche Reich auf den Weltausstellungen vor dem Ersten Weltkrieg." Comparativ 5, no. 6 (1999): 61-88.

Fulwider, Chad. "The Kaiser's Most Loyal Subjects? The German View of America and German-Americans during World War I." PhD diss., Emory University, 2008.

-. German Propaganda and U. S. Neutrality in World War I. Columbia, MO, 2016.

Füssl, Karl-Heinz. Deutsch-Amerikanischer Kulturaustausch im 20. Jahrhundert. Bildung Wissenschaft - Politik. Frankfurt, 2004.

Gassert, Philipp. "Amerikanismus, Antiamerikanismus, Amerikanisierung. Neue Literatur zur Sozial-, Wirtschafts- und Kulturgeschichte des amerikanischen Einflusses in Deutschland und Europa." Archiv für Sozialgeschichte 39 (1999): 531-556.

-. Amerika im Dritten Reich. Ideologie, Propaganda und Volksmeinung 1933-1945. Stuttgart, 1997.

Gay, Peter. Weimar Culture: The Outsider as Insider. New York, 1968.

-. Die Republik der Außenseiter. Geist und Kultur in der Weimarer Zeit, 1918-1933. Frankfurt, 1970.

Geitz, Henry, Jürgen Heidenking, and Jurgen Herbst, eds. German Influences on Education in the United States to 1917. New York, 1995.

Gemelli, Guiliana, ed. American Foundations in Europe: Grant-Giving Policies, Cultural Diplomacy and Trans-Atlantic Relations, 1920-1980. Brussels, 2003. 
Geppert, Dominik. Pressekriege: Öffentlichkeit und Diplomatie in den deutsch-britischen Beziehungen. Munich, 2007.

Gerwarth, Robert. The Vanquished: Why the First World War Failed to End. New York, 2016.

Gienow-Hecht, Jessica. "Cultural Transfer." In Explaining the History of American Foreign Relations, edited by Michael Hogan and Thomas Paterson, 257-278. New York, 2004.

-. Transmission Impossible: American Journalism as Cultural Diplomacy in Postwar Germany, 1945-55. Baton Rouge, LA, 1999.

-. Sound Diplomacy: Music and Emotions in Transatlantic Relations, 1850-1920. Chicago, 2009.

-. "The Anomaly of the Cold War: Cultural Diplomacy and Civil Society since 1850." In The United States and Public Diplomacy: New Directions in Cultural and International History, edited by Kenneth Osgood and Brian Etheridge, 25-56. The Hague, 2010.

-, and Marc Dornfried, eds. Searching for a Cultural Diplomacy. New York, 2010.

Glaser-Schmidt, Elisabeth. "Von Versailles nach Berlin. Überlegungen zur Neugestaltung der deutsch-amerikanischen Beziehungen in der Ära Harding." In Liberalitas. Festschrift für Erich Angermann zum 65. Geburtstag, edited by Norbert Finzsch and Hermann Wellenreuther, 319-342. Wiesbaden, 1992.

Goebel, Michael. "Decentering the German Spirit: The Weimar Republic's Cultural Relations with Latin America." Journal of Contemporary History 44, no. 2 (2009): 221-245.

Gottwald, Robert. Die deutsch-amerikanischen Beziehungen in der Ära Stresemann. Berlin, 1965.

Graml, Hermann. Bernhard von Bülow und die deutsche Außenpolitik. Munich, 2012.

-. Zwischen Stresemann und Hitler. Die Außenpolitik der Präsidialkabinette Brüning, Papen und Schleicher. Munich, 2001.

Greenberg, Udi. Weimar Century: German Emigres and the Ideological Foundations of the Cold War. Princeton, NJ, 2014.

Gross, Stephen G. Export Empire: German Soft Power in Southeastern Europe, 1890-1945. Cambridge, UK, 2015.

Gruber, Carol S. Mars and Minerva: World War I and the Uses of Higher Learning in America. Baton Rouge, LA, 1975.

Grupp, Peter. Deutsche Außenpolitik im Schatten von Versailles 1918-1920: zur Politik des Auswärtigen Amts vom Ende des Ersten Weltkriegs und der Novemberrevolution bis zum Inkrafttreten des Versailler Vertrags. Paderborn, 1988.

-. "Voraussetzungen und Praxis deutscher amtlicher Kulturpropaganda in den neutralen Staaten während des Ersten Weltkrieges." In Der erste Weltkrieg: Wirkung, Wahrnehmung und Analyse, edited by Wolfgang Michalka, 799-825. Munich, 1994.

-. "Harry Graf Kessler und das Auswärtige Amt. Funktionselite und elitärer Außenseiter." In Eliten in Deutschland und Frankreich im 19. Und 20 Jahrhundert. Strukturen und Beziehungen, Vol. 1, edited by Rainer Hudemann and Georges-Henri Soutou, 293-302. Munich, 1994.

Gründer, Horst. Walter Simons als Staatsmann, Jurist und Kirchenpolitiker. Neustadt an der Aisch, 1975.

Grundmann, Siegfried. Einsteins Akte. Einsteins Jahre in Deutschland aus der Sicht der deutschen Politik. Berlin, 1998.

Grüttner, Michael, et al., eds. Geschichte der Universität unter den Linden. Vol.2, Die Berliner Universität zwischen den Weltkriegen. Berlin, 2012.

Grüttner, Michael. "Nachkriegszeit." In Geschichte der Universität unter den Linden, edited by Grüttner et al., 2:5-65.

-. "Studentenschaft in Demokratie und Diktatur." In Geschichte der Universität unter den Linden, edited by Grüttner et al., 2:187-294.

Gullace, Nicoletta. "Allied Propaganda and World War I: Interwar Legacies, Media Studies and the Politics of War Guilt." History Compass 9, no. 9 (2011): 686-700. 
Hahn, Eric. J. C. "The German Foreign Ministry and the Question of War Guilt in 19181919." In German Nationalism and the European Response 1890-1945, edited by Carole Fink and Isabel Hull, 43-70. London, 1985.

Halpern, Stephen Mark. "The Institute of International Education: A History." PhD diss., Columbia University, 1969.

Hammerstein, Notker. Die Deutsche Forschungsgemeinschaft in der Weimarer Republik und im Dritten Reich. Wissenschaftspolitik in Republik und Diktatur, 1920-1945. Munich, 1999.

Hanna, Martha. The Mobilization of Intellect: French Scholars and Writers during the Great War. Cambridge, 1996.

Hardtwig, Wolfgang, ed. Politische Kulturgeschichte der Zwischenkriegszeit 1918-1939. Göttingen, 2005.

Harp, Stephen L. Marketing Michelin: Advertising and Cultural Identity in Twentieth-Century France. Baltimore, 2001.

Hart, Justin. Empire of Ideas: The Origins of Public Diplomacy and the Transformation of U.S. Foreign Policy. New York, 2013.

Harvolk, Edgar. Eichenzweig und Hakenkreuz. Die Deutsche Akademie in München (19241962) und ihre volkskundliche Sektion. Cologne, 1990.

Hausmann, Frank-Rutger. Anglistik und Amerikanistik im Dritten Reich. Frankfurt, 2003.

-. Ernst Wilhelm Bohle. Gauleiter im Dienst von Partei und Staat. Berlin, 2009.

Heinemann, Ulrich. Die verdrängte Niederlage: Politische Öffentlichkeit und Kriegsschuldfrage in der Weimarer Republik. Göttingen, 1983.

Helbich, Wolfgang. Amerika ist ein freies Land ... Auswanderer schreiben nach Deutschland. Darmstadt, 1985.

Herwig, Holger. "Clio Deceived: Patriotic Self-Censorship in Germany after the Great War." International Security 12, no. 2 (1987): 5-44.

He $\beta$, Jürgen C. 'Das ganze Deutschland soll es sein'. Demokratischer Nationalismus in der Weimarer Republik am Beispiel der Deutschen Demokratischen Partei. Stuttgart, 1978.

Hiden, John. "The Weimar Republic and the Problem of Auslandsdeutsche." Journal of Contemporary History 12 (1977): 273-289.

Hillgruber, Andreas. "'Revisionismus': Kontinuität und Wandel in der Außenpolitik der Weimarer Republik." Historische Zeitschrift 237, no. 3 (Dec 1983): 597-621.

Hoenicke-Moore, Michaela. Know Your Enemy: The American Debate on Nazism, 1933-1945. New York, 2010.

Hoffmann, Christhard. "Eduard Meyers England- und Amerikabild." Wissenschaftliche Zeitschrift der Humboldt-Universität zu Berlin. Reihe Geistes- und Sozialwissenschaften 40 (1991): 45-53.

Holborn, Hajo. "Diplomats and Diplomacy in the Early Weimar Republic." In The Diplomats, 1919-1939, edited by Gordan A. Craig and Felix Gilbert, 123-171. Princeton, 1953.

Horne, John. "Demobilizing the Mind: France and the Legacy of the Great War, 1919-1939." French History \& Civilization 2 (2009): 101-119.

-. "Kulturelle Demobilmachung 1919-1939. Ein sinnvoller historischer Begriff?" In Politische Kulturgeschichte der Zwischenkriegszeit, edited by Hardtwig, 129-150.

Hunter, Robert F. “'Tourism Empire': The Thomas Cook \& Son Enterprise on the Nile, 18681914." Middle Eastern Studies 40, no. 5 (2004): 28-54.

Impekoven, Holger. Die Alexander von Humboldt-Stiftung und das Ausländerstudium in Deutschland 1925-1945. Bonn, 2013.

Irish, Tomás. "From International to Interallied: Transatlantic University Relations in the Era of the First World War, 1905-1920." Journal of Transatlantic Studies 13, no. 4 (2015): 311-325.

-. The University at War, 1914-1925. Britain, France and the United States. London, 2015.

-. "Peace through History? The Carnegie Endowment for International Peace's Inquiry into European Schoolbooks, 1921-1924." History of Education 45, no. 1 (2016): 38-56. 
-. "The Moral Basis of Reconstruction? Humanitarianism, Intellectual Relief and the League of Nations, 1918-1925." Modern Intellectual History 17, no. 3 (2020): 769-800.

Iriye, Akira. "Culture and Power: International Relations as Intercultural Relations." Diplomatic History 3, no. 2 (1979): 115-128.

-. "Culture." The Journal of American History 77, no. 1 (1990): 99-107.

Jacobsen, Hans Adolf. Nationalsozialistische Außenpolitik, 1933-1938. Frankfurt, 1968.

-. "Auswärtige Kulturpolitik als Geistige Waffe. Karl Haushofer und die Deutsche Akademie [1923-1937]." In Deutsche auswärtige Kulturpolitik seit 1871, edited by Düwell and Link, 218-256.

-, and Arthur L. Smith. The Nazi Party and the Foreign Office. New York, 2007.

Jähnicke, Burkhard. Washington und Berlin zwischen den Kriegen. Die Mixed Claims Commission in den transatlantischen Beziehungen. Baden-Baden, 2003.

Jansen, Christian. "Auf dem Mittelweg von rechts. Akademische Ideologie und Politik zwischen 1914 und 1933." In Auch eine Geschichte der Universität Heidelberg, edited by Karin Buselmeier, Dietrich Harth and Christian Jansen, 163-193. Mannheim, 1985.

-. Professoren und Politik. Politisches Denken und Handeln der Heidelberger Hochschullehrer 1914-1935. Göttingen, 1992.

Jarausch, Konrad. "American Students in Germany, 1815-1914." In German Influences on Education in the United States to 1917, edited by Henry Geitz, Jürgen Heidenking and Jurgen Herbst, 195-211. New York, 1995.

Joeres, Niels. "Architekt von Rapallo, Der deutsche Diplomat Ago Maltzan im Kaiserreich und in der frühen Weimarer Republik." PhD diss., Universität Heidelberg, 2005.

Johnson, Niel M. George Sylvester Viereck: German-American Propagandist. DeKalb, IL, 1972.

Johnson, Charles T. Culture at Twilight: The National German-American Alliance, 1901-1918. New York, 1999.

Jonas, Manfred. The United States and Germany: A Diplomatic History. Ithaca, NY, 1984.

Jungblut, Peter. "Unter vier Reichskanzlern. Otto Hammann und die Pressepolitik der deutschen Reichsleitung 1890 bis 1916." In Propaganda. Meinungskampf, Verführung und politische Sinnstiftung 1789-1989, edited by Ute Daniel and Wolfram Siemann, 101-116. Frankfurt, 1994.

Junker, Detlef. "Jacob Gould Schurman, die Universität Heidelberg und die deutsch-amerikanischen Beziehungen." In Semper Apertus. Sechshundert Jahre Ruprecht-Karls-Universität Heidelberg, edited by Wilhelm Doerr, 1386-1986, 3:328-358. Berlin, 1985.

-. "Continuity of Ambivalence: German Views of America." In Transatlantic Images and Perceptions, edited by Barclay and Glaser-Schmidt, 243-263.

-. Der unteilbare Weltmarkt. Das ökonomische Interesse in der Außenpolitik der USA 19331941. Stuttgart, 1975.

-. Kampf um die Weltmacht. Die USA und das Dritte Reich, 1933-1945. Düsseldorf, 1988.

Kaiser, Wolfram. "The Great Derby Race: Strategies of Cultural Representation at Nineteenth-Century World Exhibitions." In Culture and International History, edited by Jessica Gienow-Hecht and Frank Schumacher, 45-59. New York, 2003.

Kathe, Steffen. Kulturpolitik um jeden Preis. Die Geschichte des Goethe-Instituts 1951 bis 1990. Cologne, 2005.

Kazal, Russell. "Becoming 'Old Stock'. The Waning of German-American Identity in Philadelphia, 1900-1930." Phd diss., University of Pennsylvania, 1998.

Keene, Jennifer. "A 'Brutalizing' War? The USA after the First World War." Journal of Contemporary History 50, no. 1 (2015): 78-99.

Keitz, Christine. Reisen als Leitbild. Die Entstehung des modernen Massentourismus in Deutschland. Cologne, 1997.

-. "Grundzüge einer Sozialgeschichte des Tourismus in der Zwischenkriegszeit." In Reisekultur in Deutschland. Von der Weimarer Republik zum 'Dritten Reich', edited by Peter Brenner, 49-71. Tübingen, 1997.

Keller, Phyllis. States of Belonging: German-Americans and the First World War. Boston, 1980. 
Kellermann, Henry. Cultural Relations as an Instrument of U.S. Foreign Policy. Washington, DC, 1978.

Kevles, Daniel J. "George Ellery Hale, the First World War and the Advancement of Science in America." Isis 59, no. 4 (Winter 1968): 427-437.

-. "Into Hostile Political Camps': The Reorganization of International Science in World War I." Isis 62, no. 1 (1971): 47-60.

Keylor, William R. "Versailles and International Diplomacy." In The Treaty of Versailles: A Reassessment after 75 Years, edited by Manfred Boemeke, Gerald Feldman, and Elisabeth Glaser, 469-505. New York, 1998.

-. "How They Advertised France: The French Propaganda Campaign during the Breakup of the Franco-American Entente, 1918-1923." Diplomatic History 17, no. 3 (1993): 351-373.

Kießling, Friedrich. "(Welt-)Öffentlichkeit." In Dimensionen internationaler Geschichte, edited by Jost Dülffer and Wilfried Loth, 85-105. Cologne, 2012.

-, and Gregor Schöllgen, eds. Bilder für die Welt. Die Reichsparteitage der NSDAP im Spiegel der ausländischen Presse. Cologne, 2006.

-. "Das Paradox der Geheimdiplomatie. Offizielle Außenpolitik und Öffentlichkeit vor 1914." In Außenpolitik im Medienzeitalter, edited by Bösch and Hoeres, 73-94.

Kipphan, Klaus. Deutsche Propaganda in den Vereinigten Staaten 1933-1941. Heidelberg, 1971.

Kind-Kovacs, Friederike. "The Great War, the Child's Body and the American Red Cross." European Review of History 23 (2016): 33-62.

Kirchhoff, Jochen. "Die forschungspolitischen Schwerpunktlegungen der Notgemeinschaft der deutschen Wissenschaft, 1925-1929, im transatlantischen Kontext. Überlegungen zur vergleichenden Geschichte der Wissenschaftsorganisation." In Wissenschafsfördernde Institutionen in Deutschland, edited by Rüdiger vom Bruch and Eckart Henning, 70-86. Berlin, 1999.

Kirschbaum, Erik. The Eradication of German Culture in the United States 1917-1918. Stuttgart, 1986.

Klautke, Egbert. Unbegrenzte Möglichkeiten. Amerikanisierung in Deutschland und Frankreich 1900-1933. Stuttgart, 2003.

-. "Anti-Americanism in Twentieth-Century Europe." Historical Journal 54, no. 4 (2011): $1125-1139$.

Klingemann, Carsten. "Das 'Institut für Sozial- und Staatswissenschaften' an der Universität Heidelberg zum Ende der Weimarer Republik und während des Nationalsozialismus." Jahrbuch für Soziologiegeschichte 1990: 79-120.

Kloosterhuis, Jürgen. Friedliche Imperialisten. Deutsche Auslandsvereine und auswärtige Kulturpolitik, 1906-1918. Frankfurt, 1994.

-. "Deutsche auswärtige Kulturpolitik und ihre Trägergruppen vor dem Ersten Weltkrieg." In Deutsche auswärtige Kulturpolitik seit 1871, edited by Düwell and Link, 7-36.

Klotzsche, Mario. "Die 'akademische Ausländerfrage' in den Hochschulnachrichten. Ein Beitrag zur Untersuchung des öffentlichen Diskurses über Fremde an deutschen Hochschulen vor dem 1. Weltkrieg." In Universitäten als Brücken in Europa, edited by Harmut Rüdiger Peter and Natalia Tikhonov, 195-212. Frankfurt, 2003.

Korenblat, Steven D. "A School for the Republic? Cosmopolitans and Their Enemies at the Deutsche Hochschule für Politik, 1920-1933." Central European History 39 (2006): 394430.

Koshar, Rudy. "What Ought to Be Seen. Tourists' Guidebooks and National Identities in Modern Germany and Europe." Journal of Contemporary History 33, no. 3 (July 1998): 323-340.

Koszyk, Kurt. Gustav Stresemann. Der kaisertreue Demokrat. Eine Biographie. Cologne, 1989.

Kotowski, Mathias. Die öffentliche Universität. Veranstaltungskultur der Eberhard-Karls-Universität Tübingen in der Weimarer Republik. Stuttgart, 1999.

Krakau, Knud. "Einführende Überlegungen zur Entstehung und Wirkung von Bildern, die sich Nationen von sich und anderen machen." In Deutschland und Amerika. Perzeption 
und historische Realität, edited by Willi Paul Adams and Knud Krakau, 9-18. Berlin, 1985.

Kramer, Paul. "Is the World Our Campus? International Students and U.S. Global Power in the Long Twentieth Century." Diplomatic History 33, no. 5 (2009): 775-806.

Krekeler, Norbert. Revisionsanspruch und geheime Ostpolitik der Weimarer Republik. Die Subventionierung der deutschen Minderheit in Polen 1919-33. Stuttgart, 1973.

Krige, John, and Helke Rausch. American Foundations and the Coproduction of World Order in the Twentieth Century. Göttingen, 2012.

Krüger, Peter. "Struktur, Organisation und außenpolitische Wirkungsmöglichkeiten der leitenden Beamten des Auswärtigen Dienstes 1921-1933." In Das Diplomatische Korps 1871-1945, edited by Klaus Schwabe, 101-170. Boppard am Rhein, 1985.

-. “German Disappointment and Anti-Western Resentment, 1918-1919." In Confrontation and Cooperation, edited by Schröder, 323-336.

-. "Das Doppelte Dilemma: Die Außenpolitik der Republik von Weimar zwischen Staatensystem und Innenpolitik." German Studies Review 22, no. 2 (1999): 247-267.

-. "Die Weimarer Republik und die Geschichte ihrer internationalen Beziehungen: Notizen zu einer Gratwanderung mit Wegscheiden." Historische Zeitschrift 273, no. 3 (2001): 675688.

-. Carl von Schubert. Außenpolitiker aus Leidenschaft. Sein Beitrag zur internationalen Politik und europäischen Ordnung in der Ära der Weimarer Republik. Berlin, 2017.

-, ed. Carl von Schubert (1882-1947). Sein Beitrag zur internationalen Politik und europäischen Ordnung in der Ära der Weimarer Republik. Ausgewählte Dokumente. Berlin, 2017.

Krumeich, Gerd. "Versailles 1919. Der Krieg in den Köpfen." In Versailles 1919. ZieleWirkung-Wahrnehmung, edited by Gerd Krumeich. Essen, 2001, 53-64.

-. "Ernest Lavisse und die Kritik an der deutschen 'Kultur', 1914-1918." In Kultur und Krieg, edited by Mommsen, 143-154.

Kuehl, Warren F., and Lynn K. Dunn. Keeping the Covenant: American Internationalists and the League of Nations, 1920-1939. Kent, 1997.

Kuisel, Richard. Seducing the French: The Dilemma of Americanization. Los Angeles, 1993.

Kunczik, Michael. Geschichte der Öffentlichkeitsarbeit in Deutschland. Cologne, 1997.

-. "British and German Propaganda in the United States from 1914-1917." In Propaganda in the $20^{\text {th }}$ Century: Contributions to its History, edited by Jürgen Wilke, 25-51. New York, 1998.

Kupsky, Gregory. “The True Spirit of the German People’: German Americans and National Socialism, 1919-1955." PhD diss., Ohio State University, 2010.

-. "Gustav Oberlaender." In Immigrant Entrepreneurship: German-American Business Biographies, 1720 to the Present. Vol. 4, 1918-1945: The Age of the World Wars, edited by Jeffrey Fear. German Historical Institute. http://www.immigrantentrepreneurship.org/entry. php?rec $=56$

Lang, Reuben Clarence. "Die Meinung in den USA über Deutschland im Jahr des Ruhrkampfes und des Hitlerputsches." Saeculum 17 (1966): 402-416.

Laitenberger, Volkhard. Akademischer Austausch und Auswärtige Kulturpolitik, 1923-1945. Göttingen, 1976.

-. "Organisations- und Strukturprobleme der auswärtigen Kulturpolitik und des akademischen Austauschs in den 20er und 30er Jahren." In Deutsche auswärtige Kulturpolitik seit 1871, edited by Düwell and Link, 72-96.

Laqua, Daniel, ed. Internationalism Reconfigured: Transnational Ideas and Movements between the World Wars. London, 2011.

-. "Activism in the 'Students' League of Nations' International Student Politics and the Confédération Internationale des Étudiants, 1919-1939." The English Historical Review 132, no. 556 (2017): 605-637.

Larsen, Daniel. "Abandoning Democracy: Woodrow Wilson and Promoting German Democracy, 1918-1919." Diplomatic History 37, no. 3 (2013): 476-508. 
Lebzelter, Gisela. "Schwarze Schmach. Vorurteile-Propaganda-Mythos." Geschichte und Gesellschaft 11 (1985): 27-58.

Leffler, Melvyn. The Elusive Quest: America's Pursuit of European Stability and French Security, 1919-1933. Chapel Hill, NC, 1979.

Lehmkuhl, Ursula. "Diplomatiegeschichte als internationale Kulturgeschichte: Ansätze, Methoden und Forschungsergebnisse zwischen historischer Kulturwissenschaft und soziologischem Institutionalismus." Geschichte und Gesellschaft 27, no. 3 (2001): 394-423.

Lerg, Charlotte. Universitätsdiplomatie. Wissenschaft und Prestige in den transatlantischen Beziehungen, 1890-1920. Göttingen, 2019.

-. "Die Ehrendoktorwürde im Dienste der transatlantischen Diplomatie. Politische Dimensionen einer akademischen Praxis im 20. Jahrhundert." In Akademische Wissenskulturen. Praktiken des Lehrens und Forschens vom Mittelalter bis zur Moderne, edited by Martin Kintzinger and Sita Steckel, 301-322. Basel, 2015.

-. "Uses and Abuses of the First German-American Professorial Exchange, 1905-1914." In German-American Educational History: Topics, Trends, Fields of Research, edited by Anne Overbeck and Jürgen Overhoff, 63-80. Bad Heilbrunn, 2017.

Levenstein, Harvey. Seductive Journey: American Tourists in France from Jefferson to the Jazz Age. Chicago, 1998.

Levine, David. The American College and the Culture of Aspiration, 1915-1940. Ithaca, NY, 1998.

Levine, Emily. "Baltimore Teaches, Göttingen Learns: Cooperation, Competition, and the Research University." American Historical Review 121, no. 3 (2016): 780-823.

Lincove, David A. "The British Library of Information in New York: A Tool of British Foreign Policy, 1919-1942." Libraries and the Cultural Record 46, no. 2 (2011): 156-184.

Link, Werner. Die amerikanische Stabilisierungspolitik in Deutschland 1921-32. Düsseldorf, 1970.

Longerich, Peter. Propagandisten im Krieg. Die Presseabteilung des Auswärtigen Amtes unter Ribbentrop. Cologne, 1987.

Ludtke, Alf, Inge Marssolek, and Adelheid von Saldern, eds. Amerikanisierung. Traum und Alptraum im Deutschland des 20. Jahrhunderts. Stuttgart, 1996.

Luebke, Frederick C. Bonds of Loyalty: German-Americans and World War I. DeKalb, IL, 1974.

-."German-American Leadership Strategies between the World Wars." In Germans in the New World: Essays in the History of Immigration, edited by Frederick Luebke, 51-78. Urbana and Chicago, 1990.

Lurz, Meinhold. "Die 550-Jahrfeier der Universität Heidelberg als nationalsozialistische Selbstdarstellung von Reich und Universität." Ruperto Carola 57 (1976): 35-41.

Luther, Tammo. Volkstumspolitik des deutschen Reiches, 1933-1938. Die Auslandsdeutschen im Spannungsfeld zwischen Traditionalisten und Nationalsozialisten. Stuttgart, 2004.

MacLeod, Roy. "Wissenschaftlicher Internationalismus in der Krise. Die Akademien der Alliierten und ihre Reaktion auf den Ersten Weltkrieg." In Die Preußische Akademie der Wissenschaften zu Berlin 1914-1945, edited by Wolfram Fischer, 317-349. Berlin, 2000.

Mai, Ekkehard. "Präsentation und Repräsentativität: Interne Probleme deutscher Kunstausstellungen im Ausland (1900-1930)." Zeitschrift für Kulturaustausch 31, no. 1 (1981): $107-123$.

Manela, Erez. The Wilsonian Moment: Self-Determination and the International Origins of Anticolonial Nationalism. New York, 2007.

Manz, Stefan. Constructing a German Diaspora: The "Greater German Empire," 1871-1914. London, 2014.

-. "Diaspora and Weltpolitik in Wilhelmine Germany." In Germans as Minorities during the First World War, edited by Panikos Panayi, 27-46. London, 2014.

Marchand, Roland. Advertising the American Dream: Making Way for Modernity, 1920-1940. Berkeley, CA, 1985. 
Marling, Karal Ann. George Washington Slept Here: Colonial Revivals and American Culture, 1876-1986. Cambridge, MA, 1988.

Marsch, Ulrich. Notgemeinschaft der Deutschen Wissenschaft. Gründung und frühe Geschichte 1920-1925. Frankfurt am Main, 1994.

Marszolek, Inge. "Der erste Nordatlantikflug von Europa nach Amerika. Transatlantische Aushandlungen über Helden, Ehre, Nation und Modernität." In Ehrregime. Akteure, Praktiken und Medien lokaler Ehrrungen in der Moderne, edited by Dietmar von Reeken and Malte Thiessen, 69-88. Göttingen, 2016.

Martin, Benjamin. The Nazi-Facist New Order for European Culture. Cambridge, MA, 2016.

Matthews, Jeffrey. Alanson B. Houghton: Ambassador of the New Era. Lanham, MD, 2004.

McKercher, B. J.C. "The British Diplomatic Service in the United States and the Chamberlain Foreign Office's Perceptions of Domestic America, 1924-1927: Images, Reality and Diplomacy." In Shadow and Substance in British Foreign Policy, 1895-1939, edited by B. J. C. McKercher and D. J. Moss, 221-247. Edmonton, 1984.

Meineke, Stefan. "Friedrich Meinecke und der 'Krieg der Geister"' In Kultur und Krieg, edited by Mommsen, 97-117.

Metzger, Chantal, Hartmut Kaelble, and Helke Rausch, eds. "Transatlantischer Kulturtransfer im 'Kalten Krieg. Perspektiven für eine historisch vergleichende Transferforschung." Special issue, Comparativ 16, no. 4 (2006).

Metzler, Gabriele. “'Welch ein deutscher Sieg!' Die Nobelpreise von 1919 im Spannungsfeld von Wissenschaft, Politik und Gesellschaft." Vierteljahreshefte für Zeitgeschichte 44, no. 2 (1996): 173-200.

Meyer, Michael. Symbolarme Republik? Das politische Zeremoniell der Weimarer Republik in den Staatsbesuchen zwischen 1920 und 1933. Frankfurt, 2014.

Michels, Eckard. "Deutsch als Weltsprache? Franz Thierfelder, the German Academy in $\mathrm{Mu}$ nich and the Promotion of the German Language Abroad, 1923-1945." German History 22 (2004): 206-228.

-. Von der Deutschen Akademie zum Goethe-Institut. Sprach- und auswärtige Kulturpolitik 1923-1960. Cologne, 2005.

Mitchell, Nancy. The Danger of Dreams: German and American Imperialism in Latin America. Chapel Hill, NC, 1999.

Mommsen, Wolfgang. "Die deutschen kulturellen Eliten im Ersten Weltkrieg." In Kultur und Krieg, edited by Mommsen, 1-15.

Mommsen, Wolfgang, ed. Kultur und Krieg: Die Rolle der Intellektuellen, Künstler und Schriftsteller im Ersten Weltkrieg. Cologne, 1996.

Moritz, Werner. "Außenbeziehungen der Universität." In Die Universität Heidelberg im Nationalsozialismus, edited by Wolfgang Eckard, Volker Sellin, Eike Wolgast, 147-172. Berlin, 2006.

Moser, John E. Twisting the Lion's Tail: Anglophobia in the United States, 1921-1948. London, 1999.

Moser, Maynard. "Jacob Gould Schurman." PhD diss., University of California, Santa Barbara, 1976.

Müller, Carmen. Weimar im Blick der USA. Amerikanische Auslandskorrespondenten und öffentliche Meinung zwischen Perzeption und Realität. Münster, 1997.

Müller, Hans Jürgen. Auswärtige Pressepolitik und Propaganda zwischen Ruhrkampf und Locarno, 1923-1925. Eine Untersuchung über die Rolle der Öffentlichkeit in der Außenpolitik Stresemanns. Frankfurt am Main, 1991.

Müller, Manfred. "Nationalsozialistische Einflüsse auf die Vorbereitung und den Ablauf der Reichsgedächtnisfeier für Goethe 1932 in Weimar." Zeitschrift für Germanistik 14, no. 3 (2004): 608-613.

Nagler, Jörg. "From Culture to Kultur: Changing American Perceptions of Imperial Germany, 1870-1914." In Transatlantic Images and Perceptions, edited by Barclay and Glaser-Schmidt, 131-154. 
-. Nationale Minoritäten im Krieg: "Feindliche Ausländer" und die amerikanische Heimatfront während des Ersten Weltkrieges. Hamburg, 2000.

Nagy, Zsolt. "National Identities for Export: East European Cultural Diplomacy in Inter-War Pittsburgh." Contemporary European History 20, no. 4 (2011): 435-453.

Neiberg, Michael. "Blinking Eyes Began to Open: Legacies from America’s Road to the Great War, 1914-1917.” Diplomatic History 38, no. 4 (Sep. 2014): 801-812.

Neizert, Dieter. "Das Amt' zwischen Versailles und Rapallo. Die Rückschau des Staatssekretärs Ernst von Simson." Vierteljahreshefte für Zeitgeschichte 60, no. 3 (2012): 443-490.

Nelson, Keith. "Black Horror on the Rhine. Race as a Factor in Post-World War I Diplomacy." Journal of Modern History 42, no. 4 (1970): 606-627.

-. Victors Divided: America and the Allies in Germany, 1918-1923. Berkeley, CA, 1975.

Niedhart, Gottfried. Die Außenpolitik der Weimarer Republik. $2^{\text {nd }}$ ed. Cologne, 2006.

Nielson, Jonathan M. "The Scholar as Diplomat: American Historians at the Paris Peace Conference of 1919." International History Review 14, no. 2 (1992): 228-251.

Ninkovich, Frank. The Diplomacy of Ideas: U.S. Foreign Policy and Cultural Relations, 19381950. Cambridge, 1981.

-. Global Dawn: The Cultural Foundation of American Internationalism, 1865-1890. Boston, 2010.

Nolan, Mary. Visions of Modernity: American Business and the Modernization of Germany. New York, 1994.

-. The Transatlantic Century: Europe and America, 1890-2010. New York, 2012.

Norton, Donald. "Karl Haushofer and the German Academy, 1925-1945." Central European History 1, no. 1 (1968): 80-99.

Norton, Robert E. "Wilamowitz at War." International Journal of the Classical Tradition 15, no. 1 (2008): 74-97.

Norwood, Stephen H. The Third Reich in the Ivory Tower: Complicity and Conflict on American Campuses. New York, 2009.

-. "Legitimating Nazism: Harvard University and the Hitler Regime, 1933-1937." American Jewish History 92, no. 2 (2004): 189-223.

Nottmeier, Christian. Adolf von Harnack und die deutsche Politik 1890-1930. Eine biographische Studie zum Verhältnis von Protestantismus, Wissenschaft und Politik. Tübingen, 2004.

O'Brien, Phillips Payson. "The American Press, Public, and the Reaction to the Outbreak of the First World War." Diplomatic History 37, no. 3 (2013): 446-475.

Offner, Arnold. American Appeasement: United States Foreign Policy and Germany, 19331938. Cambridge, MA, 1969.

-."The United States and National Socialist Germany." The Fascist Challenge and the Policy of Appeasement, edited by Wolfgang Mommsen and Lothar Kettenacker, 413-427. London, 1983.

-. "Research on American-German Relations: A Critical View." In America and the Germans, edited by Trommler and McVeigh, 1:168-182. Philadelphia, 1985.

Orgill, Nathan. “Three and a Half Men': The Buelow-Hammann System of Public Relations before the First World War." PhD diss. Duke University, 2009.

Osgood, Kenneth, and Brian C. Etheridge, eds. The United States and Public Diplomacy: New Directions in Cultural and International History. Leiden, 2010.

Paletschek, Sylvia. "Tübinger Hochschullehrer im Ersten Weltkrieg: Kriegserfahrungen an der 'Heimatfront' Universität und im Feld." In Kriegserfahrungen. Studien zur Sozial- und Mentalitätsgeschichte des Ersten Weltkriegs, edited by Gerhard Hirschfeld, Gerd Krumeich, Dieter Langewiesche, and Hans-Peter Ullmann, 83-106. Essen, 1997.

-. "Was heißt 'Weltgeltung deutscher Wissenschaft'? Modernisierungsleistungen und -defizite der Universitäten im Kaiserreich." In Gebrochene Wissenschaftskulturen. Universität und Politik im 20. Jahrhundert, edited by Michael Grüttner, Rüdiger Hachtmann, Konrad H. Jarausch, Jürgen John, and Matthias Middell, 29-54. Göttingen, 2010. 
Patel, Kiran. Soldiers of Labor: Labor Service in Nazi Germany and New Deal America, 19331945. New York, 2005.

Paulmann, Johannes, ed. Auswärtige Repräsentationen. Deutsche Kulturpolitik nach 1945. Cologne, 2005.

Paulus, Stefan. Vorbild USA? Amerikanisierung von Universität und Wissenschaft in Westdeutschland 1945-1976. Cologne, 2010.

Perkins, Bradford. The Great Rapprochement: England and the United States, 1895-1914. New York, 1968.

Peter, Hartmut Rüdiger. "Politik und Akademisches Ausländerstudium 1905-1913. Preußisches Beispiel und sächsisch-badische Variationen." In Universitäten als Brücken in Europa, edited by Harmut Rüdiger Peter and Natalia Tikhonov, 175-194. Frankfurt, 2003.

Piller, Elisabeth. "German Child Distress, American Humanitarian Aid and Revisionist Politics, 1918-1924." Journal of Contemporary History 51, no. 3 (2016): 453-486.

-. "European Student Relief, Humanitarianism, and Post-World War I Reconciliation." In Online Atlas on the History of Humanitarianism and Human Rights, edited by Fabian Klose, Marc Palen, Johannes Paulmann, and Andrew Thompson, urn:nbn:de:0159-2019042427

-. "The Transatlantic Dynamics of European Cultural Diplomacy: Germany, France and the Battle for U.S. Affections In the 1920s." Contemporary European History, forthcoming 2021.

Plumpe, Werner. Carl Duisberg, 1861-1935. Anatomie eines Industriellen. Cologne, 2016.

Pommerin, Rainer. Der Kaiser und Amerika. Die USA in der Politik der Reichsleitung 18901914. Cologne, 1986.

-. "Die Gründung des Germanischen Museums an der Harvard Universität. Zur Geschichte deutscher Kulturpolitik in den USA unter Kaiser Wilhelm II." Archiv für Kulturgeschichte 61 (1979): 420-429.

-."Seekabel und Nachrichtenbüros. Determinanten des Deutschlandbilds im Zeitalter des Imperialismus 1871-1914." Vierteljahresschrift für Sozial- und Wirtschaftsgeschichte 73, no. 4 (1986): 520-531.

Pöppinghaus, Ernst-Wolfgang. Moralische Eroberungen? Kultur und Politik in den deutsch-spanischen Beziehungen der Jahre 1919-1933. Frankfurt, 1999.

Popp, Richard K. The Holiday Makers: Magazines, Advertising, and Mass Tourism in Postwar America. Baton Rouge, LA, 2012.

Proctor, Tammy. "An American Enterprise? British Participation in US Food Relief Programmes (1914-1923)." First World War Studies 5, no. 1 (2014): 29-42.

Rausch, Helke. "US-amerikanische 'Scientific Philanthropy' in Frankreich, Deutschland und Großbritannien zwischen den Weltkriegen." Geschichte und Gesellschaft 33, no. 1 (2007): 73-98.

Reeken, Dietmar von, and Malte Thiessen. "Ehrregime. Perspektiven, Potenziale und Befunde eines Forschungskonzepts." In Ehrregime. Akteure, Praktiken und Medien lokaler Ehrrungen in der Moderne, edited by Dietmar von Reeken and Malte Thiessen, 11-29. Göttingen, 2016.

Reiling, Johannes. Deutschland: Safe for Democracy? Deutsch-amerikanische Beziehungen aus dem Tätigkeitsbereich Heinrich F. Alberts, kaiserlicher Staatsekretär der Reichskanzlei, der Weimarer Republik, Reichsminister, Betreuer der Ford-Gesellschaften im Herrschaftsgebiet des Dritten Reiches 1914 bis 1945. Stuttgart, 1997.

Remy, Steven P. The Heidelberg Myth: The Nazification and Denazification of a German University. Cambridge, MA, 2002.

-. "We Are No Longer the University of the Liberal Age': The Humanities and National Socialism in Heidelberg." In Nazi Germany and the Humanities: How German Academics Embraced Nazism, edited by Wolfgang Bialas and Anson Rabinbach, 21-49. London, 2007.

Reinbothe, Roswitha. Deutsch als internationale Wissenschaftssprache und der Boykott nach dem Ersten Weltkrieg. Frankfurt, 2006. 
Remak, Joachim. "'Friends of the New Germany': The Bund and German-American Relations." Journal of Modern History 29, no. 1 (1957): 38-41.

Rennella, Mark, and Whitney Walton. "Planned Serendipity: American Travelers and the Transatlantic Voyage in the Nineteenth and Twentieth Centuries." Journal of Social History 38, no. 2 (2004): 365-383.

Retterath, Hans-Werner. "Deutschamerikanertum und Volkstumsgedanke. Zur Ethnizitätskonstruktion durch die auslandsdeutsche Kulturarbeit zwischen 1918 und 1945." PhD diss. Marburg University, 2000.

Richardson, Malcolm. "Philanthropy and the Internationality of Learning: The Rockefeller Foundation and National Socialist Germany." Minerva 28 (1990): 21-58.

-, ed. Weimars Transatlantischer Mäzen: Die Lincoln-Stiftung 1927-1934. Ein Versuch demokratischer Elitenförderung in der Weimarer Republik. Essen, 2008.

Rietzler, Katharina. "Before the Cultural Cold Wars: American Philanthropy and Cultural Diplomacy in the Interwar Years." Historical Research 84, no. 223 (2011): 148-164.

-. "Philanthropy, Peace Research and Revisionist Politics: Rockefeller and Carnegie Support for the Study of International Relations in Weimar Germany." In "Beyond the Nation: United States History in Transnational Perspective," edited by Thomas Adam and Uwe Luebken. Supplement 5, Bulletin of the German Historical Institute (2008): 61-79.

-. "American Foundations and the Scientific Study of International Relations in Europe, 1910-1940." PhD diss., University College London, 2009.

-. "Experts for Peace: Structures and Motivations of Philanthropic Internationalism in the Interwar Years." In Internationalism Reconfigured: Transnational Ideas and Movements Between the World Wars, edited by Daniel Laqua, 45-65. London, 2011.

Ringer, Fritz. The Decline of the German Mandarins: The German Academic Community, 1890-1933. Cambridge, MA, 1969.

Rinke, Stefan. Der Letzte Freie Kontinent. Deutsche Lateinamerikapolitik im Zeichen transnationaler Beziehungen, 1918-1933. Stuttgart, 1996.

-. Zwischen Weltpolitik und Monroe Doktrin: Botschafter Speck von Sternburg und die deutsch-amerikanischen Beziehungen, 1898-1908. Stuttgart, 1992.

Rippley, LaVern J. "Ameliorated Americanization: The Effect of World War I on German-Americans in the 1920s." In America and the Germans, edited by Trommler and McVeigh, 2:217-231.

Ritter, Gerhard A. "Internationale Wissenschaftsbeziehungen und auswärtige Kulturpolitik im deutschen Kaiserreich." Zeitschrift für Kulturaustausch 31 (1981): 5-16.

Ritter, Ernst. Das Deutsche Ausland-Institut in Stuttgart 1917-1945. Ein Beispiel deutscher Volkstumsarbeit zwischen den Weltkriegen. Wiesbaden, 1971.

Rosenberg, Emily. Spreading the American Dream: American Economic and Cultural Expansion, 1890-1945. New York, 1982.

-. "Missions to the World: Philanthropy Abroad." In Charity, Philanthropy and Civility in American History, edited by Lawrence J. Friedman and Mark D. McGarvie, 241-257. New York, 2003.

Rosendorf, Neal. "Be El Caudillo's Guest. The Franco Regime's Quest for Rehabilitation and Dollars after World War II via the Promotion of U.S. Tourism to Spain." Diplomatic History 30, no. 3 (2006): 366-406.

Roos, Julia. "Nationalism, Racism and Propaganda in Early Weimar Germany: Contradictions in the Campaign against the 'Black Horror on the Rhine." German History 30, no. 1 (2012): 45-74.

Ross, Corey. "Mass Politics and the Techniques of Leadership: The Promise and Perils of Propaganda in Weimar Germany." German History 24, no. 2 (2006): 184-211.

Ross, Steward Halsey. Propaganda for War: How the United States Was Conditioned to Fight the Great War of 1914-1918. Jefferson, NC, 1996. 
Rossini, Daniela. “Censorship in World War I: The Action of Wilson's Committee on Public Information." In Political Repression in U.S. History, edited by Cornelis van Minnen and Sylvia Hilton, 103-116. Amsterdam, 2009.

Rossol, Nadine. Performing the Nation in Interwar Germany: Sports, Spectacle and Political Symbolism, 1926-1936. London, 2010.

Rupieper, Hermann. "Alanson B. Houghton: An American Ambassador in Germany, 1922 1925." International History Review 1, no. 4 (1979): 490-508.

-. "Das amerikanische Deutschlandbild der Zwischenkriegszeit." In Deutschland und der Westen, edited by Henning Köhler, 131-139. Berlin, 1984.

Saldern, Adelheid von. "Emotions of Comparisons: Perceptions of European Anti-Americanism in US Magazines of the 1920s." In Emotions in American History: An International Assessment, edited by Jessica Gienow-Hecht, 139-157. New York, 2010.

Salewski, Michael. "Das Weimarer Revisionssyndrom." Aus Politik und Zeitgeschichte B2/80 (Jan. 1980): 14-25.

Sanders, M. L., and Philip M. Taylor. British Propaganda during the First World War, 1914-18. London, 1982.

Sanders, M.L. "Wellington House and British Propaganda during the First World War." The Historical Journal 18, no. 1 (1975): 119-146.

Saunders, Thomas J. Hollywood in Berlin: American Cinema and Weimar Germany. Berkeley, CA, 1995.

Sirois, Herbert. Zwischen Illusion und Krieg: Deutschand und die USA 1933-1941. Paderborn, 2000.

Schieder, Wolfgang, and Christoph Dipper. "Propaganda." In Geschichtliche Grundbegriffe, edited by Otto Brunner, Werner Conze, and Reinhart Koselleck. Vol. 5, Pro-Soz, 69-112. Stuttgart, 1984.

Schmidt, Alexander. Reisen in die Moderne. Der Amerika-Diskurs des deutschen Bürgertums vor dem Ersten Weltkrieg im europäischen Vergleich. Berlin, 1997.

Schmidt, Henry J. "The Rhetoric of Survival: The Germanist in America from 1900 to 1925." In America and the Germans, edited by Trommler and McVeigh, 2:204-216.

Schmidt, Oliver Matthias. "A Civil Empire by Co-option: German-American Exchange Programs as Cultural Diplomacy, 1945-1961.” PhD diss., Harvard University, 1999.

Schober, Carolin. Das Auswärtige Amt und die Kunst in der Weimarer Republik. Kunst- und Kunstgewerbeausstellungen als Mittel deutscher auswärtiger Kulturpolitik in Frankreich, Italien und Großbritannien. Frankfurt am Main, 2004.

Schoenthal, Klaus Ferdinand. "American Attitudes Toward Germany, 1918-1932." PhD diss., Ohio State University, 1959.

Schröder, Ernst, ed. Otto Wiedfeldt als Politiker und Botschafter der Weimarer Republic. Essen, 1971. Special print from Beiträge zur Geschichte von Stadt und Stift Essen 86 (1971): 159-238.

Schröder, Hans-Jürgen, ed. Confrontation and Cooperation: Germany and the United States in the Era of World War I, 1900-1924. Providence, RI, 1993.

Schröder, Hans-Jürgen. Deutschland und die Vereinigten Staaten, 1933-1939. Wirtschaft und Politik in der Entwicklung des Deutsch-Amerikanischen Gegensatzes. Wiesbaden, 1970.

-. "Das Dritte Reich und die USA." In Die USA und Deutschland, 1918-1975, edited by Manfred Knapp, Werner Linke, and Hans-Jürgen Schröder, 107-152. Cologne, 1978.

Schröder-Gudehus, Brigitte. Deutsche Wissenschaft und Internationale Zusammenarbeit. 1914-1928. Geneva, 1966.

-."Internationale Wissenschaftsbeziehungen und auswärtige Kulturpolitik, 1919-1933. Vom Boykott und Gegenboykott zu ihrer Wiederaufnahme." In Forschung im Spannungsfeld von Politik und Gesellschaft. Geschichte und Struktur der Kaiser-Wilhelm- und Max Planck-Gesellschaft, edited by Rudolf Vierhaus and Rüdiger vom Bruch, 858-885. Stuttgart, 1990. 
-. "Challenge to Transnational Loyalties: International Organizations after the First World War." Science Studies 3, no. 2 (1973): 93-118.

Schug, Alexander. "Missionare der globalen Konsumkultur. Corporate Identity und Absatzstrategien amerikanischer Unternehmen in Deutschland im frühen 20. Jahrhundert." In Politische Kulturgeschichte der Zwischenkriegszeit, edited by Hardtwig, 307-339.

Schwabe, Klaus. "Zur politischen Haltung der deutschen Professoren im 1. Weltkrieg." Historische Zeitschrift 193 (1961): 601-634.

-. Wissenschaft und Kriegsmoral. Die deutschen Hochschullehrer und die politischen Grundfragen des Ersten Weltkrieges. Göttingen, 1969.

-. Deutsche Revolution und Wilson-Frieden. Die amerikanische und deutsche Friedensstrategie zwischen Ideologie und Machtpolitik, 1918/1919. Düsseldorf, 1971.

-. Woodrow Wilson, Revolutionary Germany and Peacemaking. Chapel Hill, NC, 1985.

-. "The United States and the Weimar Republic: A 'Special Relationship' That Failed." In America and the Germans, edited by Trommler and McVeigh, 2:18-29.

-. "America's Contribution to the Stabilization of the Early Weimar Republic" In Germany and America: Essays on Problems of International Relations and Immigration, edited by Hans Trefousse, 21-28. New York, 1980.

Seckendorf, Martin. "Kulturelle Deutschtumspflege im Übergang von Weimar zu Hitler am Beispiel des deutschen Ausland-Institutes (DAI). Eine Fallstudie." In Völkische Wissenschaft. Gestalten und Tendenzen der deutschen und österreichischen Volkskunde in der ersten Hälfte des 20. Jahrhunderts, edited by Wolfgang Jacobeit, Hansjost Lixfeld, and Olaf Bockhorn, 115-135. Vienna, 1994.

Semmens, Kristin. Seeing Hitler's Germany: Tourism in the Third Reich. London, 2005.

Seng, Joachim. "Das Goethe-Jahr 1932." In Der Reichskunstwart. Kulturpolitik und Staatsinszenierung in der Weimarer Republik 1918-1933, edited by Christian Welzbacher, 196-216. Weimar, 2010.

Shore, Elliott. "The Kultur Club." In Confrontation and Cooperation, edited by Schröder, 127134.

Siebe, Daniela. Germania Docet. Ausländische Studenten, auswärtige Kulturpolitik und deutsche Universitäten. 1870-1933. Husum, 2009.

Siemann, John G. "The American Response to Weimar. Public Perception and Foreign Policy Development in the Decade of the 1920s." PhD diss., Columbia University, 1986.

Smith, Arthur L. The Deutschtum of Nazi Germany and the United States. The Hague, 1965.

Steiner, Zara. "Foreign Ministries Old and New." International Journal 37, no. 3 (1982): 349377.

-. and M.L. Dockrill. “The Foreign Office Reforms, 1919-21.” The Historical Journal 17, no. 1 (1974): 131-156.

Charles Strickland. "American Aid to Germany, 1919-1921." The Wisconsin Magazine of History 45, no. 4 (1962): 256-270.

-. "American Aid for the Relief of Germany 1919-1921." MA thesis, University of Wisconsin, 1959.

Stöckmann, Jan. "Studying the International, Serving the Nation: The Origins of International Relations Scholarship in Germany, 1912-1933." International History Review 38, no. 5 (2016): 1055-1080.

Studt, Christoph. "Ein 'geistiger Luftkurort' für deutsche Historiker. Hermann Onckens Austauschprofessur in Chicago 1905/6." Historische Zeitschrift 264 (1997): 360-389.

Syga-Dubois, Judith. Wissenschaftliche Philanthropie und transatlantischer Austausch in der Zwischenkriegszeit. Die sozialwissenschaftlichen Förderprogramme der Rockefeller Stiftungen in Deutschland. Cologne, 2019.

Taschka, Sylvia. Diplomat ohne Eigenschaften. Die Karriere des Hans-Heinrich Dieckhoff (1884-1952). Stuttgart, 2006.

Taylor, Philip M. "The Foreign Office and British Propaganda during the First World War." The Historical Journal 23, no. 4 (1980): 875-898. 
-. "The New Propaganda Boom." The International History Review 2, no. 3 (1980): 485-502.

-. The Projection of Britain, British Overseas Publicity and Propaganda 1919-1939. Cambridge, 1981.

Thompson, John A. Reformers and War. American Progressive Publicists and the First World War. Cambridge, 1987.

Trommler, Frank, and Joseph McVeigh, eds. America and the Germans: An Assessment of a Three-Hundred-Year History. 2 vols. Philadelphia, 1985.

Trommler, Frank. "Inventing the Enemy: German-American Cultural Relations, 1900-1917." In Confrontation and Cooperation, edited by Schröder, 99-126.

-. "The Lusitania Effect: America's Mobilization against Germany in World War I." German Studies Review 32, no. 2 (2009): 241-266.

-. Kulturmacht ohne Kompass. Deutsche auswärtige Kulturbeziehungen im 20. Jahrhundert. Cologne, 2013.

Tronchet, Guillaume. "Diplomatie universitaire ou diplomatie culturelle? La Cité internationale universitaire de Paris entre deux rives (1920-1940)." In La Babel étudiante. La Cité internationale universitaire de Paris (1920-1950), edited by Dzovinar Kévonian and Guillaume Tronchet, 59-88. Rennes, 2013.

Tschörtner, H.D. Gespräche und Interviews mit Gerhart Hauptmann (1894-1946). Berlin, 1994.

Tutt, Alexander David. "Ausländerbetreuung an der Universität Heidelberg, 1928-1938. Das Akademische Auslandsamt und die Vergangenheit." BA thesis, Universität Heidelberg, 2012.

Twardowski, Fritz von. Anfänge deutscher Kulturpolitik zum Ausland. Bonn/Bad Godesberg, 1970.

Tworek, Heidi. News from Germany: The Competition to Control World Communications. Cambridge, MA, 2019.

Ungern-Sternberg, Franziska von. Kulturpolitik zwischen den Kontinenten, Deutschland und Amerika. Das Germanische Museum in Cambridge, Mass. Cologne, 1994.

Ungern-Sternberg, Jürgen von. "Wie gibt man dem Sinnlosen einen Sinn? Zum Gebrauch der Begriffe 'deutsche Kultur'und 'Militarismus' im Herbst 1914.” In Kultur und Krieg, edited by Mommsen, 77-96.

Ungern-Sternberg, Wolfgang von, and Jürgen von Ungern-Sternberg. Der Aufruf "An die Kulturwelt!": Das Manifest der 93 und die Anfänge der Kriegspropaganda im Ersten Weltkrieg. Stuttgart, 1996.

Verhey, Jeffrey. "Some Lessons of War: The Discourse on Propaganda and Public Opinion in Germany in the 1920s." In War, Violence and Modern Condition, edited by Bernd Hüppauf, 99-118. Berlin, 1997.

Vincent, Paul. The Politics of Hunger: The Allied Blockade of Germany, 1915-1919. Athens, $\mathrm{OH}, 1985$.

Vogel, Walter. "Die Organisation der amtlichen Presse- und Propagandapolitik des Deutschen Reiches von den Anfängen unter Bismarck bis zum Beginn des Jahres 1933." Special issue, Zeitungswissenschaft 16 (Aug./Sep. 1941).

Wachtell, Cynthia. "Representations of German Soldiers in American World War I Literature." In 'Huns' vs. 'Corned Beef': Representations of the Other in American and German Literature and Film on World War I, edited by Thomas Schneider and Hans Wagener, 59-83. Göttingen, 2007.

Wala, Michael. Weimar und Amerika. Botschafter Friedrich von Prittwitz und Gaffron und die deutsch-amerikanischen Beziehungen von 1927 bis 1933. Stuttgart, 2001.

-. “'Gegen eine Vereinzelung Deutschlands'. Deutsche Kulturpolitik und akademischer Austausch mit den Vereinigten Staaten von Amerika in der Zwischenkriegszeit." In Deutschland und die USA in der internationalen Geschichte des 20. Jahrhunderts, edited by Manfred Berg and Philipp Gassert, 303-315. Stuttgart, 2004. 
-. "Revising Ethnic Identity: The Foreign Office, the Reichswehr, and German-Americans during the Weimar Republic." In German-American Immigration and Ethnicity in Comparative Perspective, edited by Wolfgang Helbich and Walter Kamphoefner, 326-342. Madison, WI, 2004.

Walton, Whitney. "Internationalism and the Junior Year Abroad. American Students in France in the 1920s and 1930s." Diplomatic History 29, no. 2 (2005): 255-278.

-. "National Interests and Cultural Exchange in French and American Educational Travel, 1914-1970." Journal of Transatlantic Studies 13, no. 4 (2015): 344-357.

-. Internationalism, National Identities and Study Abroad: France and the United States, 18901970. Stanford, 2010.

Weber, Peter. "Ernst Jäckh and the National Internationalism of Interwar Germany." Central European History 52, no. 3 (2019): 402-423.

Wegener, Jens. “'An Organization, European in Character' - European Agency and American Control at the Centre Européen, 1925-1940." In American Foundations and the Coproduction of World Order in the Twentieth Century, edited by John Krige and Helke Rausch, 37-60. Göttingen, 2012.

Weidenfeller, Gerhard. VDA. Verein für das Deutschtum im Ausland. Allgemeiner deutscher Schulverein [1881-1918]. Ein Beitrag zur Geschichte des deutsche Nationalismus und Imperialismus im Kaiserreich. Frankfurt am Main, 1976.

Weinberg, Gerhard L. "Hitler's Image of the United States." American Historical Review 69, no. 4 (1964): 1006-1021.

-. "From Confrontation to Cooperation: Germany and the United States, 1933." In America and the Germans, edited by Trommler and McVeigh, 2:45-58.

Welch, David, ed. Nazi Propaganda: The Power and the Limitations. Totowa, NJ, 1983.

-. Germany, Propaganda and Total War, 1914-1918. The Sins of Omission. London, 2000.

-. "Cultural Propaganda." In Propaganda and Mass Persuasion: A Historical Encyclopedia, 1500-Present, edited by Nicholas J. Cull, David Culbert, and David Welch, 101. Santa Barbara, CA, 2003.

Welzbacher, Christian. Edwin Redslob. Biografie eines unverbesserlichen Idealisten. Berlin, 2009.

Wiedemann-Citera, Barbara. Die Auswirkungen des Ersten Weltkriegs auf die Deutsch-Amerikaner im Spiegel der New Yorker Staatszeitung, der New Yorker Volkszeitung und der New York Times 1914-1926. Frankfurt, 1993.

Wilcox, Clifford. "World War I and the Attack on Professors of German at the University of Michigan." History of Education Quarterly 33, no. 1 (Spring 1993): 59-84.

Wilhelm, Cornelia. Bewegung oder Verein. Nationalsozialistische Volkstumspolitik in den USA. Stuttgart, 1998.

Wilke, Jürgen. "Deutsche Auslandspropaganda im Ersten Weltkrieg: Die Zentralstelle für Auslandsdienst." In Pressepolitik und Propaganda: Historische Studien vom Vormärz bis zum Kalten Krieg, edited by Jürgen Wilke, 79-125. Cologne, 1997.

-. "German Foreign Propaganda in the United States during World War I: The Central Office for Foreign Services." In Propaganda in the 20th Century: Contributions to Its History, edited by Jürgen Wilke, 7-23. Cresskill, NJ, 1998.

Windsor, Tara. "Rekindling Contact: Anglo-German Academic Exchange after the First World War." In Anglo-German Scholarly Networks in the Long Nineteenth Century, edited by Heather Ellis and Ulrike Kirchberger, 212-231. Leiden, 2014.

Winn, Jospeh W. "Nicholas Murray Butler, the Carnegie Endowment for International Peace, and the Search for Reconciliation in Europe, 1919-1933." Peace \& Change 31, no. 4 (2006): 555-584.

Wippermann, Klaus. Politische Propaganda und Staatsbürgerliche Bildung. Die Reichszentrale für Heimatdienst in der Weimarer Republik. Bonn, 1976.

Wirsching, Andreas, and Jürgen Eder, eds. Vernunftrepublikanismus in der Weimarer Republik. Politik, Literatur, Wissenschaft. Stuttgart, 2008. 
Wittgens, Herman. "The German Foreign Office Campaign against the Versailles Treaty: An Examination of the Kriegsschuldreferat in the United States." PhD diss., University of Washington, 1970.

Wroblewski, Martin. Moralische Eroberungen als Instrumente der Diplomatie. Die Informations- und Pressepolitik des Auswärtigen Amts 1902-1914. Göttingen, 2016.

Wüstenbecker, Katja. Deutsch-Amerikaner im Ersten Weltkrieg. US-Politik und nationale Identitäten im Mittleren Westen. Stuttgart, 2007.

Young, Patrick. "A Place Like Any Other? Publicity, Hotels and the Search for a French Path to Tourism." In Touring Beyond the Nation: A Transnational Approach to European Tourism History, edited by Eric Zuelow, 127-149. Farnham, 2011.

Young, Robert J. Marketing Marianne: French Propaganda in America, 1900-1940. New Brunswick, NJ, 2004. 


\section{Index}

A

AEG (Allgemeine Elektricitäts-Gesellschaft) 168, 238

Alexander von Humboldt Foundation 223-226, 243, 335

Alliance Française 65, 208

Althoff, Friedrich 60, 68

America Department (Amerikaabteilung) of the Foreign Ministry 27, 29, 111, 120, 149, 176, $180,185,254,311,316,376,381$

Amerika-Institut (Berlin) 60-61, 66, 74-75, 88, 120, 124-126, 128, 132, 135, 158, 165, 180 , $249,253,255,308,345,364,366,382$

America Work Student Service (Amerika-Werkstudenten-Dienst) 224-229, 236-242, 242 $319,330,364,383,387-388$

American Committee for Devastated France 51, 121

American Committee on Public Information 232

American Council on Education 230

American Friends Service Committee 137, 139, 208

American Legion 51, 124, 129, 152, 156

American Library Association 230

American Relief Administration 138-141

American University Union 230, 234

American-German Student Exchange 202, 207, 223, 227-230, 235-236, 243, 272, 320, 370, $372-373,383$

Americanization 25-26, 71-72, 99, 177, 196, 238, 306

anti-Americanism 19, 47, 134, 168, 182, 217, 242, 292, 323, 350, 377

anti-German sentiment 30, 40-41, 51-52, 63, 65, 84-86, 90, 93, 98, 109, 132, 153, 157-158, $181,216,280,285,319,354-356$

antisemitism 246, 350, 354-355, 366, 368, 370-372, 375

Association of German Universities (Verband der deutschen Hochschulen) 29, 111, 134, $216-217,219,225,247$

Association of Germandom Abroad (Verein für das Volkstum im Ausland) 29, 71, 173, 179, 184 


\section{B}

Baker, Newton D. 371

Baden, Max von 17, 44

Bayer 28, 166, 224, 238

Beard, Charles 361

Beck, Friedrich (Fritz) 244-245, 319, 373

Becker, Carl Heinrich 165, 249, 254, 260

Beethoven, Ludwig van 89, 91-92, 99, 207, 337

Belgium 15, 40-41, 85-86, 90, 92, 103, 108, 118, 150, 216, 233, 267, 321, 355

Bernhardi, Friedrich von 92

Bernstorff, Johann Heinrich von 30, 45, 47, 50, 61, 70-71, 73, 80-81, 84, 97, 124-125, 130-131, 165, 324, 383

Bertling, Karl Oscar 124-125, 180-181, 253, 364, 366, 373

Bethmann-Hollweg, Theobald von 68-69, 80-81, 102

Bismarck, Otto von 24, 62-63, 101

"Black Horror on the Rhine". See Occupation of the Rhineland

Bloom, Sol 340

Boas, Franz 91, 146, 207

Bolshevism, fears of 20, 46, 49, 138, 194, 232-233, 333, 379

Bonhoeffer, Dietrich 240

Bonn, Moritz Julius 88, 94, 104, 165-166, 168, 249, 254, 335, 342

Bosch, Robert 30, 165, 197, 238

boycott of German science 35-36, 114, 134, 212, 215-220, 225, 247, 258, 268, 389

Boyé, Adolf 54

Brentano, Lujo 131

Briand-Kellogg Pact, 1928 266, 324

Brüning, Heinrich 332-334, 341, 349, 352, 389

Bryce, Sir James 65, 70

Busch, Adolphus 74

Bülow, Bernhard von 62-63, 101

Bülow, Bernhard Wilhelm von 333

Burgess, John 78

Busse, Adolph 205

Butler, Nicholas Murray 28, 60, 75-76, 132, 157, 231, 251-257, 268, 270, 320, 322, 344-345, $347,370-373,376$

\section{$\mathrm{C}$}

Carl Schurz 73, 196, 201, 336-338, 347-348, 390

Carl Schurz Professorship (University of Wisconsin) 73, 238

Carl Schurz Memorial Foundation 28, 204-209, 320, 330-331, 344-345, 370-371, 373

Carnegie Endowment for International Peace 28, 132, 152, 167, 230-234, 249, 251-255, 345-346, 387, 389-391

Central Office for Foreign Services (Deutsche Zentralstelle für Auslandsdienst) 87, 102-103, 109,122

Chicago 179, 186, 189

Chicago Daily News 53

churches 71, 92, 124, 139, 141, 152-154, 156, 177, 240, 281, 355

Cincinnati 369

Cité Internationale Universitaire 244, 384

colonies, German 43

Columbia University 60-61, 75-76, 78, 94, 132, 231, 255, 376

- Deutsches Haus 60-61, 99, 205, 216, 268, 320

Confederation Internationale des Étudiants 35 
consulates, American 144, 147-148, 342

consulates, German 83, 172, 180, 186-187, 190-193, 198, 203-204, 241, 243, 297, 308, 344, 372

Coolidge, Calvin 117, 258

Cooper, William Alpha 206, 335

Council on Foreign Relations 249

Creel, George 40, 99-100

Croly, Herbert 53

Cronau, Rudolf 193

Cuno, Wilhelm 122, 152, 238

Curtius, Julius 176, 334-335, 338

D

DAAD. See German Academic Exchange Service

D’Abernon, Edgar Vincent 324

Davidsen, Hermann 176, 185, 260, 313-316

Dawes, Charles G. 189

Dawes Plan 20, 156-158, 186, 198, 236, 286, 305

Deissmann, Adolf 219, 249

Dernburg, Bernhard 87, 124-125

Deutelmoser, Erhard 102

Deutsche Akademie (München) 111, 173, 204-205, 335, 339, 342, 345-347, 364

Deutsche Allgemeine Zeitung 47

Deutsches Ausland-Institut 173, 183, 206, 345-346

Deutscher Schutzbund 173

Dewey, John 229-230

Dibelius, Martin 265

Dieckhoff, Hans-Heinrich 134, 155-156, 360, 375-376

diplomatic reform. See Schüler Reforms

disarmament 49, 239-240, 331, 352, 355-356

Dodd, William 28, 371

Draeger, Hans 336, 364, 366

Drechsler, Walther 120, 125, 176, 185

Dresel, Ellis Loring 46

Duggan, Stephen 229-231, 235, 241, 271-272, 370-373

Duisberg, Carl 30, 165-166, 224, 238, 244-245, 335

E

Ebert, Friedrich 54

Eckener, Hugo 117, 238

Economic Policy Association (Wirtschaftspolitische Gesellschaft) 307-308, 366

Einstein, Albert 131, 238, 249, 354, 372

Eliot, Charles W. 75-76, 85

Emergency Society of German Science (Notgemeinschaft der deutschen Wissenschaft) 128, 141,238

English-Speaking Union 197, 208

Erkelenz, Anton 30, 165, 168, 195-197, 319, 336, 390

Erzberger, Matthias 108

Espionage Act, 1917120

European Student Relief 138-141

$\mathbf{F}$

The Fatherland 96-97

Faust, Albert Bernhardt 205-207, 259, 337 
Feis, Herbert 349

Fife, Robert 205, 207

Films 25, 88, 103, 113, 152, 287-288, 293, 306, 332, 344, 358, 367

Foerster, Wilhelm 234

Ford Motors 228

Foreign Policy Association 249

foreigners, German agitation against 111, 118-119, 143-146, 148-150, 222, 354

France 23, 49, 51-52, 69, 131, 146, 156-157, 163, 211, 215-217, 223, 230, 233-234, 236, $284-286,291,355,382,384$

- German competition with 32, 37, 44, 49, 63-65, 67, 71, 76, 79, 81, 84, 91, 101, 121-123, $125,128,149,151-154,159,206,208,215,221-222,225,227,237,241,244,246,269$, $271,278-280,285,290-292,298-303,305-306,315-316,321,342,386-387$

France-America Society 79, 121, 157

Francke, Kuno 65, 74, 206-207, 268

Franke, Otto 205, 219, 247

Frankfurter Zeitung 147

Friedrich, Carl Joachim 223, 226, 235, 387

Fuehr, Karl Alexander 120, 176, 185

G

Gärtner, Margarete 308, 366

General Motors 228

Gerard, James W. 88, 97, 182

Gerlach, Hellmut von 234

German Academic Exchange Service (Deutscher Akademischer Austauschdienst, DAAD) $29,223-226,229,236-238,247,271,319,335-336,363-369,373,380,387$

German Americans 22, 27, 31, 53, 59, 129, 136, 146, 149, 153, 171-210, 313, 320, 336

- assimilation 72, 99, 177, 181, 184, 190-191, 196, 202

- German hope in 53, 71-75, 81, 84, 96-97, 120-122, 176-184, 189-190, 195-197, 202, 322, $339,359-361$

- organizations of $72,74,96,137-141,181-183,204-209,344,346$

- repression against 52, 78, 98-99, 100, 138, 140, 181, 208, 330

Germans Abroad (Auslandsdeutsche) 71, 113, 173-176, 358

German Center Party (Zentrum) 218

German Democratic Party (Deutsche Demokratische Partei, DDP) 166, 168, 195, 201, 336

German Foreign Ministry. See also Kulturabteilung, Cultural Department of the Foreign Ministry

German Hotel League (Deutscher Hotelverband) 278

German Ministry of the Interior 125, 173

German Ministry of Propaganda 357, 359-360, 363, 368-369, 390

German National Conservative Party (Deutschnationale Volkspartei, DNVP) 163

German National Liberal Party (Nationalliberale) 15, 102, 105

Germanistic Society 60, 138, 140-141, 146, 205, 207

Germanists 65, 204-209, 293, 335, 344-345, 348, 362

German language teaching 68, 191, 205

German People's Party (Deutsche Volkspartei, DVP) 48, 166, 197

German Railways 279, 310-312, 316

German schools abroad 68, 113, 128, 173-175, 382

German Tourist Information Office, New York City 285-297, 308, 313-317, 319, 344, 355, 365-366, 384

German Tourism Promotion Bureau (Reichszentrale für deutsche Verkehrswerbung) 143, 278-279, 285, 288-295, 299, 310-316, 366

Gilbert, Parker 258 
Goebbels, Joseph 357-358, 367

Goethe, Johann Wolfgang von 89, 91-92, 99, 207, 259, 293

Goethe celebrations, 1932 336-337, 340-341, 343-348, 351-352

Goethe Medal for Art \& Science 346

Goethe-Institut 335, 382

Göttingen University 258, 263, 375

Great Britain 63, 109, 125-126, 131, 148, 250, 254, 299-300, 321, 355, 367, 382, 384-385

- German competition with 64-66, 71, 73, 81, 83-86, 90, 103, 106, 119-120, 196-197, 208, $211,219,221,223,227,233,271,303,321,342,357,383,387$

Great Depression 267, 329, 331-332

Groener, Wilhelm 110

Grothe, Hugo 184

H

Haber, Fritz 238, 249

Hadley, Arthur 78

Hamburg 105, 111, 268, 338, 342

Hammann, Otto 62

HAPAG 122, 168, 197, 238, 277, 303

Harding, Warren G. 49, 51, 54, 127, 151, 156

Harnack, Adolf von 85, 94, 110, 130-131, 213-214, 238, 249

Harper's Bazaar 286, 302

Hartmann, Waldemar 365

Harvard University 59-60, 65, 75, 84, 94, 268, 373

Hauptmann, Gerhart 99, 344-345, 351

Heidelberg University 65, 155, 166, 223, 226, 235, 251, 259, 261-268, 320, 322, 331, 350-351, 368-369, 373-374

Heilbron, Friedrich 114

Heinrich, Prince of Prussia 58-61, 72, 117

Hentig, Werner Otto von 186-187, 192, 194, 241

Heuser, Frederick 146, 205, 207, 335, 345, 347, 370

Hindenburg, Paul von Beneckendorff und von 189, 194, 200, 206, 305, 334, 338, 341-342, $346-347,351-352$

Hitler, Adolf 201, 240, 351, 353, 355-359, 366

Hochschule für Politik, Berlin 168, 251-252, 255-256, 268, 319

Hoetzsch, Otto 249-250

Hoffmann, Conrad 139

Hohlfeld, Alexander 205-206

Holleben, Theodor von 70

Hoops, Johannes 249

Hoover, Herbert 25, 53, 138-139, 283, 341

Houghton, Alanson B. 219, 259, 284, 334

House, Edward 130

Hughes, Charles Evans 53, 151

I

IG Farben 168, 197, 356

Immigration Legislation, 1924 129, 186, 190, 277

Imperial Naval Office (Reichsmarineamt) 62, 86

Independent 51

inflation 127-128, 142-149, 218, 221-223, 281-283

Institute for Social and Political Science (Heidelberg) 251, 264, 364

Institute of International Education 167, 221, 223, 229-236, 243, 271-272, 368-373, 387

International Academic Office (Deutsche Akademische Auslandstelle) 225, 244, 270 
International Committee of the Red Cross 35

International Institute of Intellectual Cooperation 218

International Research Council 35-37

International Student Service 245

internationalism, cultural 74-76, 229-236, 249, 256, 272-273, 346, 371-373, 386-387

isolationism $30,51-53,70,235,276,355,385$

Italy 208, 222, 233-234, 291, 302, 376

\section{$\mathbf{J}$}

Jäckh, Ernst 30, 86, 103-104, 155, 165-168, 249, 251-252, 319, 363, 387, 390-391

Jagow, Gottlieb von 110-111, 114

Janssen, Henry 205

Japan 76, 376

Junior Year in Munich 226, 268, 331, 368

Jusserand, Jules 152

K

Kant, Immanuel 89, 91-92, 259, 390

Karo, Georg 248

Kessler, Harry Graf 188

Kiep, O(tto) C(arl) 356

Kiesel, Karl 311

Klenze, Camillo von 140, 205-207, 335, 348

Krupp Iron Works 28, 136, 187, 228, 259, 307

Kühlmann, Richard von 105-106, 334

Kühnemann, Eugen 73-74, 88-90, 97, 260, 345, 351

'Kultur' 67, 91, 95, 98-100, 126, 136, 141, 204, 281, 313, 315

Kulturabteilung, Cultural Department of the Foreign Ministry 113-115, 125, 127, 132, 142, $148,155,176,185,215,219,224,346,381-382$

- budget 29, 113, 115, 128, 176, 382

- Cultural Advisory Council (Kulturbeirat) 154

- staff 113-115

L

Lafayette, Marquis de 338, 348, 384

Lamprecht, Karl 86

Laswell, Harold 256

Laughlin, Clara 280

League of German Tourism Associations (Bund deutscher Verkehrsvereine) 277, 281, 311, 313

League of Nations 36, 51-52, 113, 163, 221, 240, 245, 252, 256, 287, 356

League of Red Cross Societies 35

Lessing, Otto 206

Library of Congress 124

Literary Digest 39, 48, 95

Löbe, Paul 337-338

Locarno 163, 252, 256, 287, 333

Luckner, Felix Graf von 193

Ludendorff, Erich 107-108

Lufthansa 304

Lusitania 15, 95-98, 108, 267

Luther, Hans 354, 360, 362, 376, 384 
$\mathbf{M}$

Mach, Edmund von 52, 122, 180-181, 183

Maltzan, Adolf Georg Otto von 164, 187-190, 192-196, 198, 200-201, 209, 251-253, 263, $311-312,323$

Manifesto of the $9389,92-93,131-132,257$

Mann, Thomas 254, 372

Mehnert, Klaus 240-241

Mendelssohn Bartholdy, Albrecht 165, 168, 249, 268

Meyer, Eduard 47, 77, 93-95, 217, 219, 255

Monroe Doctrine 63-64, 66, 82, 324, 389

Monroe, Paul 231

Morgan, Anne 121

Moroccan Crises, 1905 and 1911 67, 79

Morsbach, Adolf 30, 165, 223, 229, 238, 271-272, 319, 336, 363-366, 368, 373

Mowrer, Edgar Ansel 353

Mowrer, Lilian 302

Mücke, Hellmuth von 193

Münsterberg, Hugo 60, 65, 74, 85

Munich 143-144, 204, 244-245, 337-338, 343, 373-374

Music 25, 61, 67, 99, 110, 129, 134-135, 188, 246, 293-294, 332, 337, 363, 367, 385

$\mathbf{N}$

Nagel, Charles 140, 149, 205, 207

Nation 52

National German-American Alliance 72, 75, 96, 178-179

National Socialism 350-351, 353-354, 358-360, 365, 368, 390

National Socialist Party's Foreign Section (Auslandsorganisation der NSDAP) 358

National Tourism Council (Reichsausschuss für Fremdenverkehr) 311, 335

Nativism 53, 74, 78, 97, 120, 126, 129-130, 140, 149, 158, 177, 180, 183, 185-186, 190, 200, 205

Neurath, Konstantin Frhr. von 366

New Republic 53, 135

New York City 87, 117, 151, 186, 204, 221, 230, 244, 271-272, 285, 315, 372, 384, 386

New York Times 53, 145, 282

New York World 98

New Yorker Staats-Zeitung 74, 140, 207, 287

Nietzsche, Friedrich 92

Noelle-Neumann, Elisabeth 240

Northcliffe, Alfred Lord 143, 148, 278

North German Lloyd 168, 197, 277, 285, 303

O

Oberlaender, Gustav 205, 330, 346, 370, 374

Occupation

- of the Rhineland 18, 23, 43, 49, 52, 109, 118, 122-124, 163, 184, 324, 332, 379

- of the Ruhr 112, 118, 150-157, 234, 256, 307, 380

Office National du Tourisme 278-279, 315

Office National des Universités et des Écoles Françaises 221

Olympics 35, 300, 367, 374

Oncken, Hermann 89, 94, 96, 249, 337

Outlook 51

$\mathbf{P}$

Pan-German League (Alldeutscher Verband) 64, 71, 78 
Papen, Franz von 238, 352

Peace Treaty, German-American 126-127, 130, 138, 142-143

Peace Treaty of Versailles 39, 41, 110, 137, 144, 174, 178, 277, 308

- revision of 43-44, 52-53, 123-124, 189, 235, 332

Penck, Albrecht 30, 219, 249

Pétain, Philippe 340

Planck, Max 214, 249

Press policy 29, 68, 112, 151-152, 189, 323-324

- American news correspondents 22, 24, 112, 153-154, 266, 323, 334, 353, 356-357

- Press department of the German Foreign Ministry 88, 102-103, 111-112, 120, 125, 151, 182,334

Pritchett, Henry 371

Prittwitz und Gaffron, Erich von 253-254

Prittwitz und Gaffron, Friedrich Wilhelm von 192, 199-202, 267-268, 292, 309, 322, $337-338,340,345,347-350,352,376,390-391$

Prohibition 72, 74, 129, 177-179, 194

Professorial exchange 60-61, 66, 74-79, 88, 94, 132, 134, 216, 229, 268, 272

propaganda

- German discussion on 15-17, 23, 53-55, 85-88, 101-111, 119-123, 150-155, 178-185, 282, 354-359, 362

- American reaction to 36, 40, 93-95, 98-99, 119-122, 272, 281, 287, 296, 361, 369, 385

Prussian Ministry of Culture 29, 60, 65-69, 73, 76, 81, 88, 94, 115, 125, 165, 215, 223, 249, $254,260,364$

\section{Q}

$\mathbf{R}$

Rapallo Treaty 187

rapprochement, German-American 20-21, 23, 131, 150, 157, 200, 256-261, 265, 316, $319-325,347,386-387$

Rathenau, Walther 49

Redlich, Josef 122

Redslob, Edwin 346, 352

Reichstag 15-16, 18, 67, 106, 176, 192, 195, 197, 214, 247, 266, 270, 333-334, 337-339, $341-342,354$

Remme, Karl 227-228

Reparations 19-20, 39, 42-44, 48-49, 54, 109, 118, 123, 135-136, 146, 149-151, 157, 163 , $235,239,245,282,305,331-333,341,352,355$

Rhodes Scholarship 64, 223

Ridder Family. See New Yorker Staats-Zeitung

Richter, Werner 387

Riezler, Kurt 57, 68, 100

Rockefeller Foundation 231-233, 250-251, 256, 371

Rockefeller International House, New York City 244

Rohrbach, Paul 68, 86-87, 101-105, 130, 192

Roosevelt, Theodore 59-60, 70, 98

Roosevelt, Franklin Delano 375-376

Rosenwald, Julius 205, 207

Rühlmann, Paul 109, 122

S

Sackett, Frederic 333-335, 338, 342, 349, 354

Saturday Evening Post 40, 331

Schacht, Hjalmar 238, 254, 354 
Schairer, Reinhold 30, 165, 168, 225, 227, 238, 244-246, 270-271, 319, 336, 387, 390

Scheidemann, Philipp 18

Schiff, Jacob 74

Schiller, Friedrich 99, 207, 337

Schmidt-Ott, Friedrich 88, 94, 97, 217, 219, 238

Schmitz, Ernst 287-296, 307, 312-313, 315, 319, 366

Schnee, Ada 308

Schnee, Heinrich 108, 247, 308

Schönemann, Friedrich 180-181, 183, 228

Schoonmaker, Frank 276, 298, 303, 305-306

Schreiber, Georg 127, 218, 242

Schubert, Carl von 163, 185, 333

Schüking, Walther 249

Schüler, Edmund 196

Schüler Reforms 101-115, 185

Schulze-Gaevernitz, Gerhart von 249-250

Schurman, Jacob Gould 199, 208, 258-266, 270, 319-320, 335, 337, 344, 350, 373

Sherwood, Eddy. See YMCA

Siemens 168, 238

Simonds, Frank H. 323, 325

Simons, Walter 30, 44, 130

Smoot-Hawley tariff, 1930332

Social Democratic Party (Sozialdemokratische Partei, SPD) 17-18, 46, 163, 197, 336

Solf, Wilhelm 45

Speyer, James 140, 205, 207

Spur 286

'Stab-in-the-back' myth 47, 107, 192, 199

Sternburg, Hermann Speck von 70

Stern-Rubarth, Edgar 110-111

Steuben, Friedrich Wilhelm von 199, 207, 336-341, 345, 347-348, 384, 390

Steuben Society 178-179, 181-183, 203, 205, 337, 339, 390

Stimson, Henry L. 352

Stone, Shepard 246, 321, 388

Stresemann, Gustav 15-16, 20, 22-23, 29-30, 48-49, 102, 109, 115, 154, 156-157, 163-167, $174,187-188,197,200,247-248,253-254,258,261-267,305,320,322-323,325,330$, $333-334,337$

student exchange 202, 220-251, 271-272, 320-321, 349, 365, 368-369 386-387, 390

submarine warfare 15-16, 36, 41, 95, 98, 100, 104, 250

Society of Friends of the USA (Hamburg) 345

South America 21, 31, 49, 63-64, 67, 69, 78, 82, 148, 173, 175, 210, 233, 376-377, 382, 389

$\mathrm{T}$

Terramare Office 311-313, 364

Thierfelder, Franz 205, 347, 382

Thomas, Wilbur K. 208, 370, 372

Thun, Ferdinand 149, 205-207

Thwing, Charles 273

tourism 31, 142-149, 158, 275-317, 331, 356, 361-367, 380-381, 385

Town \& Country 302

Treitschke, Heinrich von 92 
$\mathrm{U}$

universities $22,60-61,63,72-73,75-76,78-79,87,90-95,99-100,110-111,127-128$, 133-135, 138, 141, 148, 154, 158, 202, 205-206, 211-273, 289, 293, 344-346, 350, 354, $362-363,368-370,373,375$

Universities Bureau of the British Empire 221

U. S. Congress 118, 120, 172, 193-194, 199, 230, 233, 263, 340, 361, 385

U. S. Department of Commerce 283, 299-300

U. S. Department of Labor 224, 330

U. S. Department of State 28, 70, 193, 233, 282, 284, 349, 374, 385

$\mathrm{V}$

Vagts, Alfred 63, 240

Vanity Fair 275-276, 298, 302

Vereinigung Carl Schurz 22, 165, 195-198, 201-202, 307-308, 319, 330, 335-339, 341, 345, $364,366,390$

Viereck, George Sylvester 52, 96, 122, 129, 181, 184, 355-356

Vogue 286, 302

Volk und Heimat 179

Vossische Zeitung 266

W

Wagner, Adolf 78

Walz, John A. 205

Warburg, Max 30, 44, 74, 165, 238

Warburg, Paul 74, 140, 205, 207, 229

war debt 44, 121, 156, 331

war guilt 89, 106, 109, 122-123, 128, 167, 192, 198, 234, 239-240, 256, 258, 265, 321, 336

Washington, George 338, 340, 342, 348

- bicentennial 336, 340-343

Weber, Alfred 155, 165-166, 219, 223, 228, 249, 264, 319

Wellington House 85

Weltpolitik 63, 67-69, 81, 166, 233, 266

Wiedfeldt, Otto 54-55, 133, 136, 147, 152-154, 158, 187-188, 209, 228, 259, 282, 346, 385

Wilhelm II 18-19, 41, 45, 52, 58-60, 63, 66, 218, 303, 305

Williamstown Conference 249-251

Wilson, Woodrow 15, 17-19, 36, 41, 44-47, 84, 99, 106, 130, 144, 217, 386

Wirtschaftshilfe der deutschen Studentenschaft 224

Wittke, Carl 342

Wolff Telegraphic Bureau 112, 334

Working Committee of German Associations (Arbeitsausschuss deutscher Verbände) $123-124,336$

World Court 52

World Student Christian Movement 221, 225

$\mathbf{Y}$

YMCA 139, 224, 227, 229-230, 244, 308-309, 365

Young Reparations Plan 324-325, 332

$\mathbf{Z}$

Zeppelin 117-118, 157-158, 304

Zimmermann, Arthur 16, 97, 103

Zimmermann Telegramm 16, 100, 104 
Despite powerful war resentments, German-American relations improved rapidly after World War I. The Weimar Republic and the United States even managed to forge a strong transatlantic partnership by 1929. How did this happen?

Elisabeth Piller's groundbreaking study upends the common assumption that Weimar was incapable of selling itself abroad, illustrating instead that it pursued an innovative public diplomacy campaign engaging German Americans, U.S. universities, and American tourists abroad to normalize relations and build a politically advantageous friendship with the United States.

In her deeply researched, vividly illustrated history of cultural-diplomatic relations between Weimar Germany and the United States, Elisabeth Piller charts a new course in the history of transatlantic interwar diplomacy. Victoria de Grazia, Columbia University

Dr. Piller has achieved a masterful synthesis of diplomatic, intellectual, and cultural history. Michael Kimmage, Catholic University of America

Winner of the Franz Steiner Prize in Transatlantic History 